\section{Қазақ экономика, қаржы жжәне халықаралық сауда университетінің FAP PUECW}

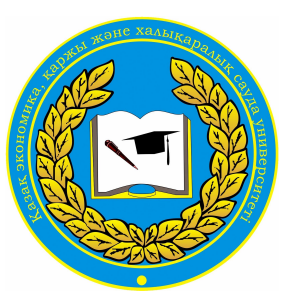

№4(41)
BECM\#UR

Казахского университета экономики, финансов и межнународной торговли

\title{
Главный редактор:
}

C.A. Абдыманапов - ректор КазУЭФМТ, академик МАН ВШ, д.пед.н., профессор математики

Заместитель главного редактора:

Б.С. Есенгельдин - д.э.н., профессор

Научный редактор:

Б.Т. Аймурзина - Д.э.н., профессор

Ответственный редактор:

Г.С. Укубасова - PhD, к.э.Н., ассоц. профессор

\section{Редакционная коллегия:}

A. Azanoba

Л. Baca

Т.В.Шталь

Т.В. Воронина

А.А. Бексултанов

E. Әмірбекұль

А.Н. Токсанова

3.К. Жаныбаева

М.Ж. Каменова

М.К. Алиев

Д.М. Турекулова

А.Х. Галиева

Р.Д. Берназарова
$\mathrm{PhD}$, (США)

$\mathrm{PhD}$, профессор (Венгрия)

д.э.н., профессор (Украина)

д.э.Н., профессор (Россия)

д.э.н., профессор (Кыргызстан)

д.э.н., профессор (Казахстан)

д.э.н., профессор (Казахстан)

к.э.н., доцент (Казахстан)

д.э.н., профессор (Казахстан)

д.э.н., профессор (Казахстан)

д.э.н., профессор (Казахстан)

д.э.н., ассоц. профессор (Казахстан)

технический секретарь (Казахстан)

Свидетельство о постановке на переучет периодического печатного издания,

Информационного агентства и сетевого издания № KZ67VPY00015604 от 03.10.2019 г.

Выдано Министерством информации и общественного развития Республики Казахстан 


\section{МАЗМҰНЫ}

\section{ЭКОНОМИКА}

Темірбаева Г.Р., Әбілдина А.Ш., Жанбаев Р.А., Құлыбеков М.Т. Экономикадағы дағдарыс жағдайларында моноқалаларда өмір сапасын арттыру мәселелері .8

Тұргамбаев М.Қ., Желю В., Легостаева А.А. Инвестициялық жобаларды кешенді бағалауға әр түрлі бағалардың әсерінің салмақ коэффициенттері жүйесін әзірлеу..

Турекулова Д.М., Оразбаева К.Н., Ниязов М.Н., Естурлиева А.И. Өндіріс қалдықтарын мемлекеттік басқаруды жетілдірудің экономикалық моделі.

Накипова Г.Е., Шалабаева А.Ж. Қазақстан Республикасында мемлекеттік-жекеменшік әріптестікті жүзеге асырудың кейбір ерекшеліктері.

Несипбаев Р.Е., Мусатаева А.А., Борисова Е.И. Қарағанды облысын дамытудың

2016-2020 жылдарға арналған бағдарламасын әзірлеу мен іске асырудың тиімділігі.

Елшібаев Р.Қ. Қазақстан Республикасының технологиялық кәсіпорындарын

дамытуды қаржыландыру.....

Үкібасова Ғ.С., Ибрагимова Н.В. Кәсіпорынның өндіру және экономикалық қызметіндегі

$\mathrm{S} \& \mathrm{OP}$ процесінің маңыздылығы.

Андекина Р.Э., Аймавамбетова А.Д. Металдарды өндіруші компанияда SWOT-талдауды

пайдалана отырып стратегияны әзірлеу...

Шайкин Д.Н., Есембекова Д.Т., Валиева М.М., Копылова О.В. Елдің көші-қон әлеуеті тиімді экономикалық жүйені қалыптастыру факторы ретінде.

Дуламбаева Р.Т., Турекулова А.Н., Жаныбаева З.К., Беделбаева А.Е. Өңірлердің

бәсекеге қабілеттілігін талдау және бағалау әдістерін зерттеу..

Саду Ж.Н., Кушебина Г.М. Қазақстан Республикасының мал шаруашылығы саласындағы

ауыл шаруашылығы өнімдерін өндірушілерді қолдаудың мемлекеттік шаралары.

Рахимбекова А.Е., Казыбаева А.М. Қазақстан Республикасында медициналық

қызметтердің заманауи нарығын дамыту үрдістері.

Айткалиева A.M. Иерархияны талдау әдісі негізінде мемлекеттік-жеке меншік

әріптестік жобаларының тиімділігін бағалау..

\section{МЕНЕДЖМЕНТ ЖӘНЕ МАРКЕТИНГ}

Тұрсымбаева М.Ж., Шаймерденова А.Қ. Қазақстан Республикасы жарнама нарығының дамуын талдау...

Рахметова А.М., Будешов Е.Г. Халықтың тұрмыс сапасының негізі ретінде

Қазақстанның денсаулық сақтау жүйесін мемлекеттік басқару.

Ескалиева А.Ж., Мусина А.А., Ивалиева Л.Н., Лукпанова Ж.О. Адами капиталды

дамытудағы халықаралық тәжірибе

Нұрпейісова М.М. Қазақстандағы ішкі және кіру туризмнің бейнесі мен

тартымдылығының қалыптасуы.

Жуманова Б.К., Алашбаева Н.М., Имашев А.Б., Байгабулова К.К. Қазақстанның

көліктік-логистикалық жүйесін басқаруда цифрлық технологияны енгізу..

Аркенова Ж.Р. Мемлекеттік стратегиялық жоспарларды іске асыруда ғылыми-зерттеу

ұйымдарының әлеуетін пайдалану мүмкіндіктері.

Мухан Б.С., Есиркепова А.М., Тулеметова А.С. Қазақстан Республикасының жеңіл

өнеркәсіп нарығын дамытудың негізгі бағыттары..

Маканова А.У., Тургинбаева А.Н., Смагулова Г.С., Смагулов К.Е. Зерттеу университетін

трансформациялаудың басқару аспектілері: шетелдік тәжірибе. 


\section{ҚАРЖЫ ЖӘНЕ ЕСЕП}

Нұрымов А.А., Уахитжанова А.М. Ауыл шаруашылығын дамытудың қаржылық аспектісі......191 Аймурзина Б.Т., Есенгельдин Б.С., Каменова М.Ж. Қазақстандағы қазіргі заманғы салық механизмінің тиімділігін бағалау.

Құдайбергенов Н.А., Адилова Ә.М., Әлиев М.Қ., Алтьнббеков М.А. Шағын және орта кәсіпорындардағы есеп саясатын құрудың маңыздылығы мен мәселелері

Сейдахметова Ф.С., Карабаев Э.Б. Бухгалтерлік есеп және мемлекеттік аудит саласында кадрлар даярлау мәселелері.

Кажмухаметова А.А., Тусибаева Г.С., Акимова Б.Ж. Қоғамдық тамақтану

кәсіпорындарының қаржылық нәтижелерінің есептік құрамы.

Есенгельдинова С.Ж., Усенбаев Т.М., Бозшагулова С.О. Қаржылық жаһандану жағдайында Қазақстанның төлем жүйесін дамыту.

Абжалова Б.А., Шахарова А.Е. Қазақстан Республикасының сыртқы мемлекеттік аудитін цифрлық трансформациялау.

Амирова Г.К. Қазақстанның ғылыми саласын дамытудың ұйымдастырушылық және қаржылық аспектілері. 


\section{СОДЕРЖАНИЕ}

\section{ЭКОНОМИКА}

Темирбаева Г.Р., Абильдина А.Ш., Жанбаев Р.А., Кулубеков М.Т. Проблемы повышения качества жизни в моногородах в условиях кризисных явлений в экономике.

Тургамбаев М.К., Желю В., Легостаев А.А. Разработка системы весовых коэффициентов влияния различных оценок на комплексную оценку инвестиционных проектов.

Турекулова Д.М., Оразбаева К.Н., Ниязов М.Н., Естурлиева А.И. Экономическая модель совершенствования государственного управления отходами производства................................28

Накипова Г.Е., Шалабаева А.Ж. Некоторые особенности реализации государственно-

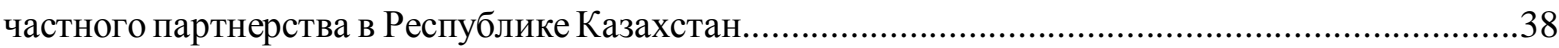

Несипбаев P.E., Мусатаева А.А., Борисова Е.И. Эффективность разработки и реализации программы развития Карагандинской области на 2016-2020 годы.

Елиибаев P.К. Финансирование развития технологических предприятий

Республики Казахстан.

Укубасова Г. С., Ибрагимова Н.В. Значение S\&OP-процесса в производственной и экономической деятельности предприятия.

Андекина Р.Э., Аймагамбетова А.Д. Разработка стратегии на основе SWOT-анализа компании, производящей металлургические продукты..

Шайкин Д.Н., Есембекова Д.Т., Валиева М.М., Копылова О.В. Миграционный потенциал

страны как фактор формирования эффективной экономической системы.

Дуламбаева Р.Т., Турекулова А.Н., Жаныбаева З.К., Беделбаева А.Е.

Исследование методов анализа и оценки конкурентоспособности регионов.................................88

Саду Ж.Н., Кушебина Г.М. Государственные меры поддержки сельскохозяйственных товаропроизводителей отрасли животноводства в Республике Казахстан.

Рахимбекова A.E., Казыбаева A.M. Конкурентоспособность и тенденции развития современного рынка медицинских услуг в Республике Казахстан.

Айткалиева A.M. Оценка эффективности проектов государственно-частного

партнерства на основе метода анализа иерархии.

\section{МЕНЕДЖМЕНТ И МАРКЕТИНГ}

Турсумбаева М.Ж., Шаймерденова А.К. Анализ развития рекламного рынка Республики Казахстан.

Рахметова A.M., Будешов Е.Г. Государственное управление системой здравоохранения Казахстана как основа качества жизни населения.

Ескалиева А.Ж., Мусина А.А., Игалиева Л.Н., Лукпанова Ж.О. Международный опыт развития человеческого капитала.

Нурпеисова М.М. Формирование имиджа и привлекательности внутреннего и въездного туризма в Казахстане

Жуманова Б.К., Алашбаева Н.М., Имашев А.Б., Байгабулова К.К. Внедрение

цифровизации в управление транспортно-логистической системой Казахстана.

Аркенова Ж.Р. Возможности использования потенциала научно-исследовательских организаций в реализации государственных стратегических планов

Мухан Б.С., Есиркепова А.М., Тулеметова А.С. Основные направления развития рынка легкой промышленности Республики Казахстан.

Маканова А.У., Тургинбаева А.Н., Смагулова Г.С., Смагулов К.Е. Управленческие аспекты трансформации исследовательских университетов: зарубежный опыт. 


\section{ФИНАНСЫ И УЧЕТ}

Нурумов А.А., Уахитжсанова А.М. Финансовый аспект развития сельского хозяйства.

Аймурзина Б.Т., Есенгельдин Б.С., Каменова М.Ж. Оценка эффективности современного налогового механизма в Казахстане.

Кудайбергенов Н.А., Адилова А.М., Алиев М.К., Алтынбеков М.А. Важность и проблемы формирования учетной политики на малых и средних предприятиях.

Сейдахметова Ф.С., Карабаев Э.Б. Вопросы подготовки кадров в области бухгалтерского учета и государственного аудита

Кажмухаметова А.А, Тусибаева Г.С., Акимова Б.Ж. Учетная составляющая финансовых результатов предприятий общественного питания.

Есенгельдинова С.Ж., Усенбаев Т.М, Бозшагулова С.О. Развитие платежной системы Казахстана в условиях финансовой глобализации....

Абжалова Б.А., Шахарова А.Е. Цифровая трансформация внешнего государственного аудита Республики Казахстан..

Амирова Г.К. Организационные и финансовые аспекты развития научной сферы

Казахстана. 


\section{CONTENTS}

\section{ECONOMICS}

Temirbayeva G., Abildina A., Zhanbayev R., Kulubekov M.

The issues of improving the quality of life in monocities within crisis conditions in economy...........................8

Turgambaev M., Zhelyu V., Legostaeva A. Development of a weight coefficients system influence of different values on the integrated assessment of investment projects.

Turekulova D., Orazbayeva K., Niyazov M., Yesturliyeva A. Economic model for improving the state management of production waste..

Nakipova G., Shalabayeva A. Some features of the implementation of public-private

partnership in the Republic of Kazakhstan.

Nessipbayev R., Mussatayeva A., Borisova Ye. Efficiency of development and

implementation of the development program of the Karaganda region for 2016-2020.

Yelshibayev R. Financing the development of technological enterprises in the

Republic of Kazakhstan.

Ukubassova G., Ibragimova $N$. The importance of the S\&OP-process in the production

and economic activities of the enterprise.

Andekina R., Aimagambetova A. Strategy development by using swot analysis in a metals manufacturing company.

Shaikin D., Yesembekova D., Valiyeva M., Kopylova O. Migration potential of the country

as a factor in the formation of an effective economic system.

Dulambayeva R., Turekulova A., Zhanybayeva Z., Bedelbayeva A. Research of methods for analyzing and evaluating regional competitiveness.

Sadu Zh., Kushebina G. State support measures on agricultural producers livestock industries in the Republic of Kazakhstan...

Rakhimbekova A., Kazybayeva A. Competitiveness and development trends of the modern market of medical services in the Republic of Kazakhstan..

Aitkaliyeva A. Evaluating the effectiveness of public-private partnership projects based on the hierarchy analysis method.

\section{MANAGEMENT AND MARKETING}

Tursumbayeva M., Shaimerdenova A. Analysis of the development of the advertising market of the Republic of Kazakhstan.

Rakhmetova A., Budeshov Ye. State management of healthcare system as the basis for the quality of life in Kazakhstan.

Yeskaliyeva A., Mussina A., Igaliyeva L., Lukpanova Zh. International Experience of

Human Capital Development.

Nurpeisova M. Formation of the image and attractiveness of domestic and inbound tourism in Kazakhstan.

Zhumanova B., Alashbayeva N., Imashev A., Baigabulova K. Implementation of digitalization in the management of transport and logistics system of Kazakhstan.

Arkenova $\mathrm{Zh}$. Opportunities to use the potential of research organizations in the implementation of state strategic plans...

Mukhan B., Yessirkepova A., Tulemetova A. Main directions of development of the light industry market of the Republic of Kazakhstan.

Makanova A., Turginbayeva A., Smagulova G., Smagulov K. Management aspects of the transformation of research universities: foreign experience. 


\section{FINANCE AND ACCOUNTING}

Nurumov A., Uakhitzhanova A. Financial aspect of agricultural development

Aimurzina B., Yessengeldin B., Kamenova M. Assessment of the effectiveness of the modern tax mechanism in Kazakhstan.

Kudaibergenov N., Adilova A., Aliyev M., Altynbekov M. Issues related to the formation of accounting policies for small and medium-sized businesses.

Seidakhmetova F., Karabayev E. Actual issues of personnel training in the field of accounting and state audit.....

Kazhmukhametova A., Tussibayeva G., Akimova B. Accounting component of financial results of public catering enterprises.

Yessengeldinova S., Ussenbayev T., Bozshagulova S. Development of the payment system of Kazakhstan in the context of financial globalization.

Abzhalova B., Shakharova A. Digital transformation of the external state audit of the Republic of Kazakhstan...

Amirova $G$. Organizational and financial aspects of the scientific sphere development

in Kazakhstan. 
DOI 10.52260/2304-7216.2020.4(41).1

УДК 338.01.36

ГРНТИ 06.52.17

Г.Р. Темирбаева*,

А.Ш. Абильдина, к.э.н. ${ }^{2}$

P.А. Жанбаев, к.э.н. ${ }^{2}$

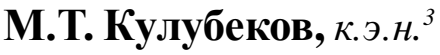

Жезказганский университет им. О.А. Байконурова ${ }^{l}$

2. Жезказган

НАО «Алматинский университет

энергетики и связи им. Г. Даукеева»

2. Алматы

Костанайский инженерно-экономический

университет им. М. Дулатова

2. Костанай

e-mail: aalimbaeva@mail.ru

* - основной автор (автор для корреспонденции)

\section{ПРОБЛЕМЫ ПОВЫШЕНИЯ КАЧЕСТВА ЖИЗНИ В МОНОГОРОДАХ В УСЛОВИЯХ КРИЗИСНЫХ ЯВЛЕНИЙ В ЭКОНОМИКЕ}

Важнейшим фактором и индикатором экономического потенцииала депрессивных регионов, к которым можно отнести монопоселения, выступает показатель качества жизни населения. В моногородах, которые являются особым объектом внимания и управления, отслеживание состояния и изменения качества жизни должно стать важнейшим инструментом и параметром мониторинга сочиально-экономического положения.

Мировой финансово-экономический кризис и кризис связанный с последствиями короновирусной инфекиии привел к спаду во многих отраслях промышленности и обострил ситуачию на монопрофильных территориях.

На основе анализа социально-экономического положения моногорода Жезказган выявлено, что пандемия еще больше усугубила сочиально-экономические проблемы: высокий уровень безработииы, низкий уровень доходов населения и качества жизни, отток населения. В связи с этим статья посвящена проблеме поиска эффективного механизма управления повышением качества жизни в иелом и, в особенности, на депрессивных территориях с монопромышленной специализацией. Статья представляет собой углубление ряда исследований и публикаџий авторов по проблеме поиска путей экономической стабилизачии в монопромыщленных регионах. Предложены ключевые опорные позиции построения системы управления качеством жизни в моногороде в условиях общей нестабильности, усиленной спадом, вызванным пандемией 2019-2020 годов.

Ключевые слова: моногород, качество жизни, система управления, сочиально-экономическое развитие, кризис, диверсификация, депрессивный регион, структура экономики, базовые компоненты, механизм.

Кілт сөздер: моноқ̧ала, өмір сапасы, басққару жүйесі, әлеуметті-экономикальққ даму, давдарыс, диверсификация, депрессиялықаймақ, экономиканың құрылымы, негізгі компоненттер, механизм. 
Keywords: monocity, quality of life, management system, socio-economic development, crisis, diversification, depressive region, economic structure, basic components, mechanism.

Введение. Вопросы экономической, социальной и экологической безопасности населения в современном обществе, находящие свое отражение в показателях качества жизни, выдвигаются на первый план. Сегодня в свете обострившихся геополитических процессов, процессов демократизации общественной жизни, экономических реформ, цикличности кризисов, новых вызовов возникшей в мире пандемии, как никогда, актуален поиск новых форм и подходов к проблеме качества жизни. Мировой финансово-экономический кризис и кризис связанный с последствиями короновирусной инфекции привел к спаду во многих отраслях промышленности и обострил ситуацию на монопрофильных территориях. При этом серьезнее всего пострадали узкоспециализированные города [1].

Решение проблемы качества жизни населения в условиях промышленного моногорода Центрального Казахстана, учитывая при этом негативные стороны и особенности специфики депрессивного региона, является не до конца исследованным направлением в социально-экономической проблематике.

На сегодня имеет место стабильная тенденция уменьшения абсолютной численности населения города, сужение его воспроизводства, провоцируемые как естественными причинами, так и устойчивой миграцией населения, оттоком экономически активного населения и молодежи в крупные центры. Как следствие, снижается качество трудовых ресурсов и их доходность. В настоящее время обеспеченность социальной инфраструктурой населения характеризуется достаточно высоким уровнем разобщенности и несбалансированности. Это препятствует опе- ративному регулированию и своевременной корректировке планов.

Вызывает сомнение работоспособность и результативность Программы развития города Жезказгана, так как она разработана без ориентации на оценку ее эффективности, нет механизма, который бы направлял действие этой программы на конкретный результат.

Целью исследования определено выявление базовых принципов построения результативной системы, которая позволит эффективно управлять процессами качества жизни в кризисный период в моногородах.

Задачи:

- исследовать состояние экономики моногорода в условиях действия факторов пандемии;

- обосновать необходимость разработки действенного в условиях кризиса механизма управления повышением качества жизни населения, основанного на научнообоснованной методологии решения проблем системного характера;

- определить опорные базовые компоненты системы управления качеством жизни в моногороде в условиях общей нестабильности, усиленной спадом, вызванным пандемией 2020 года.

В исследовании использованы эмпирические общенаучные методы исследования, в том числе методы наблюдения и сбора фактов, анализа и синтеза. С целью анализа социально-экономического потенциала моногорода использован сценарный метод, позволяющий производить его сравнительную оценку [2].

Обзор литературы. Качество жизни является предметом исследования самых разных областей знаний - философии, медицины, экологии, экономики, социологии. Как предмет изучения науки качество жизни 
рассмотрено теорией экономического благосостояния. В научном употреблении термин появился в 1950-х годах, а более предметное его обоснование, соответствующее современный реалиям, дано в 1958 году Дж. Гэлбрейтом [3].

Одни ученые являются сторонниками концепции субъективного качества жизни, другие, а их значительно больше, связывают с удовлетворенностью человека своим бытием. Имеют место трактовки качества жизни как образа жизни, или стиля жизни, иногда как просто благосостояние. На наш взгляд качество жизни гораздо более емкое и широкое понятие, чем уровень жизни.

В этом смысле мы придерживаемся понимания уровня жизни как степени материальной обеспеченности людей, позволяющей удовлетворять их разнообразные потребности, а условия жизни как те обстоятельства, которые сопутствуют человеку (обществу) в процессе его жизнедеятельности и способствуют удовлетворению различных потребностей [4].

Ряд авторов утверждает, что оценка уровня качества жизни может иметь как внешний подход, когда оценивается степень удовлетворенности людьми своих потребностей, так внутренний, когда сами люди оценивают удовлетворенность качеством жизни, например, путем социологического опроса [5].

Автор В.Н. Бобков говорит, что качество жизни - это социологическая категория, охватывающая все сферы общества, поскольку все они заключают в себе жизнь людей и ее качество, что качество жизни имеет две стороны - объективную и субъективную [6].

Объективный анализ социально-экономического развития г. Жезказган выявил определенные угрозы стабильности социально-экономического состояния.

Известно, что экономика моногорода базируется на функционировании градообразующего предприятия, а это еще больше усугубляет социально-экономические проблемы. В основном экономические проблемы моногородов связаны с низкой степенью диверсификации экономики, перспективами развития градообразующего предприятия, высокой зависимостью занятости населения и бюджета моногородов от деятельности градообразующего предприятия. Как следствие - социальные проблемы: высокий уровень безработицы, низкий уровень доходов населения и качества жизни, отток населения, а также возможная тенденция роста социальной напряженности [7].

По нашему мнению, проблему качества жизни населения нужно рассматривать в региональном ракурсе, поскольку и стартовые позиции для роста качества жизни, и сам процесс функционирования экономического механизма в моногородах и регионах значительно отличается от условий мегаполисов. В этом случае задача нормализации социально-экономической обстановки в моногородах требует нестандартного, инновационного подхода. Выбор сделан в пользу создания системы управления качеством жизни в моногороде на основе базовых приоритетных направлений развития.

Обзор предшествующих научных исследований, проведенных в мире и в Республике Казахстан, относящихся к исследуемой теме, показывает, что практически не учитывается фактор экономического развития и потенциала города как материальной основы улучшения качества жизни населения, поскольку механизм управленческого воздействия на эти процессы носит косвенный, опосредованный характер.

Основная часть. Сегодня является общеустановленным фактом то, что случившаяся на мировом пространстве пандемия Коронавируса Covid-19, имеет серьезные отрицательные последствия для экономик всех стран. Казахстанская экономика также начала испытывать первые негативные последствия вынужденных карантинных мер. По подсчетам специалистов валовый внут- 
ренний продукт Казахстана за первые пять месяцев 2020 года снизился на 1,7\%. К концу года в правительстве обещают более оптимистичный прогноз - спад ВВП должен составить «всего» $0,9 \%$ [8].

Волатильность курса тенге и инфляция объективно адекватно негативно отразились на таких показателях как доходы, размер заработных плат и занятость граждан. Только статистика показателя занятости дает картину предполагающую определенную обеспокоенность. Так, в мае число безработных, по данным Министерства труда и социальной защиты, возросло до 1,45 млн человек с 442,4 тыс. на конец марта. К началу 3 квартала в профильном ведомстве ожидают роста безработицы до 1 млн человек [9].

Таким образом, перечисленные выше факторы подтверждают в целом преимущественно негативный прогноз для экономики страны и кризисное состояние, хотя и в начальной стадии. Все это замкнется на состоянии республиканского бюджета. По окончании первого квартала дефицит составил 632,9 млрд тенге, который увеличился в 2,2 раза по сравнению с соответствующим периодом 2019 года. Без учета же поступлений от продажи нефти дефицит составил 1,4 трлн тенге, или 10,8\% к ВВП, что на 41,2\% больше по сравнению с соответствующим периодом 2019 года. По прогнозам Всемирного банка к декабрю 2020 года дефицит вырастет до 13,2\% к ВВП, а правительственный долг сразу на $26,9 \%$, а также 9,7\% падения вклада нефтяного сектора в ВВП. В результате прогнозируется отрицательное значение ВВП Казахстана в 1,8-4\% [10].

Известно, что экономика моногорода базируется на функционировании градообразующего предприятия, а это еще больше усугубляет социально-экономические проблемы. В основном экономические проблемы моногородов связаны с низкой степенью диверсификации экономики, перс- пективами развития градообразующего предприятия, высокой зависимостью занятости населения и бюджета моногородов от деятельности градообразующего предприятия. Как следствие - социальные проблемы: высокий уровень безработицы, низкий уровень доходов населения и качества жизни, отток населения, а также возможная тенденция роста социальной напряженности [6].

Объективный анализ социально-экономического развития г. Жезказган выявил определенные угрозы стабильности социально-экономического состояния [11]. Демографическая ситуация в городе является типичной и находится на среднем уровне в сравнении с аналогичными регионами Казахстана.

В таблице 1 приведены данные по основным показателям социально-экономического развития г. Жезказган за январьиюнь 2020 года в сравнении с аналогичным периодом 2019 года.

Как видно, несмотря на рост по некоторым основным показателям, таким как объем промышленной продукции (работ, услуг), инвестиции в основной капиталобъем розничного товарооборота субъектов малого предпринимательства, объем строительных работ, наблюдается увеличение количества безработных. Показатель фиксированной безработицы составил $1,8 \%$. Особое внимание заслуживает показатель отрицательной миграции, что вызывает снижение показателя активной части населения.

В последнее время ситуация усугубляется падением спроса на продукцию базового предприятия ТОО «Корпорция Казахмыс» и снижением цен на его продукцию. Тем не менее, базовая отрасль экономики города остается традиционной, экономика практически не диверсифицируется. Все это приводит к несбалансированности рынка труда. Структура экономики города не меняется в пользу сектора 
услуг, процессы развития качественного и количественного развития трудовых ресурсов находятся в стадии застоя. Все эти негативные моменты не могут не вызывать социальную нестабильность и напряженность у населения моногорода. Одними из основных направлений Программы развития города Жезказгана 2012-2020 годы является «Социальная сфера»[11]. Да, данное направление предусматривало достаточно обширный перечень социальных факторов, призванных обеспечивать повышение качества жизни в городе. Но эта программа представляется простым набором и перечислением позиций, имеющих социальное направление. Не учтена приоритетность направлений социальной политики, что объективно необходимо в виду их многоаспектности и разноплановости.

Таблица 1

Основные показатели социально-экономического развития г. Жезказган за январь-июнь 2020 года в сравнении с аналогичным периодом 2019 года*

\begin{tabular}{|c|c|c|c|c|}
\hline № & Показатели & ед.изм & $\begin{array}{c}\text { январь- } \\
\text { июнь } \\
2019 \text { года }\end{array}$ & $\begin{array}{c}\text { январь- } \\
\text { июнь } \\
2020 \text { года }\end{array}$ \\
\hline 1. & $\begin{array}{l}\text { Объем пром.продукции (работ,услуг), } \\
\text { в действующих ценах }\end{array}$ & млн тенге & 258546,9 & 286254,6 \\
\hline 2. & Инвестиции в основной капитал & млн тенге & 6237,3 & 13839,9 \\
\hline 3. & $\begin{array}{l}\text { Количество } \quad \text { активно } \\
\text { субъектов малого предприющих } \\
\text { суримательства }\end{array}$ & единиц & 5738 & 5737 \\
\hline 4. & Объем розничного товарооборота & млн тенге & 17722,9 & 21466,4 \\
\hline 5. & Объем строительных работ & млн тенге & 3160,7 & 4008,1 \\
\hline 6. & Численность безработных & чел. & 559 & 772 \\
\hline 7. & Сальдо миграции: & \multicolumn{3}{|c|}{$\begin{array}{l}\text { (минус) } 171 \quad \text { (прибыло-756 } \\
\text { выбыло-927 чел.) }\end{array}$} \\
\hline
\end{tabular}

*Составлена авторами

Формирование механизма управления повышением качества жизни населения в региональном аспекте является актуальной проблемой в контексте реализации инициатив Президента Касым-Жомарта Токаева.

Мы основываемся на рассмотрении качества жизни как управляемого процесса, представляющего собой совокупность взаимосвязанных скоординированных подпроцессов, осуществляемых для достижения соответствующей конкретным требованиям цели. Целью процесса управления качеством жизни является удовлетворение потребностей и ожиданий человека, общества результативным и эффективным способом [12].
Сложившаяся социально-экономическая ситуация в депрессивных регионах РК требует разработки действенного механизма управления повышением качества жизни населения в которой будет применена научно обоснованная методология оценки ее эффективности. Это может служить основой к формированию стратегии и программ социально-экономического развития моногородов для решения проблемы преодоления депрессивности на основе инновационных подходов.

Это позволит местным органам власти эффективно управлять процессами, влияющими на качество жизни населения, и в конечном итоге своевременно осуществляя 
мониторинг, предпринимать корректирующие и предупреждающие действия.

Целесообразно полагать, что цель управления повышением качества жизни на региональном уровне - создание результативной системы, которая бы позволяла эффективно управлять процессами качества жизни в кризисный период в моногородах. В связи с чем, мы определили базовые компоненты системы управления качеством жизни в моногороде в условиях общей нестабильности, усиленной спадом, вызванным пандемией 2020 года, представленные на рисунке (рис. 1).

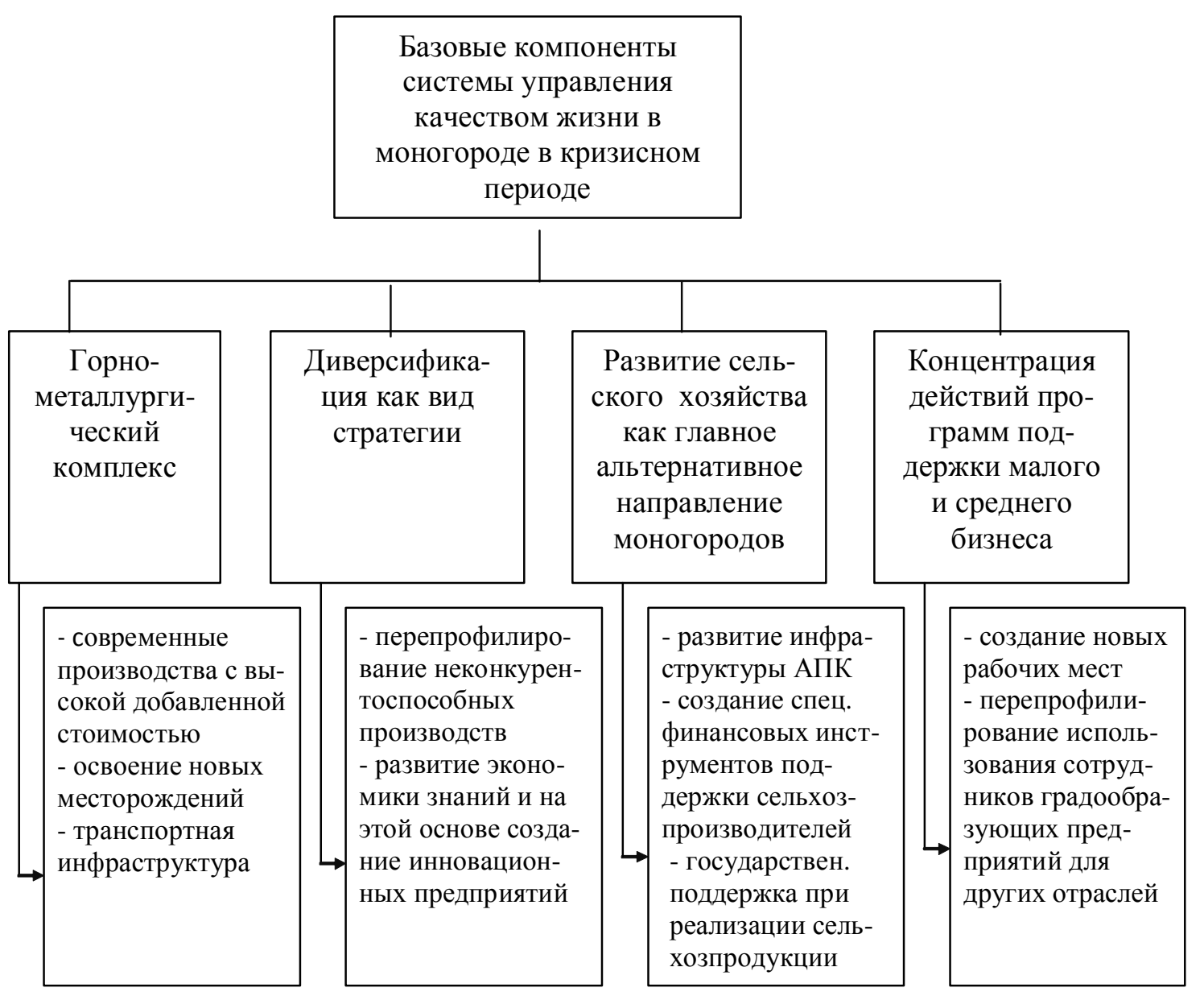

\section{Рисунок 1. Базовые компоненты системы управления качеством жизни в моногороде}

\section{*Составлен авторами}

Конечно, невозможно предположить быстрое решение проблемы моногородов, устранив их монопромышленную специализацию. Наш подход рассчитан на среднесрочный период, предполагающий реализацию в течение 10 лет. Способствовать эти процессам должны увеличение скорости технологического обновления эко- номики в целом. Диверсификация предполагает изменение структуры экономики в них, уменьшив долю горно-металлургического производства до 30-40 \%. Конечной целью является диверсификация экономики в моногородах и повышение на этой основе качества жизни.

Выводы. Экономика Казахстана в на- 


\section{Экономика}

стоящее время начала испытывать первые негативные последствия вынужденных карантинных мер. Пандемия, носящая глобальный характер, еще больше усугубила социально-экономические проблемы моногородов: высокий уровень безработицы, низкий уровень доходов населения и качества жизни, отток населения, а также тенденция к росту социальной напряженности. Только за первое полугодие 2020 года по моногороду Жезказган отмечается увеличение количества безработных почти в 1,5 раза, а сальдо отрицательной миграции - минус 171 чел.

Все это требует разработки действенного в условиях кризиса механизма управления повышением качества жизни населения, основанного на научно-обоснованной методологии решения проблем системного характера. Для создания результативной системы управления качеством жизни на региональном уровне мы определили опорные базовые компоненты системы управления качеством жизни в моногороде в условиях общей нестабильности, усиленной спадом, вызванным пандемией 2020 года.

\section{ЛИТЕРАТУРА}

1. Салимжанов Н.О., Коразбекова К.У., Аятов А.С. Развитие и проблемы моногородов в Казахстане // Сборник материалов Международной научно-практической конференции «Современный учитель дисциплин естественно-научного цикла». Издательство: Ишимский педагогический институт им. П.П. Ершова (филиал) ФГАОУ ВО «Тюменский государственный университет». - 2019 г. - C. 84-85. https://www.elibrary.ru/item.asp?id=36982567

2. Манаева И.В., Болтенкова Ю.В. Методические рекомендации по выбору сценария развития моногорода // Проблемы развития территорий. - 2016. - Вып.6 (86). - С. 197-198.

3. Гелбрейт Дж. К. Экономические теории и цели общества. - М.: Директ-Медиа, 2007. - 347 c.

4. Морозова Е.А. Качество жизни населения: теория и практика социологического изучения. - Кемерово: Кемеровский государственный университет. - 2018. - №3. C. $35-41$.

5. Гриценко Н.Н. Социальное государство // Социальная политика: Энциклопедический словарь // Под общ. ред. д.э.н. , проф. Н.А. Волгина; отв. ред. д.ф.н. Т.С. Сулимова. - М.: Академический проект; Трикста. - 2005. - С. 550-553.

6. Бобков В.Н., Гулюгина А.А., Зленко Е.Г., Одинцова Е.В. Сравнительные характеристики индикаторов качества и уровня жизни в российских регионах: субъекты, федеральные округа, Арктика // Уровень жизни населения регионов России. - 2017. - №1. C. 50-64.

7. Шеденов У.К., Мырзалиев Б.С Проблемы развития монопрофильных городов Казахстана // Вестник КазНУ. - 2013. - №4. - С. 25-29.

8. Как пандемия коронавируса повлияла на экономику Казахстана и что с этим делать?// Информационный портал «КАПИТАЛ» (Центр деловой информации Kapital.kz). - Online Astana Finance Days.29.06.2020. https://kapital.kz/economic/88182/kak-pandemiyakoronavirusa-povliyala-na-ekonomiku-kazakhstana-i-chto-s-etim-delat.html.

9. Обзор инфляции. Июнь 2020 года // Квартальное издание Национального банка Республики Казахстан. - Обзор инфляции. Июнь 2020. - C. 15. https://bsbnb.nationalbank.kz/ cont/\%D0\%9E\%D0\%98\%20\%D0\%B8\% D1\%8E\%D0\%BD\%D1\%8C\%2020201.pdf

10. Мазоренко Д. Что происходило с казахстанской экономикой в первые полгода и 
что ее ждет дальше // Vласть. Интернет журнал. Экономика времен коронавируса 24.07.2020. https://vlast.kz/jekonomika/40940-ekonomika-vremen-koronavirusa.html.

11. Программа развития города Жезказган на 2016-2020 гг. (Электронный ресурс). Режим доступа: http://economic.jezkazgan.gov.kz/ru/4269.html].

12. Нестеренко Л.А. Процессы повышения качества жизни: региональный аспект // Молодой ученый. - 2011. - №12. - Т.1. - С. 161-166.

\section{REFERENCES}

1. Salimzhanov N.O., Korazbekova K.U., Ajatov A.S. Razvitie i problemy monogorodov v Kazahstane // Sbornik materialov Mezhdunarodnoj nauchno-prakticheskojkonferencii «Sovremennyj uchitel' disciplin estestvenno-nauchnogo cikla». Izdatel'stvo: Ishimskij pedagogicheskij institut im. P.P. Ershova (filial) FGAOU VO “Tjumenskij gosudarstvennyj universitet”. -2019 g. - S. 84-85 https:// www.elibrary.ru/item.asp?id=36982567 [in Russian].

2. Manaeva I.V., Boltenkova Ju.V. Metodicheskie rekomendacii po vyboru scenarija razvitija monogoroda // Problemy razvitija territorij. - 2016. - Vyp.6 (86). - S.197-198 [in Russian].

3. Gelbrejt, Dzh. K. Jekonomicheskie teorii i celi obshhestva. - M.: Direkt-Media, 2007. 347 s. [in Russian].

4. Morozova E.A. Kachestvo zhizni naselenija: teorija i praktika sociologicheskogo izuchenija// Kemerovo: Kemerovskij gosudarstvennyj universitet. - 2018. - №3. - S. 35-41 [in Russian].

5. Gricenko N. N. Social'noe gosudarstvo // Social'naja politika: Jenciklopedicheskij slovar' // Pod obshh. red. d. je. n. , prof. N. A. Volgina; otv. red. d. f. n. T. S. Sulimova. - M.: Akademicheskij proekt; Triksta, 2005. - S. 550-553 [in Russian].

6. Bobkov V.N., Guljugina A.A., Zlenko E.G., Odincova E.V. Sravnitel' nye harakteristiki indikatorov kachestva i urovnja zhizni v rossijskih regionah: sub\#ekty, federal'nye okruga, Arktika // Uroven’ zhizni naselenija regionov Rossii. - 2017. - № 1. - S. 50-64 [in Russian].

7. Shedenov U.K., Myrzaliev B.S. Problemy razvitija monoprofil' nyh gorodov Kazahstana // Vestnik KazNU. - 2013. - №4. - S. $25-29$ [in Russian].

8. Kak pandemija koronavirusa povlijala na jekonomiku Kazahstana i chto s jetim delat'?// Informacionnyj portal «KAPITAL» (Centr delovoj informacii Kapital.kz). - Online Astana Finance Days. 29.06.2020. https://kapital.kz/economic/88182/kak-pandemiya-koronavirusa-povliyala-naekonomiku-kazakhstana-i-chto-s-etim-delat.html [in Russian].

9. Obzor infljacii. Ijun' 2020 goda // Kvartal'noe izdanie Nacional'nogo banka Respubliki Kazahstan. - Obzor infljacii. Ijun' 2020. - S.15. https://bsbnb.nationalbank.kz/cont/\%D0\%9E\% D0\%98\%20\%D0\%B8\% D1\%8E\%D0\%BD\%D1\%8C\%2020201.pdf [in Russian].

10. Mazorenko D. Chto proishodilo s kazahstanskoj jekonomikoj v pervye polgoda i chto ee zhdet dal'she // Vlast'. Internet zhurnal. Jekonomika vremen koronavirusa 24.07.2020. https://vlast.kz/ jekonomika/40940-ekonomika-vremen-koronavirusa.html [in Russian].

11. Programma razvitija goroda Zhezkazgan na 2016-2020gg. (Jelektronnyj resurs). Rezhim dostupa: http://economic.jezkazgan.gov.kz/ru/4269.html] [in Russian].

12. Nesterenko L.A. Processy povyshenija kachestva zhizni: regional'nyj aspekt // Molodoj uchenyj. - 2011. - №12. - T.1. - S. 161-166 [in Russian]. 


\title{
Экономика
}

\section{Г.Р. Темирбаева, А.Ш. Абильдина, Р.А. Жанбаев, М.Т. Кулубеков \\ ЭКОНОМИКАДАҒЫ ДАҒДАРЫС ЖАҒДАЙЛАРЫНДА МОНОҚАЛАЛАРДА ӨМІР САПАСЫН АРТТЫРУ МӘСЕЛЕЛЕРІ}

\begin{abstract}
Андатпа
Депрессивті дамитын аймақтардың (оларға моноқалаларды да жатқызуға болады) экономикалық әлеуетінің маңызды факторы мен индикаторы ретінде тұрғындарының өмір сүру сапасы туындайды. Басқарудың маңызды объектісі болып табылатын моноқалаларда өмір сапасының жағдайы мен өзгеруін бақылау - әлеуметтік-экономикалық жағдайды мониторингілеудің маңызды құралы мен параметрі.

Әлемдік қаржы-экономикалық дағдарыс және коронавирусты инфекция салдарымен байланысты дағдарыс өнеркәсіптің көптеген салаларында құлдырауға әкеліп, монопрофильді аймақтардағы жағдайды ушықтырды. Жезқазған моноқаласының әлеуметтік-экономикалық жағдайын талдау негізінде пандемия аймақтың әлеуметтік-экономикалық жағдайын одан да артық ушықтырғаны анықталды: жұмыссыздықтың жоғары деңгейі, тұрғындардың табысының және өмір сапасының төмен деңгейі, тұрғындардың көші-қонуы.

Осы ретте мақала өмір сапасын арттыруды жалпы басқарудың тиімді механизмін іздеу мәселесіне арналған, соның ішінде моноөнеркәсіпті маманданған депрессивті аймақтарда. Мақала авторлардың моноөнеркәсіпті аймақтарда экономикалық тұрақтылықтың жолдарын іздеу мәселесі бойынша бірқатар зерттеулер мен басылымдарының жалғасын көрсетеді. 2019-2020 жылдардағы пандемиядан болған құлдырау негізіндегі жалпы тұрақсыздық жағдайында моноқалаларда өмір сапасын басқару жүйесін құрудың басты позициялары ұсынылған.
\end{abstract}

\section{G. Temirbayeva, A. Abildina, R. Zhanbayev, M. Kulubekov}

\section{THE ISSUES OF IMPROVING THE QUALITY OF LIFE IN MONOCITIES WITHIN CRISIS CONDITIONS IN ECONOMY}

\section{Annotation}

The performance rate of life quality of population is the most significant factor and indicator of the economic potential of depressive regions, to which the mono-settlements or mono-industry based towns can be attributed. In monocities that are the particular focus area and subjects to management, the tracking of life quality conditions and of their change ratio must be the most important tool and parameter of monitoring the socio-economic situation.

The global financial and economic crisis and turmoil resulted from the impacts of the coronavirus pandemic lead to the slowdown in many industrial sectors and aggravated and even worsened the situation in single-industry regions.

The analyses of the socio-economic situation of Zhezkazganmonocity revealed that the pandemic had further and deeply deteriorated the socio-economic problems: high unemployment rate, low income bracket of citizen and poor life quality, out migration. Thus this research paper covers the issues of the search for effective management mechanisms of improving the life quality in common and particularly in depressive areas with mono-industry profile. The paper is the in-depth study of the series of the research and publications of the author in regards to the search for the ways of economic stabilization in mono-industry regions. The vital basic positions are suggested in developing the management system of the life quality in a monocity amid general instability, strained by depression, decline caused by pandemic of 2019-2020.

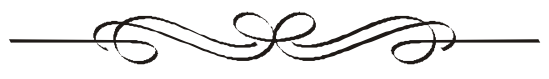


DOI 10.52260/2304-7216.2020.4(41).2

УДК 338.001.36

ГРНТИ 06.52.35

\author{
М.К. Тургамбаев*, докторант $P h D^{l}$ \\ В. Желю, $P h D$, профессор ${ }^{2}$

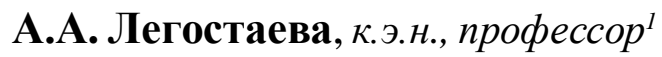 \\ Карагандинский экономический \\ университет Казпотребсоюза ${ }^{1}$ \\ 2. Караганда, Казахстан \\ Софийский университет им. К. Охридского \\ г. София, Болгария \\ e-mail: medet.turgambayev@gmail.com \\ * - основной автор (автор для корреспонденции)
}

\section{РАЗРАБОТКА СИСТЕМЫ ВЕСОВЫХ КОЭФФИЦИЕНТОВ ВЛИЯНИЯ РАЗЛИЧНЫХ ОЦЕНОК НА КОМПЛЕКСНУЮ ОЦЕНКУ ИНВЕСТИЦИОННЫХ ПРОЕКТОВ}

Обеспечение повышения эффективности управленческой деятельности как в общественном, так и в частном секторе экономики во многом связано с внедрением проектных решений. При этом особую актуальность приобретают вопросы связанные с оценкой эффективности таких проектов. Одними из важнейших видов проектов выступают инвестиционные проекты.

В статье рассматриваются методические подходы к комплексной оченке эффективности инвестиционных проектов на основе статистического анализа деятельности инвестиционных проектов, в условиях динамики развития отраслевых факторов экономики Казахстана. Разработана модель комплексной оценки эффективности инвестиционного проекта, где на базе статистической весовой характеристики анализируемых факторных признаков, предлагается рассмотреть трендовую составляющую развития факторных показателей. Наличие сформировавшейся общей тенденции развития экономических показателей по направлениям инвестиций в отраслевую экономику страны характеризуют полученные расчетные значения. Можно отметить, что в любом обществе, базовой ос-новой развития и укрепления экономики служат инвестиции, которые способствуют повышению уровня жизни и ведущую роль в формировании этой республиканской политики должнь играть регионь.

Примененный в исследовании комплексный всесторонний подход позволяет проводить учет множественных факторов и тем самым, улучшить прогнозно-аналитические показатели расчетов. Получаемые расчетные оценки макроэкономических показателей в масштабе государства, также рассматривают инвестиционные потоки на уровне отраслей промышленности регионов. При этом, использование аналитических данных по конкретным инвестициионным проектам позволяет проводить корректировку с учетом влияния наиболее важных и приоритетных инвестиционных проектов.

Ключевые слова: инвестиционный проект, инвестициии, эффективность, весовой коэффициент, комплексная оценка, индекс рентабельности, временной ряд, факторный признак, тенденциия, сравнительный анализ, отраслевая экономика, анализ, оценка.

Кілт сөздер: инвестициильқ жоба, инвестицчиялар, тиімділік, салмақ коэффициенті, кешенді бавалау, кірістілік индексі, уақыьт құатары, фактор атрибуты, тенденция, сальстырмаль талдау, салальқ экономика, талдау, багалау. 


\section{Экономика}

Keywords: investment project, investments, efficiency, weighting coefficient, complex assessment, profitability index, time series, factor attribute, trend, comparative analysis, sectoral economics, analysis, evaluation.

JEL classification: C10, C13, C52

\section{любого управленческого решения инвести-} ционного характера выступает общая оценка достигнутого уровня инвестиционного развития, которая прежде всего, опирается на оценку имеющихся данных об инвестиционной активности с одной стороны и макроэкономических показателей развития национальной экономики с другой. Данный научный постулат определяет своей целью необходимость развития методических основ разработки механизмов комплексной оценки и прогнозирования эффективности инвестиционных проектов.

Степень сочетания данных методов определяет научную задачу по разработке механизмов комплексной оценки и прогнозирования эффективности инвестиционных проектов. Основу методологии проводимого исследования составляет диалектика, предопределяющая изучение явлений в постоянном развитии и взаимосвязи. В аналитической части работы применялись методы системного и комплексного анализа, классификации, предметнологического и сравнительного анализа, экономико-статистические методы обработки информации, корреляционный и регрессионный анализ.

Поэтому, исходя из поставленных задач для проводимого исследования, следует провести ранжирование основных факторов, которые оказывают влияние на выбор наиболее приоритетных направлений для инвестиционных вложений. Данную задачу следует выполнить на основе формирования системы весовых коэффициентов влияния различных оценок на комплексную оценку, на базе статистического анализа деятельности инвестиционных проектов.

Обзор литературы. В научной литера- туре вопросы оценки экономической эффективности инвестиций исследуются на протяжении многих лет. Базовые основы по современной теории анализа эффективности инвестиций были заложены еще Макконнеллом и Кейнсом, а в последующем развиты такими зарубежными учеными, как П.М. Хавранек, Ю. Бригхем, В. Беренс, Г. Бирман, С. Шмидт, Л. Гапенски, М. Бромвич, Л.Дж. Гитман, М.Д. Джонк.

Весьма широко исследуются вопросы построения моделей, которые позволяют дать оценку эффективности инвестиционных потоков по сферам экономической деятельности. В работах многих авторов описаны методы и модели, которые позволяют дать оценку эффективности функционирования рыночных систем (Ч. Йин, Й. Вен, 2013 [1]), проводится рассмотрение моделей оценки риска инвестирования (К. Сяо, Й. Жан, 2015 [2]; Р. Клюппельберг, К. Костадинова, 2008 [3]; Й. Вен, Ч. Йин, 2013 [1]; А. Матсумото, Ф. Зидаровзки, 2015 [4]), проводится исследование моделей экономического роста (Р. Айрес, В. Воудоурис, 2014 [5]; Т. Палокангас, Ю. Лемийоки, 2009 [6]) и др.

Однако, несмотря на наличие значительного количества научных публикаций затрагивающих вопросы оценки экономической эффективности инвестиций, продолжают сохраняться и многие неразработанные аспекты, которые связаны с адаптированием методических рекомендаций по оценке эффективности инвестиций к современным условиям. Все это определяет высокую степень актуальности проблем для дальнейшего изучения и исследования вопросов разработки систем весовых коэффициентов влияния различных оценок на комплексную оценку инвестиционных проектов. 
Основная часть. На основании проведенного экономико-математического анализа имеющихся данных по инвестиционным вложениям в отраслевую экономику на территории РК можно сделать вывод, что основными факторами, характеризующими развитие отраслевой экономики Казахстана, являются факторы, приведенные в таблице 1.

Показатели производства и образования доходов по видам экономической деятельности*

\begin{tabular}{|c|c|c|c|c|}
\hline Год & $\begin{array}{c}\text { Валовая } \\
\text { добавленная } \\
\text { стоимость }\end{array}$ & $\begin{array}{c}\text { Оплата } \\
\text { труда }\end{array}$ & $\begin{array}{c}\text { Другие налоги на } \\
\text { производство за } \\
\text { вычетом других } \\
\text { субсидий на } \\
\text { производство }\end{array}$ & $\begin{array}{c}\text { Потребление } \\
\text { основного } \\
\text { капитала }\end{array}$ \\
\hline 1 & 2 & 3 & 4 & 5 \\
\hline \multicolumn{5}{|c|}{ Промышленность, млн тенге } \\
\hline \multicolumn{5}{|l|}{$\ldots$} \\
\hline 2017 & 14213439,0 & 3747374,6 & 428870,0 & 1920951,3 \\
\hline 2018 & 17421280,9 & 4567785,8 & 437996,8 & 2409576,6 \\
\hline 2019 & 17423846,0 & 4592739,7 & 502808,5 & 2155045,9 \\
\hline \multicolumn{5}{|c|}{ Сельское, лесное и рыбное хозяйство, млн тенге } \\
\hline$\ldots$ & & & & \\
\hline 2017 & 2315182,2 & 514336,6 & 2345,7 & 262797,3 \\
\hline 2018 & 2717499,1 & 669704,4 & 2393,5 & 295839,2 \\
\hline 2019 & 2821695,2 & 662998,4 & 2511,5 & 314855,5 \\
\hline \multicolumn{5}{|c|}{ Строительство, млн тенге } \\
\hline & & & & \\
\hline 2017 & 2896652,7 & 1288442,0 & 11211,2 & 555432,5 \\
\hline 2018 & 3285914,9 & 1468853,2 & 11769,1 & 628493,0 \\
\hline 2019 & 3411751,0 & 1531108,5 & 13383,7 & 716851,0 \\
\hline \multicolumn{5}{|c|}{ Транспорт и складирование, млн тенге } \\
\hline$\ldots$ & & & & \\
\hline 2017 & 4442189,6 & 1153213,7 & 51286,4 & 781900,1 \\
\hline 2018 & 5065480,5 & 1388637,9 & 51686,0 & 903338,3 \\
\hline 2019 & 5386855,2 & 1401000,9 & 59735,6 & 965460,2 \\
\hline \multicolumn{5}{|c|}{ Информация и связь, млн тенге } \\
\hline & & & & \\
\hline 2017 & 1021040,7 & 453660,0 & 14441,0 & 120676,2 \\
\hline 2018 & 1182681,6 & 508946,1 & 14731,4 & 134010,4 \\
\hline 2019 & 1147888,0 & 527312,2 & 16918,3 & 117597,41 \\
\hline \multicolumn{5}{|c|}{ Образование, млн тенге } \\
\hline. & & & & \\
\hline 2017 & 1476573,8 & 1098107,6 & 2792,0 & 59910,4 \\
\hline 2018 & 1657450,4 & 1228409,5 & 2246,2 & 91828,2 \\
\hline 2019 & 1733936,7 & 1287158,3 & 2856,3 & 80455,2 \\
\hline
\end{tabular}




\begin{tabular}{|c|r|r|r|r|}
\hline 1 & 2 & 3 & 4 & \multicolumn{1}{|c|}{5} \\
\hline \multicolumn{5}{|c|}{ Здравоохранение и социальные услуги, млн тенге } \\
\hline$\ldots$ & & & & \\
\hline 2017 & 1075532,5 & 582353,5 & 1899,5 & 97354,7 \\
\hline 2018 & 1172754,3 & 658050,0 & 1730,9 & 87599,2 \\
\hline 2019 & 1288221,6 & 657832,4 & 2080,6 & 77759,2 \\
\hline
\end{tabular}

*Составлена автором по данным Агентства РК по статистике

Приведенная в таблице 1 система статистических показателей производства и образования доходов по видам экономической деятельности необходима для достоверной оценки результатов функционирования и прогнозирования дальнейшего развития инвестиционной деятельности в развитии экономики страны.

Целевая задача проводимых инвестиционных вложений заключается в нахождении эффективной отраслевой ниши для их размещения, которая впоследствии обеспечила бы значительную прибыль. Именно коэффициент рентабельности является одним из основных параметров, который может характеризовать уровень продуктивности капиталовложений. Из этого следует, что эффективность инвестиций представляет собой финансовый показатель, который дает возможность определить прибыльность или убыточность осуществленного инвестирования [7]. Для составления расчетной формулы используются определенные сокращения, где коэффициент инвестиционной рентабельности отражается как ROI, по формуле следующего вида:

$$
\mathrm{ROI}=\frac{\text { ЧП }}{\text { И }} * 100 \%,
$$

где ROI - коэффициент инвестиционной рентабельности;

И - объем инвестиций;

ЧП - чистая прибыль.

Следует вывод о том, что рентабельность проекта инвестирования является процентным соотношением прибыли в соответствии к объему инвестиций.
Для этого следует взять выборку значений показателей производства и образования доходов по видам экономической деятельности и выполнить расчет показателя «Чистая прибыль, чистые смешанные доходы» по следующей формуле:

$$
\text { ЧП = ВДС }-(\mathrm{OТ}+\text { ДНП + ПОК }),
$$

где ЧП - чистая прибыль, чистые смешанные доходы;

ОТ - оплата труда;

ВДС - валовая добавленная стоимость;

ДНП - другие налоги на производство за вычетом других субсидий на производство;

ПОК - потребление основного капитала.

Чтобы определить весовые коэффициенты для каждого из факторов, необходимо разделить суммарное значение показателя за исследуемый интервальный период на величину размерности временного ряда:

$$
\rho_{\mathbf{k}}=\frac{\mathbf{S}_{\mathbf{k}}}{\mathbf{n}}
$$

где $\rho_{\mathrm{k}}$ - весовой коэффициент значимости каждого фактора инвестиционных вложений;

$\mathrm{n}$ - размерности временного ряда;

$\mathrm{Sk}$ - суммарное значение показателя «коэффициент рентабельности инвестиций» за исследуемый интервальный период.

Результаты расчетов по выполненным формулам (1), (2) и (3), приведены в таблице 2. 


\section{Показатели инвестиционных вложений по уровню годовой рентабельности инвестиций, млн тенге*}

\begin{tabular}{|c|c|c|c|c|}
\hline Показатель & Год & $\begin{array}{c}\text { Чистая прибыль, } \\
\text { чистые смешанные } \\
\text { доходы }\end{array}$ & $\begin{array}{c}\text { Размер инвести- } \\
\text { ционных вложений }\end{array}$ & $\begin{array}{c}\text { Коэффициент } \\
\text { рентабельности } \\
\text { инвестиций }\end{array}$ \\
\hline 1 & 2 & 3 & 4 & 5 \\
\hline \multirow{5}{*}{$\begin{array}{l}\text { Инвестиции в } \\
\text { основной капитал } \\
\text { по направлениям } \\
\text { использования - } \\
\text { Промышленность }\end{array}$} & 2015 & 4767380,1 & 3863090 & 1,234 \\
\hline & 2016 & 6851589,8 & 4320396 & 1,586 \\
\hline & 2017 & 8116243,1 & 4769588 & 1,702 \\
\hline & 2018 & 10005921,7 & 6567368 & 1,524 \\
\hline & 2019 & 10173251,7 & 7813990 & 1,302 \\
\hline \multicolumn{4}{|c|}{ Коэффициент рентабельности инвестиций, среднее значение } & 1,509 \\
\hline \multirow{5}{*}{$\begin{array}{l}\text { Инвестиции в основ. } \\
\text { капитал по направле- } \\
\text { ниям использов. - } \\
\text { Сельское, лесное и } \\
\text { рыбное хозяйство }\end{array}$} & 2015 & 1198642,0 & 163907 & 7,313 \\
\hline & 2016 & 1419199,3 & 253691 & 5,594 \\
\hline & 2017 & 1535702,6 & 348481 & 4,407 \\
\hline & 2018 & 1749562,0 & 365001 & 4,793 \\
\hline & 2019 & 1841089,4 & 501633 & 3,670 \\
\hline \multicolumn{4}{|c|}{ Коэффициент рентабельности инвестиций, среднее значение } & 5,671 \\
\hline \multirow{5}{*}{$\begin{array}{l}\text { Инвестиции в } \\
\text { основной капитал } \\
\text { по направлениям } \\
\text { использования - } \\
\text { Строительство }\end{array}$} & 2015 & 998483,6 & 98102 & 10,178 \\
\hline & 2016 & 1005050,6 & 63667 & 15,786 \\
\hline & 2017 & 1041567,0 & 92918 & 11,210 \\
\hline & 2018 & 1176799,6 & 114244 & 10,301 \\
\hline & 2019 & 1150407,7 & 124378 & 9,249 \\
\hline \multicolumn{4}{|c|}{ Коэффициент рентабельности инвестиций, среднее значение } & 12,484 \\
\hline \multirow{5}{*}{$\begin{array}{l}\text { Инвестиции в основ. } \\
\text { капитал по направле- } \\
\text { ниям использов. - } \\
\text { Транспорт и } \\
\text { складирование }\end{array}$} & 2015 & 1953967,7 & 1138572 & 1,716 \\
\hline & 2016 & 2152468,5 & 1176239 & 1,830 \\
\hline & 2017 & 2455789,4 & 1262907 & 1,945 \\
\hline & 2018 & 2721818,3 & 1453136 & 1,873 \\
\hline & 2019 & 2960658,4 & 1156126 & 2,561 \\
\hline \multicolumn{4}{|c|}{ Коэффициент рентабельности инвестиций, среднее значение } & 1,760 \\
\hline \multirow{5}{*}{$\begin{array}{l}\text { Инвестиции в } \\
\text { основной капитал } \\
\text { по направлениям } \\
\text { использования - } \\
\text { Образование }\end{array}$} & 2015 & 211950,7 & 198607 & 1,067 \\
\hline & 2016 & 201911,5 & 207507 & 0,973 \\
\hline & 2017 & 315763,8 & 257223 & 1,228 \\
\hline & 2018 & 334966,5 & 205265 & 1,632 \\
\hline & 2019 & 363466,9 & 212124 & 1,713 \\
\hline \multicolumn{4}{|c|}{ Коэффициент рентабельности инвестиций, среднее значение } & 1,195 \\
\hline \multirow{5}{*}{$\begin{array}{l}\text { Инвестиции в основ. } \\
\text { капитал по направле- } \\
\text { ниям использов. - } \\
\text { Здравоохранение и } \\
\text { социальные услуги }\end{array}$} & 2015 & 159833,8 & 74649 & 2,141 \\
\hline & 2016 & 326867,7 & 64334 & 5,081 \\
\hline & 2017 & 393924,8 & 93717 & 4,203 \\
\hline & 2018 & 425374,2 & 113229 & 3,757 \\
\hline & 2019 & 550549.4 & 137659 & 3,999 \\
\hline \multicolumn{4}{|c|}{ Коэффициент рентабельности инвестиций, среднее значение } & 2,835 \\
\hline \multirow{2}{*}{$\begin{array}{l}\text { Инвестиции в } \\
\text { основной капитал }\end{array}$} & 2015 & 456942,9 & 105371 & 4,337 \\
\hline & 2016 & 410076,3 & 57739 & 7,102 \\
\hline
\end{tabular}




\section{Экономика}

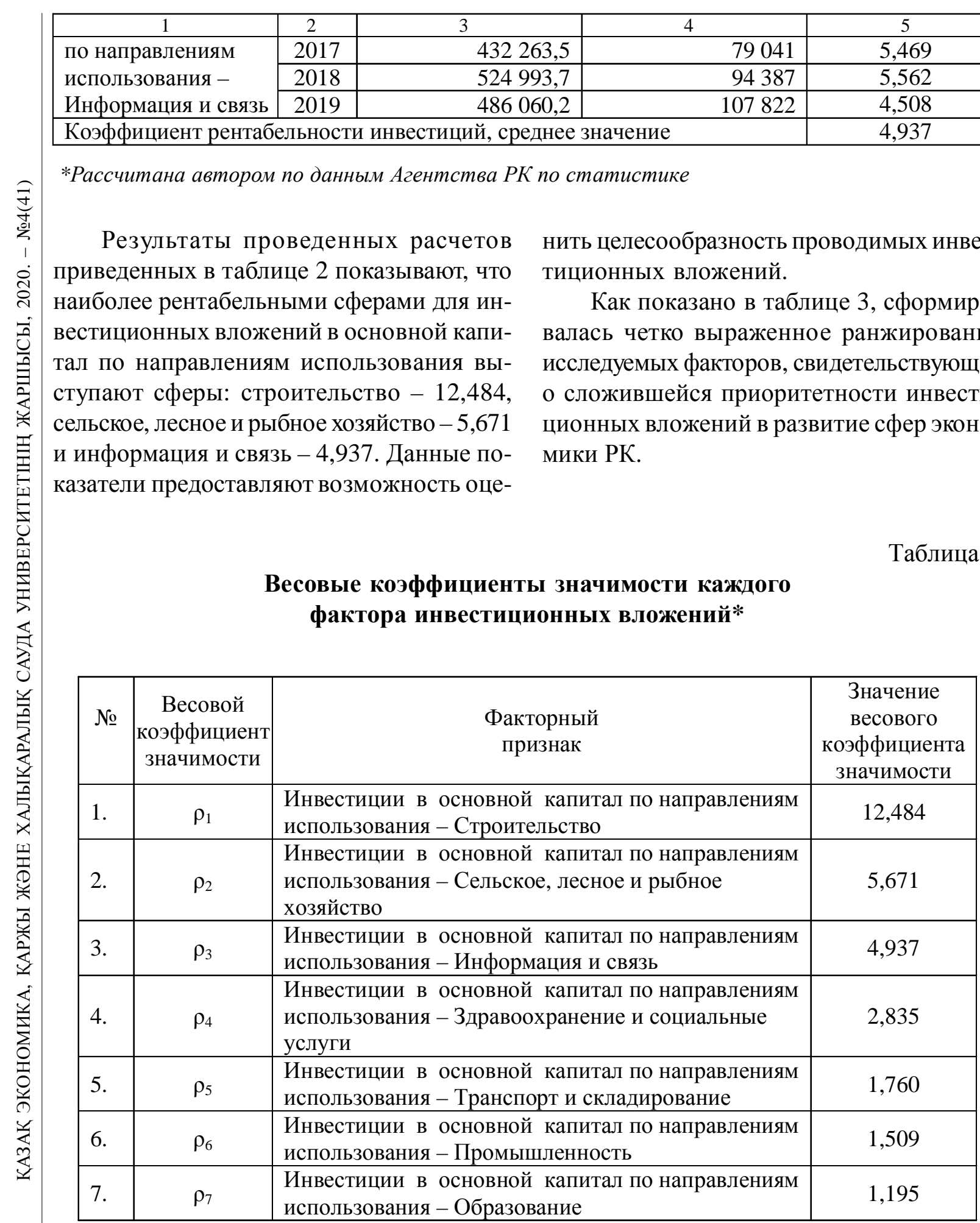

Составлена на основе расчета статистических данных

В подобной ситуации, для сформировавшихся весовых коэффициентов значимости для каждого фактора инвестиционных вложений, приведенных в таблице 3, возникает проблема расширения полноты научной экспертизы для привлекательности инвестиционных проектов на основе комплексной оценки, учитывающей и 
отражающей в интегральном показателе многогранную совокупность соответствующих интересов и предпочтений для потенциального инвестора, и тем самым обеспечивающей высокий уровень надежности такой экспертизы.

Поэтому, в качестве следующей важной статистической весовой характеристики анализируемых факторных признаков предлагается рассмотреть трендовую составляющую развития факторных показателей.

Ни один вид статистических показателей, исключая разве что средние, не используется так часто в экономическом анализе, как средний темп роста.

Средний темп роста можно получить путем расчета, как геометрическую среднюю из ряда цепных (последовательных) темпов роста. Цепной темп роста характеризуется отношением какого-либо уровня динамического ряда к предыдущему уровню и выражается в долях единицы или в процентах. В долях единицы его называют коэффициентом роста.

Непосредственно для всех ключевых показателей, определяющих инвестиционные вложения и факторов влияния цифровой экономики на их трендовую составляющую, рассмотрим проверку гипотезы о существовании тенденции, характеризующей долговременную основную закономерность развития этих показателей.

Для этого проводится сравнение средних уровней ряда, т.е. исследуемый временной ряд делят на две примерно равные части по числу входящих членов, каждая из которых рассматривается как самостоятельная выборочная совокупность с нормальным распределением. В случае, если исследуемый временной ряд имеет тенденцию, то средние, рассчитанные для каждой из совокупностей, должны значимо различаться между собой [8].

Проведем определение наличия тренда (основной тенденции) по данным таблицы 2.
Делим ряд на две части: $n_{1}=4, n_{2}=3$. По каждому ряду вычисляем выборочные дисперсии и среднее значение:

$$
\begin{aligned}
& \bar{y}_{1}=\frac{\sum_{i=1}^{n_{1}} x_{i}}{n_{1}} ; \quad S_{1}^{2}=\frac{\sum_{i=1}^{n_{1}}\left(x_{i}-\bar{x}\right)^{2}}{n_{1}} ; \\
& \bar{y}_{2}=\frac{\sum_{j=1}^{n_{2}} x_{j}}{n_{2}} ; \quad S_{2}^{2}=\frac{\sum_{j=1}^{n_{2}}\left(x_{j}-\bar{x}\right)^{2}}{n_{2}} .
\end{aligned}
$$

$\bar{y}_{1}=3690542,75 ; \quad S_{1}^{2}=2,11199 E+11 ;$

$\bar{y}_{2}=6383648,675 ; \quad S_{2}^{2}=1,56161 E+12$.

Выполняем проверку гипотезы о равенстве дисперсии при уровне значимости $\alpha=0,05$.

$$
H_{0}:{\sigma_{1}}^{2}=\sigma_{2}{ }^{2}, \quad H_{1}: \sigma_{1}{ }^{2} \neq \sigma_{2}{ }^{2} .
$$

Для ответа на эти вопросы служит Fраспределение [3].

$$
F_{\text {pacu }}=\frac{S_{2}{ }^{2} / \sigma_{x}^{2}}{S_{1}{ }^{2} / \sigma_{y}^{2}}=\frac{1,56161 \mathrm{E}+12}{2,11199 \mathrm{E}+11}=7,394 .
$$

Так как $\mathrm{F}_{\text {расч }}<\mathrm{F}_{\text {кр }}(0,05 ; 3,2)$, то нет оснований отвергать нулевую гипотезу. По данным наблюдения дисперсии генеральных совокупностей равны $\sigma^{2}{ }_{1}=\sigma^{2}{ }_{2}$, исправленные выборочные дисперсии $\left(\mathrm{S}_{1}^{2}\right.$ и $\mathrm{S}_{2}{ }^{2}$ ) различаются незначимо, (расхождение между ними случайно). Тогда можно проверить основную гипотезу:

$$
\begin{gathered}
H_{0}: \bar{y}_{1}=\bar{y}_{2} ; \quad H_{1}: \bar{y}_{1} \neq \bar{y}_{2} . \\
T_{p a c u}=\frac{\bar{y}_{1}-\bar{y}_{2}}{\sqrt{\left(n_{1}-1\right) S_{1}^{2}+\left(n_{2}-1\right) S_{2}^{2}}} \sqrt{\frac{n_{1} n_{2}\left(n_{1}+n_{2}-2\right)}{n_{1}+n_{2}}} \approx \\
\approx \frac{3690542,75-6383648,67}{\sqrt{(4-1) \cdot(2,11199 E+11)+(3-1) \cdot(1,56161 E+12)}} . \\
\cdot \sqrt{\frac{4 \cdot 3 \cdot(4+3-2)}{4+3}} \approx-4,067 .
\end{gathered}
$$

Сравниваем $\mathrm{T}_{\text {расч }}$ с табулированным значением $\mathrm{t}_{\mathrm{kp}}(\alpha, \kappa)$ - критическая точка распределения Стьюдента. 
где $\kappa=n-2$ степень свободы, $\alpha-$ заданный уровень значимости.

$$
\kappa=7-2=5 ; \mathrm{t}_{\text {кр }}(0,05 ; 5)=2,57 .
$$

Так как $\left|\mathrm{T}_{\text {расч }}\right|>\mathrm{t}_{\text {кр }}(0,05 ; 5)$, тогда не имеется оснований отвергать нулевую гипотезу о том, что временной ряд имеет тенденцию, так как средние, вычисленные для каждой совокупности, существенно (т.е. значимо) различаются между собой. Отсюда можно сделать вывод, что тренд валовой добавленной стоимости присутствует.

Далее проведем анализ рядов динамики, для изучения тенденций развития факторных показателей во времени. Большое

*Составлена на основе расчета статистических данных значение в условиях интенсификации факторных показателей имеет показатель, отображающий наращивание факторного потенциала.

Темп наращивания является важным статистическим показателем динамики факторных показателей. Темп наращивания, который в условиях интенсификации экономики измеряет наращивание во времени экономического потенциала рассчитывается по формуле:

$$
\mathrm{T}_{\mathrm{H}}=\Delta \mathrm{y}_{\text {ці }} / \mathrm{y}_{1} \text {. }
$$

Расчетные значения других показателей приведены в таблице 4.

Таблица 4

\section{Весовые коэффициенты расчетных значений показателей инвестиций в основной капитал по направлениям использования*}

\begin{tabular}{|c|c|r|r|r|r|r|}
\hline $\begin{array}{c}\text { Пе- } \\
\text { риод }\end{array}$ & $\begin{array}{c}\text { Инвестиции в основной } \\
\text { капитал по направлениям } \\
\text { использования - } \\
\text { Промышленность, млн тенге }\end{array}$ & $\begin{array}{c}\text { Абсо- } \\
\text { лютный } \\
\text { прирост }\end{array}$ & $\begin{array}{c}\text { Темп } \\
\text { приро- } \\
\text { ста, \% }\end{array}$ & $\begin{array}{c}\text { Темпы } \\
\text { роста, } \\
\%\end{array}$ & $\begin{array}{c}\text { Абсолютное } \\
\text { содержа- } \\
\text { ние 1\% } \\
\text { прироста }\end{array}$ & $\begin{array}{c}\text { Коэффи- } \\
\text { циент } \\
\text { роста, \% }\end{array}$ \\
\hline 2013 & 3069814 & 0 & 0 & 100,00 & 30698,14 & 0,00 \\
\hline 2014 & 3508871 & 439057 & 14,30 & 114,30 & 30698,14 & 14,30 \\
\hline 2015 & 3863090 & 354219 & 10,09 & 110,09 & 35088,71 & 11,54 \\
\hline 2016 & 4320396 & 457306 & 11,84 & 111,84 & 38630,9 & 14,90 \\
\hline 2017 & 4769588 & 449192 & 10,40 & 110,40 & 43203,96 & 14,63 \\
\hline 2018 & 6567368 & 1797780 & 37,69 & 137,69 & 47695,88 & 58,56 \\
\hline 2019 & \multicolumn{6}{|c|}{ Средний коэффициент роста, \% } \\
\hline
\end{tabular}

Проведенные вычисления представленные в таблице 4 характеризуют интенсивность происходящих изменений от одного временного периода к другому периоду. Рассчитанные цепные показатели получены путем сравнения соседних уровней временного ряда динамики - со следующим и предыдущим уровнями. Цепные показатели не зависят от длины ряда динамики и от того, какой уровень принят за его начало.

Весами здесь служат уровни предшествующих периодов. Следует отметить, что веса изменяются вместе с изменением $t$, причем удельный вес уровней рядов с большими темпами растет, а с меньшими падает. Характеристик расчетных значений приведены в таблице 5. 
Расчетные значения тенденций развития основных показателей инвестиций в основной капитал по направлениям использования*

\begin{tabular}{|c|c|c|c|c|c|c|}
\hline Показатель & $\frac{F \text { расч. }}{F \text { табл. }}$ & $\begin{array}{c}F \text {-кри- } \\
\text { терий }\end{array}$ & $\frac{\text { Трасч. }}{\text { Tтабл. }}$ & $\begin{array}{l}T \text {-кри- } \\
\text { терий }\end{array}$ & $\begin{array}{c}\text { Динамика } \\
\text { тенденции } \\
\text { развития } \\
\text { (рост/спад) }\end{array}$ & $\begin{array}{l}\text { Коэф. } \\
\text { роста, } \\
\%\end{array}$ \\
\hline $\begin{array}{l}\text { Инвестиции в основной капитал } \\
\text { по направлениям использования - } \\
\text { Промышленность }\end{array}$ & $\frac{7,394}{9,55}$ & $\begin{array}{l}\text { Fpac } \\
<\text { Fкр }\end{array}$ & $\frac{4,067}{2,57}$ & $\begin{array}{l}\mid \text { Трас } \mid \\
>\text { Ткр }\end{array}$ & рост $\pi$ & 22,08 \\
\hline $\begin{array}{l}\text { Инвестиции в основной капитал } \\
\text { по направлениям использования - } \\
\text { Сельское, лесное и рыбное хоз-во }\end{array}$ & $\frac{2,568}{9,55}$ & $\begin{array}{l}\text { Fpac } \\
<\text { Fкр }\end{array}$ & $\frac{5,331}{2,57}$ & $\begin{array}{l}\mid \text { Трас } \mid \\
>\text { Ткр }\end{array}$ & рост $\pi$ & 1,68 \\
\hline $\begin{array}{l}\text { Инвестиции в основной капитал } \\
\text { по направлениям использования - } \\
\text { Транспорт и складирование }\end{array}$ & $\frac{0,969}{9,55}$ & $\begin{array}{l}\text { Fрас } \\
<\text { Fкр }\end{array}$ & $\frac{0,532}{2,57}$ & $\mid \begin{array}{c}\text { Tрас } \\
<\text { Ткр }\end{array}$ & спадк & $-1,38$ \\
\hline $\begin{array}{l}\text { Инвестиции в основной капитал } \\
\text { по направлениям использования - } \\
\text { Строительство }\end{array}$ & $\frac{0,767}{9,55}$ & $\begin{array}{l}\text { Fрас } \\
<\text { Гккр }\end{array}$ & $\frac{3,465}{2,57}$ & $\begin{array}{l}\mid \text { Трас } \mid \\
>\text { Ткр }\end{array}$ & рост $\pi$ & 0,30 \\
\hline $\begin{array}{l}\text { Инвестиции в основной капитал } \\
\text { по направлениям использования - } \\
\text { Здравоохранение и соц. услуги }\end{array}$ & $\frac{0,788}{9,55}$ & $\begin{array}{l}\text { Fpac } \\
<\text { Fкр }\end{array}$ & $\frac{1,745}{2,57}$ & $\mid \begin{array}{c}\text { Tрас } \\
<\text { Ткр }\end{array}$ & рост $\pi$ & 0,16 \\
\hline $\begin{array}{l}\text { Инвестиции в основной капитал } \\
\text { по направлениям использования - } \\
\text { Образование }\end{array}$ & $\frac{0,871}{9,55}$ & $\begin{array}{l}\text { Fрас } \\
<\text { Fкр }\end{array}$ & $\frac{1,611}{2,57}$ & $\mid \begin{array}{c}\text { Tрас } \\
<\text { Ткр }\end{array}$ & рост $\pi$ & 0,27 \\
\hline $\begin{array}{l}\text { Инвестиции в основной капитал } \\
\text { по направлениям использования - } \\
\text { Информация и связь }\end{array}$ & $\frac{0,221}{9,55}$ & $\begin{array}{l}\text { Fрас } \\
<\text { Fкр }\end{array}$ & $\frac{0,368}{2,57}$ & $\mid \begin{array}{c}\text { Tрас } \\
<\text { Ткр }\end{array}$ & спадк & $-0,02$ \\
\hline
\end{tabular}

*Составлена на основе расчета статистических данных

Таким образом, по результатам проведенного исследования получены количественные характеристики сформировавшейся тенденции развития основных показателей инвестиций в основной капитал по направлениям использования. По данным таблицы 5, коэффициент роста показателей отраслей промышленности и сферы сельского, лесного и рыбного хозяйства характеризуют более активную динамику развития, что также положительно характеризует перспективу инвестиционных вложений в данные сферы экономики. Таким образом, можно утверждать, что поступления от данных инвестиционных проектов будут иметь положительный финансовый эффект.
Выводы. Проведенная экономикоматематическая апробация результатов исследования позволяет сделать ряд выводов:

1. На основании изучения текущего состояния проблемы по совершенствованию инструментальных механизмов проведения комплексной оценки инвестиционных проектов была разработана система весовых коэффициентов влияния различных оценок на комплексную оценку инвестиционных проектов.

2. Проведена разработка модели комплексной оценки эффективности инвестиционного проекта, где на базе статистической весовой характеристики анализируемых факторных признаков, проводится рас- 
смотрение трендовой составляющей развития факторных показателей.

Представленные показатели, входящие в оценочную систему, в полной мере характеризуют изучаемый объект в интересующих исследователя направлениях. Поскольку в нашем случае, показатели пред- назначены для оценки качества инвестиционных вложений в национальную отраслевую экономику на территории РК, они отражены в доступном для понимания экспертам статистическом формате и способствуют выработке и принятию эффективных управленческих решений.

\section{ЛИТЕРАТУРА}

1. Wen Y., Yin C. An extension of Paulsen-Gjessing's risk model with stochastic return on investments // Mathematics and Economics. - 2013. - Vol. 52(3). - S. 469-476.

2. Zhang J., Xiao Q. Optimal investment of a time-dependent renewal risk model with stochastic return // Journal of Inequalities and Applications. - 2015. - Vol. Iss. 1. - S. 12.

3. Kostadinova R., Kliippelberg C. Integrated insurance risk models with exponential Lévy investment // Insurance. Mathematics and Economics. - 2008. - Vol. 42 (2). - S. 560-577.

4. Szidarovszky F., Matsumoto A. Nonlinear multiplier-accelerator model with investment and consumption delays // Structural Change and Economic Dynamics. - 2015. - Vol. 33. - S. 1-9.

5. Ayres R., Voudouris V. The economic growth enigma: Capital, labour and useful energy? // Energy Policy. - 2014. - Vol. 64. - S. 16-28.

6. Lehmijoki U., Palokangas T. Population growth overshooting and trade in developing countries // Journal of Population Economics. - 2009. - Vol. 22. - № 1. - S. 43-56.

7. Карбетова Ш.Р., Карбетова 3.Р. Методические указания по комплексной оценке эффективности инвестиционных проектов. - Астана: КазУЭФМТ, 2006. - 160 с.

8. Статистическое моделирование и прогнозирование: Учеб. пособие / Г.М. Гамбаров и др.; Под ред. А.Г. Гранберга. - М.: Финансы и статистика, 1990. - 383 с.

\section{REFERENCES}

1. Wen Y., Yin C. An extension of Paulsen-Gjessing's risk model with stochastic return on investments // Mathematics and Economics. -2013. - Vol. 52 (3). - S. 469-476.

2. Zhang J., Xiao Q. Optimal investment of a time-dependent renewal risk model with stochastic return // Journal of Inequalities and Applications. - 2015. - Vol. Iss. 1. - S. 12.

3. Kostadinova R., Klüppelberg C. Integrated insurance risk models with exponential Lévy investment // Insurance. Mathematics and Economics. - 2008. - Vol. 42 (2). - S. 560-577.

4. Szidarovszky F., Matsumoto A. Nonlinear multiplier-accelerator model with investment and consumption delays // Structural Change and Economic Dynamics. - 2015. - Vol. 33. - S. 1-9.

5. Ayres R., Voudouris V. The economic growth enigma: Capital, labor and useful energy? // Energy Policy. - 2014. - Vol. 64. - S. 16-28.

6. Lehmijoki U., Palokangas T. Population growth overshooting and trade in developing countries // Journal of Population Economics. - 2009. - Vol. 22. - No. 1. - S. 43-56.

7. Karbetova Sh.R., Karbetova Z.R. Guidelines for the comprehensive assessment of the effectiveness of investment projects. - Astana: KazUEFIT, 2006. - 160 p.

8. Statistical modeling and forecasting: Textbook allowance / G.M. Gambarov, N.M. Zhuravel, Yu.G. Korolev and others; Ed. A.G. Granberg. - M .: Finance and statistics, 1990. - 383 s. 


\title{
М.Қ. Тұрғамбаев, В. Желю, А.А. Легостаева \\ ИНВЕСТИЦИЯЛЫҚЖОБАЛАРДЫ КЕШЕНД БАҒАЛАУҒА ӘР ТУРЛ БАҒАЛАРДЫН ӘСЕРІНІН САЛМАҚ КОЭФФИЦИЕНТТЕРІ ЖУЙЕСІН ӘЗІРЛЕУ
}

\begin{abstract}
Андатпа
Экономиканың қоғамдық, сол сияқты жеке секторында да басқару қызметінің тиімділігін арттыруды қамтамасыз ету көбінесе жобалық шешімдерді енгізумен байланысты. Сонымен қатар мұндай жобалардың тиімділігін бағалауға байланысты мәселелер ерекше өзекті болып табылады. Жобалардың маңызды түрлерінің бірі инвестициялық жобалар болып табылады.

Мақалада Қазақстан экономикасының салалық факторларының даму серпіні жағдайында инвестициялық жобалардың қызметін статистикалық талдау негізінде инвестициялық жобалардың тиімділігін кешенді бағалаудың моделі әзірленді және әдістемелік тәсілдері қарастырылады, онда талданатын факторлық белгілердің статистикалық салмақтық сипаттамасы негізінде факторлық көрсеткіштерді дамытудың трендтік құрамдасын қарау ұсынылады. Елдің салалық экономикасына инвестициялар бағыттары бойынша экономикалық көрсеткіштердің қалыптасатын жалпы даму үрдісінің болуы алынған есептік мәндерді сипаттайды.

Зерттеу барысында қолданылатын кешенді тәсіл бірнеше факторларды ескеруге мүмкіндік береді және сол арқылы есептеулердің болжамдық және аналитикалық көрсеткіштерін жақсартады. Ұлттық масштабтағы макроэкономикалық көрсеткіштердің нәтижелері аймақтық салалар деңгейіндегі инвестициялар ағындарын да қарастырады. Сонымен бірге нақты инвестициялық жобалар бойынша талдамалық деректерді пайдалану ең маңызды және басым инвестициялық жобалардың әсерін ескере отырып түзетуге мүмкіндік береді.
\end{abstract}

\section{Turgambaev, V. Zhelyu, A. Legostaeva}

\section{DEVELOPMENT OF A WEIGHT COEFFICIENTS SYSTEM INFLUENCE OF DIFFERENT VALUES ON THE INTEGRATED ASSESSMENT OF INVESTMENT PROJECTS}

\begin{abstract}
Annotation
Ensuring an increase in the efficiency of management activities in both the public and private sectors of the economy is largely associated with the implementation of design solutions. At the same time, issues related to the assessment of the effectiveness of such projects are acquiring special relevance. Investment projects are one of the most important types of projects.

The article discusses methodological approaches to a comprehensive assessment of the effectiveness of investment projects on the basis of a statistical analysis of the activities of investment projects, in the context of the dynamics of the development of sectoral factors of the economy of Kazakhstan. A model for a comprehensive assessment of the effectiveness of an investment project has been developed, where, based on the statistical weight characteristics of the analyzed factor indicators, it is proposed to consider the trend component of the development of factor indicators. The presence of the formed general trend in the development of economic indicators in the areas of investment in the sectoral economy of the country is characterized by the calculated values obtained.

The comprehensive comprehensive approach applied in the study allows taking into account multiple factors and thereby improve the forecast and analytical indicators of calculations. The resulting estimates of macroeconomic indicators on a national scale also consider investment flows at the level of regional industries. At the same time, the use of analytical data on specific investment projects allows for adjustments taking into account the impact of the most important and priority investment projects.
\end{abstract}

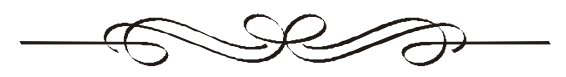


Д.М. Турекулова*, д.э.н., профессор ${ }^{l}$

К.Н. Оразбаева, д.т.н., профессор ${ }^{l}$

М.Н. Ниязов, докторант $P h D^{l}$

А.И. Естурлиева, к.э.н., доцент ${ }^{2}$

Казахский университет экономики, финансов и

международной торговли ${ }^{1}$

2. Нур-Султан

Каспийский государственный университет

технологий и инжиниринга им. Ш. Есенова ${ }^{2}$

2. Aктау

e-mail: kulman_o@mail.ru

* - основной автор (автор для корреспонденции)

\section{ЭКОНОМИЧЕСКАЯ МОДЕЛЬ СОВЕРШЕНСТВОВАНИЯ ГОСУДАРСТВЕННОГО УПРАВЛЕНИЯ ОТХОДАМИ ПРОИЗВОДСТВА}

В статье приведены результаты исследования по построению и описанию экономической модели, которая применима для совершенствования государственного управления отходами производства промышленных предприятий. Показано, что для решения задач государственного управления отходами производства промышленных предприятий и потребления с учетом их антропогенных воздействий на окружаюшую природную среду, можно эффективно применить методы экономико-математического моделирования и оптимизации. Определены основные виды показателей и загрязнения, которые следует учитывать при экономико-экологическом моделировании и оптимизации производства. Проанализированы исследовательские работы, в которых рассмотрены вопросы прогнозирования экономического и экологического состояния экономико-экологических систем. Предложено математическое описание основных показателей экономико-экологической системы. Также в статье сформулированы задачи оптимизачии производства по экономическим критериям с учетом экологических требований и нормативов, и предложен подход к ее решению.

Предложена универсальная модель, которая может быть использована для иелей микроэкономики на уровне любого предприятия, промышленного комплекса, отраслевого выпуска продукции. Кроме того, сформулированная задача оптимизации производства на основе предложенной модели, позволяет оптимизировать производство с учетом экологических критериев и ограничений.

Ключевые слова: экономико-экологическая модель, государственное управление, отходы производства, оптимизация, экономические критериии, экологические критериии, экономико-экологическая система, устойчивое управление, производственная функиия, природоемкость.

Кілт сөздер: экономикалық және экологиялық модель, мемлекеттік басқ̧ару, өндіріс қалдықтары, оңтайландыру, экономикалық критерий, экологиялық критерий, экономикалық және экологиялық жүйе, тұрақты басқару, өндірістік функиия, табиват сыйымдылығы.

Keywords: economic and ecological model, public administration, production waste, optimization, economic criterion, ecological criterion, economic and ecological system, sustainable management, production function, environmental intensity.

JEL classification: C 61 
Введение. При решении задач государственного управления отходами производства и потребления, а также проблем, связанных с антропогенными воздействиями на природную среду, широко применяется метод экономико-математического моделирования. Это связано тем, что в экологических системах возникает множество взаимосвязей, сила и постоянство которых непрерывно меняются. Соответственно прогнозировать и определить изменение состояния эколого-экономической системы на действие конкретных факторов, ее влияние на окружающую среду возможно только на основе сложного анализа существующих в ней количественных взаимоотношений и закономерностей, а также качественной оценки [1].

Для этого необходимо применить методы экономико-математического моделирования процессов определения состояния экономико-экологической системы. В случае адекватности экономико-экологические модели, построенные на основе математических методов, позволяют воспроизводить такие процессы, наблюдение которых в реальности или эксперименте потребовало бы много сил и больших промежутков времени [2].

Эколого-экономические модели разрабатываются на основе математических методов и используются при долгосрочном прогнозировании экономического роста и общей оценки влияния человеческой деятельности на окружающую природную среду.

Целью данной работы является исследование и решение основных вопросов построения экономико-экологических моделей совершенствования государственного управления отходами производства. Для достижения поставленной цели ставятся и решаются следующие задачи исследования:

- определения основных видов показателей и загрязнения, которые учитываются при экономико-экологическом мо- делировании;

- математическое описание основных показателей экономико-экологической системы;

- формализация задачи оптимизации производства по экономическим критериям при условиях выполнения определенных экологических норм.

При выполнении задач исследования в этой работе используются методы экономического анализа, системного анализа и математические методы.

Обзор литературы. Экономико-экологическая система - это ограниченная определенной территорией часть ноосферы, в которой природные, социальные и производственные структуры и процессы связаны взаимно поддерживающими потоками вещества, энергии и информации [3].

Таким образом, эколого-экономическая система состоит из экономической и экологической подсистем, предоставляющие ресурсы обществу.

Следует отметить, что в исследованиях до середины XX века проблемы взаимодействия экономики и экологии обсуждались в основном в ключе ограниченности природных ресурсов, а негативное влияние хозяйственной деятельности на окружающую среду не являлось предметом рассмотрения экономической науки [4].

Не изучались и обратные связи между экологической деградацией и экономическим развитием, состоянием трудовых ресурсов, качеством жизни населения. Лишь в 70-х гг. ХХ века, в значительной степени благодаря работам Римского клуба было показано, что на современном этапе, на пути дальнейшего экономического развития общества возникли новые лимитирующие факторы, которые можно условно обозначить как «экологические ограничители» экономического роста, отражающие масштабы и последствия негативного воздействия хозяйственной деятельности на окружающую среду $[5,6]$. 
К концу XX века на основе метода системной динамики Дж. Форрестера были построены первые, так называемые «модели мира», направленные на разработку сценариев экономико-экологического развития [7]. Для описания модели изменения экологической ситуации Дж. Форрестер использовал схему построения формализованных моделей нелинейных динамических процессов. Их недостатки заключались в чрезмерно высокой степени обобщения переменных, которые характеризуют процессы. В начале 90-х годов основополагающей и общепризнанной в деятельности международных организаций и многих стран стала концепция устойчивого развития, которая говорит о возможности гармоничного совмещения задач дальнейшего экономического роста и сохранения окружающей среды.

Одной из наиболее популярных является модель Д. Пирса и К. Тернера, которая показывает обратные связи в экономико-экологической системе. Окружающая среда является источником природных ресурсов и экологических благ, а также служит для поглощения и размещения отходов производства и потребления [8].

Первая межотраслевая модель, учитывающая экологический фактор, была разработана В.В. Леонтьевым и Д. Фордом [9]. В.В. Леонтьев представляет межотраслевой баланс как совокупность потоков товаров и услуг, отображаемых в таблице «затратывыпуск», и характеризующих основные структурные изменения отдельных секторов экономики.

В проанализированных работах недостаточно отражены вопросы совершенствования государственного управления отходами производства на основе экономикоэкологической модели. Эти вопросы подробно исследуются в предлагаемом исследовании.

Основная часть. В силу возрастания эффекта накопления техногенного воздей- ствия на окружающую среду практическое решение задач оптимизации, эффективное на короткие периоды времени в микроэкономическом масштабе, приводит к существенным затратам в макроэкономическом плане. И в контексте этой проблемы наряду с энергетическим аспектом наиболее значимым для Казахстана является аспект загрязнений, так как идет выталкивание из экономически развитых стран в развивающиеся страны не только энергоемких технологий, но и производств с большими загрязнениями биосферы.

В настоящее время в Казахстане на системном уровне не налажен раздельный сбор твердо-бытовых отходов (ТБО). Практический весь объем образуемых ТБО размещается на полигонах. Несмотря на ежегодный рост объемов образуемых ТБО, утилизируется и перерабатывается лишь небольшая их часть - до $5 \%$ от ежегодно образуемого его объема, а весь остальной объем размещается на полигонах. На территории страны имеются 4586 полигонов ТБО, из них $3983(86,9 \%)$ не отвечают действующим в стране экологическим и санитарным нормам, стандартам работ и технологическим требованиям по складированию и захоронению ТБО (таблица 1).

Анализ существующих проблем полигонов ТБО во всех населенных пунктах показал, что действующая система управления ТБО не соответствует полной мере современным требованиям: размещение полигонов под складирование отходов осуществляется без инженерных и гидрогеологических обоснований; не осуществляется раздельный сбор, отсутствуют предприятия по использованию и переработке компонентов отходов; не проводятся экологический мониторинг в районе полигонов захоронения отходов; не проводится работа по минимизации отходов; не весь объем образованных ТБО поступает на санкционированные свалки, что приводит к образованию несанкционированных сва- 
лок. Как известно, одним из эффективного подхода к решению перечисленных воп- росов является применение методов экономико-экологического моделирования.

Таблица 1

Количество полигонов ТБО в разрезе областей по данным 2016 года*

\begin{tabular}{|c|c|c|c|c|c|c|c|}
\hline \multirow{2}{*}{$\begin{array}{l}\text { № } \\
\Pi / \Pi\end{array}$} & \multirow[b]{2}{*}{$\begin{array}{c}\text { Регион } \\
\text { (область, город) }\end{array}$} & \multirow{2}{*}{$\begin{array}{c}\text { Количество } \\
\text { населенных } \\
\text { пунктов } \\
\end{array}$} & \multicolumn{5}{|c|}{ Количество полигонов ТБО } \\
\hline & & & всего & узаконены & $\%$ & $\begin{array}{c}\text { не } \\
\text { узаконены }\end{array}$ & $\%$ \\
\hline 1. & Акмолинская & 641 & 502 & 18 & 3,5 & 484 & 96,5 \\
\hline 2. & Актюбинская & 410 & 470 & 8 & 1,7 & 462 & 98,3 \\
\hline 3. & Алматинская & 772 & 462 & 10 & 2,2 & 452 & 97,8 \\
\hline 4. & Атырауская & 61 & 9 & 9 & 100 & 0 & - \\
\hline 5. & ВКО & 590 & 476 & 9 & 1,9 & 467 & 98,1 \\
\hline 6. & Жамбылская & 375 & 214 & 69 & 32,2 & 145 & 67,8 \\
\hline 7. & ЗКО & 475 & 467 & 143 & 30,6 & 324 & 69,4 \\
\hline 8. & Карагандинская & 317 & 213 & 20 & 9,4 & 193 & 90,6 \\
\hline 9. & Костанайская & 657 & 461 & 175 & 38 & 286 & 62 \\
\hline 10. & Кызылординская & 158 & 145 & 3 & 2 & 142 & 98 \\
\hline 11. & Мангистауская & 17 & 14 & 14 & 100 & 0 & - \\
\hline 12. & Павлодарская & 412 & 316 & 4 & 1,2 & 312 & 98,8 \\
\hline 13. & CKO & 719 & 630 & 5 & 0,8 & 625 & 99,2 \\
\hline 14. & ЮКО & 879 & 205 & 114 & 55,6 & 91 & 54,4 \\
\hline 15. & г. Нур-Султан & 1 & 2 & 2 & 100 & 0 & - \\
\hline 16. & г. Алматы & 1 & 0 & 0 & - & 0 & - \\
\hline & Всего: & 6485 & 4586 & 603 & 13,1 & 3983 & 86,9 \\
\hline
\end{tabular}

* Составлена по данным источника [1]

К основным видам загрязнений, которые необходимо учитывать при экономико-экологическом моделировании относятся: отходы производства и потребления; загрязнение атмосферного воздуха; сбросы сточных вод.

При решении любой оптимизационной задачи используются математические модели исследования, при этом под математической моделью понимается уравнение, связывающее параметр оптимизации с факторами на него воздействующими. Для экономико-экологического моделирования рассмотрим любое предприятие, загрязняющее окружающую среду, в качестве «черного ящика». В этом случае предполагается, что выделенная система связана со средой через совокупность входов и вы- ходов. Выходы модели описывают результаты деятельности системы, а входы - ресурсы и ограничения. Модель в этом случае отражает два важных и существенных ее свойства: целостность и обособленность от среды [10]. Такая модель, несмотря на ее внешнюю простоту и отсутствие сведений о внутренней структуре, оказывается часто полезной и достаточной для практического использования.

Применение математических моделей для прогнозирования целевых индикаторов программ развития страны в рамках парадигмы устойчивого развития территории будет положительно влиять на управленческий процесс в целом, способствовать росту сферы планирования развития РК, повышению качества разработки и 


\section{Экономика}

реализации программ развития [11].

Структуру модели экономико-экологической системы можно представить, как на рисунке 1. В приведенной структуре: 1предоставление природных ресурсов; 2 - доставление трудовых ресурсов; 4 - производство продуктов; 5 - обеспечение качества среды обитания; 6 - выбросы отходов; 7 - самовосстановление природной среды; 8 - социальное развитие; 9 - воспроизводство.

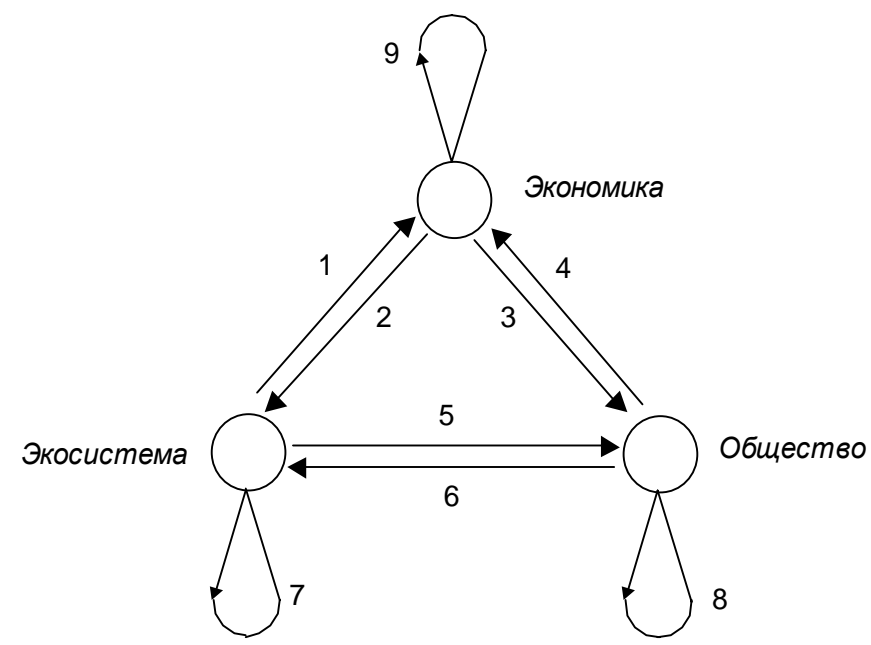

Рисунок 1. Структура, описывающая взаимосвязь между элементами
эколого-экономической системы*

*Составлен автором по данным источника [4]

В качестве выходных параметров будем рассматривать конечный продукт, изготавливаемый предприятием и эмиссии в окружающую среду. Для оценки эффективности функционирования природно-продуктовой системы используется показатель природоемкости $-E_{N}$, характеризующий тип и уровень экономико-экологического развития. На макроуровне $E_{N}$ определяется как затраты используемых природных ресурсов $(P)$ на единицу $В В П$ :

$$
E_{N}=P / B B \Pi \text {. }
$$

Второй тип показателей природоемкости (e) определяется затратами природного ресурса $R_{N}$ на единицу конечной продукции объема $V$, произведенной на основе этого ресурса:

$$
e=R_{N} / V
$$

В качестве такого показателя может служить энергоемкость - $e$, представляющая энергетические затраты на единицу конечной продукции.

В статистике широко распространен показатель, обратный коэффициенту природоемкости, - показатель природной ресурсоотдачи $-\sigma$.

$$
\sigma=V / R_{N}
$$

Для экстенсивного типа развития экономики, присущего для экономики Казахстана, характерна высокая природоемкость и низкая природная ресурсоотдача. В условиях реформ структурной и инвестиционной политики важнейшая задача государства - минимизация природоемкости или максимизация природной ресурсоотдачи:

$$
e \rightarrow \min \text { или } \sigma \rightarrow \max .
$$


Следующим основным показателем экологической системы является устойчивое развитие. Термин «устойчивое развитие» подразумевает: удовлетворение потребностей настоящего времени, не ставящее под угрозу способность будущих поколений удовлетворять свои потребности; учет социальных и экологических факторов; учет долгосрочных последствий принимаемых решений.

Возникла концепция критического природного капитала как необходимых для жизни природных благ, которые невозможно заменить искусственным путем. К ним относятся: ландшафты, редкие виды флоры и фауны, климат и т.д. С учетом критического природного капитала $N^{*}$ устойчивое развитие может быть дополнено ограничением на исчерпание во времени этой величины. Для неубывающей во времени производственной функции, аргументами которой являются агрегированные переменные труда $L$, капитала $K$ и природного ресурса $N$

$$
F_{t}(K, L, N) \leq F_{t+1}(K, L, N)
$$

необходимо соблюдение условия неубывания во времени величины критического природного капитала $N^{*}$

$$
N_{t} * \leq N_{t+1} * \text {, }
$$

а также условие частичной замены природного капитала $N$ на искусственный $N^{s}$ или невозобновимого ресурса на возобновимый ресурс:

$$
N_{t}=N_{t}^{*}+N^{s}{ }_{t} .
$$

Сформулируем задачу оптимизации производства при условиях выполнения определенных экологических норм:

Пусть $F\left(x_{1}, x_{2}, \ldots x_{n}\right)$ - целевая функция выпуска, характеризующая производство, использующее $n$ ресурсов. Будем полагать, что имеется $m$ видов загрязнения от данного производства, которые заданы матрицей интенсивностей загрязнений: $c_{p}=\left\|c_{i j}\right\|, i=1,2, \ldots, m ; j=1,2, \ldots, n$,

где $c_{i j}>0$ - количество $j$-го загрязнения, продуцируемое при использовании единицы $i$-го ресурса. Тогда вектор загрязнений $\bar{w}$ определяется формулой

$$
\begin{gathered}
\bar{w}^{T}=C_{p} \bar{x}^{T} \text { или } \\
w_{k}=\sum_{j=1}^{n} c_{k j} x_{j}, k=1,2,3, \ldots, m
\end{gathered}
$$

где $\bar{x}$ - вектор-строка используемых ресурсов.

Введем матрицу $A$ коэффициентов ограраничений на ресурсы, и вектор ограничений $\bar{b}$, определяемый возможностями производства. В рассмотрение необходимо ввести также вектор экологических нормативов $\bar{w}^{*}-$ допустимых отходов по каждому виду загрязнения. Эти нормативы обычно устанавливаются по существующим нормам ПДК (предельно допустимых концентраций).

Тогда задача оптимизации выпуска продукции формулируется следующим образом - найти максимум функции:

$$
F\left(x_{1}, x_{2}, \ldots, x_{n}\right)=F(\bar{x}) \rightarrow \max
$$

на допустимом множестве:

$$
\left\{\begin{array}{c}
\bar{x} \geq \overline{0}, \bar{z} \geq 0, \\
A \bar{x}^{T} \leq \bar{b}^{T}, \\
\bar{w} \leq \bar{w}^{*}
\end{array}\right.
$$

Приведенная постановка задачи оптимизации производства при условии соблюдения экологических норм соответствует устойчивому развитию и может быть решена известными методами решения задач оптимизации.

В отличие от традиционных оптимизационных моделей, допустимое множество которых формируется только двумя первыми производственными соотношениями (11), эта модель включает еще и ограничение на «чистоту производства». Для соблюдения последнего условия в (11), ко- 


\section{Экономика}

торое имеет вид ограничения по каждому типу загрязнения:

$$
\sum_{j=1}^{n} c_{k j} x_{j} \leq w_{k}^{*}, k=1,2, \ldots, m,
$$

т.е. необходимо делать выбор в сторону более совершенных технологий или заменять «грязные» ресурсы на более чистые. В противном случае из-за ограничений (12) допустимые объемы используемых ресурсов $\bar{x}$ могут оказаться столь незначительными, что нельзя будет обеспечить экономически приемлемый объем выпуска продукции.

Модель (10) - (11) относится к области макроэкономики, когда выпуск можно отождествить с ВВП страны или с валовой продукцией региона. Тогда условие (12) является управлением технологической политики.

Для микроэкономики на уровне отдельного производства эта модель не будет работать, поскольку производитель заинтересован прежде всего в достижении наибольшего выпуска (11), а вопрос о соблюдении экологических норм (12) остается для него второстепенным так как это требование никак не отражено в целевой функции. Для учета экологического фактора и микроэкономике необходимо перейти к стоимостным выражениям в целевой функции и оплате превышения норм загрязнения. Пусть $p$ - агрегированная цена производимой продукции, а компоненты вектора

$$
z=\left(z_{1}, z_{2}, \ldots, z_{m}\right)
$$

означают расходы на устранение загрязнений в случае превышения соответствующих норм (при нарушении третьего условия в (11). Тогда функция дохода от выпуска продукции $F(\bar{x})$ имеет вид:

$$
P=p F(\bar{x})-\bar{z} \bar{\delta},
$$

где $\bar{\delta}$ - вектор «включений» платежей за загрязнения

$$
\delta_{j}=\left\{\begin{array}{l}
0, w_{j} \leq w_{j}^{*}, \\
1, w_{j}>w_{j}^{*} .
\end{array}\right.
$$

$\bar{w}$ - вектор загрязнений, определяемый формулами (9) и (8), $w_{j}^{*}$ - компоненты вектора предельно допустимых загрязнений

$$
\bar{w}^{*}=\left(w_{1}^{*}, w_{2}^{*}, \ldots, w_{m}^{*}\right) .
$$

Для простоты принимается, что платежи за загрязнение окружающей среды включены в оплату за природопользование - т.е. второй член в функции дохода со знаком минус - это оплата сверхнормативной нагрузки на окружающую среду. В этом случае (14) можно рассматривать как производственную функцию, аргументами которой являются ресурсы $\bar{x}$, загрязнения $\bar{w}$, предельно допустимые нормы $w$ и платежи за загрязнение окружающей среды $\bar{z}$.

Таким образом, модель оптимизации дохода от выпуска продукции с использованием вектора ресурсов $\bar{x}$ при технологии, характеризуемой производственной функцией $F$, имеет вид:

$$
\left\{\begin{array}{c}
\bar{x} \geq \overline{0} \\
A \bar{x}^{T} \leq \bar{b}^{T}
\end{array}\right.
$$

найти максимум функции (14), (15), (13) на допустимом множестве решений при заданном ограничении $\bar{w}^{*}=\left(w_{1}^{*}, w_{2}{ }^{*}, \ldots, w_{m}^{*}\right)$.

В этой модели присутствуют как возможности самого производства (заданы матрица $A$ коэффициентов ограничений и вектор $\bar{b}$ ограничений на ресурсы), так и нормативы технологического воздействия на окружающую среду и расходы на ликвидацию последствий их превышения (векторы $\bar{z}$ и $\left.\bar{w}^{*}\right)$. Непосредственно из нее видно, что при «жестком» экологическом законодательстве производитель вынужден будет применять более совершенные технологии с целью снижения удельных техногенных отходов - коэффициентов матрицы $C_{p}$ в (8). Именно так обстоит дело в странах с развитой экономикой.

Выводы. Основная идея статьи заключается в совершенствовании процесса государственного управления отходами производства с применением экономико-эколо- 
гических моделей. В результате проведенных исследований получена модель оптимизации производства с учетом экономических и экологических критериев. Новизна полученных результатов в том, что построена модель, относящая к области макроэкономики, а приведенные задачи оптимизации производства на основе этой модели, позволяют оптимизировать производства с учетом экологических требований и нормативов. В работе получены следующие основные результаты:

- определены основные виды показателей и загрязнения, учитываемых при экономико-экологическом моделировании;

- основных показателей экономико- экологической системы;

- формализована задача оптимизации производства по экономическим критериям при выполнении экологических норм и предложен подход к ее решению.

Таким образом, поставленная цель работы достигнута, а все задачи исследования решены. Полученные результаты может быть использованы на практике для эффективного решения задачи оптимизации производства по экономическим критериям соблюдая экологические требования.

Статья подготовлена по результатам исследований по гранту №АР08857332 Комитета науки Министерства образования и науки Республики Казахстан.

\section{ЛИТЕРАТУРА}

1. Интымакова А.Т. Моделирование процессов государственного управления в сфере охраны окружающей среды (на примере управления охраной окружающей среды. Диссертация на соискание степени доктора $\mathrm{PhD}$ по спец. «Государственное и местное управление». - Астана, 2016. - 115 с.

2. Kornilov A.M., Pazyuk K.T. Economic and mathematical modeling of solid waste recycling and the use of secondary material raw materials // Economics. - 2018. - Vol. 47. - № 2. - P. 33-47.

3. Липенков А.Д. Моделирование эколого-экономических систем: Учеб. пособие / А.Д. Липенков. - Челябинск: Челяб. гос. ун-т, 2015. - 157 с.

4. Гурмана В.И. Моделирование социо-эколого-экономической системы региона: Монография / В.И. Гурман, Е.В. Рюмин. - М.: Наука, 2011. - 237 с.

5. Большаков А.С. Моделирование в менеджменте: Учеб. пособие / А.С. Большаков. - М.: МГУ, 2018. - 470 с.

6. Goncharov V.V. Management within the main phases of the management cycle // Production Planning \& Management. - 2018. - Vol. 18. - № 3. - P. 33-49.

7. Неуймин Я.Г. Модели в науке и технике. Теория и практика: Моногр. Я.Г. Неуймин, А.В. Кузнецов. - СПб: СПГУ, 2015. - 215 с.

8. Друкер П.Ф. Задачи менеджмента в XXI веке: Учеб. пособие / П.Ф. Друкер. - М.: Высшая школа, 2016. - 547 с.

9. Болтянский В.Г. Математические методы оптимального управления: Учеб. пособие / В.Г. Болтянский. - М.: КНОРУС, 2014. - 210 с.

10. Шелобаев С.И. Экономико-математические методы и модели: Учеб. пособие / С.И. Шелобаев. Изд. 2-е, перераб. и доп. - М.: ЮНИТИ-ДАНА, 2015. - 285 с.

11. Емелина Н.К., Курманалина А.Қ., Қалқабаева Г.М., Құдайбергенова С.Қ. Қазақстан Республикасының тұрақты дамуын үлгілеу және болжамдау // Қазақ экономика, қаржы және халықаралық сауда университетінің жаршысы. - 2020. - № 2(39). - 68-74 б. 


\section{REFERENCES}

1. Intymakova A.T. Modelirovaniye protsessov gosudarstvennogo upravleniya v sfere okhrany okruzhayushchey sredy (na primere upravleniya okhranoy okruzhayushchey sredy). Dissertatsiya na soiskaniye stepeni doktora $\mathrm{PhD}$ po spetsial' nosti «Gosudarstvennoye i mestnoye upravleniye. - Astana, 2016. - 115 s. [in Russian].

2. Kornilov A.M. Pazyuk K.T. Economic and mathematical modeling of solid waste recycling and the use of secondary material raw materials // Economics. - 2018. - Vol. 47. - № 2. - P. 33-47.

3. LipenkovA.D. Modelirovaniye ekologo-ekonomicheskikh sistem: Ucheb. posobiye [Modeling of ecological and economic systems: Training manual] / A.D. Lipenkov. - Chelyabinsk: Chelyab. gos. univer, 2015. - 157 s. [in Russian].

4. Gurmana V.I. Modelirovaniye sotsio-ekologo-ekonomicheskoy sistemy regiona: Monografiya [Modeling the socio-ecological-economic system of the region: Monograph] / V.I. Gurmana, Ye.V. Ryumina. - M.: Nauka, 2011. - 237 s. [in Russian].

5. Bol'shakov A.S. Modelirovaniye v menedzhmente: Ucheb. pos. [Modeling in management: Training manual] / A.S. Bol'shakov. - M.: MGU, 2018. - 470 s. [in Russian].

6. Goncharov V.V. Management within the main phases of the management cycle// Production Planning \& Management. - 2018. - Vol. 18. - № 3. - P. 33-49.

7. Neuymin YA.G. Modeli v nauke itekhnike. Teoriya i praktika: Monografiya [Models in Science and Technology. Theory and practice: Monograph]. YA.G. Neuymin, A.V. Kuznetsov. - SPb: SPGU, 2015. - 215 s. [in Russian].

8. Druker P.F. Zadachi menedzhmenta v XXI veke: Ucheb. pos. [Management tasks in the XXI century: Training manual] / P.F. Druker. - M.: Vysshaya shkola, 2016. - 547 s. [in Russian].

9. Boltyanskiy V.G. Matematicheskiye metody optimal' nogo upravleniya: Ucheb. pos. [Mathematical methods of optimal control: Training manual] / V.G. Boltyanskiy. - M.: KNORUS, 2014. 210 s. [in Russian].

10. Shelobayev S.I. Ekonomiko-matematicheskiye metody i modeli: Ucheb. posobiye [Economic and mathematical methods and models: Training manual] / S.I. Shelobayev. Izd. 2-ye, pererab. i dop. - M.: YUNITI-DANA, 2015. - 285 s. [in Russian].

11. Emelina N.K., Kurmanalina А.Қ., Қаlқаbaeva G.M., Құdajbergenova S.Қ. Қаzaқstan Respublikasynyң turaқty damuyn yligeleu zhəne bolzhamdau. - Қаzaқ ekonomika, қarzhy zhəne halyқaralyқ sauda universitetiniң zharshysy. - 2020. - № 2(39). - 68-74 b. [in Kazakh].

\section{Д.М. Турекулова, К.Н. Оразбаева, М.Н. Ниязов, А.И. Естурлиева}

\section{ӨНДІРІС ҚАЛДЫҚТАРЫН МЕМЛЕКЕТТІК БАСҚАРУДЫ ЖЕТІЛДІРУДІҢ ЭКОНОМИКАЛЫК МОДЕЛІ}

\section{Андатпа}

Мақалада өндірістік қалдықтарды мемлекеттік басқаруды жетілдіруге қолданылатын экономикалық модельді құру және сипаттау бойынша зерттеу нәтижелері келтірілген. Экономикалық және экологиялық модельдеу мен өндірісті оңтайландыру кезінде ескеру қажет негізгі көрсеткіштер мен ластану түрлері анықталды. Экономикалық және экологиялық жүйелердің экономикалық және экологиялық жағдайын болжау мәселелері қарастырылған зерттеу жұмыстарына талдау жасалды. Экономикалық және экологиялық жүйенің негізгі көрсеткіштерінің математикалық сипаттамасы ұсынылған. Сондай-ақ мақалада экологиялық талаптар мен стандарттарды ескере оты- 
рып, өндірісті экономикалық критерийлер бойынша оңтайландыру міндеті тұжырымдалған және оны шешу тәсілдемесі ұсынылған.

Микроэкономика мақсаттары үшін кез келген кәсіпорын, өндірістік кешен және өнеркәсіптік өнім деңгейінде қолдануға болатын әмбебап модель ұсынылған. Басқа белгілі модельдерден алынған нәтижелердің жаңалығы мен ерекшелігі - құрастырылған модельді макроэкономика саласында да қолдануға болады. Сонымен қатар әзірленген модельге негізделген өндірісті оңтайландыру проблемасы экологиялық критерийлер мен шектеулерді ескере отырып, өндірісті оңтайландыруға мүмкіндік береді.

\section{Turekulova, K. Orazbayeva M. Niyazov, A. Yesturliyeva \\ ECONOMIC MODEL FOR IMPROVING THE STATE MANAGEMENT OF PRODUCTION WASTE}

\section{Annotation}

The article presents the results of a study on the construction and description of an economic model that is applicable to improve the state management of industrial waste. The main types of indicators and pollution that should be taken into account in economic and environmental modeling and production optimization have been determined. Analyzed research works in which the issues of forecasting the economic and ecological state of economic and ecological systems are considered. A mathematical description of the main indicators of the economic and ecological system is proposed. Also, the article formulates the task of optimizing production according to economic criteria, taking into account environmental requirements and standards, and an approach to its solution is proposed.

A universal model is proposed that can be used for the purposes of microeconomics at the level of any enterprise, industrial complex, and industrial output. The novelty and originality of the results obtained from other well-known models is that the constructed model is applicable in the field of macroeconomics. In addition, the formulated production optimization problem based on this proposed model allows production to be optimized taking into account environmental criteria and restrictions.

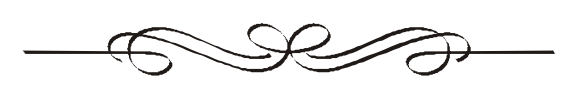


Г.Е. Накипова*, д.э.н., профессор, проректор по научной работе, стратегическому и инновачионному развитию

А.Ж. Шалабаева, докторант $P h D$

Карагандинский экономический университет Казпотребсоюза

2. Караганда

e-mail: aikynzhake@gmail.com

* - основной автор (автор для корреспонденции)

\section{НЕКОТОРЫЕ ОСОБЕННОСТИ РЕАЛИЗАЦИИ ГОСУДАРСТВЕННО- ЧАСТНОГО ПАРТНЕРСТВА В РЕСПУБЛИКЕ КАЗАХСТАН}

В статье представлен анализ развития государственно-частного партнерства в Республике Казахстан. Авторами продемонстрирована актуальность данного явления в инновационной экономике и обосновывается необходимость его дальнейтего развития в иелях поддержания сочиально-экономического роста экономики. Обозначены характерные особенности эволюиии государственно-частного партнерства. Показаны основные нормативные акты, регулирующие деятельность субъектов государственно-частного партнерства в Республике Казахстан. Приведены количественные и качественные показатели по внедрению механизма ГЧП в разрезе регионов и выявлены регионы, демонстрируюшие высокий уровень вовлеченности при реализачии проектов. Авторами приведены факторы, способствующие активизации и росту количества проектов. Обоснованы преимущества взаимодействия государства и субъектов предпринимательства, среди которых можно выделить - трансферт новых технологий, методик и знаний, что в конечном результате приводит к повышению качества предоставляемых услуг. Обозначены характерные особенности реализачии данной формы взаимодействия в Казахстане и продемонстрировань основные направления развития. Проведенное исследование позволило авторам сделать вывод о том, что государственно-частное партнерство на сегодняшний день демонстрирует эффективность и позволяет использовать преимущества каждой из участвуюших сторон в иелях достижения общественно значимых результатов.

Ключевые слова: государственно-частное партнерство, взаимодействие, органы государственной власти, субъекты предпринимательства, результативность, инвестиционные проекты, эффективность, бизнес, новый государственный менеджмент, государственные услуги.

Кілт сөздер: мемлекеттік-жекешелік әріптестік, өзара іс-қуимыл, мемлекеттік билік органдары, кәсіпкерлік субъектілері, нәтижелілік, инвестициялық жобалар, тиімділік, бизнес, жаңуа мемлекеттік менеджмент, мемлекеттік қъызметтер көрсету.

Keywords: public-private partnership, interaction, public authorities, business entities, efficiency, investment projects, efficiency, business, new public management, public services.

JEL classification 32

Введение. Актуальность и особенность государственно-частного партнерства (ГЧП) заключается в том, что оно, выступая в качестве публичного управления экономикой, является организационноэкономическим фактором сотрудничества государственных структур и субъектов предпринимательства, обеспечивающим 
социально- экономический рост в развитии страны.

Одной из причин внедрения механизма государственно-частного партнерства в нашей стране является потребность в инвестициях, обеспечивающих реализацию социально-значимых объектов. На сегодняшний день ГЧП используется как один из самых эффективных инструментов инновационной системы, который способствует динамичному росту и развитию регионов.

Необходимость применения инструментов ГЧП, в особенности при реализации инфраструктурных проектов, подчеркивал Первый Президент Н. Назарбаев: "Для привлечения частного капитала нужно использовать все возможные виды и формы ГЧП: доверительное управление госимущуеством, сервисные контракты и др. При этом следует максимально упростить и ускорить все прочедуры согласования, особенно в отночении небольших проектов. ГЧП долюжны стать основнылм механизмом развития инфраструктуры, в том числе соичиальной» [1].

В Казахстане государственно-частное партнерство в основном представлено инфраструктурными проектами, реализация которых характеризуется значительными рисками. Техническая сложность строительства и эксплуатации таких проектов, а также процессы планирования как правило, являются источниками риска. Данные риски следует выявлять, количественно оценивать и управлять ими. И в данном случае, эффективный проектный менеджмент применяемый в деятельности субъектов частного сектора, может быть успешно инкорпорирован при реализации проектов в рамках государственно-частного партнерства. Таким образом, государственно-частное партнерство представляет собой взаимовыгодное сотрудничество для обеих сторон.

Методы исследования. В рамках данного исследования применялись следующие методы: экономико-статистический, метод научного обобщения и монографический методы научного исследования. Информационную базу исследования составили научные труды, а также сборники аналитической информации в области государственно-частного партнерства.

Обзор литературы. Вопросы эффективного взаимодействия государства и бизнеса в рамках ГЧП набирают свою актуальность в последнее десятилетие. О чем свидетельствуют работы не только казахстанских, но и зарубежных ученых. Так, российские ученые Варнавский В.Г., Клименко А.В., Королев В.А. [2] на основе анализа теории государственно-частного партнерства, а также современных российской и мировой практики рассматривают методологические и практические аспекты его становления и развития.

Среди отечественных авторов можно выделить работу Есдаулетовой А.А. и Джунусбековой Г.А. [3], в которой исследуются приоритетные отрасли проектов ГЧП в развитых и развивающихся странах, а также в странах с переходной экономикой, и вносятся предложения о необходимости обеспечения определенных условий для успешного функционирования данного механизма. Основные тенденции развития государственно-частного партнерства в Республике Казахстан нашли отражение в научной работе Мадиева Ж.А. [4].

Учеными Таубаевым А.А., Талимовой Г.У., Сайфуллиной Ю.М., Борисовой Е. И. [5] на основе анализа зарубежного опыта применения основных форм государственно-частного партнерства обосновывается необходимость развития региональной индустриально-инновационной инфраструктуры.

Государственно-частное партнерство на сегодняшний день представляет большой интерес для изучения, и в данной статье авторами будуг определены некоторые аспекты данного явления и проведен анализ развития с учетом региональных особенностей. 
Основная часть. Государственночастное партнерство возникло в середине прошлого столетия и изначально обозначало совместное финансирование различного рода образовательных программ в рамках частно-государственного альянса. Затем данные инструменты стали применяться к широкому перечню различных совместных проектов, охватывающих широкий спектр отраслей народного хозяйства.

В большей степени проекты государственно-частного партнерства реализовывались в ходе создания стратегически важной для национальных экономик инфра- структуры в сфере тяжелой индустрии, энергетики, автомобильных и железных дорог, телекоммуникаций, социально-значимых объектов, магистральных нефтегазопроводов [2].

Реализация инфраструктурных проектов ГЧП позволяет повысить качество государственных услуг, а также использовать не только капитал, но и успешные практики в области инвестиционного и проектного менеджмента. Вместе с тем дает возможность направить высвободившиеся бюджетные средства на другие цели социальноэкономического развития [4].

Таблица 1

\section{Преимущества сторон при использовании инструментов государственно-частного партнерства*}

\begin{tabular}{|c|c|}
\hline ГОСУДАРСТВО & БИЗНЕС \\
\hline $\begin{array}{l}\text { Эффективное использование земельных } \\
\text { ресурсов }\end{array}$ & $\begin{array}{l}\text { - Получение инвестиций на долгосрочной } \\
\text { основе }\end{array}$ \\
\hline $\begin{array}{l}\text { - Сокращение расходов на создание и } \\
\text { поддержание социальной инфраструктуры }\end{array}$ & - Обеспеченность заказами \\
\hline $\begin{array}{l}\text { П Профессиональное управление } \\
\text { проектами ГЧП }\end{array}$ & $\begin{array}{l}\text { - Независимость в принятии } \\
\text { управленческих решений }\end{array}$ \\
\hline - Снижение финансовых и прочих рисков & $\begin{array}{l}\text { - Обеспеченная государственными } \\
\text { гарантиями рентабельность }\end{array}$ \\
\hline
\end{tabular}

* Составлена авторами на основе источника [2]

Инновационный характер такого подхода заключается в возможности совместного использования преимуществ различных форм собственности в рамках ГЧП с гарантированным сохранением полномочий участников партнерства [2].

В рамках данной формы партнерства предполагается, что инвестор привлекается к дальнейшей эксплуатации и организации деятельности объекта, и в некоторых случаях, возможно, его вхождение в число собственников объекта.

Можно выделить некоторые отличительные особенности, характерные для данной схемы партнерства при реализации инфраструктурных проектов.

Развитие механизма государственночастного партнерства в Казахстане необходимо соотносить с основными мировыми трендами, как в части законодательного регулирования, так и практики подготовки и реализации проектов. В этой связи ведется активная работа по инкорпорированию опыта ведущих мировых центров ГЧП и актуализации нормативно-правовой базы, исходя из современных и перспективных направлений развития теории и практики ГЧП [4]. 


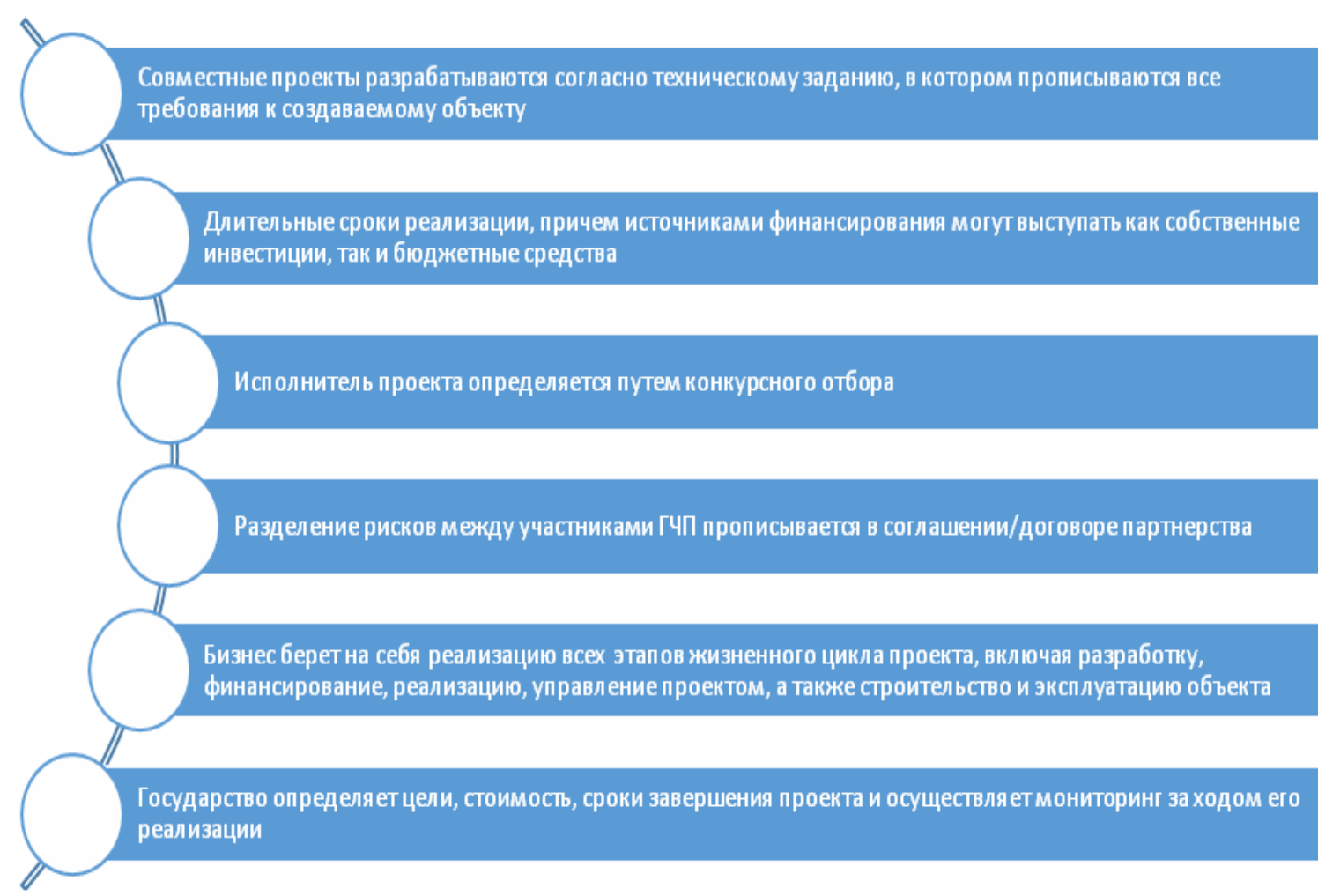

Рисунок 1. Особенности государственно-частного партнерства при реализации инфраструктурных проектов*

*Составлен авторами на основе источника [2]

Развитию государственно-частного партнерства в Республике Казахстана способствовал, прежде всего, тот фактор, что в модернизации инфраструктуры нуждалось значительное количество объектов социальной сферы. Данные мероприятия требовали поиска дополнительных источников финансирования. Все это стало толчком к имплементации опыта развитых стран по реализации концепции государственночастного партнерства.

Первые проекты государственно-частного партнерства были реализованы в Казахстане в 2005-2007 годах (рис. 2).

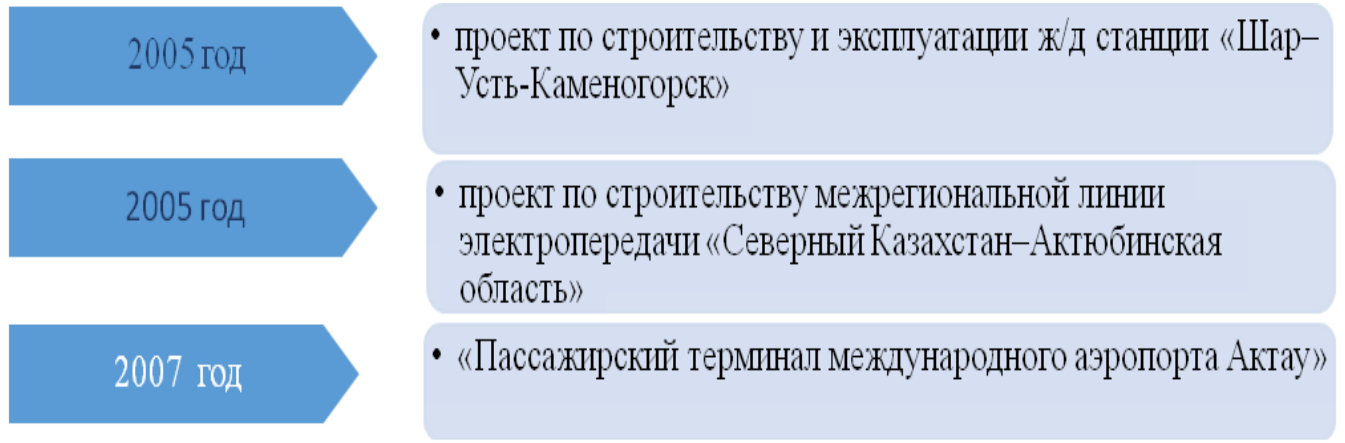

Рисунок 2. Первые проекты ГЧП, реализованные в Казахстане*

*Составлен авторами на основе источника [4] 
Общая стоимость этих проектов составила 46,2 млрд тенге.

Ограниченность количества проектов обусловлена тем фактором, что в тот период времени участники ГЧП руководствовались действовавшим Законом о концессиях, который предусматривал реализацию только крупных инфраструктурных проектов. Однако даже незначительное количество реализованных проектов позволило оценить все преимущества механизма ГЧП.

Этап реализации вышеназванных проектов стал отправной точкой в развитии отечественной практики государственночастного партнерства. Первоначально была проведена обширная работа в сфере совер- шенствования законодательной и институциональной базы. В 2015 г. был принят новый Закон РК «О государственно-частном партнерстве», который снял ряд ограничений по сферам применения ГЧП, что позволило расширить состав участников, формы и виды контрактов, а также внедрить возможность частной финансовой инициативы.

В результате внедрения данных нововведений процесс развития ГЧП демонстрировал хорошие результаты. Если в 2006 г. было 2 проекта, то в 2018 г. количество проектов увеличилось до 304, а к 01.10.2020 г. составило уже 815 договоров на общую сумму 1,16 трлн тенге (рис. 3) [4].

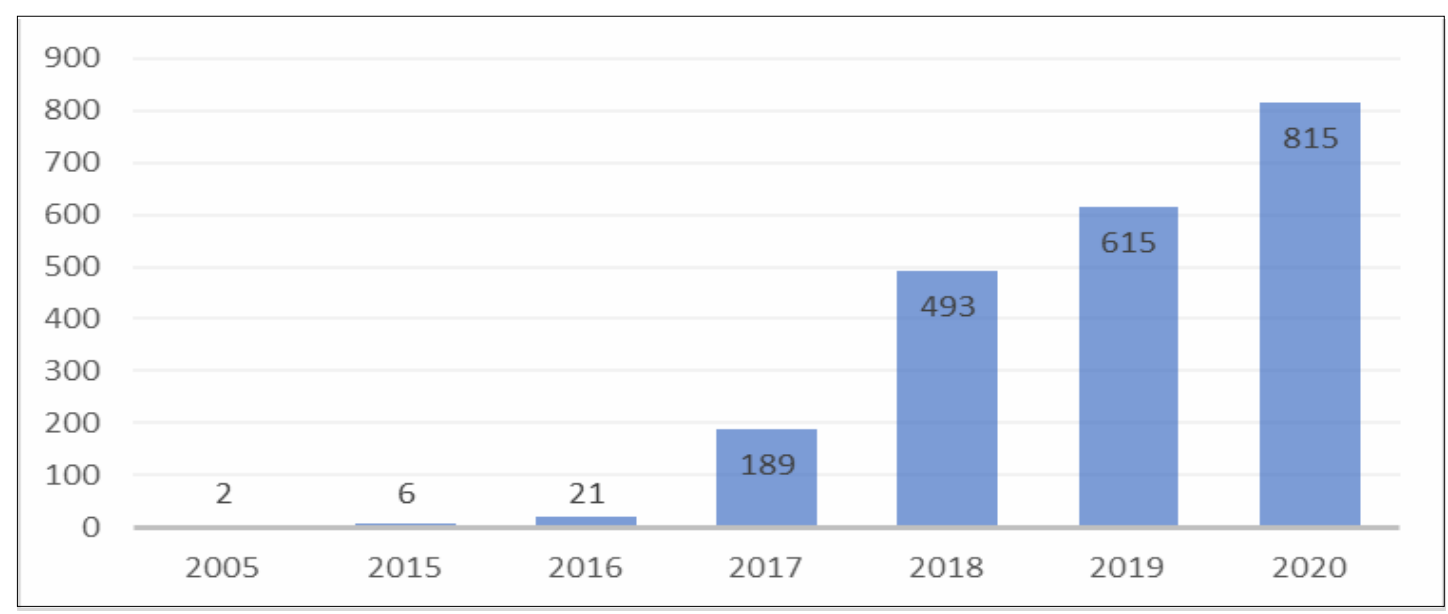

Рисунок 3. Количество проектов ГЧП в период с 2006 по 2020 годы*

* Составлен авторами на основе источника [6]

Согласно данным Единой базы проектов Казахстанского центра государственно-частного партнерства объем инвестиций в разрезе регионов по состоянию на 03.10.2020 г. представлен на рисунке 4.

Как видно из рисунка 4, явным лидером по инвестициям в рамках ГЧП является Туркестанская область, со значительным отрывом, далее следуют Алматинская область (28,2 млрд) и Атырауская область (26,8 млрд), а также города республиканского значения - Нур-Султан (23,7 млрд) и Шымкент (22 млрд), остальные регионы демонстрируют достаточно низкие показатели по объемам инвестиций.

Количественные параметры по проектам в региональном аспекте представлены на рисунке 5.

Однако, если же обратить внимание на количественные показатели, то картина в разрезе регионов кардинально меняется, за исключением Туркестанской области. В количественном измерении в лидеры вышла Восточно-Казахстанская область (187), средние показатели демонстрируют регионы южной части Казахстана: Туркес- 
танская область (105), Жамбылская область (66) и Кызылординская область (57). За-

мыкает список регионов по количеству проектов Мангистауская область (9).

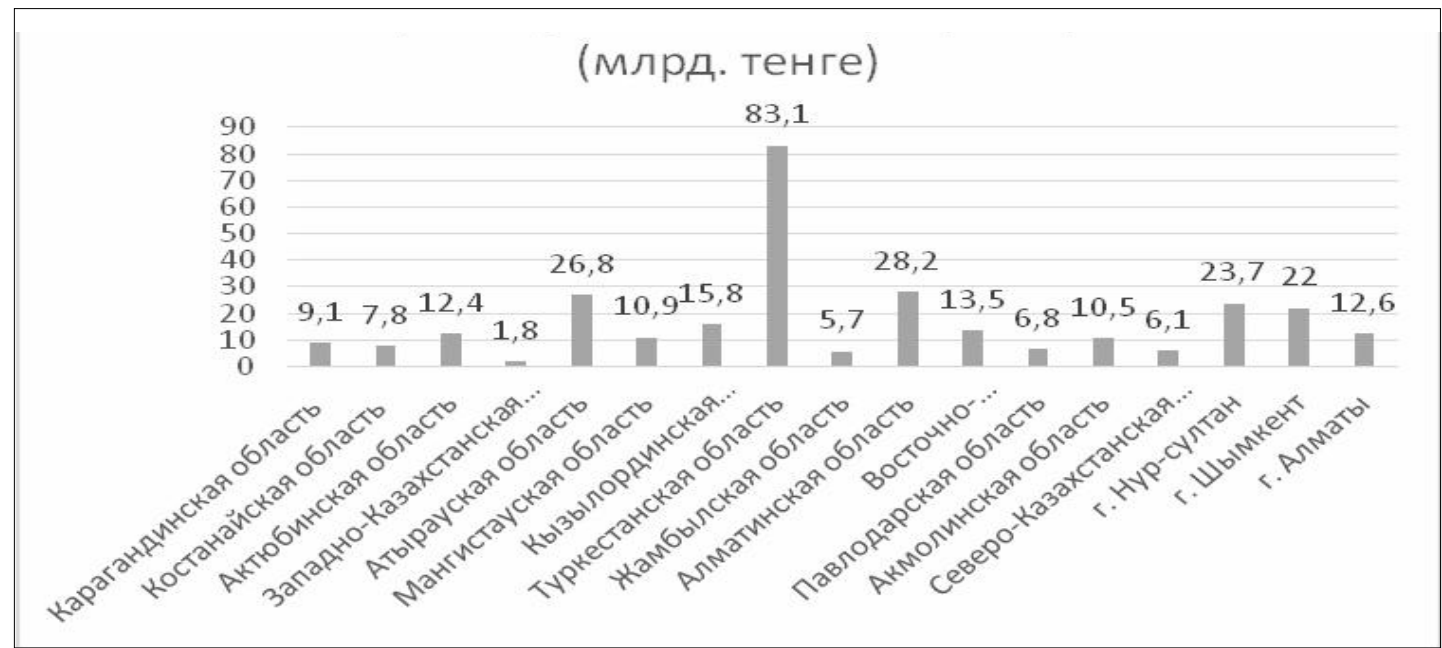

Рисунок 4. Объем инвестиций в рамках ГЧП в разрезе регионов*

* Составлен авторами на основе источника [7]

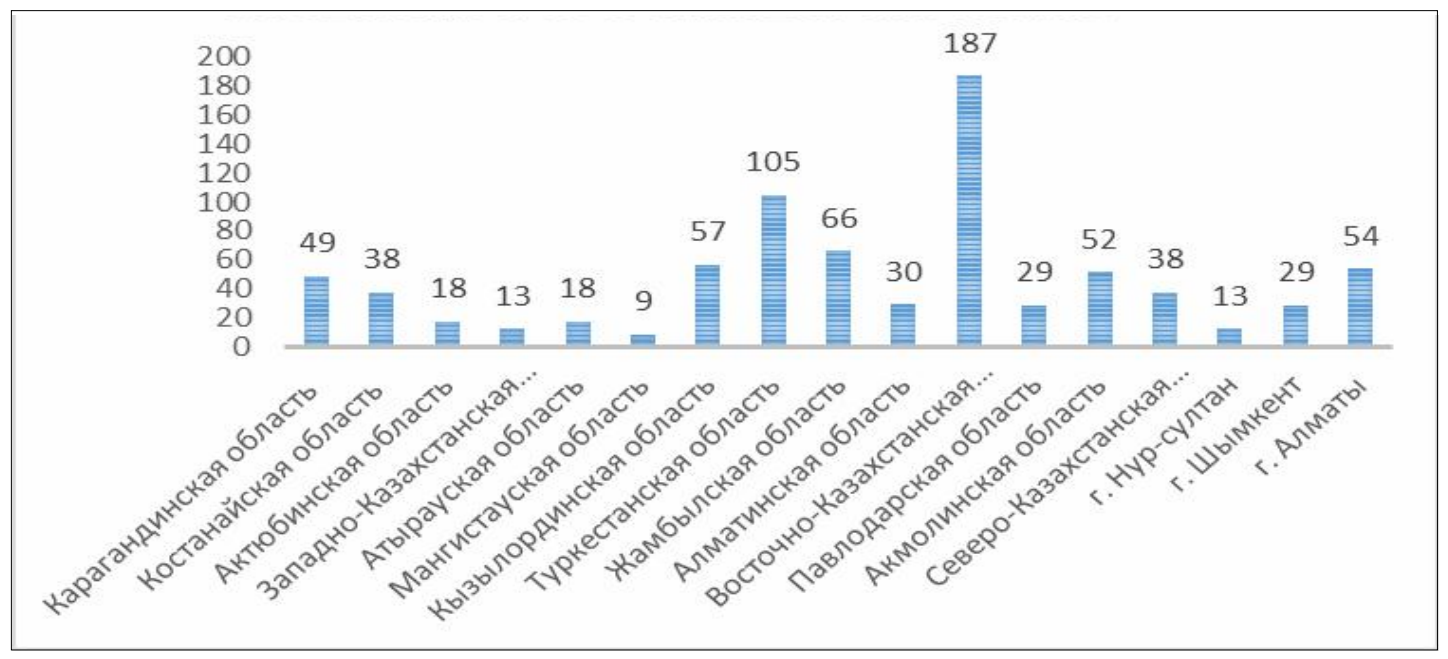

Рисунок 5. Данные по количеству проектов в разрезе регионов*

*Составлен авторами на основе источника [7]

Следует отметить, что на активизацию и рост количества проектов повлияли такие факторы, как внедрение частной финансовой экспертизы, повышение самостоятельности местных исполнительных органов (МИО), создание региональных центров ГЧП [6]. Открытие 16 региональных центров позволило повысить эффективность и облегчить процедуры по сопро- вождению местных бизнес-инициатив. Кроме того, работа этих центров позволяет развивать кадровый потенциал в этой сфере как на центральном уровне, так и на местном уровне.В целом, следует развивать региональную индустриально-инновационную инфраструктуру на базе создаваемых региональными СПК свободно-экономических зон, которые в мировой прак- 
тике признаны ведущими формами поддержки промышленных инноваций [5].

Для эффективной реализации проектов ГЧП, на наш взгляд, необходимо обратить внимание также и на совершенствование процедур подготовки ГЧП проектов.

Выводы. Государственно-частное партнерство способно эффективно функционировать только в условиях благоприятной институциональной среды. В Казахстане заложены нормативные основы регулирования ГЧП, что способствует его поступательному и всестороннему развитию. Закон «О государственно-частном партнерстве» (2015 г.) напрямую способствовал эффективному развитию ГЧП, вследствие нововведений и снятия ряда ограничений.

Несмотря на положительную динамику развития ГЧП в Казахстане, негативное влияние на деятельность субъектов предпринимательства оказала пандемия. Меры государственной поддержки частного сектора, а также различные налоговые преференции и льготы позволили бы снизить давление на частный сектор и продолжать работу в данном направлении.

В ходе исследования был выявлен значительный дисбаланс в количественном и качественном разрезе в региональном аспекте. Следовало бы уделить больше внимания решению этого вопроса, чтобы обеспечить распределение инвестиций в соответствии с социальными и экономическими потребностями регионов. Актуальным остается вопрос подготовки специалистов, способных на профессиональном уровне осуществлять управление в рамках реализации проектов ГЧП.

\section{ЛИТЕРАТУРА}

1. Послание Президента Республики Казахстан - Лидера нации Н.А. Назарбаева народу Казахстана. - Астана, 31 января 2017 года.«Третья модернизация Казахстана: глобальная конкурентоспособность». Текст: электронный //Официальный сайт Президента РК, 2017. - URL: https://www.akorda.kz/ru/addresses/addresses_of_president/poslanie-prezidentarespubliki-kazahstan-nnazarbaeva-narodu-kazahstana-31-yanvarya-2017-g (Дата обращения: 29.08.2020).

2. Варнавский В.Г., Клименко А.В., Королев В.А. Государственно-частное партнерство: теория и практика. - М.: ГУ-ВШЭ, 2010. - 287 с.

3. Есдаулетова А., Джунусбекова Г.А. Роль государственно-частного партнерства в развитии инвестиционной деятельности в Казахстане // Вестник КЭУ: экономика, философия, педагогика, юриспруденция. - 2014. - № 3. - С. 74-78.

4. Мадиев Ж. Основные тенденции развития государственно-частного партнерства в Республике Казахстан. - 2019. - № 1. - С. 7-11.

5. Таубаев А.А., Талимова Г.У., Сайфуллина Ю.М., Борисова Е.И. Приоритет государственно-частного партнерства при финансировании наукоемкого сектора экономики // Корпоративное управление и инновационное развитие экономики Севера // Вестник Научно-исследовательского центра корпоративного права, управления и венчурного инвестирования Сыктывкарского государственного университета. - 2019. - № 3. - С. 56-64.

6. https://www.zakon.kz/4944163-vystuplenie-ministra-natsionalnoy.html (Дата обращения: 29.08.2020).

7. https://kzppp.kz/projects/ (Дата обращения: 02.10.2020). 


\section{REFERENCES}

1. Poslanie Prezidenta Respubliki Kazahstan - Lidera natsii N.A.Nazarbaeva narodu Kazahstana. - Astana, 31 ianvaria 2017 goda. «Tretia modernizatsiia Kazahstana: globalnaia konkurentosposobnost». Tekst: elektronnyi. Ofitsialnyi sait Prezidenta RK. - 2017. - URL: https:// www.akorda.kz/ru/addresses/addresses_of_president/poslanie-prezidenta-respubliki-kazahstannnazarbaeva-narodu-kazahstana-31-yanvarya-2017-g (Data obracsheniia:29.08.2020). [in Russian].

2. Varnavskij V.G., Klimenko A.V., Korolev V.A. Gosudarstvenno-chastnoe partnerstvo: teoriya i praktika. - M.: GU-VSHE, 2010. - 287 s. [in Russian].

3. Esdauletova A., Dzunusbekova G.A. Rol gosudarstvenno-chastnogo partnerstva v razvitii investitsionnoi deiatelnosti v Kazahstane // Vestnik KEU: ekonomika, filosofiia, pedagogika, iurisprudentsiia. - 2014. - № 3. - S. 74-78 [in Russian].

4. Madiyev Zh. Osnovnye tendencii razvitiya chastno-gosudarstvennogo artnerstva v Respublike Kazakhstan. - 2019. - № 1. - S. 7-11 [in Russian].

5. Taubaev A.A., Talimova G.U., Sajfullina Yu.M., Borisova E.I. Prioritet gosudarstvennochastnogo partnerstva pri finansirovanii naukoemkogo sektora e'konomiki// Korporativnoe upravlenie i innovaczionnoe razvitie e 'konomiki Severa // Vestnik Nauchno-issledovatel'skogo czentra korporativnogo prava, upravleniya i venchurnogo investirovaniya Sy'kty'vkarskogo gosudarstvennogo universiteta. - 2019. - № 3. - S. 56-64 [in Russian].

6. https://www.zakon.kz/4944163-vystuplenie-ministra natsionalnoy.html (Data obracsheniia: 29.08.2020) [in Russian].

7. https:// kzppp.kz/projects/ (Data obracsheniia: 29.08.2020) [in Russian].

\section{Г.Е. Накипова, А.Ж. Шалабаева}

\section{ҚАЗАҚСТАН РЕСПУБЛИКАСЫНДА МЕМЛЕКЕТТІК-ЖЕКЕМЕНШІК ӘРІПТЕСТІКТІ ЖУЗЕГЕ АСЫРУДЫҢ КЕЙБІР ЕРЕКШЕЛІКТЕРІ}

Андатпа

Мақалада Қазақстан Республикасындағы мемлекеттік-жекешелік әріптестіктің дамуына талдау жасалған. Авторлар бұл құбылыстың өзектілігін көрсетіп, экономиканың әлеуметтік-экономикалық өсуін қолдау мақсатында оны одан әрі дамыту қажеттілігін негіздейді. Мемлекеттікжекешелік әріптестік эволюциясының тән ерекшеліктері белгіленген. Сонымен қатар Қазақстан Республикасындағы мемлекеттік-жекешелік әріптестік субъектілерінің қызметін реттейтін негізгі нормативтік актілер де көрсетілген. Өңірлер бөлінісінде МЖӘ тетігін енгізу бойынша сандық және сапалық көрсеткіштерді келтіре отырып, жобаларды іске асыру кезінде тартылудың жоғары деңгейін көрсететін өңірлер анықталған. Мақалада авторлар жобалар санының өсуіне ықпал ететін факторларды келтіреді. Мемлекет пен кәсіпкерлік субъектілерінің өзара іс-қимылының артықшылықтары негізделген, олардың арасында жаңа технологиялар, әдістемелер мен білім трансфертін бөліп көрсетуге болады, бұл сайып келгенде көрсетілетін қызметтер сапасының артуына алып келеді. Қазақстанда өзара іс-қимылдың осы нысанын іске асырудың сипатты ерекшеліктері белгіленді және дамудың негізгі бағыттары көрсетілді. Жүргізілген зерттеу авторларға бүгінгі таңда мемлекеттік-жекешелік әріптестік тиімділікті көрсетеді және әлеуметтік маңызды нәтижелерге қол жеткізу үшін қатысушы тараптардың әрқайсысының артықшылықтарын пайдалануға мүмкіндік береді деген қорытынды жасауға болады. 


\section{G. Nakipova, A. Shalabayeva \\ SOME FEATURES OF THE IMPLEMENTATION OF PUBLIC-PRIVATE PARTNERSHIPIN THE REPUBLIC OF KAZAKHSTAN}

\section{Annotation}

The article presents an analysis of the development of public-private partnership in the Republic of Kazakhstan. The authors demonstrate the relevance of this phenomenon and justify the need for its further development in order to maintain the socio-economic growth of the economy. The characteristic features of the evolution of public-private partnership are outlined. The main normative acts regulating the activities of public-private partnership entities in the Republic of Kazakhstan are shown.

The quantitative and qualitative indicators for the implementation of the PPP mechanism in the context of regions are presented, and regions that demonstrate a high level of involvement in project implementation are identified. The authors present factors that contribute to the activation and growth of the number of projects. The advantages of interaction between the state and business entities are justified, among which we can distinguish the transfer of new technologies, techniques and knowledge, which ultimately leads to an increase in the quality of services provided. The characteristic features of the implementation of this form of interaction in Kazakhstan are outlined and the main directions of development are demonstrated. The conducted research allowed the authors to conclude that public-private partnership nowadays demonstrates efficiency and allows using the advantages of each of the participating parties to achieve socially significant results.

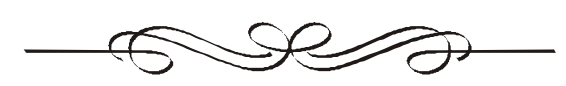


DOI 10.52260/2304-7216.2020.4(41).5

ӘОЖ 332.145

FTAMP 06.61.33
P.Е. Несипбаев*, докторант PhD

А.А. Мусатаева, $P h D$., доиент

Е.И. Борисова, э.в.к., доиент

Казтұтынуодавы Караванды экономикальққ университеті Қараванды қ. e-mail: nessipbayev_r@mail.ru * - негізгі автор (хат-хабарларға арналған автор)

\section{ҚАРАҒАНДЫ ОБЛЫСЫН ДАМЫТУДЫН 2016-2020 ЖЫЛДАРҒА АРНАЛҒАН БАҒДАРЛАМАСЫН ӘЗІРЛЕУ МЕН ІСКЕ АСЫРУДЫН ТИІМДІЛІГІ}

Мақ̆алада аумақты дамыту бавдарламаларын әзірлеу қажеттілігі анықталып, «Қараванды облысын дамытудың 2016-2020 жылдарва арналван бавдарламасын» әзірлеу мен іске асыру барысындагы артықшылықтар, кемшіліктер мен сәйкессіздіктер көрсетілген. Бұл мақ̆алада стратегиялық басққару ұzымдары қарастырылады, длеуметтік блок салаларын басққару мысалында стратегиялық және авымдагы басққарудың айырмашылықтары сипатталван. Сондай-ақ өңірдің аумақтық шаруашылывын басқұарудың мәні, халықтыңң тіршілігін қ̧амтамасыз ету мен әлеуметтік қъызмет көрсетуді іске асыру, тұтастай алванда аумақтық шаруашылықты жетілдіру, олардың невұрлым жовары деңгейдегі жаңуа сапалық сипаттамаларын алу мәселелері зерттелді. Маққала авторларының пікірінше, аумақтық экономиканы басқ̧арудың негізгі нысаны басқ̧ару органы шеңберіндегі авымдаzы және стратегиялық басқарудың үйлесімі больп табылады. Авымдаzы және стратегиялық басқаруды біріктіруге бавытталван басқ̧ару құрылымдарын құрудың негізгі тәсілдерінің егжейтегжейлі сипаттамасы ұсынылган. Басқару органының ішкі құрылымын құрува, басқарудың әр түрлі түрлерін ұйымдастырудың ерекшеліктерін ескеруге өте мұқият қарауды қажет ететін осы тәсілді жүзеге асыруга ерекше назар аударылады. Авторлар стратегиялық жоспарларды іске асырудың негізгі нәтижелерін анықтады, сонымен қатар аумақтың стратегиялық дамуының түпкі нәтижесі орындалган іс-шаралардың әлеуметтік әсеріне құол жеткізу болып табылады, бұл аймақтың осы аумавында тұратын халықтың әл-ауққатын арттырудан тұрады. Мақала ққазіргі экономика мәселелеріне қыызывушылық танытатын көпшілік оқырмандарва арналzан.

Кілт сөздер: өңір, аумақтық даму бавдарламасы, мемлекеттік бавдарлама, мемлекеттік жоспарлау жүйесі, нысаналь индикаторлар, талдау, жоспарлау, стратегия, экономика, мақсат.

Ключевые слова: регион, программа территориального развития, государственная программа, система государственного планирования, иелевые индикаторы, анализ, планирование, стратегия, экономика, иель.

Keywords: region, territorial development program, state program, state planning system, target indicators, analysis, planning, strategy, economy, celle.

JEL classification: R19, R22

Кіріспе. Қазіргі кезде қарқын алған, уақыт сынынан өткен бағдарламалық-мақсатты әдістің кең таралуы осы әдісті Қазақстан Республикасының тәуелсіздік жылда- рынан кейін ғана қолдана бастағандығында. Яғни осы әдісті тереңірек зерттей келе, оның қазақстандық моделінің кемшіліктерін анықтай келе, еліміздің әлеуметтік-экономикалық 
дамуын үдете алу мүмкіндігінде.

«Қарағанды облысын дамытудың 20162020 дейінгі бағдарламасы» [1] Қазақстан Республикасының 2020 жылға дейінгі Стратегиялық даму жоспарын, Мемлекет басшысының 2015 жылғы 30 қарашадағы «Қазақстан жаңа жаһандық нақты ахуалда: өсім, реформалар, даму» атты Қазақстан халқына Жолдауын іске асыру шеңберінде әзірленді. Бағдарлама Қазақстан Республикасы Президентінің 2011 жылғы 21 шілдедегі № 118 Жарлығымен бекітілген Елді аумақтық-кеңістікте дамытудың 2020 жылға дейінгі болжамды схемасын іске асыру тетіктерінің бірі болып табылады. Болжамды схема - өңірлік саясатты іске асырудың құралы, оның мақсаты өңірлердің әлеуметтікэкономикалық әлеуетін тиімді пайдалану негізінде олардың орнықты дамуы үшін жағдай жасау болып табылады.

Бағдарламаның 2020 жылға дейінгі алдағы кезеңге арналған мақсаттарына қол жеткізу мынадай міндеттерді шешу арқылы жүзеге асырылатын болады:

- елдің аумақтық дамуын жетілдіру;

- мемлекет үшін стратегиялық маңызы бар өндірістің жаңа капитал сыйымды салаларын құру;

- аймақтың экономикалық дамуы мен әлеуметтік саласының күрделі мәселелерін шешудің негізгі мақсаттары мен міндеттерінің жүйелік сипаты;

- бюджеттен тыс қорларды, коммерциялық және мемлекеттік кәсіпорындардың меншікті қаражатын, шетел инвесторларының қорларын қосымша тартатын бюджеттік ресурстарды мақсатты пайдалануда мультипликативтік әсерді пайдалану мүмкіндігі.

Зерттеудің ақпараттық негізі - нормативтік құқықтық актілер, Қазақстан Республикасы мен әлемдік ресми статистикалары, мемлекеттің ақпараттық сайттары, ғылыми конференциялар материалдары, мерзімді басылымдар, ғаламдық ақпараттық желі «Интернет».
Зерттеудің әдісі мен міндеттері. Аталмыш мақсатқа қол жеткізу үшін келесі міндеттер алға қойылып, шешілді:

1) өңірлік бағдарламалардың мәнін ашып, түрлері мен функцияларын қарастыру;

2) өңірлік бағдарламаларды әзірлеу мен жүзеге асыру механизмін зерттеу;

3) өңірлік бағдарламаларды әзірлеу мен іске асырудың шетелдік тәжірибесін талдау;

4) Қарағанды облысын дамытудың 2016-2020 жылдарға арналған бағдарламасын әзірлеу және жетілдіруге қатысты ұсыныстар енгізу;

5) өңірлік даму бағдарламаларын әзірлеу тетігін жетілдіру жолдарын анықтау.

Әдебиеттік шолу. Бағдарламаларды Қазақстан Республикасының орталық, жергілікті атқарушы органдары және Қазақстан Республикасы Үкіметінің жанындағы консультативтік-кеңесші органдар стратегиялық және индикативтік жоспарларға сәйкес өмірдің экономикалық, әлеуметтік және басқа да салаларының маңызды проблемаларын шешу үшін әзірлейді.

«Қазақстан Республикасында салалық (секторлық) және өңірлік бағдарламаларды әзірлеу мен іске асыру ережесі туралы» Қазақстан Республикасы Үкіметінің 2004 жылғы 26 ақпандағы № 231 қаулысы [1].

«Салалық бағдарламаларды әзірлеу, іске асыру, мониторингілеу, бағалау және бақылау ережесін бекіту туралы» Қазақстан Республикасы Үкіметінің 2010 жылғы 18 наурыздағы № 218 қаулысы [2].

«Қазақстан Республикасындағы мемлекеттік жоспарлау жүйесін бекіту туралы» Қазақстан Республикасы Үкіметінің 2017 жылғы 29 қарашадағы № 790 қаулысы [3]. Қарағанды облысы мәслихаттың 2017 жылы 12 желтоқсандағы XIII сессиясының № 263 шешімімен бекітілген «Қарағанды облысын дамытудың 2016-2020 жылдарға арналған бағдарламасы» [4].

«Қазақстан Республикасындағы Мемлекеттік жоспарлау жүйесінің кейбір мәсе- 
лелері туралы» Қазақстан Республикасы Ұлттық экономика министрінің 2018 жылғы 19 ақпандағы № 64 бұйрығы [5].

«Қазақстан Республикасының денсаулық сақтау саласын дамытудың 2016-2019 жылдарға арналған «Денсаулық» мемлекеттік бағдарламасын бекіту туралы» Қазақстан Республикасы Үкіметінің 2018 жылғы 15 қазандағы № 634 қаулысы [6].

«Қазақстан Республикасының Стратегиялық даму жоспарын, Елді аумақтық-кеңістікте дамытудың болжамды схемасын, мемлекеттік бағдарламаларды, мемлекеттік органдардың стратегиялық жоспарларын және аумақтарды дамыту бағдарламаларын әзірлеу жөніндегі әдістеме» Қазақстан Республикасы Ұлттық экономика министрінің 2018 жылғы 19 ақпандағы № 64 бұйрығына 1-қосымша [7].

Өңірлердің стратегиялық дамуын нормативті-құқықтық дамыту мәселелері отандық және жақын шетелдік мемлекеттік басқару саласының зерттеушілерінің сәйкес ғылыми еңбектерінде [8-11] қарастырылып, жүйелі түрде негіздеу мен жетілдіру жолдары ұсынылған. Бұл зерттеулердің басты тұжырымдары мақаланың негізгі бөліміне арқау болды.

Негізгі бөлім. Қазіргі таңда «Қазақстан Республикасындағы мемлекеттік жоспарлау жүйесін бекіту туралы» Қазақстан Республикасы Үкіметінің 2017 жылғы 29 қарашадағы № 790 қаулысына [3] сәйкес аумақты дамыту бағдарламалары мемлекеттік жоспарлау жүйесі құжаттарының қатарына енеді. Құжатқа сәйкес стратегиялық және бағдарламалық құжаттарды, мемлекеттік органдардың стратегиялық жоспарларын, өңірлерді дамыту бағдарламаларын талдау, үлгілеу, басымдықтарын, нысаналы көрсеткіштерін, стратегиялық мақсаттары мен міндеттерін айқындап, оларға қол жеткізу, ресурстық қамтамасыз ету жолдарын айқындау үдерісін әзірлеу болып табылады.

Яғни, аумақтық бағдарламалар «Қазақстан-2050» Стратегиясы, «Қазақстан Рес- публикасының 2025 жылға дейінгі Стратегиялық даму жоспары», «Елді аумақтықкеңістікте дамытудың болжамды схемасы», мемлекеттік бағдарламаларды, мемлекеттік органдардың стратегиялық жоспарларын, әлеуметтік-экономикалық даму болжамын іске асыру мақсатында әзірленуде.

Аумақты дамыту бағдарламасының құрылымы мынадай бөлімдерді қамтиды:

1) паспорт (негізгі сипаттамалары);

2) ағымдағы жағдайды талдау;

3) негізгі бағыттар, мақсаттар, нысаналы индикаторлар (көрсеткіштер) және оларға қол жеткізу жолдары;

4) қажетті ресурстар.

Бізбен талдауға алынған «Қарағанды облысын дамытудың 2016-2020 жылдарға арналған бағдарламасы» [4] келесі бөлімдерден тұрады:

Бөлім 1. Бағдарлама паспорты.

Бөлім 2. «Ағымдық жағдайды талдау». Бұл бөлім «Аумақтың әлеуметтік-экономикалық жағдайын талдау», «Аумақтың орташа шұғыл басымдылықта тұрақты әлеуметтік-экономикалық дамуының және бәсеке артықшылықтарын, негізгі мәселелерінің, тәуекелдерінің, ұстап тұру факторларының кешенді сипаттамасы» деген екі бөлімшелерден тұрады. Әр бөлімшеде салалар бойынша талдаулар жүгізілген.

Бөлім 3. «Негізгі бағыт, мақсаттар, нысаналы көрсеткіштер мен оларға қол жеткізу жолдары». Аталмыш бөлім Қарағанды облысын дамытудың негізгі 6 бағытын қамтиды. Олар:

Бағыт 1. Экономика.

Бағыт 2. Әлеуметтік сала.

Бағыт 3. Қоғамдық қауіпсіздік және құқықтық тәртіп.

Бағыт 4. Инфрақұрылым.

Бағыт 5. Экология және жер ресурстары. Бағыт 6. Мемлекеттік қызметтер.

Бөлім 4. Қажетті ресурстар.

Енді осы бағдарламаны ҚР Ұлттық экономика Министрінің «Қазақстан Республикасындағы мемлекеттік жоспарлау жүйе- 


\section{Экономика}

сінің кейбір мәселелері туралы» бұйрығына [5] сәйкестігіне талдауға көшейік.

Мазмұны жағынан бағдарламада жалпы
105 индикатор бар. 1-кестеде әр бағыт бойынша индикаторлар саны көрсетілген.

1 -кесте

\section{Қарағанды облысын дамытудың 2016-2020 жылдарға арналған бағдарламасында көрсетілген индикаторлар саны*}

\begin{tabular}{|c|c|c|}
\hline № & Бағыт & Индикаторлар саны \\
\hline 1. & Экономика & 27 \\
\hline 2. & Әлеуметтік сала & 39 \\
\hline 3. & Қоғамдық қауіпсіздік және тәртіп & 12 \\
\hline 4. & Инфрақұрылым & 13 \\
\hline 5. & Экологиялық және жер ресурстары & 13 \\
\hline 6. & Мемлекеттік қызметтер & 1 \\
\hline
\end{tabular}

Жоғарыдағы кестеден әр салада индикаторлар санының едәуір айрықшаланатынын байқауға болады.

Бағдарламаның паспортына тоқтала кетсек. «Атауы», «Әзірлеуге арналған негіздеме», «Облыстың негізгі сипаттамалары», «Негізгі бағыттары», «Мақсаттары» деген бағандардағы ақпараттар дұрыс келтірілген. Бірақ нысаналы көрсеткіштер бағанындағы бірнеше сәйкессіздікті атап өту керек.

1. «Экономика» бағыты бойынша «Алдыңғы жылға қатысты \%-бен өңдеу өнеркәсібіндегі еңбек өнімділігінің таза өсімі» [4] индикаторы артық деп есептейміз. Біздің ойымызша, «2015 жылға қатысты \%-бен өңдеу өнеркәсібіндегі еңбек өнімділігінің таза өсімі» индикаторы да жеткілікті.

2. «Экономика» бағыты бойынша «2012 жылғы деңгеймен салыстырғанда машина жасаудағы еңбек өнімділігінің үлестік артуы» [4] индикаторындағы 2012 жылғы көрсеткішпен салыстыру қолданыстағы заңнамаға сәйкес келмейді. Себебі ҚР Ұлттық экономика министрінің «Қазақстан Республикасындағы мемлекеттік жоспарлау жүйесінің кейбір мәселелері туралы» бұйрығының 7-ші тарауының 140-шы пунктінде [5] жазылғандай «нысаналы көрсет- кіштер бағдарлама әзірленетін жоспарлы қезеңнің алдындағы соңғы 2 жылда нақты қол жеткізілген мәндерді көрсетумен келтіріледі» делінген.

3. «Экономика» бағыты бойынша «Ұйымдастырылған шаруашылықтардағы ірі қара мүйізді және ұсақ қара мүйізді мал басының үлесі» көрсеткішінде [4] «ірі қара мал», «кішкентай мал», «тұқымды өзгерістерге қатысатын ірі қара мүйізді және ұсақ қара мүйізді мал үлесі», «ірі қара мал», «кіші мал» терминдерінде «кішкентай мал» және «кіші мал» сөздерінің дұрыс қолданбауында.

4. Әлеуметтік бағыт бойынша «Жаратылыстану-математика пәндері бойынша мектеп тамамдаушылардың арасында білім беру бағдарламаларын өте жақсы меңгерген оқушылардың үлесі, \%-бен» көрсеткіші біздің ойымызша білім беру қызметтерінің жоғары бәсекеге қабілеттілігін жақсарту мақсатына сәйкес келмейді. Мектеп оқушыларын белгілі бір пән бағыттары бойынша бөліп-жарып қарастыруға болмайды деп ойлаймыз. Себебі Мемлекеттік стратегиялар мен бағдарламаларда жастар білім деңгейін тек бір бағыт бойынша емес, жалпы көтеру көзделген. 
5. Әлеуметтік бағыт бойынша «10 мың адамға шаққандағы дәрігерлер саны», «10 мың адамға шаққандағы орта медициналық қызметкердің саны» көрсеткіштері медициналық қызметті дамытудың заманауи үлгісіне жатпайды және Қазақстан Республикасының денсаулық сақтау саласын дамытудың 2016-2019 жылдарға арналған «Денсаулық» мемлекеттік бағдарламасында [6] аталмыш индикаторлар белгіленбеген.

6. Әлеуметтік бағыттағы тағы бір «Дене шынықтырумен және спортпен шұғылданатын азаматтарды қамту» индикаторы бойынша ақпарат жинау мүмкін болып табылмайды. Азаматтардың спортпен айналысуы немесе айналыспауы абстрактілі ұғым болып табылады.

7. Бағдарлама паспортындаға маңызды сәйкессіздіктің бірі - «Қажетті ресурстар» бағанының жоқтығы. «Қазақстан Республикасының Стратегиялық даму жоспарын, Елді аумақтық-кеңістікте дамытудың болжамды схемасын, мемлекеттік бағдарламаларды, мемлекеттік органдардың стратегиялық жоспарларын және аумақтарды дамыту бағдарламаларын әзірлеу жөніндегі әдістемеде» [7] осындай бағананың болу керектігі туралы талап қойылған.

Келесі «Негізгі бағыт, мақсаттар, нысаналы индикаторлар мен оларға жету жолдары» бөліміне талдау жасайық:

1. Бағдарламада «2015 жылға Қарағандағы өңдеу өнеркәсібіндегі еңбек өнімділігінің таза өсімі, \%-бен» [4] көрсеткішіндегі мәліметтерді қарайтын болсақ, таза өсім 2015 жылы 100\%, 2016 жылы 129,4\%, 2017 жылы 100,1\%, 2018, 2019, 2020 жылдары 100,2\% деп көрсетілген. «Ағымдық жағдайды талдау» бөлімінде бұндай көрсеткіш бойынша мәлімет келтірілмеген.

2. «1.5 мақсатындағы «Аумақта шағын және орта бизнесті дамыту үшін ыңғайлы бизнес-орта» кестесінде берілген «Жалпы өңірлік өнімдегі шағын және орта бизнестің үлесі, \%» көрсеткішінің 2020 жылғы өсу болжамы 12,9\% деп бекітілген. 2015 жылы
12,7\% болғанын ескерсек, 5 жылдың ішінде тек 0,2\%-ға өсу «Қазақстан-2050» Стратегиясында қойылған 2030 жылы ЖІӨ-дегі шағын, орта бизнес үлесі 2 есеге артуы керек деген мақсатын қанағаттандырмайды.

3. «1.7 мақсатындағы «Инвесторлар үшін тартымды жағдай жасау және инновацияны дамыту» кестесіндегі «Халықтың жан басына шаққандағы негізгі капиталға моно және шағын қалаларда инвестициялардың өсу қарқыны, \%-бен» көрсеткіші үлестің орнына ақша сомасында ұсынылған.

4. Әлеуметтік сала бағытындағы келесі жайттарды топтастырып қарағанымыз жөн. Себебі бұл көрсеткіштер бойынша қойылған мақсат ағымдағы жағдайдан керісінше нашарлау сипатында. Мәселен, «2.3 мақсатындағы «Денсаулық сақтау жүйесін дамыту және азаматтардың денсаулығын арттыру» кестесінде ең негізгі «Жаспен есептелетін туылғанда болжанатын өмір сүру ұзақтығы» көрсеткішінің 2020-шы жылы қойылған мақсаты 70,46 жас, ал 2015 жылы 70,77 жас екен. «2.5 мақсатының «Азаматтарды әлеуметтік қорғаудың тиімді жүйесі» кестесіндегі екі индикатор: «1000 адамға шаққандағы жазатайым жағдайлардың жиілігіне қатысты өндірістегі жарақат» 2015 жылы 0,54 болса, 2020 жылы 0,70-ті құрауы тиіс; «Еңбек заңнамасын бұзушылықтардың үлесі және оның құқық бұзушылықтардың жалпы санындағы \%-ы» 2015 жылы 98,8, 2020 жылы 99,2 көрсеткішін құрауы тиіс. Яғни көрсеткіш азаюдың орнына көбеюі тиіс екен.

5. «Атаулы әлеуметтік көмек алушылар ішіндегі еңбекке жарамды адамдардың үлесі, \%-бен» және «Атаулы көмек алатын жұмыссыздар және өзін-өзі жұмыспен қамтамасыз етушілердің жалпы санынан жұмыспен қамтуға көмектесудің белсенді түрлеріне тартылған атаулы көмек алушылар үлесі, \%» көрсеткіштеріндегі кейбір жылғы мәліметтер мүлдем жоқ.

6. «4.4 мақсатындағы «Қоғамдық жолаушылар көлігіне қол жетімділік» кестесіндегі жалғыз «Жолаушылар автокөлігі қа- 
тынасымен қамтылмаған елді мекендер үлесі, \%» көрсеткіші 2015 жылы 45 пайыз болса, 2020 жылы 0 пайыз деген мақсат қойылыпты. Біздің ойымызша, облыстағы әрбір елді-мекен, оның ішінде кішігірім ауылдарға жолаушы автокөлігін жүргізу біріншіден қомақты қаражатты талап етеді, екіншіден кейбір ауылдар үшін тиімсіз.

7. 5-ші бағыттағы «5.2 мақсаттың «Жерді, суды, орманды және жануарлар әлемін оңтайлы пайдалану» кестесінде келтірілген 9 көрсеткіштің төртеуінде ешқандай деректер келтірілмеген. Бұл да «Қазақстан Республикасының Стратегиялық даму жоспарын, Елді аумақтық-кеңістікте дамытудың болжамды схемасын, мемлекеттік бағдарламаларды, мемлекеттік органдардың стратегиялық жоспарларын және аумақтарды дамыту бағдарламаларын әзірлеу жөніндегі әдістемеге» [7] сәйкес келмейді.

Жоғарыда жасалған талдау негізінде мынадай қорытынды жасауға болады:

- бағдарламаны әзірлеуде заманауи талаптарға сәйкес келетін жүйелі тәсілдердің болмауы және стратегиялық даму жоспарының кемшілігі;

- теориялық және әдіснамалық зерттеу жеткіліксіз, яғни ғылыми-зерттеу орталықтарының қатысуымен;

- мақсатты бағдарламалардың елеулі бөлігін табысты іске асырудың маңызды құрамдас бөлігі болып табылатын мемлекеттік-жеке меншік әріптестіктің (МЖӘ) тиімді ұйымдастырушылық, құқықтық және қаржылық механизмдерінің жоқтығы;

- бағдарламаның әзірленуі мен орындалуына мониторинг жүргізудің нақты механизмінің жоқтығы [8];

- бағдарламаның түпкілікті нәтижелерін бағалауға арналған көрсеткіштердің болмауы;

- бағдарламаның қанағаттанарлықсыз орындалуы үшін жауапкершілік механизмдерінің болмауы.

Осы күрделі мәселелерді шешу үшін қажет болған жағдайда түзетулерді енгізе отырып, қалыптасқан өңірлік дамуды басқару жүйесін кешенді және дәйекті жаңғырту қажет.

Жалпы, біздің ойымызша мұндай кемшіліктер орын алмас үшін, кез келген бағдарламаға жобалау және әзірлеу кезеңінде айрықша назар аударып, сараптамадан өткізу керек.

Қорытынды. Қарағанды облысының 2011-2015 және 2016-2020 жылдарға арналған екі бағдарламасын талдай келе келесідей қорытынды шығардық. Экономиканы және әлеуметтік саланы дамытудың өңірлік бағдарламаларын әзірлеуді, қаржыландыруды және іске асыруды талдау нәтижесі өңірлік бағдарламаларды ұйымдастырушылық және қаржылық мәселелерді шешуде елеулі қиындықтар әлі күнге дейін сақталуын көрсетті. Атап айтқанда, бұл бағдарламаны іске асыру үшін республикалық бюджеттен іс жүзінде қаражат бөлу туралы. Өкінішке орай, соңғы жылдары аймақтық бағдарламаларды қаржыландырудың жеткіліксіздігі байқалады.

Жүргізілген талдаулар нәтижесінде келесідей ұсыныс жасай аламыз. Өңірлік бағдарламалардың дұрыс әзірленіп, тиімді іске асыруды қадағалайтын аймақтық деңгейде келесі органдар құру керек:

- бағдарлама дирекциясы;

- бағдарламаның техникалық-экономикалық кеңесі.

Бағдарлама дирекциясы - бұл бағдарламаны іске асыру үдерісін жедел басқару үшін жауапты атқарушы орган. Бағдарламаның техникалық-экономикалық кеңесі бағдарлама іс-шараларын іске асыруға байланысты негізгі құқықтық, техникалық, экономикалық, ұйымдастырушылық және басқа да мәселелерді шешуге бағытталған бағдарламаны іске асырудың жалпы стратегиясын айқындау үшін өкілетті орган болып табылады. Қазақстанның 2025 жылға дейінгі даму стратегиясының тұжырымдамасына сүйене отырып, біз әлеуметтікэкономикалық дамудың өңірлік жоспарын 
жетілдірудің келесі әдістерін ұсына аламыз:

1. Облыстық, республикалық және қалалық билік органдарының өкілеттіктер жүйесін саралау және заңнамалық актілердің келісілген жүйесін құру:

- өз өкілеттіктерінің әрбір деңгейін түпкілікті қамтамасыз ету мақсатында «Өңірлік дамуды мемлекеттік реттеу туралы» заңының қабылдануы;

- өңірлік саясатты жүзеге асыру бойынша биліктің жұмыс істеуінің айқын схемасын және рәсімдерін әзірлеу;

- заңнамалық актілер жүйесі республикалық заңнамамен (тік) өзара үйлесімді болуы керек, оны нақты аймақтардың шарттарында көрсетілуге тиіс;

- аймақтық заңнама жүйесі халықаралық инвестициялық және қаржылық институттардың өздерімен бірге аймақтарды аккредиттеу және халықаралық жобалар мен бағдарламаларға қатысу қажеттілігін ескеруі тиіс;

- негізгі заңдар негізінде және олардың жұмыс істеуін қамтамасыз ету үшін аймақтық нормативтік-құқықтық базаны құру қажет.

2. Аймақтың жағдайын бағалаудың те- тіктерін тереңдетіп және егжей-тегжейлі әзірлеу (өндірістің перспективалы бағыттары, өндірісті кеңейту және жаңаларын жасау үшін қазіргі мүмкіндіктер, аймақтың экспорттық әлеуетін бағалау):

- өңірлік әлеуметтік-экономикалық көрсеткіштердің федералдық мониторингі жүйесін құру (ҚР Үкіметі Аппаратының, ҚР Ұлттық экономика министрлігінің, ҚР Қаржы министрлігінің және т.б.) мониторингін және болжау жүйесін синхрондау;

- өңірлердің әлеуметтік-экономикалық дамуына бағытталған аймақтық, жергілікті стратегиялық бастамаларды іске асыру, әлеуметтік инфрақұрылымды дамыту жобаларын іске асыруға ынталандыру және осындай жобаларды іске асыруда аймақтық, жергілікті билік органдарына көмек көрсету.

Бұдан басқа жүргізлген талдаудың қорытындысы елдің 2020 жылға дейінгі аумақтық кеңістіктіктің дамуының болжамды даму бағдарламасы мен Өңірді дамытудың 2025 бағдарламасымен сәйкестендіріледі.

Осылайша, бағдарламаны көп мақсатты жоспарлау мәселелерін шешудің кешенді әдісін пайдалану тек өңірдің дамуының жоғары деңгейіне жетуі мүмкін.

\section{ӘДЕБИЕТТЕР}

1. «Қазақстан Республикасында салалық (секторалдық) және өңірлік бағдарламаларды әзірлеу мен іске асыру ережесі туралы» Қазақстан Республикасы Үкіметінің 2004 жылғы 26 ақпандағы № 231 қаулысы. http://adilet.zan.kz/kaz/docs/P040000231

2. «Салалық бағдарламаларды әзірлеу, іске асыру, мониторингілеу, бағалау және бақылау ережесін бекіту туралы» Қазақстан Республикасы Үкіметінің 2010 жылғы 18 наурыздағы № 218 қаулысы. http://adilet.zan.kz/kaz/docs/P100000218

3. «Қазақстан Республикасындағы мемлекеттік жоспарлау жүйесін бекіту туралы» Қазақстан Республикасы Үкіметінің 2017 жылғы 29 қарашадағы № 790 қаулысы. http:// adilet.zan.kz/kaz/docs/P1700000790

4. Қарағанды облысы мәслихаттың 2017 жылы 12 желтоқсандағы XIII сессиясының № 263 шешімімен бекітілген «Қарағанды облысын дамытудың 2016-2020 жылдарға арналған бағдарламасы». https://g.engime.org/arafandi-oblisi-meslihatti-2017-jili-12-jeltosandafi-xiiisess.html

5. «Қазақстан Республикасындағы Мемлекеттік жоспарлау жүйесінің кейбір мәселелері туралы» Қазақстан Республикасы Ұлттық экономика министрінің 2018 жылғы 19 ақпандағы № 64 бұйрығы. http://adilet.zan.kz/kaz/docs/V1800016493 


\section{Экономика}

6. «Қазақстан Республикасының денсаулық сақтау саласын дамытудың 2016-2019 жылдарға арналған «Денсаулық» мемлекеттік бағдарламасын бекіту туралы» Қазақстан Республикасы Үкіметінің 2018 жылғы 15 қазандағы № 634 қаулысы. http://adilet.zan.kz/kaz/ docs/V1400009872

7. «Қазақстан Республикасының Стратегиялық даму жоспарын, Елді аумақтықкеңістікте дамытудың болжамды схемасын, мемлекеттік бағдарламаларды, мемлекеттік органдардың стратегиялық жоспарларын және аумақтарды дамыту бағдарламаларын әзірлеу жөніндегі әдістеме» Қазақстан Республикасы Ұлттық экономика министрінің 2018 жылғы 19 ақпандағы № 64 бұйрығына 1-қосымша. http://adilet.zan.kz/kaz/docs/V1400009872

8. Mussatayeva A.A. The Effectiveness of State Administration: Problems and Solution Approaches// Middle-East Journal of Scientific Research 14 (10). - 2013. - P. 1331-1336.

9. Мирошников С.Н. Проблемы и направления стратегического планирования в региональном развитии //Актуальные вопросы экономики. - 2019. - С. 61-77. DOI: 10.24411/ 2071-6435-2019-10102

10. Zhikharevich B.S., Pribyshin T.K. Urban Development Strategies: Russian Practice 20142019. Prostranstvennaya Ekonomika = Spatial Economics. - 2019. - Vol. 15. - No. 4. - P. 184-204. https://dx.doi.org/10.14530/se.2019.4.184-204

11. Ловягин В.Ф., Мушич Ю.А. Управление городскими территориями: планирование управленческих решений: Монография. - Новосибирск: СГГА, 2011. - С. 144.

\section{REFERENCES}

1. «Қаzақstan Respublikasynda salalyқ (sektoraldyқ) zhəne өңirlik baғdarlamalardy әzirleu men iske asyru erezhesi turaly» Қаzaқstan Respublikasy Ykimetiniң 2004 zhylғу 26 ақраndaғy N 231 қaulysy [ Resolution of the Government of the Republic of Kazakhstan dated February 26, 2004 N 231 «on the rules for the development and implementation of industry (sector) and regional programs in the Republic of Kazakhstan»] http://adilet.zan.kz/kaz/docs/P040000231 [in Kazakh].

2. «Salalyқ baғdarlamalardy əzirleu, iske asyru, monitoringileu, baғalau zhəne bақуlau erezhesin bekitu turaly» Қаzaқstan Respublikasy Ykimetiniң 2010 zhylғy 18 nauryzdaғy № 218 Қaulysy [Resolution of the Government of the Republic of Kazakhstan dated March 18, 2010 No. 218 «on approval of the Rules for development, implementation, monitoring, evaluation and control of industry programs»] http://adilet.zan.kz/kaz/docs/P100000218 [in Kazakh].

3. «Қаzақstan Respublikasyndaғу memlekettik zhosparlau zhyjesin bekitu turaly» Қаzaқstan Respublikasy Ykimetiniң 2017 zhylғy 29 қаrashadaғy № 790 қаulysy [ Resolution of the Government of the Republic of Kazakhstan dated November 29, 2017 No. 790 «on approval of the state planning system in the Republic of Kazakhstan»] http://adilet.zan.kz/kaz/docs/P1700000790 [in Kazakh].

4. Қағағаndy oblysy məslihattyң 2017 zhyly 12 zheltoқsandaғy XIII sessijasynyң № 263 sheshimimen bekitilgen «Қaraғandy oblysyn damytudyң 2016-2020 zhyldarғa arnalғan baғdarlamasy» [ Approved by the decision of the XIII session of the Karaganda regional maslikhat dated December 12, 2017 No. 263 «Development program of the Karaganda region for 2016-2020»]. https:// g.engime.org/arafandi-oblisi-meslihatti-2017-jili-12-jeltosandafi-xiii-sess.html

5. «Қаzақstan Respublikasyndaғy Memlekettik zhosparlau zhyjesiniң kejbir məseleleri turaly» Қаzaқstan Respublikasy Ұlttуқ јekonomika ministriniң 2018 zhylғу 19 ақраndaғу № 64 bұjryғу [Order of the minister of national economy of the Republic of Kazakhstan from February 19, 2018 No. 64 «on some issues of the state planning systemin the Republic of Kazakhstan»] http://adilet.zan.kz/ kaz/docs/V1800016493 [in Kazakh]. 
6. «Қазақstan Respublikasynyң densaulyқ saқtau salasyn damytudyң 2016-2019 zhyldarғa arnalғan «Densaulyқ» memlekettik baғdarlamasyn bekitu turaly» Қаzaқstan Respublikasy Ykimetiniң 2018 zhylғу 15 қаzandaғy № 634 қаulysy [ Resolution of the Government of the Republic of Kazakhstan dated October 15, 2018 No. 634 «on approval of the state program for health development of the Republic of Kazakhstan «Densaulyk» for 2016-2019»] http://adilet.zan.kz/kaz/docs/V1400009872 [in Kazakh].

7. «Қазақstan Respublikasynyң Strategijalyқ damu zhosparyn, Eldi aumaқtук-kеңistikte damytudyң bolzhamdy shemasyn, memlekettik baғdarlamalardy, memlekettik organdardyң strategijalyқ zhosparlaryn zhəne aumaқtardy damytu baғdarlamalaryn əzirleu zhөnindegi ədisteme» Қаzaқstan Respublikasy Ұlttyқ jekonomika ministriniң 2018 zhylғу 19 ақраndағу № 64 bұjryғyna 1-қоsymsha [Appendix 1 to the order of the Minister of national economy of the Republic of Kazakhstan dated February 19, 2018 No. 64 «methodology for developing the Strategic development plan of the Republic of Kazakhstan, the Forecast scheme of territorial and spatial development of the country, state programs, strategic plans of state bodies and territorial development programs»]. http://adilet.zan.kz/kaz/docs/ V1400009872 [in Kazakh].

8. Mussatayeva A.A. The Effectiveness of State Administration: Problems and Solution Approaches // Middle-East Journal of Scientific Research 14 (10). - 2013. - P. 1331-1336.

9. Miroshnikov S.N. Problemy i napravlenija strategicheskogo planirovanija v regional'nom razvitii //Aktual'nye voprosy jekonomiki. - 2019. - S. 61-77. DOI: 10.24411/2071-6435-201910102 [in Russian].

10. Zhikharevich B.S., Pribyshin T.K. Urban Development Strategies: Russian Practice 20142019//Prostranstvennaya Ekonomika [Spatial Economics]. - 2019. - Vol. 15. - № 4. - P. 184-204. https://dx.doi.org/10.14530/se.2019.4.184-204.

11. Lovyagin V.F., Music J.A. Management of urban areas: planning management decisions: Monograph. - Novosibirsk: SGGA, 2011. - P. 144 [in Russian].

\section{Р.Е. Несипбаев, А.А. Мусатаева, Е.И. Борисова}

\section{ЭФФЕКТИВНОСТЬ РАЗРАБОТКИ И РЕАЛИЗАЦИИ ПРОГРАММЫ РАЗВИТИЯ КАРАГАНДИНСКОЙ ОБЛАСТИ НА 2 016-2020 ГОДЫ}

\section{Аннотация}

В статье выявлена необходимость разработки программ развития территории, отражены преимущества, недостатки и несоответствия при разработке и реализации «Программы развития Карагандинской области на 2016-2020 годы». В данной статье рассматриваются понятия стратегического управления, описаны различия стратегического и текущего управления на примере управления отраслями социального блока. Также изучена сущность управления территориальным хозяйством региона, а также вопросы реализации жизнеобеспечения и социального обслуживания населения, совершенствования территориального хозяйства в целом, получения ими новых качественных характеристик более высокого уровня. По мнению авторов статьи, основной формой управления территориальной экономикой является сочетание текущего и стратегического управления в рамках органа управления. Представлено подробное описание основных подходов к созданию управленческих структур, направленных на интеграцию текущего и стратегического управления. Особое внимание уделяется реализации данного подхода, который требует очень тщательного подхода к построению внутренней структуры органа управления, учета особенностей организации различных видов управления. Авторами определены основные результаты реализации стратегических планов, а также конечным результатом стратегического развития территории является 


\section{Экономика}

достижение социального эффекта выполненных мероприятий, заключающегося в повышении благосостояния населения, проживающего на данной территории региона. Статьи для широкого круга читателей, интересующихся вопросами современной экономики.

\section{R. Nessipbayev, A. Mussatayeva, Ye. Borisova \\ EFFICIENCY OF DEVELOPMENT AND IMPLEMENTATION OF THE DEVELOPMENT PROGRAM OF THE KARAGANDA REGION FOR 2016-2020}

\section{Annotation}

The article identifies the need to develop programs for the development of the territory, identifies advantages, shortcomings and inconsistencies in the development and implementation of the "Program for the development of Karaganda region for 2016-2020". This article discusses the concepts of Strategic Management, describes the differences between Strategic and current management on the example of managing areas of the social bloc. The essence of the management of the territorial economy of the region, as well as the implementation of life support and social services of the population, improvement of the territorial economy as a whole, their acquisition of new qualitative characteristics at a higher level were also studied. According to the authors of the article, the main form of management of the territorial economy is a combination of current and strategic management within the framework of the governing body. Adetailed description of the main approaches to building management structures aimed at combining current and strategic management is presented. Special attention is paid to the implementation of this approach, which requires a very careful approach to building the internal structure of the management body, taking into account the specifics of the organization of various types of management. The authors identified the main results of the implementation of strategic plans, in addition, the final result of the strategic development of the territory is to achieve the social impact of the implemented measures, which consists in increasing the well-being of the population living in this territory of the region. The article is intended for a wide range of readers interested in the problems of the modern economy. 
DOI 10.52260/2304-7216.2020.4(41).6

УДК 338.28

ГРНТИ 06.73.21

\author{
Р.К. Елшибаев*, к.э.н., ассои. профессор \\ Университет Нархоз \\ 2. Aлматьи \\ e-mail: rakymzhan.yelshibayev@bk.ru \\ * - основной автор (автор для корреспонденции)
}

\section{ФИНАНСИРОВАНИЕ РАЗВИТИЯ ТЕХНОЛОГИЧЕСКИХ ПРЕДПРИЯТИЙ РЕСПУБЛИКИ КАЗАХСТАН}

В статье изложен ход и результаты исследования экономических отношений, возникающчих в процессе финансирования казахстанских технологических предприятий. Автором, посредством применения соответствующих общелогических и частных экономических методов проведения исследований, решена научная задача по формированию стратегии мобилизации и использования финансовых ресурсов для эффективного развития технологической промышленности Республики Казахстан.

Комплекс исследовательского инструментария включает такие методы, как: формально-логический анализ, абстрагирование, графический анализи экономико-статистический анализ. Каждый из методов использовался адекватно его функииональным возможностям и разрешающим способностям. Это позволило автору последовательно решать соответствующие этапные задачи исследования. Вначале изучить экономическую сущность системы финансирования развития казахстанских технологических предприятий, затем обосновать необходимость государственного регулирования данной системь. Далее определить роль и место интернет-трейдинга в системе экономических отношений между населением и участниками финансового рынка, и в завершении разработать теоретическую модель финансирования развития технологических предприятий Казахстана, адаптированную под современные экономические реалии Республики.

Полученные выводы исследования представляют собой потенцииальную теоретикометодическую базу для использования соответствующими государственными органами при разработке и внесении изменений и дополнений в законодательные и нормативные акты, регулирующие вопросы мобилизации и использования финансовых ресурсов для развития технологических предприятий Республики Казахстан.

Ключевые слова: технологическое предприятие, методы финансирования, стратегия мобилизации, финансовые ресурсы, инновационная инфраструктура, технологический кластер, фондовый рынок, интеграция образования, науки и бизнеса, повышение конкурентоспособности предприятия.

Кілт сөздер: технологиялық кәсіпорын, қаржыландыру ддістері, жұмылдыру стратегиясы, қаржы ресурстары, инновачиялық инфрақұрылым, технологиялық кластер, қор нарыгы, білім, вылым және бизнес интеграциясы, кәсіпорынның бәсекеге қуабілеттілігін арттыру.

Keywords: technology enterprise, financing method, mobilization strategy, financial resources, innovative infrastructure, technology cluster, stock market, integration of education, science and business, improving the competitiveness of the enterprise.

Введение. Сегодня мир стоит на пороге четвертой промышленной революции «Industry 4.0», явлении, при котором будут значительно развиты и в большей мере ком- мерциализированы такие прорывные научно-технологические проекты как облачный компьютинг, BigData, киберфизические системы, искусственный интеллект (ИИ), 
3D-печать, переход на возобновляемые источники энергии, Интернет вещей и т.д.

Отвечая на вызовы современности Президент Казахстана К. Токаев в Послании народу Казахстана от 01 сентября 2020 г. пояснил, что важным источником финансирования науки, как двигателя прогресса в современных условиях, являются средства крупных предприятий. Поэтому Правительству поручено обеспечить централизацию сбора и распределения через бюджет норм об отчислении 1\% от капитальных вложений крупных предприятий на развитие науки и технологий.

Также, принципиально новой идеей, изложенной Главой государства в текущем Послании, является «шефство» со стороны крупного бизнеса над региональными университетами в целях привлечения науки для решения прикладных проблем национального уровня [1].

На наш взгляд, обозначенные инициативы Президента являются недостающим элементом в механизме развития технологических предприятий Республики Казахстан, что определяет актуальность проведения настоящего исследования.

Цель работы состоит в решении научной задачи по формированию стратегии мобилизации и использования финансовых ресурсов развития технологических предприятий Республики Казахстан

Объектом исследования являются экономические отношения, возникающие в процессе финансирования казахстанских технологических предприятий.

Применение в данном исследовании метода формально-логического анализа и аналогии позволило изучить экономическую сущность процесса финансирования развития технологических предприятий и уточнить сами понятия «технологическое предприятие», «технологический кластер», «инновационная инфраструктура» и т.д.

При изучении инфраструктурного обеспечения системы государственного ре58 гулирования развития технологических предприятий Республики Казахстан, применялся метод сбора информации и, частично, метод абстрагирования для эффективного поиска, группировки, обработки и обобщения необходимого материала.

С помощью метода графического анализа обеспечена наглядность анализируемых инструментов поддержки инновационной деятельности предприятий, отражены их география, динамика и объемы финансирования.

Методом экономико-статистического анализа были выделены системные проблемы объекта исследования, комплексное решение которых послужило фундаментом для построения теоретической модели финансирования развития технологических предприятий Республики, адаптированной под современные экономические реалии Казахстана.

Также в работе использовались экспертные оценки независимых исследователей и материалы, опубликованные в открытых электронных источниках: www. akorda.kz, www.sciencedirect.com, www. qaztech.vc, www.atameken.kz.

Общая логика работы базируется на комплексном и системном подходе с использованием современного научного аппарата.

Обзор литературы. Повышению коммерческой успешности инноваций посвящены многочисленные зарубежные труды: Miller R., Blais R.A. [2], Tidd J., Bessant J. [3], Hippel E. [4], Lundvall B.A., Johnson B., Andersen E. [5] и многих других, в то время как в Казахстане эта проблема до настоящего времени глубоко не исследована.

К отечественным автором, занимающимся исследованиями инновационной деятельности предприятий,относятся Альжанову Н.Ш., Сабитулы А. [6], Гаджиев Ф.А. [7], Абдыгапарова С.Б. [8], Зверькову Т.Н. [10] и другие.

В целом, несмотря на многочисленные 
работы отечественных и зарубежных экономистов, рассматриваемая тема требует дальнейшего развития понятийного аппарата, выявления методов, форм и источников финансирования технологического развития компаний, разработки методологических положений формирования стратегии финансирования, способствующей повышению их конкурентоспособности.

Актуальность проблемы и недостаточная разработанность представлений о стратегии финансирования технологического развития компаний определили гипотезу настоящего исследования - повышение эффективности государственной политики в области финансирования развития технологических предприятий приведет к наращиванию темпов экономического развития.

Основная часть. Сегодня мир стоит на пороге очередной промышленной революции, явлении, при котором постоянно возрастает роль научно-технического прогресса в обеспечении конкурентоспособности национальных экономик. В таких условиях поддержка и форсированное развитие инновационной деятельности в стране приобретает стратегическое значение, ведь инновации на сегодняшний день - это не прихоть, а необходимость выживания, сохранения конкурентоспособности нации и ее дальнейшее процветание.

Под инновацией понимается процесс от возникновения и разработки исходной идеи к созданию новых продуктов, услуг и технологий, споследующим созданием опытного образца или модели, подтверждающих их практическую целесообразность. Инновационные процессы зарождаются в отдельных отраслях науки, а завершаются в сфере производства, вызывая в ней качественно новые прогрессивные изменения, способные обеспечить решение сложных, не разрешимых на прежней технологической базе производственных задач. Промышленные предприятия пришли к пониманию необходимости внедрения технологических инноваций, поэтому на современном этапе технологическая модернизация все больше рассматривается ими как один из главных факторов повышения конкурентоспособности производимой продукции, поддержания высоких темпов развития и уровня доходности [2, 265 с.].

Современное технологическое предпринимательство строится вокруг новейших технологий, прогрессивных структур организации и управления предприятиями. В обособленную форму технологическое предпринимательство отделилось в 1990-х годах, когда в Кремниевой долине стали появляться и работать первые инновационные стартапы.

Поскольку официальный статус предпринимателя приобретается после государственной регистрации физического лица, как участника индивидуального предпринимательства или юридического лица, как предприятия с привлечением наемного труда, то рассматривать две эти экономические категории следует как тождественные.

1. Технологическое предприятие - тип компании, чья деятельность сосредоточена на разработке и производстве технологических продуктов или предоставлении технологии как услуги [3, 455 с.].

2. Технологическое предприятие является субъектом предпринимательской деятельности, который сосредоточен главным образом на разработке и производстве технологических продуктов [4, 213 с.].

3. Технологичная компания - это компания, все составные элементы (отделы, службы, департаменты) которой работают настолько четко и отлаженно, что компания функционирует так же совершенно, как механизм, созданный на основе высоких технологий [5, 214 с.].

Разные авторы дают разные определения данного понятия, однако все они соответствуют утверждению, что технологическое предпринимательство - это цифровой организм, который питает синтез из эффек- 
тивного менеджмента, высококлассного технического сопровождения и своевременного финансирования перспективных, наукоемких разработок с целью удовлетворения рыночного спроса. Эффективность функционирования такого организма зависит от уровня интеграции науки, образования, производства и рынка в стране. Таким образом, развитие технологических предприятий неразрывно связано с конъюнктурой рынка, с их полноценным ресурсным обеспечением, с профессионализмом руководствующего звена и отраслевых специалистов, в совокупности формирующих общую инновационную инфраструктуру.

На сегодняшний день в Казахстане применяется следующие инструменты поддержки инновационной деятельности:

Инструмент 1. Инновационный грант.

Инструмент 2. Проектное финансирование.
Инструмент 3. Финансирование через венчурные фонды.

Инструмент 4. Предоставление услуг по бизнес-инкубированию [6, 50 с.].

Инструмент 1. Инновационный грант это бюджетные деньги, которые государство выдает на безвозмездной основе для коммерциализации технологий и технологическое развитие предприятий.

В рамках администрирования сервисных инструментов заявителями на инновационные гранты могут стать следующие категории лиц:

- физические лица, зарегистрированные в качестве индивидуального предпринимателя, осуществляющие деятельность в Казахстане;

- юридические лица, осуществляющие деятельность на территории РК.

В 2019 году для участия в конкурсе поступило более 55000 заявок.

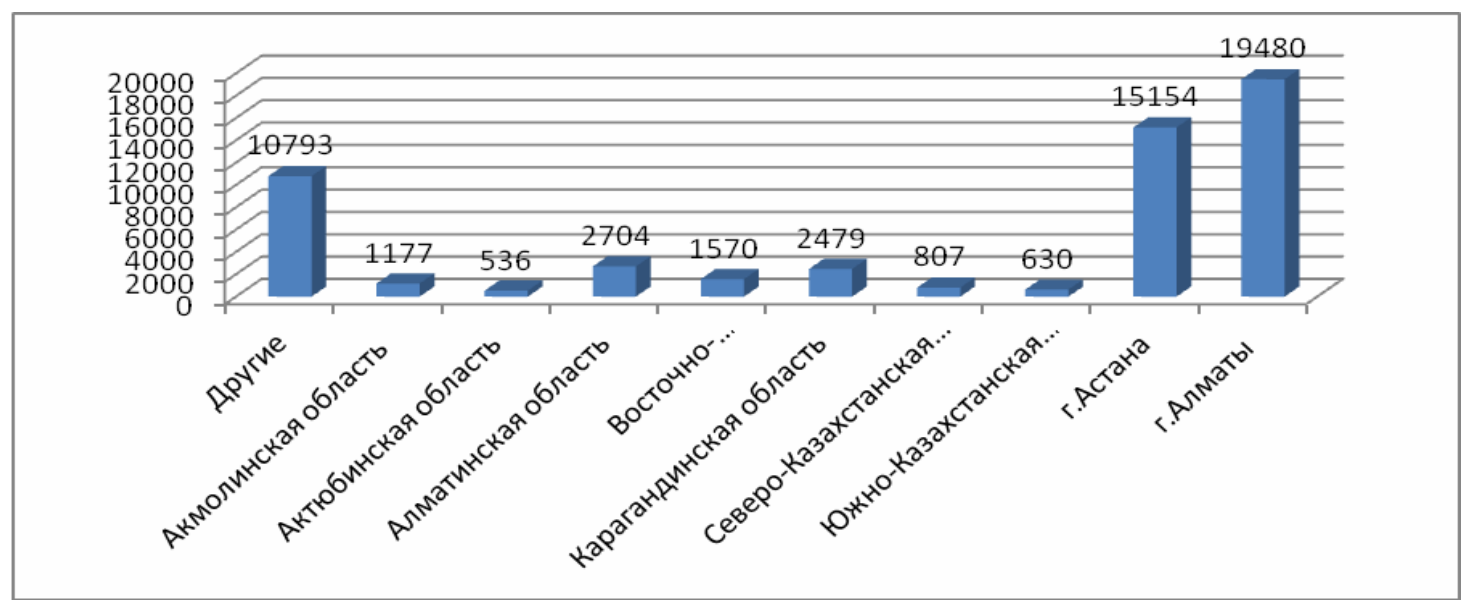

\section{Рисунок 1. Объем и география заявок на предоставление инновационных грантов [7, 41 с.]}

Сумма, выделенная на инновационные гранты, составила 7,5 млрд тенге. Гранты были предоставлены на выполнение опытно-конструкторских работ и рисковых исследований прикладного характера, подготовку технико-экономического обоснования, патентование объекта интеллектуальной собственности в иностранных государ- ствах и международных патентных организациях, приобретение инновационных технологий [7, 41 с.].

Инструмент 2. Проектное финансирование - это финансирование инвестиционного проекта, при котором источник обслуживания долговых обязательств - денежные потоки, генерируемые самим проектом. 


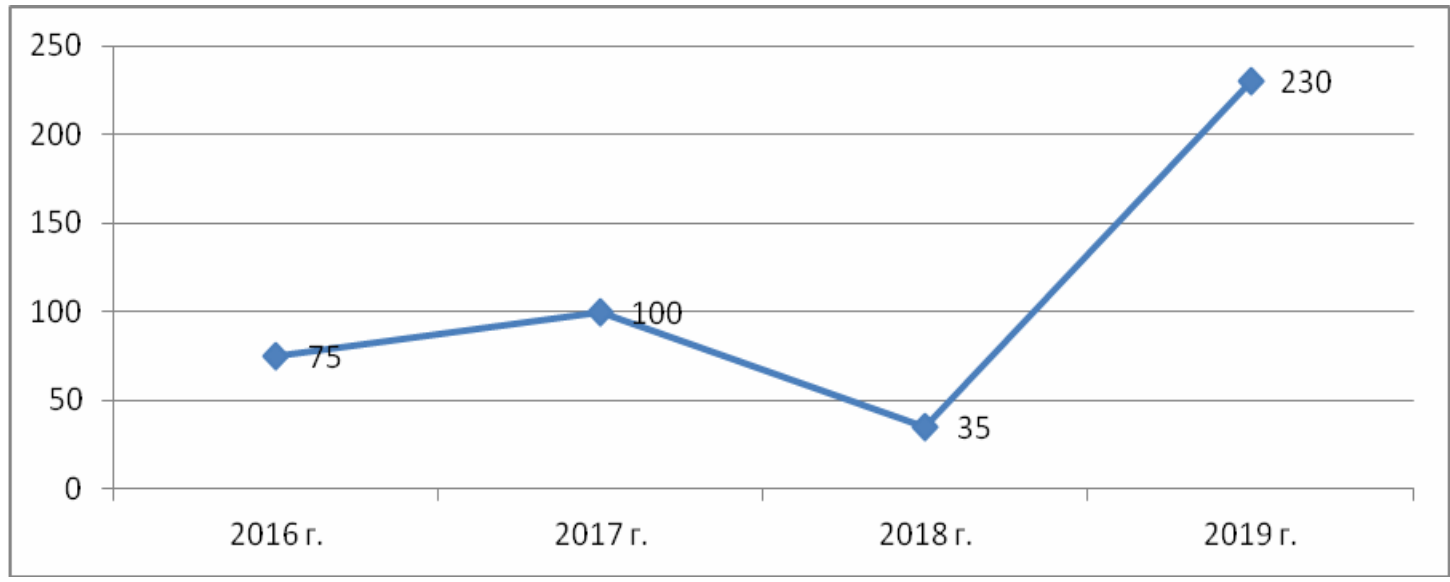

\section{Рисунок 2. Расходы государственного бюджета на технологические} инновации в промышленности, (млрд тенге) [8, 189 с.]

Как видно из приведенного выше рисунка, расходы государства на технологические инновации в промышленности по второму типу финансирования (проектное финансирование) за исследуемый период носили динамичный характер. В 2016 году затраты государства составляли 75 млрд тенге. Годом позже показатель увеличился на 25\% и составил 100 млрд тенге. Однако, в связи финансовыми трудностями, возникшими в 2018 году на фоне глобального снижения цен на энергоносители затраты государственного бюджета заметно сократились до 35 млрд тенге. Наиболее высокий показатель затрат на технологические инновации в промышленности наблюдается в 2019 году - 230 млрд тенге [8, 189 с.].

Чтобы оценить эффективность рассматриваемого инструмента необходимо отследить связь между изменением государственных затрат на технологические инновации и изменением инновационной активности предприятий.

Инструмент 3. Финансирование через венчурные фонды. Венчурный капитал это долгосрочный, рисковый капитал, инвестируемый в акции новых и быстрорастущих технологических компаний с целью получения высокой прибыли после ре- гистрации акций этих компаний на фондовой бирже [9, 409 с.].

Для содействия развитию технологического предпринимательства через инструменты венчурного финансирования, бизнес-инкубирования и технологического консалтинга в Казахстане создано АО «Qaz TechVentures», прежде именуемое AO «Национальное агентство по технологическому развитию».

Инструмент 4. Предоставление услуг по бизнес-инкубированию. Бизнес-инкубирование - это форма нефинансовой поддержки и развития технологического предпринимательства, основными элементами которой выступают бизнес-акселераторы и технопарки.

В Республике Казахстан функционируют два типа технопарков: национальные и региональные. Среди национальных научно-технологических парков следует выделить Парк информационных технологий (ПИТ) в п. Алатау.

На региональном уровне системообразующими составными частями технопарков являются промышленные предприятия регионов, научные и академические организации. Кроме того, в стране функционируют 9 центров коммерциализации научных исследований [10, 27-28 с.]. 


\section{Экономика}

Сегодня можно с уверенностью заключить, что уровень технологического развития на предприятиях спал. Причинами этого сами предприятия называют «отсутствие необходимости в нововведениях вследствие более ранних инноваций» (в основном для неактивных предприятий), «нехватка капитала в пределах предприятия» и «отсутствие рыночного спроса».

В качестве путей решения системных проблем предлагается алгоритм построения системы финансирования развития технологических предприятий, который состоит из следующих элементов:

1. Институциональная поддержка, которая включает:

- государственное гарантирование 70-85\% от объема кредитования на научноинновационные проекты;

- принятие целевых технологических программ;

- предоставление инновационно-активным предприятиям преимуществ на рынке;

- привлечение инвестиций неформальных венчурных инвесторов на ранних этапах финансирования проектов;

- создание полноценной системы двухстороннего трансферта технологий;

- стимулирование создания бизнесструктур учеными совместно с бизнесом на основе реализации научных проектов, финансируемых государством;

- установление критериев поддержки инноваций в системе госзакупок.

2. Модернизация системы образования:

- избавиться от устаревших и невостребованных научных и образовательных дисциплин, одновременно усилив востребованные и перспективные направления;

- изменить направленность и акценты учебных планов среднего, профессионально-технического и высшего образования, включив программы по обучению практическим навыкам и получению практической квалификации;

- создать ориентированные на пред- принимательство учебные программы, образовательные курсы и институты.

3. Технологические кластеры. Под кластером обычно подразумевается группа фирм, исследовательских организаций и разного ряда вспомогательных структур, сосредоточенных на определенной географической территории и обладающих достаточными ресурсами, в том числе квалифицированными кадрами (учеными, инженерами, конструкторами, менеджерами и представителями других профессий) для эффективного инновационного развития специализированной области индустрии.

На территории кластера необходимо обеспечить благоприятную среду для кооперации организаций, участвующих в инновационных процессах, интенсивное общение участников процесса: крупных компаний, малого и среднего бизнеса, инноваторов и изобретателей.

4. Привлечение средств населения посредством фондовых рынков: Казахстанской фондовой биржи (KASE) иAО «Международный финансовый центр «Астана» (МФЦА):

- разработать адаптированные инвестиционные инструменты, способствующие привлечению интереса брокеров и дилеров как профессиональных участников фондового рынка;

- разработать систему мер, способствующих повышению надежности и эффективности ПИФов и других структур, участвующих в привлечении сбережений населения для целей финансирования деятельности венчурных фондов;

- оказание непосредственной помощи в выводе акций технологических предприятий на фондовый рынок Казахстана и зарубежные фондовые рынки;

- создание информационного банка данных по технологическим предприятиям Казахстана и информирование потенциальных инвесторов о наличии перспективных проектов. 
Реализация вышеперечисленных мероприятий создаст условия для формирования целостного взгляда на систему финансирования технологических предприятий Республики Казахстан как на действенный инструмент повышения конкурентоспособности нации.

Выводы. Цели и задачи, поставленные автором при проведении исследования достигнуты. Выдвинутая автором гипотеза о том, повышение эффективности государственной политики в области финансирования развития технологических предприятий приведет к наращиванию темпов экономического развития страны, также подтверждена.

В результате проведения исследования:

- уточнено содержание понятия «технологическое предприятие» и изучена экономическая сущность процесса финансирования развития технологических предприятий;

- обоснована необходимость государственного регулирования системы финанси- рования развития технологических предприятий Казахстана;

- определено место интернет-трейдинга в системе экономических отношений между населением и участниками финансового рынка по поводу сделок привлечения и перераспределения финансовых ресурсов;

- разработана теоретическая модель финансирования развития технологических предприятий Казахстана, адаптированная под современные экономические реалии Республики.

Практическая значимость исследования состоит в разработке методов финансирования за счет государственных и негосударственных источников, учитывающих долгосрочные цели и приоритеты развития Республики Казахстан. Результаты могут быть положены в основу формирования и реализации как технологической политики регионов, так и отдельных видов экономической политики Республики, имеющих технологический аспект.

\section{ЛИТЕРАТУРА}

1. Послание Главы государства Касым-Жомарта Токаева народу Казахстана. «КАЗАХСТАН В НОВОЙ РЕАЛЬНОСТИ: ВРЕМЯ ДЕЙСТВИЙ». 01.09.2020 г. // Официальный сайт Президента Республики Казахстан. www.akorda.kz

2. Miller R., Blais R.A., 2018. Models of innovation in industrial sector // IEEE Transactions on Engineering Management, 40(3). - P. 264-273. www.sciencedirect.com

3. Tidd J., Bessant J., 2016. Managing innovation: Integrating technological, market and organizational change. Fourth Ed. - Chichester: John Wiley and Sons. - 455 p. www.sciencedirect.com

4. HippelE., 2016. The dominant role of users in the scientific instrument innovation process // Research Policy, 5(3). - P. 212-239. www.sciencedirect.com

5. Lundvall B.A., Johnson B., Andersen E., 2013. National Systems Of Production, Innovation And Competence Building // Research Policy, 2(31). - P. 214-225. www.sciencedirect.com

6. Альжанова Н.Ш., Сабитулы А. Инновационная активность, как движущий фактор предпринимательской деятельности Казахстана // Вестник КазНУ им. аль-Фараби. - 2018. - № 6. - С. 48-55.

7. Гаджиев Ф.А. Трансакционный подход к исследованию эффективности институтов стимулирования технологического предпринимательства // Казахстан-Спектр. - 2019. № 4. - С. 36-44.

8. Абдыгапарова С.Б. Технологическая модернизация экономики Казахстана: Учеб. пособие для студентов бакалавриата и магистратуры. - Алматы: Экономика, 2020. - 264 с. 


\section{Экономика}

9. Shojaei S., Motavaseli M., Bitaab A., Chitsazan H., Mohammadi G., 2018. Institutional barriers to venture capital financing // Journal of Entrepreneurship in Emerging Economies, 10(3). - P. 409-427. www.sciencedirect.com

10. Зверькова Т.Н. Технопарки как инструмент повышения эффективности технологического предпринимательства // Вестник КазУЭФМТ. - 2018. - № 3. - С. 23-29.

\section{REFERENCES}

1. Poslanie Glavy gosudarstva Kasym-Zhomarta Tokaeva narodu Kazahstana. «KAZAHSTAN V NOVOJ REALNOSTI: VREMY a DEJSTVIJ». 01.09.2020 g. // Oficialnyj sajt Prezidenta Respubliki Kazahstan. www.akorda.kz [in Russian].

2. Miller R., Blais R.A., 2018. Models of innovation in industrial sector // IEEE Transactions on Engineering Management, 40(3). - P. 264-273. www.sciencedirect.com

3. Tidd,J., Bessant J., 2016. Managing innovation: Integrating technological, market and organizational change. Fourth Ed. - Chichester: John Wiley and Sons. - 455 p. www.sciencedirect.com

4. HippelE., 2016. The dominant role of users in the scientific instrument innovation process // Research Policy, 5(3). - P. 212-239. www.sciencedirect.com

5. Lundvall B.A., Johnson B., Andersen E., 2013. National Systems Of Production, Innovation And Competence Building // Research Policy, 2(31). - P. 214-225. www.sciencedirect.com

6. Alzhanova N.Sh., Sabituly A. Innovacionnaya aktivnost, kak dvizhushhij faktor predprinimatelskoj deyatelnosti Kazahstana // Vestnik KazNU imeni al-Farabi. - 2017. - № 6. - S. 48-55 [in Russian].

7. Gadzhiev F.A. Transakcionnyj podhod k issledovaniyu effektivnosti institutov stimulirovaniya tehnologicheskogo predprinimatelstva // Kazahstan-Spektr. - 2019. - № 4. - S. 36 -44 [in Russian].

8. Abdygaparova S.B. Tehnologicheskaya modernizacii ekonomiki Kazahstana: Ucheb. posobie dlya studentov bakalavriata i magistratury. - Almaty: Ekonomika, 2020. - 264 s. [in Russian].

9. Shojaei S., Motavaseli M., Bitaab A., Chitsazan H., Mohammadi G., 2018. Institutional barriers to venture capital financing // Journal of Entrepreneurship in Emerging Economies, 10(3). - P. 409-427. www.sciencedirect.com

10. Zverkova T.N. Texnoparki kak instrument povysheniya effektivnosti texnologicheskogo predprinimatelstva // Vestnik KazUEFMT. - 2018. - №4. - S. 23-29.

\section{Р.Қ. Елшібаев \\ ҚАЗАҚСТАН РЕСПУБЛИКАСЫНЫН ТЕХНОЛОГИЯЛЫҚ КӘСІПОРЫНДАРЫН ДАМЫТУДЫ ҚАРЖЫЛАНДЫРУ}

\section{Аңдатпа}

Мақалада қазақстандық технологиялық кәсіпорындарды қаржыландыру процесінде туындайтын экономикалық қатынастарды зерттеу барысы мен нәтижелері баяндалған. Автор зерттеулер жүргізудің тиісті жалпы логикалық және жеке экономикалық әдістерін қолдану арқылы Қазақстан Республикасының технологиялық өнеркәсібін тиімді дамыту үшін қаржы ресурстарын жұмылдыру және пайдалану стратегиясын қалыптастыру жөніндегі ғылыми міндетті шешті.

Зерттеу құралдарының жиынтығына формальды-логикалық талдау, абстракциялау, графикалық талдау және экономикалық-статистикалық талдау сияқты әдістер кіреді. Әдістердің әрқайсысы оның функционалды мүмкіндіктері мен рұқсат ету қабілеттеріне сәйкес қолданылды. Бұл авторға зерттеудің тиісті кезеңдік міндеттерін дәйекті түрде шешуге мүмкіндік берді. Алдымен 
қазақстандық технологиялық кәсіпорындардың дамуын қаржыландыру жүйесінің экономикалық мәнін зерттеу, содан кейін осы жүйені мемлекеттік реттеу қажеттілігін негіздеу. Бұдан әрі халық пен қаржы нарығына қатысушылар арасындағы экономикалық қатынастар жүйесіндегі интернеттрейдингтің рөлі мен орнын айқындау және соңында республиканың қазіргі заманғы экономикалық болмысына бейімделген Қазақстанның технологиялық кәсіпорындарын дамытуды қаржыландырудың теориялық моделін әзірлеу.

Зерттеудің алынған тұжырымдары Қазақстан Республикасының Технологиялық кәсіпорындарын дамыту үшін қаржы ресурстарын жұмылдыру және пайдалану мәселелерін реттейтін заңнамалық және нормативтік актілерді әзірлеу және оларға өзгерістер мен толықтырулар енгізу кезінде тиісті мемлекеттік органдардың пайдалануы үшін әлеуетті теориялық-әдістемелік базаны білдіреді.

\title{
R. Yelshibayev
}

\section{FINANCING THE DEVELOPMENT OF TECHNOLOGICAL ENTERPRISES IN THE REPUBLIC OF KAZAKHSTAN}

\begin{abstract}
Annotation
The article describes the course and results of the study of economic relations that arise in the process of financing Kazakhstan's technological enterprises. The author, through the use of appropriate General and private economic methods of research, solved the scientific problem of forming a strategy for the mobilization and use of financial resources for the effective development of the technological industry of the Republic of Kazakhstan.

The complex of research tools includes such methods as: formal logical analysis, abstraction, graphical analysis, and economic and statistical analysis. Each of the methods was used adequately for the ero functionality and resolution capabilities. This allowed the author to consistently solve the corresponding stage tasks of the study. First, to study the economic essence of the system of financing the development of Kazakhstan's technological enterprises, then to justify the need for state regulation of this system. Next, determine the role and place of Internet trading in the system of economic relations between the population and financial market participants, and finally develop a theoretical model for financing the development of technological enterprises in Kazakhstan, adapted to the current economic realities of the Republic.

The findings of the study represent a potential theoretical and methodological basis for use by relevant state bodies in the development and introduction of amendments and additions to legislative and regulatory acts regulating the mobilization and use of financial resources for the development of technological enterprises in the Republic of Kazakhstan.
\end{abstract}

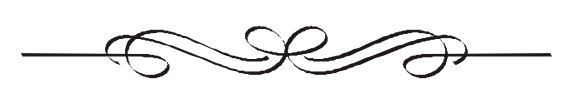


Г.С. Укубасова*, PhD, к.э.н., профессор

Н.В. Ибрагимова, магистр экономики

Казахский университет экономики, финансов и

международной торговли

2. Нур-Султан

e-mail: g_ukubasova@kuef.kz

* - основной автор (автор для корреспонденции)

\section{ЗНАЧЕНИЕ $S$ \& ОР-ПРОЦЕССА В ПРОИЗВОДСТВЕННОЙ И ЭКОНОМИЧЕСКОЙ ДЕЯТЕЛЬНОСТИ ПРЕДПРИЯТИЯ}

В статье раскрываются вопросы, касающиеся Sales and Operations Planning, как проиесса системного планирования объемов производства, закупок, хранения, перемещений и поставок потребителям продукции, который позволяет оптимизировать расходы указанных прочессов, а также процессов логистики, касающихся этапов производственнохозяйственной деятельности предприятия.

Sales and operations planning - это своего рода новый взгляд и подход к осуществлению проиесса планирования производственной деятельности предприятия, а так же к его логистической деятельности, дающий возможность адаптироваться к современным тенденциям развития экономики как на микро, так и на макроуровне. Обнаружены проблемы в планировании и организации прочессов производства и сбыта продукиии на предприятиях, которые приводят к множественным частным корректировкам различного вида производственных планов и тем самым тормозят прочессы их деятельности.

Предложено внедрять предприятиям на широкой основе систему $S \& O P$, поскольку она способна обеспечить высокую точность прогноза спроса и является залогом отсутствия потерь во всей цепочке поставок, а также способствует оптимизации работы компании в целом. Объектом исследования в статье является процесс планирования продаж и операщий (Sales and Operations Planning, S\&OP) на предприятиях.

Ключевые слова: процесс планирования продаж и операций, закупки, поставки, логистическая иепочка, иикл, перемещение, оптимизаиия, спрос, внешняя среда, математическая модель.

Кілт сөздер: сату және операцияларды жоспарлау проиесі, сатып алу, жеткізу, логистикалық тізбек, ичикл, жылжыту, оңтайландыру, сұраныс, сыртқы орта, математикалық модель.

Keywords: sales and operations planning process, custom, shipments, logistics chain, cycle, moving, optimization, demand, external environment, mathematical model.

JEL classification: M 11

Введение. Актуальность исследования заключается в том, что на сегодняшний день многие предприятия, особенно предприятия промышленного комплекса, стремятся оптимизировать свои затраты, а также процессы производства продукции, с целью сокращения расходов и снижения себе66 стоимости. Система Sales and Operations Planning способна помочь предприятиям решить указанные проблемы, вовремя выявлять «узкие» места в производственных и логистических процессах предприятия.

Основной целью данного исследования является раскрытие сущности и мето- 
дики внедрения процесса Sales and Operations Planning в современных экономических условиях. В качестве ключевых задач исследования можно выделить следующие:

- раскрыть понятие и сущность процесca Sales and Operations Planning, его важность в современных экономических условиях;

- провести сравнительный анализ традиционного подхода к планированию на производстве и современного с применением S\&OP-процесса;

- показать эффективность внедрения в производственно-хозяйственную деятельность предприятий системы Sales and Operations Planning.

Научные результаты, полученные в ходе исследования, позволяют сделать вывод о том, что Sales and Operations Planning это новый взгляд и подход к осуществлению процесса планирования производственной деятельности предприятия, дающий возможность адаптироваться к современным тенденциям развития экономики как на микро, так и на макроуровне.

Методами исследования послужили такие методы как, метод анализа и синтеза, метод эмпирического исследования, а так же метод прогнозирования и сетевого моделирования.

Sales and Operations Planning - это процесс системного планирования объемов производства, закупок, хранения, перемещений и поставок потребителям продукции компании в качестве стратегических запасов от 1-3 месяцев до 1-2 лет с целью наилучшего удовлетворения ожидаемого спроса и получения максимальной прибыли [1].

Sales and Operations Planning на сегодняшний день является одной из самых эффективных систем управления производственными процессами на предприятии, особенно на предприятиях промышленного сектора, поскольку позволяет оптимизировать все процессы, происходящие как внутри, так и вне предприятия.
Обзор литературы. На сегодняшний день вопросам Sales and Operations Planning уделено достаточно внимания со стороны отечественных и зарубежных ученых, а также специалистов, однако многие аспекты этой проблемы остаются в настоящий момент дискуссионными и требуют дополнительных исследований.

Несмотря на большое количество трудов ученых по данной проблеме (Ахмедьянов А.У., Айтхожина А.C. [1], Thomas F. Walace [2], Магомедов Ш.Ш. [3], Thomas Staeblein и Katsuki Aoki [4], Kumar R. и Samir K. [5], Лукинский B.C. [6], Алферова Л.В., Григорьева Н.М. [7], Кубаев К.Е. [8], и др.), все-таки, их большая часть посвящена отдельным аспектам проблемы, при этом комплексно совокупность факторов, оказывающих влияние на Sales and Operations Planning исследователями не pacсматривалась, в связи с чем, сохранилась необходимость изучения данной темы, осмысления накопленных знаний, с точки зрения, совершенствования вопросов планирования продаж и операций. Многие современные ученые говорят о том, что процесс Sales and Operations Planning дает способ управления всем бизнесом целиком, позволяет охватывать единым образом все процессы производства. Такой подход, по их мнению, очень важен в контексте качественного управления предприятием и, соответственно, росте прибыльности и устойчичивости предприятия. Это процесс является уникальной бизнес-практикой, внедряемой на современных предприятиях, особенно на предприятиях, стремящихся производить конкурентоспособную продукцию.

Основная часть. Планирование продаж и операций на предприятии можно рассматривать как альтернативу принятому годовому бюджетному планированию, но концепция и методика, заложенные в процесс планирования продаж и операций, дают абсолютно новые возможности для более обоснованных решений, как в кон- 
тексте цепи поставок, так и в области управления продажами и экономикой организации. Данный подход, с одной стороны, позволяет более эффективно управлять производственно-логистическими ресурсами, а с другой - построить более системное управление спросом и взаимоот- ношениями с клиентами с целью получения максимальной отдачи от собственных и привлекаемых производственных и логистических активов.

Традиционный подход к планированию подразумевает итерационное согласование планов по цепочке (рис. 1).

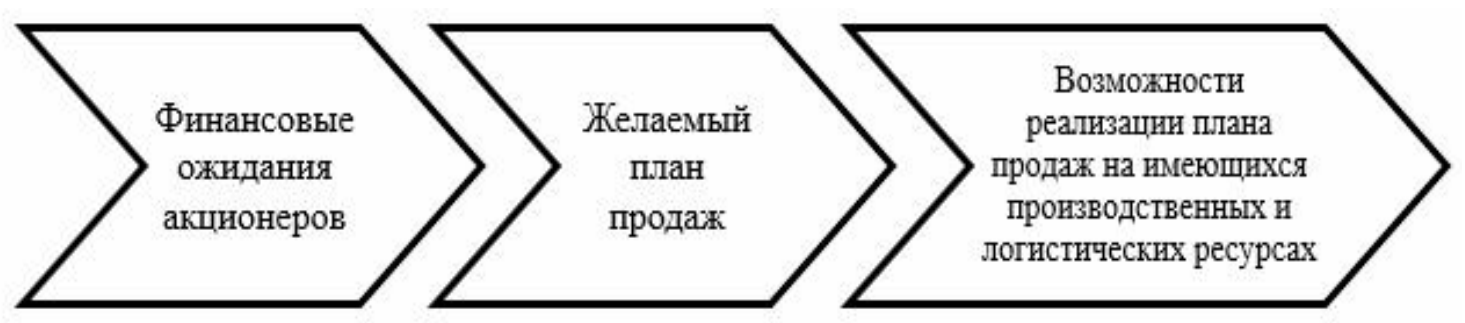

Рисунок 1. Цепочка согласования планов при традиционном планировании*

*Составлен авторами по источнику [2]

Такой вариант планирования неизбежно приводит к множественным частным корректировкам плана то в подразделении продаж, то в производстве и логистике в попытке выйти на его компромиссный вариант, удовлетворяющий частным интересам каждого отдельного участника, но при этом зачастую не учитывает общие для компании критерии эффективтности и качества интегрированного плана. Концепция Sales and Operations Planning ocновывается на следующем важном принципе: критерии качества плана должны определяться не только и не столько краткосрочными выгодами, сколько среднесрочной оценкой маржинальной прибыли, которую компания сможет получить в заданном промежутке времени, если правильно распорядится имеющимися и новыми ресурсами для удовлетворения наиболее выгодного спроса [2].

Еще одним важным отличием концепции планирования продаж и операций от традиционного планирования является изначальная ориентация не на желаемый плановый объем продаж, а на согласованный прогноз спроса - независимую потребность в готовой продукции, обусловленную конъюнктурой рынка.

И только после сопоставления прогнозного спроса с производственными, логистическими и финансовыми ограничениями, компания имеет возможность объективно спланировать будущие продажи, согласовав их со всеми имеющимися ограничениям.

Таким образом, Sales and Operations Planning это своего рода новый взгляд и подход к осуществлению процесса планирования производственной деятельности предприятия, дающий возможность адаптироваться к современным тенденциям развития экономики, как на микро, так и на макроуровне.

Внедрение S\&OP-процесса ведет к снижению издержек во всей цепочке поставок и позволяет минимизировать так называемые «потерянные продажи» и «замороженные» в виде запаса деньги [3].

Что дает внедрение S\&OP-процесса в компании? Прогноз спроса, находясь в самом начале цепочки поставок, оказывает огромное влияние на расходы компании.

Именно поэтому высокая точность прогноза спроса является залогом отсутствия потерь во всей цепочке поставок и 
одной из важнейших задач для оптимальной работы компании в целом. Внедрение

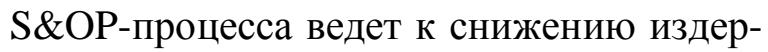

жек во всей цепочке поставок, в том числе обеспечивает (рис. 2):

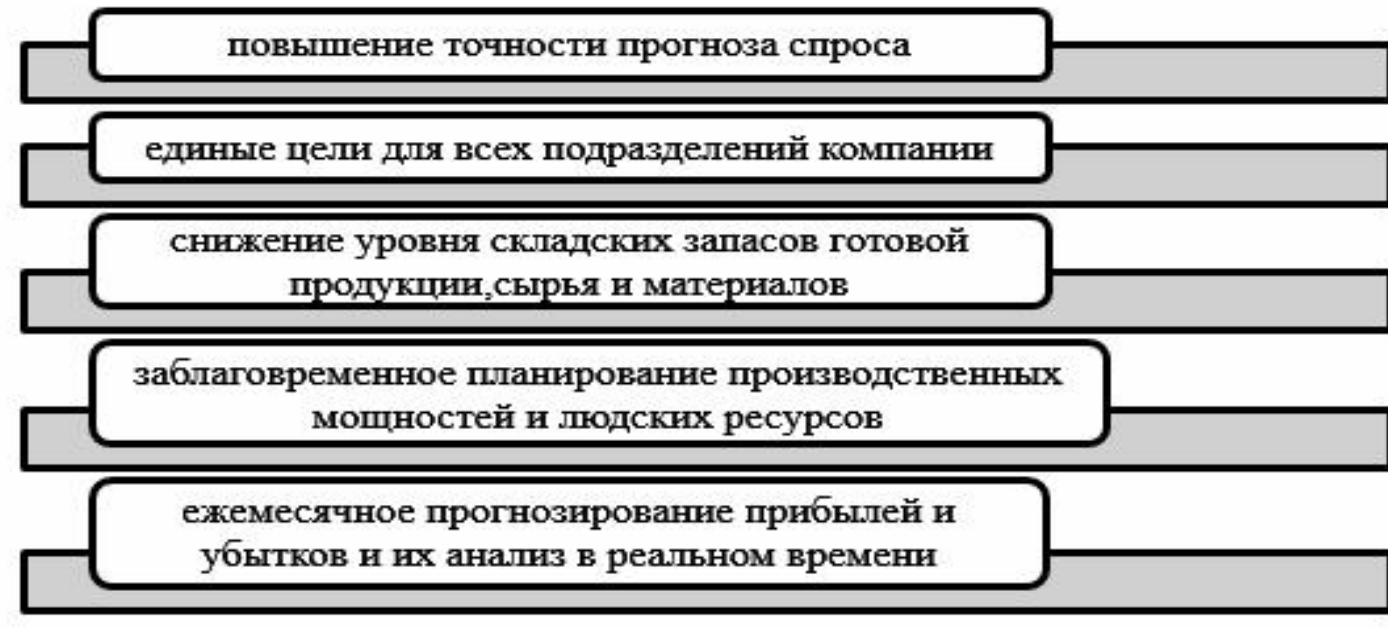

Рисунок 2. Обеспечение процессов деятельности предприятия посредством системы S\&OP*

*Составлен авторами по источнику [3]

B результате внедрения S\&OP-процесса можно получить следующее (рис. 3).

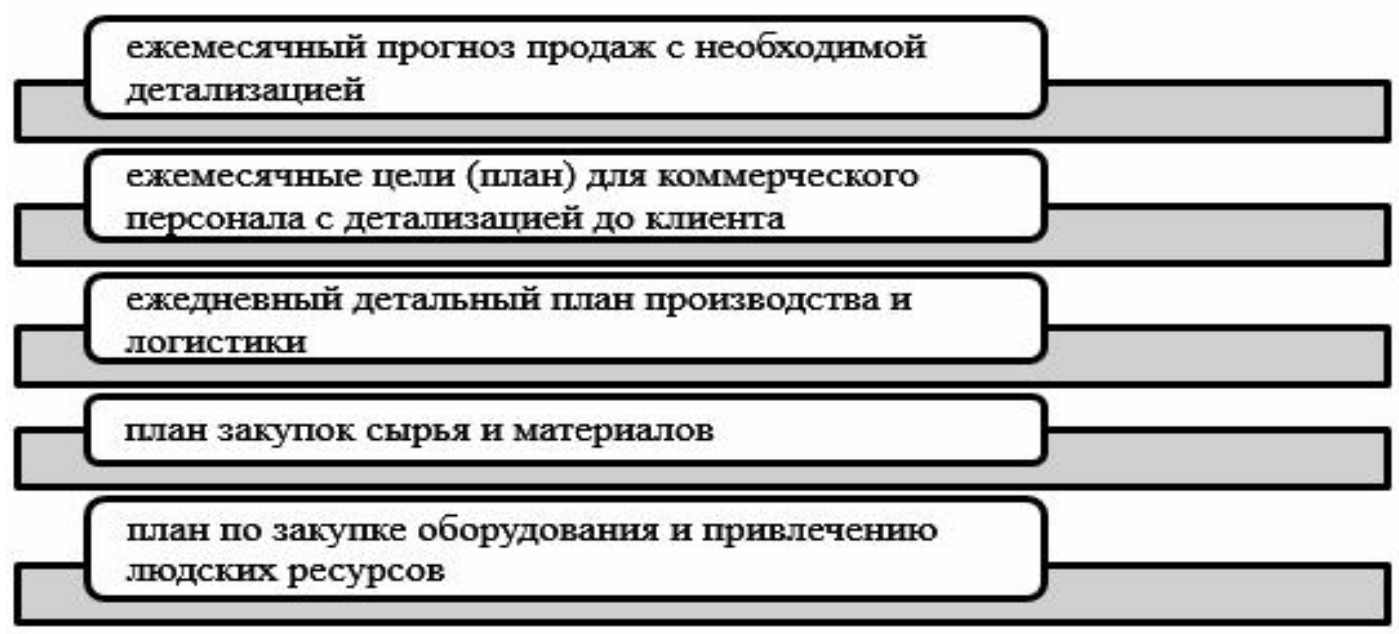

Рисунок 3. Влияние S\&OP-процесса на улучшение деятельности предприятия*

*Составлен авторами по источнику [3]

Такой подход позволяет избежать практики, когда прогноз меняется только по решению, принятому руководством предприятия.

Международный рынок S\&OP-систем достаточно широк и ежегодно растет на 7,2\% в среднем. По прогнозам Allied Market Research (AMR) в 2021 году он достигнет
41,69 млрд долл.США. По данным Panorama Consulting Solutions чаще всего на рынке в 2020 году внедряли S\&OP-системы американского вендора Oracle [4].

На сегодняшний день выбор потребителей данных систем сложился таким образом (табл. 1). 
Показатели приоритетности выбора S\&OP-систем среди покупателей на мировом рынке*

\begin{tabular}{|l|l|c|}
\hline$№$ п/п & Наименование вендора & Доля на рынке, $\%$ \\
\hline 1. & Oracle & 16 \\
\hline 2. & SAP HANA & 15 \\
\hline 3. & Sage & 8 \\
\hline 4. & Epicor & 7 \\
\hline 5. & Infor & 5 \\
\hline 6. & Microsoft & 5 \\
\hline
\end{tabular}

* Составлена авторами по источнику [4]

Как видно из таблицы 1, Oracle занимает лидирующее место на рынке продаж $\mathrm{S} \& \mathrm{OP}-$ систем, затем на $1 \%$ отстает немецкая компания SAP HANA и далее такие компании как Sage, Epicor, Infor, Microsoft.

Период окупаемости 50\% таких сис- тем составляет в среднем 3 года.

Компании, внедрившие в процесс производства указанные S\&OP-системы, добились повышения результатов производственной деятельности по следующим направлениям (табл. 2).

Таблица 2

\section{Показатели повышения результатов деятельности предприятия после внедрения S\&OP-системы*}

\begin{tabular}{|l|l|c|}
\hline № п/п & \multicolumn{1}{|c|}{ Направления повышения результатов деятельности } & \% повышения \\
\hline 1. & Обеспечение доступности к процессам производства & 80 \\
\hline 2. & Надежности работы системы и данных & 55 \\
\hline 3. & Увеличение интегрированности процессов & 46 \\
\hline 4. & Продуктивность и производительность & 44 \\
\hline 5. & Эффективность принятия решений & 43 \\
\hline 6. & Сокращение затрат & 37 \\
\hline
\end{tabular}

*Составлена авторами по источнику [5]

$42 \%$ компаний, внедрившие данные системы, признали вложения своих средств в их внедрение успешными, а $68 \%$ полностью удовлетворены их техническими характеристиками.

Это говорит о растущем спросе на данные системы организации и контроля за производственными процессами предприятий в мировом масштабе, что свидетельствует о желании современных управленцев не только оптимизировать, но и улуч- шить производственную деятельность, а значит, добиться высокой ее эффективности.

Важным этапом внедрения S\&OP-процесса является финансовая составляющая, то есть постепенный переход на ежемесячное обновление отчета о планируемых прибылях и убытках.

Классический S\&OP-процесс может быть представлен последовательностью из 8 шагов, которая занимает целый месяц (рис. 4). 


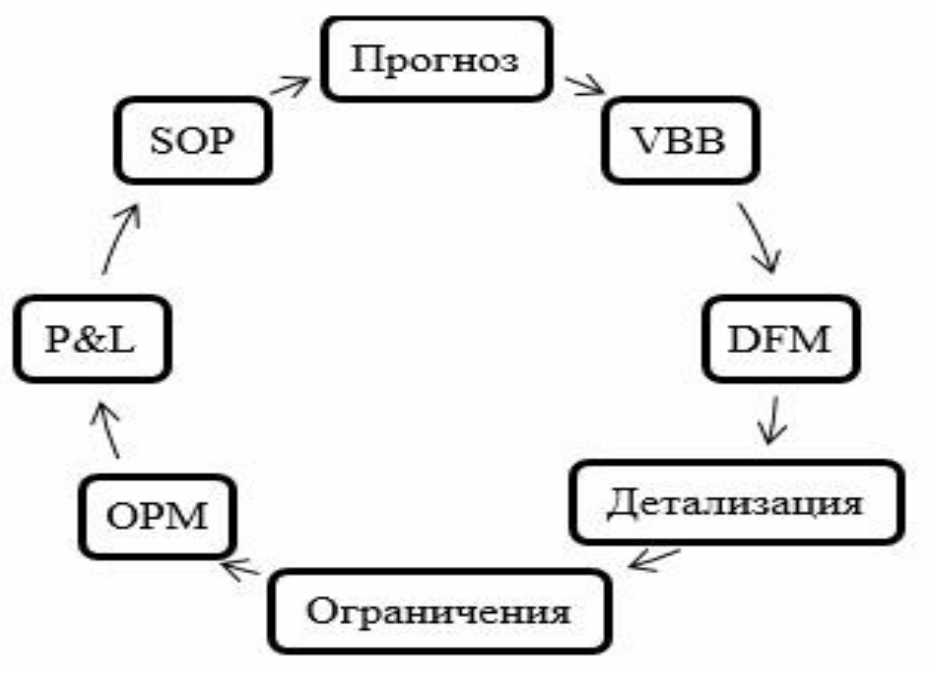

Рисунок 4. Алгоритм классического S\&OP-процесса*

*Разработан авторами по источнику [6]

И если в конце месяца руководство компании понимает, что получившийся P\&L его не устраивает, изменить что-либо можно только через месяц. Оперативность управления теряется и так каждый последующий цикл.

Поэтому целесообразно предложить несколько иной подход к организации процесса S\&OP. В этом случае появляется возможность осуществлять так называемый «Что-Если?» анализ P\&L в реальном времени, так как цикл сокращается (рис. 5).
Смысл такого подхода состоит в том, чтобы сначала сделать все необходимое для расчета $\mathrm{P} \& \mathrm{~L}$, и только затем показать информацию руководству на единственной встрече S\&OP-процесса. Определенное программное обеспечение позволяет пересчитывать P\&L непосредственно на встрече по прогнозированию спроса, когда происходит изменение и согласование плана продаж (посредством изменения VBB), то есть в реальном времени (изображено красной стрелкой) [6].

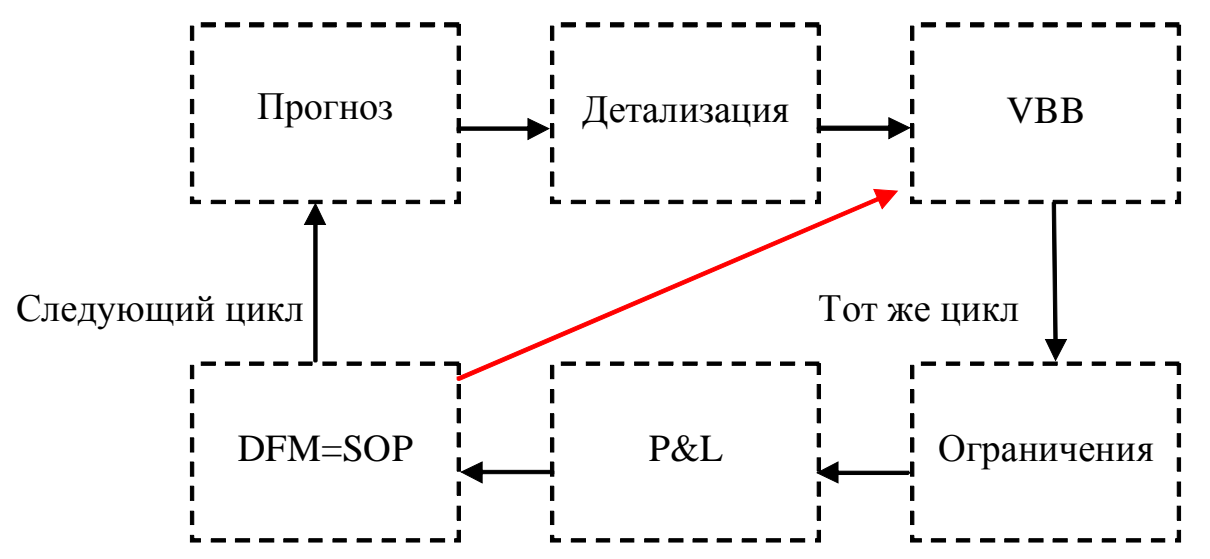

Рисунок 5. Алгоритм предлагаемого подхода к S\&OP-процессу*

*Составлен авторами по источнику [7] 
И если руководство компании видит, что полученный P\&L не соответствует стратегическому плану (бюджету) компании, P\&L может быть пересчитан непосредственно на встрече, по результатам изменения плана продаж, отпускных цен.

Стандартный S\&OP-процесс позволяет увеличивать точность прогнозирования на основании первичных продаж. Однако наступает момент, когда повысить точность прогноза спроса только за счет первичных продаж уже нельзя.

Ресурс для повышения точности - вторичные продажи, которые можно получить с помощью определенного программного инструмента. Увеличение точности возможно благодаря ключевому принципу работы всей цепочки поставок, который можно кратко сформулировать так: чем ближе к покупателю, тем точнее план [7].

Такой подход позволяет избежать значительных колебаний спроса, вызванных так называемым «эффектом кнута». И если компания реализует значительную часть своей продукции через дистрибьюторов, использовать данные по вторичным продажам для процесса планирования продаж и операций особенно важно.

Система S\&OP успешно внедряется и на казахстанских предприятиях.

К примеру, транспортно-логистическая компания «Astrum service» внедрила в процесс своей деятельности данную систему с целью оптимизации процесса формирования и обработки портфеля заказов, а так же загрузки мощностей предприятия [9]. До внедрения S\&OP-системы на данном предприятии в целом весь процесс занимал временной интервал в среднем от 25 до 30 суток, по некоторым процессам от 41 до 49 дней, что составляет практически 1,5 месяца.

После внедрения S\&OP-системы, данный процесс сократился на 14 суток или 2 недели, что существенно повлияло на весь процесс производства в целом. Так, если процесс производства до внедрения меро- приятий составлял 30 суток, то после внедрения составляет до 16 суток, то есть в месяц предприятие может совершать не один, а два полных процесса, увеличив при этом и производительность труда и объемы выпуска продукции, и объем прибыли как минимум в два раза.

Если до внедрения мероприятий, коэффициент прямоточности составлял 0,6 , то после внедрения мероприятий, он составил:

Кпр1=10/25=0,4

Кпр2=17/35=0,5

Кпр1 снизился на 0,2, а Кпр2 на 0,1. Это считается положительной динамикой, так как снижение значения данного коэффициента говорит об эффективности внедрения S\&OP-системы.

Экономическая эффективность от внедрения S\&OP-системы на данном предприятии составила 2956,5 тыс. тенге, то есть улучшилась на 50\%, так же, как и прибыль предприятия [8].

Выводы. Подводя итог, можно сделать вывод о том, что внедрение процесса Sales and Operations Planning на предприятии позволяет оптимизировать материальные, временные и прочие издержки производства; увеличить объемы продаж продукции, объемы прибыли предприятия; успешно наладить логистические процессы, а также работу с клиентами (покупателями), обеспечить эффективность производственных процессов.

Sales and Operations Planning позволяет осуществить высокую точность прогноза спроса, является залогом отсутствия потерь во всей цепочке поставок предприятия и позволяет решать важнейшие производственные задачи для оптимальной работы компании в целом.

Кроме того, внедрив данный процесс на предприятии с помощью программного обеспечения, можно избежать существенных необоснованных потерь, имеющих место на предприятии в ходе осуществления производственной деятельности. 
Меры, направленные на сокращение продолжительности производственного цикла с помощью S\&OP-системы, оказывают общее положительное экономическое воздействие. Они создают предпосылки для улучшения использования производственных мощностей, снижая долю накладных расходов в удельной стоимости.
Так, сокращение продолжительности всех элементов производственного цикла на казахстанском транспортно-логистическом предприятии ТОО «Astrum service» явилось важным условием для улучшения многих технических и экономических показателей предприятия.

\section{ЛИТЕРАТУРА}

1. Ахмедьянов А.У., Айтхожина А.С. Технологический процесс погрузочно-разгрузочных работ на транспорте: Учебник. - Астана: ЕНУ им. Л.Н. Гумилева, 2016. - 434 с.

2. Thomas F. Walace, 2015. Sales and Operations Planning Thehow-tohandbook 2 ndedition Thomas F. Walace\&Company. - 151 p.

3. Магомедов Ш.Ш. Управление товарным ассортиментом и запасами: Учебник для бакалавров / Ш.Ш. Магомедов. - Электрон. Текстовые данные. - М.: Дашков и К, 2019. 176 c. http://www.iprbookshop.ru/85673.html. - ЭБС «IPRbooks».

4. Thomas Staeblein, Katsuki Aoki, April 2015. Planning and scheduling in the automotive industry: A comparison of industrial practice at German and Japanese makers // International Journal of Production Economics. - Vol. 162. - P. 258-272.

5. Kumar Rakesh and Srivastava, Samir K, 2014. «A Framework for Improving 'Sales \& Operations Planning», Metamorphosis, 13(1). - P. 16-25.

6. Лукинский В.С. Логистика и управление цепями поставок: Учебник и практикум для среднего профессионального образования / В.С. Лукинский, В.В. Лукинский, Н.Г. Плетнева. - М.: Изд. Юрайт, 2019. - 359 c. https://biblio-online.ru/bcode/442475

7. Алферова Л.В. Исследование систем управления: Учеб. пособие / Л.В. Алферова, Н.М. Григорьева. - Челябинск, Саратов: Южно-Уральский институт управления и экономики, Ай Пи Эр Медиа, 2019. - 560 c. http://www.iprbookshop.ru/81477.html. - ЭБС «IPRbooks».

8. Кубаев К.Е. Рынок транспортных услуг: становление, особенности, механизм функционирования (на примере РК): Моногр. - Алматы: ИП «Сагаутдинова», 2015. - 149 с.

9. Раимбеков Ж.С., Сыздыкбаева Б.У. Эконометрический анализ взаимовлияния и связи транспорта и экономического роста // Вестник КазУЭФМТ. - 2020. - №2 . - С.5-15.

\section{REFERENCES}

1. Ahmed'yanov A.U., Aithozhina A.S. Tehnologicheskii process pogruzochno-razgruzochnyh rabot na transporte: Uchebnik. - Astana: YENU im.L.Gumileva, 2016. - 434 s. [In Russian].

2. Thomas F.Walace, 2015. Sales and Operations Planning Thehow-tohandbook 2 ndedition Thomas F. Walace\&Company. - 151 p. [In English].

3. Magomedov Sch. Sch. Upravlenie tovarnyim assortimentom i zapasami: Uchebnik dlya bakalavrov / Sch.Sch. Magomedov. - Elektron.tekstovye dannye. - M.: Daschkov i K, 2019. - 176 s. http://www.iprbookshop.ru/85673.html. - EBS «IPRbooks» [In Russian].

4. Thomas Staeblein, Katsuki Aoki, April 2015. Planning and scheduling in the automotive industry: A comparison of industrial practice at German and Japanese makers, International Journal of Production Economics. - Vol. 162. - P. 258-272 [In English]. 
5. Kumar Rakesh and Srivastava, Samir K., 2014. «A Framework for Improving 'Sales \& Operations Planning», Metamorphosis, 13(1). - P. 16-25 [In English].

6. Lukinskiy V.S. Logistika I upravleniye tsepyami postavok: Uchebnik i praktikum dlya srednego professional'nogo obrazovaniya / V.S. Lukinskiy, V.V. Lukinskiy, N.G. Pletneva. - M.: Izd. «Yurayt», 2019. - 359 s. https://biblio-online.ru/bcode/442475 [In Russian].

7. Alferova L.V. Issledovanie system upravleniya: Ucheb. posobie / L.V. Alferova, N.M. Grigor'eva. - Chelyabinsk, Saratov: Yuzhno-Ural' skii institute upravleniya i ekonomiki, Ai PiEr Media, 2019. - 560 s. http://www.iprbookshop.ru/81477.html. -EBS «IPRbooks» [In Russian].

8. Kubaev K.E. Rynok transportnyh uslug: stanovlenie, osobennosti, mehanizm funkcionirovaniya (na primere RK): Monogr. - Almaty: IP «Sagautdinova», 2015. - 149 s. [In Russian].

9. Raimbekov Zh.S., Syzdykbayeva B.U. Ekonometricheskiy analiz vzaimovliyaniya i svyazi transporta i ekonomicheskogo rosta // Vestnik KazUEFMT. - 2020. - №2. - S. 5-15 [In Russian].

\section{Ғ.С. Үкібасова, Н.В. Ибрагимова \\ КӘСІПОРЫННЫҢ ӨНДІРУ ЖӘНЕ ЭКОНОМИКАЛЫҚ ҚЫЗМЕТІНДЕГІ \\ S\&OP-ПРОЦЕСІНІҢ МАНЫЗДЫЛЫҒЫ}

\section{Андатпа}

Мақалада S\&OP-ке қатысты мәселелер көрсетілген процестердің шығындарын оңтайландыруға мүмкіндік беретін өнімдерді өндіру, сатып алу, сақтау, өткізу және тұтынушыларға жеткізу көлемдерін жүйелі жоспарлау процесі ретінде, кәсіпорынның өндірістік-шаруашылық қызметінің кезеңдеріне, логистика процестеріне қатысты ашылады. Өндіріс жоспарларының әр түрлі түрлерін бірнеше жеке түзетуге әкелетін және сол арқылы оның қызмет ету процестерін тежейтін кәсіпорындарда өндіріс және сату процестерін жоспарлау мен ұйымдастырудағы проблемалар анықталды. Кәсіпорындарға S\&OP жүйесін кеңінен енгізу ұсынылды, өйткені ол сұранысты болжаудың жоғары дәлдігін қамтамасыз ете алады және жеткізілім тізбегінде шығындардың болмауының кепілі болып табылады, сонымен қатар компанияның жұмысын оңтайландыруға көмектеседі.

Мақаладағы зерттеу нысаны - кәсіпорындардағы сату мен операцияларды жоспарлау процесі.

\section{G. Ukubassova, N. Ibragimova \\ THE IMPORTANCE OF THE S\&OPPROCESS IN THE PRODUCTION AND ECONOMIC ACTIVITIES OF THE ENTERPRISE}

\section{Annotation}

The article covers issues related to sales and operations planning, as a process of system planning of production volumes, purchases, storage, movement and delivery of products to consumers, which allows you to optimize the costs of these processes, as well as logistics processes related to There are problems in planning and organizing the processes of production and marketing of products to enterprises, which lead to multiple individual adjustments of various types of production plans and thereby slow down the processes of its activities. It is proposed to introduce the S\&OP system to enterprises on a broad basis, since it is able to provide high accuracy of demand forecasting and is a guarantee of no losses in the entire supply chain, as well as helps to optimize the company's work as a whole.

The object of research in the article is the process of planning sales and operations at enterprises.

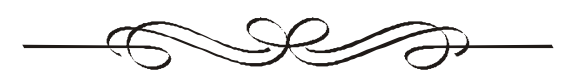


R. Andekina*, $P h D$, acting associate professor ${ }^{l}$ A. Aimagambetova, c.e.s, senior lecturer ${ }^{2}$ Turan-Astana University ${ }^{l}$ Nur-Sultan $c$. Korkytata Kyzylorda University ${ }^{2}$ Kyzylordac. e-mail: andekinaregina@gmail.com * - main author (author for correspondence)

\section{STRATEGY DEVELOPMENT BY USING SWOT ANALYSIS IN A METALS MANUFACTURING COMPANY}

A company's condition and its role in the competitive market largely depends on its ability to react to the various impacts, cuased by entrernal and external environment. This paper reveals the results of SWOT analysis conducted to the Kazakhstani metals company. Based on the findings of the research a number of recommendations to the company management were developed. The paper is of scientific and pratical value, since the company has never applied the SWOT analysis before to develop a strategic plan. Moreover, this research contributes with the real case-study of the domestic company, the results of which could be applied to other sectors manufacturers. Discovered strong and weak charaterisitcs, risks and opportunities of the company lead to the development of suggestions to the management for further strategic plan development and to focus on marketing activities. Previously to this paper, financial condition of the company has been comprehensively analyzed and organizational structure thorouly studied.

Keywords: SWOT analysis, strategy, decision-making, metal manufacturing company, risks, production, marketing, ferrous metals, nonferrous metals.

Кілт сөздер: SWOT-талдау, стратегия, шешім қаббылдау, металл өндіретін компания, тәуекелдер, өндіріс, маркетинг, түсті металдар, қара металдар.

Ключевые слова: SWOT-анализ, стратегия, принятие решений, металлообрабатывающая компания, риски, производство, маркетинг, иветные металлы, черные металль.

JEL classification: L10, L19

Introduction. In a market economy, the degree of influence of the external environment significantly exceeds the influence of the internal environment. As the once closed economy is integrated into the system of world economic relations, their expansion and deepening, the influence and significance of the external environment will inevitably increase. Therefore, in order to be competitive even in the domestic market, Kazakhstan's business structures are forced to produce products that are superior in their quality parameters not only to domestic, but also to foreign analogues. This article considers the company, which operates in metal manufacturic sector.
The activity of collecting, harvesting and processing of metal scrap and waste forms a kind of sub-sector of metallurgical production. At present, its purpose within the metallurgical industry is to provide metcombinates with high-quality raw materials for further production of metals and finished products from it.

This article analyzes the company XYZ, which has been existing on the market for a long time and has already won a competitive position. The life cycle phase that the organization has entered can be described as the maturity phase. It is characterized by a stable organizational structure, loyal customers and suppliers, and a formalized 
decision-making process. However, the analysis reviled that the sales volume is unstable and varies every time.

During all the years of operation on the market, which is more than four decades, the company's management has not made any attempts to apply the SWOT analysis for developing the company's strategic plans. Therefore, the main purpose of this study was to conduct the SWOT analysis of the company and develop recommendations in accordance with the findings. Therefore, this study has practical value along with the scientific. The method was chosen because it helps to distinguish the assets as well as the limits of the company within its competitors.

Literature review. The SWOT anaylis widely used in various sectors of economy to asses the external and internal environment of the company. As Krol suggests, the SWOT analysis aims to show the relationships and interactions between company's strong sides, opportunities, risks and limits [1]. Therefore, this analysis explores the important factors to the subject of research. It comprises of three stages, which are defining strong and weak sides, discovering opportunities and threads, and eventually, based on findings, to develop strategic recommendations. This paper presents exactly these steps.

Moreover, Houben et al. imply that responding to the internal strengths and weaknesses in of paramount importance for strategic management [2]. Therefore, a number of Kazakhstani companies conduct the SWOT analysis and act accordingly [3-6].

If Bogomolova [7] presents the theory and practice of the SWOT analysis, other Russian scientists [8-9] provide the examples of applying this method to the companies. Therefore, conducting SWOT analysis to the company in metal manufacturing sector in Kazakhstan would be informative and helpful for further research in this area.

Findings and discussion. It should be noted that previously to this study financial analysis of the company, its organizational structure has been studied. This paper focuses only on SWOT analysis and developesrecoomendations based on findings from this analysis. Taking into consideration previous research findings. The SWOT analysis presented in the figure 1 below.

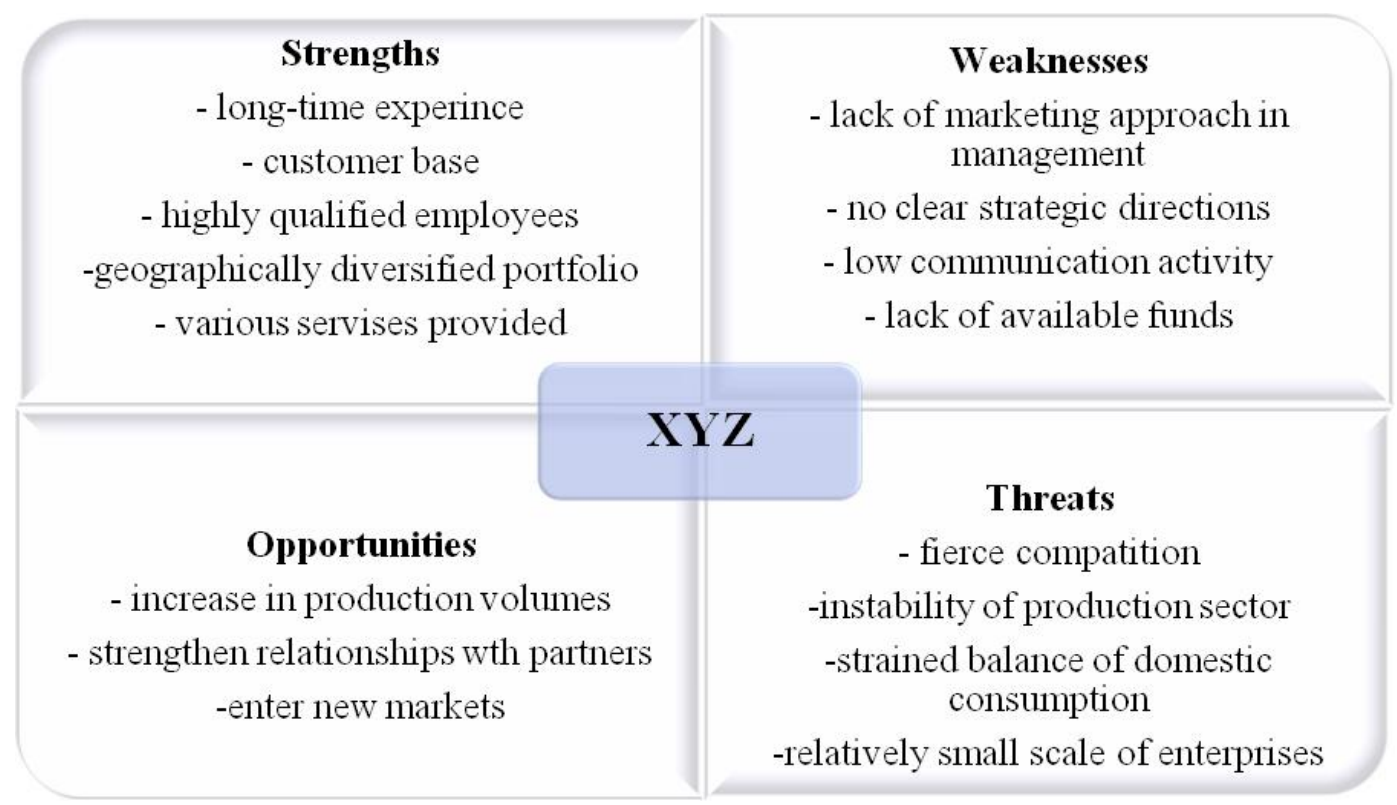

Figure 1. SWOT analysis of the XYZ company*

*Note - developed by the authors 
At the first stage of SWOT analysis, it is necessary to consider the strengths and weaknesses of the company.

The strengths of the subject company are determined by the relatively large experience of the enterprise and the presence of a well-developed customer base. The second strong point is the selection of exclusively highly qualified employees, which consequently leads to the need for high remuneration, but at the same time, has a positive impact on the success of the enterprise.

The third strong point of the company is a geographically diversified portfolio of regular customers, including large enterprises of the metallurgical industry in England, Turkey, the United Arab Emirates, and so forth.

The fourth strength of the company is the availability of several services provided to the portfolio in addition to the harvesting, processing and marketing (export) scrap and waste of ferrous and nonferrous metals. The company leases warehouses with the provision of related services, railway docks, production areas, crane pads and provides services for loading / unloading.

However, along with the strengths of the activities there are some shortcomings, which form the weaknesses of the organization.

The first weak point is the lack of marketing approaches in management, and consequently, the production and sales orientation on business processes, rather than the market orientation. The second weakness is a lack of clear strategic directions of further development of business.

The third weak point is low communication activity in the market. The lack of a unified concept for promoting products and services to potential partners - suppliers of scrap metal and customersconsumers of secondary non-ferrous and ferrous metals. Thus, marketing functions completely fall out of the company's management system. The fourth weak point is that there are no available funds for further development and growth of the enterprise.

Opportunities are defined as factors that enable the company to implement any new business processes, tasks, etc. The following opportu- nities for the analyzed enterprise can be noted.

The first possibility is the development (increase in production volumes) of the metallurgical complex, which is the main consumer of secondary metal resources. With this growth, the growth of the demand for the products of such enterprises is obvious. The second option is to strengthen relationships with partners - suppliers of ferrous and non-ferrous scrap and customers.

The third possibility is to enter new markets. As noted above, the partnership provides several other types of services for businesses located in geographically remote regions, and as a result, it has the opportunity to expand the provision of services for core activities by positioning itself as a reliable partner for customers who consume services for non-core activities of the partnership.

The influence of the external environment on the business creates not only a number of opportunities, but also threats, i.e. such factors that can damage the company's activities and deprive it of its existing advantages. Among the existing threats to the partnership are the followings.

The first threat is fierce competition. Here, especially noticeable is the restraining influence on the business of the company are enterprises from the strategic group of competitors that "take" in similar geographical markets possible suppliers of black and non-ferrous scrap metal, as well as customers-customers of secondary metal resources.

The second threat is an increase in risks due to the instability of the production sector of the economy. The third threat is the strained balance of domestic consumption of metal resources. The fourth threat is the relatively small scale of the enterprise, which may result in a decline in activity due to lack of proper control or, for example, the departure of at least one employee.

Based on the findings from SWOT analysis, a number of recommendations to the company have been developed. The first recommendation would be to improve the efficiency of the companyit is necessary to develeop an effective strategy.An organization's strategy is a comprehensive plan of action that sets priorities for strategic objectives, resources, and a rational way to achie- 


\section{Экономика}

ve strategic goals. The main objective of the recommended strategy selection of the partnership is to transfer it from the present state to the future financial condition desired by management.

We should start with the fact that it is necessary to resort to the management process itself, which determines the sequence of actions of the partnership in developing and implementing the strategy. It should include:

- setting goals;

- strategy formulation;

- determining the necessary resources;

- maintaining relationships with the external environment, which alloworganizations to solve the tasks.

Development and strategy is carried out at the highest level of management and is based on the solution of the above tasks. At this stage of decision-making, the President of the company needs to evaluate alternative ways of the company's activities and choose the best options to achieve the goals set, the first of which will be to increase profitability

Based on the analysis, the management of the partnership is recommended to consider strategies for concentrated growth. If these strategies followed, first the company would need to improve their product or to increase the volume of its implementation, most likely resorting to external financing. As for the market, the partnership needs to look for ways to improve its position in the existing market for tenants of warehouses and railway dead ends.

However, as mentioned above, given the state of scientific, technical and personnel potential, material and technical base and the actual lack of state support, it will be very difficult for them to compete in the domestic and foreign markets and ensure profitability growth, especially given the current situation on the scrap metal market.

In this regard, the importance of another reserve for improving the economic efficiency of entrepreneurship increases many times - the ability of entrepreneurs to combine factors of production and services to obtain advantages in the market. In the course of this activity, there is a continuous assessment of external and internal opportunities that open up to the business structure, as well as threats from the external environment, and the risks associated with them. This requires ranking all events by two parameters: relevance, which characterizes the speed of the event, and the benefits (for opportunities) and risks (for threats) associated with these events.

Thus, in the current circumstances and based on the assessment of the financial condition of the company, the following ways to increase profitability were recommended:

- choosing a strategy to strengthen positions in the market for lessors of warehouses and railway dead ends;

- conducting a qualitative analysis of the market and competitive environment, while sparing no expense in paying for the work of a specialist who is ready to contribute to the development of the enterprise through the introduction of marketing activities in the company that are not available at the moment;

- using a more optimized capital structure and applying the effect of financial leverage in the future, which will help to attract the financial resources necessary to strengthen positions in the market, increase the return on equity and reduce income tax, which in the complex will be one of the tools to increase the profitability;

- improving the quality of service delivery, which will be possible by attracting financial resources for renovation of premises, repairs, etc. and purchasing new premises to generate more profit and expand the volume of services sold.

These recommendations will help the analyzed facility not only to stay afloat with a temporary ban on the export of scrap metal, but also to diversify the risks that may arise in the future, by increasing the focus on the provision of rental services, expanding the technical base, as well as by optimizing the capital structure.

Conclusion. This paper described one of the most widely spread methods for strategic decisions SWOT analysis, exploring the strong and weak sides of the metal manufacturing company, as well as discovering its market opportu- 
nities and threats. It is believed that the research results have the potential for large application by the companies of this sector. Recommendations for the strategic development plan of the company were provided, taking into consideration its financial condition. Which has been analyzed pre- viously. Organizational structure was also taken into account. Since the company management has never conducted the SWOT analysis before, it can be stated that the findings of the research are very applicable and are of practical value to the company and its management.

\section{REFERENCES}

1. Krol M., Sygut P. SWOT-analysis in the company manufactures steel structures // Archives of Engineering Knowledge. - 2016. - №1(1). - P. 59-61.

2. Houben G., Lenie K., Vanhoof K. A knowledge based SWOT-analysis system as an instrument for strategic planning in small and medium sized enterprises // Decision Support Systems. 1999. - № 26. - P. 125-135.

3. Burkitbayev Y.U. SWOT-analysis of balanced scorecard system at JSC «National Medical Holding» // Clinical medicine of Kazakhstan. - 2014. - № 33. - P. 41-43.

4. Karabasov R.A. SWOT-analiz posrtoeniya distributsii kompanii na rynke g.Astana [SWOT analysis of establishing distribution company on the Astana city market] // Vestnik Innovatsionnogo Evraziiskogo Universiteta. - 2012. https://articlekz.com/article/13296 [In Russian].

5. Dzhumadilova Sh.G. SWOT-analiz sostoyaniya neftegazovoi otrasli Kazakhstana [SWOTanalysis of the condition of oil and gas sector] // Vestnik KAZNU. - 2013. https://articlekz.com/ article/8687 [In Russian].

6. Kaztranscom. Annual report. 2019 // Godovoi otchet. 2019. https://kaztranscom.kz [In Russian].

7. Bogomolova V.G. SWOT-analiz: Teoriya i prakitika primeneniya [SWOT-analysis: theory and practice of application] // Ekonomicheskii analiz: teoriya i praktika. - 2004. - №17(32). S. 57-60 [In Russian].

8. Bondarenko V.A. Voronova R.S. Provedenie SWOT-analiza v rynochnoi aktivnosti firmy na primere OOO «Kargill» [Conducting SWOT-analysis in market activity of the example of Kargil com-pany] // Koncept. - 2015. - №24. - S.1-9 [In Russian].

9. Churkina V., Sukhova O.V. Primenenie metoda SWOT-analiza v issledovanii sistemy upravleniya organizacii [Applying SWOT-analysis in researching the system of organizational management] // Materialy nauchno-prakticheskoi konferenzii. Obschestvo itsivilizatsiya: Tendentsii i perspektivy razvitiya sovremennogo obshcestva v XXI veke. - 2016. - S.16-20 [In Russian].

\section{ЛИТЕРАТУРА}

1. Krol M., Sygut P. SWOT-analysis in the company manufactures steel structures // Archives of Engineering Knowledge. - 2016. - №1(1). - C. 59-61.

2. Houben G., Lenie K., Vanhoof K. A knowledge based SWOT-analysis system as an instrument for strategic planning in small and medium sized enterprises // Decision Support Systems. 1999. - № 26. - C. 125-135.

3. Burkitbayev Y.U. SWOT-analysis of balanced scorecard system at JSC «National Medical Holding» // Clinical medicine of Kazakhstan. - 2014. - № 33. - C. 41-43.

4. Карабасов P.A. SWOT-анализ построения дистрибуции компании на рынке г. Астана // Вестник Инновационного Евразийского Университета. -2012. URL: https://articlekz.com/ article/13296 (Дата обращения: 15.01.2020). 


\section{Экономика}

5. Джумадилова Ш.Г. SWOT-анализ состояния нефтегазовой отрасли Казахстана // Вестник КазНУ. -2013. URL:https://articlekz.com/article/8687. URL: https://articlekz.com/article/ 8687. (Дата обращения: 10.01.2020).

6. Казтранском. Годовой отчет. - 2019. URL: https://kaztranscom.kz. (Дата обращения: 15.03.2020).

7. Богомолова В.Г. SWOT-анализ: Теория и практика применения // Экономический анализ: теория и практика. - 2004. - № 17(32). - С. 57-60.

8. Бондаренко В.А., Воронова Р.С. Проведение SWOT-анализа в рыночной активности на примере ООО «Каргил» // Концепт. - 2015. - №24. - С. 1-9.

9. Чуркина В., Суркова O.В. Применение метода SWOT-анализа в исследовании системы управления организации // Матер. науч.-практ. конф. Общество и цивилизация: Тенденции и перспективы современного общества в XXI веке. - 2016. - С.16-20.

\section{Р.Э. Андекина, А.Д. Аймағамбетова \\ МЕТАЛДАРДЫ ӨНДІРУШІ КОМПАНИЯДА SWОТ-ТАЛДАУДЫ ПАЙДАЛАНА ОТЫРЫП СТРАТЕГИЯНЫ ӘЗІРЛЕУ}

\section{Андатпа}

Мақалада қазақстандық металл өндіруші компаниясы үшін жүргізілген SWOT-талдау нәтижелері ашып көрсетілген. Жүргізілген зерттеу нәтижелері негізінде компания басшылығына бірқатар ұсыныстар әзірленді. Бұл мақала ғылыми және практикалық құндылықа ие, себебі берілген компания стратегиялық жоспарды әзірлеу үшін SWOT-талдауды ешқашан қолданбаған. Сонымен қатар зерттеу нақты отандық компанияның кейс-стадиы болғандықтан, оның нәтижелерін басқа салалық өндірушілерге де қолдануға мүмкіндік туғызады. Компанияның анықталған күшті және әлсіз сипаттамалары, қауіптері мен мүмкіндіктері басшылыққа стратегиялық жоспарды одан әрі әзірлеу және маркетингтік қызметке назар аудару сияқты ұсыныстар әзірлеуге әкеледі. Осыған дейін берілген компанияның қаржылық жағдайы жан-жақты талданып, оның ұйымдық құрылымы егжей-тегжейлі зерттелді.

\section{Р.Э. Андекина, А.Д. Аймагамбетова \\ РАЗРАБОТКА СТРАТЕГИИ НА ОСНОВЕ SWОТ-АНАЛИЗА КОМПАНИИ, ПРОИЗВОДЯЩЕЙ МЕТАЛЛУРГИЧЕСКИЕ ПРОДУКТЫ}

\section{Аннотация}

В данной статье раскрываются результаты SWOT-анализа, проведенного для казахстанской металлопромышленной компании. На основе результатов проведенного исследования был разработан ряд рекомендаций руководству компании. Исследование имеет научную и практическую ценность, поскольку компания никогда ранее не применяла SWOT-анализ для разработки стратегического плана. Более того, поскольку это реальный кейс-стади отечественной компании, результаты исследования могут быть применены и к другим отраслевым производителям страны. Выявленные сильные и слабые характеристики, риски и возможности компании приводят к выработке предложений руководству по дальнейшей разработке стратегического плана и сосредоточению внимания на маркетинговой деятельности. Ранее автором было всесторонне проанализировано финансовое состояние компании и детально изучена ее организационная структура.

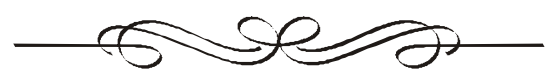




\section{МИГРАЦИОННЫЙ ПОТЕНЦИАЛ СТРАНЫ КАК ФАКТОР ФОРМИРОВАНИЯ ЭФФЕКТИВНОЙ ЭКОНОМИЧЕСКОЙ СИСТЕМЫ}

В статье рассмотрена проблема изучения миграционного потенциала, выступающего одной из ключевых движущих сил при формировании экономической системы государства. В рамках осуществления теоретического изучения и проведения анализа научной литературы сформулирован и дополнен понятийно-категориальный аппарат, раскрывающий точки зрения и научные подходы зарубежных ученых-исследователей различных направлений, занимающихся вопросом анализа миграчионного потенциала в регионе. Авторами дополнен и осуществлен расчет коэффициента вариации, характеризующий колеблемость миграиионных процессов в Северном регионе Казахстана. Согласно выполненным расчетам наибольшее значение данного показателя отмечается в Акмолинской области, что говорит о высоком уровне статистической колеблемости сальдо миграчии в данном регионе. В иелом, авторы указывают на необходимость учета полученных результатов при разработке начиональных и региональных программных документов, иелью которых является дальнейшее эфрективное развитие миграционных процессов, направленное наобеспечение устойчивого сочиально-экономического развития.

Ключевые слова: миграция, потенциал, фактор, формирование, экономика, система, коэффиџиент, вариация, эффективность, регион.

Кілт сөздер: көші-қуон, әлеует, фактор, құалыптасу, экономика, жүйе, коэффициент, вариация, тиімділік, аймак̧.

Keywords: migration, potential, factor, formation, economy, system, coefficient, variation, efficiency, region.

JEL classification: F22, O15, R23

Введение. Одной из актуальных проблем современной экономики является анализ перемещения населения из одной местности в другую через границы государств, что способствует формированию и развитию миграционного потенциала соответствующего региона. Миграционный потенциал является одним из ключевых показателей при осуществлении социально-экономической политики, потому что качественные характеристики мигрантов во мно- гом влияют на развитие инновационной составляющей государства, определяют его текущее состояние, конкурентные преимущества и перспективы дальнейшего роста, а также стремление занять лидирующие позиции в конкретном регионе.

В связи с этим, целью исследования является раскрытие и уточнение сущности термина «миграционный потенциал» на основе изучения современной социальноэкономической литературы, а также раз- 


\section{Экономика}

витие методологии его оценки. Для достижения поставленной цели авторами решены следующие задачи:

- изучены и приведены точки зрения демографов, экономистов и социологов, занимающихся исследованием миграционного потенциала;

- представлены существующие способы оценки миграционного потенциала, которые дополнены анализом показателей, которые характеризуют тенденции его развития;

- дана авторская оценка динамики миграционного потенциала, основывающаяся на расчете коэффициента вариации сальдо миграции на примере областей, образующих Северный регион Казахстана;

- сформулированы выводы, практическая имплементация которых позволит обеспечить устойчивое развитие регионов нашей страны и сбалансировать миграционные потоки.

В статье использованы методы сравнения и сопоставления статистических абсолютных и относительных показателей, характеризующих определенные генеральные совокупности.

Для формирования и развития эффективной организации и осуществления миграционной политики имеются соответствующие законодательные императивы, которые направлены на обеспечение привлечения квалифицированной рабочей силы, а также передовых, современных и инновационных технологий, недопущение роста влияния дестабилизирующих факторов на экономическое развитие, возникающих при проникновении в страну криминала, ведущего преступную деятельность. Также в рамках миграционной политики принято обращать на трудоизбыточные и трудодефицитные регионы.

Категория «миграционный потенциал» стала использоваться в научной литературе сравнительно недавно. Однако термин «потенциал» при проведении ис- следований стали применять в начале XX века в таких науках как демография, социология, экономика, философия и т.д.

Авторы отмечают, что после распада СССР и образования новых независимых государств категория «миграционный потенциал» все чаще становилась объектом исследований ученых постсоветского пространства, многие из которых предпринимали попытки оценки миграционного потенциала этих стран.

Обзор литературы. Рассмотрим некоторые научные позиции ряда авторов, исследующих миграционный потенциал в современных условиях.

Согласно научной позиции Мукомель В.И., величина миграционного потенциала определяется такими двумя факторами, как демографическая емкость (численность и состав мигрантов) и установки на выезд из государства проживания. При этом к базовой величине для оценки миграционного потенциала автор относит численность населения [1].

Заслуживает внимания трактовка термина «миграционный потенциал», данная Локосовым В.В., согласно которой он представляет ту часть населения предполагаемых стран-доноров, которая обладает возможностью мигрировать в государство-реципиент и соответствует по своим характеристикам его требованиям, т.е. геополитически и экономически заданным критериям отбора, предъявляемым к иммигрантам будущим гражданам страны [2].

Гришанова А.Г., Кожевникова Н.И. рассматривают миграционный потенциал как совокупность потенциальных мигрантов, обладающих накопленным собственным (и окружающих людей) опытом переселений, обусловливающим их способность к перемене места жительства [3].

В целом, позиция авторов коррелирует с определением категории «миграционный потенциал», представленным Рыбаковским Л.Л. Миграционный потенциал - это 
та часть населения предполагаемых страндоноров, которая обладает возможностью мигрировать в государство-реципиент и соответствует по своим характеристикам его требованиям, т.е. геополитически и экономически заданным критериям отбора, предъявляемым к иммигрантам - будущим гражданам страны [4].

Основная часть. Согласно авторской позиции миграционный потенциал может рассматриваться в двух аспектах - количественном и качественном.

Количественная составляющая мигра- ционного потенциала представляет собой определенную численность людей. Качественное измерение миграционного потенциала включает языковые, этнические, культурные, религиозные и другие особенности.

Оценку миграционного потенциала региона принято осуществлять на основе таких абсолютных показателей, как количество выбывшего и прибывшего населения, а также сальдо миграции.

В таблице 1 приведена информация о динамике миграции населения в Республике Казахстан в 2017-2019 годы.

Таблица 1

Динамика миграции населения в Республике Казахстан в 2017-2019 гг.*

человек

\begin{tabular}{|l|r|r|r|r|r|r|r|r|r|}
\hline \multirow{2}{*}{ Регион } & \multicolumn{3}{|c|}{ Прибыло } & \multicolumn{3}{c|}{ Выбыло } & \multicolumn{3}{c|}{ Сальдо миграции } \\
\cline { 2 - 11 } & 2017 & \multicolumn{1}{|c|}{2018} & 2019 & 2017 & 2018 & 2019 & 2017 & 2018 & 2019 \\
\hline $\begin{array}{l}\text { Республика } \\
\text { Казахстан }\end{array}$ & 943757 & 900931 & 1122507 & 965887 & 930052 & 1155477 & -22130 & -29121 & -32970 \\
\hline Акмолинская & 38622 & 30727 & 39010 & 38963 & 36148 & 45817 & -341 & -5421 & -6807 \\
\hline Актюбинская & 36801 & 30615 & 39674 & 38451 & 32734 & 42478 & -1650 & -2119 & -2804 \\
\hline Алматинская & 115934 & 84052 & 119662 & 118606 & 99518 & 139797 & -2672 & -15466 & -20135 \\
\hline Атырауская & 25157 & 20326 & 25020 & 24988 & 20705 & 26910 & 169 & -379 & -1890 \\
\hline $\begin{array}{l}\text { Восточно- } \\
\text { Казахстанская }\end{array}$ & 63005 & 53022 & 58961 & 76961 & 65892 & 75504 & -13956 & -12870 & -16543 \\
\hline Жамбылская & 30245 & 35565 & 51893 & 47558 & 47266 & 66888 & -17313 & -11701 & -14995 \\
\hline $\begin{array}{l}\text { Западно- } \\
\text { Казахстанская }\end{array}$ & 39289 & 33002 & 38521 & 41309 & 35156 & 41600 & -2020 & -2154 & -3079 \\
\hline Карагандинская & 44340 & 37581 & 53697 & 56025 & 49180 & 64967 & -11685 & -11599 & -11270 \\
\hline Костанайская & 38373 & 36456 & 41631 & 44716 & 42041 & 48347 & -6343 & -5585 & -6716 \\
\hline $\begin{array}{l}\text { Кызыл- } \\
\text { Ординская }\end{array}$ & 30282 & 31728 & 39344 & 34936 & 35446 & 44968 & -4654 & -3718 & -5624 \\
\hline Мангистауская & 44917 & 34623 & 44272 & 44071 & 33609 & 41080 & 846 & 1014 & 3192 \\
\hline Павлодарская & 28970 & 28870 & 35853 & 35878 & 34367 & 41718 & -6908 & -5497 & -5865 \\
\hline $\begin{array}{l}\text { Северо- } \\
\text { Казахстанская }\end{array}$ & 23053 & 20703 & 23889 & 28516 & 25400 & 29832 & -5463 & -4697 & -5943 \\
\hline Туркестанская & 57859 & 101917 & 129734 & 90282 & 139183 & 143059 & -32423 & -37266 & -13325 \\
\hline г. Нур-Султан & 134652 & 114417 & 162191 & 101141 & 91618 & 128825 & 33511 & 22799 & 33366 \\
\hline г. Алматы & 123293 & 110647 & 142277 & 93096 & 79565 & 102179 & 30197 & 31082 & 40098 \\
\hline г. Шымкент & 68965 & 96680 & 76878 & 50390 & 62224 & 71508 & 18575 & 34456 & 5370 \\
\hline
\end{tabular}

* Составлена авторами на основе источника [5]

Как видно из таблицы 1 в 2019 году наибольшее количество выбывшего населения отмечается в Алматинской, Жамбылской и Восточно-Казахстанской областях. В этих регионах сальдо миграции является отрицательным. Положительное сальдо миграции в 2019 году сложилось в Мангистауской области, столице, городе Нур-Султане, а также в двух крупнейших мегаполисах нашей страны (г. Алматы, Шымкент). 
Описанные выше методы по оценке миграции являются общепринятыми. Вместе с этим, они не позволяют ответить на вопрос о степени устойчивости развития динамики данного показателя как на уровне региона, так и страны в целом. То есть, результаты, полученные по ним, не позволяют произвести сравнительную оценку вариации единиц совокупности и, таким образом, определить степень устойчивости развития данного показателя за определенный период.

Данный вопрос решается на основе расчета и дальнейшего анализа такого статистического показателя, как коэффициент вариации. Он определяется следующим образом [6, с. 60]:

$$
\mathrm{V}=\frac{\sigma}{\overline{\mathrm{x}}} \cdot 100 \%,
$$

где $\underline{V}$ - коэффициент вариации;

$\mathrm{x}$ - среднее значение признака в совокупности;

$\sigma$ - среднеквадратическое отклонение.

Как отмечает Шмойлова Р.А., статистическая совокупность считается однородной, если коэффициент вариации не превышает 33\% [7, с. 128].
Чем больше значение этого показателя, т.е. колеблемость коэффициента вариации, тем меньше проявляется однородность рассматриваемой совокупности и наблюдается значительный разброс значений признака вокруг средней. Применительно к оценке миграционных потоков следует сказать, что, чем больше значение и амплитуда колебаний этого коэффициента, тем менее стабильный характер он имеет.

Среднеквадратическое отклонение ( $\sigma)$ и среднее значение признака в совокупности ( $\mathrm{x})$ находятся, соответственно, следующим образом:

$$
\begin{gathered}
\sigma=\sqrt{\frac{\sum(\mathrm{x}-\overline{\mathrm{x}})^{2}}{\mathrm{n}}} . \\
\overline{\mathrm{x}}=\frac{\sum \mathrm{x}}{\mathrm{n}},
\end{gathered}
$$

где $\overline{\mathrm{x}}$ - значения признака для каждой единицы совокупности;

$\mathrm{n}$ - число признаков в совокупности.

В таблице 2 приведены данные об уровне экономической активности населения по возрастным группам и рассчитанные значения коэффициентов вариации данного показателя в Республике Казахстан.

\begin{abstract}
Расчет коэффициентов вариации по сальдо миграции населения

\begin{tabular}{|c|c|c|c|c|c|c|c|c|}
\hline \multirow{2}{*}{$\begin{array}{l}\text { № } \\
\text { ח/ח }\end{array}$} & \multirow{2}{*}{ Регион } & \multicolumn{4}{|c|}{$\begin{array}{c}\text { Сальдо миграции, } \\
\text { человек }\end{array}$} & \multirow{2}{*}{$\begin{array}{c}\bar{x}, \\
\text { человек }\end{array}$} & \multirow{2}{*}{$\sigma$} & \multirow{2}{*}{$\begin{array}{l}\mathrm{V}, \\
\%\end{array}$} \\
\hline & & 2016 г. & 2017 г. & 2018 г. & 2019 г. & & & \\
\hline 1. & $\begin{array}{l}\text { Республика } \\
\text { Казахстан }\end{array}$ & -21145 & -22130 & -29121 & -32970 & $-26341,50$ & 4390,97 & 16,67 \\
\hline 2. & Акмолинская & -15219 & -341 & -5421 & -6807 & $-6947,00$ & 4783,59 & 68,86 \\
\hline 3. & Костанайская & -7722 & -6343 & -5585 & -6716 & $-6591,50$ & 688,23 & 10,44 \\
\hline 4. & Павлодарская & -6877 & -6908 & -5497 & -5865 & $-6286,75$ & 554,24 & 8,82 \\
\hline 5. & $\begin{array}{l}\text { Северо- } \\
\text { Казахстанская }\end{array}$ & -7244 & -5463 & -4697 & -5943 & $-5836,75$ & 828,29 & 14,19 \\
\hline
\end{tabular}
Северного региона Казахстана, включающего в себя Акмолинскую, Костанайскую, Павлодарскую и Северо-Казахстанскую области*
\end{abstract}

*Составлена на основе статистических данных источника [5] 
Анализируя данную таблицу и рисунок 1, можно сказать, что максимальное значение рассматриваемого показателя приходится на Акмолинскую область $(69,86 \%)$, что в 6,6 раза больше, чем в Кос- танайской области и в 4,85 раза больше, чем в Северо-Казахстанской области.

Наименьшее значение данного показателя отмечено в Павлодарской области, которое составило $8,82 \%$.

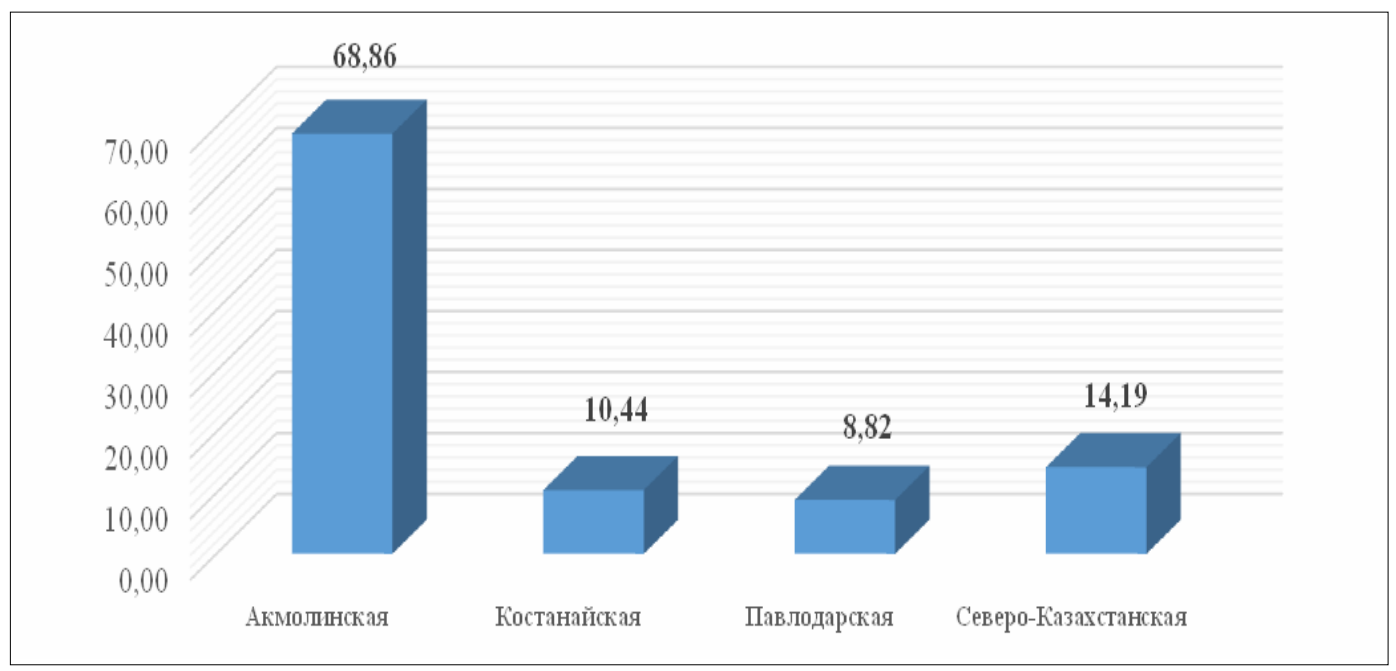

Рисунок 1. Значения коэффициента вариации по сальдо миграции населения по регионам Северного Казахстана, \%

Таким образом, при составлении программ устойчивого развития региона при анализе миграционных потоков необходимо обратить особое внимание на сальдо миграции населения в Акмолинской области, в которой согласно выполненным расчетам коэффициент вариации превышает $33 \%$, что свидетельствует о неоднородности статистической совокупности.

Выводы. Обобщая вышесказанное, мы считаем, что для осуществления эффективного регулирования миграции населения региональным органам власти при разработке и реализации государственных программ развития следует обращать особенное внимание на:

- обеспечение устойчивой и продуктивной занятости граждан путем содейст- вия в трудоустройстве по месту жительства;

- повышение экономической активности граждан через организацию собственного дела;

- развитие кадрового потенциала для реализации программ индустриально-инновационного развития;

- совершенствование системы оказания адресной социальной помощи;

- обучение и содействие в трудоустройстве самозанятого, безработного и малообеспеченного населения на рынке труда.

Реализация данных мероприятий, по мнению авторов, позволит обеспечить устойчивое развитие регионов нашей страны, сбалансировать миграционные потоки и, в конечном счете, повысить качество жизни казахстанцев.

\section{ЛИТЕРАТУРА}

1. Мукомель В.И. Миграционный потенциал и перспективы иммиграции соотечественников из государств СНГ и Балтии // Этнология. - 2001. - № 3. - С. 47-56. 


\title{
Экономика
}

2. Локосов В.В. Миграционные процессы в России. - М.: Экон-информ, 2014. - 383 с.

3. Гришанова А.Г., Кожевникова Н.И. Миграционный потенциал: теоретические аспекты // Народонаселение. - 2016. - № 1. - С. 42-51.

4. Рыбаковский Л.Л., Кожевникова Н.И. Оценка возможных и необходимых масштабов привлечения иммигрантов в Россию: Моногр. - М.: «Экон-Информ», 2010. - 103 с.

5. Демографический ежегодник Казахстана: Статист. сборник под ред. Н.С. Айдапкелова (на казахском и русском языках). - Нур-Султан, 2020. - 276 с.

6. Елисеева И.И. Статистика: Учебник. - М.: ООО «ВИТРЭМ», 2002. - 448 с.

7. Шмойлова Р.А. Практикум по теории статистики: Учеб. пособие. - М.: Финансы и статистика, 1999. - 416 с.

\section{REFERENCES}

1. Mukomel V.I. Migrationnyi potentsial i perspektivy immigratsii sootechestvennikov iz gosudarstv SNG i Baltii // Etnologiya. - 2001. - № 3. - S. 47-56 [in Russian].

2. Lokosov V.V. Migratsionnye process v Rossii. - M.: Econ-inform, 2014. - 383 s. [in Russian].

3. Grishanova A.G., Kozhevnikova N.I. Migratsionnyi potentsial: teoreticheskie aspekty // Narodonaselenie. - 2016. - № 1. - S. 42-51 [in Russian].

4. Rybakovsky L.L., Kozhevnikova N.I. Otsenka vozmozhnyhi neobhodimyh masshtabov privlecheniya immigtrantov v Rossiu: Monogr. - M.: «Econ-Inform«, 2010. - $103 \mathrm{~s}$. [in Russian].

5. Demographicheskiy ezhegodnik Kazakhstana: Statisticheskiy sbornik pod red. N.S. Aidapkelova (na kazahskom i russkom yazykah). - Nur-Sultan, 2020. - 276 s. [in Russian].

6. Eliseeva I.I. Statistika: Uchebnik. - M.: OOO «VITREM«, 2002. - 448 s. [in Russian].

7. Shmoilova R.A. Praktikum po teorii statistiki: Ucheb. posobie. - M.: Finansy i statistika, 1999. - 416 s. [in Russian].

\section{Д.Н. Шайкин, Д.Т. Есембекова, М.М. Валиева, О.В. Копылова \\ ЕЛДІҢ КӨШІ-ҚОН ӘЛЕУЕТІ ТИІМДІ ЭКОНОМИКАЛЫҚ ЖҮЙЕНІ ҚАЛЫПТАСТЫРУ ФАКТОРЫ РЕТІНДЕ}

\begin{abstract}
Андатпа
Мақалада мемлекеттің экономикалық жүйесін қалыптастырудағы негізгі қозғаушы күштердің бірі болып табылатын көші-қон әлеуетін зерттеу мәселесі қарастырылған. Ғылыми әдебиеттерді теориялық зерттеу мен талдауды жүзеге асыру аясында аймақтағы көші-қон әлеуетін талдаумен айналысатын әр түрлі бағыттағы шетелдік зерттеуші ғалымдардың көзқарастары мен ғылыми тәсілдерін қамтитын тұжырымдамалық-категориялық аппарат қалыптастырылып толықтырылды. Авторлар Қазақстанның солтүстік өңіріндегі көші-қон процестерінің ауытқуын сипаттайтын вариация коэффициентін толықтырды және есептеуді жүзеге асырды. Жасалған есептеулерге сәйкес осы көрсеткіштің ең үлкен мәні Ақмола облысында байқалады, ол осы саладағы көшіқон сальдосының статистикалық ауытқуының жоғары деңгейін көрсетеді. Жалпы авторлар мақсаты тұрақты әлеуметтік-экономикалық дамуды қамтамасыз етуге бағытталған көші-қон процестерін одан әрі тиімді дамыту болып табылатын ұлттық және өңірлік бағдарламалық құжаттарды әзірлеу кезінде алынған нәтижелерді есепке алу қажеттілігін көрсетеді.
\end{abstract}




\title{
D. Shaikin, D. Yesembekova, M. Valiyeva, O. Kopylova \\ MIGRATION POTENTIAL OF THE COUNTRY AS A FACTOR IN THE FORMATION OF AN EFFECTIVE ECONOMIC SYSTEM
}

\begin{abstract}
Annotation
The article deals with the problem of studying the migration potential, which is one of the key drivingforces in the formation of the state's economic system. As part of the theoretical study and analysis of scientific literature, the conceptual and categorical apparatus containing the points of view and scientific approaches of foreign researchers in various fields dealing with the analysis of migration potential in the region is formulated and supplemented. In this regard, the authors supplemented and calculated the coefficient of variation that characterizes the fluctuation of migration processes in the Northern region of Kazakhstan. According to the calculations, the highest value of this indicator is noted in the Akmola region, which indicates a high level of statistical fluctuation of the migration balance in this region. In general, the authors point out the need to take into account the results obtained in the development of national and regional policy documents, the purpose of which is to further effective development of migration processes aimed at ensuring sustainable socio-economic development.
\end{abstract}

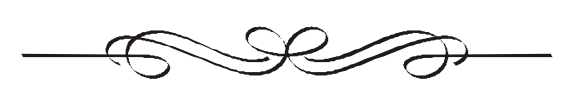


P.Т. Дуламбаева*, э.в.д., профессор ${ }^{1}$

А.Н. Турекулова, $P h D$ докторы ${ }^{2}$

3.К. Жаныбаева, э.г.к., дочент ${ }^{2}$

А.Е. Беделбаева, магистр, ава оқытушы ${ }^{3}$

Қазақсттан Республикасы Президентінің жанындавы

Мемлекеттік басқару академиясы ${ }^{I}$

Нұр-Сұлтан к.

Қазақ экономика, қаржы және халықаралық сауда университеті ${ }^{2}$

Нұр-Сұлтан к.

Ілияс Жансүгіров атындавы Жетісу университеті ${ }^{3}$

Талдықорван қ.

email: dametken.t@gmail.com

* - негізгі автор (хат-хабарларға арналған автор)

\section{ӨНІРЛЕРДІҢ БӘСЕКЕГЕ КАБІЛЕТТІЛІГІН ТАЛДАУ ЖӘНЕ БАҒАЛАУ ӘДІСТЕРІН ЗЕРТТЕУ}

Мақъала өңъірлердің бәсекеге қ̧абілеттілігін бавалау әдістері мен ддістемелерін зерттеуге арналван. Өңірлердің бәсекеге қ̧абілеттілігінің теориялық негіздеріне зерттеу, аймақ̆тың бәсекеге қ̧абілеттілігін бавалаудың тұжырымдалары мен құолданыставы әдістемелеріне талдау жасалды және осы әдістемелерді құлдану бойынша нақты ұсыныстар әзірленді және невұрлым жиі құолданылатын көрсеткіштер жүйесіне шолу жасалды. Аймақтың әлеуметтік-экономикалық даму тенденцияларын талдау үшін макроэкономикалық көрсеткіштерге негізделген сандық бавалау әдістері, бавалаудың интегралды ддістері, аймақтардың бәсекеге қабілеттілігін рейтингтік, сараптамалық және шетелдік бавалау әдістері қарастырылды. Өңірлердің бәсекеге құабілеттілігін талдау мен багалау ддістерінің негізгі ерекшеліктері анықталды және бавалау әдістерінде әлеуметтік факторларва басымдық берілетіндігі, аймақты бавалаудың сандық ддістерін бір-бірінен бөлек әрі кешенді қолданува болатындывы, шетелдік ддістемелерде көптеген көрсеткіштер жүйесі құолданылатындызы, ол кешенді талдау жүргізуге мүмкіндік беретіндігі туралы қорытынды жасалды.

Кілт сөздер: өңірлердің бәсекеге қзабілеттілігі, әлеуметтік-экономикалық даму, ддіс, әдістеме, көрсеткіштер жүйесі, сандық бавалау, интегралды ддіс, рейтингтік бавалау, сараптамальқ бавалау ддісі, әлеуметтік фактор.

Ключевые слова: конкурентоспособность регионов, сочиально-экономическое развитие, метод, методика, система показателей, количественная оиенка, интегральный метод, рейтинговая оценка, метод экспертных оценок, социальный фактор.

Keywords: regional competitiveness, socio-economic development, method, methodology, indicator system, quantitative assessment, integral method, rating assessment, expert assessment method, social factor.

Kiрiспе. Бүгінгі таңда мемлекеттің дамуы көбінесе оның жекелеген өңірлерінің, аймақтарының бәсекеге қабілеттілігімен анықталады. Қазақстандағы аймақтық бәсекеге қабілеттіліктің дамуын оның эконо- микалық өсуінің детерминанты, аймақтың экономикалық дамуының негізгі шарты және аймақаралық ынтымақтастықты дамытудың қажетті факторы ретінде қарастыруға болады. Өңірлердің бәсекеге қабілет- 
тілігінің даму тенденциялары, белгілі бір аймақтың бәсекелестік артықшылықтарының өзгеруі мемлекет экономикасын дамытудың негізгі драйверлері болып табылады.

Қарастырылып отырған тақырыпқа байланысты көптеген зерттеулердің бар болуына қарамастан, аймақтардың бәсекеге қабілеттілігін талдау және бағалау туралы жүйелі тұжырымдардың жетіспеушілігі өткір сезілуде. Өңірлердің бәсекелестік артықшылықтарын қалыптастыру және арттыру мәселелері неғұрлым терең әдістемелік өңдеуді талап етеді. Аталған мәселелердің өзектілігі, теориялық және әдіснамалық пысықталуының жеткіліксіздігі зерттеудің тақырыбын, мақсаттары мен міндеттерін таңдауды айқындады.

Зерттеудің мақсаты - өңірлердің бәсекеге қабілеттілігін бағалаудың теориялық және әдістемелік тәсілдерін зерттеп, оларды қолдану бойынша ұсыныстар әзірлеу болып табылады. Зерттеудің міндеттері: өңірлердің бәсекеге қабілеттілігінің теориялық негіздерін зерттеу, өңірдің бәсекеге қабілеттілігін бағалаудың қолданыстағы әдістемелеріне талдау жүргізу; аумақтың бәсекеге қабілеттілігінің бағалау әдістемелерін қолдану бойынша нақты ұсыныстар әзірлеу.

Зерттеудің теориялық және әдіснамалық негізін аймақтық экономика саласындағы жетекші экономист ғалымдардың еңбектері мен қолданбалы жұмыстары құрады. Зерттеу әдістемесі жүйелік тәсілге негізделген. Зерттеу құралы ретінде диалектика және синергетика, пәндік-логикалық, функционалдық және ситуациялық талдау әдістері пайдаланылды.

Зерттеудің тәжірибелік маңыздылығы бәсекеге қабілеттілікті бағалаудың және өңірлік дамуды талдаудың әдістемелік құралдарын жетілдіруге бағытталған тұжырымдар мен ұсыныстар аймақтық экономиканы реттеу саласындағы теңгерімді басқару шешімдерін негіздеу кезінде қолдану мүмкіндігінен көрініс табады.

Әдебиеттік шолу. Өңірлік экономика тәуелсіз ғылыми пән ретінде өткен ғасырдың ортасынан бастап белсенді дамыды. Өңірлер мен елдің бәсекеге қабілеттілігін бағалаудың теориялық және әдіснамалық негіздері, сондай-ақ өңірлердің әлеуметтікэкономикалық дамуының жекелеген мәселелері А. Ревайкин [1], Е.Губанова, В. Клещ [2], В. Меркушов [3], Л. Ушвицкий, В. Парахина [4], Н. Ларина, А. Макаев [5], Б. Жихаревич, А. Крыловский [6] еңбектерінде, сондай-ақ Дүниежүзілік экономикалық форум мен менеджмент институтының (Institute of Management Development) зерттеулерінде қарастырылды.

Аймақтың бәсекеге қабілеттілігін бағалаудың тұжырымдамасын М. Портер ұсынған. Ол бәсекеге қабілеттілікті аймақтың басқа аймақтармен салыстырғанда ресурстарды, жұмыс күші мен капиталды пайдалану өнімділігі, жан басына шаққандағы жалпы аймақтық өнімнің мөлшері мен динамикасында интеграцияланған көрсеткіштермен анықталады деп тұжырымдады [7].

А. Селезневтің пікірінше, аймақтың бәсекеге қабілеттілігі экономикалық, әлеуметтік, саяси және басқа факторларға байланысты аймақтың және оның жекелеген тауар өндірушілерінің ішкі және сыртқы нарықтардағы жағдайы арқылы көрінеді [8].

Л. Шеховцеваның анықтамасы ұсынылған тұжырымдамалардан ерекшеленеді, ол М. Портер ұсынған елдің бәсекеге қабілеттілік тұжырымдамасына сүйене отырып, аймақтың бәсекеге қабілеттілігін өңірлік ресурстарды, ең алдымен жұмыс күші мен капиталды пайдалану өнімділігі ретінде көрсетеді [9].

Осылайша, қарастырылып отырған тақырыпқа байланысты көптеген зерттеулердің бар болуына қарамастан, өңірлердің бәсекеге қабілеттілігін талдау және бағалаудың әдіснамалық пысықталуы жеткіліксіз дәрежеде.

Негізгі бөлім. Қазіргі уақытта бағалау кезінде қойылған әр түрлі мақсаттарға байланысты аймақтардың бәсекеге қабілет- 


\section{Экономика}

тілігін бағалаудың авторлық әдістері алуан түрлі. Әр түрліәдістердің авторлары аймақтың бәсекеге қабілеттілігін бағалау көрсеткіші кешенді екендігімен келіседі. Өңірлердің бәсекеге қабілеттілігін бағалаудың неғұрлым жиі қолданылатын көрсеткіштер жүйесіне келесілер жатады:

- өңірдің экономикалық даму деңгейі көрсеткіштерінің жүйесі;

- өңірдің инвестициялық тартымдылығы көрсеткіштерінің жүйесі;

- бәсекелестік артықшылықтар көрсеткіштерінің жүйесі;

- өңірлік тиімділік көрсеткіштерінің жүйесі;

- аймақ тұрғындарының өмір сүру дең- гейі мен сапасының көрсеткіштер жүйесі және басқалары.

Халықаралық тәжірибеде статистикалық көрсеткіштерге, сауалнамаларға және күрделі индекстерге негізделген Дүниежүзілік экономикалық форумның бәсекеге қабілеттілігін бағалауәдістемелері аса танымал.

Аймақтың әлеуметтік-экономикалық даму тенденцияларын талдау үшін макроэкономикалық көрсеткіштерге негізделген сандық бағалау әдістерін, бағалаудың интегралды әдістерін, аймақтардың бәсекеге қабілеттілігін рейтингтік бағалау, сараптамалық бағалау әдістерін және шетелдік әдістерді қарастырайық.

\section{Өңірдің бәсекеге қабілеттілігін бағалау әдістері*}

\begin{tabular}{|l|l|}
\hline \multicolumn{1}{|c|}{ Әдіс атауы } & \multicolumn{1}{c|}{ Сипаттамасы } \\
\hline \multicolumn{1}{|c|}{1} & \multicolumn{1}{c|}{2} \\
\hline \multicolumn{1}{|c|}{ Өңірдің әлеуметтік-экономикалық даму үрдістерін талдау үшін макроэкономикалық } \\
\multicolumn{1}{|c|}{ көрсеткіштер негізінде бағалаудың сандық әдістері }
\end{tabular}




\begin{tabular}{|c|c|}
\hline 1 & 2 \\
\hline $\begin{array}{l}\text { 6. Өңірлердің даму } \\
\text { рейтингісі (РРP) }\end{array}$ & $\begin{array}{l}\text { Әдіс үш саладағы аймақтың даму деңгейін сипаттайтын } 15 \\
\text { статистикалық көрсеткішке негізделген: әлеуметтік, } \\
\text { экономикалық, әлеуметтік-экономикалық инфрақұрылым }\end{array}$ \\
\hline $\begin{array}{l}\text { 7. Индексті есептеу негізін- } \\
\text { де өңірлердің бәсекеге қабі- } \\
\text { леттілігін бағалау (Н.И. Ла- } \\
\text { рина, А.И. Макаев) [5] }\end{array}$ & $\begin{array}{l}\text { Мәні белгілі бір индикаторлардың осы көрсеткіш бойынша } \\
\text { елдің жағдайын бағалайтын жалпыға ауысуы }\end{array}$ \\
\hline \multicolumn{2}{|r|}{ Эксперттік бағалау әдісі } \\
\hline $\begin{array}{l}\text { 8. Эксперттік бағалау әдісі } \\
\text { (Б.Жихаревич, } \\
\text { А. Крыловский) [6] }\end{array}$ & $\begin{array}{l}\text { Объективті бағалауды қалыптастыру үшін сарапшылармен } \\
\text { жұмысты ұйымдастыруды және олардың пікірлерін сандық } \\
\text { және сапалық түрде өндеуді қамтиды }\end{array}$ \\
\hline \multicolumn{2}{|r|}{ Шетелдік әдістер } \\
\hline $\begin{array}{l}\text { 9. Еуропалық } \\
\text { комиссияның әдісі }\end{array}$ & $\begin{array}{l}\text { Бенчмаркинг әдістемесін қолдану, атап айтқанда өңірдің } \\
\text { меншікті көрсеткіштерін бәсекелестердің көрсеткіштерімен } \\
\text { салыстыру. } 4 \text { негізгі көрсеткіш қолданылады: экономика, } \\
\text { демография, білім беру, еңбек нарығы }\end{array}$ \\
\hline $\begin{array}{l}\text { 10. Еуразиялық } \\
\text { бәсекеге қабілеттілік } \\
\text { институтының әдісі }\end{array}$ & $\begin{array}{l}\text { Өңірлік дамудың өзекті көрсеткіштері ғана бағаланып } \\
\text { қоймай, өңір басқарушысында «озық даму және бизнеспен } \\
\text { серіктестік» стратегиясының болуы да бағаланады. Өңірлік } \\
\text { дамудың 10-нан астам көрсеткіштері қолданылады }\end{array}$ \\
\hline $\begin{array}{l}\text { 11. Дүниежүзілік экономи- } \\
\text { калық форум мен менедж- } \\
\text { мент институтының әдісі } \\
\text { (Institute of Management } \\
\text { Development, IMD) }\end{array}$ & $\begin{array}{l}\text { Елдердің бәсекеге қабілеттілігін бағалау үшін қолданылады. } \\
333 \text { критерий пайдаланылады, олар } 4 \text { топқа біріктірілген: } \\
\text { экономикалық қызмет, үкіметтің тиімділігі, бизнестің } \\
\text { тиімділігі, инфрақұрылым }\end{array}$ \\
\hline
\end{tabular}

*Авторлармен құрастырылган

Сандық және интегралды бағалау әдістері әлеуметтік-экономикалық даму тиімділігінің интегралды көрсеткіштері негізінде есептеледі. Интегралдылық аймақ ішіндегі жеке процестердің динамикасын сипаттайтын жеке көрсеткіштердің жиынтығын есептеумен қамтамасыз етіледі. Бірақ бәсекеге қабілеттіліктің интеграцияланған индикаторын табу қиын, өйткені, әдетте, салыстырылатын сипаттамалар гетерогенді және физикалық сипаттамалармен салыстыруға келмейтіндіктен, әр түрлі көрсеткіштердің біртекті негізін білу қажет.

Егер басқа аймақтар арасында аймақтың бәсекелестік жағдайын анықтау және өзара салыстыру қажет болса, онда әр түрлі зерттеушілер арасында үлкен танымалдыққа ие болған аймақтың бәсекеге қабілеттілігін бағалаудың рейтингтік әдісін қолдануға болады. Бұл әдіспен бәсекеге қабілеттілікті өлшеу үшін индикаторларды таңдаудың әр түрлі нұсқалары бар және рейтингтегі әдіснамаға байланысты.

Талдауды жүргізу үшін сапартамалық статистикалық деректерді қолдану керек, оларды топтарға біріктіру қажет. Рейтингтік бағалаудың қорытынды көрсеткішін есептеу үшін әрбір көрсеткіш бойынша салыстыру жүргізу және осы көрсеткіштер мәндерінің төмендеу тәртібімен өңірлерді саралау қажет. Осыған байланысты салыстырылатын объектілердің жиынтығындағы ең жоғары нәтижелерден аймақтың бәсекеге қабілеттілігіне объективті баға беріледі.

Ю. Фридманның зерттеушілер тобы өз әдістемесіне сәйкес аймақтың позицияларын салыстыратын бес факторға сүйене отырып, аймақтың бәсекеге қабілеттілігін бағалайды. Бұл факторлардың қатарына мыналар кіреді: 


\section{Экономика} деңгейі;

- өңірдің экономикалық әлеуетінің

- өңірдің экономикалық әлеуетін пайдалану тиімділігі;

- өңірдің тұрғындар үшін тартымдылығы;
- өңірдің бизнес үшін тартымдылығы; -аймақ экономикасының жаңашылдығы.

Бұдан әрі бұл факторлар құрылымы 1-суретте көрсетілген 26 көрсеткіш бойынша салыстырылады.

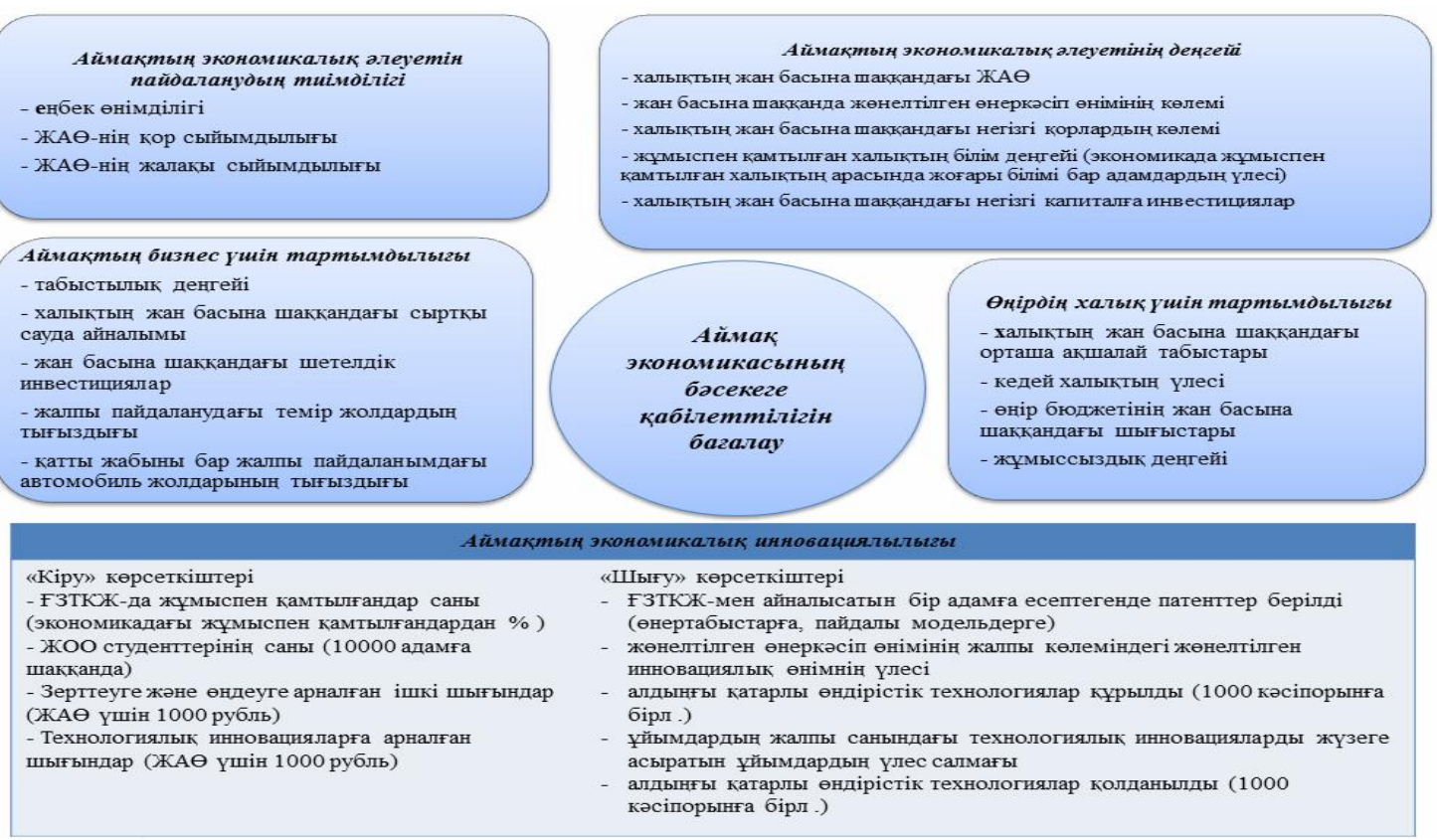

\section{1-сурет. Аймақтың бәсекеге қабілеттілігін бағалау көрсеткіштерінің құрылымы *}

*Автормен [10] негізінде әзірленген

Есептеулер үшін ақпараттық базаны анықтағаннан кейін, әр индикатор үшін аймақ экономикасының қауіпсіздігін жергілікті бағалау есептеледі. Бұл жерде математикалық құралдарды қолдану ұсынылады. Зерттеудің соңғы кезеңі аймақ экономикасының қорғалуын интегралды бағалау болып табылады. Осы мақсаттар үшін белгілі бір көрсеткіштің аймақтың бәсекеге қабілеттілік деңгейіне ықтимал әсерін түпкілікті түсіну үшін аймақтың жергілікті қауіпсіздік бағалауларынан орташа өлшенген әдіс және корреляциялық-регрессивті талдау әдісі қолданылады [10].

Аймақтың бәсекеге қабілеттілігін бағалаудың ең көп таралған әдісі - сараптамалық әдіс. Бұл әдістің артықшылығы - тәжірибесі бар көптеген сарапшыларды қамту мүмкіндігі, бірақ сарапшылардың пікірлерінің субъективтілігі және сарапшылардың сауалнамасы нәтижесінде алынған мәліметтер сенімді екендігіне кепілдік жоқ.

Әлемдік тәжірибе көрсетіп отырғандай, орнықты экономикалық дамуэкономика салаларын жан-жақты әртараптандыру негізінде шаруашылық жүргізудің инновациялық моделіне көшу кезінде ғана мүмкін болады [11].

Осылайша, өңірлердің бәсекеге қабілеттілігін талдау мен бағалаудың әдістері мен әдістемелері сан алуан және өзіндік ерекшеліктері бар.

Қорытынды. Бәсекеге қабілеттілікті бағалау әдістерін талдай отырып, бірнеше қорытынды жасауға болады: 
1. Аймақты бағалаудың сандық әдістерін бір-бірінен бөлек те, кешенді де қолдануға болады, бұл объективті баға алуға мүмкіндік береді.

2. Қарастырылған әдістердің әрқайсысында аймақтың бәсекеге қабілеттілігін анықтауға және басқа бәсекелес аймақтар арасындағы аймақтың жағдайын өзгертетін индикаторларды анықтауға арналған белгілі бір көрсеткіштер жиынтығы бар.

3. Өңірдің бәсекеге қабілеттілігін бағалау әдістерінде әлеуметтік факторларға (білім деңгейі, адами және зияткерлік капитал, көші-қон, қылмыс деңгейі және т.б.) басымдық беріледі. Бұл факторлар бәсекеге қабілетті өнім өндіру, қызмет көрсету, ғылым мен техника жетістіктерін пайдалану негізінде жұмыстар жүргізу есебінен өңірдің бәсекеге қабілеттілігін арттыруға көмектеседі. Сон- дай-ақ, осы әдістемелерде өңірдің инвестициялық әлеуеті ескеріледі. Қазіргі уақытта инвесторларды тарту үшін ресурстық базаға қарағанда жақсы дамыған инфрақұрылым болуы керек, сондықтан бұл фактор өте маңызды.

4. Шетелдік әдістемелерде көптеген көрсеткіштер қолданылады, бұл ең кешенді талдау жүргізуге мүмкіндік береді. Қазақстандық әдістемелерде белгілі бір бағыты бар немесе қоғам өмірінің аз салаларын қамтитын көрсеткіштер пайдаланылады, бұл өңірдің бәсекеге қабілеттілігіне неғұрлым егжей-тегжейлі талдау жүргізуге мүмкіндік береді.

Мақала Қазақстан Республикасы Білім және ғылым министрлігі Ғылыми комитетінің №AP08857332 гранты бойынша зерттеу нәтижелері негізінде дайындалған.

\section{ӘДЕБИЕТТЕР}

1. Ревайкин А.С. Об интегральном показателе социально-экономического развития территории // Мониторинг социально-экономических процессов в Республике Карелия. - Петрозаводск: КарНЦ РАН. - 2000. - 165 с.

2. Губанова Е.С., Клещ В.С. Преодоление социально-экономического неравенства как условие устойчивого сбалансированного пространственного развития региона // Экономические и социальные перемены: факты, тенденции, прогноз. - 2019. - № 5. - С. 44-57.

3. Меркушов В.В. Интегральная оценка уровня конкурентоспособности региона // Межрегиональные экономические сопоставления: Сб. статей. - М., 2004. - С. 24-38.

4. Ушвицкий Л.И., Парахина В.Н. Конкурентоспособность региона как новая регалия: сущность, методы оценки, современное состояние // Сборник научных трудов СевКавГТУ. Серия «Экономика». - 2005. - № 1. - С. 2-8.

5. Ларина Н.И., Макаев А.И. Роль экономических кластеров в усилении конкурентных преимуществ стран и регионов в условиях глобализации // Пространственный аспект стратегии социально-экономического развития региона. - Новосибирск: ИЭОПП СО РАН. - 2006. - C. 93-136.

6. Жихаревич Б.С., Крыловский А.Б. Опыт сравнительной оценки качества стратегического планирования в регионах Северного Кавказа // Экономика развития региона: проблемы, поиски, перспективы: ежегодник. - Волгоград: Изд-во ВолГУ. - 2011. - С. 217-229.

7. Портер М. Конкурентное преимущество: как достичь высокого результата и обеспечить его устойчивость? / М. Портер; пер. с англ. - М.: Альпина Бизнес Букс, 2005. - 715 с.

8. Селезнев А. Инфраструктура рынка и конкурентоспособность России (методологические вопросы анализа и оценки) // Экономист. - 1996. - № 2. - С. 9-15.

9. Шеховцева Л.С. Конкурентоспособность региона: факторы и метод создания // Маркетинг в России и за рубежом. - 2001. - № 4. - С. 11-15. 


\section{Экономика}

10. Фридман Ю.А., Речко Г.Н., Писаров Ю.А. Экономическая безопасность, экономическая защищенность и конкурентоспособность: региональный аспект / Вестник Кузбасского технического университета. - 2015. - № 1. - С. 122-125.

11. Наренова Н.А., Кенжебаева М.Т., Блялова А.К., Жантаева А.М. Факторы устойчивого экономического развития Казахстана // Вестник Казахского университета экономики, финансов и международной торговли. - 2020. - №2(39). - С. 77-85.

\section{REFERENCES}

1. Revajkin A.S. Ob integralnom pokazatele socialno-ekonomicheskogo razvitiya territorii // Monitoring socialno-ekonomicheskih processov v Respublike Kareliya. - Petrozavodsk: KarNC RAN. - 2000. - 165 s. [in Russian].

2. Gubanova E.S., Kleshch V.S. Preodolenie socialno-ekonomicheskogo neravenstva kak uslovie ustojchivogo sbalansirovannogo prostranstvennogo razvitiya regiona //Ekonomicheskie i social'nye peremeny: fakty, tendencii, prognoz. - 2019. - № 5. - S. 44-57 [in Russian].

3. Merkushov V.V. Integralnaya ocenka urovnya konkurentosposobnosti regiona // Mezhregionalnye ekonomicheskie sopostavleniya: Sb. statej. - M., 2004. - S. 24-38 [in Russian].

4. Ushvickij L.I., Parahina V.N. Konkurentosposobnost regiona kak novaya regaliya: sushchnost, metody ocenki, sovremennoe sostoyanie // Sbornik nauchnyh trudov SevKavGTU. Seriya «Ekonomika». - 2005. - № 1. - S. 2-8 [in Russian].

5. Larina N.I., Makaev A.I. Rol ekonomicheskih klasterov v usilenii konkurentnyh preimushchestv stran i regionov v usloviyah globalizacii // Prostranstvennyj aspekt strategii socialno-ekonomicheskogo razvitiya regiona. - Novosibirsk: IEOPP SO RAN. - 2006. - S. 93-136 [in Russian].

6. Zhiharevich B.S., Krylovskij A.B. Opyt sravnitelnoj ocenki kachestva strategicheskogo planirovaniya $v$ regionah Severnogo Kavkaza //Ekonomika razvitiya regiona: problemy, poiski, perspektivy: ezhegodnik. - Volgograd: Izd-vo VolGU. - 2011. - S. 217-229 [in Russian].

7. Porter M. Konkurentnoe preimushchestvo: kak dostich vysokogo rezultata i obespechit ego ustojchivost? / M. Porter; perevod s angl. - M.: Alpina Biznes Buks, 2005. - 715 s. [in Russian].

8. Seleznev A. Infrastruktura rynka i konkurentosposobnost Rossii (metodologicheskie voprosy analiza i ocenki) // Ekonomist, 1996. - № 2. - S. 9-15 [in Russian].

9. Shekhovceva L.S. Konkurentosposobnost regiona: faktory i metod sozdaniya // Marketing v Rossii i za rubezhom. - 2001. - № 4. - S. 11-15 [in Russian].

10. Fridman Yu.A., Rechko G.N., Pisarov Yu.A. Economic securitatem, economic securitate et aemulatione, secundum Regionis / Acta Universitatis Kuzbass Technical. - 2015. - No. 1. S. 122-125 [in Russian].

11. Narenova N.A., Kenzhebaeva M.T., Bljalova A.K., Zhantaeva A.M. Faktory ustojchivogo jekonomicheskogo razvitija Kazahstana // Vestnik Kazahskogo universiteta jekonomiki, finansov i mezhdunarodnoj torgovli. - 2020. - № 2(39). - S. 77-85 [in Russian].

Р.Т. Дуламбаева, А.Н. Турекулова, З.К. Жаныбаева, А.Е. Беделбаева

\section{ИССЛЕДОВАНИЕ МЕТОДОВ АНАЛИЗА И ОЦЕНКИ КОНКУРЕНТОСПОСОБНОСТИ РЕГИОНОВ}

\section{Аннотация}

Статья посвящена исследованию методов и методик оценки конкурентоспособности регионов. Исследованы теоретические основы и изучены концепции оценки конкурентоспо- 
собности регионов, проведен анализ существующих методик и выработаны конкретные рекомендации по их применению. Проведен обзор наиболее часто используемой системы показателей оценки конкурентоспособности регионов. Для анализа тенденций социально-экономического развития региона были рассмотрены методы количественной оценки, основанные на макроэкономических показателях, интегральные методы оценки, рейтинговая оценка конкурентоспособности регионов, методы экспертных оценок и зарубежные методы оценки. Определены основные особенности методов анализа и оценки конкурентоспособности регионов. Сделаны выводы о том, что в методах оценки конкурентоспособности региона предпочтение отдается социальным факторам; количественные методы оценки региона могут использоваться как отдельно друг от друга так и комплексно; в зарубежных методиках используется система многих показателей, что позволяет проводить комплексный анализ.

\section{R. Dulambayeva, A. Turekulova, Z. Zhanybayeva, A. Bedelbayeva}

\section{RESEARCH OF METHODS FOR ANALYZING AND EVALUATING REGIONAL COMPETITIVENESS}

\section{Annotation}

The article is devoted to the study of methods and techniques for assessing the competitiveness of regions. The theoretical foundations of regional competitiveness are studied, the analysis of existing methods for assessing the competitiveness of the region is carried out, and specific recommendations are developed for the use of methods for assessing the competitiveness of the territory. The review of the most frequently used system of indicators for assessing the competitiveness of regions is carried out. To analyze trends in the socio-economic development of the region, quantitative assessment methods based on macroeconomic indicators, integrated assessment methods, rating assessment of regional competitiveness, expert assessment methods, and foreign assessment methods were considered. The main features of methods for analyzing and evaluating the competitiveness of regions are determined. It is concluded that in the methods of assessing the competitiveness of the region, preference is given to social factors; quantitative methods of assessing the region can be used both separately from each other and in a complex way; foreign methods use a system of many indicators, which allows for a comprehensive analysis.

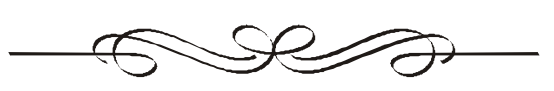


Ж.Н. Саду*, к.э.н., ст. преподаватель ${ }^{1}$

Г.М. Кушебина, к.э.н., доиент ${ }^{2}$

Казахский университет экономики, финансов и

международной торговли ${ }^{l}$

2. Нур-Султан

Костанайский инженерно-экономический университет им. М. Дулатова

2. Костанай

e-mailsdm_2008@mail.ru

* - основной автор (автор для корреспонденции)

\section{ГОСУДАРСТВЕННЫЕ МЕРЫ ПОДДЕРЖКИ СЕЛЬСКОХОЗЯЙСТВЕННЫХ ТОВАРОПРОИЗВОДИТЕЛЕЙ ОТРАСЛИ ЖИВОТНОВОДСТВА В РЕСПУБЛИКЕ КАЗАХСТАН}

В статье раскрывается текущая ситуачия в жсивотноводстве Казахстана, представлена диналика численности поголовья скота и птицы, оказывающая влияние на рост валовой продукции животноводства. Показана динамика производства продуктов животноводства, как одного из приоритетных направлений обеспечения продовольственной безопасности страны, а также потребления продуктов животноводства на внутреннем рынке за 2015-2019 годы. Определены основные проблемы в отрасли животноводства.

Раскрыты меры, применяемые государством по поддержке сельскохозяйственных товаропроизводителей через прямое субсидирование из местного бюджетов, в иелях стимулирования увеличения численности племенного поголовья, увеличения удельного веса племенных животных к общему поголовью, а также объемов производства продукиии животноводства, повышения ее качества и конкурентоспособности.

Ключевые слова: агропромышленный комплекс, сельское хозяйство, государственное регулирование, государственная поддержка, субсидирование, отрасль животноводства, производство животноводческой продукиии, племенное животноводство, проблемы животноводства, сельскохозтоваропроизводители.

Кілт сөздер: агроөнеркасіптік кешен, ауыл шаруашылывы, мемлекеттік реттеу, мемлекеттік қолдау, субсидиялау, мал шаруашылывы саласы, мал шаруашылывы өнімдерін өндіру, асыл тұқыммды мал шаруашыльвы, мал шаруашылывы проблемалары, ауыл шаруашылызы тауарларын өндірушілер.

Keywords: agro-industrial complex, agriculture, state regulation, state support, subsidies, livestock industry, livestock production, livestock breeding, livestock problems, agricultural producers.

JEL classification: Q13, Q14

Введение. Без высокоэффективного аграрного сектора невозможно обеспечение устойчивого развития государства, его продовольственной безопасности, лежащей в основе социального благополучия общества. Решающим фактором благополучия аграрного сектора является наличие механиз- мов эффективного государственного регулирования. Государственное регулирование агропромышленного комплекса (АПК) и сельских территорий, в целях обеспечения продовольственной безопасности, осуществляется посредством: развития кредитования в сфере АПК и сельских терри- 
торий; субсидирования АПК; реализации механизмов стабилизации цен на социально значимые продовольственные товары; закупа сельскохозяйственной продукции по гарантированной закупочной цене; регулирование экспорта и импорта товаров АПК.

В своем выступлении на расширенном заседании Правительства Президент страны К.-Ж. Токаев отметил, что ситуация в агропромышленном комплексе вызывает обоснованные нарекания, не удалось раскрыть экспортный потенциал и решить вопросы полноценной продовольственной обеспеченности страны. Было указано о необходимости нового, выверенного подхода в аграрном секторе, создания условий для переработки сырья внутри страны, привлечения инвестиций и новейших агротехнологий, обеспечения стабильности мер господдержки, повышения их эффективности [1].

Во всех странах мира сельскому хозяйству государством уделяется приоритетное внимание. Именно в сфере сельскохозяйственной продукции применяются наиболее жесткие протекционистские меры для защиты своего рынка. Эффективная аграрная политика, включая государственную поддержку, является одним из главных условий развития сельского хозяйства. В этой связи, вопросы необходимости сильной государственной поддержки отечественного производителя, без которой невозможно достижение конкурентоспособности АПК и отрасли животноводства, в частности, являются актуальными.

Цель исследования. Исследование направлено на изучение текущего состояния отрасли животноводства, выявление основных проблем в животноводческой отрасли и обоснование приоритетных направлений, применяемых государством по поддержке сельскохозяйственных товаропроизводителей.

В ходе выполнения исследования были использованы следующие методы: аналитические, экономико-статистические, сравнительно-структурного анализа.

Обзор литературы. Анализ последних исследований и публикаций показывает, что к вопросам совершенствования государственной поддержки сельскохояйственных товаропроизводителей, государственного регулирования агропромышленного комплекса Казахстана и их важности в обеспечении продовольственной безопасности нашей страны обращались многие современные исследователи: Шуленбаева Ф.А. [2], Каменова М.Ж., Турсумбаева М.Ж. [3], Дюзельбаева Г.М., Маляренко О.И. [4] и другие.

В проведенных исследованиях раскрываются основные концептуальные подходы, методологические и методические основы, пути и направления формирования экономического механизма хозяйствования в аграрном секторе и экономики страны в целом с учетом государственного вмешательства.

Несмотря на активную разработку этих вопросов, на сегодняшний день изучены далеко не все аспекты государственной поддержки и регулирования сельскохозяйственных товаропроизводителей в целом и в животноводстве, в частности, что определяет необходимость углубления исследований по данной проблеме с учетом современных условий экономики.

В качестве информационной базы были использованы статистические данные с 2015 по 2019 годы Комитета по статистике Министерства национальной экономики РК, информационно-аналитические обзоры, республиканские программы, в частности, Государственная программа развития агропромышленного комплекса РК на 2017-2021 годы.

Основная часть. Природные условия Казахстана, их многообразие обуславливают значительные потенциальные возможности для развития животноводства. В Казахстане традиционно занимаются овцеводством, коневодством, верблюдоводством, разведением крупного рогатого 
скота. Однако ресурсы животноводства пока используются неэффективно и конкурентоспособность мясной продукции на мировом рынке низка. Тем не менее, Казахстан сохраняет достаточно уверенный рост в развитии животноводства. Большое внимание сейчас уделяется не только повышению объема производства, но и увеличению уровня его эффективности и рентабельности. Вместе с тем, поголовье крупного рогатого скота (КРС) увеличивается на протяжении 2015-2019 годов [5].

Изменилась структура хозяйствования. Ранее в 1990-х годах около 70\% поголовья приходилось в сельхозформированиях, 30\% - в крестьянских и личных подсобных хозяйствах. В настоящее время в организованных хозяйствах содержится 44,9\% поголовья КРС.

Валовый выпуск продукции (услуг) отрасли животноводства в январе-декабре 2019 года в целом по республике составил 2306,4 млрд тенге, что на 4,0\% выше уровня соответствующего периода предыдущего года (2050,4 млрд тенге). Рост объема производства продукции животноводства обусловлен увеличением объемов забоя скота и птицы в живом весе на $5,5 \%$, надоев сырого коровьего молока $-3,2 \%$.

За счет количества увеличения сельхозформирований наблюдается тенденция увеличения численности КРС по сравнению с показателями предыдущего года на 4,0\% до 7437,6 тыс. голов, лошадей - на $6,8 \%$ до 2825,8 тыс. голов, птицы - на 2,0\% до 45,2 млн голов, овец - на 2,7\% до 16,9 млн голов, верблюдов - на $3,5 \%$ до 214,8 тыс. голов, свиней - на 2,9\% до 822,2 тыс. голов. Поголовье коз снизилось на $2,2 \%$ до 2233, 7 тыс. голов (табл.1).

Таблица 1

Динамика численности поголовья скота и птицы за 2015-2019 годы*

\begin{tabular}{|l|c|r|r|r|r|r|}
\hline \multicolumn{1}{|c|}{ Наименование } & Ед.изм. & \multicolumn{1}{c|}{2015 г. } & \multicolumn{1}{c|}{2016 г. } & \multicolumn{1}{c|}{2017 г. } & \multicolumn{1}{c|}{2018 г. } & \multicolumn{1}{c|}{2019 г. } \\
\hline Крупный рогатый скот & тыс. голов & 6183,9 & 6413,2 & 6764,2 & 7137,9 & 7437,6 \\
\hline в т.ч. коровы & тыс. голов & 2999,3 & 3209,9 & 3362,4 & 3569,2 & 3773,1 \\
\hline Овцы и козы & тыс. голов & 18015,5 & 18184,2 & 18329,0 & 18677,9 & 19091,9 \\
\hline Свиньи & тыс. голов & 887,6 & 834,2 & 815,1 & 802,7 & 822,2 \\
\hline Лошади & тыс. голов & 2070,3 & 2259,2 & 2415,7 & 2623,7 & 2825,8 \\
\hline Верблюды & тыс. голов & 170,5 & 180,1 & 193,1 & 202,2 & 214,8 \\
\hline Птицы & тыс. голов & 35632,9 & 36910,0 & 39913,5 & 44452,9 & 45197,1 \\
\hline
\end{tabular}

*Составлена на основе источника [6]

Увеличилось производство товарного молока коровьего на 2,8\% до 3967,9 тыс. тонн, производство яиц куриных снизилось на $1,1 \%$ до 5513,4 млн штук за счет технологического процесса смены поголовья, а также прекращения деятельности ТОО «Птицефабрика Целиноградская». В целом, основная доля производства яиц снизилась в Алматинской области на 73,5 млн штук, Акмолинской - на 26,1 млн штук и СевероКазахстанской - на 6,4 млн штук. Произ- водство мяса птицы составило - 222,9 тыс. тонн, говядины - 501,4 тыс. тонн, баранины - 151,9 тыс. тонн. За январь-декабрь 2019 года производство мяса в убойном весе во всех категориях хозяйств увеличилось на 5,8\% и составило 1120,9 тыс. тонн. Вместе с тем, в сельхозформированиях отмечается увеличение объемов производства мяса на $11,4 \%$, молока на $6,2 \%$. Средний удой молока на 1 корову остался на уровне прошлого года и составил 
2347 кг, средний выход яиц на 1 куру-несушку снизился к уровню прошлого года на 2,9\% и составил 239 шт. При этом средний удой молока в сельхозпредприятиях на 1 корову увеличился на 13,5\% и составил 4660 кг.

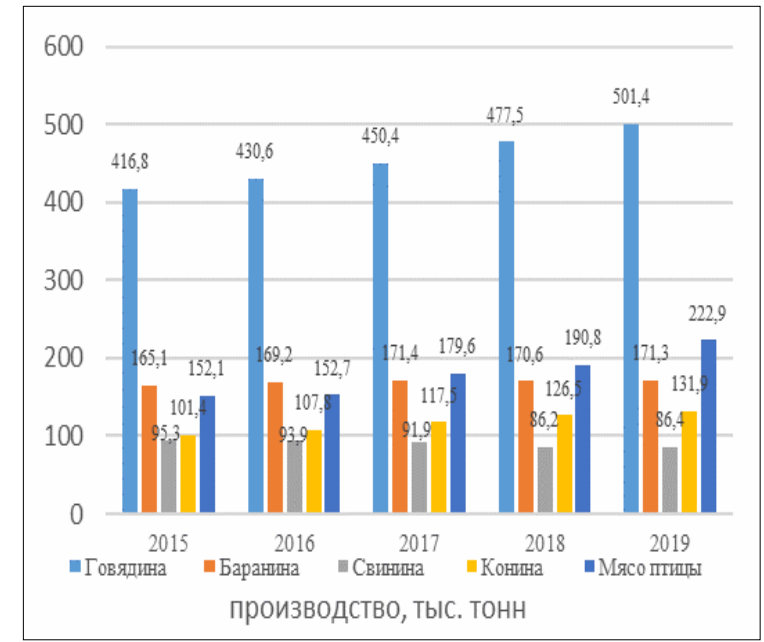

Рисунок 1. Производство и внутреннее потребление продуктов животноводства за 2015-2019 годы*

* Составлен авторами на основе источника [7]

В результате Министерство сельского хозяйства на полгода ввело запрет на экспорт живого скота в связи с увеличением экспорта живого скота в 2019 году по сравнению с 2018 годом: в 3 раза или 156 тыс. голов крупного рогатого скота и в 7 раз или 263 тыс. голов мелкого рогатого скота. Несмотря на 45-50\%-ю загруженность казахстанских мясокомбинатов, цены на продукцию мясного животноводства растут. При согласовании запрета НПП РК «Атамекен» считает, что для стабилизации внутреннего рынка, решения вопроса перетока и обеспечения рентабельности фермеров, необходимо выплачивать разницу в виде субсидий фермерам при высокой цене на мясо или живого КРС на рынках сопредельных государств [8].

Следует отметить, в Казахстане около 40\% скота принадлежит частным подворьям и домашним хозяйствам, которые
Несмотря на увеличение объемов производства животноводческой продукции, отечественное производство по отдельным позициям не покрывает потребность населения в мясной и молочной продукции и наполовину (рис. 1).

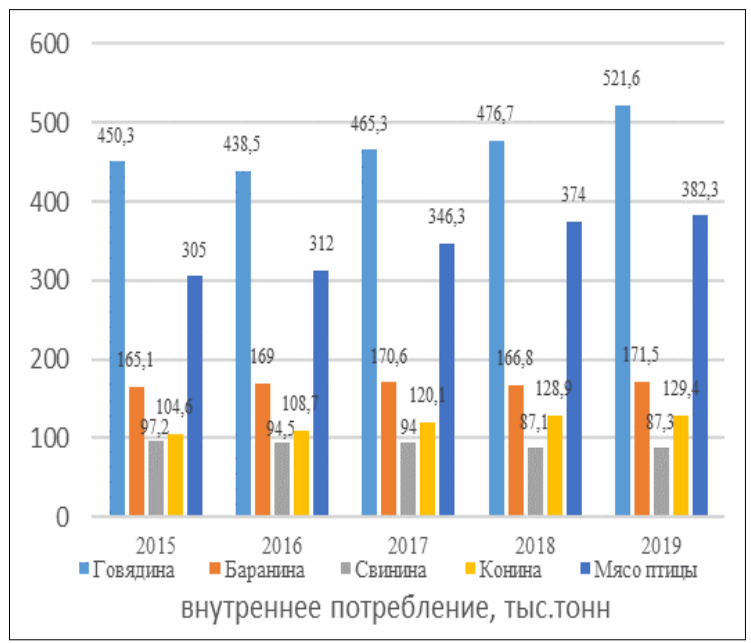

не всегда способны обеспечить скот нужными условиями и большинство из них не имеют возможности оснащать свои хозяйства соответствующим техническим оборудованием, что в свою очередь оказывает существенное влияние на качество производимой продукции. Для примера, в Республике Беларусь почти 100\% скота находится в крупных организованных молочных хозяйствах, в Российской Федерации - более $50 \%$.

В связи с тем, что часть поголовья сосредоточена в хозяйствах населения, отрасли животноводства присущи такие характеристики, как низкий генетический потенциал животных и связанная с этим низкая продуктивность, отсутствие использования современных технологий содержания, кормления и других технологий, обеспечивающих продуктивность и качество продукции, недостаточный уход за здоровьем 
животных. Большое влияние на продуктивность животноводства оказывает качество кормовой базы. Для получения мясной и молочной продукции хорошего качества, помимо соответствующих условий необходимо владеть масштабной и качественной кормовой базой. Большинство существующих пастбищ не предполагает наличие водоемов ввиду своего месторасположения, что также снижает возможность содержания скота. Требует внимания и вопрос завоза крупного рогатого скота из-за рубежа. Необходимо обратить внимание на соответствие местным климатическим условиям, современное обнаружение и исключение завоза больных животных и др. [9].

Вместе с тем, объемы государственной поддержки сельского хозяйства РК ежегодно увеличиваются, так за последние пять лет объем субсидий вырос в 2 раза и в 2019 году составил 115,6 млрд тенге (для сравнения в 2015 году - 69,0 млрд тенге).

Государственные меры поддержки сельскохозяйственных товаропроизводителей (СХТП) осуществляются через прямое субсидирование СХТП из местного бюджетов по двум направлениям: развитие племенного животноводства и производство продукции животноводства. Субсидирование данных направлений осуществляется в рамках Правил субсидирования развития племенного животноводства, повышения продуктивности и качества продукции животноводства [10].

Субсидирование на развитие племенного животноводства включает: частичное удешевление (до 50\%) стоимости приобретенного отечественными товаропроизводителями племенного молодняка КРС, овец, коз, жеребцов, свиней, верблюдов и суточных цыплят; удешевление затрат на ведение селекционной и племенной работы с маточным поголовьем КРС, овец, свиней, маралов (оленей), а также пчелосемьями; удешевление затрат физических и юридических лиц на содержание племенных быков-произ100 водителей мясных и молочно-мясных пород, используемых для воспроизводства товарного и общественного стада, баранов для воспроизводства товарной отары; удешевление стоимости приобретенного однополого и двуполого семени племенного быка молочных и молочно-мясных пород; субсидирование услуг по трансплантации эмбрионов; возмещение затрат племенных и дистрибьюторных центров на оказание услуг по искусственному осеменению маточного поголовья КРС и овец в сельскохозяйственных кооперативах, а также в крестьянских (фермерских) хозяйствах [7, с. 67]. На рисунке 2 отображено субсидирование развития племенного животноводства по молочному и мясному скотоводству, птицеводству, овцеводству за 2015-2019 годы.

Субсидирование повышения продуктивности и качества продукции животноводства направлено на: удешевление стоимости бычков, реализованных на откорм в откормочные площадки вместимостью не менее 1000 голов единовременно; удешевление затрат откорма бычков для откормочных площадок вместимостью не менее 1000 голов единовременно; удешевление стоимости реализованных ягнят; удешевление стоимости производства молока (коровьего, кобыльего, верблюжьего), мяса птицы (мясо бройлерной птицы, мясо индейки, водоплавающей птицы), пищевого яйца (куриное яйцо), тонкой и полутонкой шерсти; удешевление стоимости затрат на корма маточному поголовью молочного направления [7, с. 68]. Субсидирование по видам произведенной продукции за 2015-2019 годы представлено на рисунке 3.

Данные меры господдержки применяются в целях стимулирования увеличения численности племенного поголовья, увеличения удельного веса племенных животных к общему поголовью, а также объемов производства продукции животноводства, повышения ее качества и конкурентоспособности. 


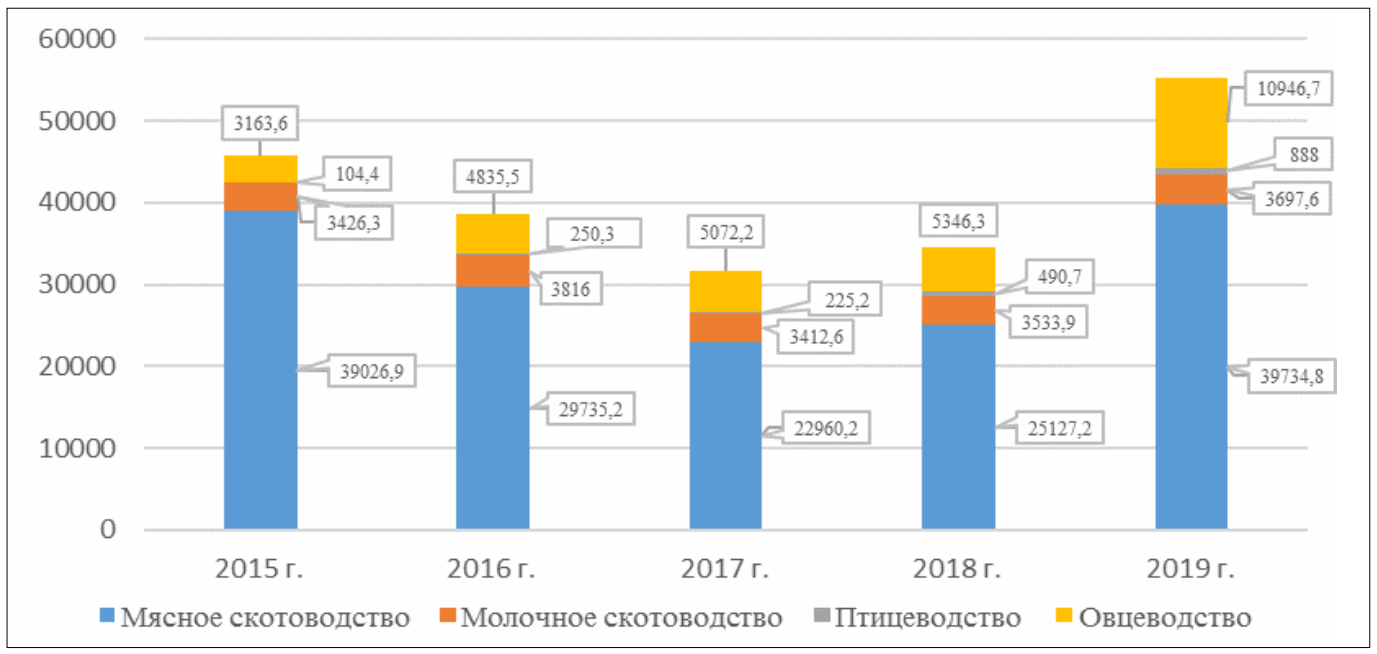

Рисунок 2. Субсидирование развития племенного животноводства по направлениям, (млн тенге)*

*Составлен авторами на основе источника [7]

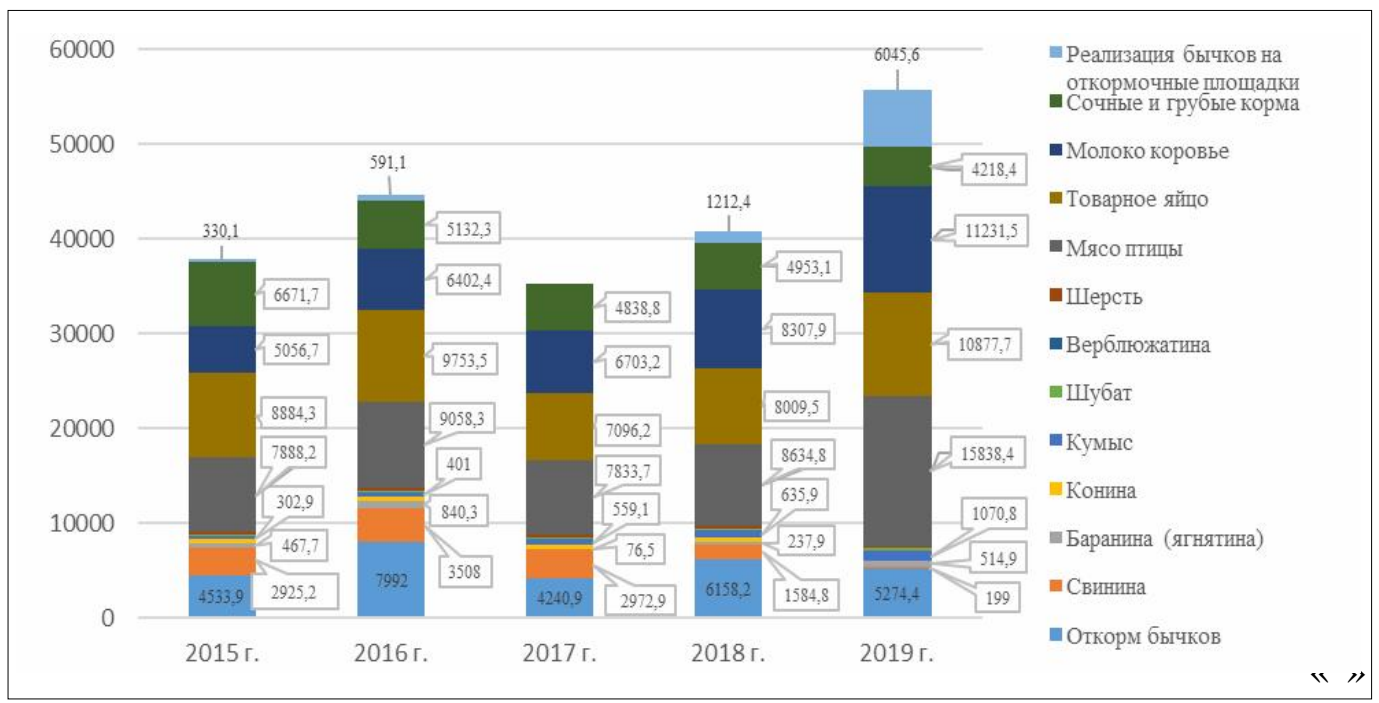

Рисунок 3. Субсидирование произведенной продукции по видам, (млн тенге)*

* Составлен авторами на основе источника [7]

В рамках государственной программы развития АПК планируется поэтапно сокращать неэффективные субсидии (товарно-специфические субсидии на единицу продукции), которые напрямую искажают ценообразование и относятся по методике ВТО к «желтой» корзине [11].

В результате повысится доступность финансирования сельскохозяйственных товаропроизводителей и высвободившиеся субсидии смогут быть направлены на эффективные финансовые инструменты, такие как: развитие племенного животноводства, субсидирование процентной ставки по кредитам, лизинг сельхозтехники и животных, инвестиционное субсидирование, субсидирование страховых премий, развитие системы кредитных товариществ и институтов гарантирования займов [7, с. 69].

В завершение необходимо отметить, 
что действующая система субсидирования недостаточно эффективна, так как не предусматривает достижение конкретных заранее определенных результатов, обязательное внедрение эффективных технологий и др. К тому же неустойчивость видов и условий субсидирования, неотработанные окончательные критерии вызывают недовольство сельскохозяйственных товаропроизводителей. Так, по данным НПП «Атамекен», за последние 5 лет правила субсидирования менялись 47 раз [8]. С другой стороны, сельскохозяйственные товаропроизводители привыкли ориентироваться только на бюджетные субсидии. Вместе с тем, такие субсидии, следует направлять на приоритетные направления АПК, связанные с обеспечением продовольственной безопасности страны, где без поддержки государства не обойтись, что в свою очередь обеспечит стабильность правил субсидирования. Конкретные индикаторы результатов должны быть определены и для получателей субсидий, и для сектора АПК в целом. При этом за достижение данных индикаторов прямую ответственность должны нести и руководители соответствующих государственных органов, и получатели субсидий. Таким образом, основанием для дальнейшей финансовой поддержки государства должно служить достижение поло- жительных тенденций в аграрном секторе, а не быстрое освоение субсидий.

Выводы. Полученные результаты исследования процессов, протекающих в отрасли животноводства, позволяют сформулировать следующие основные проблемы: мелкотоварность производства, низкая продуктивность сельскохозяйственных животных, неразвитость кормовой отрасли, недостаток свободных земель для животноводства, недостаток квалифицированных кадров, научных исследований, отсутствие стабильных рынков сбыта, слабая конкурентоспособность, проблемы ветеринарии.

Следует отметить, что в настоящее время государственные меры поддержки сельскохозяйственных товаропроизводителей отрасли животноводства осуществляются в основном путем бюджетного кредитования либо участия в формировании или увеличении уставного капитала специализированных организаций, а также субсидирования. При этом последнее должно осуществляться при условиях экономической эффективности субсидирования и повышения качества и конкурентоспособности производимой продукции, а основанием для дальнейшей государственной поддержки должно служить достижение положительных тенденций в аграрном секторе Казахстана.

\section{ЛИТЕРАТУРА}

1. Выступление Президента К-Ж.Токаева 24.01.2020 г. [Электрон. pecypc]. - https:// www.akorda.kz/ru/speeches/internal_political_affairs/in_speeches_and_addresses/vystuplenieprezidenta-kasym-zhomarta-tokaeva (Дата обращения: 19.08.2020).

2. Шуленбаева Ф.А., Дарибаева А.К., Шаймерденова А.К. Кредитование субъектов АПК в Казахстане и за рубежом // Вестник КазУЭФМТ. - 2020. - № 1(38), - С. 56-65.

3. Каменова М.Ж., Турсумбаева М.Ж. Состояние проблемы обеспечения продовольственной безопасности в Республике Казахстан // Вестник КазУЭФМТ. - 2020. - № 1 (38). - C. 66-74.

4. Dyuzelbayeva G., Malyarenko O. The role of state regulation in the development of the agro-industrial complex of the region (Kostanay region) // Agrarian Bulletin of the Urals. - 2020 . - № 2(193). - P. 70-77.

5. Есымханова 3.К., Саду Ж.Н. Тенденции регулирования сферы АПК Казахстана в 
условиях ресурсосбережения // Вестник КазУЭФМТ. - 2020. - № 1(38). - С. 56-65.

6. Статистические данные Комитета по статистике МНЭ РК. [Электрон. ресурс]. http://stat.gov.kz/faces/homePage (Дата обращения: 17.07.2020).

7. Парламентские слушания на тему «Вопросы развития АПК». Комитет по аграрным вопросам, природопользованию и развитию сельских территорий. - Нур-Султан, 2020.

8. Выступление Жумагазиева Э. Запрет на экспорт КРС: «Такая корова нужна самому»! [Электрон. pecypc]. - https://atameken.kz/ru/news/ 34510-zapret-na-eksport-krs-takaya-korovanuzhna-samomu (Дата обращения: 21.07.2020).

9. Информационно-аналитический обзор на тему: «Вопросы развития АПК». - НурСултан: Аппарат сената. ИАО. - 2020, февраль. - 55 с.

10. Правила субсидирования развития племенного животноводства, повышения продуктивности и качества продукции животноводства от 15.03.2019 г. №108. [Электрон. pecypc]. - http://adilet.zan.kz/rus/docs/V1900018404 (Дата обращения: 21.07.2020).

11. Государственная программа развития АПК РК на 2017-2021 годы. Указ Президента РК от 14.02.2017 года № 420 (с изм. и доп. от 12.07.2018 г. № 423). [Электрон. peсурс]. https://primeminister.kz/ru/ gosprogrammy/gosudarstvennaya-programma-razvitiya-agropromyshlennogo-kompleksa-rk-na-2017-2021-gody (Дата обращения: 21.07.2020).

\section{REFERENCES}

1. Vystuplenie Prezidenta K-Zh.Tokaeva 24.01.2020 g. [Elektron. resurs]. - https://www. akorda.kz/ru/speeches/internal_political_affairs/in_speeches_and_addresses/vystuplenie-prezidentakasym-zhomarta-tokaeva (Data obrashcheniya: 19.08.2020) [in Russian].

2. Shulenbaeva F.A., Daribaeva A.K., Shaymerdenova A.K. Kreditovanie sub"ektov APK v Kazakhstane i za rubezhom // Vestnik KazUEFMT. - 2020. - No.1 (38). - S. 56-65 [in Russian].

3. Kamenova M.Zh., Tursumbaeva M.Zh. Sostoyanie problemy obespecheniya prodovol'stvennoy bezopasnosti v Respublike Kazakhstan // Vestnik KazUEFMT. - 2020. - No.1(38). S. 66-74 [in Russian].

4. Dyuzelbayeva G., Malyarenko O. The role of state regulation in the development of the agro-industrial complex of the region (Kostanay region) // Agrarian Bulletin of the Urals. - 2020. No.2 (193). - P. 70-77 [in English].

5. Esymkhanova Z.K., Sadu Zh.N. Tendentsii regulirovaniya sfery APK Kazakhstana v usloviyakh resursosberezheniya // Vestnik KazUEFMT. - 2020. - No.1 (38). - S. 56-65 [in Russian].

6. Statisticheskie dannye Komiteta po statistike MNE RK [Elektron. resurs]. - http://stat.gov.kz/ faces/homePage (Data obrashcheniya: 17.07.2020) [in Russian].

7. Parlamentskie slushaniya na temu «Voprosy razvitiya APK». Komitet po agrarnym voprosam, prirodopol'zovaniyu i razvitiyu sel'skikh territoriy. - Nur-Sultan, 28.02.2020. - 84 s. [in Russian].

8. Vystuplenie Zhumagazieva E. Zapret na eksport KRS: «Takaya korova nuzhna samomu»! [Elektron. resurs]. - https://atameken.kz/ru/news/34510-zapret-na-eksport-krs-takaya-korovanuzhna-samomu (Data obrashcheniya: 21.07.2020).

9. Informatsionno-analiticheskiy obzor na temu: «Voprosy razvitiya APK».- Nur-Sultan: Apparat senata. IAO. - 2020, fevral'. - 55 s. [in Russian].

10. Pravila subsidirovaniya razvitiya plemennogo zhivotnovodstva, povysheniya produktivnosti $\mathrm{i}$ kachestva produktsii zhivotnovodstva ot 15.03.2019 g. No.108. [Elektron. resurs]. - http://adilet.zan.kz/ rus/docs/V1900018404 (Data obrashcheniya: 21.07.2020) [in Russian].

11. Gosudarstvennaya programma razvitiya APK RK na 2017-2021 gody. Ukaz Prezidenta 


\title{
Экономика
}

RK ot 14.02.2017 goda № 420 (s izm. i dop. ot 12.07.2018 g. No.423). [Elektron. resurs]. - https:/ /primeminister.kz/ru/gosprogrammy/gosudarstvennaya-programma-razvitiya-agropromyshlennogokompleksa-rk-na-2017-2021-gody (Data obrashcheniya: 21.07.2020) [in Russian].

\author{
Ж.Н. Саду, Г.М. Кушебина
}

\section{ҚАЗАҚСТАН РЕСПУБЛИКАСЫНЫН МАЛ ШАРУАШЫЛЫҒЫ САЛАСЫНДАҒЫ АУЫЛ ШАРУАШЫЛЫҒЫ ӨНІМДЕРІН ӨНДІРУШІЛЕРДІ ҚОЛДАУДЫҢ МЕМЛЕКЕТТІК ШАРАЛАРЫ}

\begin{abstract}
Аңдатпа
Мақалада Қазақстанның мал шаруашылығындағы ағымдағы жағдай ашылады, мал шаруашылығы жалпы өнімінің өсуіне ықпал ететін 2015-2019 жылдардағы мал басы мен құс санының динамикасы ұсынылды. Елдің азық-түлік қауіпсіздігін қамтамасыз етудің, сондай-ақ 2015-2019 жылдары ішкі нарықта мал шаруашылығы өнімдерін тұтынудың басым бағыттарының бірі ретінде мал шаруашылығы өнімдерін өндіру серпіні көрсетілген. Мал шаруашылығы саласындағы негізгі проблемалар анықталды.

Асыл тұқымды мал басының санын ұлғайтуды ынталандыру, асыл тұқымды малдың жалпы басына шаққандағы үлес салмағын, сондай-ақ мал шаруашылығы өнімін өндіру көлемін ұлғайту, оның сапасы мен бәсекеге қабілеттілігін арттыру мақсатында жергілікті бюджеттерден тікелей субсидиялау арқылы ауыл шаруашылығы тауарын өндірушілерді қолдау бойынша мемлекет қолданатын шаралар ашылды.
\end{abstract}

\section{Zh. Sadu, G. Kushebina \\ STATE SUPPORT MEASURES \\ ON AGRICULTURAL PRODUCERS LIVESTOCK INDUSTRIES IN THE REPUBLIC OF KAZAKHSTAN}

\section{Annotation}

The article reveals the current situation in cattle breeding in Kazakhstan, presents the dynamics of the number of livestock and poultry for 2015-2019, which affects the growth of gross livestock production. The dynamics of the production of livestock products is shown as one of the priority areas for ensuring the country's food security, as well as the consumption of livestock products in the domestic market for 2015-2019. It is identified the main problems in the livestock industry.

It is identified the need to improve the issues of state support for the agro-industrial complex of Kazakhstan, the importance of state regulation of the agrarian sector of Kazakhstan in order to ensure the food security of the country and some measures of state regulation of the development of the agroindustrial complex are given.

Disclosed are the measures used by the state to support agricultural producers through direct subsidies from local budgets in order to stimulate an increase in the number of pedigree livestock, increase the share of pedigree animals in the total livestock, as well as the volume of livestock production, improve its quality and competitiveness.

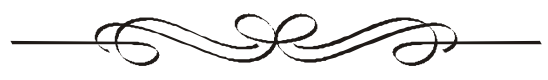


A.E. Rakhimbekova*, $P h D$, assoc. professor ${ }^{l}$

A.M. Kazybayeva, $P h D$, assoc. professor ${ }^{2}$ The Kazakh University of Economics, Finance and International Trade ${ }^{l}$

Nur-Sultan c. Almaty Management University ${ }^{2}$ Almaty c. e-mail: @rahim_asel@mail.ru * - main author (author for correspondence)

\section{COMPETITIVENESS AND DEVELOPMENT TRENDS OF THE MODERN MARKET OF MEDICAL SERVICES IN THE REPUBLIC OF KAZAKHSTAN}

This article reflects the main directions of development of the health care system of the Republic of Kazakhstan. To effectively manage health care, as well as to ensure that citizens exercise the rights and obligations guaranteed by the state, a common understanding, including in law enforcement practice, of legal norms in the field of health care is necessary.

The analysis of the healthcare system showed the presence of systemic problems that need to be solved with the help of economic levers and increasing the competitiveness of medical organizations. These problems directly affect not only the healthcare system, but also the country's economy as a whole.

Keywords: competitiveness, health care, economic growth, efficiency, social problems, systemic crisis, educational programs, international healthcare system, quality system, Kazakhstan.

Кілт сөздер: бәсекеге қ̧абілеттілік, денсаулық сақтау, экономикалық өсу, тиімділік, әлеуметтік мәселелер, жүйелік давдарыс, білім беру бавдарламалары, денсаулық сақтаудың халыққаральқ жүйесі, сапа жүйесі, Қазақстан.

Ключевые слова: конкурентоспособность, здравоохранение, экономический рост, эффективность, социальные проблемы, системный кризис, образовательные программы, международная система здравоохранения, система качества, Казахстан.

JEL classification: I 15

Introduction. Mechanisms have been implemented to increase the independence of management of public medical organizations. Elements of corporate governance have been introduced in state medical organizations: supervisory boards with the participation of independent directors have been created, practices have been introduced to independently determine the level of salaries of medical workers and independently determine the staffing table. The rating of state medical organizations is conducted in terms of management indicators, clinical and scientific activities, as well as the level of corporate governance.
With the introduction of compulsory health insurance, the role of the medical community in ensuring the quality of medical care increases. An institutional mechanism for improving the quality of medical services has been implemented by creating an advisory and advisory body - the Joint Commission on the Quality of Medical Services. More than 30 standards for the organization of medical care have been introduced, over 1300 clinical protocols based on evidence-based medicine have been approved. Health technology assessment is underway.

The purpose of the study is to determine the 


\section{Экономика}

main trends in the development of the healthcare system.

The methods and techniques of systemic, comparative, functional, economic and statistical structural analysis and synthesis, observation, interviews, questionnaires, the method of hierarchical decomposition and organizational design were used as a methodological basis for the study.

Maintaining and promoting health presupposes the active care and responsibility of a person for their physical and mental well-being. In order for people to change behavior in favor of health, measures will be taken to increase the literacy of the population on health issues. Aculture of healthy life will be formed through the channels of information exchange that are most in demand for each target audience. For example, projects will be implemented in the media to promote a healthy lifestyle. Mass events are planned to protect the health of citizens and the formation of a healthy lifestyle, rejection of risky behavior and bad habits.

Literature review. The theoretical basis of the work is the scientific works of domestic, as well as scientists and practitioners from near and far abroad in the field of competition and competitiveness, economics, management and marketing, as well as economics and healthcare organization.

A significant contribution to the development of competition theory was made by J.M. Clark [1], M. Porter[2], P. Samuelson[3], F.A. Hayek [4]. and others. Among Kazakhstani researchers W.B. Baimuratov [5], R.T. Dulambaev [6], E.S. Karibzhanov [7], G.A. Kaliev [8], N.K. Mamyrov [9] and others. In the works of these scientists, mathematical models, theories and various forms of competitive relations were described. Competition issues in the healthcare sector were not considered by these researchers.

Despite the significant number of works dedicated to the general theoretical issues of the competitiveness of various institutions, at the moment there is no coherent theory of the competitiveness of economic entities in the field of health care.

Main part. With the aim of a continuous quality management system, a national accredita- tion system for medical organizations has been introduced that meets international standards (International Society for Quality in Healthcare, ISQua). Today, $30 \%$ of medical organizations suppliers of the FSMS - have national accreditation. Seven leading medical organizations in the country are internationally accredited by JCI.

At the legislative level, state regulation of prices for medicines is enshrined, and a transition to reference pricing has been made. To achieve the strategic goal of increasing the availability and quality of medicines, the procurement procedure for medicines within the guaranteed volume of medical care has undergone a number of organizational innovations: the procurement is carried out online in open access for the entire population. 49 long-term contracts were concluded with 30 domestic manufacturers for more than 1,500 names of medicines and medical devices, which made it possible to save money on expensive logistics and expand procurement volumes. For the rational use of medicines, the Kazakhstani national formulary is supported, developed with the participation of Kazakhstani and international experts and containing medicines with proven clinical efficacy.

In preparation for compulsory health insurance, medical information systems have been introduced, paperless maintenance of medical records is being introduced. Electronic health passports for the country's population have been generated. Centralized registers have been formed, which are necessary for the exchange of data on the provided medical care. Standards have been approved to ensure uniform approaches to the formation of an IT architecture for digital healthcare. The development of the healthcare integration platform was completed. The development of information systems has expanded the range of automated government services, reduced paperwork in medical organizations, and improved the quality of information about medical and pharmaceutical services.

Private spending in 2018 amounted to 679.5 billion tenge, or $1.2 \%$ of GDP, or $38.5 \%$ of current health spending. Compared to OECD count- 
ries, where the share of private spending in current health spending is $26.8 \%$, this figure is high. Compared to 2017, private spending increased by $8.4 \%$ in 2018 . Direct payments by the population for health services account for $33 \%$ of current expenditures ( $86 \%$ in private expenditures). A large share of payments by the population for health services is the cost of drug provision 353 billion tenge $(60.7 \%)$.

At the end of 2018, the percentage of equipping state healthcare organizations with medical equipment was $72.5 \% .272$ healthcare organizations require major repairs. The deterioration of medical equipment was $37 \%$, only $55 \%$ of all medical equipment is $100 \%$ used.

At the beginning of 2019, the availability of computers in healthcare organizations is $94.1 \%$. At the level of cities and regional centers, $65.8 \%$ of healthcare organizations are provided with access to the Internet.

In healthcare organizations of the republic, the introduction of medical information systems (hereinafter-MIS) amounted to $65.1 \%$.

At the regional level, MIS created and filled in 16.3 million electronic health passports, which is $89 \%$ of the total population [9].

Measures will be taken annually to promote healthy nutrition among the population. Promotion of rational nutrition is provided; increasing the availability of healthy food, food control in educational institutions.

To assess progress and the current situation according to the WHO methodology, epidemiological studies will be conducted in 2021 and 2025 to assess risk factors for non-communicable diseases, tobacco use, and alcohol consumption.

Thus, the effectiveness of measures taken in the field of public health will be assessed through studies that will determine the objective state of people's health and have timely statistical information about Kazakhstan in world databases [10].

The state, represented by the authorized bo$\mathrm{dy}$ for control and quality assurance of the safety of goods and services, will play a key role in the verification and registration of medicines, food additives, genetically modified organisms and new food products. Monitoring and control of the quality and safety of food products, including falsified and genetically modified products, will be provided.

Monitoring of the roadmap for the implementation of the International Health Regulations (hereinafter - IHR) and the global health program for 2019-2023 will continue [11].

To improve preparedness for responding to public health emergencies, training will be provided for employees of transport hubs for initial screening [13].

Modern technologies for the utilization and processing of industrial and solid domestic waste will be introduced with the involvement of investors. The reporting by the authorized body in the field of healthcare on medical waste in the state cadastre of waste will be monitored in order to comply with safety and environmental standards.

Measures will be taken to improve the efficiency of management, prevention, diagnosis and treatment of infectious diseases.

According to the international obligations of Kazakhstan, an interdepartmental program (roadmap) will be implemented to curb antimicrobial resistance. Interaction with WHO and other international organizations on the problems of antimicrobial resistance will continue.

Work will continue to cover the population with immunization, including through information and explanatory work to reduce the population's refusal from preventive vaccinations. The introduction of vaccination against human papillomavirus (hereinafter - HPV) in the List of infectious diseases against which preventive vaccinations are carried out will be considered.

Within the framework of international commitments, coverage of antiretroviral therapy for people living with HIV infection will be increased, with the provision of necessary medical care within the framework of the guaranteed volume of medical care. Preventive measures to contain HIV infection in the concentrated stage will continue. 


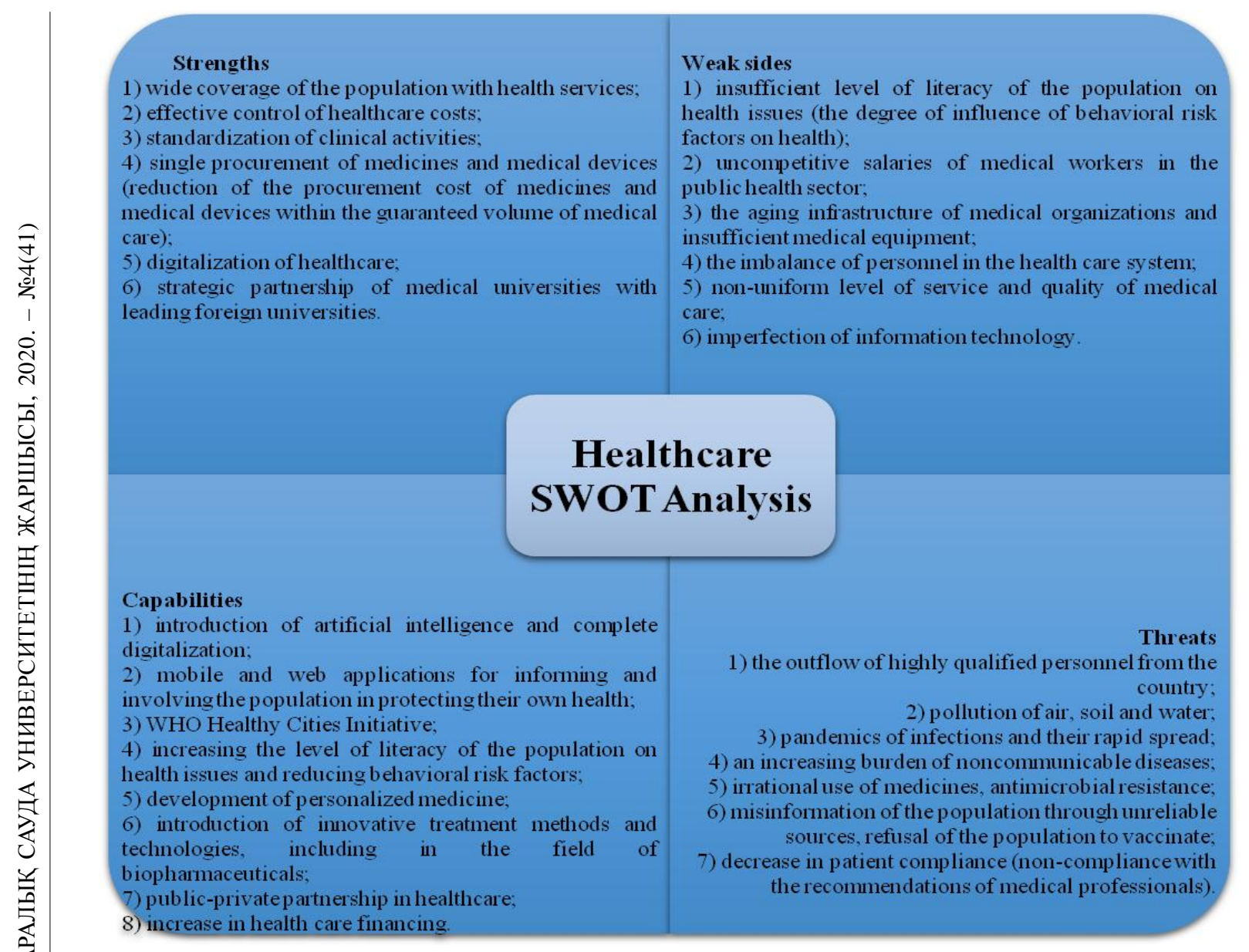

Picture 1. Healthcare SWOT Analysis*

* Based on author research

The main directions for the development of primary health care will be implemented until 2022 with the subsequent maintenance of primary health care through priority funding. Primary health care and public health spending will be increased to
$60 \%$ of total health funding. The indicator will be the share of expenditures on outpatient and polyclinic care (hereinafter referred to as APC) and public health within the guaranteed volume of medical care and compulsory health insurance.

Table 1

The achievement of Healthcare system objectives*

\begin{tabular}{|l|c|c|c|c|c|c|c|c|c|c|}
\hline$№$ & Resultsindicators & Unitrev. & 2018 & 2019 & 2020 & 2021 & 2022 & 2023 & 2024 & 2025 \\
\hline 1 & 2 & 3 & 4 & 5 & 6 & 7 & 8 & 9 & 10 & 11 \\
\hline \multicolumn{7}{|c|}{ Implementation of compulsory health insurance and promotion of voluntary health insurance } \\
to achieve universal health coverage \\
\hline 1.
\end{tabular}


Экономика

\begin{tabular}{|c|c|c|c|c|c|c|c|c|c|c|}
\hline \begin{tabular}{|l|}
1 \\
\end{tabular} & 2 & 3 & 4 & 5 & 6 & 7 & 8 & 9 & 10 & 11 \\
\hline 3. & $\begin{array}{l}\text { Share of private household } \\
\text { spending in total health } \\
\text { spending }\end{array}$ & $\%$ & 38,5 & 36,2 & 34,0 & 32,2 & 30,7 & 27,1 & 26,9 & 26,9 \\
\hline 4. & $\begin{array}{l}\text { The share of expenses for } \\
\text { AMS and OZ within the } \\
\text { guaranteed volume of me- } \\
\text { dical care and compulsory } \\
\text { health insurance }\end{array}$ & $\%$ & - & 49,4 & 58,1 & 58,9 & 59,7 & 59,6 & 59,8 & 60.0 \\
\hline \multicolumn{11}{|c|}{ Improving the investment climate in the medical industry } \\
\hline & $\begin{array}{l}\text { The level of equipment of } \\
\text { medical organizations with } \\
\text { medical equipment }\end{array}$ & $\%$ & 69,5 & 73 & 77 & 82 & 86 & 92 & 100 & 100 \\
\hline & $\begin{array}{l}\text { Depreciation rate of } \\
\text { buildings of medical } \\
\text { organizations }\end{array}$ & $\%$ & 59,7 & 57 & 55 & 52 & 47 & 44 & 41 & 38 \\
\hline & $\begin{array}{l}\text { Share of private investment } \\
\text { in healthcare }\end{array}$ & $\%$ & 37 & 36,2 & 38,9 & 42,8 & 44,0 & 43,5 & 43,2 & 41,3 \\
\hline \multicolumn{11}{|c|}{ Goodgovernanceinhealthcare } \\
\hline 8. & $\begin{array}{l}\text { Share of FMSS accredited } \\
\text { healthcare providers }\end{array}$ & $\%$ & 30 & 35 & 40 & 45 & 50 & 55 & 60 & 70 \\
\hline 9. & $\begin{array}{l}\text { Percentage of healthcare } \\
\text { organizations that have } \\
\text { received at least } 4 \text { stars in } \\
\text { the management rating }\end{array}$ & $\%$ & 37 & 38 & 39 & 40 & 41 & 42 & 43 & 45 \\
\hline
\end{tabular}

*Note: based on [12]

For coordination and methodological support of medical organizations in each region of the country, regional centers of the best practices of primary care (hereinafter referred to as CLP) will be developed. CCPs will develop and implement new technologies in the provision of primary health care services. Based on international experience, the Community Health Program will be developed and implemented to involve the population in health issues, including with the support of non-governmental organizations. This program will effectively organize sanitary and preventive work. The issue of attracting and training health education workers will be worked out. For example, representatives of the population with secondary education can be involved in paid work in PHC organizations as health education workers. For this, the experience of countries with similar economies and socio-demographic picture in attracting health educators will be studied. Such workers in a number of countries around the world are actively involved in improving the literacy of the population on health issues and are involved in the timely receipt of health services by people.

Technologies will be introduced to facilitate decision-making regarding the health of an individual, groups of people, and the country's population as a whole. Innovative technologies for processing data arrays will be used to search for patterns, correlations, and cause-effect relationships in relation to public health, personalized medicine, and the effectiveness of the health care system. Tools will be introduced to generate and assess indicators of disease burden, disease prevalence and risk factors.

From 2020, a full-fledged transition to the system of compulsory social health insurance is planned, which will ensure the expansion of the list and volume of medical care and drug provision for citizens of the country, increase the availability of medical care for the most vulnerable categories 
of citizens (children, the elderly, and other benefit categories of citizens), as well as will create financial mechanisms to protect the population from unexpectedly high costs associated with the provision of expensive medical care, will create conditions for the modernization of medical organizations [14].

Taking into account the compulsory health insurance, the new model of financing the healthcare industry will be brought to 5\% of GDP by 2024. At the same time, the volume of public spending on health care in relation to the state budget will rise from $9.3 \%$ in 2019 to $13.1 \%$ by 2024. By contrast, the share of private health spending in total health spending will decline from $36.2 \%$ in to $26.9 \%$ by 2025 .

Additional health spending will be used to expand preventive measures (from $4 \%$ to $10 \%$ by 2024) and the development of outpatient care and public health services (up to $60 \%$ of total spending).

Achievement of these objectives will be ensured by creating sources of sufficient funding, equitable and effective pooling of risks on the basis of joint responsibility for health, strategic procurement of health services, and monitoring the quality of health care delivery and results.

The effectiveness of the functioning of the compulsory social health insurance system will be ensured, including by expanding work to involve the population in the compulsory social health insurance system, especially the category of selfemployed citizens.

A set of measures to improve the mechanisms for financing medical care will include a constant increase in the efficiency of the processes for calculating and predicting the volume of medical care, taking into account the needs of the population and international experience.

A set of measures to improve the quality and efficiency of management of health care entities will include the introduction of modern mechanisms for managing organizations, including project management, risk management, management aimed at achieving results, financial management, development of leadership skills, etc.
Project management tools will be introduced at all levels of the Program implementation, including by opening project offices in all areas of the Program, which will increase the efficiency, timeliness and quality of projects being implemented.

The project approach to the implementation of the Program provides for the formation of a project infrastructure, consisting at the republican level of the Program Management Board, the Program Expert Council, the Program Management Office and the Situation Center. A charter and a program management plan will be developed for effective implementation of projects.

Conclusion. Interaction with international organizations will continue to harmonize the regulatory framework, taking into account the undertaken obligations in the field of healthcare, promoting the main initiatives of Kazakhstan abroad (promoting the Astana declaration), as well as ensuring the transfer of knowledge and new technologies to the healthcare sector.

In particular, cooperation with the OECD will continue on the development of national health accounts, improving the system for collecting and analyzing administrative data, patient safety and improving the quality of medical services and, in general, on the development of the health system.

Cooperation with UN organizations (UNFPA, UNICEF, UNDP) will continue on the implementation of the set tasks of the UN SDGs, the introduction of a patronage medical system, the development of adolescent services and schoolmedicine.

Collaboration with WHO on programs aimed at protecting and strengthening public health, antibiotic resistance programs, disease prevention, and ensuring universal health coverage will be strengthened.

Cooperation with the US Food and Drug Administration in terms of introducing international practices in the field of quality control of goods and services will become promising.

For the effective management of healthcare, as well as ensuring the implementation by citizens of the rights and obligations guaranteed by the state, a common understanding, including 
in law enforcement practice, of the legal norms in the field of healthcare is necessary.

For these purposes, unified comments to the Code of the Republic of Kazakhstan "On the health of the people and the health care system" will be developed and implemented with an exhaustive explanation of each norm.

The health indicators of the population of the Republic of Kazakhstan largely reflect the complexities of socio-economic transformations and health care reforms. Despite some positive demographic changes (population growth in $\mathrm{Ka}$ zakhstan, life expectancy reached 70 years), there are still very high losses frominjuries, from diseases of the circulatory system, and malignant neoplasms. Among the key economic, social, environmental and political determinants of health, the following are highlighted: growth of life expectancy, aging of the population, social inequality and property stratification of society; uneven development of regions; environmental degradation and anthropogenic impact on the environment; political component in the development of health care; lifestyle change. Thus, the presented problems affect the health of the nation as a whole.

\section{REFERENCES}

1. Clark J. Workable Competition, LA, 1940. - 303 p.

2. Porter M. International competition: Textbook. - M.: Publishing house. house «Williams», 2000. $-255 \mathrm{p}$.

3. Samuelson P. Economics, 20 edition, GRAW HILL: MC GRAW HILLINDIA, 2019. - 125 p. $117 \mathrm{p}$.

4. Hayek F. Economics, philosophy, United Kingdom: University of Chicago Press , 1948. -

5. BaimuratovW. Methods of assessment and analysis, capital investment prospects. - Almaty, 1972. - P. 12-18.

6. Dulambayev R. Makroekonomica. - Almaty: KazGU, 2011. - 180 p. [In Russian].

7. Doskeyeva G.ZH. Finansirovaniye sistemy zdravookhraneniya v usloviyakh konkurentsii Kazakhstan: teoriya, praktika: ekonom. gil. dok. ... avtor. - Almaty, 2010. - S. 43 [In Russian].

8. Sansyzbaeva G.N. Provision of pharmaceutical assistance to the population of the Republic of Kazakhstan at the present stage // Republican scientific journal «Bulletin» of the South Kazakhstan State Pharmaceutical Academy. - Shymkent, 2014. - T. 3. - No. 3(68). - P. 159-161.

9. Rakhimbekova A.E. Healthcare economics - the most important tool to influence the quality of life in the Republic of Kazakhstan // Bulletin of Karaganda University. Series Economy. - Karaganda: KarSU named after E.A. Buketova, 2014. - No. 1. - P. 49-55.

10. Stratulat I.S., Ermekbaev K.K., Asylbekova G.O., Nitkaliev K.U. Methodical recommendations. - Astana, 2012. $-50 \mathrm{p}$. $243 \mathrm{p}$.

11. Global Tuberculoses Control: report 2018/ World Health Organization. - Geneva, 2018. -

12. Official website of the Statistics Agency of the Republic of Kazakhstan. http://www.stat.kz

13. Rakhimbekova A.E. Ways to improve efficiency of use of investment in the basic capital of the organization // Bulletin of the Kazakh University of Economics, Finance and International Trade. Nur-Sultan, 2020. - No. 4. - 113-120 pp.

14. Akopyan A.S.The problem of modernization of healthcare in 2020 and the phase of institutional transformation of the network of state institutions // Qualitative clinical practice. -2010. - No. 1. URL: https://cyberleninka.ru/article/n/problema-modernizatsii-zdravoohraneniya-2020-i-fazyinstitutsionalnoy-transformatsii-seti-gosudarstvennyh-uchrezhdeniy (Date of access: 02.11.2020). 


\section{ЛИТЕРАТУРА}

1. Clark J. Workable Competition, LA, 1940. - 303 p.

2. Porter M. International competition: Textbook. - M.: Publishing house. house «Williams», 2000. $-255 \mathrm{p}$.

3. Samuelson P. Economics, 20 edition, GRAW HILL: MC GRAW HILLINDIA, 2019. - 125 p. $117 \mathrm{p}$

4. Hayek F. Economics, philosophy. - United Kingdom: University of Chicago Press, 1948. -

5. Baimuratov W. Methods of assessment and analysis, capital investment prospects. - Almaty, 1972. - P. 12-18.

6. Дуламбаев Р. Макроэкономика. - Алматы: КазГУ, 2011. - 180 с.

7. Доскеева Г.Ж. Финансирование системы здравоохранения в условиях конкуренции в Республике Казахстан: теория, практика. - Алматы, 2010. - С. 43.

8. Sansyzbaeva G.N. Provision of pharmaceutical assistance to the population of the Republic of Kazakhstan at the present stage // Republican scientific journal «Bulletin» of the South Kazakhstan State Pharmaceutical Academy. - Shymkent, 2014. - T. 3. - No. 3(68). - P. 159-161.

9. Rakhimbekova A.E. Healthcare economics - the most important tool to influence the quality of life in the Republic of Kazakhstan // Bulletin of Karaganda University. Series Economy. - Karaganda: KarSU named after E.A. Buketova. - 2014. - No. 1. - P. 49-55.

10. Stratulat I.S., Ermekbaev K.K., Asylbekova G.O., Nitkaliev K.U. Methodical recommendations. - Astana, 2012. $-50 \mathrm{p}$.

11. Global Tuberculoses Control: report 2018/ World Health Organization. - Geneva, 2018. $243 \mathrm{p}$.

12. Official website of the Statistics Agency of the Republic of Kazakhstan. http://www.stat.kz

13. Rakhimbekova A.E.Ways to improve efficiency of use of investment in the basic capital of the organization // Bulletin of the Kazakh University of Economics, Finance and International Trade. Nur-Sultan, 2020. - No. 4. - 113-120 pp.

14. Akopyan A.S. The problem of modernization of healthcare in 2020 and the phase of institutional transformation of the network of state institutions // Qualitative clinical practice. - 2010. - No. 1. URL: https://cyberleninka.ru/article/n/problema-modernizatsii-zdravoohraneniya-2020-i-fazyinstitutsionalnoy-transformatsii-seti-gosudarstvennyh-uchrezhdeniy (Date of access: 02.11.2020).

\section{А.Е. Рахимбекова, А.М. Казыбаева \\ ҚАЗАҚСТАН РЕСПУБЛИКАСЫНДА МЕДИЦИНАЛЫҚ ҚЫЗМЕТТЕРДІҢ ЗАМАНАУИ НАРЫҒЫН ДАМЫТУ ҮРДІСТЕРІ}

\section{Андатпа}

Бұл мақалада Қазақстан Республикасы денсаулық сақтау жүйесінің негізгі даму бағыттары көрсетілген. Денсаулық сақтауды тиімді басқару, сондай-ақ азаматтардың мемлекет кепілдік берген құқықтар мен міндеттерді жүзеге асыруын қамтамасыз ету үшін денсаулық сақтау саласындағы құқықтық нормаларды, оның ішінде құқық қолдану практикасында бірыңғай түсіну қажет.

Денсаулық сақтау жүйесінің талдаушылары жүйелік проблемалар бар екенін көрсетті. Бұл проблемалар денсаулық сақтау жүйесіне ғана емес, жалпы ел экономикасына тікелей әсер етеді. 
А.Е. Рахимбекова, А.М. Казыбаева

\title{
КОНКУРЕНТОСПОСОБНОСТЬ И ТЕНДЕНЦИИ РАЗВИТИЯ СОВРЕМЕННОГО РЫНКА МЕДИЦИНСКИХ УСЛУГ В РЕСПУБЛИКЕ КАЗАХСТАН
}

\begin{abstract}
Аннотация
В данной статье отражены основные направления развития системы здравоохранения Республики Казахстан. Для эффективного управления здравоохранением, а также обеспечения реализации гражданами прав и обязанностей, гарантированных государством, необходимо общее понимание, в том числе в правоприменительной практике, правовых норм в сфере здравоохранения.

Анализ системы здравоохранения показал наличие системных проблем которые необходимо решить с помощью экономических рычагов и повышения конкурентоспособности медицинских организации. Данные проблемы напрямую затрагивают не только систему здравоохранения, но и экономику страны в целом.
\end{abstract}

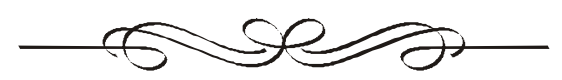


А.М. Айткалиева*, $P h D$ докторанть

Қазақ экономика, қаржы және

хальққаральқ сауда университеті

Нұр-Сұлтан қ

e-mail: anar.aitkaliyeva@mail.ru

* - негізгі автор (хат-хабарларға арналған автор)

\section{ИЕРАРХИЯНЫ ТАЛДАУ ӘДІСІ НЕГІЗІНДЕ МЕМЛЕКЕТТІК-ЖЕКЕ МЕНШІК ӘРІПТЕСТІК ЖОБАЛАРЫНЫҢ ТИІМДІЛІГІН БАҒАЛАУ}

Мақ̆алада мемлекеттік-жеке меншік әріптестік жобаларының тиімділігін бавалау тәсілдері құарастырылzан. Зерттеу барысында МЖӘ шеңберінде іске асырылатын жобалардың тиімділігін бавалаудың әр түрлі ддістерін қолдануга салыстырмаль бава берілді. МЖӘ жобаларын іске асыру барысында экономикалық ққана емес, сонымен құатар әлеуметтік тиімділікті айқындауга мүмкіндік беретін МЖӘ тиімділігін бавалау ддіснамасын дайындау бойынша ұсыныстар әзірленді.

Сонымен қ̧атар мемлекеттік-жеке меншік әріптестік жобаларын жүзеге асыру кезенінде олардың экономикалық және әлеуметтік тиімділігін анықтаува мүмкіндік беретін ақпараттық жүйе әзірленді.

Кілт сөздер: мемлекеттік-жеке меншік әріптестік, тиімділік, ддістеме, жоба, бавалау, иерархия, иерархияны талдау ддісі, факторлар, критерий, ТОФИ.

Ключевые слова: государственно-частное партнерство, эффективность, методология, проект, оиенка, иерархия, метод анализа иерархий, факторы, критерий, ТОФИ.

Keywords: public-private partnership, efficiency, methodology, project, evaluation, hierarchy, hierarchy analysis method, factors, criterion, TOPI .

JEL classification: L 32, C 83

Kiрiспе. Қазіргі уақытта инвестициялық жобалау саласындағы жұмыстардың маңызды бағыттарының бірі МЖӘ жобаларының тиімділік мәселелерін зерттеу болып табылады. Мемлекеттік-жеке меншік жобалардың тиімділігін бағалау әдістері дәстүрлі әдістерден ерекшеленеді, себебі, бір жағынан қаржылық тиімділігін талдау нәтижесінде жеке меншік сектордың инвестицияларын бағалау қажет, екінші жағынан, шығындарды және қоғамдық сектордың тиімділігін талдау негізінде мемлекет мүддесін есепке алу керек және ұлттық экономиканың тұрақты өсуіне өзара тиімділігін қорытындылауды қажет етеді .

Осыған байланысты қаржы-экономикалық модельдеу мәселесіне басты назар аудару қажет. Егжей-тегжейлі және сауатты модель шарттардың кез келген өзгерістері кезінде жобаның дамуын жоспарлауға және талдауға мүмкіндік береді. Қаржы модельдері тәуекелдерді бағалауды айтарлықтай жеңілдетеді және стратегиялық шешімдер қабылдаудың тиімділігін арттырады. Базалық ҚЭМ аясында жобаның таза келтірілген құны немесе базалық NPV есептеледі.

Тиімділікті бағалаудың қолданыстағы жүйелері мынадай көрсеткіштерді пайдаланады: NPV, IRR, ENPV, өзін-өзі ақтау мерзімі, ең аз шығындарды талдау және жанама әсерлер. Бұл әдістер тек қана экономикалық тиімділікті есептейді, ал жобаның әлеуметтік маңыздылығы қарастырылмай қалады.

Біздің мақсатымыз - жобалардың тиім- 
ділігін есептеу үшін қосымша критерийлерді енгізу, яғни әлеуметтік-экономикалық, қоғамдық-саяси факторларды есепке алатын кешенді бағалау жүйесін құрастыру.

Біз әзірлеген әдістеменің негізінде американдық ғалым Т. Саатидың шешім қабылдау мәселесіне жүйелік көзқарастың математикалық құралы ретінде әзірлеген «иерархияны талдау әдісі» (Analitich ierarchy process) жатыр. Бұл мақалада біз МЖӘ жобаларының тиімділігін анықтау кезінде осы әдісті қолдану мүмкіндіктерін ашып көрсетеміз.

Әдебиеттік шолу. Т.С. Новикова [1], Э.И. Габдуллина [2] сияқты Ресей ғалымдарының көзқарастарын жинақтай отырып, қазіргі әдебиетте мемлекеттік-жеке меншік әріптестік жобаларын бағалау тәсілдерінің елеулі айырмашылықтары МЖӘ ұйымдастырудың орындылығын, негізділігін және мүмкіндігін айқындайтын негізгі қағидаттармен анықталатынын байқадық.

МЖӘ жобасының тиімділігін дәстүрлі бағалауды зерттеу, оның, жобаның техникалық-экономикалық негіздемесін әзірлеуге мүмкіндік беретін мемлекеттік-жекеменшік әріптестік жобаларының тиімділігін бағалау алгоритмі негізінде жүргізілетінін қорытындылауға мүмкіндік берді [3, 4].

Мемлекеттік-жекеменшік әріптестік мәселелерін, инвестициялық процесті қаржыландыру теориясына, қаржылық-талдаужәне жоспарлау мәселелеріне В.Г. Варнавский, А.В. Клименко, В.А. Королев [5], Ю.В. Соловьев [6], Дж. Делмон [7] және басқа да шетелдік ғалымдардың жұмыстары арналған.

Тиімді мемлекеттік-жекеменшік әріптестік мәселелерінің теориялық негізін отандық ғалымдардың еңбектері $[8,9]$ құрады.

Ғылыми зерттеулерді тұжырымдай отырып, біз зерттеуде МЖӘ аясында жүзеге асырылатын жобалардың тиімділігін бағалаудың әр түрлі әдістерін қолдануға салыстырмалы бағалау жүргіздік. Иерархияны талдау әдісін американдық математик Т. Саати ұсынған [10], бұл әдіс бізге сандық көрсеткіштермен қатар әлеуметтік, психологиялық және т.б. бейресми көрсеткіштердің әсерін ескеруге мүмкіндік берді. Осы зерттеу аясында иерархияны талдау әдісі әр түрлі сапалық факторлар мен саяси жағдайлардың басымдықтары мен салмағын анықтау үшін де қолданылды.

Негізгі бөлім. МЖӘ жобасының тиімділігін дәстүрлі бағалау мына бағыттар бойынша жүргізіледі:

- жеке әріптесті тарта отырып және оны тартпай, жобаны іске асыру рентабельділігін салыстыру;

-МЖӘ жобасын жүзеге асыру үшін тәуекелдер түрлерін анықтау, оларды бағалау, тәуекелдерді басқару нысандарын айқындау;

- МЖӘ-нің егжей-тегжейлі экономикалық негіздемесі.

1-суретте ұсынылған мемлекеттік-жеке меншік әріптестік жобаларының тиімділігін бағалау алгоритмі үш кезеңнен тұрады [2]:

Бірінші кезеңге ұсынылған МЖӘ жобасын сапалы бағалау, мына элементтер кіретін жобаның ақпараттық базасы кіреді.

Екінші кезеңде тиімділіктің әр түрлі санаттарынан шыға отырып, әріптестік қарым-қатынастар қажеттілігі туралы қорытынды шығарылады.

Үшінші кезең - сандық талдау кезеңі әр түрлі жақтан (қаржы, экономика тұрғысынан) МЖӘ жобасының орындылығын бағалауды болжайды және оған МЖӘ эталондық моделінде айқындалғандай, барлық қаржыландыру көздерін есепке алып, қаржы құрылымы кіруі қажет.

Осы алгоритм бойынша жобаның орындылығы мен негізділігін және жобаны жүзеге асырудың ең тиімді түрін анықтауға мүмкіндік береді.

Батыс тәжірибесінде МЖӘ тиімділігі әдетте Value for money (VfM) әдісі, яғни жоба құнының, оны орындау сапасының ең тиімді қатынасы арқылы анықталады. Яғни жобаның мақсаттарына минималды шығындар мен инвестицияланған ресурстарға барынша қайтарым арқылы қол жеткізу керек. 


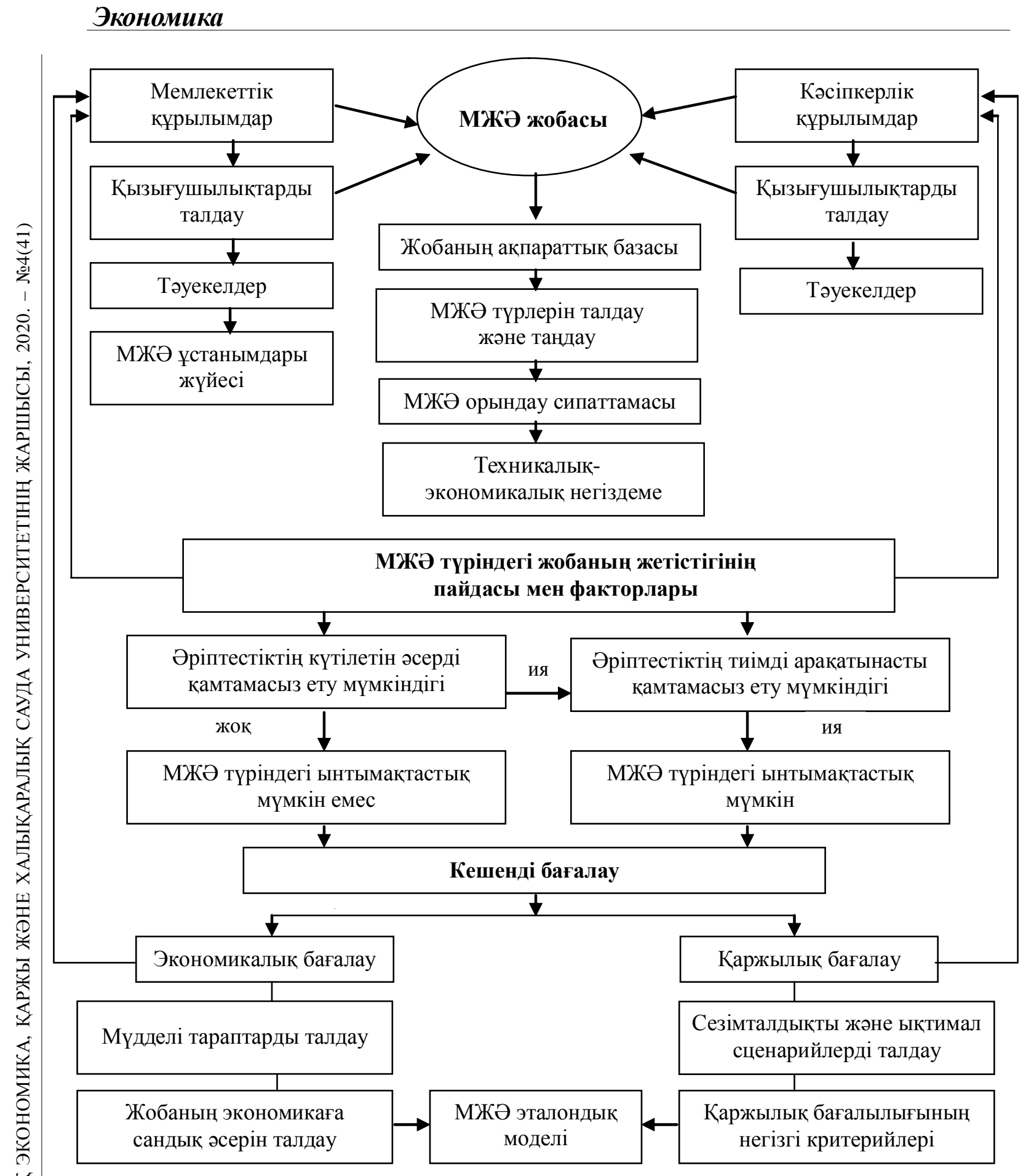

\section{1-сурет. Мемлекеттік-жеке әріптестік жобаларының тиімділігін бағалау алгоритмі*}

*Автормен әзірленген

VfM тәсілі экономикалық, нәтижелілік және тиімділік сияқты үш талабына бір уақытта қол жеткізуді болжайды. Экономикалық деп нәтиженің жеткілікті сапасы ке116 зінде ресурстардың минималды ықтимал шығындары түсіндіріледі. Нәтижелілік күтілетін нәтижеге қол жеткізуді, ал тиімділік қолдағы ресурстарды қолдана отырып, максималды 
ықтимал нәтиже алуды көздейді [5].

VfM тәсілінде МЖӘ тетіктерін қолданудың негізділігінің математикалық дәлелі ретінде сандық талдауға үлкен мән берілді. Ic жүзінде әдіснамалық мәселелер мен талдау үшін ақпараттың болмауы VfM сандық талдауын тым субъективті етеді, ал сандық өрнектердің ерекшелігі мен қарапайымдылығы шенеуніктерді нақты жағдайға зиян келтіретін сандық нәтижелерге шамадан тыс сенім артуға итермелеуі мүмкін.

МЖӘ жобаларының тиімділігін бағалау коммерциялық және бюджеттік құрамдастарының тиімділігін ғана емес, сонымен қатар оның әлеуметтік-экономикалық тиімділігіне бағалау жүргізу қажеттілігіне сүйене отырып құрылуға тиіс.

Сондықтан, МЖӘ жобасының бюджеттік және әлеуметтік-экономикалық тиімділігін бағалауға мүмкіндік беретін арнайы көрсеткіштер жүйесін қамтитын МЖӘ жобаларын талдау әдістемесін әзірлеу қажеттілігі туындады.

Мақалады ұсынылған әдістеменің негізінде американдық ғалым Томас Саатидың шешім қабылдау мәселесіне жүйелік тәсілдің математикалық құралы ретінде әзірлеген «Иерархияны талдау әдісі» («Analitich ierarchy process») жатыр. Бұл әдіс сараптамалық бағалау әдісі болып табылады.

Иерархияны талдау әдісі шешім қабылдау мәселесін иерархия түрінде түсінікті және ұтымды түрде құрылымдауға мүмкіндік береді. Ол баламалар мен оңтайлы стратегияны таңдау, ресурстарды бөлу, болашақты жоспарлау, ықтимал сценарийлерді саралау, ауқымды мәселелерді шешу және стратегиялық жоспарлау кезінде факторлардың басымдығын анықтаумен байланысты шешімдерді қабылдау үшін қолданылады.

ИТӘ негізіндегі бағалау кезең-кезеңмен жүргізіледі.

Бірінші кезеңде жобаның мақсаты, мақсатқа жетудің баламалы нұсқалары және баламалардың сапасын бағалау үшін өлшемшарттары бар иерархия түрінде мәселенің сапалы моделі құрылады.

1-қадам - иерархия элементтерін: мақсатын, ортақ және жеке факторлар мен баламаларды анықтау.

2-қадам - мәселені иерархия түрінде құрастыру.

Екінші кезеңде қосарланған салыстыру әдісін қолдана отырып, иерархияның барлық элементтерінің артықшылықтары анықталады.

3-қадам - Т.Саатидің фундаменталды шәкілі бойынша матрицаға кірген әр деңгейдің элементтерін қос-қостап салыстыру.

4-қадам - ИТӘ әдіснамасына сәйкес әр матрицада басымдықтар векторларын, максималды меншіктімәнін, келісімділік индексін және келісімділік қатынасын есептеу.

Үшінші кезеңде иерархиядағы элементтердің басымдықтарын сызықтық жинақтау арқылы ғаламдық балама басымдықтарын синтездеу жүргізіледі.

Төртінші кезеңде алынған нәтижелер негізінде шешім қабылданады.

Осы әдісті қолданып, МЖӘ жобаларының тиімділігі туралы шешімді қабылдау үшін бес деңгейлі иерархиялық модель құрылды (2-сурет).

Бірінші деңгей - мақсат.

Екінші деңгей - МЖӘ жобасының тиімділік дәрежесіне себепші болатын жалпы факторлар.

Жалпы факторларды декомпозициялау нәтижесінде үшінші деңгейдің элементтері - факторлар алынды.

Үшінші деңгейдің элементтері иерархияның төртінші деңгейін құрайтын критерийлерден тұрады

Бесінші деңгей - баламалар.

Әзірленген жобаның тиімділік критерийлерінің иерархиясы жоба жайында жеткілікті ақпараты бар сарапшыға критерийлер мен баламаларды қадам-қадаммен салыстырып, оның тиімділігі туралы шешім қабылдауға мүмкіндік береді.

Нәтижесінде, модель баламалардың әрқайсысы үшін интеграцияланған көр- 
сеткішті есептеп береді, ең жоғары көрсет- ралып отырған жобаның тиімділік деңкіш ұсынылатын шешімге, бұл жерде қа- гейіне сәйкес келеді.

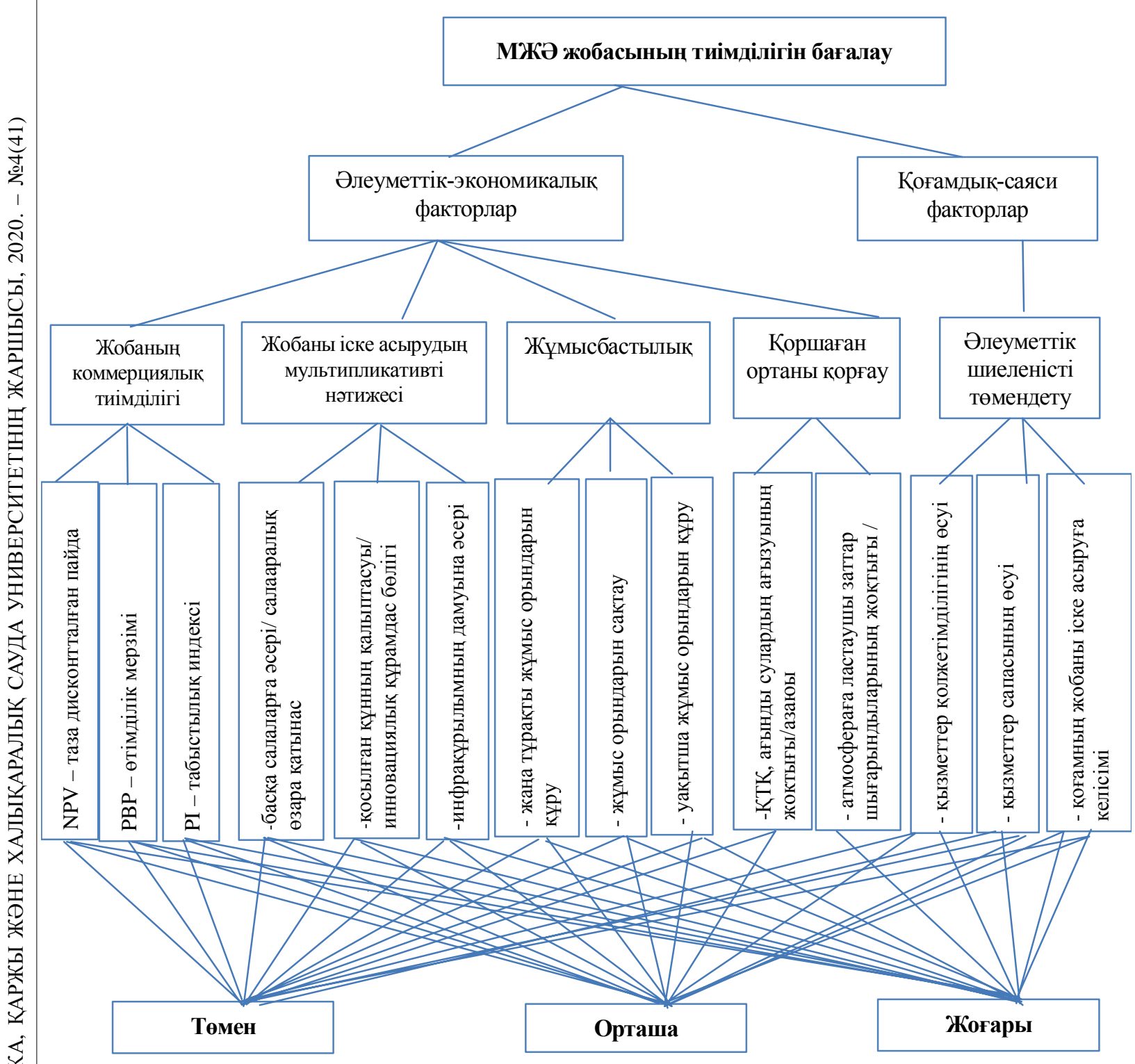

\section{2-сурет. Жобалардың тиімділігін бағалаудың иерархиялық моделі* \\ *Автормен әзірленген}

МЖӘ жобалардың тиімділігі туралы шешім қабылдауға қатысатын сарапшылар құрамын құру кезеңінде олардың біліктілігін бағалаудың жеке әдістемесі қолданылады. Сарапшының біліктілігі - бұл оның кәсіби білімінің, сезгіштігінің және тәжірибесінің негізінде сараптамалық зерттеу объектісі туралы шынайы ой-пікір айта білу қабілеті.
Сарапшы біліктілігінің сандық өлшемі ретінде біліктілік коэффициенті $\left(\mathrm{K}_{\text {біл }}\right)$ алынды, ол мына формуламен есептелінеді:

$$
\text { Кбіл }=\frac{\text { Кхаб }+ \text { Кдәл }}{2},
$$

мұндағы К каб - сарапшының бағаланатын мәселе саласындағы хабардарлық коэффи- 
циенті, сарапшының он балдық шәкіл бойынша өзін-өзі бағалауы арқылы анықталады (1-кесте);
$\mathrm{K}_{\text {дәл }}$ - сарапшының ой-пікірінің дәлелділік коэффициенті, сарапшының эталондық кестені толтыруы арқылыанықталады (2-кесте).

1 -кесте

\section{Сарапшының бағаланатын мәселе саласындағы хабардарлық көрсеткіштері*}

\begin{tabular}{|l|l|l|}
\hline \multicolumn{1}{|c|}{ Қаралатын мәселе бойынша хабардарлық дәрежесі } & $\begin{array}{c}\text { Өзін-өзі } \\
\text { бағалауы } \\
\text { балмен }\end{array}$ & $\begin{array}{c}\text { Ескерту } \\
\text { (қалауы } \\
\text { бойынша) }\end{array}$ \\
\hline Мен бұл мәселемен таныс емеспін & 0 & \\
\hline $\begin{array}{l}\text { Мен бұл мәселемен жақсы таныс емеспін, } \\
\text { бірақ ол мені қызықтыратын салаға жатады }\end{array}$ & 123 & \\
\hline $\begin{array}{l}\text { Мен бұл мәселемен қанағаттанарлықтай таныспын, } \\
\text { оны шешуге тікелей қатысқан емеспін }\end{array}$ & 456 & \\
\hline $\begin{array}{l}\text { Мен бұл мәселемен жақсы таныспын, } \\
\text { іс жүзінде оны шешуге қатысамын }\end{array}$ & 789 & \\
\hline $\begin{array}{l}\text { Бұл мәселе менің мамандығымның шеңберіне кіреді, } \\
\text { терең білемін }\end{array}$ & 10 & \\
\hline
\end{tabular}

*Кесте автормен құрылды

\section{Дәлелділік коэффициентін анықтау үшін бастапқы деректер*}

\begin{tabular}{|c|c|c|c|}
\hline \multirow[t]{2}{*}{ Дәлелділік дереккөздері } & \multicolumn{3}{|c|}{$\begin{array}{c}\text { Дереккөздің сіздің пікіріңізге әсер ету } \\
\text { дәрежесі }\end{array}$} \\
\hline & Жоғары & Орташа & Төмен \\
\hline Сіздің теориялық біліміңіз & 3 & 2 & 1 \\
\hline Сіздің практикалық тәжірибеңіз & 5 & 4 & 2 \\
\hline Отандық авторлардың еңбектері & $1 / 2$ & $1 / 2$ & $1 / 2$ \\
\hline Шетел авторларының еңбектері & $1 / 2$ & $1 / 2$ & $1 / 2$ \\
\hline $\begin{array}{l}\text { Шетелдегі істердің жай-күйімен } \\
\text { сіздің жеке басыңыздың таныс болуы }\end{array}$ & $1 / 2$ & $1 / 2$ & $1 / 2$ \\
\hline Сіздің сезгіштігіңіз & $1 / 2$ & $1 / 2$ & $1 / 2$ \\
\hline
\end{tabular}

*Кесте автормен құрылды

$\mathrm{K}_{\text {біл }}$ мәні сарапшылардың біліктілік деңгейін көрсетеді:

- 0,8-ден 1,0-ге дейін - жоғары деңгей;

- 0,5-тен 0,8-ге дейін - орташа деңгей;

- 0-ден 0,5-ке дейін - төмен деңгей.

Құрылған сарапшылар тобы жобаға сараптама жүргізеді. Жобаны сараптамадан өткізгеннен кейін сарапшылар әдістемеде сипатталған иерархияға сәйкес баға қояды. ИТӘ-нің алгоритмі үшін бастапқы деректер сарапшылардың бағалауы болып табылады. Барлық сараптамалық бағаларды жинағаннан кейін әр сарапшы үшін жоба бағасын есептеу керек. Ол үшін салыстыру матрицалары құрылады.

Жиналған бағаларды ТОФИ ақпарат- 


\section{Экономика}

тық жүйесіне енгіземіз. ТОФИ технологиясы МЖӘ жобаларының тиімділігін бағалау жүйесін іске асыруға арналған құрал ретінде таңдалынған. ТОФИ технологиясы пәндік саланы зерделеу әдіснамасынан және ұсынылатын әдіснаманы автоматтандыратын ақпараттық-талдамалық жүйеден тұрады $[10,11]$.

Осылайша, жобаның тиімділігі критерийлерінің иерархиясы жоба туралы жеткілікті ақпараты бар сарапшыға критерийлер мен баламаларды кезең-кезеңімен салыстыра отырып, оның тиімділігі туралы шешім қабылдауға мүмкіндік береді. Нәтижесінде, модель баламалардың әрқайсысы үшін интеграцияланған индикаторды есептейді, оның ең жоғарғы көрсеткіші қарастырылып отырған жобаның тиімділік деңгейіне сәйкес келеді. Жобаның тиімділігі компоненттердің максималды мәнімен анықталады, бірақ егер мәндер сәйкес келсе, онда тиімділік төмендеу бағытында анықталады.

Қорытынды. Зерттеу нәтижелері мем- лекеттік-жеке меншік әріптестік жобаларын бағалау тәсілдерінің дәстүрлі тәсілдерден айтарлықтай ерекшеленетінін көрсетті, өйткені бір жағынан қаржылық тиімділікті талдау негізінде жеке сектордың инвестицияларына бағалау жүргізу қажет, екінші жағынан, қоғамдық сектордағы шығындар мен пайданы талдау негізінде мемлекеттің мүдделерін ескеру қажет. Экономикалық әдебиеттерді талдау нәтижесінде жабалардың тиімділігін бағалау кезінде жобаның әлеуметтік тиімділігі факторы аз зерттелгенін көрсетті.

Зерттеу барысында МЖӘ шеңберінде жүзеге асырылатын жобалардың тиімділігін бағалаудың әр түрлі дәстүрлі әдістеріне талдау жүргізілді. Авторлар ИТӘ негізінде бағалау әдіснамасын қолдану негізінде жобаның тиімділігін бағалауды ұсынып отыр. Бұл әдіснаманы қолдану дәстүрлі экономикалық факторлардың ғана емес, сондай-ақ әлеуметтік, қоғамдық-саяси факторлардың әсерін ескере отырып, жобаның тиімділігін анықтауға мүмкіндік береді.

\section{ӘДЕБИЕТТЕР}

1. Новикова Т.С. Проблемы оценки эффективности инвестиционных проектов государственно-частного партнерства // Креативная экономика. - 2009. - № 9(33). - С. 128-133.

2. Габдуллина Э.И. Оценка эффективности проектов ГЧП как механизма взаимодействия власти и бизнеса в регионе // Современные проблемы науки и образования. -2012 . - № 2. - C. 8-13.

3. Токсанова А.Н., Абдыманапов С.А., Галиева А.Х. и др. // Оценка эффективности проектов государственно-частного партнерства: Монография. - Астана: Мастер ПО, 2017. $-312 \mathrm{c}$.

4. Токсанова А.Н., Айткалиева А.М. Методология комплексной оценки эффективности проектов государственно-частного партнерства» // Вестник КазУЭФМТ. - 2017. - № 2. C. $42-47$.

5. Варнавский В.Г., Клименко А.В., Королев В.А. Государственно-частное партнерство: теория и практика. - М.: ГУ-ВШЭ, 2010. - 254 с.

6. Соловьев Ю.В. Зарубежный опыт измерения и обеспечения эффективности в сфере государственно-частного партнерства. - СПб.: Реноме, 2012. - 546 с.

7. Делмон Дж. Государственно-частное партнерство в инфраструктуре: практическое руководство для органов государственной власти. - Астана: Изд-во АО «Казахстанский центр государственно-частного партнерства», 2010. - 160 с.

8. Развитие механизмов государственно-частного партнерства в Республике Казахстан: Монография / Под ред. С.А. Абдыманапова. - Астана: Изд. Есиль, 2015. - 123 с. 
9. Утебаев Б.С., Аленова К.Т., Турарбеков М.А. Государственно-частное партнерство в обеспечении инновационного развития // Вестник КазУЭФМТ. -2020. - №2. - С. 15-23.

10. Саати Т. Принятие решений. Метод анализа иерархии. - М.: Изд-во «Радио и связь». $-1993 .-278 \mathrm{c}$.

11. Габбасов М.Б. Онтология технологии ТОФИ // Сборник трудов по информационной безопасности. - Астана, 2013. - С. 56-63.

\title{
REFERENCES
}

1. Novikova T.S. Problemy ocenkij effektivnosti investicionnyh proektov gosudarstvennochastnogo partnerstva // Kreativnajaj ekonomika. - 2009. - № 9(33). - S. 128-133 [in Russian].

2. Gabdullina Je.I. Ocenka effektivnosti proektov GChP kak mehanizma vzaimodejstvija vlasti i biznesa v regione // Sovremennye problemy nauki i obrazovanija - 2012. - № 2. - S.8-13 [in Russian].

3. Toksanova A.N., Abdymanapov S.A., Galieva A.H. i dr. // Ocenkaj effektivnosti proektov gosudarstvenno-chastnogo partnerstva: Monografija. -Astana: Master PO, 2017. -312 s. [in Russian].

4. Toksanova A.N., Ajtkalieva A.M. Metodologija kompleksnoj ocenkij effektivnosti proektov gosudarstvenno-chastnogo partnerstva» // Vestnik KazUEFMT. - 2017. - №2. - S. 42 -47 [in Russian].

5. Varnavskij V.G., Klimenko A.V., Korolev V.A. Gosudarstvenno-chastnoe partnerstvo: teorija i praktika. - M.: GU-VShJe, 2010. - 254 s. [in Russian].

6. Solov'ev Ju. V. Zarubezhnyj opyt izmerenija i obespechenijaj effektivnosti v sfere gosudarstvenno-chastnogo partnerstva. - SPb.: Renome, 2012. - 546 s. [in Russian].

7. Delmon Dzh. Gosudarstvenno-chastnoe partnerstvo v infrastrukture: prakticheskoe rukovodstvo dlja organov gosudarstvennoj vlasti. - Astana: Izd-vo AO «Kazahstanskij centr gosudarstvenno-chastnogo partnerstva», 2010.-160 c. [in Russian].

8. Razvitie mehanizmov gosudarstvenno-chastnogo partnerstva $v$ Respublike Kazahstan: Monografija / Pod red. S.A. Abdymanapova. - Astana: Izd. Esil', 2015. - 123 s. [in Russian].

9. Utebaev B.S., Alenova K.T., Turarbekov M.A. Gosudarstvenno-chastnoe partnerstvo v obespechenii innovacionnogo razvitija // VestnikKazUEFMT. - 2020. - № 2. - S. 15-23 [in Russian].

10. Saati T. Prinjatie reshenij. Metod analiza ierarhii. - M.: Izd-vo «Radio i svjaz’», 1993. 278 s. [in Russian].

11. Gabbasov M.B. Ontologija tehnologii TOFI//Sbornik trudov po informacionnoj bezopasnosti. -Astana, 2013. - C. 56-63. [inRussian].

\section{А.М. Айткалиева}

\section{ОЦЕНКА ЭФФЕКТИВНОСТИ ПРОЕКТОВ ГОСУДАРСТВЕННО-ЧАСТНОГОПАРТНЕРСТВА НА ОСНОВЕ МЕТОДА АНАЛИЗА ИЕРАРХИИ}

\begin{abstract}
Аннотация
В данной статье рассмотрены подходы к оценке эффективности проектов государственночастного партнерства. В ходе исследования была дана сравнительная оценка применения различных методов оценки эффективности проектов, реализуемых в рамках ГЧП. В статье разработаны предложения по разработке методологии оценки эффективности ГЧП, позволяющей определить не только экономическую, но и социальную эффективность в ходе реализации проектов ГЧП.

Кроме того, разработана информационная система, позволяющая определить экономическую и социальную эффективность проектов ГЧП.
\end{abstract}




\section{A. Aitkaliyeva}

\section{EVALUATING THE EFFECTIVENESS OF PUBLIC-PRIVATE PARTNERSHIP PROJECTS BASED ON THE HIERARCHY ANALYSIS METHOD}

\section{Annotation}

This article discusses approaches to evaluating the effectiveness of public-private partnership projects. In the course of the study, a comparative assessment of the use of various methods for evaluating the effectiveness of projects implemented in the framework of PPP was given. The article contains proposals for developing a methodology for evaluating the effectiveness of PPP, which allows determining not only economic, but also social efficiency in the course of implementing PPP projects.

In addition, an information system has been developed to determine the economic and social effectiveness of PPP projects.

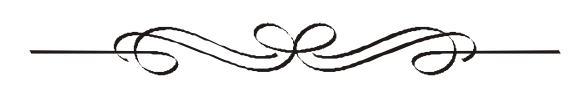


DOI 10.52260/2304-7216.2020.4(41).14

ӘОЖ: 659.13

FTAMP 06.81.55

\author{
М.Ж. Тұрсымбаева*, э.д.к., доиент \\ А.К. Шаймерденова, магистр, оқытушы \\ Қазақ экономика, қаржы және хальққаральққ \\ сауда университеті \\ Нұр-Сұлтан к. \\ e-mail: tursumbayeva_m@mail.ru \\ * - негізгі автор (хат-хабарларға арналған автор)
}

\title{
ҚАЗАКСТАН РЕСПУБЛИКАСЫ ЖАРНАМА НАРЫҒЫНЫН ДАМУЫН ТАЛДАУ
}

Мақ̆алада тауарлар мен қъызметтер туралы ақпаратты таратудың маркетингтік арнасы ретінде жарнама түсінігін дамытудың теориялық және практикалық ережелерін жинау мен талдау негізінде Қазақсттан Республикасының жарнама нарывының жаzдайы мен даму бавыты талданды. Мақ̧аланы жазу барысында отандық және шетелдік валымдардың еңцектері, Статистика комитетінің статистикальқ есептілік материалдары, сондай-ақ Қазақсттан Республикасының жарнама нарывын дамыту мәселелерін зерттеумен айналысатын ИМСИ Elim маркетингтік агенттігінің талдамалық есептері, TNS Central Аsia компаниясының зерттеу нәтижелері зерделенді. Қазақсттан Республикасының жарнама нарыгының құзіргі жавдайда даму үрдістері, жарнама нарыгының құрылымына жарнамалық өнімдер бойынша талдау, жарнама құралдарының жылдан-жылга даму бавыттарына талдау жүргізу нәтижесінде қ̧орытындылар жасалды.

Кілт сөздер: нарық, жарнама, жарнамалық қыззмет, Интернет-жарнама, тележарнама, Digital, SMM, онлайн-жарнама, контент, рейтинг.

Ключевые слова: рынок, реклама, рекламная деятельность, Интернет-реклама, телереклама, Digital, SMM, онлайн-реклама, контент, рейтинг.

Keywords: market, advertising, advertising activity, Internet advertising, TV advertising, Digital, SMM, online advertising, content, rating.

JEL classification: M 37

Кіріспе. Жарнаманы қарастыру қажеттілігі бір жағынан нарықтың қызмет етуінің экономикалық заңдылықтарының әрекет ету механизмінің жалпы талаптарына, екінші жағынан, қоғамның практикалық қажеттіліктеріне негізделген. Жарнама - бұл заманауи қоғамның серпінді, тез дамып келе жатқан бөлігі. Ол әрдайым әлемдегі өзгерістерге: саяси, экономикалық, қоғамдық өзгерістерге сай жетілдіріледі. Жарнама түрі, оның құрамы мен нысаны өндірістің, техника мен кадрлардың дамуына тығыз байланысты.

Қазіргі Қазақстан Республикасының аумағында кез келген компанияның жарнамалық қызметі заңнамамен реттеледі [1]. Аталған құжат Қазақстан экономикасының маңызды инфрақұрылымдық бөлігі болып табылатын жарнама нарығын тиімді дамыту үшін барынша қолайлы жағдайлар жасауға ықпал етті. Заң әлемдегі жарнаманы реттеу құралдарының алдыңғы оң қызметін, сондай-ақ біздің ел шеңберінде жарна- 
маны әлемдік жарнамалық құқықтық реттеуді іс жүзінде қолдануды ескеретін нормалар жүйесін қамтиды.

Бүгінгі күнде жарнама ісіндегі аса күрделі проблемалардың бірі жарнама беруші мен әлеуетті аудитория арасында табысты коммуникация құру болып табылады. Клиентті жарнамашылар тарту үшін жарнамалық хабарламаны берудің жаңа тәсілдері жасалып, оны орналастырудың жаңа арналары таңдалады. Осындай жаңа, жылдамдамып келе жатқан арналардың бірі Интернет болып табылады. Бұл бағытта жарнаманың жаңа түрлерін әзірлеу бойынша тұрақты жұмыс жүргізілуде: орналастырудың қолайлы құралдары, жарнама контентімен және мақсатты аудитория мен өзара іс-қимыл тәсілдері қарастырылады.

Нарықтық экономикалық жүйені құру қазіргі кезеңде жарнама нарығын қалыптастырумен қатар жүруі тиіс, себебі экономиканың жарнамалық шағын жүйесін дамытудың артта қалуы тұтастай алғанда жүйенің жұмыс істеу тиімділігіне тікелей әсер етеді.

Зерттеу мақсаты. Қазақстан Республикасы аумағындағы жарнама нарығын зерттеу, оны қалыптастыру, қазіргі заманғы жарнаманың даму тенденциялары мен тиімділігін арттыру жолдарын анықтау, Қазақстан Республикасының жарнама нарығының келешекте дамуына болжам жасау.

Зерттеу үшін теориялық және эмпирикалық әдістер қолданылды: аналитикалық және экономикалық-статистикалық әдістер, жүйелік, салыстырмалы және құрылымдықлогикалық талдаудың жалпы ғылыми әдістері. Қорытындылар мен ұсынымдар отандық экономистердің зерттеулерінде тұжырымдалған теорияларға, Қазақстан Республикасының жарнама нарығын қалыптастыру туралы статистикалық деректерді талдауға негізделді.

Әдебиеттік шолу. Жарнамалық қызметті зерттеудің теориялық негіздерімен көптеген ғалымдар айналысуда. Жарнама бойынша еңбектерде (Сэндидж Ч. [2], Дюзельбаева Г.М. [3], Котлер Ф., Армстронг Г. [4], Смыкова М.Р. [5]) жарнаманың көптеген анықтамалары берілген. Дегенмен, кейбір анықтамаларда ақпараттық аспект жоқ, ал жарнама адам психикасына әсер ету ретінде ғана қарастырылған. Көптеген экономистердің ойынша, жарнама тұтынушы ақылға қонымды таңдауға көмектесетін ақпаратты ұсынады. Сонымен бірге қазақстандық жарнаманың өзіндік және шетелдік тәжірибесін талдауды қажет етеді. Жарнаманы дамыту сатылары мен жолдарын талдау Қазақстан Республикасының жарнама практикасын дамытудың қандай сатысында тұрғанын және жарнаманың одан әрі қалай дамуы тиіс екенін түсінуге мүмкіндік береді. Қазақстандық жарнаманың ұзақ емес тәжірибесі және көптеген өңірлердегі жағдайлардың ерекшелігі жинақталған теориялық әзірлемелерді толық көлемде пайдалануға мүмкіндік бермейді. Қазақстандық тұтынушылардың жарнаманы қабылдау ерекшеліктерін білмей фирманың өткізу саясатын тиімді жүргізуде жақсы нәтижелерге қол жеткізу қиын.

Негізгі бөлім. Соңғы жылдары жарнама нарығының құрылымы ақпараттық және цифрлық технологиялардың белсенді дамуымен байланысты болып отыр. Сандық жағынан бұл тәсіл көлемі артқан теле және интернет-жарнаманы басқа медиақұралдармен салыстыра отырып, 2013 және 2019 жылғы деректерді салыстырайық.

Суреттен радио, баспасөз және теледидар сияқты сегменттерді соңғы бірнеше жылда Интернеттің ығыстырып, көрсеткіштердің төмендегенін көре аламыз.

TNS Central Asia мәліметтері бойынша радиода, баспасөзде, сыртқы жарнамада жарнаманың жиынтық көлемі 2016 жылмен салыстырғанда 2019 жылы долларлық эквивалентте 37\%-ға және теңгелік эквивалентте 3\%-ға төмендеді. БАҚ-тағы жарнама берушілердің жалпы саны $12 \%$-ға, яғни 3011 субъектіге дейін азайды, жарнама 
берушілер саны теледидарда - 7,2\%-ға, с сенімді өсімдікөрсетті [6]. радиода - 10,4\%-ға, баспасөзінде - 7,2\%-

Сондай-ақ Қазақстанның жарнама наға, сыртқы жарнамада - 3,2\%-ға азайды. рығының құрылымын жарнамалық өнімдер Керісінше 2019 онлайн жарнама нарығы бойыншаталдау келесісуретте көрсетілген [6].

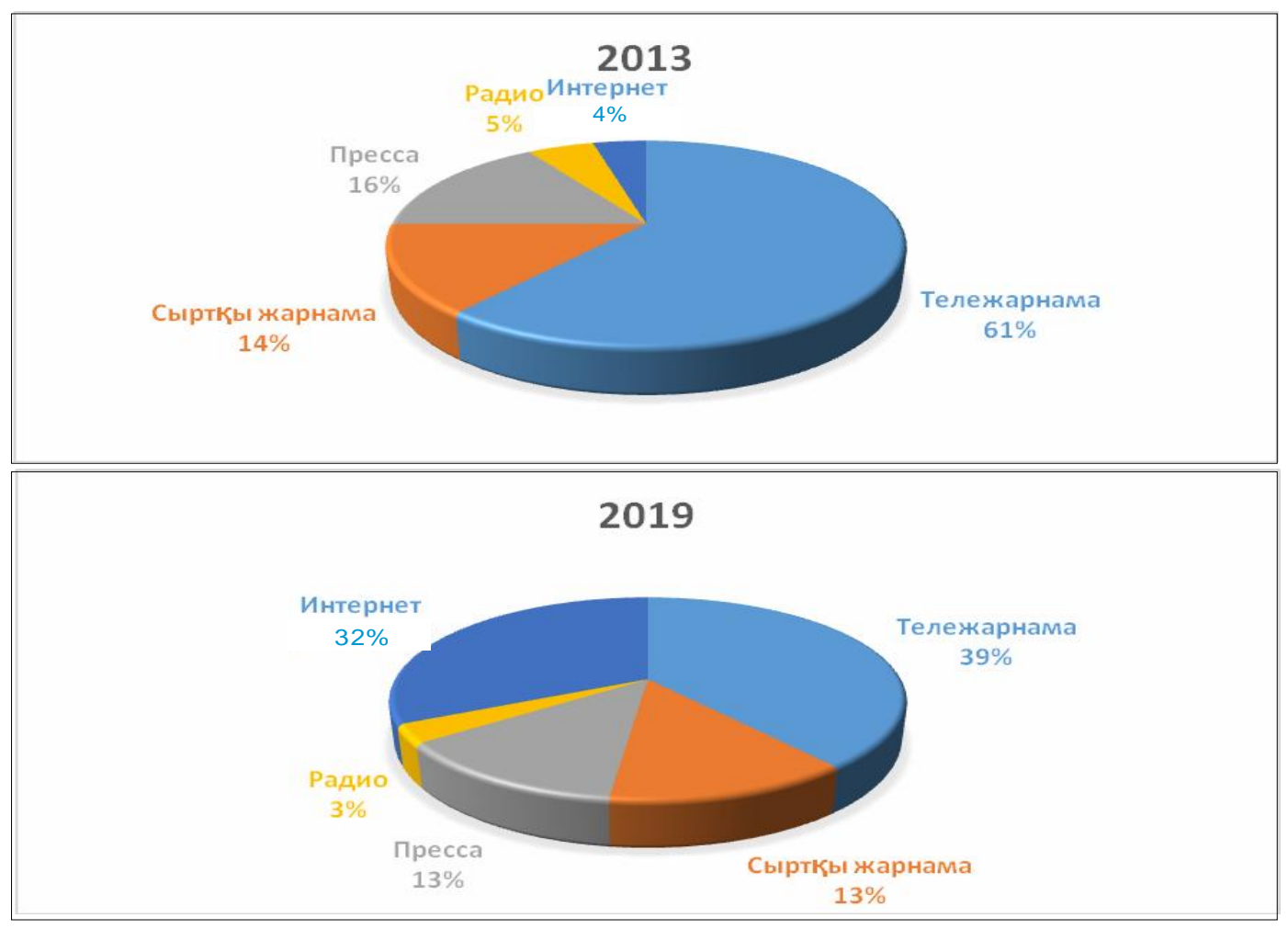

\section{1, 2-сурет. Қазақстан Республикасындағы жарнама нарығының құрылымы*}

*TNS Central Asia компаниясының зерттеу нәтижелері бойынша құрылды[6]

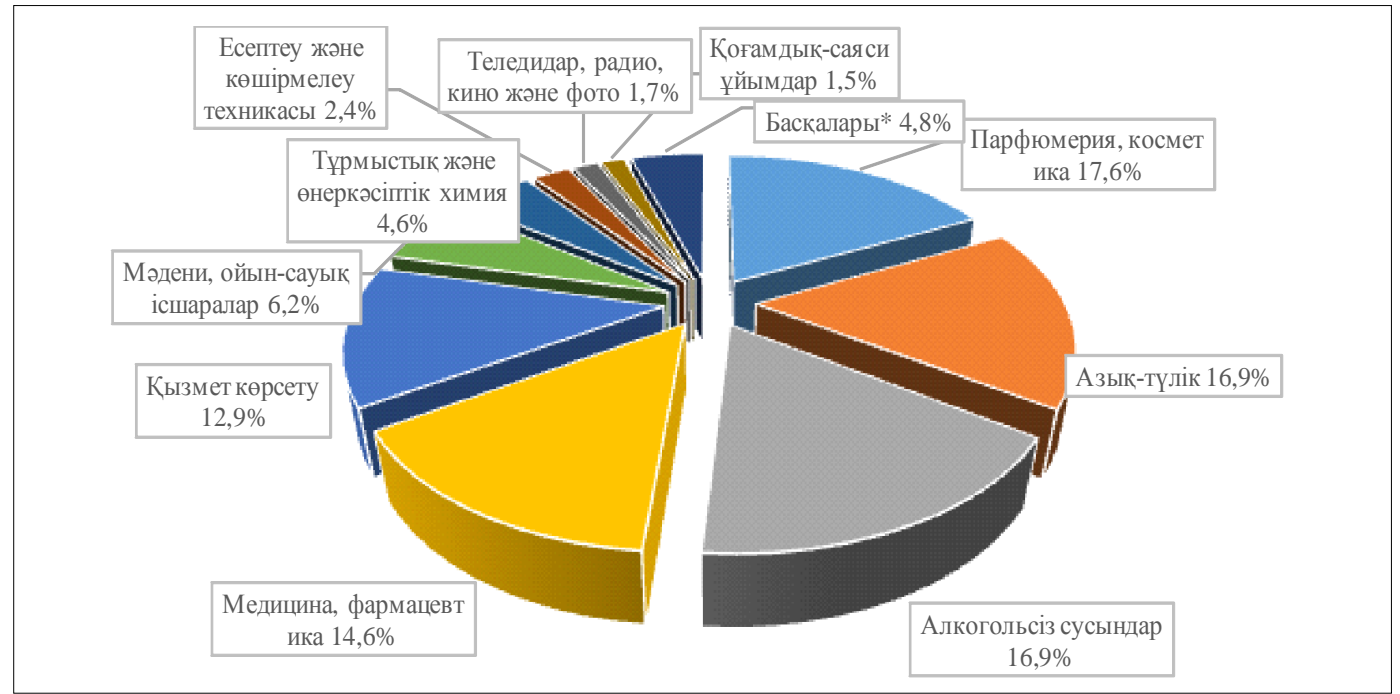

3-сурет. Жарнамалық өнімдер бойынша Қазақстан Республикасының 2019 жылғы жарнама нарығының құрылымы*

*TNS Central Asia компаниясының зерттеу нәтижелері бойынша құрылды [6] 


\section{Менеджмент жюәне маркетинг / Менеджммент и маркетинг}

Парфюмерия, косметика-17,6\%, азықтүлік тауарларының жарнамасы - 16,9\%, алкогольсіз сусындар - 16,9\%, медицина, фармацевтика $-14,6 \%$, қызмет көрсету 12,9\%-ды құраған. Яғни нарықтың 2/3 бөлігі азық-түлік, алкогольсіз сусындар, парфюмерия, қызмет көрсету мен дәрі-дәрмектердің жарнамасына тиесілі.

Қазақстанда негізгі жарнама берушілер шетел компаниялары басым үлесті алып отыр. Ал жарнамалық нарық бюджетінің 78,5\% TOP-50 жарнама берушілеріне тиесілі. 2019 жылдың бірінші жартысында жарнамалық бюджеттің көшбасшысы СосаCola болды. Unilever және Nestle өз позиция- ларын сақтады (сәйкесінше екінші және үшінші). Ал Procter \& Gamble бесінші орынға көтерілді.

2019 жылдың бірінші жартысында, TOP-50 жарнама берушілердің қатары IDS Borjomi Georgia, Sopharma Pharmaceuticals, Sportmaster Kazakhstan, Burger King, KFC, Bayer Kazakhstan, Olx.kz, Medcom-MP, LG Electronics Almaty Kazakhstan, Van Melle-мен толықтырылды [6].

Қазақстандағы жарнама қызметінің негізгі бөлігін Алматы қаласы, екінші орында Нұр-Сұлтан қаласы, үшінші орында Қарағанды қаласы алып отыр. Оны жарнама көлемі бойынша 1-кестеден көре аламыз [7].

1-кесте

Қазақстандағы жарнама көлемі, млн тенге, 2012-2018 жж.*

\begin{tabular}{|l|r|r|r|r|r|r|r|}
\hline \multicolumn{1}{|c|}{ Аумақтар } & \multicolumn{1}{c|}{2012} & \multicolumn{1}{c|}{2013} & \multicolumn{1}{c|}{2014} & \multicolumn{1}{c|}{2015} & \multicolumn{1}{c|}{2016} & \multicolumn{1}{c|}{2017} & \multicolumn{1}{c|}{2018} \\
\hline $\begin{array}{l}\text { Қазақстан } \\
\text { Республикасы }\end{array}$ & 136316,9 & 154466,1 & 154116,5 & 151811,6 & 178849,9 & 194310,2 & 215520,5 \\
\hline Ақмола & 132,8 & 259,8 & 776,4 & 281,8 & 320,2 & 1232,9 & 596,5 \\
\hline Ақтөбе & 734,8 & 779,5 & 843,7 & 684,1 & 667,6 & 1216,7 & 1097,2 \\
\hline Алматы & 1281,5 & 2593,9 & 2803,3 & 1784,7 & 1280,0 & 1449,8 & 1878,8 \\
\hline Атырау & 415,8 & 400,4 & 561,6 & 253,1 & 2141,4 & 1448,0 & 1306,7 \\
\hline Батыс Қазақстан & 735,6 & 685,5 & 583,3 & 780,7 & 1140,1 & 2179,3 & 1895,2 \\
\hline Жамбыл & 449,6 & 611,3 & 845,1 & 926,8 & 795,8 & 912,4 & 960,0 \\
\hline Қарағанды & 3875,5 & 3574,2 & 3250,7 & 2639,2 & 2856,9 & 4130,8 & 3438,6 \\
\hline Қостанай & 1483,6 & 1126,2 & 1141,8 & 1742,6 & 1986,1 & 2171,7 & 1878,3 \\
\hline Қызылорда & 197,6 & 262,5 & 293,8 & 905,2 & 898,3 & 817,5 & 800,7 \\
\hline Маңғыстау & 393,9 & 571,4 & 553,5 & 846,9 & 341,4 & 1194,6 & 1495,3 \\
\hline Оңтүстік Қазақстан & 1181,5 & 1600,7 & 2570,7 & 1943,3 & 2520,8 & 3694,1 & 3631,3 \\
\hline Павлодар & 1602,6 & 1999,5 & 1814,4 & 1815,8 & 1156,7 & 1611,3 & 2006,3 \\
\hline Солтүстік Қазақстан & 815,4 & 1128,1 & 578,7 & 670,5 & 1229,9 & 1359,8 & 1340,4 \\
\hline Шығыс Қазақстан & 2494,0 & 2584,8 & 3207,7 & 2964,1 & 2181,4 & 2866,4 & 3561,4 \\
\hline Астана қ. & 6721,2 & 5290,2 & 6243,4 & 13157,8 & 11618,8 & 12122,9 & 23978,3 \\
\hline Алматы қ. & 113801,5 & 130998,1 & 128048,4 & 120415,0 & 147714,6 & 155901,9 & 165655,5 \\
\hline
\end{tabular}

*Қазақ̧стан Республикасы статистика мәліметтерінен алынды [6]

Кестеден көріп отырғанымыздай, жылдан-жылға жарнама көлемі артып келеді, жарнама агенттіктерінің басым бөлігі Алматы қаласында орналасқан.

Қазақстандық интернет-жарнама нарығы өз дамуының шыңын бастан өткеруде. Алайда, оның танымалдығына қарамастан, 126
Қазақстандағы жарнаманың ең кең тараған құралы теледидар болып табылады. Бұл үрдіс көп жылдар бойы сақталып келеді. Мамандардың болжамына қарамастан, сандық теледидардың қарқынды дамуы мен көрермендердің ауқымды аудиториясының болуына байланысты оның рейтингісі тө- 
мендеген жоқ. Дегенмен соңғы уақытта видеожарнама сияқты ұқсас контент есебінен оны біртіндеп Интернеттің ығыстыруы байқалады. Алдағы уақытта Digital теледидарды артқа тастап, медианың негізгі түрі болады деген болжам жасалуда.

Select Communication Group мәліметтері бойынша, 2019 жылы Қазақстанда интернет-жарнама көлемі келесідей бөлінді: 1,6 млрд теңге - мәтінмәндік жарнама көлемі, 1,8 млрд теңге - баннерлік жарнама, 0,7 млрд теңге - онлайн видео, ал SMM (әлеуметтік желілердегі маркетинг) - 0,2 млрд теңге.

Алдағы жылдарда digital үлесі 37,6\% (2017 жылы 32,2\%) жетеді деп күтілуде. Теледидар үлесі $35,9 \%$ құрайды $(38,1 \%$, 2017 ж.). Мәтінмәндік жарнама дәстүрлі баспа БАҚ (газеттер мен журналдар) басып озады деп күтілуде [8].

Қазақстанда жарнама тиімділігі мен қазақстандықтардың қандай әлеуметтік желілерді жиі пайдаланатынын 2018 жылы ИМСИ Elim маркетингтік компаниясының жүргізген зерттеулер нәтижесі негізінде жарнама түрлерінің талдауларына сүйенсек, ең тиімді жарнама бірінші орында - әлеуметтік желілер (49,5\% әлеуметтік желілер + Instagram). Екінші орынға- Google іздеу қызметі. «Әлеуметтік желілер» және «Google іздеу қызметі» жауаптарына тағы да «интернет», мессенджерлер және интернет-браузерлер (Safari, Opera, Mozilla) сияқты жауаптарды қосқанда сұралған аудитория арасында сандық ортаны пайдаланудың абсолюттік үстемдігін көре аламыз [8].

Сонымен қатар, біздің ойымызша, Қазақстандағы жарнама индустриясының тез әрі тиімді дамуына кедергі болатын көптеген жайлар да бар. Біздің жарнама нарығындағы проблемалардың бірі, өкінішке орай, интернеттегі жарнаманың рұқсат етілгендігі, мемлекеттік органдардың реттеу нәтижесінде жарнама заңнамасының бұзылуына мониторингтің болмауы.

Бұқаралық ақпарат құралдарындағы жарнаманы дамытудағы тағы бір шектеу факторы - ата-аналар мен балалар дәстүрлі түрде қолданып жүрген көптеген өнімдерге қолданылатын кәмелетке толмағандардың суреттерін қолдануға қатысты қолданыстағы шектеулер. Орталық Азияда, әсіресе Қазақстанда отбасы маңызды құндылық болып табылады, сондықтан жарнамалық мазмұн көмегімен бірнеше ұрпақтардың өзара байланысын және отбасылық дәстүрлерді ғана емес, мәдени және ұлттық құндылықтарды да сәтті көрсетуге болады.

Сондай-ақ жарнама индустриясының дамуына кедергі келтіретін нәрсе - бұл фармацевтика мен медициналық мақсаттағы бұйымдарды жарнамалауға рұқсат алудың күрделі және ұзақ процедурасы. Қысқа мерзімді перспективада мемлекеттік органдардың нарық қатысушыларымен бірлесіп, осы рәсімдерді жеңілдететін жұмыстарды жүргізуі маңызды. Көптеген шет елдерде жарнамадағы фармацевтикалық категория инвестициялар бойынша жетекші орынды алады. Алайда, Қазақстанда жағдай басқаша - фармацевтика бірінші жарнамалық санаттар арасында төртінші орынды алады. Қазақстан өзінің жарнамалық нарығы бойынша ЦАРА (Орта Азиялық жарнама агенттігі) аумағындағы көшбасшы, бірақ жан басына жарнамалық шығындар бойынша Ресей мен Украинадан едәуір төмен. Егер Қазақстанда бұл бір адамға 8 доллар болса, Ресейде - 51 доллар, ал Украинада - бір адамға 15 доллар [6].

Заңнамалық шектеулермен қатар, мұндай жағдайдың себептерінің бірі брендке жарнамалық инвестициялардың маңыздылығы мен қажеттілігі болып табылады: брендті тану, тұтынушының оған деген адалдығы, құндылықтарды түсіну, сонымен қатар ойластырылған және зерттеуге негізделген шығармашылық және ілгерілеу. 2018 жылы TV GRP 30-дың 20 жарнамалаушыларының ішінде (30 секундтық бейнелер рейтингі) 14\%-ы ғана жергілікті жарнама берушілер, қалған 66\%-ы шетелдік компаниялар екендігі алаңдатарлық жағдай [8]. 


\section{Менеджмент жюәне маркетинг / Менеджмент и маркетинг}

Қазақстандық өндірушілерге тек жарнама жасап, қатардан қалмау жеткіліксіз, сонымен бірге брендтің құндылықтарын мақсатты аудиторияға үнемі жеткізіп отыру маңызды. Сонымен қатар тұрақсыз жағдайда тұтынушының қалауы мен мінез-құлқының өзгеруіне бірден назар аударып, әрекет ету керек. Осыған байланысты агенттік сараптама, нақты өлшемдер, сауатты шығармашылық даму, медиа-стратегиялары көптеген салаларға дамуда сенімді серпіліс жасауға мүмкіндік беретін негізгі өнім. Осы және басқа да көптеген сұрақтарды ЦАРА (Орта Азиялық жарнама агенттігі) ұйымдастырған салалық іс-шараларда мамандар көтеріп отыр.

Жүйелі күнделікті жұмыс нарық үшін дәстүрлі бұқаралық ақпарат құралдарындағы жарнама ережелері мен шарттарын жұмсарту, медиа-өлшеулерді жақсарту, жаңа әзірлемелер мен жобаларға инвесторларды тарту, дарынды қазақстандық жастарды жарнама бизнесіне тарту және жаңа технологияларды енгізу үшін маңызды. Қазір жарнама - бұл тек адамдардың ғана емес, сонымен қатар технологияның да ісі.

Оны жоғары кәсіби деңгейде жүргізетін, қаржылық ресурстарды тиімді пайдаланатын және жоғары сапалы жарнаманы қамтамасыз ететін жарнама агенттіктерін құру жарнаманың тиімділігін арттыруға көмектеседі. Жарнамалық агенттіктер жан-жақты нарықтық зерттеулер мен нарықты бағалауды жүргізеді, олар компьютерлік технологиямен жабдықталған, алынған ақпаратты тез және дәл өндеуге мүмкіндік береді [9].

2010 жылдан бастап теледидарға деген қызығушылық 6\%-ға төмендеді, ал Интернетті пайдалану, оның ішінде Интернеттегі видео арқылы 3,5 есеге өсті. Бірақ біздің жағдайымызда халықтың тығыздығы төмендігі, ауыл тұрғындарының көп болуы $42 \%$, сондай-ақ интернеттің шалғай жерлерде нашар таралуы сияқты факторларды назардан тыс қалдыруға болмайды. Теледидар мен Интернет - бұл екі тиімді байла- ныс арнасы. Теледидарлық жарнама қысқа мерзім ішінде максималды қамтуға, Интернет-жарнама тар мақсатты аудиторияға қол жеткізуге мүмкіндік береді. Интернет-сегмент осы арна жақсы таныс және тиімді болатын аудитория өскен сайын өз позициясын күшейтеді. Интернетте 15-30 жас аралығындағы аудиторияға қол жеткізу жеңіл. Сондай-ақ онлайн-жарнама арқылы электрондық коммерцияның пайда болуымен тұтынушыларды тікелей онлайн сатып алуларға тарту оңайырақ.

Қорытынды. Қазақстан Республикасындағы жарнама нарығының қазіргі жайкүйіне жүргізілген талдау нәтижесінде қазіргі уақытта республикадағы жарнама қызметі жандануда деген қорытынды жасауға болды. Негізінен процесс ірі және орта қалалардың ішінде, облыс және аудан орталықтарында жүруде. Қазақстандағы заманауи жарнама өзінің қалыптасу кезеңін бастан кешуде, яғни жарнамалық бизнес қағидаттарын танудың белсенді процесі жүріп жатыр. Жоғарыда көрсетілген талдау негізінде жасалған қорытындылар:

1. Интернетте жарнаманы дамыту. Интернет - экономикалық дағдарыс жағдайында жарнама үшін тиімді алаң. Интернетте жарнама құны басқа тасымалдаушылармен салыстырғанда жоғары емес. Жасы, жынысы, табысы, мүдделері бойынша таргеттеумүмкіндігі бар. Атап айтқанда, Қазақстан үшін ең ыңғайлы нұсқа - әлеуметтік желілердегі жарнама. Барлық ірі жарнама беруші компаниялар әлеуметтік желілерде өзінің парақшасы бар, онда тұтынушыларды қызықтыратын барлық ақпаратты табуға болады. Осы парақшаны көру және оған жазылу үшін пайдаланушыларды тарту үшін, тиісінше компанияның өнімі туралы таныстыру үшін, жарнамаға аз қаражат жұмсап, айтарлықтай нәтижеге қол жеткізуге болады. Интернеттегі жарнамаларды сипаттамалық мәтінмен және бейнемен бірге алып, көрсету жиілігін реттеуге және хабарландыру орнын таңдауға болады. 
2. Теледидар өнім туралы ақпаратты таратудың тиімді тәсілі болып табылатынына қарамастан, бұл барлық тауарлар мен қызметтер үшін қолайлы емес. Қазақстандық кәсіпкерлерге жарнаманы таратудың басқа да құралдарына назар аудару керек. Тапсырыс беруші өз өнімін, оның жарнамасын қайда және қалай жақсы орналастыратынын нақты түсінуі қажет. Мысалы, теледидар мен радио арналарда бағдарламалық қамсыздандыру өнімін жылжыту орынсыз.

3. Жарнамадан оң нәтижеге қол жеткізу үшін оны іске қоспас бұрын жарнамалық зерттеулер жүргізу және жарнама стратегиясын жасау қажет. Өкінішке орай, жергілікті кәсіпкерлер көбінесе бұл жайды ескермейді және соның есебінен көп қаражат шығындалады. Жарнама стратегиясын әзірлеу жарнама кезіндегі қателіктерді болдырмауға, тұтынушының жарнамалық хабарламаны дұрыс түсінбеуімен байланысты қауіптерді азайтуға және жарнаманың тиімділігін арттыруға көмектеседі.

4. Қызметкерлердің кәсібилігі клиент- тердің көптеген мәселелерін шешеді. Жақсы нәтижеге қол жеткізу үшін адам ресурстарына ақша салған орынды. Тренингтер, семинарлар, дәрістер, кәсіби әдебиеттер, ipi тәжірибелік компанияларда өз саласының кәсіпқойларымен тәжірибе алмасу - бұл мемлекет пен жарнама компаниялары Қазақстанда жарнаманы дамыту үшін едәуір ғана үлес қосады. Компанияның жетістігі 90\%-ы өз қызметкерлерінің кәсібилігі мен дағдыларына байланысты. Сонда ғана отандық компаниялардың сапалы өнімдер жасау үшін шетелдік серіктестерге жүгінудің қажеттілігі болмайды. Және заманауи қондырғылардың болуы мамандардың құнын екі есеге арттырады.

Қорытындылай келе, бүгінде Қазақстанда жарнама нарығы өзгеріске ұшырауда, қазіргі дамуы қарқынды жүруде. Осы кезеңді және қазіргі дағдарысты өткеннен кейін әлеуетті сатып алушыларға нысанды әсер ету қажеттілігі анықталып, маркетингтік зерттеулермен қатар, толық циклдік жарнамалық кампанияларды әзірлеу кезеңі туындайды деп ойлаймыз.

\section{ӘДЕБИЕТТЕР}

1. Жарнама туралы 2003 жылғы 19 желтоқсандағы № 508-II Қазақстан Республикасының Заңы.

2. Сэндидж Ч. Реклама: теория и практика. - М.: Мысль, 2014. - 512 с.

3. Дюзельбаева Г.М. Современное состояние рекламного рынка в Казахстане // Экономика и управление в XXI веке: тенденции развития. - 2015. - №2. - С. 77-79.

4. Котлер Ф., Армстронг Г. Маркетинг негіздері: Окулық. - 17-басылым. - Алматы: Ұлттық аударма бюросы, 2019. - 736 б.

5. Смыкова М.P. Маркетинг: Учеб. пособие. - Алматы: Изд-во «NURPRESS». - 2014. - C. 184.

6. TNS Central Asia компаниясының зерттеу нәтижелері. - 2020. http://www. kantar.kz

7. Қазақстан Республикасы Ұлттық экономика министрлігінің Статистика комитетінің ресми сайты. http://www.stat.gov.kz

8. ИМСИ Elim әлеуметтік және маркетингтік зерттеулер институтының зерттеу нәтижелері. - 2018. http://www.marketingcenter.kz

9. Тасмағамбетов А.Б. Қазіргі жағдайдағы инновация маркетингінің ерекшеліктері // ҚахЭҚХСУ Жаршысы. - 2020. - №1. - Б. 84-92. 


\section{REFERENCES}

1. Zharnama turaly 2003 zhylgy 19 zheltoksandagy No. 508-II Kazakstan Respublikasynyn Zany [The Advertising Law of the Republic of Kazakhstan. - No. 508-II of 19.12.2003] [in Kazakh].

2. Sendidg Ch. Reklama: teorija i praktika [Sendidg Ch. Advertising theory and practice]. - M.: Mysl, 2014. - S. 512 [in Russian].

3. Djuzelbayeva G.M. Sovremennoe sostojanie reklamnogo rynka v Kazahstane [Djuzelbayeva G. The current state of the advertising market in Kazakhstan] // Ekonomika i upravlenie v XXI veke: tendencii razvitija. - 2015. - No. 2. - S. 77-79 [in Russian].

4. Kotler P., Armstrong G. Marketing negizderi [Kotler P., Armstrong G. Marketing basics]: Okulyk. - 17-basylym. - Almaty: Ulttyk audarma bjurosy, 2019. - 736 b. [in Kazakh].

5. Smykova M.R. Marketing: Ucheb. posobie [Smykova M. Marketing: Study guide]. - Almaty: Izd-vo «NURPRESS», 2014. - S. 184 [in Kazakh].

6. TNS Central Asia kompanijasynyn zertteu natizheleri [TNS Central Asia company research results]. - 2020. http://www.kantar.kz/ [in Kazakh].

7. Kazakstan Respublikasy Ulttyk ekonomika ministrliginin Statistika komitetinin resmi sajty [The website of Committee on Statistics of the Ministry of National Economy of the Republic of Kazakhstan]. http://www.stat.gov.kz [in Kazakh].

8. IMSI Elim aleumettik zhane marketingtik zertteuler institutynyn zertteu natizheleri [The research results of Institute for Marketing and Sociological Research IMSI Elim]. - 2018. http://www. marketingcenter.kz [In Kazakh].

9. Tasmaganbetov A.B. Kazirgi jagdaidagy innovacia marketingining erekshilikteri [Features of innovative marketing in modern conditions] // Vestnik KazUEFMT. - 2020. - No. 1. - S. 84-92.

\section{М.Ж. Турсумбаева, А.К. Шаймерденова}

\section{АНАЛИЗ РАЗВИТИЯ РЕКЛАМНОГО РЫНКА РЕСПУБЛИКИ КАЗАХСТАН}

\section{Аннотация}

В статье рассмотрено состояние и направления развития рекламного рынка Республики Казахстан на основе сбора и анализа теоретических и практических положений по развитию понятия рекламы как маркетингового канала распространения информации о товарах и услугах. При написании статьи использовались работы отечественных и зарубежных ученых, материалы статистической отчетности Комитета по статистике, а также аналитические отчеты маркетингового агентства IMSI Elim, занимающегося изучением развития рекламного рынка Республики Казахстан, результаты исследования TNS Central Asia. В результате анализа тенденций развития рекламного рынка Республики Казахстан в современных условиях, структуры рекламного рынка по рекламной продукции и направлений развития рекламных инструментов из года в год, авторами были сделаны выводы. По результатам исследования, на наш взгляд, наблюдается замедление роста объема рекламных услуг по всем направлениям в целом, особенно в сегменте наружной рекламы и радио, в связи с чем мы рассматриваем вопрос перехода от традиционных СМИ к интернет-пространству, что открывает более широкие возможности для рекламодателей и способствует развитию прямого общения с целевыми потребителями. 


\title{
M. Tursumbayeva, A.Shaimerdenova
}

\section{ANALYSIS OF THE DEVELOPMENT OF THE ADVERTISING MARKET OF THE REPUBLIC OF KAZAKHSTAN}

\begin{abstract}
Annotation
The article analyzes the state and direction of development of the advertising market of the Republic of Kazakhstan based on the collection and analysis of theoretical and practical situations on the development of the concept of advertising as a marketing channel for distribution information about products and services. While writing the article, the work of domestic and foreign scientists, the statistical reports of the Committee on Statistics, and an analytical reports of the IMSI Elim marketing agency, which studies the development of the advertising market of the Republic of Kazakhstan, the results of the TNS Central Asia study were used. As a result of the analysis of trends in the development of the advertising market of the Republic of Kazakhstan in modern conditions, the structure of the advertising market for advertising products and the development directions of advertising tools from year to year, the authors made leads.
\end{abstract}

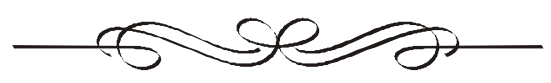


А.М. Рахметова*, к.э.н., профессор

Е.Г. Будешов, докторант $P h D$

Карагандинский экономический университет Казпотребсоюза

2. Караганда

e-mail: yeraly_budeshov@mail.ru

* - основной автор (автор для корреспонденции)

\section{ГОСУДАРСТВЕННОЕ УПРАВЛЕНИЕ СИСТЕМОЙ ЗДРАВООХРАНЕНИЯ КАЗАХСТАНА КАК ОСНОВА КАЧЕСТВА ЖИЗНИ НАСЕЛЕНИЯ}

В статье обоснована объективная необходимость совершенствования государственного управления качеством жизни населения в Республике Казахстан, путем анализа системы показателей здравоохранения, оказывающих влияние на его развитие. Авторами выявлен ряд нерешенных проблем на основе проведенного сравнительно-сопоставительного анализа основных показателей системы здравоохранения и предложены соответствующие рекомендачии в части совершенствования механизма управления сферой здравоохранения, с учетом возможной адаптации передовой практики развитых европейских государств. Особое внимание уделяется анализу системы здравоохранения, как важнейшему аспекту в государственном управлении качеством жизни населения страны. На основе анализа ряда показателей, используемых для измерения прогресса и достижения иели предусмотрены ключевые национальные индикаторы, характеризующие качество жизни населения и результаты процесса государственного управления системой здравоохранения. Учитывая, что эта система ориентирована на повышение соииально-экономического и уровень такого институционального развития, который не уступает уровню развития стран - членов Организации экономического сотрудничества и развития (далее - ОЭСР), авторами предложены рекомендации для достижения этой цุели.

Ключевые слова: государственное управление, качество жизни населения, здравоохранение, финансирование, материнская смертность, младенческая смертность, естественный прирост, ожидаемая продолжительность жизни, индекс здоровья, ицифровизация.

Кілт сөздер: мемлекеттік басқару, халықтың тұрмыс сапасы, денсаулық сақтау, қ̧аржыландыру, аналар өлімі, нәресте өлімі, табиzи өсім, күтілетін өмір сүру ұзақтывы, денсаульқ индексі, ичифрландыру.

Keywords: public administration, quality of life, healthcare, financing, maternal mortality, infant mortality, natural growth, life expectancy, health index, digitalization.

JEL classification: I 10, I 18

Введение. Агрегированный показатель «качество жизни населения», приобретающий в современных условиях общественного развития все большее значение включает в себя совокупность показателей, каждый из которых характеризует одну из многочисленных сторон жизнедеятельности субъекта [1].

Под качеством жизни понимают сос- тояние здоровья и уровень образования, наличие жилья и достойного труда, социальную среду обитания и другие условия [2].

Здравоохранение является одной из важнейших составных частей социальной сферы общества. Способы решения проблем, которые стоят перед управляющими органами этой системы, напрямую влияют не только на состояние здоровья отдельных 
граждан, но и на продолжительность их жизни, что отражается и общем качестве жизни населения [3].

В связи с этим, в разработанных государством стратегических документах отмечается важность повышения эффективности системы управления и финансирования системы здравоохранения [4].

Так, в документе системы государственного планирования на среднесрочный период в Стратегическом плане развития Республики Казахстан до 2025 года говорится, что «Высокое качество жизни будет обеспечено, в том числе, через качественное и доступное здравоохранение [5].

Вместе с тем, актуальность совершенствования действующего механизма государственного управления системой здравоохранения обусловлена сохранением таких проблем, как: дефицит квалифицированных медицинских кадров, недостаточная оснащенность медицинским оборудованием, высокий уровень младенческой (на 1000 родившихся) и материнской (на 100000 родившихся) смертности. При этом уровень младенческой (на 1000 родившихся) и материнской (на 100000 родившихся) смертности в Казахстане 7,93 и 14,8 (2017 год), соответственно, достаточно высок по сравнению со значениями аналогичных показателей в развитых странах ОЭСР за тот же период: Норвегия $(2,1$ и 2,0$)$; Швеция $(2,2$ и $4,0)$; Испания $(2,5$ и 4,0$)$ на фоне низкого уровня ожидаемой продолжительности жизни населения, который почти на 10 лет меньше чем в среднем по ОЭСР (80 лет), что безусловно требует более тщательного изучения эффективности процесса государственного управления системой здравоохранения в Казахстане.

Кроме того, актуальность темы исследования подчеркивается позицией Казахстана в рейтинге Всемирного экономического форума. Так, согласно отчета о Глобальном индексе конкурентоспособности (далее - ГИК) по итогам 2019 года, Казах- стан по индикатору «Здоровье» занял 95 место из 141 стран, также уступив две позиции по сравнению с результатми за предыдущие 2015-2016 годы (93 место) [6].

Целью настоящего исследования является на основе анализа государственного управления качеством жизни населения, в области здравоохранения, выявить существующие проблемы, ограничивающие качественное предоставление услуг здравоохранения населению, и, предложить рекомендации, направленные на их решение и улучшение отрасли здравоохранения в Республике Казахстан.

Методологической основой исследования являются долгосрочные и среднесрочные стратегии развития, концепции и государственные программы в области государственного управления качеством жизни населения, в части качества медицины. В процессе выполнения исследования были использованы такие приемы и методы как: эмпирический, аналитический, синтетический, сравнительно-логический. Информационную базу исследования составили нормативно-правовые акты, диссертации, монографии и публикации отечественных и зарубежных ученых в области государственного управления качеством жизни населения, а также статистические сборники о здоровье населения в РК и деятельности организаций здравоохранения.

Обзор литературы. Исследование развития сферы здравоохранения в контексте государственного управления качеством жизни населения основывается на изучении современных научных трудов зарубежных и отечественных ученых-экономистов таких как Сурмач М.Ю., Кузнецов В.В., Биртанов Е.А., Омирбаева Б.С. и др. [7,8,9,10].

Так, согласно определению автора Сурмач М.Ю., качество жизни связанное со здоровьем - это оценка людьми субъективных факторов, определяющих их здоровье на данный момент, заботу о здоровье и действия, способствующие его укрепле- 
нию; умение достигать и поддерживать уровень функционирования, позволяющий людям следовать их жизненным целям и отражающий уровень их благополучия [7].

По мнению Кузнецова В.В. для повышения эффективности здравоохранения целесообразно применение системного подхода, при понимании того, что конечной целью его (здравоохранения) деятельности должно быть качество жизни людей, влияющее на состояние человека и качество его труда, когда определены взаимосвязи между качеством человека, качеством его жизни, системы менеджмента качества медицинской организации, качеством медицинского обеспечения населения [8].

Серьезное исследование проведено в научном труде Биртанова Е.А., в котором отмечено, что отрасль здравоохранения, представляющая собой единую развитую социально-ориентированную систему, призванную обеспечить доступность, своевременность, качество и преемственность оказания медицинской помощи, является одной из основных и приоритетных в Республике с точки зрения устойчивого и стабильного роста благосостояния населения [9].

Заслуживает внимания также утверждение Омирбаевой Б.С., определение которой представлено следующим образом: «Состояние здоровья населения напрямую зависит от уровня финансирования отрасли, количества и качества подготовки медицинских кадров, а также уровня доходов и качества жизни населения [10].

Таким образом, изучение научной литературы в данной области позволяет обозначить необходимость повышения качества, эффективности, доступности, пациенториентированности системы здравоохранения с соблюдением принципов всеобщего охвата населения и солидарной ответственности за здоровье для обеспечения высокого качества жизни населения.

Основная часть. В Республике Казахстан государственное управление качест- вом жизни населения регламентируется основным программным документом общенационального, межотраслевого характера, определяющий стратегию, стратегические направления, цели, задачи, а также ожидаемые результаты развития определенной сферы деятельности с указанием необходимых ресурсов. Управление сферой здравоохранение проводится на основе реализиции Государственной программы развития здравоохранения Республики Казахстан «Денсаулық» на 2016-2019 годы (далее - Программа) утвержденной Постановлением Правительства Республики Казахстан от 15 октября 2018 года № 634 [11].

В целях достижения поставленных целей формулируются основные задачи Программы, решение которых отражается соответствующими показателями: развитие системы общественного здравоохранения; совершенствование профилактики и управления заболеваниями; повышение эффективности управления и финансирования системы здравоохранения; повышение эффективности использования ресурсов и совершенствование инфраструктуры и другие.

Так, за период 2015-2019 годы, в разрезе основных показателей отмечены следующие тенденции: снижение коэффициента рождаемости на 4,18\% (2015 год 22,72\% на 1000 человек; 2019 год -21,77\%); сокращение общего коэффициента смертности населения на 4,12\% (2015 год - 7,52 на 1000 человек, 2019 год - 7,21); снижение показателя естественного прироста населения в 2019 году до уровня 14,56, что на 4,21\% меньше по сравнению с 2015 годом.

Особое место в системе показателей, оценивающих качество услуг здравоохранения являются показатели смертности. К ключевым тенденциям, сложившимся за исследуемый период являются: снижение младенческой смертности на 10,7\% (2015 год - 9,41 на 1000 родившихся живыми, 2019 год - 8,4); снижение коэффициента материнской смертности в 2019 году на 13,3\% 
до уровня 13,7\% на 100000 родившихся; чем в 2 раза (2015 год - 4,1 на 100000 наснижение смертности от туберкулеза более селения, 2019 год - 2,0) (табл. 1).

Таблица 1

\section{Коэффициенты смертности населения Республики Казахстан} за 2015-2019 годы*

\begin{tabular}{|l|r|r|r|r|r|r|}
\hline \multicolumn{1}{|c|}{ Показатели } & 2015 & 2016 & 2017 & 2018 & 2019 & $\begin{array}{c}\text { Темп } \\
\text { прироста } \\
2019 / 2015, \\
\text { (\%) }\end{array}$ \\
\hline $\begin{array}{l}\text { Коэффициент младенческой } \\
\text { смертности (на 1000 родившихся) }\end{array}$ & 9,41 & 8,59 & 7,93 & 8,03 & 8,4 & $-10,7$ \\
\hline $\begin{array}{l}\text { Коэффициент материнской смерт- } \\
\text { ности (на 100000 родившихя) }\end{array}$ & 15,80 & 15,7 & 14,8 & 14,0 & 13,7 & $-13,3$ \\
\hline $\begin{array}{l}\text { Смертность от болезней системы } \\
\text { кровообращения (БСК) } \\
\text { (на 100000 населения) }\end{array}$ & 193,8 & 178,92 & 174,83 & 167,38 & 164 & $-15,4$ \\
\hline $\begin{array}{l}\text { Смерность от злокачественных } \\
\text { новообразований (на 100000 } \\
\text { населения) }\end{array}$ & 92,0 & 88,16 & 83,9 & 80,96 & 79,38 & $-13,7$ \\
\hline $\begin{array}{l}\text { Смертность от несчастных } \\
\text { случаев, отравлений и травм } \\
\text { (на 100000 населения) }\end{array}$ & 82,5 & 75,05 & 69,38 & 67,15 & 65,25 & $-20,9$ \\
\hline $\begin{array}{l}\text { Смертность от туберкулеза } \\
\text { (на 100000 населения) }\end{array}$ & 4,1 & 3,4 & 3,0 & 2,4 & 2,0 & $-51,2$ \\
\hline
\end{tabular}

* Составлена авторами по данным Комитета по статистике Министерства национальной экономики Республики Казахстан на основе [12]

Несмотря на позитивные тенденции снижения младенческой смертности за период 2015-2019 годы, плановое значение данного коэффициента не было достигнуто (по плану-7,8, по факту-8,4). В числе основных причин недостижения планируемого значения показателя следует отметить: экстремально низкая масса тела; дыхательные патологии, факты асфиксии в результате сложных родов; врожденная пневмония и другие.

Аналогичная ситуация в области материнской смертности (плановое значение на 2019 год - 11,2 при факте-13,7). В качестве причин недостижения планового показателя эксперты в области здравоохранения отмечают такие, как: выявление неучтенных случаев смерти беременных и рожениц по причинам заболеваний и осложнений бе- ременности и родов; обострение хронических заболеваний и развитие тяжелых осложнений беременности и родов и другие (так, из всех беременных, поступивших под наблюдение в 2018 году, доля здоровых составила всего 70,6\%); дефицит квалифицированных кадров (акушер-гинекологов (дефицит 33\%), анестезиологов-реаниматологов (дефицит 48\%); недостаточная оснащенность медицинским оборудованием медицинских организаций родовспоможения и детства (в 2018 году оснащенность медицинским оборудованием составила $72,8 \%$ ) и другие.

Одним из главных показателей всеобщего охвата услугами здравоохранения является обеспеченность медицинскикми кадрами, медицинской инфраструктурой и оборудованием. За анализируемый период чис- 
ленность врачей и среднего медицинского персонала в стране в абсолютном количестве увеличилась на 5,8 и 9,7\%, соответственно, однако их численность на 10000 человек населения практически не изменилась.

В частности, за 2015-2019 годы в Казахстане сократилось как число больничных организаций (на $16,8 \%$ ), так и число амбулаторно-поликлинических организаций (на 36,6\%). С сокращением количества больничных организаций, наблюдается сокращение числа и больничных коек на $6,1 \%$. Важно отметить, что снижение количества медицинских учреждений и сокращение количества медицинских коек не привели к оптимизации кад- ровых ресурсов здравоохранения, в частности наблюдается дефицит численности врачей на 10000 населения. Основным фактором, детерминирующим нехватку кадровых ресурсов системы здравоохранения, является низкая мотивация и стимулирование трудовой деятельности.

Стратегическое управление системой здравоохранения тесно связано с обеспечением высокого кадрового потенциала отрасли. В связи с этим, целесообразно рассмотреть текущее состояние показателей финансирования системы здравоохранения, в том числе динамику расходов на здравоохранение Республики Казахстан за 2015-2018 годы (табл. 2).

Таблица 2

\section{Основные показатели финансирования системы здравоохранения в Казахстане за период 2015-2018 годы*}

\begin{tabular}{|c|c|c|c|c|c|}
\hline Наименование & 2015 & 2016 & 2017 & 2018 & $\begin{array}{l}\text { Темп прироста } \\
\text { 2018/2015, (\%) }\end{array}$ \\
\hline ВВП, млрд тенге & 40884,1 & 46971,1 & 54378,8 & 61819,5 & 51,2 \\
\hline $\begin{array}{l}\text { Текущие расходы } \\
\text { на здравоохранение, } \\
\text { (млрд тенге) }\end{array}$ & 1244,4 & 1612,3 & 1656,1 & 1765,7 & 41,9 \\
\hline $\begin{array}{l}\text { Государственные расхо- } \\
\text { ды на здравоохранение, } \\
\text { (млрд тенге) }\end{array}$ & 783,8 & 948,8 & 1026,3 & 1086,2 & 38,6 \\
\hline $\begin{array}{l}\text { Частные расходы на } \\
\text { здравоохранение, } \\
\text { (млрд тенге) }\end{array}$ & 461,5 & 664,6 & 633,4 & 679,5 & 47,2 \\
\hline $\begin{array}{l}\text { Добровольные } \\
\text { медицинские взносы } \\
\text { (ДМС), (млрд тенге) }\end{array}$ & 62,5 & 91,1 & 83,2 & 107,2 & 71,5 \\
\hline $\begin{array}{l}\text { Карманные расходы } \\
\text { населения на здравоох- } \\
\text { ранение, (млрд тенге) }\end{array}$ & 399,0 & 573,5 & 550,2 & 572,3 & 43,4 \\
\hline
\end{tabular}

Как видно из данных таблицы 2, на фоне роста ВВП за весь исследуемый период (темп прироста 51,2), отмечено увеличение как государственных (темп прироста
$38,6)$, так и резкое увеличение частных расходов на здравоохранение (темп прироста $47,2)$ и карманных расходов населения на здравоохранение (темп прироста 43,4). В 
идеале рост расходов государства в какой то степени должна компенсировать расходы населения на услуги здравоохранения, отражая качественные эффекты в области оптимизации расходов населения и повышения качества их жизни в целом.

Анализ динамики расходов на здравоохранение с 2015 по 2018 годы показал рост общих расходов на здравоохранение почти в 1,5 раза за исследуемый период, однако текущие расходы на здравоохранение в 2018 году составили 1 трлн 765 млрд тенге и показывают снижение в номинальном выражении на 6,6\% по сравнению с предыдущим годом (1 трлн 656 млрд тенге). При этом доля текущих расходов на здравоохранение к ВВП $(2,9 \%)$ остается небольшой, что более чем в 3 раза меньше среднего показателя среди стран ОЭСР в 2018 году $(8,8 \%)$ и ежегодно сокращается [13].

Следует отметить, что в структуре текущих расходов государственные расходы составляют $61,5 \%$, частные расходы $38,5 \%$ (из них прямые платежи населения 32,4\%, взносы предприятий и ДМС 6,1\%). Ввиду этого, предметом внимания являются наблюдаемые в Казахстане высокие частные расходы, которые создают угрозу доступности услуг здравоохранения, усиливают неравенство в уровне получения медицинских услуг и возлагают дополнительные финансовые нагрузки на население страны, связанные с необходимостью приобретения дорогостоящего лечения, с вытекающими последствиями для экономического роста.

Проведенный анализ текущих тенденций в области развития системы здравоохранения Республики Казахстан показывает, что несмотря на достигнутые за анализируемый период индикаторы и показатели результатов Программы, имеются следующие нерешенные проблемы:

- низкая ожидаемая продолжительность жизни населения в Казахстаене - на сегодняшний день почти на 10 лет меньше, чем в среднем по ОЭСР (80 лет). Сохра- няется значительная разница между ожидаемой продолжительностью жизни мужчин и женщин: за 2018 год - 8,35 года;

- высокий уровень общей смертности в сравнении со средним уровнем стран ОЭСР, в т.ч. коэффициент младенческой смертности на 1000 родившихся в 2018 году в среднем по ОЭСР составляет 4,6\%, в Норвегии $-2,1 \%$, в Германии и Ирландии $3,1 \%$, в Великобритании и Швейцарии - 3,6 и $3,7 \%$, соответственно, в США и РФ - 5,6 и $6,1 \%$, а в Казахстане - 8,03\% [14];

- низкая мотивация труда медицинского персонала, низкий уровень финансирования здравоохранения и высокий уровень частных расходов на здравоохранение. Повышенный уровень частных расходов принято объяснять недостаточностью государственного финансирования и вызванной ею невозможностью получить необходимую помощь бесплатно в рамках общественной системы здравоохранения;

- дефицит кадров, недостаточность непрерывного профессионального образования и опыта имеющихся медицинских работников и недостаточная, местами устаревшая материально-техническая база медицинских организаций и другие.

Выводы. Анализ и осмысление выявленных проблем, позволили сформулировать необходимые выводы и определить приоритетные направления в области совершенствования действующей системы управления качеством жизни населения в части повышения качества услуг здравоохранения:

- необходимо преобразовать преимущественно централизованную организационно-финансовую модель системы здравоохранения, которая характеризуется значительной ролью государства на децентрализованное управление здравоохранением при разработке соответствующего перекрестного механизма институционального контроля центральными и местными органами исполнительной власти, негосударственными и общественными органи- 
зациями. В этой связи, заслуживают внимания зарубежный опыт Испании, где центральные власти предоставляют каждому региону общий грант, размер которого формируется исходя из численности региона и с учетом географического положения. Также целевое использование этих средств не прописывается и региональные власти вправе самостоятельно решать в каком назначении их расходовать;

- с целью снижения коэффициентов младенческой и материнской смертности следует обеспечить привлечение кадров в особенности в разрезе регионов путем повышения уровня доходов и предоставления социального пакета, организовать воспроизводство врачебного и среднего персонала посредством непрерывного постдипломного образования, а также повышение эффективности службы планирования семьи;

- оптимизировать систему финансирования здравоохранения путем завершения внедрения Обязательного социального медицинского страхования (далее - ОСМС), которое позволит обеспечить повышение доступности и качества медицинской по- мощи, снижение неформальных платежей, повышение социальной ответственности граждан за свое здоровье;

- в целях снижения количества медицинских ошибок, повышения качества и скорости обслуживания пациентов, обеспечения доступности, безопасности и пациент-ориентированности необходимо реализовать комплексную цифровизацию отрасли здравоохранения с обеспечением соответствующей материально-технической базой медицинских организаций, в т.ч. в региональном разрезе.

Таким образом, в результате анализа современных тенденций в области развития системы отечественного здравоохранения, выявления существующих и ограничивающих качество услуг здравоохранения проблем, а также предложенных к реализации рекомендаций, на наш взгляд, возможно существенно улучшить здоровье населения, демографическую ситуацию в стране и увеличить ожидаемую продолжительность жизни в Казахстане, как результирующе показателя качества жизни населения для обеспечения устойчивого социально-экономического развития страны.

\section{ЛИТЕРАТУРА}

1. Садовая Е.С., Сауткина В.А. Качество жизни населения мира: измерение, тенденции, институты. - М.: ИМЭМО РАН, 2012. - 208 с.

2. Кажыкен М.3. Благосостояние человека: Монография. - Алматы: АльПари кооперация, 2014. - 210 с.

3. Рахметова А.М., Будешов Е.Г. Качество жизни населения: теория и анализ мировых тенденций // VII междунар. науч.-практич. конф. молодых ученых «Зеленый бизнес: жизнь ради будущего» / Под ред. Г.И. Купаловой. - К.: ЦП Компринт, Киевский национальный университет им. Тараса Шевченко. - Украина, 2019. - С. 102-111.

4. Послание Президента Республики Казахстан - Лидера нации Н.А. Назарбаева Народу Казахстана. Стратегия «Казахстан-2050» Новый политический курс состоявшегося государства. http://adilet.zan.kz/rus/docs/K1200002050

5. Указ Президента РК от 15 февраля 2018 года № 636. Стратегический план развития РК до 2025 года. https://www.akorda.kz/ru/official_documents/strategies_and_programs

6. Отчет о глобальной конкурентоспособности 2018. Всемирный экономический форум.http://www3.weforum.org/docs/GCR2018/05FullReport/The Global CompetitivenessReport 2018.pdf 
7. Сурмач М.Ю. Качество жизни подростков Республики Беларусь: связь со здоровьем / М.Ю. Сурмач. - Гродно: ГрГМУ, 2013. - 228 с.

8. Кузнецов В.В. Современные аспекты исследования эффективности здравоохранения для повышения качества жизни населения // Качество и жизнь. - 2019. - № 1(21). - С. 84-89.

9. Биртанов Е.А. Организационно-методические и финансово-экономические основы инновационно-инвестиционной стратегии развития системы здравоохранения Республики Казахстан // Дис. док.мед. наук. - Алматы, 2010. - 335 с.

10. Омирбаева Б.С. Формирование конкурентоспособного здравоохранения: теория, методология, пути реализации // Дис. док.филос. PhD. - Астана, 2018. - 150 с.

11. Постановление Правительства Республики Казахстан от 15 октября 2018 года № 634. Государственная программа развития здравоохранения Республики Казахстан «Денсаулық» на 2016-2019 годы. //http://adilet.zan.kz/rus/docs/P1800000634

12. Статистические бюллетени отрасли здравоохранения. Комитет по статистике Министерства национальной экономики РК. https://www.stat.gov.kz/official/industry/63/statistic/5

13. Аналитический отчет НС3 2018. Республиканский центр развития здравоохранения Министерства здравоохранения Республики Казахстан. http://www.rcrz.kz/index.php/ ru/2017-03-12-10-51-14/nats-scheta-zdravookhraneniya-ntsz

14. Доклад о состоянии здравоохранения в мире. Всемирная организация здравоохранения. http://www.who.int

\section{REFERENCES}

1. Sadovaja E.S., Sautkina V.A. Kachestvo zhizni naselenija mira: izmerenie, tendencii, instituty [The quality of life of the world's population: measurement, trends, institutions]. -M.: IMJeMO RAN, 2012. - S. 208 [in Russian].

2. Kazhyken M.Z. Blagosostojanie cheloveka [Human well-being]: Monografija. - Almaty: Al'Pari kooperacija, 2014. - S. 210 [in Russian].

3. RahmetovaA.M., Budeshov E.G. Kachestvo zhizni naselenija: teorija i analiz mirovyh tendencij [The quality of life of the population: theory and analysis of global trends] // VII mezhdunarodnaja nauchno-prakticheskaja konferencija molodyh uchenyh «Zelenyj biznes: zhizn' radi budushhego» / Pod red. G.I. Kupalovoj. - K.: CP Komprint, Taras Shevchenko National University of Kyiv. Ukraine, 2019. - S. 102-111 [in Russian].

4. Poslanie Prezidenta Respubliki Kazahstan-Lidera nacii N.A. Nazarbaeva Narodu Kazahstana. Strategija «Kazahstan-2050» Novyj politicheskij kurs sostojavshegosja gosudarstva [«Strategy Kazakhstan-2050»: new political course of the established state» address by the President of the Republic of Kazakhstan, Leader of the Nation, N. Nazarbayev]. http://adilet.zan.kz/rus/docs/ K1200002050 [in Russian].

5. Ukaz Prezidenta Respubliki Kazahstan ot 15 fevralja 2018 goda № 636. Strategicheskijplan razvitija Respubliki Kazahstan do 2025 goda [The strategic plan for development of the Republic of Kazakhstan until the year 2025 decree of the President of the Republic of Kazakhstan No. 636 dated February 15, 2018].https://www.akorda.kz/ru/official_documents/strategies_and_programs [in Russian].

6. Otchet o global'noj konkurentosposobnosti 2018. Vsemirnyj jekonomicheskij forum [The Global Competitiveness Report 2018. World Economic Forum]. http://www3.weforum.org/docs/ WEF_The Global Competitiveness Report 2018.pdf [in Russian].

7. Surmach M.Ju. Kachestvo zhizni podrostkov Respubliki Belarus': svjaz' so zdorov'em [The quality of life of adolescents in the Republic of Belarus: a connection with health] / M.Ju. Surmach. - 


\section{Менеджмент жюәе маркетинг / Менеджмент и маркетинг}

Grodno: GrGMU, 2013. - S. 228 [in Russian].

8. Kuznecov V.V. Sovremennye aspekty issledovanija jeffektivnosti zdravoohranenija dlja povyshenija kachestva zhizni naselenija [Modern aspects of research on the effectiveness of healthcare to improve the quality of life] // Quality and life. - 2019. - No. 1(21). - S. 84-89 [in Russian].

9. Birtanov E.A. Organizacionno-metodicheskie i finansovo-jekonomicheskie osnovy innovacionno-investicionnoj strategii razvitija sistemy zdravoohranenija Respubliki Kazahstan [Organizational, methodological and financial and economic foundations of the innovation and investment strategy for the development of the healthcare system of the Republic of Kazakhstan] // Thesis of the Doctor of Medical Sciences. - Almaty, 2010. - S. 335 [in Russian].

10. Omirbaeva B.S. Formirovanie konkurentosposobnogo zdravoohranenija: teorija, metodologija, puti realizacii [Formation of competitive healthcare: theory, methodology, ways of implementation] // PhD thesis. - Astana, 2018. - S. 150 [in Russian].

11. Postanovlenie Pravitel'stva Respubliki Kazahstan ot 15 oktjabrja 2018 goda № 634. Gosudarstvennaja programma razvitija zdravoohranenija Respubliki Kazahstan «Densaulyқ» na 20162019 gody [The State Health Development Program of the Republic of Kazakhstan «Densaulyk» for 2016-2019. Decree of the Government of the Republic of Kazakhstan dated October 15, 2018 No. 634]. //http://adilet.zan.kz/rus/docs/P1800000634 [in Russian].

12. Statisticheskie bjulleteni otrasli zdravoohranenija [Health Industry Statistical Bulletins]. Statistics committee of the Ministry of NationalEconomy of the Republic of Kazakhstan. https://www. stat.gov.kz/official/industry/63/statistic/5 [in Russian].

13. Analiticheskij otchet NSZ 2018 [NHA Analytical Report 2018]. Republican center for health development of the Ministry of Health of the Republic of Kazakhstan. http://www.rcrz.kz/ index.php/ru/2017-03-12-10-51-14/nats-scheta-zdravookhraneniya-ntsz [in Russian].

14. Doklad o sostojanii zdravoohranenija v mire [World health report]. World health organization. http://www.who.int [in Russian].

\section{А.М. Рахметова, Е.Г. Будешов \\ ХАЛЫҚТЫҢ ТҰРМЫС САПАСЫНЫҢ НЕГІЗІ РЕТІНДЕ ҚАЗАҚСТАННЫҢ ДЕНСАУЛЫҚ САҚТАУ ЖҮЙЕСІН МЕМЛЕКЕТТІК БАСКАРУ}

\section{Андатпа}

Мақалада Қазақстан Республикасындағы халықтың тұрмыс сапасын мемлекеттік басқарудың объективтік қажеттілігі оның дамуына әсер ететін денсаулық сақтау көрсеткіштер жүйесін бағалау арқылы негізделген. Авторлармен денсаулық сақтау жүйесінің негізгі көрсеткіштеріне өткізілген салыстырмалы-салғастырмалы талдауының негізінде шешілмеген бірқатар мәселелер айқындалып, еуропалық дамыған мемлекеттердің озық тәжірибесін ықтимал бейімдеуді ескере отырып, денсаулық сақтау саласының басқару тетігін жетілдіру бөлігінде сәйкес ұсынымдар келтірілген. Авторлармен елдегі халықтың тұрмыс сапасын мемлекеттік басқарудағы ең маңызды аспектісі ретінде денсаулық сақтау жүйесінің талдауына ерекше көңіл бөлінеді. Өрлеуді өлшеу мен қойылған мақсатқа қол жеткізу үшін қолданылатын бірқатар көрсеткіштер талдауының негізінде авторлармен халықтың тұрмыс сапасын және денсаулық сақтау жүйесін мемлекеттік басқару үрдісінің нәтижелерін сипаттайтын түйінді ұлттық индикаторлар қарастырылған. Қазақстан Республикасындағы мемлекеттік басқару жүйесінің әлеуметтік-экономикалық дамуды және институционалдық даму деңгейін Экономикалық ынтымақтастық және даму ұйымының (одан әрі - ЭЫДҰ) мүше елдерінің даму деңгейінен кем түспейтін дәрежеге дейін жоғарылатуға бағыт талғандығын ескере отырып, авторлармен осы мақсатқа қол жеткізу үшін ұсыныстар келтірілген. 


\title{
A. Rakhmetova, Ye. Budeshov
}

\section{STATE MANAGEMENT OF HEALTHCARE SYSTEM AS THE BASIS FOR THE QUALITY OF LIFE IN KAZAKHSTAN}

\begin{abstract}
Annotation
This paper substantiates the objective need to improve the state management of the quality of life in the Republic of Kazakhstan by analyzing the system of health indicators affecting its development. Based on a comparative analysis of the main health system indicators, the authors identify a number of unresolved issues and propose appropriate recommendations for improving the management mechanism of the health sector, also considering possible adaptation of best practices of developed European countries. In particular, based on the analysis of a number of indicators used to measure progress and achieve the goal, the authors provide key national indicators that characterize the living standards and the results of the public healthcare system administration process. Taking into account that the system of public administration in the Republic of Kazakhstan focuses on increasing socio-economic and the level of such institutional development that is well up to the level of development of the member countries of the Organization for Economic Cooperation and Development (hereinafter referred to as the OECD), the authors propose recommendations for achieving this goal.
\end{abstract}

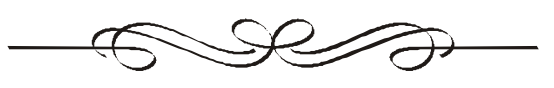


A. Yeskaliyeva*, master, senior lecturer ${ }^{l}$

A. Mussina, doctor of economics sciences, professor ${ }^{2}$

L. Igaliyeva, master, senior lecturer ${ }^{l}$

Zh. Lukpanova, candidate of economics sciences,

associate professor ${ }^{2}$

NC JSC «Atyrau University named after Kh. Dosmukhamedov»l

Atyrau c.

Kazakh University of Economics, Finance and International Trade ${ }^{2}$

Nur-Syltan c.

e-mail: Assel_2704@mail.ru

* - main author (author for correspondence)

\section{INTERNATIONAL EXPERIENCE OF HUMAN CAPITAL DEVELOPMENT}

The article describes the basic concepts of human capital in the interpretation of different authors, describes the experience and shortcomings of the formation and development of human capital in the countries of the Organization for Economic Cooperation and Development.

We need to speed up the creation of our own advanced education system that includes citizens of all ages. In the Message of the President of the Republic of Kazakhstan the head of state to the people, one of the priorities of solving strategic directions and tasks should be a constant inclination to change the main priorities of educational programs and the development of the ability to acquire new knowledge.

Keywords: human capital, OECD, education, innovations, innovation economy, investments, productive forces, international experience, new economy, Kazakhstan.

Кілт сөздер: адам капиталь, ЭҚҰД, білім, инновациялар, инновацияльқ экономика, инвестиииялар, өндірістік күштер, халықаралық тәжірибе, жаңуа экономика, Қазақстан.

Ключевые слова: человеческий капитал, ОЭСР, образование, инноваџии, инноваџионная экономика, инвестиции, производительные силы, международный опыт, новая экономика, Казахстан.

JEL classification: 015

Introduction. The future directions of the world economy are currently determined by the nature of the countries' transition to a new stage of development of productive forces: from the industrial stage, where large-scale mechanized machine production dominated, to the postindustrial one, where services, science, education, etc. will dominate. Production processes, of course, will retain their significance, but its economic efficiency will be determined primarily using highly qualified, trained personnel, new knowledge, technologies and management methods.

Thus, the way of production and transfer of knowledge and, in fact, the man himself - his intellectual potential comes to the fore.

During the years of independent development in Kazakhstan, a number of economic and social reforms were carried out; as a result, the country was brought to the leading positions in the CIS from a crisis, including the standard of living of the population, the economy is becoming more and more socially oriented. Today there are tasks of a higher order: the approval of a healthy lifestyle and the development of medicine, an increase in the life expectancy of the population. In this regard, the President of the Republic of Kazakhstan 
provides 5 clear indicators of the disclosure of the potential of Kazakhstanis: high-quality educational system; the health of the nation; the development of Kazakh culture; revision of social packages of civil servants; increased attention to citizens with disabilities $[1,2]$.

Achievement of these goals is associated with solving problems of raising the standards of quality of life of the population and the formation of human capital.

Literature review. Most scientists, researchers believe that human capital is the most valuable resource of society, much more important than natural or accumulated wealth. Already, in all countries, human (intellectual) capital predetermines the pace of economic development and scientific and technological progress. The corresponding public interest in the education system as the basis to produce this capital is increasing.

Thus, scientist A. Smith wrote that "an increase in productivity of useful labor depends primarily on increasing the worker's dexterity and skills, and then on improving the machines and tools with which he worked".

K. Marx noted: "labor, which has the value of higher, more complex labor compared to average social labor, is a manifestation of such a labor force, the formation of which requires higher costs, the production of which requires more working time, and which has therefore a higher cost than simple labor. If the cost of this force is higher, then it manifests itself in higher labor and materializes, therefore for equal periods of time in relatively higher costs" [3].

Applying the concept of "human capital" at present, one should understand the role of social institutions, find out not only social parameters, but also carry out an economic analysis of the influence of social factors on the economy.

Human capital refers to the knowledge, skills and abilities of a person that contribute to the growth of his productive power. Human capital, as defined by most economists and scientists, consists of acquired knowledge, skills, motivations, and energy that human beings are endowed with and which can be used for a certain period to produce goods and services.

According to A.I. Dobrynin, "human capital is a complex category of social reproduction, having a systemic structural and functional organization" [4].

S.A. Dyatlov believes that "the most important properties of a living human person are the ability to work and the ability to consumption, included in the structure of the performance of human forces"[5].

Human capital is the main factor of the innovation economy.

Agreeing with the opinions of the authors, it can be said that human capital is an aggregate of knowledge and skills that are used to satisfy various needs of a person, society, economy, i.e. includes tools of intellectual and managerial labor.

Main part. In world practice, there is often a growth in the value of a company when management is replaced. It follows that in modern business human capital is highly valued in the form of knowledge, skills, creative abilities and work culture.

Echopractic management creates conditions for the development of human capital: small teams, participatory management, continuous personnel training, labor culture, high competence and responsibility of each (Figure 1).

Numerous and many years of theoretical studies have not only proved that man is the main productive force of any economy, having a significant impact on growth rates, productivity, incomes and its other parameters.

The knowledge possessed by professionals is the subject of intense global competition. This means that the formation of human capital (the organization of labor and the creation of conditions for the growth of its productivity; the improvement and expansion of employees' competences, the improvement of the quality of life, etc.) remains a key issue of the state policy of any country. Not only the employees themselves and their employers, but also the top managers of the company must constantly think about what knowledge and competencies are needed today, what will be useful in the future, how to maintain, improve and apply them. 
Methods of scientific knowledge have become both general scientific and special scientific principles in the studied field of science.

Studies by international experts show that the presence of creative people capable of thinking in critical situations, competently presenting their ideas, as well as a high level of education in
Among the ways to resolve this contradiction in foreign countries used a variety of approaches: from traditional to mediated. Experience of the Organization of Economic Cooperation and Development countries (Australia, Austria, Belgium, Canada, Czech Republic, Denmark, Finland, France, Germany, Greece, Hungary, Iceland, Ire- general, do not always automatically lead society to sustainable growth and prosperity. For stable development, it is important to learn how to rationally use existing skills, to take care of them from obsolescence, exhaustion, inconsistencies with practical tasks, and to constantly pay attention to other factors of economic progress.

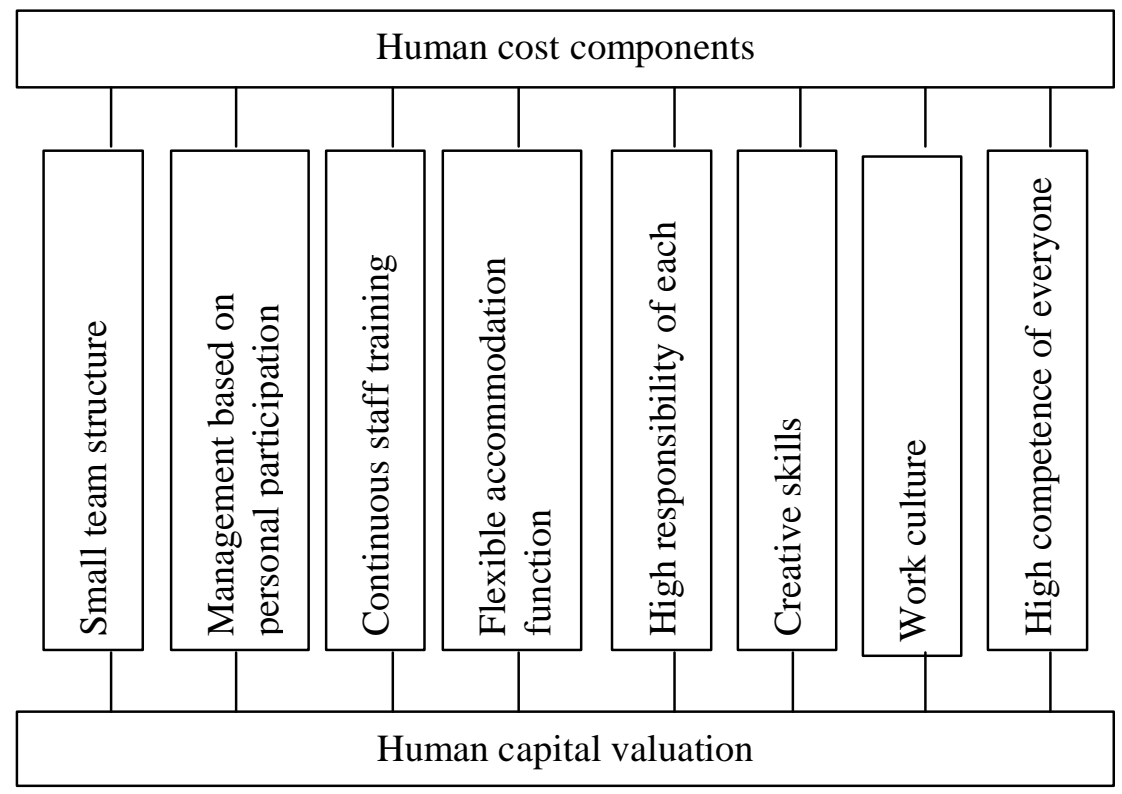

Figure 1. Components of the cost of human capital*

${ }^{*}$ Ccompiled by the author on the basis of the studied literature Thomas Clarke[6]

Data are at the end of each year

land, Italy, Japan, Korea, Luxembourg, Mexico, Netherlands, New Zeeland, Norway, Poland, Slovakia, Portugal, Spain, Sweden, Switzerland, Turkey, the United Kingdom, the United States, Chile, Estonia, Israel, Slovenia) are one of the best examples of the formation and development of human capital.

Table 1

\section{OECD member countries*}

\begin{tabular}{|l|l|l|l|}
\hline Member countries & \multicolumn{1}{|c|}{ Date of entry } & Member countries & \multicolumn{1}{c|}{ Date of entry } \\
\hline \multicolumn{1}{|c|}{ 1 } & \multicolumn{1}{c|}{2} & \multicolumn{1}{c|}{3} & 4 \\
\hline Australia & 7 June 1971 & Mexica & 18 May 1994 \\
\hline Austria & 29 September 1961 & Nederland & 13 November 1961 \\
\hline Belgium & 13 September 1961 & New Zealand & 29 May 1973 \\
\hline Great Brittain & 12 April 1961 & Norway & 4 July 1961 \\
\hline Hungary & 7 May 1996 & Poland & 22 November1996 \\
\hline
\end{tabular}


Менеджмент жюде маркетинг / Менеджмент и маркетинг

\begin{tabular}{|l|l|l|l|}
\hline \multicolumn{1}{|c|}{1} & \multicolumn{1}{c|}{ 3 } & \multicolumn{1}{c|}{4} \\
\hline Germany & 27 September 1961 & Portugal & 4 August 1961 \\
\hline Grace & 27 September 1961 & Slovakia & 14 December 2000 \\
\hline Denmark & 30 May 1961 & Slovenia & 21 July 2010 \\
\hline Israel & 7 September 2010 & USA & 12 April 1961 \\
\hline Ireland & 5 June 1961 & Turkey & 2 August 1961 \\
\hline Iceland & 5 June 1961 & Finland & 28 January 1969 \\
\hline Spain & 3 August 1961 & France & 7 August 1961 \\
\hline Italy & 29 March 1962 & Cheech & 21 December 1995 \\
\hline Canada & 10 April 1961 & Chili & 7 Mag 2010 \\
\hline Korea & 12 December 1996 & Switzerland & 28 September 1961 \\
\hline Latvia & 1 July 2016 & Sweden & 28 September 1961 \\
\hline Luxembourg & 7 December 1961 & Estonia & 9 December 2010 \\
\hline Italy & 29 March 1962 & Japan & 28 April 1964 \\
\hline
\end{tabular}

*Compiled by the author based on the literature studied [7]. Data are at the end of each year

Experts of the Organization for Economic Cooperation and Development conduct research in the field of human capital on an ongoing basis and using a variety of research methods and apparatus. Such works are very promising and relevant in the framework of the entire research topics of this international organization. Their results confirm the close relationship between economic growth, innovation, and the quality of human capital [7].

The results of the research of the Organization for Economic Cooperation and Development clearly show that innovations can steadily develop with the presence and support from the state of other economic factors:

- skilled labor, people able to invent and adapt to the market and the needs of society, new technologies;

- a favorable business environment in which investments in technology and intellectual capital are supported, as well as "experiments" of companies with new ideas and business models;

- an effective system for the creation and dissemination of knowledge through the mechanisms of human resource development, investment in the infrastructure of the knowledge economy;

- a wide range of tools that stimulate the innovative activity of companies.

Even though the positive correlation between the quality of human capital and income, produc- tivity and economic growth has long been proven in theory and practical measurements, the general and deep context of presenting (and studying) human capital development issues in conjunction with innovations and technologies is only beginning to be seen.

The most important areas of human capital development were formulated by experts of the Organization for Economic Cooperation and Development in a review of the strategies for developing competencies back in 2012 and included important areas.

In terms of developing the necessary skills, emphasis was placed on the development and use of such approaches and tools as constant monitoring of the demand for different competencies; consideration of regional specifics; motivation for applying the knowledge gained in practice; state assessment of the quality of education at all levels; ensuring equal access to education for all segments of the population; motivating employers to invest in additional employee training; conducting a soft migration policy, etc.

To increase the effectiveness of the use of skills, researchers of the Organization for Economic Cooperation and Development recommended the following measures:

- motivating companies - it is mandatory to include personnel development measures in their business strategies; 


\section{Менеджмент және маркетинг / Менеджммен и маркетинг}

- reducing migration barriers;

- promoting the development of high valueadded industries;

- promoting the teaching of modern entrepreneurship in universities[8].

The main objectives of all these efforts are related to the elimination of the lack of competencies necessary to maintain sustainable eco- nomic growth, as well as the development of education at all levels.

There are a few reasons that allow us to expect a positive return from the development of human capital for the economy and society as a whole: the higher the level of education of workers, the more active technological progress is, the public's susceptibility to innovation increases [9].

Development of relevant skills (maintaining a stable quantitative and qualitative supply of the necessary competencies, focusing on the demand of employers)

Increase / improvement of labor supply (simplification of the job search process; control over the provision of standardized working conditions; raising the retirement age; various forms of social protection for certain groups of the female population, large families, people with disabilities)

Effective use of skills

Figure 2. The most important areas of human capital development*

*Compiled by the author based on the literature studied [8] Data are at the end of each year

The more stable the social sphere (education, health care, etc.), the higher the productivity of workers can be, the longer they can remain engaged.

The strategy of the Organization for Economic Cooperation and Development for the Formation and Development of Human Capital (OECD Skills Strategy) defines the institutional conditions that have contributed to the gradual reduction of the lack of competencies and skills, improving their structure. Among them, such regulatory mechanisms as:

- emphasis on the development of "key" or "general" skills, on the basis of which it is easier to acquire "specialized" competences;

- promoting the creation and maintenance of large-scale information systems that allow students to more easily navigate available educational programs, assess their prospects, and employers understand the essence of the qualifications obtained by students;
- flexible distribution of resources among providers of educational services;

- involvement of employers in the development of strategies for the development of competencies and skills;

- development of labor market management strategies, stimulating workers to actively search for vacancies and long-term employment;

- assistance to increase staff mobility;

- formation of a demand-oriented migration regime, which includes determining the needs of the labor market, monitoring demographic and educational changes among the population (excluding migrants), creating formal channels for attracting labor, simplifying the receipt of work visas, increasing effective border control.

A major challenge for the Organization for Economic Cooperation and Development member countries is improving the academic performance and quality of education in schools. Specialists of this organization suggest using in the 


\section{Менеджмент және маркетинг / Менеджмент и маркетинг}

context of the development of the knowledge economy and innovation processes:

- voluminous, flexible curricula that increase the amount of content that students can learn and help students establish links between different blocks of knowledge (in general, this can positively affect their propensity to innovate in the widest context);

- modern educational methods in traditional disciplines, for example, metacognitive pedagogy in teaching mathematics, thanks to which students can improve mathematical thinking by solving complex and unusual tasks [10].

The development of relevant skills should occur at all levels of education. The set of tools, approaches and pedagogical practices that can be used, for example, in universities for the development of student creativity, in the member countries of the Organization for Economic Cooperation and Development is constantly and significantly expanding.

In particular, target ("problem") learning (problem-based learning) implies:

- mastering students of theoretical material;

- obtaining useful, innovative development skills;

- deep learning new knowledge.

A variety of pedagogical models, including, as already noted, metacognitive pedagogy, collective learning, play learning, online laboratories, have proven to be suitable tools for developing logical thinking and creativity among student.

People need to constantly replenish knowledge (throughout life) in order to keep up with global economic and technological changes. According to the Organization for Economic Cooperation and Development, on average, more than $40 \%$ of those employed receive the additional education they need to work (including at trainings and with the help of corporate training). To encourage such training in private companies, the Organization recommends that they seek the support of the state. We can talk about financial instruments (providing companies with tax breaks, increasing spending on vocational education, additional training and retraining of personnel), and institutional, organizational, administrative and other levers.

If we consider the competencies necessary, for example, for researchers to successfully commercialize innovations, then, in addition to basic research knowledge and experience, transferable skills should be well developed: business communication, business management, application for grants, etc. e. Only in recent years have the countries of the Organization for Economic Cooperation and Development embarked on the development of entrepreneurial education at all levels.

Support for entrepreneurship (entrepreneurial skills and competencies) in higher education is most often carried out in two directions:

- development of an entrepreneurial way of thinking: self-efficacy, creativity, understanding of risks, managing relationships, etc.;

- providing the knowledge necessary for starting and developing your own business.

One of the important areas of human capital development is investment in the vocational training of workers by employers. Experts point to the need to introduce a variety of measures to support such training, related to the dissemination of information about existing programs, the creation of an appropriate legal framework for their organization and financing, the use of tax incentives, and an increase in the financing of secondary vocational education programs.

The defining characteristic of the global innovation development of investments in human capital is the international mobility of highly qualified specialists, as well as its intensity. This is especially relevant for the development of science and technology, where progress is based on the circulation of knowledge, interaction and partnership between scientists, inventors, engineers.

Factors affecting academic mobility are in a wide range. They include growing demand for higher education throughout the world, heightened expectations regarding the quality of education abroad and future incomes, the implementation of measures for state support of students who will study abroad in national priority areas of development. 


\section{Менеджмент және маркетинг / Менеджммет и маркетинг}

Researchers at the Organization for Economic Cooperation and Development have identified a positive effect of academic mobility in at least two areas:

- the intensity of academic mobility and citation indices are directly and proportionally related;

- academic mobility is viewed by scientists as a "circulation of knowledge".

The message of the President of the Republic of Kazakhstan focuses on the development of human capital, which is considered as the basis for modernization. This approach meets modern challenges, because today, in the century of postindustrial development, innovative economy, knowledge economy, the competitive advantage of any state is a high-class specialist, professional.

Conclusion. The message of the Head of state emphasizes that the key priority of educational programs should be the development of the ability to constantly adapt to changes and learn new knowledge. This factor is because modern society inherent rapid changes. Innovation and speed are the main determinants of competitiveness in the modern world. Therefore, the ability to change along with changes in the world are the most significant today, if we do not want to stay in the "backyard of life".

In this regard, it is useful for Kazakhstani managers and experts to study the research methods and recommendations of the Organization for Economic Cooperation and Development specialists in strategic areas of development (diversification in high value-added industries; creating an innovative environment by adapting the existing knowledge and technology in the world; the use of new patterns of development of applied skills, etc.), as well as new approaches to the study and development of personnel innovation economy.

The main management resource is non-financial resources and other traditional resources, and the intelligence of professors, teachers, young scien- tists with entrepreneurial talent and leadership skills. It is in this way that the corporate culture of a university forms human capital, the development of which determines the economy of knowledge.

Higher education plays an important role in providing professional training to competent and competitive specialists for all sectors of the republic's economy, in integration with science and industry.

To improve the efficiency of human capital and create an innovative economy at the level of the advanced countries of the world, it is necessary to achieve:

- a very high level and quality of human capital through investments in its growth and development;

- high level and quality of life;

- a high level of development of fundamental science;

- a high level of development of applied sciences;

- powerful intellectual centers of technological development in the country;

- a large proportion of the sector of the new economy;

- developed and efficient innovation and venture capital systems supported by states;

- an attractive investment climate and high level of investment ratings;

- diversified economy and industry;

- competitive products in global technology markets;

- effective state regulation of the development of the country;

- the presence of transnational corporations that ensure the competitive technological and scientific development of the country;

- low inflation (below 3-5\%).

Thus, the integration of education, science and production, the development of postgraduate education on the basis of modern achievements of science and technology are today one of the priority directions of economic development.

\section{REFERENCES}

1. Message of the President of the Republic of Kazakhstan N. Nazarbayev to the people of 
Kazakhstan. «New opportunities for development in the fourth industrial revolution». 10 January 2018. https://www .mod.gov. kz/rus/poslaniya_prezidenta.

2. The state program of healthcare development of the Republic of Kazakhstan «Densaulyk» 2016-2020. https://kaznmu.kz/rus/wp-content/uploads/2016/03/densaulyk_2016-2020_0.pdf 1.02.2010 g. № 922.

3. Marks K. Kapital. T. 2-y. Perevod I.I. Stepanova-Skvortsova. - L.: 2-ya tipografiya «Pechatnyy dvor», 1952.-S. 511-513.

4. Dobrynin A.I., Tarasevich L.S. Ekonomicheskaya teoriya: Uchebnik dlya vuzov. - SPb.: Izd.ZPbGUEF, «Peterkom», 1999. - S. 366, 544.

5. Dyatlov S.A. Teoriya chelovecheskogo kapitala: Uchebnoye posobiye. - SPb.: Red. SPbUEF, 1996. - S. 38.

6. Tomas Slarke. Human capital in developing countries. Oxford Handbook of Human Capital. January 2011. - P. 30-33.

7. Thurow L.C. The Zero-Sum Society. Distribution and the Possibilities for Economic Change. - New York: Penguin Books, 1981. - P. 133-134.

8. Apospori E., Nikandrou I., Brewster S., Papaleksandris N. (2013). HRM HRM and Organizational Activities in Northern and Southern Europe // International Journal of Human Resource Management. - Vol. 19 (7). - P. 1187-1207.

9. Baird L. \& Meshoulam I. (1988). Management of two options for strategic human resource management // Academy of Management Review. - Vol. 13. - P. 116-128.

10. OECD Skills Strategy. - 2011. - P. 3.

\section{ЛИТЕРАТУРА}

1. Послание Президента Республики Казахстан Н. Назарбаева народу Казахстана. «Новые возможности развития в условиях четвертой промышленной революции». 10 января 2018 г. https://www.mod.gov. kz/rus/ poslaniya_prezidenta.

2. Государственная программа развития здравоохранения Республики Казахстан «Денсаулық» на 2016-2020гг. https://kaznmu.kz/rus/wp-content/uploads/2016/03/densaulyk_20162020_0.pdf от 1.02.2010 г.

3. Маркс К. Капитал. Т. 2-й. Перевод И.И. Степанова-Скворцова. - Л.: 2-я типография «Печатный двор», 1952. - С. 511-513.

4. Добрынин А.И., Тарасевич Л.С. Экономическая теория: Учебник для вузов. - СПб.: Изд. СПб ГУЭФ, «Петерком», 1999. - С. 366, 544.

5. Дятлов С.А. Теория человеческого капитала: Учеб. пособие. - СПб .: Ред. СПбУЭФ, 1996. $-38 \mathrm{c}$.

6. Tomas Slarke. Chelovecheskiy kapital v razvivayushchikhsya stranakh: Oksfordskiy spravochnik po chelovecheskomu kapitalu, Yanvar' 2011 g. - S. 30-33.

7. Turou L.K. Obshchestvo s nulevoy summoy. Raspredeleniye i vozmozhnosti ekonomicheskikh izmeneniy. - N'yu-York: Penguin Books, 1981. - S. 133-134.

8. Apospori E., Nikandrou I., Bryuster S., Papaleksandris N. (2013). UCHR UCHR i organizatsionnaya deyatel'nost' v Severnoy i Yuzhnoy Yevrope // Mezhdunarodnyy zhurnal upravleniya chelovecheskimi resursami. - Tom 19 (7). - S. 1187-1207.

9. Berd L. i Meshulam I. (1988). Upravleniye dvumya variantami strategicheskogo upravleniya chelovecheskimi resursami. - Akademiya upravlencheskogo obzora. - Tom 13. - P. 116-128.

10. Strategiya povysheniya kvalifikatsii OESR. -2011. - S. 3. 
Менедюмент жюәне маркетинг / Менеджмент и маркетинг

А.Ж. Ескалиева, А.А. Мусина, Л.Н. Иғалиева, Ж.О. Лукпанова

АДАМИ КАПИТАЛДЫ ДАМЫТУДАҒЫ ХАЛЫҚАРАЛЫҚ ТӘЖІРИБЕ

Андатпа

Мақалада әр түрлі авторлардың түсіндіруіндегі адами капиталдың негізгі ұғымдары қарастырылады, экономикалық ынтымақтастық және даму ұйымы елдеріндегі адами капиталды қалыптастыру мен дамытудың тәжірибесі мен кемшіліктері сипатталады.

Бізге барлық жастағы азаматтарды қамтитын озық білім берудің өзіндік жүйесін құруды жеделдету қажет. Қазақстан Республикасы Президентінің Қазақстан халқына Жолдауында стратегиялық бағыттар мен міндеттерді шешудің басымдықтарының бірі білім беру бағдарламаларының негізгі басымдықтарын өзгертуге және жаңа білім алу қабілетін дамытуға үнемі ұмтылу болуы тиіс.

\section{А.Ж. Ескалиева, А.А. Мусина, Л.Н. Игалиева, Ж.О. Лукпанова МЕЖДУНАРОДНЫЙ ОПЫТ РАЗВИТИЯ ЧЕЛОВЕЧЕСКОГО КАПИТАЛА}

\section{Аннотация}

В статье рассматриваются основные понятия человеческого капитала в трактовке различных авторов, описываются опыт и недостатки формирования и развития человеческого капитала в странах Организации экономического сотрудничества и развития.

Нам необходимо ускорить создание собственной системы опережающего образования, включающей граждан всех возрастов. В Послании Президента Республики Казахстан народу Казахстана отмечено, что одним из приоритетов решения стратегических направлений и задач должно стать постоянное стремление к изменению основных приоритетов образовательных программ и развитию способности к приобретению новых знаний.

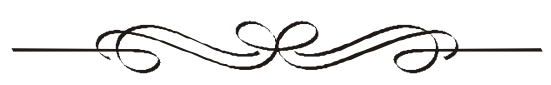


DOI 10.52260/2304-7216.2020.4(41).17

УДК 338.48 (574)

ГРНТИ 06.71.57

\author{
М.М. Нурпеисова*, к.э.н., профессор \\ НАО «Университет Нархоз» \\ 2. Aлматьл \\ e-mail: makpal.nurpeisova@narxoz.kz \\ * - основной автор (автор для корреспонденции)
}

\title{
ФОРМИРОВАНИЕ ИМИДЖА И ПРИВЛЕКАТЕЛЬНОСТИ ВНУТРЕННЕГО И ВЪЕЗДНОГО ТУРИЗМА В КАЗАХСТАНЕ
}

В статье рассмотрены основные вопросы привлекательности внутреннего и въездного туризма в Республике Казахстан, где основным туристическим продуктом являются разнообразные природные ресурсы, историческое и культурное наследие. Использованы данные Комитета республики по статистике для проведения статистического метода исследования современного состояния внутреннего и въездного туризма в Республике Казахстан.

Особое внимание в работе уделено важности развития внутреннего и въездного туризма в республике для формирования имиджа и привлекательности для иностранных туристов. Проведенное исследование в области совериенствования деятельности внутреннего и въездного туризма позволило обосновать выводы и предложить некоторые рекомендации адаптированного характера.

Ключевые слова: внутренний туризм, въездной туризм, имидж, туристический климат, туристическая отрасль, безвизовый транзит, приоритетные туристические территории (ПTT), сегмент VFR, однодневные туры, туры выходного дня.

Кілт сөздер: ішкі туризм, келу туризмі, имидж, туристік климат, туристік сала, визасыз транзит, басым туристік аумақтар (PTT), VFR сегменті, бір күндік турлар, демалыс күндері турлары.

Keywords: domestic tourism, inbound tourism, image, tourist climate, tourism industry, visafree transit, priority tourist territories (PTT), VFR segment, one-day tours, weekend tours.

JEL classification: L 83

Введение. В современных условиях развития мировой экономики туризма становится одной из ведущих и динамично развивающихся отраслей. Туризм способствует развитию ключевых секторов экономики (транспорт, связь, строительство, сельское хозяйство, производство потребительских товаров) за счет налоговых поступлений в бюджет, увеличения числа рабочих мест и притока иностранной валюты. Казахстан, занимающий выгодное геополитическое положение, обладающий значительными природными и рекреационными ресурсами и объектами мирового культурно-исторического наследия (11 объектов включены в Список всемирного культурного наследия ЮНЕСКО), уникальным природным разнообразием, имеет потенциал для разработки новых туристических продуктов и все необходимые базовые условия для того, чтобы стать крупным игроком на карте мирового туризма.

Однако, в настоящее время отрасль туризма развивается умеренным темпом с небольшим социально-экономическим эффектом в национальном масштабе. Для увеличения туристических потоков в Республику Казахстан необходимо создать благоприятные условия для развития отрасли за счет снижения барьеров и стратеги- 


\section{Менеджмент және маркетинг / Менеджммет и маркетинг}

ческого планирования отрасли.

Целью данного исследования является анализ и оценка текущего состояния внутреннего и въездного туризма в Казахстане, задачами - разработка некоторых рекомендаций адаптированного характера.

Методы. Для решения исследовательских задач использовались стандартные инструменты исследования: статистический анализ, сравнительный анализ, формально-логический, а также методы изучения информационных материалов (наблюдение, беседа, интервью) и др.

Обзор литературы. В Казахстане имеются исследования, проводимые в сфере географии туризма д.г.н., профессором Ердавлетовым С.Р. [1, 2], Камчыбековым Т.К. [3], Максименко С.В. [4]. Проведены научные изыскания в сфере туризма следующими учеными стран СНГ - Квартальновым В.А. [5], Забаевой Ю.В., Драчевой Е.Л., Исмаевым Д.К. [6], Ильиной Е.Н. [7] и др. В этих исследованиях нашли отражение общие и специфические вопросы и проблемы туризма. Определенный научный и практический интерес представляют подходы, изложенные в работах Гуляева В.Г., Селиванова И.А. [8] и др.

Обзор литературы вышеупомянутых авторов показал, что дальнейшее развитие туристкой отрасли должно опираться на их концептуальные основы и адаптированы к

специфическим условиям Казахстана.

Несмотря на обширность научной литературы по проблемам туризма, в настоящее время мало исследований, комплексно рассматривающих привлекательность внутреннего и въездного туризма в Казахстане, отсутствие ее систематизации и осмысления в рамках избранной проблемы побудили обратиться к теоретической разработке темы, связанной с формированием имиджа и привлекательности внутреннего и въездного туризма в республике и выявлению его сущности на основе анализа научного материала.

Основная часть. Развитие внутреннего и въездного туризма - одно из приоритетных направлений государственной политики. В Казахстане ведется активная работа по формированию имиджа и привлекательности местной туристической среды. По итогам 2019 года показатели развития туризма положительные. Количество иностранцев, которые приехали к нам в 2019 году, составило 8,79 млн человек, что на $14,1 \%$ больше, чем в 2018 году, а по сравнению с 2016-2017 годами - 36,7\% и 35\%, соответственно (табл.1).

По итогам 2019 года внутренний туризм увеличился сразу на 9,8\% или до 5,1 млн человек, т.е. каждый третий казахстанский турист в 2019 году отдыхал внутри страны. Зарубежные страны посетили в качестве туристов 8,2 млн казахстанцев.

Таблица 1

Количество обслуженных посетителей по типам туризма (млн чел.)*

\begin{tabular}{|l|c|c|c|c|c|}
\hline \multicolumn{1}{|c|}{ Тип туризма / годы } & 2015 & 2016 & 2017 & 2018 & 2019 \\
\hline Внутренний & 3,2 & 3,5 & 4,4 & 4,6 & 5,1 \\
\hline Въездной & 4,9 & 4,9 & 5,8 & 6,8 & 8,7 \\
\hline Выездной & 9,0 & 7,5 & 7,9 & 8,2 & 8,2 \\
\hline
\end{tabular}

*Составлена на основе данных КС МНЭ РК [9]

После проведения Международной выставки «ЕХРО-2017», туристический поток из-за рубежа в Казахстан преодолел пре152 дельную границу в 8,7 млн туристов в год. В основном Казахстан посещают граждане России, Узбекистана, Кыргызстана, Китая, 
Германии, Украины, Турции, Таджикистана, Туркменистана, Индии. Значительную роль в увеличении количества иностранных граждан в Казахстан играет наличие прямых рейсов. Для привлечения иностранных туристов в 2019 году введен 72-х часовой безвизовый транзит для граждан КНР и Индии, следующих через города Алматы и Нур-Султан.

В 2019 году были открыты новые регулярные рейсы в российском направлении, т.к. наблюдается стабильный рост туристов из России - основного зарубежного целевого рынка Казахстанапо привлечению туристов.

По итогам девяти месяцев 2019 года услугами мест размещения воспользовались 4,9 млн туристов, включая казахстанских. При этом около 60\% туристов остановились в Алматы (984,7 тыс. человек) и Алматинской области (733,7 тыс.), Нур-Султане (654,1 тыс.) и Восточно-Казахстанской области (484,8 тыс.). Объем оказанных им услуг по проживанию в совокупности достиг 92,1 млрд тенге, по сравнению с аналогичным периодом 2018 года показатель увеличился на $16,6 \%$ (рис. 1 и 2).

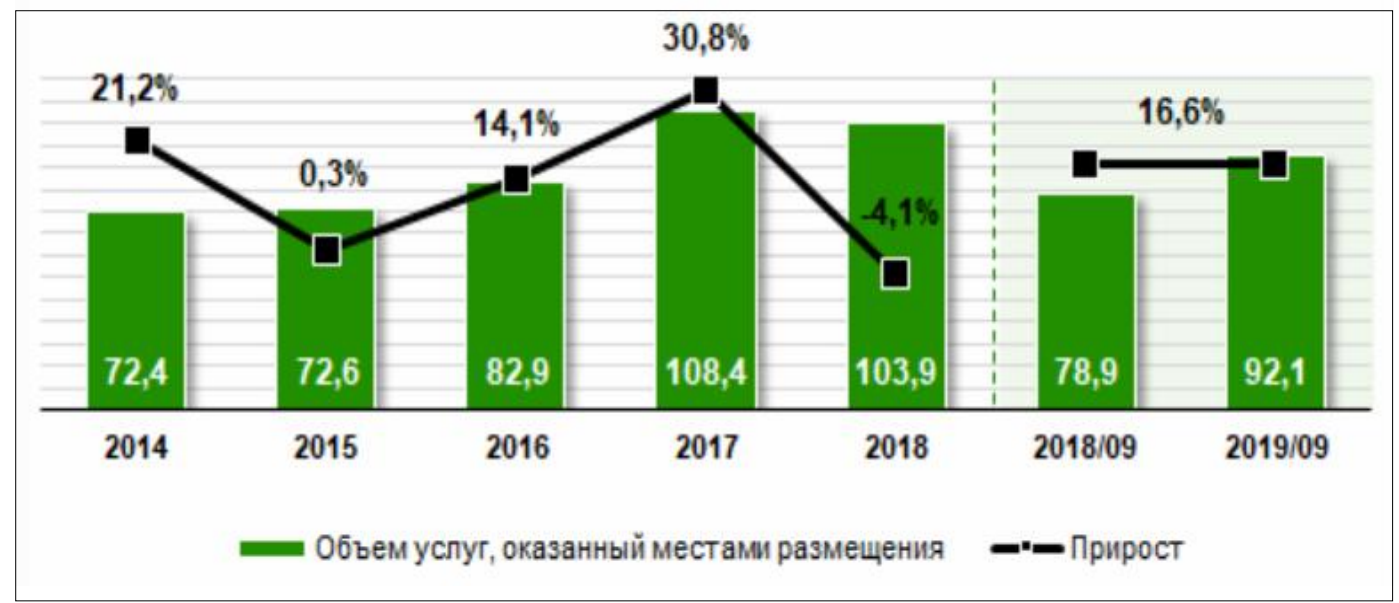

Рисунок 1. Объем услуг, оказанный местами размещения в РК (млрд тенге)

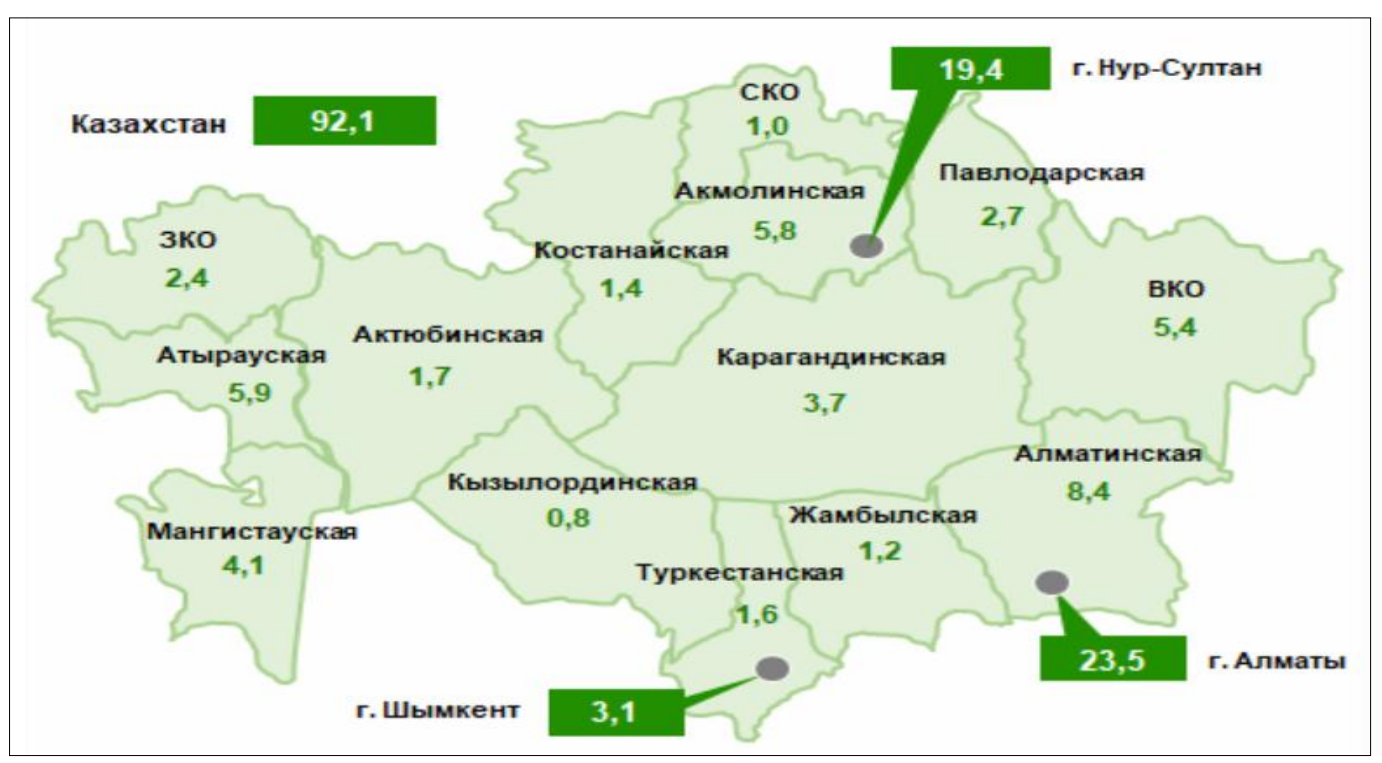

Рисунок 2. Объем услуг, оказанный местами размещения в РК в разрезе регионов (млрд тенге) 


\section{Менеджмент және маркетинг / Менеджммен и маркетинг}

Среднегодовая заполняемость размещений на протяжении последних пяти лет составляет от $22 \%$ до $25 \%$, при этом количество мест проживания туристов ежегодно растет примерно на $12,5 \%$, следовательно, идет интенсивное развитие регионального туризма в стране. Неравномерное распределение туристических потоков послужило небольшой заполняемости мест размещения и как следствие, это приводит к увеличению износа средств размещения, снижению конкуренции в регионах и ухудшению качества обслуживания.

Одновременно ведется работа по развитию внутреннего туризма в рамках программы «Рухани жаңғыру», статьи Первого Президента Республики Казахстан - Елбасы Н. Назарбаева «Семь граней Великой степи». Реконструкция городища Отырар, Сауран, Култобе, Туркестан, развитие музеев-заповедников Улытау и Танбалы, создание новых - «Бозок» в Нур-Султане и «Ботай» в Северо-Казахстанской области, уже создают условия для увеличения количества путешествий наших граждан.

Основной комплекс мероприятий закреплен в Государственной программе развития индустрии туризма Республики Казахстан на 2019-2025 годы [10].

Это целевое развитие приоритетных туристических территорий (далее-ПТТ) с упором на инфраструктуру и услуги, предоставление налоговых льгот участникам ПТТ, развитие туризма в национальных парках, дополнительные субсидии на внутренние перелеты, а также бесплатные перелеты для детей во время праздников и других мероприятий. При этом следует учитывать, что индустрия туризма очень тесно связана с другими секторами экономики. Использование туристического потенциала даст толчок развитию бизнеса и туристическая отрасль станет более привлекательной для частных инвестиций.

По статистике, в прошлом году в курортных зонах страны остановилось более
1 млн казахстанцев. Летом они все чаще посещают побережье Каспийского моря, озер Алаколь, Балхаш, и курортную зону Бурабая.

Исторический, культурный и религиозный туризм также остается активным сегментом, особенно в Туркестанской, Жамбылской, Мангистауской областях. Казахстанцы посещают так называемые «места силы», места жизни великих людей, святых, мавзолеи, храмы и другие памятники природного культурно-исторического наследия, а также священные горы, пещеры, древние поселения и другие объекты.

Активно растет количество туристов любителей приключений и спорта. Всевозможные велопробеги, марафоны и другие спортивные мероприятия стали собирать тысячи участников со всего Казахстана. Отдельно стоит отметить развивающий туризм, альпинизм и др.

Все большую популярность среди населения набирают и туры выходного дня. Такие туры уже достаточно развиты по городу Нур-Султану и Алматы. В то же время ядром этих туров стали национальные природные парки страны. Посещаемость особо охраняемых природных территорий (далее - ООПТ) растет с каждым годом. Так, в 2019 году количество посетителей национальных парков составило 1234362 человека, что в 2 раза больше по сравнению с 2010 годом (538001 человек) [11].

Чтобы сравнить казахстанские направления с популярными морскими курортами мира, необходимо развивать побережье Каспийского моря, которое было выбрано в качестве одного из приоритетов для развития пляжного туризма.

Строительство нового гостинично-туристического комплекса недалеко от города Актау (19 км от центра города) позволило создать единственный морской курорт в Центрально-азиатском регионе, предоставляющий пятизвездочный сервис «все включено» от признанного мирового бренда «IXOS». Комплекс представляет собой 


\section{Менеджмент жюәне маркетинг / Менеджммент и маркетинг}

первоклассный отдых на берегу Каспийского моря, а также активный отдых (путешествие по Каспийскому морю, по полуострову Мангышлак и плато Устюрт).

Комплекс «RIXOS» предлагает клиентам отеля 462 номера класса «стандарт» и 23 - класса «люкс», 15 вилл, водный парк развлечений «Water World», детский клуб «Rіху», конференц-залы, комнаты для деловых и частных встреч, основной ресторан и два «A'la carte» ресторан, услуги SPAсалона, спортивные площадки, несколько видов бассейнов и многое другое. Важно отметить то, что главной особенностью «Rixos Water World Aktau» является искусственная лагуна с системой подогрева и фильтрации морской воды, которая предлагает гостям наиболее комфортные условия для пляжного отдыха независимо от температуры воды в открытом море. С момента открытия отеля, за два месяца, Актау посетили 35 тыс. человек.

Такие курорты планируются развивать по всему Казахстану в рамках государственно-частного партнерства, где государство создает инфраструктуру, бизнес-отели и развлекательные заведения.

Что касается ценообразования, то стоимость отдыха необходимо учитывать с учетом сезонности, структуры туристического предложения, типа туризма и многих других сопутствующих факторов .

Среди населения Казахстана бытует мнение, что отдых в стране дороже, чем за границей. При этом часто сравнивают цены в Турции и Бурабае. Эти два направления отличаются не только уровнем развития инфраструктуры, но и туристическим предложением, продолжительностью туристического сезона и другими условиями. При этом Бурабай нельзя сравнивать с Анталией, это другой продукт, и он не может быть взаимозаменяемым даже при одинаковых ценах.

Бурабай - это направление для однодневных туров, выходных и краткосрочного отпуска продолжительностью 3-4 дня (без курортного лечения) с упором на эко-приключенческий туризм, со своеобразным климатом и очень коротким сезоном. Цены зависят от сезона, категории проживания, структуры туристического предложения, питания (все включено, только завтрак и т.д.) и многих других сопутствующих факторов. Например, летний отдых в стандартном номере с завтраком в трехзвездочных отелях курортной зоны Щучинско-Боровское обходится от 10 до 30 тыс. на взрослого. Многие отели предлагают скидки и бесплатное проживание для детей до 5 лет.

В курортной зоне Сарыагаш, стоимость проживания в стандартном номере с пятиразовым питанием и лечебной программой составляет от 11 до 15 тыс. тенге, где также предоставляются определенные скидки для детей.

На побережье озера Алаколь, средняя стоимость комнаты в базах отдыха с полным пансионом на уровне 10-12 тыс. тенге. При этом также имеются места вдвое или втрое дороже, в зависимости от запроса самого туриста. Вместе с тем, с целью снижения цен на отдых внутри страны Государственной программой туризма предусмотрено субсидирование авиабилетов для детей по принципу «Kids go free» по схеме «1 +2» (для одного родителя, двое детей) с учетом отдыха на курортах Казахстана. Эта мера позволит сэкономить семейный бюджет при покупке отдыха за городом для семьи из 5 человек в среднем на 100 тыс. тенге.

В 2018 году Правительством определены 10 лучших объектов республиканского значения и 50 объектов регионального значения [12].

В топ-10 объектов вошли города НурСултан, Щучинск-Боровская курортная зона, Баянаул, Имантау-Шалкар, берега озера Алаколь (Восточно-Казахстанская область, г. Алматы), Балхаш, горный кластер Алматинской области, Мангистау и Туркестан. Эти территории обладают наиболь- 
шим потенциалом для развития туризма, поэтому, в рамках государственной программы планируется работа по продвижению этих объектов как внутри страны, так и за рубежом.

Подборку мест разнообразного отдыха для туристов, можно сделать исходя из видов туризма, где выделяются эти 10 мест: Боровое, Бозжыра, Каинды, Рахмановские ключи, Коргалжынские озера, горы Актау и знаменитые Поющие барханы, Чарынский каньон, Белуха, озера Кольсай и Индер.

За последние 2 года была проделана значительная имиджевая работа для большего признания и привлечения туристов, проведены мероприятия, организован ряд инфотуров, блог-туров и экспедиций с участием более 30 тревел-блогеров из разных стран, собран банк из 3000 фото и 5 часов видео, переработан портал загородного туризма Kazakhstan.travel и многое другое.

Отдельно стоит отметить видеоролик на Euronews, программы на казахстанском TВ, НТВ, Россия-1 и других телеканалах.

Много исторических и культурных объектов в Казахстане, которые могут привлечь иностранных туристов, и некоторые из которых включены в Список всемирного наследия ЮНЕСКО. Все зависит от пожеланий туристов: многим интересно путешествовать по Шелковому пути, увидеть Древний Тараз, посетить Туркестан и посетить мавзолеи Ходжа Ахмеда Яссауи, Арыстан Баба, поселения Отрар и Сауран. Остальные спешат увидеть некрополи Бекет-ата и Шакпак-ата в Мангистауской области, петроглифы Тамгалы в Алматинской области или курганы Берель и Шиликта в Восточном Казахстане, а также многочисленные древние поселения и другие культовые сооружения.

Ключевым проектом, реализуемым казахстанской туристической компанией, должен стать национальный туристический портал Kazakhstan.travel [12].

На данный момент портал доступен на
6 языках - казахском, русском, английском, французском, немецком, китайском. Корейский язык будет добавлен в этом году. Портал служит вдохновением для иностранного туриста при поездке в нашу страну, рассказывает об основных особенностях и достопримечательностях.

E-hotel позволит создать единую базу отелей и других средств размещения и автоматизировать оформление электронных приглашений на электронную визу. Планируется также предоставление бесплатного интернета в 10-ти приоритетных туристических направлениях в рамках Государственной программы, выпуск мобильных Wi-Fi роутеров для иностранных туристов, которые работают как PowerBank и кнопка SOS. Для развития внутреннего туризма также был предложен проект Геймификации священных мест, призванный заинтересовать подрастающее поколение путешествиями по Казахстану.

Выводы. В заключение хочется отметить, что потенциал развития туризма в Казахстане велик, и от работы каждого, так или иначе задействованных в туристической сфере, зависит развитие привлекательности внутреннего и въездного туризма в целом и формирование имиджа республики в частности.

Согласно плану, к 2025 году казахстанские достопримечательности должны стать объектами притяжения с высококлассным сервисом и отличной инфраструктурой. Количество внутренних туристов должно вырасти до 8 млн человек, иностранных посетителей, останавливающихся в отелях, до 3 млн человек, в связи с этим предлагается:

1) министерству культуры и спорта РК необходимо определить перспективные направления по всей стране и выделить государственные средства на развитие инфраструктуры: строительство автомобильных и железных дорог, гостиниц, открытие курсов гидов и школ гостеприимства;

2) предоставить потенциальным ин- 


\section{Менеджмент жсәне маркетинг / Менеджммент и маркетинг}

весторам чрезвычайно привлекательные стимулы - бесплатную аренду земли под строительство, кредиты на строительство объектов с низкими процентными ставками, льготные тарифы на электроэнергию, воду и газ, освобождение от ряда налогов и сборов;

3) ввести сертификацию профессиональных гидов, гидов-переводчиков, гидов-экскурсоводов;

4) отменить запрет на рассмотрение приглашений иностранцев туристическими компаниями, если в течение одного года принимающие лица были привлечены к административной ответственности согласно миграционному законодательству;

5) увеличить для туристов срок пребывания с 90 дней до 1 года, с исключением от обязательства регистрации в ОВД;

6) отменить требование обязательного страхования туроператорской деятельности на внутреннем и въездном туризме;

7) внести в туристское законодательство понятие «придорожный сервис», для системно налаженной работы придорожного сервиса, что существенно влияет на качество турпродукта и на формирование самого турпродукта;

8) принять ранее разработанный проект Постановления Правительства РК «Об утверждении Правил посещения объектов туристской деятельности, расположенных на территории приграничной зоны Республики Казахстан в туристских целях», для устранения проблем въезда иностранцев и лиц без гражданства в пограничную зону.

В результате будет создана огромная промышленность, которая внесет значительный вклад в ВВП страны.

\section{ЛИТЕРАТУРА}

1. Ердавлетов С.Р. География туризма: Учебник. - 2-е изд., перераб. и доп. - Алматы: Қазақ университеті, 2010. - 387 с.

2. Ердавлетов С.Р. Туризм Казахстана: Учеб. пособие. - Алматы: Бастау, 2015. - 520 с.

3. Камчыбеков Т.К. Туризм в Казахстане: проблемы, пути решения, перспективы развития. - Б.: БГИЭК, 2007. - 256 с.

4. Максименко С.В. Туризм в Казахстане: Учеб. пособие. - Б.: БГИЭК, 2006. - 216 с.

5. Квартальнов В.А. Туризм: Учебник. - 2-е изд., перераб. и доп. - М.: Финансы и статистика, 2014. - 336 с.

6. Драчева Е.Л., Забаева Ю.В., Исмаев Д.К. Экономика и организация туризма: международный туризм: Учеб. пособие. - 4 изд., испр. и доп. - М.: Кнорус, 2013. - 576 с.

7. Ильина Е.Н. Туроперейтинг: продвижение туристического продукта: Учеб. пособие. - М.: Финансы и статистика, 2008. - 236 с.

8. Гуляев В.Г., Селиванов И.А. Туризм: экономика, управление, устойчивое развитие. Учебник. - М.: Советский спорт, 2008. - 280 с.

9. Комитет по статистике, МНЭ РК. Сборник «Развитие туризма в Казахстане в 2019 году». URL: //www. stat.kz

10. Государственная программа развития туристской отрасли Республики Казахстан на 2019-2025 годы, утверждена постановлением Правительства Республики Казахстан от 31 мая 2019 года № 360.

11. Официальный информационный ресурс Премьер-Министра Республики Казахстан. URL: http:// primeminister.kz (Дата обращения: 21 сентября 2020 года).

12. Интервью с председателем Правления АО «Национальная компания «Kazakh Tourism» У. Бисакаевым. URL: http:// primeminister.kz (Дата обращения: 21.09.2020 года). 


\section{REFERENCES}

1. Erdavletov S.R. Geografija turizma: Uchebnik. -2-e izd., pererab. i dop. - Almaty: Қаzaқ universiteti, 2010. - 387 s. [in Russian].

2. Erdavletov S.R. Turizm Kazahstana: Ucheb. posobie. - Almaty: Bastau, 2015. - 520 s. [in Russian].

3. Kamchybekov T.K. Turizm v Kazahstane: problemy, puti reshenija, perspektivy razvitija. B.: BGIJeK, 2007. - 256 s. [in Russian].

4. Maksimenko S.V. Turizm v Kazahstane: Ucheb. posobie. - B.: BGIJeK, 2006. - 216 s. [in Russian].

5. Kvartal'nov V.A. Turizm: Uchebnik. - 2-e izd., pererab. i dop. - M.: Finansy i statistika, 2014. - 336 s. [in Russian].

6. Dracheva E.L., Zabaeva Ju.V., Ismaev D.K. Jekonomika i organizacija turizma: mezhdunarodnyj turizm: Ucheb.posobie. - 4 izd., ispr. i dop. - M.: Knorus, 2013. - 576 s. [in Russian].

7. Il'ina E.N. Turoperejting: prodvizhenie turisticheskogo produkta: Ucheb. posobie. - M.: Finansy i statistika, 2008. - 236 s. [in Russian].

8. Guljaev V.G., Selivanov I.A. Turizm: jekonomika, upravlenie, ustojchivoe razvitie: Uchebnik. - M.: Sovetskij sport, 2008. - 280 s. [in Russian].

9. Komitet po statistike, MNJe RK. Sbornik «Razvitie turizma v Kazahstane v 2019 godu». URL: //www. stat.kz [in Russian].

10. Gosudarstvennaja programma razvitija turistskoj otrasli Respubliki Kazahstan na 20192025 gody. Utverzhdena postanovleniem Pravitel'stva Respubliki Kazahstan ot 31 maja 2019 goda № 360 [in Russian].

11. Oficial'nyj informacionnyj resurs Prem'er-Ministra Respubliki Kazahstan. URL: http:// primeminister.kz (Data obrashhenija: 21 sentjabrja 2020 goda) [in Russian].

12. Interv'ju s predsedatelem Pravlenija AO «Nacional'naja kompanija «Kazakh Tourism» Urkenom Bisakaevym. URL: http:// primeminister.kz (Data obrashhenija: 21 sentjabrja 2020 goda) [in Russian].

\section{М.М. Нұрпейісова \\ ҚАЗАҚСТАНДАҒЫ ШШКІ ЖӘНЕ КІРУ ТУРИЗМНІН БЕЙНЕСІ МЕН ТАРТЫМДЫЛЫҒЫНЫҢ ҚАЛЫПТАСУЫ}

\section{Андатпа}

Мақалада негізгі туристік өнімі әр түрлі табиғи ресурстар, тарихи және мәдени мұралар болып табылатын Қазақстан Республикасындағы ішкі және кіру туризмінің тартымдылығының негізгі мәселелері талқыланады. Қазақстан Республикасының ішкі және кіру туризмінің қазіргі жағдайын зерттеудің статистикалық әдісін жүргізу үшін Қазақстан Республикасы Статистика комитетінің мәліметтері пайдаланылды.

Шетелдік туристер үшін имидж бен тартымдылықты қалыптастыру үшін республикада ішкі және кіру туризмін дамытудың маңыздылығына ерекше назар аударылады. Ішкі және кіру туризмінің қызметін жетілдіру саласындағы жүргізілген зерттеулер тұжырымдарды негіздеуге және бейімделген сипаттағы кейбір ұсыныстар беруге мүмкіндік берді. 


\section{Nurpeisova}

\section{FORMATION OF THE IMAGE AND ATTRACTIVENESS OF DOMESTIC AND INBOUND TOURISMIN KAZAKHSTAN}

\section{Annotation}

The article discusses the main issues of the attractiveness of domestic and inbound tourism in the Republic of Kazakhstan, where the main tourist product of Kazakhstan is a variety of natural resources, historical and cultural heritage. The data of the Committee of the Republic of Kazakhstan on Statistics were used to conduct a statistical method for studying the current state of domestic and inbound tourism in the Republic of Kazakhstan.

Particular attention is paid to the importance of the development of domestic and inbound tourism in the republic for the formation of the image and attractiveness for foreign tourists. The conducted research in the field of improving the activities of domestic and inbound tourism made it possible to substantiate the conclusions and propose some recommendations of an adapted nature.

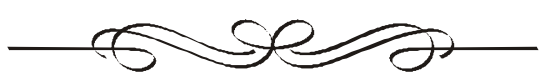


B. Zhumanova*, PhD, assoc. professor ${ }^{l}$

N. Alashbayeva, master of science, senior lecturer ${ }^{l}$

A. Imashev, $P h D$, senior lecturer ${ }^{l}$

K. Baigabulova, $P h D$, assoc. professor ${ }^{2}$

Kazakh University of Economics Finance and International Trade ${ }^{l}$

Nur-Sultan c.

Eurasian national University L.N. Gumilyova ${ }^{2}$

Nur-Sultan c.

e-mail nukanai09@bk.ru

* - main author (author for correspondence)

\section{IMPLEMENTATION OF DIGITALIZATION IN THE MANAGEMENT OF TRANSPORT AND LOGISTICS SYSTEM OF KAZAKHSTAN}

The article presents the conditions for a culture of digitalization's formation of the transport and logistics sector of the economy of Kazakhstan and considers the main stages of the implementation of the state program "Digital Kazakhstan", based on the basic principles of the development of economic sectors, through the introduction of new technologies and improvement of existing business processes. The authors define the goals and objectives of the development of the transport and logistics structure.

The consistency of the functioning of the project of an intelligent transport system is shown. Based on the results of the study of the transport industry in the framework of the modern development of the Republic of Kazakhstan's economy, the article's authors identified the main problematic aspects and constraints to further development associated with high costs of logistics services and low labor productivity. Based on the results of the study, the need for digital modernization of transport and logistics services in the sectors of the economy of Kazakhstan is justified.

Keyword: transport, transport industry, state program, digital Kazakhstan, food belt, economy, system, sector, development, function.

Кілт сөздер: көлік, көлік саласы, мемлекеттік баддарлама, ичифрлық Қазақсттан, азықтүлік белдеуі, экономика, жүйе, сектор, даму, функция.

Ключевые слова: транспорт, транспортная отрасль, государственная программа, иифровой Казахстан, продовольственный пояс, экономика, система, сектор, развитие, функция.

JEL classification: $\mathbf{R} 41$

Introduction. Currently, the importance of the transport industry in the economy of each state is increasing, since the level of transport development directly affects the competitiveness of the economy and the security of the country. Transport is the most important sector of the domestic economy of Kazakhstan, which occupies a significant share in the GDP structure. Significant territory of the Republic and low population density, high rate of economic development of Kazakhstan, achieved in recent years, form the growing demand for transportation. Accordingly, the movement of population and cargo flows within the framework of inter-economic relations, economic development and interaction of the regions of Kazakhstan every year becomes more and more popular service. In addition to the economic function, transport performs a social function, provides contacts 
of the population within the framework of kinship, friendly communication, participates in the organization of recreation, education, cultural development, as well as in solving various social problems.

In the message of the head of state to the people of Kazakhstan "Strategy" Kazakhstan2050": a new political course of the established state" [1] the task is to double the transit traffic through Kazakhstan by 2020 and 10 times - by 2050. "It is important to focus on going beyond the country to create production transport and logistics facilities" - said the President of the Republic of Kazakhstan.

The draft state program for the development of transport infrastructure until 2020 was developed with the support of the world Bank and has been approved previously by all interested state and local Executive bodies and associations. In fact, this is the first large-scale plan in the history of the country for the development of Kazakhstan's transport infrastructure and its integration into the world transport system [2].

The purpose of this study is to study modern approaches in the management of the transport and logistics system of Kazakhstan. The economic assessment of the implementation of the "Digital Kazakhstan" Program was used to study the subject.

Literature review. A great contribution to the development of the theory and practice of logistics was made by the works of Russian scientists:

Kalinina V. A., Grigorieva A. S.[3], Panova I.V. [4], Dorofeeva A. [5], Astafyeva N.V., Puzanova E.A. [6], Mazlova I.I., Gavrilova S.I. [7]. In the study of issues related with the development of the transport industry of Kazakhstan made such economists as: Mozharova V.V. [8], Erenyazova Zh.N., Talapbaeva G.E., Kultanova N.B. [9], Dnishev F., Alzhanova F. [10], Iztileuova M.S.[13], Satova R.K., Suhova L.K., Guseva L.U.[14], Kaldibayev. S.U., Bizhanova A.S., Ahmediarova A.T., Kasimova D.T. [15].

Main part. The aim of state program "Digital Kazakhstan" is economic growth, increasing competitiveness and improving the quality of life of the population. To date, the implementation of the program involves following five basic principles (figure 1).

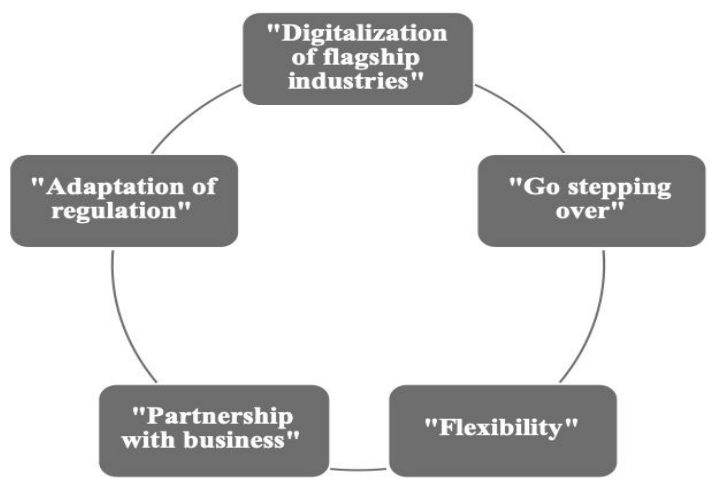

Figure 1. Basic principles*

*Compiled by the author on the basis of source [2]

The first principle, "digitalization of flagship industries" aims to implement the digital transformation of existing industries. The main task of digitalization of industries is a large-scale increase in productivity. This is achieved through the introduction of new technologies and adaptation of existing business processes. As well as creating a favorable ecosystem [3].

The second principle, "go stepping over". Kazakhstan will introduce the most advanced technologies and innovative approaches for longterm development. After all, they are able to ensure the sustainability of the future.

The third principle, "flexibility".When ma- 
king changes to the Program, in cases stipulated by the current system of state planning, the Agile approach can be applied.

The fourth principle, "partnership with business". To achieve greater efficiency, it is important to involve the private sector in the implementation process. In this regard, it is important to create appropriate conditions for large enterprises, as well as small and mediumsized businesses [4].

Attracting investment and reducing costs for the digital transformation of the enterprise is a good support for the massiveness of this process. Especially in specific areas.

The fifth principle, "adaptation of regulation". During the implementation of the program, questions naturally arise. The state should take the initiative in the legislative processes to ensure the conditions of the digitalization process. This should be done on the basis of a comparison of the study of foreign experience. That in turn will help the competitive development of the country [5].

According to the official data Of the Committee on statistics of the Ministry of national economy of the Republic of Kazakhstan (CC MNE RK), in 2018, the transport industry provided Kazakhstan with $8.3 \%$ of the total GDP produced (about 58.8 trillion tenge was the GDP of the Republic by production method). Over the past year, about 4.1 billion tons of goods were transported through the territory of Kazakhstan, which is almost twice as much as a decade ago. In General, the indicator of cargo turnover in the country increased from 369.8 billion tkm to 596.1 billion tkm in the period from 2008 to 2018 , which is $61 \%$ more [6].

The task of digitalization of transport and logistics is also one of the priority directions of digitalization of the economic sector. High-quality transport and logistics infrastructure is the key to economic development of the country. Kazakhstan today has a fairly well-developed railway network, but the road network is not sufficiently developed and air transportation is excessively expensive. A big advantage is the location of the country, its transit potential [7].

The program "Digital Kazakhstan" provides the creation of an intelligent transport system. It will combine the functions of video surveillance, traffic management, driver notification of weather conditions and electronic payment for transport services. The introduction of an intelligent transport system will reduce the number of road accidents, as well as reduce the cost of road maintenance [8]. The use of electronic document management and a system of non-stop weighing of vehicles will ensure smooth transit through the country (figure 2).

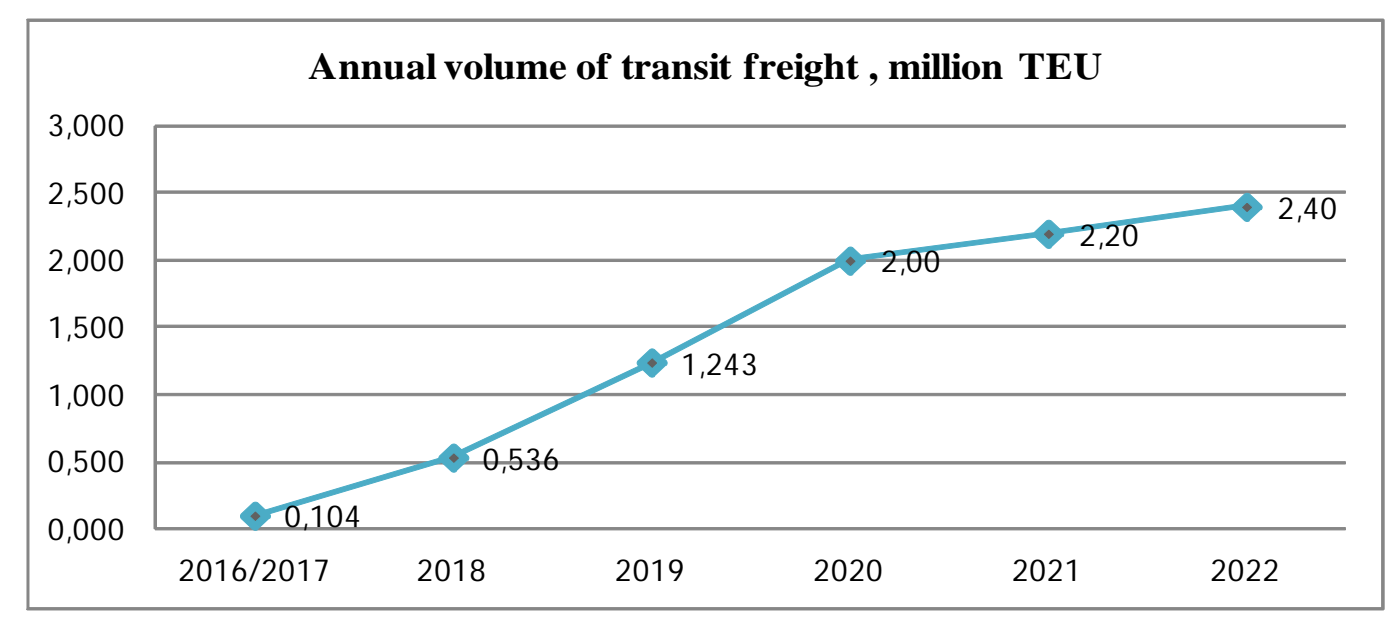

Figure 2. Expected annual volume of transit freight, million TEU*

*Compiled by the author on the basis of source [2] 
In the direction of intelligent transport system. The project "multimodal transport management System" is being implemented in stages, which provides comprehensive automation of transport management processes, management of customer and contractor base, calculations of services and vehicles (figure 3 ).

8 complexes of "Special automated measuring tools" were launched in 2017, fixing the transportation of goods in excess of the established norms. 12 SAIS complexes were launched in 2018, in 2019 it is planned to launch another 26 systems.
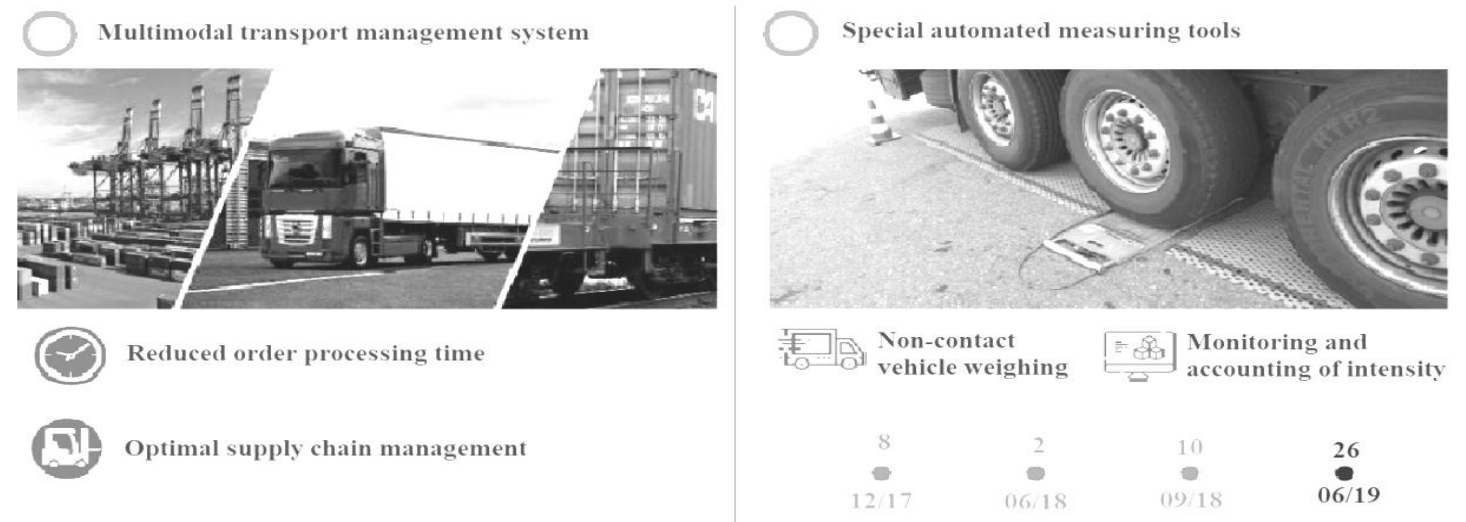

Figure 3. Digitalization of transport and logistics*

*Compiled by the author on the basis of source [15]

A road asset management system is also being implemented, within which 16 mobile laboratories have been launched. The system will provide transparency and quality monitoring of road works, both during repair and during the warranty period [9].

As a result of the implementation of the project "intelligent transport system" in 2018, 279 jobs were created. By 2025, it is planned to create an additional 1.5 thousand jobs [10].

To provide the city of Nur-Sultan with food products, the Ministry of Agriculture has developed a new roadmap for the formation of the food belt of Astana, calculated until 2021. According to which, it is planned to build a meat processing complex, 16 dairy farms and develop trade and logistics infrastructure in the Akmola region.

In 2020-2021, it is planned to build 16 dairy farms to load milk processing enterprises ( 5 in the Akmola region and 11 in the Karaganda region); in 2019-2020, the restoration of irrigated land for growing the missing volumes of vegetables.

The Ministry of Agriculture intends to develop trade and logistics infrastructure simul- taneously. For this purpose, a wholesale distribution center will be created in Nur-Sultan, which will provide an opportunity for domestic agricultural producers to enter the market of wholesale buyers at market "fair" prices, as well as reduce the cost of storing products, increase the turnover of agricultural producers [11].

Within the framework of the preferential financing program of JSC "NC "SEC "Astana”, loans were issued to Kenmart and Astykzhan shopping centers in the amount of 300 million tenge to replenish working capital in exchange for price fixing in Astana last year. As a result, fixed prices were set for 49 products. As part of the implementation of food belt projects around Astana within a radius of $50 \mathrm{~km}, 92$ projects (16 - dairy, 56 - meat and 20 - other projects) have been identified [12].

In terms of food security, digitalization will modernize the country's trade infrastructure. To form a coherent and effective trade and logistics infrastructure, a national commodity distribution system is being created. This will allow to unite transport agents, intermediaries and retailers into 


\section{Менеджмент және маркетинг / Менеджммен и маркетинг}

a single cluster, both technically and informationally. 24 wholesale distribution centers will provide connecting into a single digital system and optimizing the supply chain of products from manufacturer to consumer, creating the necessary conditions for storage, effective distribution and sale of products. Reducing commodity losses will ensure farmers with the opportunity to invest further in increased productivity. In addition, full direct access of a private manufacturer to sales markets and pre-sale trade infrastructure will significantly increase the income of both the private trader and the industry as a whole. At the same time, the consumer will receive quality, safe products and improved service. Moreover, the prices for socially important food products will be reduced by $45 \%$. This will save about 60 billion tenge for consumers annually [13].

Creation of conditions for ensuring stable supplies of food products from other regions of the Republic, the production of which is impractical in the zone of the food belt. For this purpose, the mechanism for assigning the status of "Participant of the food belt of the capital" will be introduced, which will provide the subjects of the agroindustrial complex with priority access to markets in the city, including municipal markets, etc.[14].

Development of trade and logistics infrastructure. For this purpose, a wholesale distribution center will be created in Astana to provide an opportunity for domestic agricultural producers to enter the market of wholesale buyers [15].
Implementation of additional measures to protect the market from nonconforming products. This is the strengthening of interaction of state bodies to protect the market from inappropriate products by increasing the volume of research, monitoring the safety of imported and manufactured products with media coverage of the facts of violations of the legislation requirements of the Republic of Kazakhstan.

Conclusion. In comparison with Western countries, Japan and the United States the development of IT technologies in many sectors of Kazakhstan's economy was not efficient. Obviously it is important to carry out digital modernization in industries as soon as possible. Since the competitiveness of the economy of Kazakhstan and, accordingly, the welfare of citizens directly depends on it. According to the state program "Digital Kazakhstan", the growth of labor productivity in the section" Transport and warehousing "in 2022 should be about $21 \%$.

As you know, logistics costs of domestic producers in the structure of the cost of finished products in the equity ratio is about $40 \%$. Therefore, it will be possible to reduce logistics costs several times due to the construction of infrastructure and the choice of optimal routes for the transportation of goods by manufacturers.

As a result, a number of larger problems arise. The level of automation in industrial production and the use of new technologies remains low. Lack of professional staff with sufficient competence.

\section{REFERENCES}

1. Strategija «Kazahstan-2050»: novyj politicheskij kurs sostojavshegosja gosudarstva. Poslanie Prezidenta Respubliki Kazahstan - Lidera Nacii N.A. Nazarbaeva narodu Kazahstana. - Astana, 14 dekabrja 2012 goda. http://adilet.zan.kz/rus/docs/K1200002050/links [in Russian].

2. Gosudarstvennaja programma «Cifrovoj Kazahstan». Postanovlenie Pravitel'stva Respubliki Kazahstan ot 12 dekabrja 2017 goda № 827. https://www.akorda.kz/upload/media/files/ a0632264810b20c36ed2a4f55d095ad2.docx [in Russian].

3. Kalinin V.A., Grigor'eva A.S. Innovacii v transportnoj otrasli: jeffekt ot vnedrenija tehnologii SAW RFID // Nauka i transport. Modernizacija zheleznodorozhnogo transporta. - 2013. - № 2(6). - S. 20-21 [in Russian].

4. Panova I.V. Upravlenie operacionnoj logisticheskoj dejatel'nost'ju pri vzaimodejstvii zheleznodorozhnogo i vodnogo transporta. Avtoreferat dissertacii na soiskanie uchenoj stepeni kandidata 
jekonomicheskih nauk. - Saratov, 2012. - 16 s.

5. Dorofeev A. Trendy razvitija transportnoj logistiki // Logistika. - 2011 . - №2. - S. 21-23 [in Russian].

6. Astaf'eva N.V., Puzanova E.A. Vybor kanala raspredelenija gotovoj produkcii kak vazhnejshij aspekt raspredelitel'noj logistiki. Logistika, innovacii, menedzhment v sovremennoj biznes-srede // Sbornik nauchnyh trudov. - Tom 2. - Saratov, 2010. - S. 6-10 [in Russian].

7. Mazlov I.I., Gavrilov S.I. Sovremennye problemy transportnoj logistiki v Rossii i puti ih reshenija // Mezhdunarodnyj nauchno-tehnicheskij zhurnal «Teorija. Praktika. Innovacii», aprel' 2018.

8. Mozharova V.V. Transport v Kazahstane: sovremennaja situacija, problemy i perspektivy razvitija: Monografija. - Almaty: KISI pri Prezidente RK, 2011. - 216 s. [in Russian].

9. Ernijazova Zh.N., Talapbaeva G.E., Kultanova N.B. Predposylki formirovanija klastera transportnoj logistiki v Respublike Kazahstan // Mezhdunarodnyj zhurnal prikladnyh i fundamental'nyh issledovanij. - 2014. - № 5-1. - S. 132-135 [in Russian].

10. Razvitie innovacij i progressivnyh tehnologicheskih ukladov v jekonomike Kazahstana v uslovijah industrial'noj modernizacii: instituty, mehanizmy i prioritety: Monografija / Pod red. F. Dnishev, F. Al'zhanova. - Vena, Avstrija: Associacija perspektivnyh issledovanij i vysshego obrazovanija «Vostok-Zapad», 2015. - 532 s. [in Russian].

11. Dorozhnaya karta po formirovaniyu prodovol'stvennogo poyasa goroda Astany' na 2018 2021 gody ' (s izmeneniyami ot 12.11.2018 g.). Postanovlenie Pravitel'stva Respubliki Kazakhstan ot 13 oktyabrya 2017 goda № 645 [in Russian].

12. Prodovol'stvennyj pojas Astany: Rezul'taty, plany i poruchenija. Kapital. [Jelektronnyj resurs]. - Rezhim dostupa://https://kapital.kz/economic/73480/prodovol-stvennyy-poyas-astany-rezul-tatyplany-i-porucheniya.html [in Russian].

13. Oficial'nyj informacionnyj resurs Prem'er-Ministra Respubliki Kazahstan. Regional'naja integracija, podderzhka jeksporta, vnedrenie cifrovizacii-kak razvivaetsja torgovaja otrasl' Kazahstana. 20 avgusta 2020. https://primeminister.kz/ru/news/reviews/regionalnaya-integraciya-podderzhkaeksporta-vnedrenie-cifrovizacii-kak-razvivaetsya-torgovaya-otrasl-kazahstana-2073830 [in Russian].

14. Satova R.K., Suhova L.K., Guseva L.Ju. Transport - strategicheskij resurs obespechenija bezopasnosti i povyshenija konkurentosposobnosti Kazahstana // Mezhd. nauch.-prakt. konf. «Transport Evrazii XXI veka». - Almaty, 2006. - 17-21 s. [in Russian].

15. Kaldybaev S.U., Bizhanova A.S., Ahmedijarova A.T., Kasymova D.T. Avtomattandyrylғan basқaru zhyjeleri: Оқиlуқ. - Almaty: DYuir, 2011. - 232 b. [in Kazakh].

\section{ЛИТЕРАТУРА}

1. Стратегия «Казахстан-2050»: новый политический курс состоявшегося государства Послание Президента Республики Казахстан - Лидера Нации Н.А. Назарбаева народу Казахстана. - Астана, 14 декабря 2012 года. http://adilet.zan.kz/rus/docs/K1200002050/links

2. Государственная программа «Цифровой Казахстан». Постановление Правительства Республики Казахстан от 12 декабря 2017 года № 827. https://www.akorda.kz/upload/media/ files/a0632264810b20c36ed2a4f55d095ad2.docx

3. Калинин В.А., Григорьева А.С. Инновации в транспортной отрасли: эффект от внедрения технологии SAW RFID // Наука и транспорт. - 2013. - № 2(6). - С. 20-21.

4. Панова И.В. Управление операционной логистической деятельностью при взаимодействии железнодорожного и водного транспорта: Автореф. дисс. на соиск. уч. степ. к.э.н. - Саратов, 2012. - 16 с. 


\section{Менеджмент жсәне маркетинг / Менеджмент и маркетинг}

5. Дорофеев А. Тренды развития транспортной логистики // Логистика. - 2011. № 2. - С. 21-23.

6. Астафьева Н.В., Пузанова Е.А. Выбор канала распределения готовой продукции как важнейший аспект распределительной логистики. Логистика, инновации, менеджмент в современной бизнес-среде // Сборник научных трудов. - Т. 2. - Саратов, 2010. - С. 6-10.

7. Мазлов И.И., Гаврилов С.И. Современные проблемы транспортной логистики в России и пути их решения // Междунар. науч.-технич. журнал «Теория. Практика. Инновации», апрель 2018.

8. Можарова В.В. Транспорт в Казахстане: современная ситуация, проблемы и перспективы развития. - Алматы: КИСИ при Президенте РК, 2011. - 216 с.

9. Ерниязова Ж.Н., Талапбаева Г.Е., Култанова Н.Б. Предпосылки формирования кластера транспортной логистики в Республике Казахстан // Международный журнал прикладных и фундаментальных исследований. - 2014. - № 5-1. - С. 132-135.

10. Развитие инноваций и прогрессивных технологических укладов в экономике Казахстана в условиях индустриальной модернизации: институты, механизмы и приоритеты: Монография / Под ред. Ф. Днишев, Ф. Альжанова. - Вена, Австрия: Ассоциация перспективных исследований и высшего образования «Восток-Запад», 2015. - 532 с.

11. Дорожная карта по формированию продовольственного пояса города Астаны на 2018-2021 годы (с изм. от 12.11.2018 г.). Постановление Правительства Республики Казахстан от 13 октября 2017 года № 645.

12. Продовольственный пояс Астаны: Результаты, планы и поручения. Капитал. [Электронный ресурс]. - Режим доступа: //https://kapital.kz/economic/73480/prodovol-stvennyypoyas-astany-rezul-taty-plany-i-porucheniya.html

13. Официальный информационный ресурс Премьер-Министра Республики Казахстан. Региональная интеграция, поддержка экспорта, внедрение цифровизации - как развивается торговая отрасль Казахстана. 20 августа 2020. https://primeminister.kz/ru/news/reviews/ regionalnaya-integraciya-podderzhka-eksporta-vnedrenie-cifrovizacii-kak-razvivaetsya-torgovayaotrasl-kazahstana-2073830

14. Сатова Р.К., Сухова Л.К., Гусева Л.Ю. Транспорт - стратегический ресурс обеспечения безопасности и повышения конкурентоспособности Казахстана // Межд. науч.практ. конф. «Транспорт Евразии XXI века». - Алматы, 2006. - 17-21 с.

15. Қалдыбаев С.У., Бижанова А.С., Ахмедиярова А.Т., Қасымова Д.Т. Автоматтандырылған басқару жүйелері: Оқулық. - Алматы: Дәуір, 2011. - 232 б.

\section{Б.К. Жуманова, Н.М. Алашбаева, А.Б. Имашев, К.К. Байгабулова \\ ҚАЗАҚСТАННЫҢ КӨЛІКТІК-ЛОГИСТИКАЛЫҚ ЖУЙЕСІН БАСҚАРУДА ЦИФРЛЫҚ ТЕХНОЛОГИЯНЫ ЕНГІЗУ}

\section{Андатпа}

Мақалада Қазақстан экономикасының көлік-логистикалық секторын цифрландыру мәдениетін қалыптастыру шарттары қарастырылған және жаңа технологияларды енгізу мен қолданыстағы бизнес-процестерді жетілдіру арқылы экономикалық салаларды дамытудың негізгі принциптеріне негізделген «Цифрлық Қазақстан» мемлекеттік бағдарламасын іске асырудың негізгі кезеңдері қарастырылған. Авторлар көлік-логистикалық құрылымын дамытудың мақсаттары мен міндеттерін анықтады. Интеллектуалды көлік жүйесі жобасының бірізділігі көрсетілген. 
Қазақстан Республикасы экономикасының заманауи дамуы шеңберінде көлік саласын зерттеу нәтижелері бойынша мақала авторлары логистикалық қызметтердің жоғары шығындарымен және еңбек өнімділігінің төмендігімен байланысты одан әрі дамудың негізгі проблемалық аспектілері мен шектеулерін анықтады. Зерттеу нәтижелері бойынша Қазақстан экономикасының секторларында көлік-логистикалық қызметтерді цифрлық модернизациялау қажеттілігі негізделді.

\title{
Б.К. Жуманова, Н.М. Алашбаева, А.Б. Имашев, К.К. Байгабулова \\ ВНЕДРЕНИЕ ЦИФРОВИЗАЦИИ В УПРАВЛЕНИЕ ТРАНСПОРТНО- ЛОГИСТИЧЕСКОЙ СИСТЕМОЙ КАЗАХСТАНА
}

\begin{abstract}
Аннотация
В представленной статье приведены условия формирования культуры цифровизации транспортно-логистической сферы экономики Казахстана и рассмотрены основные этапы реализации государственной программы «Цифровой Казахстан», на основе основных принципов развития отраслей экономики, за счет внедрения новых технологий и совершенствования действующих бизнес-процессов. Авторами определены цели и задачи развития транспортно-логистической структуры. Показана согласованность функционирования проекта интеллектуальной транспортной системы.

По результатам исследования транспортной отрасли в рамках современного развития экономики Республики Казахстан авторы статьи выделили основные проблемные стороны и сдерживающие факторы дальнейшего развития, связанные с высокими затратами логистических услуг и низкой производительностью труда. По итогам проведенного исследования обоснована необходимость цифровой модернизации транспортно-логистических услуг в отраслях экономики Казахстана.
\end{abstract}

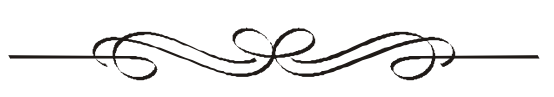


Менедюмент жюәне маркетинг / Менеджмент и маркетинг

DOI 10.52260/2304-7216.2020.4(41).19

ӘОЖ 332.22

FTAMP 06.52.35

Ж.Р. Аркенова*, PhD докторанты, аzа оқытушыь

Қазтұтынуодавы Қараванды экономикальқ университеті

Қараванды к.

e-mail: arkenova1975@mail.ru

* - негізгі автор (хат-хабарларға арналған автор)

\section{МЕМЛЕКЕТТІК СТРАТЕГИЯЛЫК ЖОСПАРЛАРДЫ ІСКЕ АСЫРУДА ҒЫЛЫМИ-ЗЕРТТЕУ ҰЙЫМДАРЫНЫН ӘЛЕУЕТІН ПАЙДАЛАНУ МУМКІНДІКТЕРІ}

Мақ̆алада зерттеу ұйымдарының выльми әлеуетін белсенді пайдалану арқылы мемлекеттік стратегиялық жоспарларды іске асыру қарастырылады. Автор елдің стратегиялық жоспарларын дамытудың вылыми-ддістемелік негізін құрайтын зерттеу ұйымдарымен байланысты вальмдардың іргелі және құолданбалы вылыми еңбектерін құарастырzан. Мақ̧алада рецензияланатын выльлми басылымдарда ұлттық вылыли қовамдастық өкілдері жариялаган елдердің вылыми-зерттеу мақалаларының саны туралы статистикалық деректер талдандан.

Автор гылыми-зерттеу ұйымдарының көмегімен стратегиялық жоспарлардың выльмми әлеуетін дамытува ықпал ететін нақты ұсыныстар берген: құолданбаль вылыми зерттеулердің тақырыбы мен мазмұны елдің стратегиялық жоспарларының негізгі міндеттеріне сәйкес келуі керек; бірлескен вылыми-зерттеу жұмыстарын орындау кезінде зерттеу институттарының орналасуын ескеру құжжет; саладан тәжірибелі мамандарды жалдау қ̧ажет.

Кілт сөздер: выльмм, вылыми әлеует, стратегиялық жоспар, вылыми-зерттеу ұйымдары, университет, зерттеу институты, инновациялық жүйе, инновациялар, кәсіпкерлік сектор, иифрлық экономика, мемлекеттік бавдарламалар.

Ключевые слова: наука, научный потенииал, стратегический план, научно-исследовательские организаций, университет, исследовательский институт, инновационная система, инновачии, предпринимательский сектор, иифровая экономика, государственные программыл.

Keywords: science, scientific potential, strategic plan, research organizations, university, research institute, innovation system, innovation, business sector, digital economy, government programs.

Кіріспе. Қазіргі жағдайда стратегиялық жоспарлау жүйесін мемлекеттік басқару тетігі ретінде ғылыми-әдістемелік сүйемелдеу стратегиялық жоспарлау құжаттарында қамтылған мәліметтердің үлкен ауқымын талдаудың біріздендірілген алгоритмдерін қалыптастыру және енгізу жағына ауысады. Күрделі әлеуметтік-экономикалық жүйелердің динамикасын, экономика салалары мен әлеуметтік салалардың жағдайын бағалау әдістерін және оңтайлы даму бағытатарын таңдау, анықталған қауіптер мен қатерлерді жеңу үшін басқарушылық шешімдер қабылдауды модельдеу үшін бағдарла- малық-математикалық құралдарды кеңінен қолдану нақты ғылыми негізделген ұсыныстарды қажет етеді.

Бұл бағытта Қазақстанда үлкен жұмыстар атқарылып келеді. Ғылыми-зерттеу ұйымдарын мемлекеттік қолдау саясаты мақсатты түрде жүзеге асырылуда. Осы орайда ұйымдарды дамыту елде іске асырылып жатқан мемлекеттік стратегиялық жоспарлармен тығыз байланыста жүзеге асырылады. Бірақ сонымен бірге дамып келе жатқан жүйенің болашақ мақсаттары да, даму мәселелері де бар.

Әлемдік тәжірибеде мемлекеттік стра- 
тегиялық жоспарларды іске асыру зерттеу ұйымдарының ғылыми әлеуетін белсенді пайдалануға, бизнестің, ғылым мен білімнің өзара тиімді мүдделеріне негізделеді. Бұдан қоғам, мемлекет үлкен әсер алады. Біздің республика үшін бұл бағыт өте маңызды.

Қазақстанның ғылыми-зерттеу бағдарламалары мен жобаларын іске асыру бойынша елеулі ғылыми әлеуеті бар. Алайда, ең iрi ұйымдарда зерттеу қызметінің шоғырлануы, ғылыми зерттеулерге ғалым қызметкерлердің қатысу деңгейінің төмендігі, жастардың әлсіз тартылуы кедергі жасап отыр. Сондықтан бұл мәселелерді қарастыру өзекті болып келеді.

Мақаланың мақсаты мемлекеттік стратегиялық жоспарларды іске асыруда зерттеу ұйымдарының ғылыми әлеуетін қарастыру болып табылады.

Мақаланың теориялық және әдіснамалық негізін университеттердің инновациялық және ғылыми қызметі мәселелері бойынша отандық және шетелдік ғалымдардың еңбектері құрады. Зерттеудің әдіснамалық негізі ретінде жүйелік, функционалдық және статистикалық талдаулар қолданылды.

Әдебиеттік шолу. Қазіргі уақытта цифрлық экономиканың ғылыми-әдіснамалық ортасын құратын мемлекеттік стратегиялық жоспарлау саласындағы зерттеу ұйымдарының іргелі және қолданбалы ғылыми еңбектері бар.

Шетелдік ғалымдар (Bramwell A., Wolfe A.) білімге негізделген экономикада университеттер технологиялық инновацияларды ілгерілетуде белсенді рөл атқаратынын атап өткен [1].

Атап айтқанда, жасанды интеллект технологиялары әлеуметтік-экономикалық дамуды стратегиялық жоспарлау және ұлттық қауіпсіздікті қамтамасыз ету жүйесінде маңызды рөл атқарады.

Есенгельдин Б.С., Ситенко Д.А. сияқты ғалымдардың ойынша, Қазақстанда университеттердің инновациялық эконо- микадағы маңызды рөлін түсіну жақында ғана пайда болды, мұны бірқатар заманауи отандық зерттеулер көрсетеді. Егер бұрын ғылымды елдің инновациялық дамуының алғышарты ретінде қайта жандандыру қажеттілігі туралы айтылған болса, ал қазіргі ғылыми еңбектерде университеттерді инновациялық үдеріске тарту қажеттілігі талқыланады [2].

Тургинбаева А.Н. және басқалар инновациялық нысандағы университеттерде жан-жақты дамытқан жөн деп санайды. Мұндай университеттер сыртқы орта талаптарына көбірек бейімделген және ұжымдық кәсіпкерліктің жаңа нысандарын дамытуға дайын [3].

Олар сондай-ақ шетелдік ғалымдармен ғылыми ынтымақтастыққа бағытталуы және ғылымды қажетсінетін өнімнің шетелдік нарықтарға шығуына ие болуы мүмкін.

Университеттерде жүргізілген ғылыми зерттеулердің нәтижелері жаңа технологияларға айналады, ал бұл технологиялар өз кезегінде қоғам мен ел экономикасының игілігі үшін пайдаланылады [4].

Власов В.А. және басқалардың пікірінше, өңірлік инновациялық жүйеде жоғары оқу орындары келесі қызмет бағыттарын дамытуға қатысады:

- коммерцияландыру үдерісіне қатысуға қабілетті зияткерлік меншік объектілерін құру;

- инновациялық инфрақұрылымды құру және дамыту (инновациялық-технологиялық орталықтар, коммерцияландыру офистері, технологиялар трансфері орталықтары, бизнес-инкубаторлар, технопарктер, сондай-ақ ғылым мен кәсіпкерліктің өзара іс-қимылының басқа да нысандары);

- жоғары оқу орындарымен өзара ісқимыл жасайтын шағын инновациялық кәсіпорындар құру;

- инновациялық экономика үшін мамандар даярлау;

- бизнес-ортада инновациялық мәдениетті қалыптастыру [5]. 
Көріп отырғанымыздай, зерттеу ұйымдары мемлекеттік және жергілікті органдарға тұжырымдамалық стратегиялар мен бағдарламаларды әзірлеуге ықпал етеді.

Негізгі бөлім. Ғылыми-зерттеу саласында, сондай-ақ қоғам өмірінің басқа салаларында реформалар қажет. Әзірленетін тетіктер экономика саласында іске асырылатындарға барабар болуы керек, яғни нарықтық өзгерістерге негізделуі және логикалық дәйектілікті қамтығаны жөн: ғылыми идея, ғылыми зерттеулер және эксперименттік әзірлемелер, содан кейін оларды өнеркәсіптік жағдайда тікелей жүзеге асыру, сондайақ мамандарды, кадрларды даярлау.

Мемлекеттік жоспарлардың тиімділігіне белгілі бір мекемелер (ғылыми-зерттеу институттары, жоғары оқу орындары) тиімді жұмыс істеген кезде емес, олар инновацияларды құрудың ұжымдық жүйесінің элементтері ретінде бір-бірімен өзара ісқимыл жасаған және ұлттық әлеуметтік институттарды ескерген кезде қол жеткізіледі.

Ұлттық инновациялық жүйеге қаты- сушылардың қызметін тікелей реттеуге мемлекеттік қатысудың мөлшері мен дәрежесін айқындау маңызды міндет болып табылады.

Оны шешудің негізі инновациялық саясатты жүзеге асырудағы мемлекеттің қызметтің болуы керек. Бір жағынан, мемлекет тиісті заңнамалық актілерді қабылдау арқылы экономикалық орта құруды анықтағаны жөн, екінші жағынан, өндірістік және экономикалық құрылымдар кешенінің иесі ретінде жұмыс істеуі және оларды дамытуға инвестициялар салуы қажет.

Ғылыми-зерттеу белсенділігінің деңгейі бойынша әлем елдерінің рейтингісі арқылы ұлттық ғылыми қоғамдастықтардың өкілдері рецензияланатын ғылыми басылымдарда жариялаған ғылыми-зерттеу мақалаларының саны туралы статистикалық деректерді қарастыруға болады. Рецензияланатын ғылыми-зерттеу жарияланымдарының көлемі бүкіл әлемде, сондай-ақ жекелеген елдер бойынша ғылыми-зерттеу және технологиялық белсенділік туралы жалпы түсінік береді (1-кесте).

1 -кесте

\section{Ғылыми-зерттеу белсенділігі бойынша мемлекеттердің 2019 жылғы рейтингісі*}

\begin{tabular}{|l|l|r|}
\hline \multicolumn{1}{|c|}{ Рейтинг } & \multicolumn{1}{|c|}{ Мемлекет } & Мақала саны \\
\hline 1 & Қытай & 528263 \\
\hline 2 & Америка Құрама Штаты & 422808 \\
\hline 3 & Үндістан & 135788 \\
\hline 4 & Германия & 104396 \\
\hline 5 & Жапония & 98793 \\
\hline 6 & Ұлыбритания & 97681 \\
\hline 7 & Ресей & 81579 \\
\hline$\ldots$. & & 2367 \\
\hline 61 & Қазақстан & \\
\hline
\end{tabular}

*Автормен [6] негізінде әзірленген

Көріп отырғанымыздай, ғылыми-зерттеу қызметінің деңгейі бойынша бірінші орынды Қытай алады. Бүгінгі таңда Қытайда, әлемнің көптеген елдеріндегідей (АҚШ, Үндістан, Ресей) сараптамалық құрылым- дардың рөлін қайта бағалау жүріп жатыр. Барлық елдер зерттеу институттарына деген көзқарасын өзгертті, олардың елдің ішкі және сыртқы саясатының стратегиялық бағыттары бойынша мемлекеттік шешімдерді 
әзірлеу үдерісінде маңыздылығын арттырды.

Қытайдың барлық ғылыми-сараптамалық институттарын 3 шартты санатқа бөлуге болады [7]:

- мемлекеттік талдау орталықтары. Бірінші санат - Қытайдың мемлекеттік кеңесімен және басқа да билік құрылымдарымен тығыз байланысқан ең ықпалды құрылымдар. Олардың басты міндеті - интеллектуалды өнімді шығару және оны шешім қабылдайтын тікелей саяси тұлғаларға жеткізу;

- мамандандырылған академиялық зерттеу институттары. Бұл санат Қытайдың Қоғамдық ғылымдар Академиясымен біріктірілген институттардан тұрады. Бұл орталықтар аз әсер етеді, өйткені олардың қызметі академиялық зерттеулерге, сондай-ақ тұжырымдамалық ұзақ мерзімді стратегиялар мен бағдарламаларды жасауға негізделген;

- университеттермен байланысты са- раптамалық орталықтар. Үшінші санатқа Қытай университеттерімен байланысқан орталықтар кіреді. Қытай үкіметі осы санаттағы институттарды негізінен шет елдермен мәдени-гуманитарлық байланыстарды кеңейту үшін пайдаланады.

Қазақстан Республикасында зерттеу ұйымдарына, ең алдымен, индустриялықинновациялық бағдарламалар шеңберінде құрылатын ғылыми-зерттеу институттарын, университеттерді жатқызған жөн. Олар өз қызметінің сипатына қарай әр түрлі деңгейдегі жаңа білім мен инновациялардың көшбасшылары болып табылады.

Қазақстан Республикасының ғылымизерттеу ұйымдарының құрылымын негізгі 4 санатқа бөледі:

- мемлекеттік сектор;

- жоғары кәсіби білім беру секторы;

- коммерциялық сектор;

- коммерциялық емес сектор (2-кесте).

Қазақстан Республикасында ғылыми-зерттеу жұмыстарымен айналысатын ұйымдар саны*

\begin{tabular}{|l|r|r|r|c|}
\hline \multicolumn{1}{|c|}{ Ұйымдар } & 2017 ж. & 2018 ж. & 2019 ж. & $\begin{array}{c}2017 \text { ж. } \\
\text { мен 2019 ж. } \\
\text { арасындағы } \\
\text { өзгеріс }\end{array}$ \\
\hline Барлығы & 386 & 384 & 386 & - \\
\hline Мемлекеттік сектор & 101 & 103 & 100 & -1 \\
\hline Кәсіптік жоғары білім секторы & 99 & 95 & 92 & -7 \\
\hline Кәсіпкерлік сектор & 146 & 149 & 158 & +12 \\
\hline Коммерциялық емес сектор & 40 & 37 & 36 & -4 \\
\hline
\end{tabular}

*Автормен [8] негізінде әзірленген

Кейінгі жылдары кәсіпкерлік секторда құрылған ғылыми-зерттеу жұмыстарымен айналысатын ұйымдардың саны өсу үстінде. Егердің олардың саны 2017 жылы 146 болса, ал 2019 жылы 158 бірлікке жеткен.

Соңғы үш жылғы мәліметтер ғылымизерттеу жұмыстарымен айналысатын ұйымдар санының өзгермегенін көрсетіп отыр. Дегенмен, кәсіптік жоғары білім және ком- мерциялық емес секторларда ғылыми-зерттеу ұйымдары азайып келеді.

Институттарды реформалау үдерістерінің нәтижесінде жұмысшылар саны едәуір төмендеген. Олардың қызметін қаржыландыру шарттары да теріс әсер етті: бюджеттен қаражаттың уақытылы бөлінбеуі, ғылыми қызметкерлер жалақысының төмендігі. Сондай-ақ, көптеген ғылыми бағыттар бойын- 
ша ғылыми зерттеулер тақырыбындағы сабақтастық үзілді. Ғылыми салаға жас ағымның күрт төмендеуін атап өткен жөн. Бұл ғылым мен экономиканы дамытудың басым бағыттарын кадрлармен қамтамасыз ету үшін үлкен қиындықтар туғызады.

Мамандануы әр түрлі масштабтағы нақты қолданбалы мәселелерді әзірлеуге және шешуге тікелей бағытталған салалық коммерциялық ғылыми-зерттеу институттарын атап өткен жөн. Оларға көптеген басқа жобалау және басқа да институттар, соның ішінде ірі кәсіпорындардың ғылымизерттеу, жобалау бөлімшелері кіреді.

Экономиканы дамытудағы әлемдік тәжірибе көрсетіп отырғандай, мемлекеттің рөлі тиісті саясатты әзірлеу үдерісімен, елдегі макроэкономикалық тұрақтылықты қамтамасыз етумен шектелмейді. Мемлекет бұдан басқа экономикалық үдерістерде үйлестіру мен стратегиялық бағыттағы қызметтерді жүзеге асыруы тиіс. Оларды іске асыру тетіктерінің ішінде ғылыми-зерттеу институттарына маңызды рөл тиесілі. Iс жүзінде олар негізінен мемлекеттің стратегиялық жоспарларын іске асыруға ықпал ететін мамандандырылған ұйымдар болып табылады. Ғылыми-зерттеу ұйымдарының рөлін үш жақты қарастыруға болады.

Біріншіден, мемлекеттік ғылыми-зерттеу институттары зерттеу үшін барлық ресурстарды пайдаланады. Университеттер де көп мөлшерде қаражат тұтынса да, ресурстардың бір бөлігін зерттеуге жұмсайды, ал қалған бөлігін білім беруге жібереді.

Екіншіден, зерттеу нәтижелерінің сапасы мемлекеттік зерттеу институттары мен кәсіпкерлік секторда әр түрлі болады. Кәсіп- керлік сектордың көптеген ғылыми жобалары өндірісте орындалғанымен, олардың көпшілігін ғалымдар емес, өндіріс мамандары жасайды.

Үшіншіден, кәсіпкерлік сектор ұйымының ғалымдары университеттерде жұмыс істейтін ғалымдарға қарағанда, зерттеуді іс жүзінде енгізу арқылы табысқа қол жеткізеді. Сонымен бірге, мемлекеттік зерттеу институттарындағы зерттеушілердің көпшілігі мемлекеттік бағдарламаларды жүзеге асыруда тиісті зерттеу нәтижелерін береді.

Қорытынды. Сонымен, ғылыми-зерттеу ұйымдарын стратегиялық жоспарларды іске асыруға қолдану үшін мынадай бағыттарды ұсынуға болады:

- қолданбалы ғылыми зерттеулердің тақырыбы мен мазмұны елдің стратегиялық жоспарларының негізгі міндеттеріне сәйкес келуі тиіс. Сондықтан зерттеу ұйымдары стратегиялық жоспарлаудың базалық құжаттарында белгіленген мемлекеттік басқару тетіктерін жетілдірудің барлық міндеттерін ескергені жөн;

- бірлескен ғылыми-зерттеу жұмыстарын орындау кезінде зерттеу институттарының орналасқан жерін анықтап алу керек. Географиялық жақындық білім мен инновацияны беру үшін маңызды, өйткені ол әр түрлі ұйымдардың зерттеушілері арасындағы өзара әрекеттесуді және кеңістікті бөлісу мүмкіндігін арттырады;

- саладан тәжірибелі мамандарды жалдау қажет. Ғылыми зерттеулердің нәтижелері тәжіриебелік бағытта болуы керек, сондықтан нәтижелерді өндірістік қызметте жедел пайдалану үшін нақты ұсыныстар беретін мамандар тартылуы тиіс.

\section{ӘДЕБИЕТТЕР}

1. Bramwell A., Wolfe A. Universities and regional economic development: The entrepreneurial University of Waterloo // Research Policy. - 2008. - T. 37. - № 8. - Р. 1175-1187.

2. Есенгельдин Б.С., Ситенко Д.А. Развитие университета в рамках формирования инновационной экономики // Саясат Policy. - 2011. - № 2. - C. 4-7.

3. Тургинбаева А.Н., Садыханова Г.А., Танассогла Ю., Тарабелла А.А. Предпринима- 
тельские университеты в казахстанском социально-экономическом ландшафте // Вестник КазНУ, серия Экономическая. - 2018. - № 3(125). - С. 117-126.

4. Dalmarco, Zawislak P., Hulsink W., Brambilla F. Knowledge flow in industry-university relations: a comparison between the Netherlands and Brazil // Paper presented at the 38th EIBA Annual Conference. - Brighton, 2012. - P. 79-85.

5. Власов В.А., Дмитриенко В.П., Клименов В.А., Негруль В.В., Селиванова Е.Е., Меиснер М.Н. Роль университета в формировании региональнои инновационной системы на примере Томского политехнического университета // Инновации. - 2006. - № 8. - C. $36-40$.

6. Рейтинг стран мира по уровню научно-исследовательской активности (2019). https:/ /gtmarket.ru/ratings/scientific-and-technical-activity

7. Китайские «мозговые центры» и Центральная Азия: новая оценка. http://twesco.org/ $\mathrm{ru} / 2019 / 05 / 20 / 370 /$

8. Қазақстанның ғылымы және инновациялық қызметі. 2015-2019 жылдар статистикалық жинағы. - Нұр-Сұлтан: Қазақстан Республикасы Ұлттық экономика министрлігі Статистикалық комитеті. - 2020. - 78 б.

\section{REFERENCES}

1. Bramwell A., Wolfe A. Universities and regional economic development: The entrepreneurial University of Waterloo // Research Policy. - 2008. - T. 37. - № 8. - P. 1175-1187.

2. Esengel'din B.S., Sitenko D.A. Razvitie universiteta v ramkah formirovanija innovacionnoj jekonomiki [Development of the University as part of the formation of an innovative economy]// Sajasat Policy. - 2011. - № 2. - S. 4-7 [in Russian].

3. Turginbaeva A.N., Sadyhanova G.A., Tanassogla Ju., Tarabella A.A. Predprinimatel'skie universitety v kazahstanskom social'no-jekonomicheskom landshafte [Entrepreneurial universities in Kazakhstan's socio-economic landscape] // Vestnik KazNU, serija Jekonomicheskaja. - 2018. № 3(125). - S. 117-126 [in Russian].

4. Dalmarco, Zawislak P., Hulsink W., Brambilla F. Knowledge flow in industry-university relations: a comparison between the Netherlands and Brazil // Paper presented at the 38th EIBA Annual Conference. - Brighton, 2012. - P. 79-85.

5. Vlasov V.A., Dmitrienko V.P., Klimenov V.A., Negrul' V.V., Selivanova E.E., Meisner M.N. Rol' universiteta $\mathrm{v}$ formirovanii regional'noi innovacionnoi sistemy na primere Tomskogo politehnicheskogo universiteta [The role of the University in the formation of a regional innovation system on the example of Tomsk Polytechnic University] // Innovacii. - 2006. - No. 8. - S. 36-40 [in Russian].

6. Rejting stran mira po urovnju nauchno-issledovatel'skoj aktivnosti (2019) [Ranking of world countries by level of research activity]. https://gtmarket.ru/ratings/scientific-and-technical-activity [in Russian].

7. Kitajskie «mozgovye centry» i Central'naja Azija: novaja ocenka [Chinese think tanks and Central Asia: a new assessment]. http://twesco.org/ru/2019/05/20/370/ [in Russian].

8. Каzaқstannyn gylymy zhane innovacijalyk kyzmeti. 2015-2019 zhyldar statistikalyk zhinagy [Science and innovation activity of Kazakhstan. Statistical collection for 2015-2019.]. - Nur-Sultan: Kazakstan Respublikasy Ulttyk jekonmika ministrligi Statistikalyk komiteti. - 2020. - 78 b. [in Kazakh]. 


\section{Ж.Р. Аркенова}

\section{ВОЗМОЖНОСТИ ИСПОЛЬЗОВАНИЯ ПОТЕНЦИАЛА НАУЧНО-ИССЛЕДОВАТЕЛЬСКИХ ОРГАНИЗАЦИЙ В РЕАЛИЗАЦИИ ГОСУДАРСТВЕННЫХ СТРАТЕГИЧЕСКИХ ПЛАНОВ}

\section{Аннотация}

В статье рассматривается реализация государственных стратегических планов на активном использовании научного потенциала исследовательских организаций. Автором рассмотрены фундаментальные и прикладные научные труды ученых, связанные исследовательскими организациями, которые создают научно-методологическую основу развития стратегических планов страны. В статье проанализирован статистические данные о количестве научно-исследовательских статей стран, опубликованных представителями национальных научных сообществ в рецензируемых научных изданиях.

Автором статьи предложены конкретные рекомендации, способствующие развитие научного потенциала стратегических планов с помощью научно-исследовательских организаций: тематика и содержание прикладных научных исследований должны соответствовать основным задачам стратегических планов страны; при выполнении совместных научно-исследовательских работ учесть расположение исследовательских институтов; необходимо нанимать специалистовпрактиков из отрасли.

\section{Zh. Arkenova \\ OPPORTUNITIES TO USE THE POTENTIAL OF RESEARCH ORGANIZATIONS IN THE IMPLEMENTATION OF STATE STRATEGIC PLANS}

\section{Annotation}

The article deals with the implementation of state strategic plans based on the active use of the scientific potential of research organizations. The author considers fundamental and applied scientific works of scientists associated with research organizations. Which create a scientific and methodological basis for the development of the country's strategic plans. The article analyzes statistical data on the number of research articles of countries published by representatives of national scientific communities in peer-reviewed scientific publications.

The author of the article offers specific recommendations that contribute to the development of the scientific potential of strategic plans with the help of research organizations: the subject and content of applied scientific research should correspond to the main objectives of the country's strategic plans; when performing joint research work, take into account the location of research institutes; it is necessary to hire practitioners from the industry. 
DOI 10.52260/2304-7216.2020.4(41).20

ӘОЖ 338.012

FTAMP 06.71.03

\author{
Б.C. Мухан*, $P h D$ докторанты ${ }^{I}$ \\ А.М. Есиркепова, э.д.д., профессор $^{2}$ \\ А.С. Тулеметова, э.z.к., $п$ пофессор ${ }^{l}$ \\ M. Әуезов атындавы Оңттүстік Қазақ̧стан университеті \\ Шымкент к. \\ Қазақсстан Респуликасы Президенті жанындавы \\ Мемлекеттік басқару академиясы ${ }^{2}$ \\ Шымкент к. \\ e-mail: mukhanbakytzhan@mail.ru \\ * - негізгі автор (хат-хабарларға арналған автор)
}

\title{
ҚАЗАҚСТАН РЕСПУБЛИКАСЫНЫН ЖЕНІЛ ӨНЕРКӘСІП НАРЫҒЫН ДАМЫТУДЫН НЕГІЗГІ БАҒЫТТАРЫ
}

Мақ̆алада тежеуші факторларды ескере отырып, жеңңіл өнеркәсіптің отандық нарыzын дамытудың басым багыттары қарастырылган. Елдің экономикалық және стратегиялық қ̧ауіпсіздігі негізінде жеңіл өнеркәсіптің дамуын зерттеген галымдардың еңбектеріне басты назар аударылган.Статистикалық деректерді талдау барысында жеңіл өнеркәсіп құрылымындагы ең үлкен үлес салмақты тоқыма саласының өнімдері алып отырганы, ал киім өндірісі соңъвы жылдары өз орнын жогалтқ̧аны анықталды.

Авторлардың пікірінше, жеңіл өнеркәсіп нарывында саланы дамытудың негізгі жүйелі мәселелері бар: жеңіл өнеркәсіптің технологиялық артта құлуы; ішкі нарықтавы отандық тауарлардың бәсекеге қ̧абілеттілігінің төмендігі; электрондық сауда нарывының дамымауы; импорттық шикізатқ̧а тәуелділік; саланың инновациялық қызметінің төмен деңгейі; тауарлар сапасының сатып алушылардың құажеттіліктеріне сәйкес келмеуі.

Авторлар Қазақстан Республикасының жеңуіл өнеркәсіп нарывын одан әрі дамыту бойынша нақты ұсыныстар берген: жаңа технологиялар мен инновацияларва ақұа салу; тауарларды жылжыту және тұтынушылардың қъалауын анықтау үшін әлеуметтік желілерді пайдалану; тауарларды өткізу үшін электрондық бизнес модельдерін қолдану.

Кілт сөздер: жеңіл өнеркәсіп, нарық, өңір, шикізат, тауар, бәсеке, тоқыма, киім, технология, инновациялар.

Ключевые слова: легкая промышленность, рынок, регион, сырье, товар, конкуренция, текстиль, одежда, технология, инновации.

Keywords: light industry, market, region, raw materials, product, competition, textiles, clothing, technology, innovation.

Кіріспе. Қазіргі жағдайда жеңіл өнеркәсіп басқа салалармен салыстырғанда аз анықталған аумақтық маманданумен сипатталады, өйткені іс жүзінде әр өңірде оның белгілі бір кәсіпорындары бар. Көбінесе, жеңіл өнеркәсіп салалары өңірлердің ішкі қажеттіліктерін қамтамасыз етеді, өңірлерде орналасқан шаруашылық кешенін толықтырады.

Алайда, елдер арасындағы сауданы жандандыру, халықаралық тауар айналымына жаңа мемлекеттер мен аумақтарды тарту әлемдік нарықты өзгертеді және өндіріс пен нарықты күнделікті сұраныстағы тауарлармен, техникалық мақсаттағы өнімдермен қанықтыру саласындағы халықаралық бәсекелестікті күшейтеді. Әлемдік жеңіл өнеркәсіп халықтың ұлғаюымен, оның әл-ауқатымен, сатып алу қабілетінің артуына байла- 
нысты тұрақты экономикалық өсумен сипатталады. Тиісінше, жеңіл өнеркәсіп өнімдерінің әлемдік нарығы серпіндідамып келеді.

Қазақстан Республикасындағы жеңіл өнеркәсіп нарығын дамыту стратегиясындағы басым бағыттар дамудың негізгі мақсаттарына қол жеткізуге үлкен дәрежеде әсер ететін басқа факторларды ескерместен бұрын, ресурстық толықтыру мен түпкілікті қаржылық нәтижелерге қол жеткізуге арналып отыр. Жеңіл өнеркәсіп кәсіпорындарын дамытудың осы жолын іске асыру үшін кәсіпорындарды дамыту стратегиясын жетілдіруге мүмкіндік беретін және тауарларды нарықта сатудың тиімді әдістері мен құралдарының болуы қажет. Осыған байланысты жеңіл өнеркәсіп кәсіпорындарының өнімдерін нарықта өткізу құралдарын жетілдіруге бағытталған зерттеулер жүргізу қажеттілігі ерекше өзектілікке ие болады.

Мақаланың мақсаты отандық жеңіл өнеркәсіп нарығының әрі қарай дамытудың бағыттарын анықтау болып табылады.

Мақаланың теориялық және әдіснамалық негізін жеңіл өнеркәсіпті дамытуға қатысты отандық және шетелдік ғалымдардың еңбектері құрады. Зерттеудің әдіснамалық негізі ретінде жүйелік және статистикалық талдаулар қолданылды.

Әдебиеттік шолу. Қазіргі жағдайда көптеген ғалымдар саланы техникалық жаңғырту және мемлекеттік қолдау мәселелерін қарастыра отырып, жеңіл өнеркәсіпке елдің экономикалық және стратегиялық қауіпсіздігін қамтамасыз етудегі рөліне ерекше назар аударады.

Н.Н. Жаркованың пікірінше, «жеңіл өнеркәсіп экономикалық және стратегиялық қауіпсіздікті қамтамасыз етуде, еңбекке қабілетті халықты жұмыспен қамтуда және жаңа геосаяси жағдайларда оның өмір сүру деңгейін арттыруда маңызды рөл атқарады» [1].

Жаңғырту мен техникалық қайта жарақтандыруға, саланың әлеуетін оңтайландыруға және қажетті құрылымдық қайта құруларға ықпал ететін ғылыми әлеуетті жедел 176 дамыту есебінен жеңіл өнеркәсіптің серпінді дамуын қамтамасыз ету инновацияларға инвестицияларды тұрақты ұлғайта отырып, өнімдер мен технологияларды жаңарта отырып, жаңа нарықтарды жаулап ала отырып, жеңіл өнеркәсіптің дамуының жаңа кезеңін айқындайды [2].

Печаткина Е.Ю. «жеңіл өнеркәсіп елдегі жалпы экономикалық жағдайға әсер ететінін атап өтті, өйткені, біріншіден, бұл капиталдың жылдам айналымы бар сала; екіншіден, оның технологиялық циклі ауыл шаруашылығын, химия өнеркәсібін және басқа салаларды өз саласына тартады, өндірістің бұл саласы капитал салымдарының салыстырмалы түрде төмен көлеміне, рентабельділіктің жоғары деңгейіне, жоғары ғылымды қажетсінуіне ие» деп көрсетті [3].

Дурру О. ойынша, «қазіргі уақытта жеңіл өнеркәсіп кәсіпорындарын дамыту инновациялық бағыттағы басымдықтарды дамудың негізгі мақсаттарына қол жеткізуге үлкен дәрежеде әсер ететін басқа факторларды ескермей, ресурстық толықтыруды және түпкілікті қаржылық нәтижелерді алуға мүмкіндік болмайды»[4].

Әрине, жеңіл өнеркәсіптің дамуы экономикалық және стратегиялық қауіпсіздікті қамтамасыз етіп ғана қоймай, әлеуметтік бағыттағы мәселелерді шешеді.Жеңіл өнеркәсіптегі капитал жылдам айналу қасиеті болғандықтан, оған әсер ететін факторларды есептеген жөн. Авторлардың пікірінше, кез келген енгізілетін жаңа технологиялар жеңіл өнеркәсіптің серпінді дамуы үшін ғылыми жаңалықтарды ескеруі қажет.

Негізгі бөлім. Қазақстан Республикасында жеңіл өнеркәсіп саласында жұмыс істейтін отандық ұйымдар салалық міндеттерді бірлесіп шешу үшін бірігіп, өзін-өзі реттейтін «Qaz Textile lndustry» жеңіл өнеркәсіп кәсіпорындарының ұлттық бірлестігін құрды.

Ұйым алдына жеңіл өнеркәсіп саласындағы отандық тауарлардың, жұмыстар мен көрсетілетін қызметтердің сапасы мен 
бәсекеге қабілеттілігін арттыру, нарыққа қатысушылардың тұтынушылар алдындағы жауапкершілігін күшейту, экономика мен қоғамның қажеттіліктерін қанағаттандыратын саланы дамыту үшін ғылыми-техникалық технологияларға қол жеткізуді енгізу, саладағы қолданбалы зерттеулер мен тәжірибелік-конструкторлық жұмыстарды дамыту және оларды одан әрі коммерцияландыру жөнінде міндет қойылды [5].

Жалпы, жеңіл өнеркәсіп өнімдерінің отандық нарығы соңғы статистикалық деректерге сәйкес 115,84 млрд теңгеге бағаланады (1-кесте).

\section{Қазақстан Республикасы жеңіл өнеркәсібінің 2015-2019 жылдар} аралығындағы өндіріс көлемі, \%*

\begin{tabular}{|l|r|r|r|r|r|r|}
\hline \multicolumn{1}{|c|}{$\begin{array}{c}\text { Жеңіл өнеркәсіптің } \\
\text { қызмет түрлері }\end{array}$} & $\begin{array}{c}2015 \text { ж., } \\
\text { млрд } \\
\text { теңге }\end{array}$ & $\begin{array}{c}2016 \text { ж., } \\
\text { млрд } \\
\text { теңге }\end{array}$ & $\begin{array}{c}2017 \text { ж., } \\
\text { млрд } \\
\text { теңге }\end{array}$ & $\begin{array}{c}2018 \text { ж., } \\
\text { млрд } \\
\text { теңге }\end{array}$ & $\begin{array}{c}2019 \text { ж., } \\
\text { млрд } \\
\text { теңге }\end{array}$ & $\begin{array}{c}\text { 2015-2019. } \\
\text { жж. өзгерісі } \\
\text { (есе) }\end{array}$ \\
\hline $\begin{array}{l}\text { Тоқыма бұйымдарын } \\
\text { өндіру }\end{array}$ & 29,49 & 37,60 & 43,49 & 52,59 & 60,24 & 2,0 \\
\hline Киім өндіру & 36,11 & 36,55 & 46,01 & 36,57 & 43,96 & 1,2 \\
\hline $\begin{array}{l}\text { Былғары және оған } \\
\text { жататын өнімдерді өндіру }\end{array}$ & 5,99 & 8,31 & 8,59 & 10,19 & 11,64 & 1,9 \\
\hline Барлығы & 71,59 & 82,46 & 98,09 & 99,35 & 115,84 & 1,6 \\
\hline
\end{tabular}

Авторлармен [6] негізінде әзірленген

Қазақстан Республикасында тоқыма бұйымдарының өндірісі 2015 жылдан бастап 2019 жылға дейін 2 есеге, киім өндірісі 1,2 есеге, былғары бұйымдарының өндірісі 1,9 есеге өскен. Жалпы соңғы бес жылда саланың тұрақты оң серпіні байқалуда, өсім орта есеппен 1,6 есе көрсеткішті құрайды.

Саланың негізгі мәселелерінің ішінде мыналарды бөліп көрсетуге болады:

- техникалық артта қалу;
- білікті мамандардың тапшылығы;

- шикізат импортына тәуелділік.

Саланы дамытудың негізгі бағыты мемлекеттік тапсырыс. Бүгінде өндірістердің бір бөлігі қарулы күш құрылымдары мен бөлімшелеріне арналған нысанды киім шығара отырып, осы жүйеде көбірек жұмыс істейді.

Жеңіл өнеркәсіп құрылымындағы ең үлкен үлес салмақты тоқыма саласының өнімі алады (2-кесте).

2-кесте

Қазақстан Республикасы жеңіл өнеркәсібінің 2015-2019 жылдар аралығындағы өндірісінің құрылымы, \%*

\begin{tabular}{|l|r|r|r|r|r|}
\hline \multicolumn{1}{|c|}{$\begin{array}{c}\text { Жеңіл өнеркәсіптің } \\
\text { қызмет түрлері }\end{array}$} & 2015 ж. & 2016 ж. & 2017 ж. & 2018 ж. & 2019 ж. \\
\hline Тоқыма бұйымдарын өндіру & 41,19 & 45,60 & 44,34 & 52,93 & 52,00 \\
\hline Киім өндіру & 50,44 & 44,32 & 46,91 & 36,81 & 37,95 \\
\hline $\begin{array}{l}\text { Былғары және оған жататын } \\
\text { өнімдерді өндіру }\end{array}$ & 8,37 & 10,08 & 8,76 & 10,26 & 10,05 \\
\hline Барлығы & 100,00 & 100,00 & 100,00 & 100,00 & 100,00 \\
\hline
\end{tabular}

*Авторлармен [6] негізінде әзірленген 


\section{Менеджсмент жюәне маркетинг / Менеджсмент и маркетинг}

Біз жүргізген талдау киім өндірісі жеңіл өнеркәсіп құрылымында өз орнын жоғалтқанын көрсетті, егер 2015 жылы киім өндірісіне 50,44\% тиесілі болса, ал 2019 жылы осы өнімнің үлес салмағы 37,95\%-ды құрайды. Бұл жеңіл өнеркәсіптің ішкі нарығында Қытай мен Түркиядан келетін арзан тауарлардың басым болуына байланысты.
Жеңіл өнеркәсіп экономика саласы ретінде мемлекеттік бюджеттерді қалыптастыруға тікелей қатысады. Ол көптеген салаларды біріктіреді, олардың ішінде тігін, аяқ киім, тоқыма, былғары, аң терісі сияқты негізгі салаларды бөліп көрсетуге болады.

Жеңіл өнеркәсіп өнімдері Қазақстан Республикасының барлық өңірлерінде шығарылады (3-кесте).

3-кесте

\section{Қазақстан Республикасының өңірлері бойынша жеңіл өнеркәсіп өнімінің 2019 жылғы үлесі*}

\begin{tabular}{|l|c|c|}
\hline \multicolumn{1}{|c|}{ Өңірлер } & $\begin{array}{c}\text { Өндірілген өнім } \\
\text { (мың теңге) }\end{array}$ & $\begin{array}{c}\text { Yлесі } \\
(\%)\end{array}$ \\
\hline Қазақстан Республикасы & 115842645 & 100 \\
\hline Шымкент қ. & 25956424 & 22,41 \\
\hline Алматы обл. & 16518973 & 14,26 \\
\hline Алматы қ. & 13468055 & 11,63 \\
\hline Түркістан обл. & 12996286 & 11,22 \\
\hline Павлодар обл. & 6993675 & 6,04 \\
\hline Қарағанды обл. & 5448485 & 4,70 \\
\hline Ақмола обл. & 4980144 & 4,30 \\
\hline Шығыс Қазақстан обл. & 4780059 & 4,13 \\
\hline Нұр-Сұлтан қ. & 4458336 & 3,85 \\
\hline Атырау обл. & 4101264 & 3,54 \\
\hline Қостанай обл. & 3757371 & 3,24 \\
\hline Жамбыл обл. & 3522805 & 3,04 \\
\hline Маңғыстау обл. & 2990811 & 2,58 \\
\hline Ақтөбе обл. & 2146032 & 1,85 \\
\hline Солтүстік Қазақстан обл. & 1602727 & 1,38 \\
\hline Қызылорда обл. & 1234340 & 1,07 \\
\hline Батыс Қазақстан обл. & 886858 & 0,77 \\
\hline
\end{tabular}

*Авторлармен [6] негізінде әзірленген

Қазақстан Республикасы Ұлттық экономика министрлігі Статистика комитетінің 2019 жылғы деректері бойынша жеңіл өнеркәсіп кәсіпорындарының өнімдері мынадай өңірлерде көбірек шығарылады: Шымкент қаласы (22,41\%), Алматы облысы $(14,26 \%)$, Алматы қаласы $(11,63 \%)$ және Түркістан облысы $(11,22 \%)$.

Бұл өңірлердің өндірістік-өнеркәсіптік әлеуеті өңірдің қажеттіліктерін ғана емес, сонымен бірге, әдетте, одан тыс жер- лерге экспортталады. Жеңіл өнеркәсіп көптеген салалармен байланысты және бүкіл халық шаруашылығы кешеніне қызмет етеді. Жеңіл өнеркәсіптің басты ерекшелігі өндіріске салынған қаражаттың тез қайтарылуымен және төмен шығындар арқылы шығарылатын өнім ассортиментінің тез өзгеруімен байланысты.

Жеңіл өнеркәсіп нарығының қазіргі жай-күйін талдау оның дамуында оң үрдістер болған кезде оның экономикалық өсуіне 


\section{Менеджмент жюне маркетинг / Менеджммент и маркетинг}

теріс әсер ететін мәселелер қалып отырғанын көрсетті. Жеңіл өнеркәсіп нарығын дамытудың негізгі жүйелік мәселелеріне мыналар жатады:

- жеңіл өнеркәсіптің технологиялық артта қалуы;

- ішкі нарықтағы отандық тауарлардың әлсіз бәсекеге қабілеттілігі;

- электрондық сауда нарығының дамымауы;

- саланың инновациялық қызметінің төмен деңгейі;

- импорттық шикізатқа тәуелділік;

- тауарлар сапасының сатып алушылардың қажеттіліктеріне сәйкес келмеуі.

Негізінен, бұл жеңіл өнеркәсіптің құрылымдық сәйкессіздігі қазіргі уақытта саланың ауқымы мен мүмкіндіктеріне өнімге деген өсіп келе жатқан сұранысты сапалы қанағаттандыруға, ішкінарықтағы отандық тауарлар үлесінің күрт төмендеуін тоқтата тұруға және елдің ұлттық қауіпсіздігін жоғалту қаупінің алдын алуға байланысты. Тозған және моральдық тұрғыдан ескірген жабдықтар сапалы өнімнің заманауи ассортиментін шығарып қана қоймай, қанағатта- нарлықсыз еңбек жағдайларын жасайды.

Қорытынды. Сонымен, жеңіл өнеркәсіп нарығын әрі қарай дамыту үшін мынадай бағыттарды ұсынуға болады:

- жаңа технологиялар мен инновацияларға қаражат салу қажет. Жеңіл өнеркәсіп кәсіпорындары үшін нанотехнологияларды, наноөнімдерді, автоматтандырылған басқару жүйелерін енгізу, сондай-ақ дизайн мен модельдеуге арналған компьютерлік бағдарламаларды қолданған жөн;

- әлеуметтік желілерді тауарларды жылжыту және тұтынушылардың қалауын анықтау үшін пайдалану. Тұтыну нарығы үшін өнім өндіретін жеңіл өнеркәсіп кәсіпорындарының экономикалық табысы мен нарықтағы алатын орны сатып алушылардың тұтынушылық қалауларын зерттеу саясатының тиімділігіне байланысты;

- тауарларды өткізу үшін электрондық бизнес модельдерін қолдану. Маркетингтің дәстүрлі арналарын пайдалану жеңіл өнеркәсіп тауарларын сатуда тиімсіз болып келеді. Сондықтан тауарларды өткізу үшін электрондық коммерцияның тәсілдерін қолдану қажет.

\section{ӘДЕБИЕТТЕР}

1. Жаркова Н.Н. Стратегия развития легкой промышленности: новые направления и целевые показатели // Экономика, предпринимательство и право. - 2017. - Том 7. - № 4. - C. 253-261.

2. Юань Чжэн. Особенности современного развития легкой промышленности как сектора экономики. https://cyberleninka.ru/article/n/osobennosti-sovremennogo-razvitiya-legkoypromyshlennosti-kak-sektora-ekonomiki

3. Печаткина Е.Ю. Особенности предприятий легкой промышленности // Вестник Челябинского государственного университета. - 2012. - № 8(262). Экономика. - Вып. 36. - C. 117-123.

4. Дурру О. Жеңіл өнеркәсіп кәсіпорындарының инновациялық дамуының ерекшеліктері // ҚазЭҚХСУ Жаршысы. - 2020. - № 2(39). - Б. 176-182.

5. В Казахстане создано национальное объединение предприятий легкой промышленности «QazTextilelndustry». https://informburo.kz/special/v-kazahstane-sozdano-nacionalnoeobedinenie-predpriyatiy-lyogkoy-promyshlennosti-qaz-textile-lndustry.html

6. Қазақстан Республикасы өнеркәсібі жұмысының негізгі көрсеткіштері (2019). Қазақстан Республикасы Ұлттық экономика министрлігінің статистика комитеті. https://stat.gov.kz/ edition/publication/material/4 


\title{
REFERENCES
}

1. Zharkova N.N. Strategija razvitija legkoj promyshlennosti: novye napravlenija i celevye pokazateli [Light industry development strategy: new directions and targets] // Jekonomika, predprinimatel'stvoipravo. - 2017. - Tom 7. - № 4. - S. 253-261 [In Russian].

2. Juan' Chzhjen. Osobennosti sovremennogo razvitija legkoj promyshlennosti kak sektora jekonomiki [Features of modern development of light industry as a sector of the economy]. https:// cyberleninka.ru/article/n/osobennosti-sovremennogo-razvitiya-legkoy-promyshlennosti-kak-sektoraekonomiki [In Russian].

3. Pechatkina E.Ju. Osobennosti predprijatij ljogkoj promyshlennosti [Features of light industry enterprises] // Vestnik Cheljabinskogo gosudarstvennogo universiteta. - 2012. - № 8(262). Jekonomika. - Vyp. 36. - S. 117-123 [In Russian].

4. Durru O. Zhenil onerkasip kasiporyndarynyn innovacijalyk damuynyn erekshelikteri [Features of innovative development of light industry enterprises] // KazEKHSU. - 2020. - № 2 (39). B.176-1727 [In Kazakh].

5. V Kazahstane sozdano nacional'noe obedinenie predprijatij ljogkoj promyshlennosti «Qaz Textile lndustry» [National Association of light industry enterprises «Qaz Textile lndustry» was established in Kazakhstan]. https://informburo.kz/special/v-kazahstane-sozdano-nacionalnoeobedinenie-predpriyatiy-lyogkoy-promyshlennosti-qaz-textile-Industry.html [In Russian].

6. Kazakstan Respublikasy onerkasibi zhumysynyn negizgi korsetkishteri (2019). [Key performance indicators of the industry of the Republic of Kazakhstan (2019)]. Kazakstan Respublikasy Ulttyқ jekonomika ministrliginin statistika komiteti. https://stat.gov.kz/edition/publication/material/4 [In Kazakh].

\author{
Б.С. Мухан, А.М. Есиркепова, А.С. Тулеметова \\ ОСНОВНЫЕ НАПРАВЛЕНИЯ РАЗВИТИЯ РЫНКА \\ ЛЕГКОЙ ПРОМЫШЛЕННОСТИ РЕСПУБЛИКИ КАЗАХСТАН
}

\begin{abstract}
Аннотация
В статье рассматриваются приоритетные направления развития отечественного рынка легкой промышленности с учетом сдерживающих факторов. Основное внимание уделено трудам ученых, которые рассматривают развитие легкой промышленности в контексте экономической и стратегической безопасности страны. В ходе анализа статистических данных выявлено, что наибольший удельный вес в структуре легкой промышленности занимает продукция текстильной отрасли, а производство одежды сдало свои позиции за последние годы.

По мнению авторов, на рынке легкой промышленности имеются основные системные проблемы развития отрасли:технологическая отсталость легкой промышленности; слабая конкурентоспособность отечественных товаров на внутреннем рынке; неразвитость рынка электронной торговли; зависимость от импортного сырья; низкий уровень инновационной деятельности отрасли; несоответствие качества товаров к потребностям покупателей.

Авторами статьи даны конкретные рекомендации по дальнейшему развитию рынка легкой промышленности Республики Казахстан: вложить денежные средства в новые технологии и инновации; использовать социальные сети для продвижения товаров и выяснения потребительских предпочтений покупателей; применять модели электронного бизнеса для сбыта товаров.
\end{abstract}




\title{
B. Mukhan, A. Yessirkepova, A. Tulemetova \\ MAIN DIRECTIONS OF DEVELOPMENT OF THE LIGHTINDUSTRY MARKET \\ OF THE REPUBLIC OF KAZAKHSTAN
}

\begin{abstract}
Annotation
The article considers the priority directions of development of the domestic light industry market, taking into account the constraints. The main attention is paid to the works of scientists who consider the development of light industry in the context of economic and strategic security of the country. The analysis of statistical data revealed that the largest share in the structure of light industry is occupied by textile products and clothing production has lost its position in recent years.

According to the authors, the light industry market has the main systemic problems in the development of the industry: technological backwardness of light industry; weak competitiveness of domestic goods in the domestic market; underdevelopment of the e-Commerce market; dependence on imported raw materials; low level of innovation in the industry; discrepancy in the quality of goods to the needs of customers.

The authors of the article give specific recommendations for the further development of the light industry market of the Republic of Kazakhstan: to invest money in new technologies and innovations; to use social networks to promote products and find out consumer preferences of buyers; to apply ebusiness models for the sale of goods.
\end{abstract}

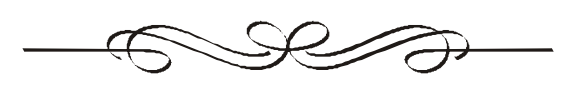


А.У. Маканова*, докторант $P$ hD

А.Н. Тургинбаева, ә.э.н., профессор

Г.С. Смагулова, к.э.н., дочент

К.Е. Смагулов, $P h D$, доиент

Казахский Национальный университет им. аль-Фараби

2. Aлматы

e-mail: Asselya.Mak@gmail.com

* - основной автор (автор для корреспонденции)

\section{УПРАВЛЕНЧЕСКИЕ АСПЕКТЫ ТРАНСФОРМАЦИИ ИССЛЕДОВАТЕЛЬСКИХ УНИВЕРСИТЕТОВ: ЗАРУБЕЖНЫЙ ОПЫТ}

В статье изучены эволючия и основные модели управления университетами в ведущих странах Организации экономического сотрудничества и развития. Авторами проведен анализ научной литературы касательно трансформации модели управления вузами от гумбольдтовского к исследовательскому университету. Выявлено, что приход к власти в развитых странах Запада политиков, придерживающихся неолиберальной идеологии, привели к изменению отношения государства к науке в целом и к университетам в частности. Вузы становятся вовлеченными в экономические отношения и субъектами реальной экономики, приоритетом их деятельности становится коммерииализация производимых услуг и продукиии. Определено, что изменение роли университетов привело и к эволюции системы управления вузами: были внедрены методы корпоративного управления, что потребовало применения и соответствуюших механизмов контроля. Так, на первый план выходят оценка эффективности и качества выполняемых исследований в университетах. Проанализировано, что в настоящее время в ведущих странах мира именно исследовательские университеты являются основой наукоемкой экономики и хабами инновачионных разработок для последующего внедрения в производство.

На основе изучения опыта зарубежных стран по управлению вузами и их трансформации в исследовательские университеты были предложены выводы, которые будут актуальными для Казахстана.

Ключевые слова: модели управления, гумбольдтовский университет, исследовательский университет, зарубежный опыт, неолиберализм, коммерциализация услуг, эволюиия системы управления, оченка эффективности, методы корпоративного управления.

Кілт сөздер: басқ̧ару модельдері, гумбольдт университеті, зерттеу университеті, шетелдік тәжірибе, неолиберализм, қызметті коммериияландыру, басқару жүйесінің эволюииясы, тиімділікті бавалау, корпоративтік басқару ддістері.

Keywords: management models, Humboldt University, research university, foreign experience, neoliberalism, commercialization of services, evolution of the management system, efficiency assessment, corporate governance methods.

Данная статья подготовлена в рамках выполнения научного проекта на тему АР08051974 «Оиенка интеллектуального капитала вузов Казахстана на основе наукометрического анализа и пути их трансформации в исследовательские университеты» грантового финансирования молодых ученых МОН РК.

JEL classification: $\mathrm{H} 79$ 
Введение. В ведущих странах мира основными субъектами научно-исследовательской деятельности являются исследовательские университеты, ученые которых реализуют наиболее передовые исследования, инновационные разработки, в последующем внедряемые в реальный сектор экономики.

Несмотря на то, что в современном мире значение вузов для национального научного комплекса не подвергается сомнению, их роль в нем долгое время ограничивалась преимущественно подготовкой кадров [1].

Роль университетов эволюционировала в сторону большей коммерциализации научных исследований на протяжении последних 50-60 лет. Что стало переломным моментом перехода от гумбольдтовского университета к исследовательским и предпринимательским университетам.

Изучение опыта эволюции системы управления вузами и трансформации их в исследовательские университеты является актуальной задачей для Казахстана, обозначившего целью формирование наукоемкой экономики, а роль вузов определена в качестве хабов инновационных разработок.

Цель научной статьи - проведение анализа эволюции зарубежных моделей управления вузами в процессе трансформации их в исследовательские университеты.

Данная цель достигается путем решения следующих задач. Первое, на основе литературного обзора выявить основные характеристики систем управления университетами в ведущих зарубежных странах. Второе, проанализировать основные этапы трансформации университетов в исследовательские. Третье, сформировать выводы и основные результаты исследования для Казахстана.

Данная статья была написана на основе литературного обзора научных трудов. Для поиска актуальных публикаций, посвященных исследованиям моделей управления исследовательскими университе- тами, были использованы функции реферативной базы данных Scopus. Посредством ключевых слов был осуществлен выбор наиболее релевантных научных работ по теме исследования. На основе компаративного метода были изучены различные модели управления исследовательскими университетами. Также были применены следующие методы: исторический; системный подход; статистический.

Обзор литературы. Модели управления университетами в зарубежных странах широко изучены в научной литературе. Так, основоположником исследований роли университетов, в так называемой модели «тройной спирали» - тесного взаимодействия государства, бизнеса и университетов - является Генри Ицковиц [2].

Видными специалистами изучения политики и управления в сфере высшего образования являются Д. Дилл [3], Ф. Китагава [4], М. Недеваи, Р. Боден [5].

Изучение процессов трансформации модели университетов от гумбольдтовской к исследовательской, предпринимательской, а также формирование «академического капитализма» принадлежит С. Слотеру и Л. Лесли [6]. Из российских ученых следует отметить труды А. Кравцова, изучавшего научную политику и систему управления вузами во Франции [1].

Опыт России по построению собственной модели управления университетами изучены в работах Р. Булыги, И. Ветровой [7].

Вопросы оценки эффективности управлением университетов, научно-исследовательской деятельностью освещены в трудах С. Трапицына [8], Г. Лазарева [9].

Основные индикаторы развития науки и технологии в вузах, а также методы анализа проводимых исследований в университетах на основе наукометрических показателей проанализированы в коллективной работе авторов М. Акоева, В. Маркусовой и др. [10]. 


\section{Менеджсмент жюде маркетинг / Менеджмент и маркетинг}

Также опыт зарубежных стран по управлению высшими учебными заведениями изучен казахстанскими авторами Ш. Шаяхметовой [11], А. Кужабековой [12].

Основная часть. На протяжении длительного периода времени, управление университетами базировалось на модели, предложенной немецким ученым Вильгельмом Гумбольдтом. Согласно данной модели свободный творческий научный поиск и сотрудничество ученого со студентом не должен зависеть от государства [11, с. 47].

В связи с этим, вплоть до 1970-х гг. университеты являлись устоявшимися и относительно консервативными институтами, которые пользовались значительной степенью автономии от государства и коллегиальными принципами управления.

Однако, в связи с приходом к власти в ведущих странах Организации экономического сотрудничества и развития (ОЭСР) политиков, придерживающихся неолиберальной идеологии, в 1970-х гг. претерпели изменения отношения как государства к науке в целом, так и к системе контроля университетами в частности. Первым шагом в данном направлении стало изменение механизма финансирования выполняемых в университетах научных исследований, которые позволили осуществлять усиленный контроль над вузами [5, с. 273].

Финансирование стало точным политическим механизмом для управления университетами, определяющими характеристиками которого являются систематическая избирательность, конкуренция и ответственность (рис.1). Деньги, потраченные на университеты и их исследования, стали не затратами, а инвестициями с ожидаемой отдачей в виде товаров и знаний. С одной стороны, данные изменения позволили университетам быть вовлеченными в более широкую правительственную систему. С другой стороны - это подорвало их статус автономных субъектов $[5,273]$.

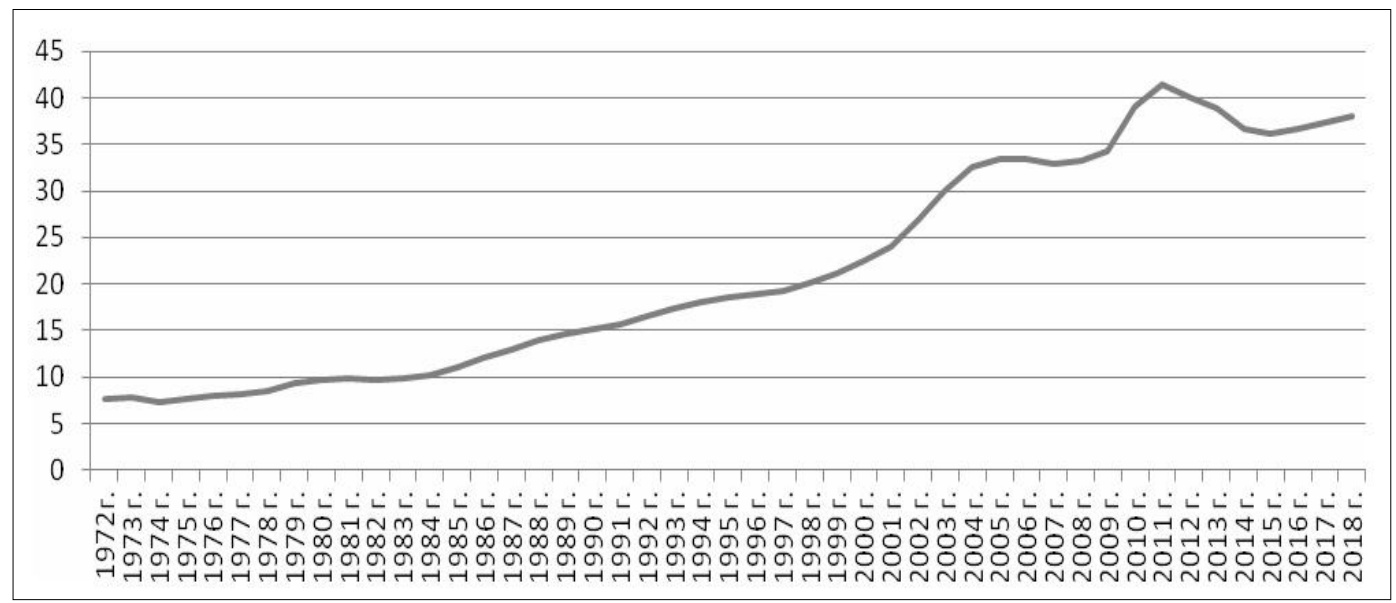

Рисунок 1. Объем федеральных расходов на университетские НИОКР за 1973-2018 гг., (в млрд долл. США)*

*Составлен авторами на основе источника [13]

Перераспределение роли вузов в качестве ключевых игроков в «экономике знаний» неолиберальных государств породило так называемую «третью миссию» университетов. По сути это был призыв к университетам наладить контакты и быть сосредоточенными на обмене знаниями между высшим образованием и бизнесом. Таким образом, государство с одной стороны сокращало объемы финансирования 
научных исследований, в основном реализуемых в университетах, с другой стороны активно привлекало бизнес к инвестициям в сферу науки. Изменение в системе управления университетом, характеризующимся методами корпоративного управления, привело к тому, что были внедрены и соответствующие механизмы контроля, основанные на надзоре, позиционном управлении и аудите особенно в отношении качества исследований [5, с. 276].

Эти новшества касались в первую очередь разработки индикаторов оценки публикационной активности: качества научного журнала, где была опубликована статья на основе показателей цитируемости, что в конечном итоге приобрело форму им пакт-фактора издания [10, с. 39].

В последующем, данные методики были усовершенствованы и в настоящее время включают различные инструменты по определению количественных и качественных характеристик научных журналов и основанных на них показателях научной эффективности отдельного ученого, организации и страны.

Первые Системы финансирования исследований, основанные на результатах (Performance-based research funding systems -
PRFS) были внедрены в конце 1980-х и начале 1990-х годов в Великобритании и Австралии. PRFS - это национальные системы оценки результатов и сследований, используемые для распределения финансирования исследований среди вузов. Разработка этих систем происходила частично как элемент широкого внедрения рыночных механизмов для повышения под отчетности и эффективности государственных исследований.

В свою очередь, при конструктивном отношении к сути рейтингования, в т.ч. на основе метода PRFS, университеты получают возможность оптимизациии совершенствования своей деятельности через анализ и корректирующие управленческие решения.

Сокращение государственного финансирования университетов (рис. 2), внедрение корпоративного управления, высокий уровень конкуренции за финансирование научных исследований, поиск заказчиков научных разработок, привели к тому, что университеты стали полноправными субъектами рыночных отношений. В целом, система высших учебных заведений характеризовалась перех одом от регулирования к рынку.

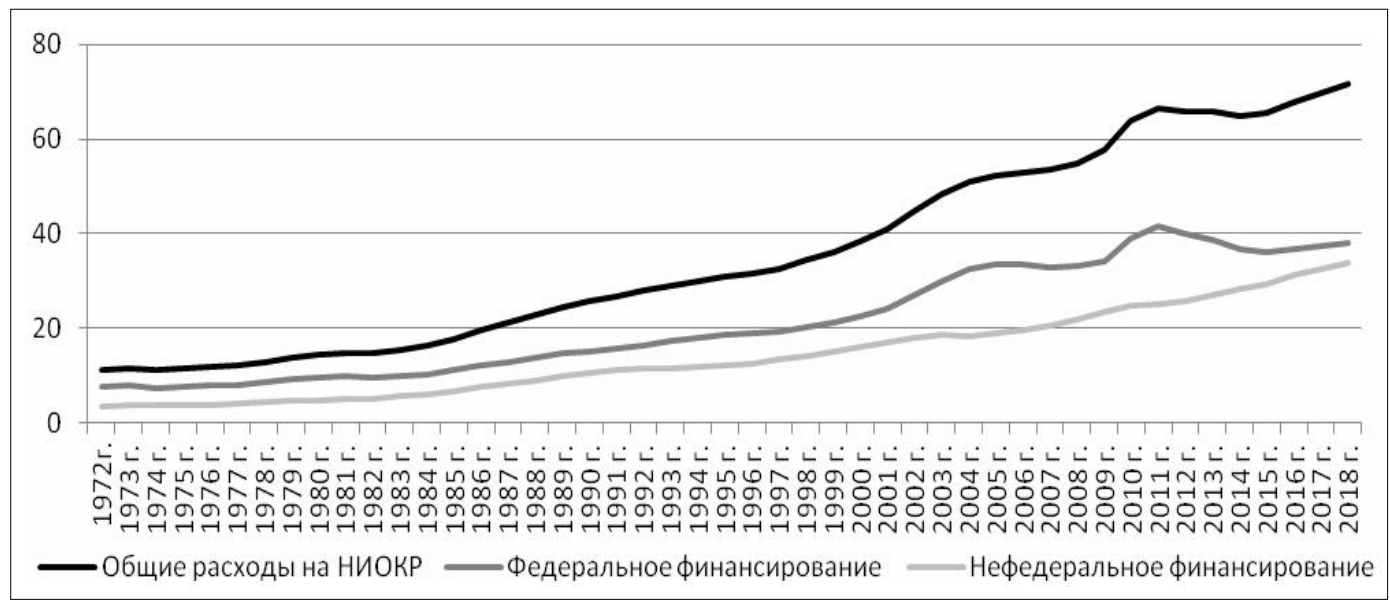

Рисунок 2. Расходы на НИОКР в университетах США по источникам финансирования 1973-2015 гг., (в млрд долл. США)*

*Составлен авторами на основе источника [14] 


\section{Менеджмент жюән маркетинг / Менеджмент и маркетинг}

В этот период в зарубежной научной литературе формируются такие термины, как «академический капитализм» и «предпринимательский университет». Что было связано с основным принципом неолиберализма в отношении вузов: коммерциализация науки и университета.

Краеугольным камнем политики в области науки и инноваций с начала $80-х$ годов встал вопрос коммерциализации академических знаний через патентование и лицензирование. Например, Закон БэяДоула разрешил американским университетам, финансируемым из федерального бюджета, подавать заявки на патенты и выдавать лицензии на эти патенты другим сторонам (рис. 3).

После принятия Закона Бэя-Доула в США во многих странах были введены аналогичные законодательные реформы, касающиеся использования интеллектуальной собственности в университетах.

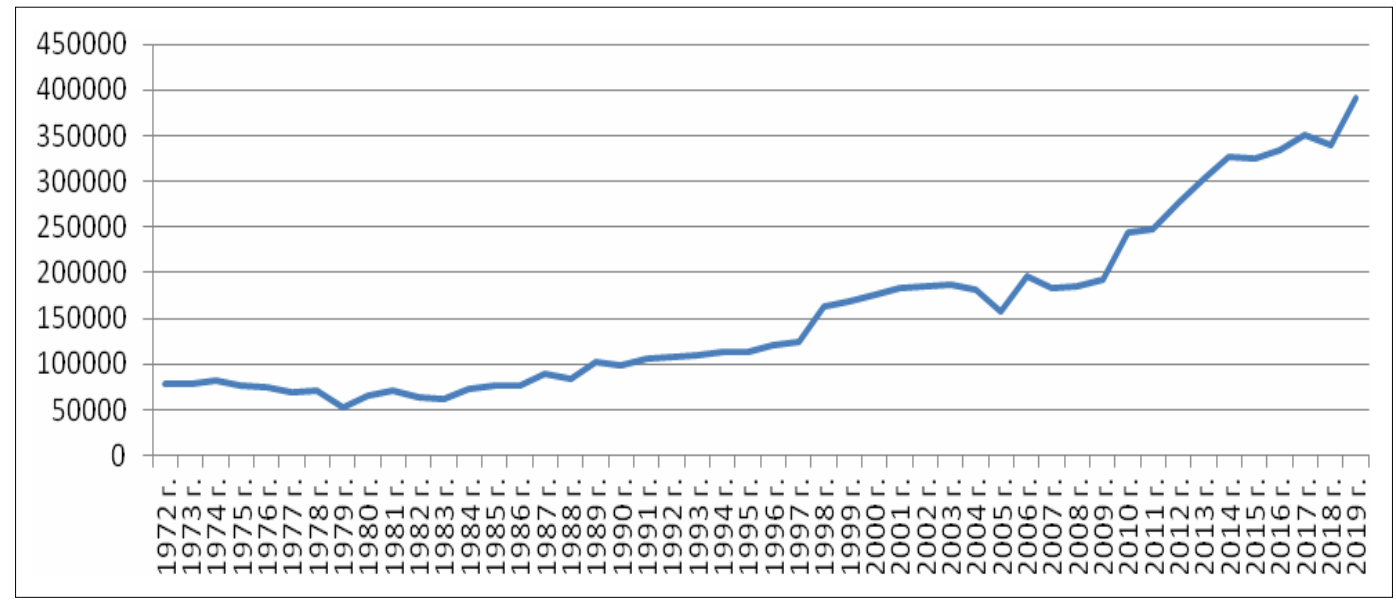

Рисунок 3. Количество патентов, зарегистрированных в США за 1972-2019 гг.*

* Составлен авторами на основе источника [15]

В целом, в зарубежной научной литературе определяют два подхода к управлению университетами: континентальноевропейский и англосаксонский. Традиционный континентально-европейский подход характеризуется централизованным государственным управлением посредством национального министерства и соответствующей правовой базой. В противоположность этому, англосаксонский подход подразумевает большую автономию университетам, которые регулируются только краткими рамочными правилами и путем делегирования /отзыва полномочий (например, полномочия по присуждению степени).

Другой формой управления является контроль над потоками финансирования для университетов. Традиционно страны Континентальной Европы, как правило, рассматривали свои университеты как подразделения государственной бюрократии и применяли механизмы целевого финансирования, в то время как англосаксонские страны, как правило, платили единовременные суммы за услуги (например, контракты на исследования).

Англосаксонская модель управления университетами привела к росту конкуренции между университетами за финансирование, что в итоге привело к научной креативности, повышению качества исследований, которые имеют прикладное значение. Таким образом, университеты не толь186 
ко играют ключевую роль в создании исследовательского потенциала страны, но все более становятся инструментами поддержки экономического роста и укрепления конкурентоспособности и инновационности экономики.

Несмотря на то, что основной тенденцией в ведущих странах является отход от прямого государственного регулирования университетов в сторону рыночных механизмов, центральные госорганы управления оказывают значительное влияние на развитие вузов. Государство реализует свои функции через целенаправленное воздействие с использованием властных полномочий через административные, правовые и социально-экономические инструменты, обеспечивающие функционирование системы вузов [11, с. 35].

Ученый Китагава Ф., анализируя трансформацию роли университетов, пришел к следующим выводам [4, с. 243]. Вопервых, возрастает роль бизнеса и промышленности в университетской исследовательской деятельности, которая изменила природу научных исследований - процесс, который назван «академическим капитализмом». Во-вторых, подход «нового менеджмента» или «нового государственного управления», который был внедрен во многих промышленно развитых странах, изменил контекст и рамочные условия для университетов и их исследований. В-третьих, в сочетании с сокращением государственного финансирования, концепция «предпринимательского-университета» представляет собой стратегические попытки университетов реагировать на эти изменения и активно взаимодей- ствовать с промышленностью и бизнесом.

Традиционно, государственная модель, базирующаяся на системе оценки эффективности деятельности университетов, является характерной для европейских стран (а также для постсоветских - прим. авторов), в которых регулирование осуществляется уполномоченными правительственными органами посредством механизмов контроля индикаторов, аккредитацией, лицензирования и др. [7, с. 13].

Выводы. В ведущих странах мира под влиянием политиков с неолиберальными взглядами изменилась роль университетов для активной коммерциализации знаний и научных достижений. Это привело и к изменению самого процесса управления вузами. В ведущих странах был внедрен новый подход к системе высшего образования, так называемый «новый менеджмент» или «новое государственное управление», что изменило контекст и рамочные условия для университетов и их исследований.

В системе высшего образования Казахстана одной из приоритетных целей является трансформация вузов в исследовательские университеты, которые должны способствовать повышению конкурентоспособности как человеческого, интеллектуального капитала, так и экономики, страны в целом. Как показывает успешный международный опыт основными элементами, отличающими исследовательские университеты, являются: высокая концентрация таланта, наличие ресурсов для учебной среды и проведения передовых научных исследований; высокоэффективный менеджмент.

\section{ЛИТЕРАТУРА}

1. Кравцов А.А. Научный комплекс и научная политика Франции в XXI в.: ключевые направления и тенденции развития // МИР (Модернизация. Инновации. Развитие). 2018. - № 4. - С. 643-656. 


\section{Менеджмент және маркетинг / Менеджмент и маркетинг}

2. Etzkowitz H., Webster A., Gebhardt C. \& Terra B. R. C. (2000). The future of the university and the university of the future: evolution of ivory tower to entrepreneurial paradigm // Research Policy. - № 29. - P. 313-330.

3. Dill D. (2003). The regulation of academic quality: An assessment of university assessment systems with emphasis on the United States. Symposium on University Evaluation for the Future: International Trends in Higher Education Reform. - Tokyo, Japan. - P. 1-13.

4. Kitagawa F. (2015). Research, Development and Innovation: International, National and Regional Perspectives. In The Palgrave international handbook of higher education policy and governance / edited by J. Huisman, H. de Boer, D. Dill. - P. 243-261.

5. Nedeva M., Boden R. (2006). Changing science: The advent of neo-liberalism// Prometheus, 24(3). - P. 269-281.

6. Slaughter S., Leslie L.L. (1997). Academic capitalism: Politics, policies, and the entrepreneurial university. - Baltimore, MD: The Johns Hopkins University Press. - 296 p.

7. Булыга Р.П., Ветрова И.Ф., Королев И.Г., Мельник М.В. Совершенствование оценки эффективности деятельности подведомственных Правительству РФ образовательных и научных учреждений: Монография. - М.: Научная библиотека, 2014. - 192 с.

8. Трапицын С.Ю. Рейтинговый подход и мониторинг в управлении эффективностью деятельности университета // Universum: Вестник Герценовского университета. - 2013. № 1. - С. 61-74.

9. Лазарев Г.И., Уварова Т.Г. Построение рейтинга вузов по результатам мониторинга эффективности деятельности // Вестник ВГУЭС. - 2013. - № 4(22). - С. 85-93.

10. Акоев М.А., Маркусова В.А., Москалева О.В., Писляков В.В. Руководство по наукометрии: Индикаторы развития науки и технологии. -Екатеринбург: ИПЦ УрФУ, 2014. - 250 с.

11. Шаяхметова Ш.Т. Государственное управление эффективностью деятельности высших учебных заведений в Республике Казахстан. - Дисс. на соиск. уч. ст. докт. фил. PhD. - Астана, 2018. - 159 с.

12. Lee J., Kuzhabekova A. (2019). Building local research capacity in higher education: a conceptual model// Journal of Higher Education Policy and Management. - № 3(41). - P. 342-357.

13. Federal Funds for research and development. - URL: https://www.nsf.gov/pubsys/ods/ getpub.cfm?nsf04332

14. Higher Education Research and Development Survey. - URL: https://www.nsf.gov/statistics/ 2020/nsf20302/overview.htm

15. U.S. patent and trademark office. - https://www.uspto.gov

\section{REFERENCES}

1. Kravcov A.A. Nauchnyj kompleks i nauchnaja politika Francii v XXI v.: kljuchevye napravlenija itendencii razvitija [Scientific complex and scientific policy of France in the XXI century: key directions and development trends] // MIR (Modernizacija. Innovacii. Razvitie). - 2018. - № 4. - S. 643-656 [in Russian].

2. Etzkowitz H., Webster A., Gebhardt C., Terra B.R. C. (2000). The future of the university and the university of the future: evolution of ivory tower to entrepreneurial paradigm// Research Policy. № 29. - P. 313-330.

3. Dill D. (2003). The regulation of academic quality: An assessment of university assessment systems with emphasis on the United States. Symposium on University Evaluation for the Future: International Trends in Higher Education Reform. - Tokyo, Japan. - P. 1-13. 
4. Kitagawa F. (2015). Research, Development and Innovation: International, National and Regional Perspectives. In The Palgrave international handbook of higher education policy and governance / edited by J. Huisman, H. de Boer, D. Dill. - P. 243-261.

5. Nedeva M., Boden R. (2006). Changing science: The advent of neo-liberalism// Prometheus, 24(3). - P. 269-281.

6. Slaughter S., Leslie L.L. (1997). Academic capitalism: Politics, policies, and the entrepreneurial university. - Baltimore, MD: The Johns Hopkins University Press. - 296 p.

7. Bulyga R.P., Vetrova I.F., Korolev I.G., Mel'nik M.V. Sovershenstvovanie ocenki jeffektivnosti dejatel'nosti podvedomstvennyh Pravitel'stvu Rossijskoj Federacii obrazovatel'nyh i nauchnyh uchrezhdenij: Monografija [Improving the performance assessment of educational and scientific institutions subordinate to the Government of the Russian Federation: monograph]. - M.: Nauchnaja biblioteka, 2014. - 192 s. [in Russian].

8. Trapicyn S.Ju. Rejtingovyj podhod i monitoring v upravlenii jeffektivnost'ju dejatel'nosti universiteta [Rating approach and monitoring in the management of university performance] // Universum: Vestnik Gercenovskogo universiteta. - 2013. - № 1. - S. 61-74 [in Russian].

9. Lazarev G.I., Uvarova T.G. Postroenie rejtinga vuzov po rezul'tatam monitoringa jeffektivnosti dejatel'nosti [Building a ranking of universities based on the results of performance monitoring] // Vestnik VGUJeS. - 2013. - № 4(22). - S. 85-93 [inRussian].

10. Akoev M.A., Markusova V.A., Moskaleva O.V., Pisljakov V.V. Rukovodstvo po naukometrii: Indikatory razvitija nauki i tehnologii [Scientometrics Guide: Science and Technology Development Indicators]. - Ekaterinburg: IPC UrFU, 2014. - 250 s. [in Russian].

11. Shajahmetova Sh.T. Gosudarstvennoe upravlenie jeffektivnost'ju dejatel'nosti vysshih uchebnyh zavedenij $v$ Respublike Kazahstan [State management of the performance of higher educational institutions in the Republic of Kazakhstan]. - Diss. na soisk. uch. st. dokt. fil. PhD. - Astana, 2018. 159 s. [in Russian].

12. Lee J., Kuzhabekova A. (2019). Building local research capacity in higher education: a conceptual model // Journal of Higher Education Policy and Management. - № 3(41). - P. 342-357.

13. Federal Funds for research and development. - URL: https://www.nsf.gov/pubsys/ods/ getpub.cfm?nsf04332

14. Higher Education Research and Development Survey. - URL: https://www.nsf.gov/statistics/ 2020/nsf20302/overview.htm

15. U.S. patent and trademark office. - https://www.uspto.gov

\title{
А.У. Маканова, А.Н. Тургинбаева, Г.С. Смагулова, К.Е. Смагулов \\ ЗЕРТТЕУ УНИВЕРСИТЕТІН ТРАНСФОРМАЦИЯЛАУДЫН БАСКАРУ АСПЕКТІЛЕРІ: ШЕТЕЛДІК ТӘЖІРИБЕ
}

\begin{abstract}
Андатпа
Мақалада экономикалық ынтымақтастық және даму ұйымдарының жетекші елдеріндегі университеттерді басқару эволюциясы мен негізгі модельдері қарастырылған. Авторлар Гумбольдт зерттеу университетіне жоғары оқу орындарын басқару моделінің өзгеруіне қатысты ғылыми әдебиеттерге талдау жасады. Неолибералдық идеологияны ұстанатын дамыған Батыс елдеріндегі саясаткерлердің билікке келуі мемлекеттің ғылымға, атап айтқанда университеттерге деген көзқарастарының өзгеруіне алып келді. Университеттер экономикалық қатынастарға және нақты экономиканың субъектілеріне айналуда, олардың қызметінің басымдығы қызмет пен өнімді
\end{abstract}




\section{Менеджмент жюәне маркетинг / Менеджмент и маркетинг}

коммерцияландыру болып табылады. Университеттер рөлінің өзгеруі жоғары оқу орындарын басқару жүйесінің эволюциясына әкелді: тиісті бақылау тетіктерін қолдануды талап ететін корпоративтік басқару әдістері енгізілді. Осылайша, университеттерде жүргізілетін зерттеулердің тиімділігі мен сапасын бағалау бірінші орынға шығады. Қазіргі уақытта әлемнің жетекші елдерінде нақтырақ айтқанда, зерттеу университеттері ғылымды қажетсінетін экономиканың негізі және кейін өндіріске енгізудің инновациялық әзірлемелер хабы болып табылатындығы талданды.

Жоғары оқу орындарын басқару және оларды зерттеу университеттеріне өзгерту бойынша шет елдердің тәжірибесін зерттеу негізінде Қазақстан үшін өзекті болатын қорытындылар ұсынылды.

\section{A. Makanova, A. Turginbayeva, G. Smagulova, K. Smagulov \\ MANAGEMENT ASPECTS OF THE TRANSFORMATION OF RESEARCH UNIVERSITIES: FOREIGN EXPERIENCE}

\section{Annotation}

The article studies the evolution and basic models of university management in the leading countries of the Organization for Economic Cooperation and Development. The authors analyzed the scientific literature regarding the transformation of the university management model from Humboldt University to a research university. It was revealed that the rise to power in developed Western countries of politicians who adhere to neoliberal ideology led to a change in the attitude of the state to science in general and to universities in particular. Universities are becoming involved in economic relations and subjects of the real economy, the priority of their activities is the commercialization of services and products. It was determined that a change in the role of universities led to the evolution of the university management system: corporate governance methods were introduced, which required the use of appropriate control mechanisms. Thus, an assessment of the effectiveness and quality of research carried out at universities comes to the fore. It has been analyzed that at present, in the leading countries of the world, research universities are the basis of the knowledge-based economy and hubs of innovative developments for subsequent implementation in production.

Based on the study of the experience of foreign countries in managing universities and their transformation into research universities, conclusions were proposed that will be relevant for Kazakhstan. 
DOI 10.52260/2304-7216.2020.4(41).22

УДК 336.647/.648

ГРНТИ 06.73.02

\author{
А.А. Нурумов*, д.э.н., профессор \\ А.М. Уахитжанова, $\mathrm{cm}$. преподаватель \\ $A O$ «Финансовая академия» \\ 2. Нур-Султан \\ e-mail: all_999@mail.ru \\ * - основной автор (автор для корреспонденции)
}

ФИНАНСОВЫЙ АСПЕКТ РАЗВИТИЯ СЕЛЬСКОГО ХОЗЯЙСТВА

Объектом исследования в данной статье является сельское хозяйство Республики Казахстан. Рассмотрены текущие приоритеть в развитии сельского хозяйства, которые сегодня распределились следуюшим образом: развитие земельных отношений, формирование эффективной системы сельскохозяйственного водопользования, оптимизация структуры посевных площадей, защита и карантин растений, развитие племенного животноводства и ветеринарии, развитие сельскохозяйственного машиностроения, страхование, кредитование, налоговая политика. Определены специфические черты сельского хозяйства, которые диверсификацию применяемых финансовых инструментов влияют на эффективность финансирования отрасли в целом. В статье предпринята попытка обоснования значимости финансовых факторов в развитии отрасли с учетом понимания рыночных прочессов и отраслевой специфики, т.к. данная отрасль в условиях рынка не всегда формирует высокие показатели эффективности, но обеспечивает решение ряда социальноэкономических задач. Выделена роль государства, необходимость его присутствия в обеспечении развития отрасли, а также продовольственной безопасности страны.

Ключевые слова: финансовые инструменты, финансирование, сельское хозяйство, рынок, продовольственная безопасность, эффективность, отраслевая особенность, кредиты, инвестиции, субсидии.

Кілт сөздер: құаржы құралдары, қаржыландыру, ауыл шаруашылывы, нарық, азықтүлік қ̧ауіпсіздігі, тиімділік, салалық ерекшелігі, кредиттер, инвестициялар, субсидиялар.

Keywords: financial instruments, financing, agriculture, market, food security, efficiency, industry peculiarity, loans, investments, subsidies.

Введение. Сельское хозяйство Республики Казахстан, представляет собой стратегически значимый сектор экономики, развитие которого оказывает влияние на многие аспекты социальной и экономической жизни общества. Именно сельское хозяйство, а именно лица задействованные в этой отрасли и население проживающее на селе наблюдали проявления негативных черт рыночных отношений. Исследование

проблем финансового обеспечения, поддержки и финансирования сельского хозяйства невозможно без изучения и понимания значимых процессов экономического развития, в т.ч. отличительными особенностями воспроизводственных процессов и регулирования.

Обзор литературы. Научным изучением вопроса эффективного регулирования и развития отраслей экономики занимались 
такие зарубежные отечественные ученые как Е.И. Шохина, И.Д. Тургель, А.Ж. Панзабекова, Д.М. Турекулова, А.Х. Муканов, Т.И. Есполов и другие $[1,2,3,4]$.

В своем послании К-Ж.К. Токаев отмечает, о необходимости традиционной поддержки аграрного сектора, а также акцентировать внимание на глубокой переработке сельхозпродукции, в контексте новой бюджетной политики, финансировать приоритетные направления и проекты, которые соответствуют удовлетворения требований государства и населения. В рамках развития сельскохозяйственной отрасли приоритетными направлениями для Республики Казахстан остаются самообеспечение социально значимыми продовольственными товарами; стабильное повышение доходов миллионов сельских жителей; повышение производительности труда в два с половиной раза; увеличение экспорта продукции АПК в два раза [5].

Цель. Эффективное финансирование сельского хозяйства - одно из важнейших факторов обеспечения продовольственной безопасности страны. Следовательно, все организованные финансовые отношения формируемые в отрасли требуют значительного внимания, а именно в контексте отраслевой специфики и дальнейшей модернизации. Исследование вопроса развития сельского хозяйства и проблем повышения эффективности применяемых финансовых инструментов в отрасли является актуальным, т.к. несмотря на стабильную поддержку субъектов сельского хозяйства, наблюдается снижение эффективности отрасли.

Задачи. Определить эффективность финансирования в обеспечении развития сельского хозяйства, как отрасли экономики Республики Казахстан и роль государство в развитии данной отрасли.

Материал и методы исследования. Базой исследования стали практические и значимые труды мировых и казахстанских исследователей посвященных вопросам финансирования сельского хозяйства, в которых описаны и применены законы рынка, а также статистические и информационные данные.

Методами исследования стали специальные методы научного познания, а именно:диалектический, абстрактно-логический, анализ и синтез системного, факторного и структурного анализа, сравнения и обобщения.

Основная часть. При разработке политики в области финансирования аграрного сектора следует обратить внимание на происходящие финансовые процессы в сельском хозяйстве ведущих мировых стран. Поддержка данной отрасли этими странами выделена как значимая и приоритетная в национальной экономике. В контексте ограниченности ресурсов и обеспечения продовольственной безопасности, ведущие страны мира повышают эффективность применяемых финансовых и экономических инструментов, данные процессы проявляются в росте уровня финансирования сельского хозяйства, направленных на оказание помощи субъектам аграрного сектора. Многие страны определяют направления развития экономики, методы регулирования и инструменты финансового механизма на ближайшие годы в соответствии с текущими мировыми тенденциями. Развитие системы рыночных отношений в сельском хозяйстве Казахстана позволяет производителям самостоятельно нести коммерческую ответственность за формирование и рациональное использование финансовых ресурсов.

Отраслевая специфика сельского хозяйства заключается в том, что результаты деятельности субъектов зависит не только от экономических факторов, но и производственных и природно-климатических факторов. Если влияние экономических норм, законов и правил возможно прогнозировать исходя из складывающейся политической и экономической обстановки в 
мире и за рубежом в рамках финансовых рынков, рынков сбыта, то в сельском хозяйстве происходит переплетение экономических и биологических процессов. Производственные факторы опосредованы биологическими процессами. Природно-климатические факторы требуют решения про- блем с применением научных инструментов при условии, что земля является незаменимым и обязательным фактором производства. Однако, даже при наличие земельных ресурсов, всегда открыт вопрос с решением проблем доступа к водным ресурсам (табл. 1).

\section{Факторы, формирующие отраслевую специфику сельского хозяйства*}

\begin{tabular}{|l|l|l|}
\hline \multicolumn{1}{|c|}{ Экономические } & Природно-климатические & \multicolumn{1}{|c|}{ Производственные } \\
\hline $\begin{array}{l}\text { Социально-экономи- } \\
\text { ческая значимость } \\
\text { сельского хозяйства }\end{array}$ & $\begin{array}{l}\text { Зависимость от } \\
\text { почвенно-климатических } \\
\text { условий }\end{array}$ & $\begin{array}{l}\text { Сезонность производства, несов- } \\
\text { падение периода производства с } \\
\text { рабочим периодом }\end{array}$ \\
\hline $\begin{array}{l}\text { Рискованность отрасли, } \\
\text { неопределенность запла- } \\
\text { нированных результатов }\end{array}$ & $\begin{array}{l}\text { Земля - незаменимый } \\
\text { фактор производства }\end{array}$ & $\begin{array}{l}\text { Использование произведенной } \\
\text { продукции для расширения или } \\
\text { восстановления производства }\end{array}$ \\
\hline $\begin{array}{l}\text { Переплетение } \\
\text { экономических и } \\
\text { биологических процессов }\end{array}$ & Зависимость от водных & $\begin{array}{l}\text { Необходимость значительной } \\
\text { территории для обеспечения } \\
\text { производства }\end{array}$ \\
\hline
\end{tabular}

*Составлена авторами

Указанные отраслевые характеристики негативно сказываются на привлечении высокой доли частных инвестиций, в т.ч. иностранных инвестиций в отрасль, а в условиях рынка отрасль нуждается в государственной финансовой поддержке, так как является основой для обеспечения продовольственной безопасности страны. Так по данным Всемирного банка на 2018 год Казахстан занимает 6 место в мире по площади сельскохозяйственных земель, по производству продукции растениеводства 22 место, по химической обработке земель 152 место, а по урожайности сельскохозяйственных культур 143 место. В целом индекс производства продуктов питания в растениеводстве составил $122 \%$, животноводстве $120 \%$, при максимальном уровне $211 \%$ [6].

Так же стоит отметить тот факт, что $45 \%$ населения приживают в сельских территориях, при $15 \%$ занятости населения в сельскохозяйственной отрасли [7].
В Казахстане было множество государственных программ по развитию агробизнеса, сельских территорий, сельского хозяйства, однако, доля сельского хозяйства в экспорте и в ВВП страны очень мала, и не видно никаких перспектив ее быстрого роста. По своей производительности и эффективности агробизнес Казахстана отстает от развитых стран в несколько раз. Развитие и повышение эффективности отрасли требует стабильных финансовых потоков в сельское хозяйство.

Финансирование есть процесс обеспечения предприятия финансовыми ресурсами [1, с. 72]. Финансирование представляет собой понятие, применяемое во многих областях, в т.ч. в теоретическом аспекте для характеристики движения денежных ресурсов по каналам финансового механизма.

В целях повышения производительности труда в сельском хозяйстве, для использования экспортного потенциала аграрного сектора правительством РК пос- 
Каржы жнәне есеп / Финансы и учет

тавлена цель внедрения современных технологий посредством привлечения иностранных инвестиций, предоставления преференций инвесторам в виде гарантирования возврата инвестиций, освобождения от некоторых видов налогов, софинансирования. Казахстаном внедряются формы страхования для поддержки сельскохозяйственного товаропроизводителя в случае неблагоприятных погодных условий.

Главной задачей при реализации механизма финансирования остается формирование финансовых ресурсов из различных источников, поиск и привлечение денежных средств с целью достижения ка- чественно нового уровня развития сельского хозяйства.

Специфика денежного оборота при формировании финансовых отношений в сельскохозяйственной отрасли, проявляется в формировании, распределении и использовании финансовых ресурсов, данная особенность определила необходимость изучения и поиска источников финансирования селського хозяйства.

Как отмечалось ранее, особенностью сельскохозяйственной отрасли является то, что для нее, как ни для какой другой отрасли, характерна ее высокая зависимость от внешних источников финансирования.

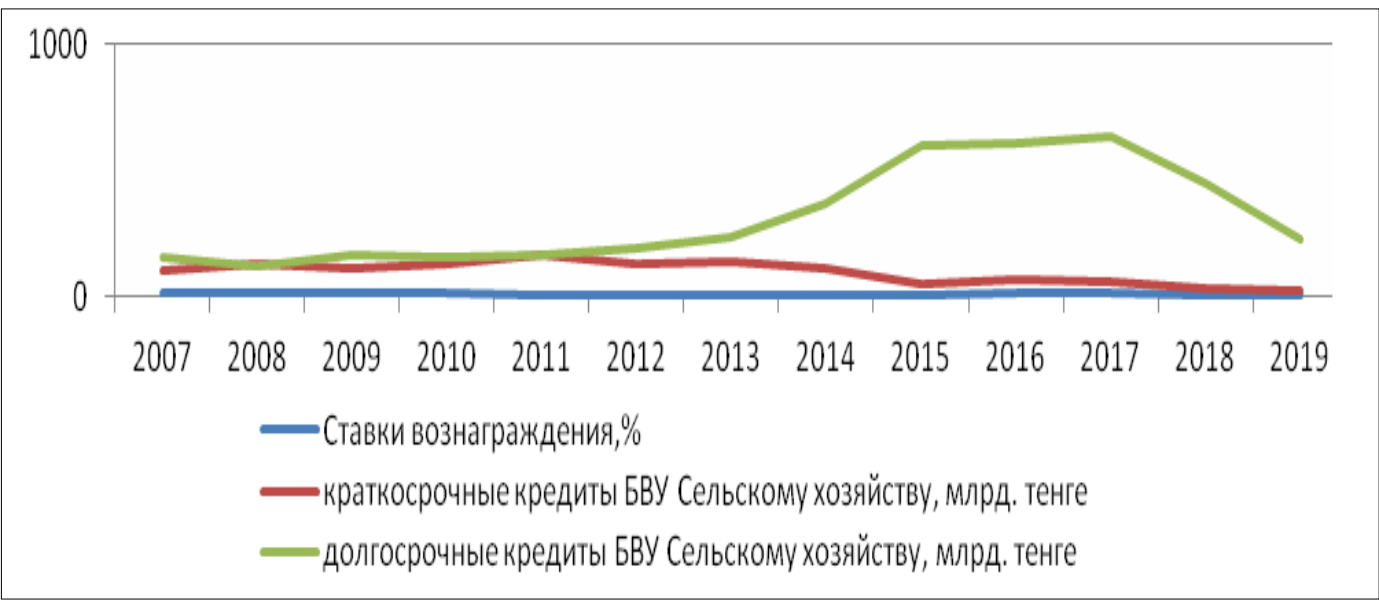

\section{Рисунок 1. Кредиты БВУ сельскому хозяйству Казахстана и ставки вознаграждения в 2007-2019 годах*}

*Построен авторами на основе данных источников [8]

На рисунке 1 показаны удельные веса краткосрочных и долгосрочных кредитов банков второго уровня (далее - БВУ) отраслям экономики в целом и сельскому хозяйству Казахстана в 2007-2019 годах и ставки вознаграждения.

Валовой приток прямых инвестиций в экономику Казахстана, а также в сельское, лесное и рыбное хозяйство от иностранных прямых инвесторов за последние 12 лет имеет вид, представленный на рисунке 2.

Рисунок 2 показывает, что в 2015 году инвесторы вернулись в Казахстан. После трех лет снижения прямых иностранных инвестиций валовой приток в 2016 году вырос на 40\% или почти на 6 млрд долл. Это свидетельствует о росте интереса иностранных инвесторов к Казахстану, который ослаб в 2013-2015 годах на фоне кризисных явлений в экономике страны. Валовой приток прямых иностранных инвестиций в РК, который поступательно рос с 2007 года, в 2013 году сократился на 17\%, потом сокращение замедлилось на $2 \%$ в 2014 году и в 2015 году опять был зафиксирован резкий спад на $38 \%$. Важную роль в привлечении 
инвестиций сыграло образование МФЦА Международного финансового центра «Астана», основные направления деятельности которого заключаются в развитии рынка капитала, управлении активами, привлечении исламских финансов, внедрении новых финансовых технологий [9].

Эффективное и конкурентоспособное сельское хозяйство способствует развитию государства в целом, поддерживает независимость от внешних факторов, особенно при внутренней нестабильности. Состояние и процессы развития отрасли определяют сельхозтоваропризводители, как основные ячейки отрасли, как элементы финансовой и институциональной инфраструктуры. Однако эти элементы не могут функционировать отдельно и в отрыве от других секторов экономики. Государство направляя финансовые ресурсы активно поддерживает отрасль (рис. 3).

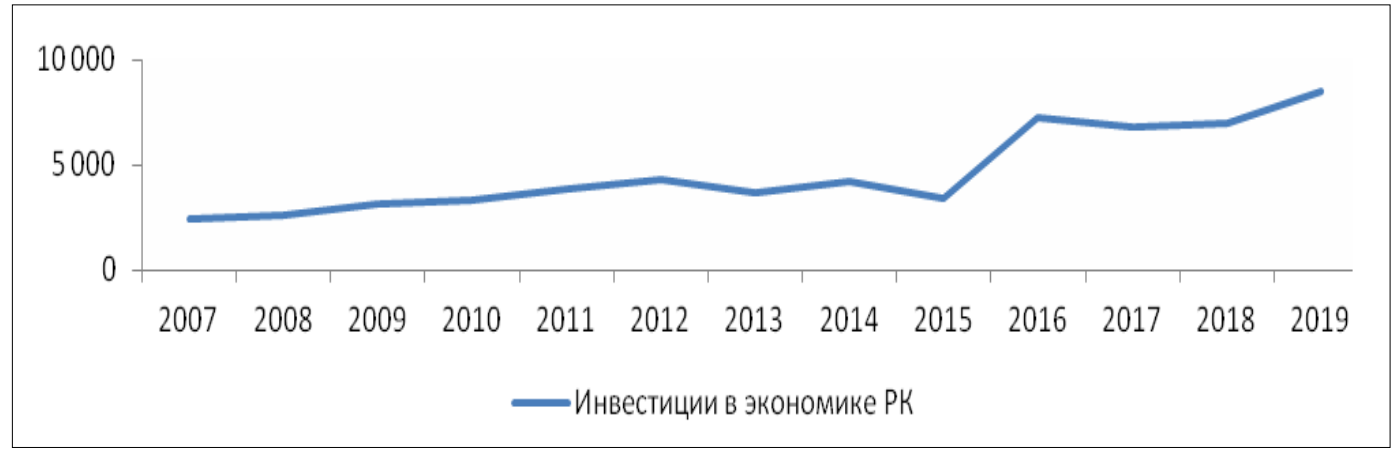

Рисунок 2. Инвестиции в сельское хозяйство

Республики Казахстан, (млрд тенге)*

*Построен авторами на основе данных источника [7]

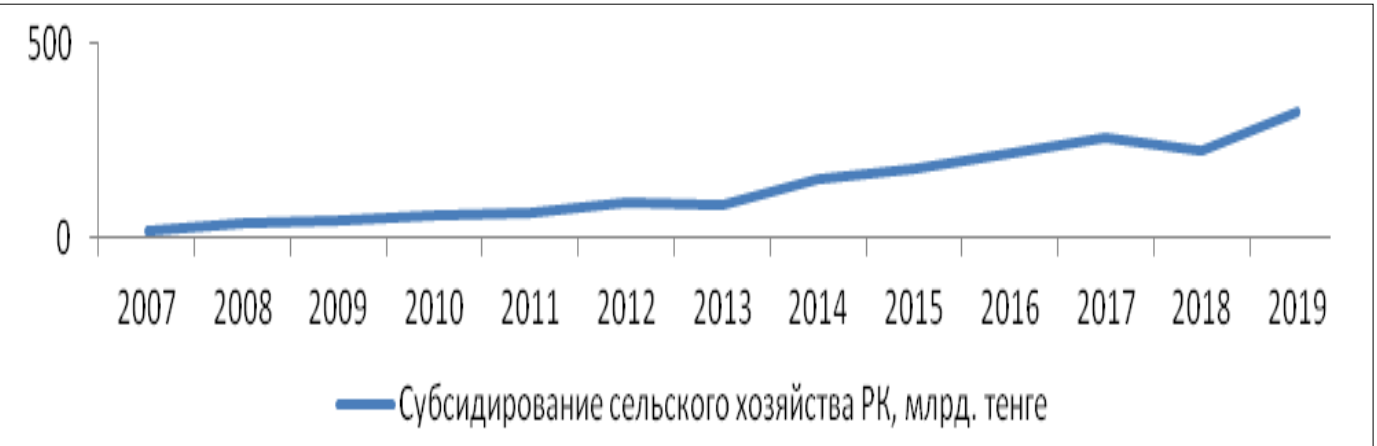

Рисунок 3. Субсидирование сельского хозяйства в 2007-2019 годах*

*Построен авторами на основе данных источника [10]

Несмотря на перечисленные негативные факторы, сельское хозяйство является драйвером роста экономики страны и показывает положительные результаты по выпуску продукции и росту занятости жителей сельских населенных пунктов.

Эффективное и конкурентоспособное сельское хозяйство способствует развитию государства в целом, поддерживает независимость от внешних факторов, особенно при внутренней нестабильности. Состояние и процессы развития отрасли определяют сельхозтоваропризводители, как основные ячейки отрасли, как элементы финансовой и институциональной инфраструктуры. Эти элементы не могут функ- 
Қаржы жнәне есеп / Финансы и учет

ционировать отдельно и в отрыве от других секторов экономики.

Объем валовой продукции вырос в 2019 году по сравнению с 2007 годом в 4,2 раза в текущих ценах, несмотря на снижение размеров субсидирования.

Современные условия развития Казахстана обуславливают необходимость государственного регулирования отрасли, с высоким уровнем эффективности. Согласно правилам ВТО, к которым присоединился Казахстан, регулируются и оцениваются допустимые и недопустимые меры государственной поддержки, однако многие страны используют протекционистские меры защиты сельскохозяйственных отраслей. Казахстан осуществляет государственную поддержку в рамках «желтой корзины», однако по сравнению со странами ЕАЭС оказывает больший уровень государственной поддержки сельскому хозяйству. Методика ВТО «желтая корзина» искажает ценообразование на продукцию животноводства и растениеводства, и в целях повышения эффективности государственной финансовой поддержки необходимо пересмотреть способы государственной поддержки, а высвободившиеся средства следует направить на такие финансовые инструменты как возмещение процентной ставки, инвестиционное суб́сидирование, агрострахование, институт гарантирования.

В силу своей специфичности в условиях рыночной экономики сельское хозяйство требует оптимального сочетания государственного участия и применения рыночных инструментов на макро- и микроуровнях в агропромышленном комплексе страны [3, с. 21]. Классификация источников финансирования обусловлена специфическими чертами отрасли, а также ролью и значимостью сельского хозяйства. Определение и оптимальное сочетание источников финансирования позволяют более адекватно понять эффективность ресурсов, создавая условия привлечения ресурсов.
Характеристики источников и эффективность финансирования необходимо дополнять юридическими компонентами, нормами и договорами.

В Казахстане делаются первые шаги по проведению оценки последствий регулирования, необходимости обеспечения эффективности государственных программ. Так, постановлением Правительства Республики Казахстан утверждены Правила, регламентирующие разработку и утверждение годового отчета о ситуации, существующей в стране в сфере регулирования предпринимательской деятельности [2, c. 84]. Казахстан имеет множество исторических, географических и территориальных факторов, которые дают возможности для производства широкого спектра линейки продовольственной продукции как для внутреннего, так и для мировых рынков при условии эффективного развития отрасли, которое возможно обеспечить только при достижения эффективности вкладываемых финансовых ресурсов [4, с. 214].

Выводы. Сельское хозяйство, является базовым условием развития любого государства, а успешное и развитое государство формирует социально-экономическое развитое общество. Особое положение сельского хозяйства в структуре отраслей экономики обусловлено изначально производством продовольственных товаров для воспроизводства трудовых ресурсов, и, во-вторых, производством сельскохозяйственного сырья для остальных отраслей экономики. Казахстан, будучи четвертым по величине территории государством в Азии, улучшает свои позиции для решения существующих структурных проблем, которые возникли в процессе становления рыночных отношений, когда сельское хозяйство, пройдя этапы преобразований, не смогло адаптироваться к новым условиям и требует значительного внимания в сложившихся современных условиях.

Финансовые факторы развития сель- 
ского хозяйства играют значимую роль в повышение эффективности отрасли и специфика сельского хозяйства делает ее зависимой от внешних источников финансирования. Внешние источники представлены инвестициями, кредитами и субсидированием. Кредитование БВУ сельского хозяйства представлено краткосрочными и долгосрочными операциями, причем имеется тенденция роста долгосрочных кредитов, данная тенденция по нашему мнению является положительным фактором, однако, уровень ставок вознаграждения достаточно высок для сельского хозяйства. При вы- соком уровне корреляции валового выпуска продукции сельского хозяйства и субсидирования, необходимо соблюдать баланс, так как в условиях рынка риски. На объемы иностранных инвестиций в сельское хозяйство и финансирование из внешних источников оказывают влияние, кроме экономических факторов, также и политические факторы, следовательно, необходимо продолжать работу по созданию благоприятного инвестиционного климата в стране, а также разрабатывать государственные программы поддержки с учетом результативности вложенных финансовых ресурсов.

\section{ЛИТЕРАТУРА}

1. Финансовый менеджмент: Учебник / Кол. авторов; под ред. проф. Е.И. Шохина. 4-е изд., стер. - М.: КНОРУС, 2012. - 480 с.

2. Тургель И.Д., Панзабекова А.Ж. Оценка регулирующего воздействия в постсоветских странах: результаты, проблемы, перспективы // Управленческие науки / MANAGEMENT SCIENCES. - 2018. - T. 8. - № 2. - C. 84-93.

3. Турекулова Д.М., Муканов А.Х. Особенности государственного регулирования АПК в Республике Казахстан // Вестник КазЭУ. - 2012. - № 6. - С. 21-27.

4. Есполов Т.И. Эффективность агропродовольственного комплекса Казахстана / Т.И. Есполов. - Алматы: НИЦ «Ғылым». - 2002. - 448 с.

5. Послание Главы государства Касым-Жомарта Токаева народу Казахстана. 1 сентября 2020 г. www.akorda.kz/ru.

6. Всемирный банк. https://www.vsemirnyjbank.org/ru/world-bank-financing-to-helpkazakhstan

7. Комитет по статистике Министерства Национальной экономики РК. http://stat.gov.kz.

8. Национальный банк РК, 2007-2019 гг. http://www. nationalbank.kz.

9. Международный финансовый центр Астана. http://aifc.edu.kz/ru.

10. Министерство сельского хозяйства РК. http://www.minagri.gov.kz.

\section{REFERENCES}

1. Financial management: Textbook / Team of authors; ed. prof. E.I. Shokhin. - 4th ed., erased. - M .: KNORUS, 2012 . - 480 p. [in Russian].

2. Turgel' I.D., Panzabekova A.Zh. Ocenka reguliruyushchego vozdejstviya v postsovetskih stranah: rezul'taty, problemy, perspektivy // Upravlencheskie nauki/ MANAGEMENT SCIENCES - 2018. - T. 8. - № 2. - S. 84-93 [in Russian].

3. Turekulova D.M., Mukanov A.H. Osobennosti gosudarstvennogo regulirovaniya APK v Respublike Kazahstan // VestnikKazEU. - 2012. - № 6. - S. 21-27 [in Russian].

4. Espolov T.I. Effektivnost' agroprodovol'stvennogo kompleksa Kazahstana / T.I. Espolov. Almaty: NIC «Gylym». - 2002. - 448 s. [in Russian]. 
Қаржы жнәне есеп / Финансы и учет

5. Poslanie Glavy' gosudarstva Kasy'm-Zhomarta Tokaeva narodu Kazakhstana. 1 sentyabrya 2020. g www.akorda.kz/ru [in Russian].

6. Vsemirnyj bank. https://www.vsemirnyjbank.org/ru/world-bank-financing-to-help-kazakhstan [in Russian].

7. Komitet po statistike Ministerstva Nacional'noj ekonomiki RK. http://stat.gov.kz [in Russian].

8. Nacional'nyj bank RK, 2007-2019 gg. http: // www. nationalbank.kz [in Russian].

9. Mezhdunarodnyj finansovyj centr Astana. http://aifc.edu.kz/ru [in Russian].

10. Ministerstvo sel'skogo hozyajstva RK. http://www.minagri.gov.kz [in Russian].

А.А. Нұрымов, А.М. Уахитжанова

АУЫЛ ШАРУАШЫЛЫҒЫН ДАМЫТУДЫҢ ҚАРЖЫЛЫҚ АСПЕКТІСІ

\begin{abstract}
Аңдатпа
Осы мақаланың зерртеу нысаны Қазақстан Республикасының ауылшаруашылығы болып табылады. Ауылшаруашылығын дамытудағы қазіргі басымдықтар келесідей қарастырылған: жер қатынастарын дамыту, ауылшаруашылық суды пайдаланудың тиімді жүйесін қалыптастыру, егіс алқаптарының құрылымын оңтайландыру, өсімдіктерді қорғау және карантин, асыл тұқымды мал шаруашылығы мен ветеринарияны дамыту, ауылшаруашылық техникасын дамыту, сақтандыру, несие беру, салық саясаты. Қолданылған қаржы құралдарын әртараптандыратын және тұтастай алғанда саланы қаржыландырудың тиімділігіне әсер ететін ауылшаруашылығының нақты ерекшеліктері анықталды. Мақалада нарықтық процестер мен салалық ерекшеліктерді түсінуді ескере отырып, саланы дамытудағы қаржылық факторлардың маңыздылығын негіздеуге әрекет жасалды. Мемлекеттің рөлі, оның саланың дамуын қамтамасыз етудегі қатысу қажеттілігі, сондай-ақ елдің азық-түлік қауіпсіздігі көрсетілген.
\end{abstract}

\title{
A. Nurumov, A. Uakhitzhanova
}

\section{FINANCIAL ASPECT OF AGRICULTURAL DEVELOPMENT}

\section{Annotation}

The object of research in this article is the agriculture of the Republic of Kazakhstan. The subject of the research is financial instruments that influence the development of the industry and are associated with the distribution, redistribution and control of financial resources among the subjects of the industry in the prism of industry specifics and the need to ensure the country's food security. Considered the current priorities in the development of agriculture today are distributed as follows: the development of land relations, the formation of an effective system of agricultural water use, optimization of the structure of sown areas, protection and quarantine of plants, the development of livestock breeding and veterinary medicine, the development of agricultural engineering, insurance, lending, tax policy. The specific features of agriculture have been identified, which diversification of the used financial instruments and affect the efficiency of financing the industry as a whole. The article attempts to substantiate the importance of financial factors in the development of the industry, taking into account the understanding of market processes and industry specifics. The role of the state, the need for its presence in ensuring the development of the industry, as well as the country's food security are highlighted.

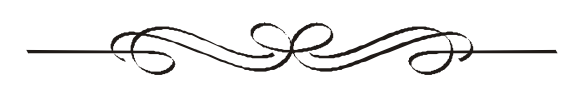


DOI 10.52260/2304-7216.2020.4(41).23

УДК 004.051:336.225 (574)

ГРНТИ 06.73.15

\author{
Б.Т. Аймурзина*, д.э.н., профессор \\ Б.С. Есенгельдин, $\partial$ э.н., профессор \\ М.Ж. Каменова, д.э.н., профессор \\ Казахский университет экономики, финансов \\ и международной торговли \\ 2. Нур-Султан \\ e-mail: aimurzina@mail.ru \\ * - основной автор (автор для корреспонденции)
}

\section{ОЦЕНКА ЭФФЕКТИВНОСТИ СОВРЕМЕННОГО НАЛОГОВОГО МЕХАНИЗМА В КАЗАХСТАНЕ}

Авторами статьи рассмотрены вопросы совершенствования налогового механизма путем достижения научно обоснованного компромисса между экономическими интересами различных субъектов налоговой политики, обеспечивающего максимально эффективное в существующих условиях решение совокупности задач сочиально-экономического развития страны. Проведен анализ уровня налоговой нагрузки Казахстана, динамики поступлений налога на добавленную стоимость, корпоративного подоходного налога и индивидуального подоходного налога в доходную часть государственного бюджета за последние годы. Выделено, что основными направлениями совершенствования налогового механизма должны быть обеспечение необходимого уровня поступления налогов в бюджетную систему страны, создание стимулов для увеличения налоговых поступлений, поддержание социального равновесия в стране налоговыми методами, создание справедливых условий и соответствуюших стимулов для налогоплательщиков в различных экономических условиях, оченка эффективности налогового механизма на каждом этапе развития страны.

В статье предложены конкретные рекомендации по совершенствованию оченки состояния современного налогового механизма.

Ключевые слова: налоговый механизм, налоговая нагрузка, налоговое бремя, продуктивность налога, эффективность налога, реальная ставка, бюджетообразующие налоги, рентабельность, оченка эффективности, стратегия.

Кілт сөздер: салық механизмі, салық жүктемесі, салық ауыртпашылывы, салықтың өнімділігі, салықтың тиімділігі, нақты мөлшерлеме, бюджет құраушы салықтар, табыстылық, тиімділікті багалау, стратегия.

Keywords: tax mechanism, tax burden, tax burden, tax productivity, tax efficiency, real rate, budget-forming taxes, profitability, efficiency evaluation, strategy.

Введение. Налоговая политика любого государства на каждом уровне должна разрабатываться в соответствии с принятыми стратегическими направлениями его социально-экономического развития. Методы налогового регулирования являются составной частью научно-обоснованной налоговой концепции. Различия в методах налогового регулирования определяются свойствами определенного вида налога, а также задачами, которые стоят перед государством. Так, целевые задачи налогового регулирования могут включать обеспечение инвестиционной активности, проведение протекционистской политики, регулирование спроса и предложения, решение социальных проблем, расширение сферы деятельности малого бизнеса. Среди новых 
Каржы жнәне есеп / Финансы и учет

ориентиров должно быть совершенствование налогового администрирования, упрощение и минимизация налоговой отчетности с переходом хозяйствующих субъектов на полный режим электронной отчетности. На должном уровне должна решаться проблема управления налоговыми потоками, поскольку обеспечивая достаточный уровень доходов бюджетной системы, налоговая система в то же время не должна создавать избыточного или неравномерного давления на экономику. Важно добиться того, чтобы уровень и структура налоговой нагрузки не ухудшали условия для экономического роста, не искажали условия конкуренции и не препятствовали притоку инвестиций, а напротив, способствовали повышению конкурентоспособности и реструктуризации экономики в пользу перерабатывающих отраслей на инновационной основе.

Эффективность реформирования системы налогового регулирования обращает внимание, прежде всего на такие структурные параметры налоговой системы, как общий уровень налоговой нагрузки на экономику и структуру налоговых поступлений. Налоги, которые являются основным источником государственных поступлений, создают финансовую базу для функционирования государственного сектора. Одним из важнейших макроэкономических аспектов налоговой системы, как доходной части бюджета, является общая налоговая нагрузка на экономику, то есть отношение суммы всех налоговых поступлений к ВВП. В связи с этим, остро возникает вопрос по необходимости оценки эффективности современного налогового механизма на каждом этапе развития.

Обзор литературы. Исследованием проблем налогового регулирования, механизмов формирования доходной части государственного бюджета и эффективности использования налоговых поступлений занимаются целый ряд казахстанских и за- рубежных ученых, специалистов-практиков. В связи с чем, актуальность проблемы оценки налогового механизма и его эффективности, особая значимость данного вопроса в условиях рыночной экономики Казахстана, обуславливают возрастающее внимание к ней, как в практическом, так и научном аспекте.

В развитии теории налоговых отношений высказываются различные точки зрения о влиянии налогов на экономику страны и соответствующих направлениях налоговой политики государства. Однако, используя данный опыт, необходимо учитывать исторические условия функционирования каждой теории. Вопросы управления финансами и налогами явились предметом исследования многих казахстанских экономистов: М. Оспанов, Г. Карагусова $[1,2]$, показывающих, что слишком много налогов и слишком высокое налоговое бремя несет отечественная экономика. В работе Ю. Дубермана [3] подчеркивается, что Казахстану требуется введение нового налогового кодекса. Проблемы совершенствования налогового механизма исследуется в трудах профессора А.А. Нурумова [4].

Однако несмотря на то, что вопросам совершенствования налогового механизма уделено значительное внимание, следует отметить, что не в полной мере достаточно исследованы механизмы, позволяющие дать оценку эффективности налоговой системы государства на каждом этапе его развития.

Методологическую основу исследования составляет комплексный подход и диалектические принципы, позволившие выявить сущностные характеристики изучаемых процессов, формы их проявления, выделить присущие им противоречия и определить тенденции их развития. Данное исследование проводилось с использованием системного и структурно-уровневого подхода, методов логического, сравнительного и статистического анализа и др.

Основная часть. Эффективность того 
или иного сектора экономики с точки зрения налогового администрирования определяет место налоговых платежей анализируемых отраслей в общей сумме налоговых поступлений. В большинстве стран с плановой экономикой доля государственных ассигнований превышала 50\% ВВП, иногда, даже, приближаясь к 70\%. Такой непропорционально высокий уровень государственных расходов имел, преимущественно, под собой идеологическую основу, воплощением которой стала разветвленная система цент- рализованного планирования и контроля.

С целью международных сопоставлений, для характеристики фактического уровня налогов в стране используют, так называемый, налоговый коэффициент, который рассчитывается как отношение суммы уплаченных налогов, включая отчисления на обязательное социальное страхование, к валовому внутреннему продукту в рыночных ценах. На рисунке 1 представлена динамика налоговой нагрузки на экономику Казахстана в течение 2014-2019 гг.

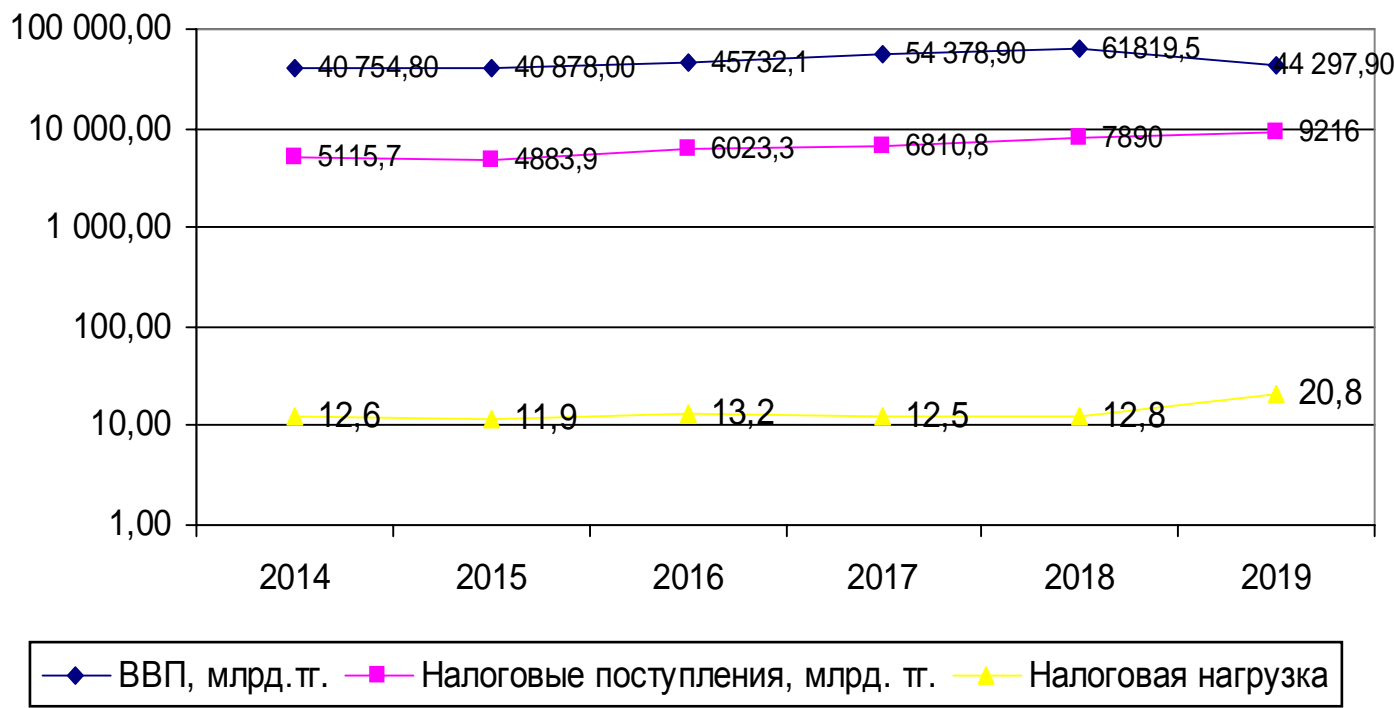

Рисунок 1. Динамика уровня налоговой нагрузки Казахстана в 2014-2019 гг.*

*Составлен по данным Министерства финансов РК [5]

Как показывает рисунок 1 средний уровень налоговой нагрузки за последние три года составил $15,4 \%$ и колебался в пределах 12,6-20,8\%. Если сравнить с развитыми странами общий уровень налогообложения в Казахстане $(15,4 \%)$ находится существенно ниже, чем в развитых странах: Дания (48,0\%), Швеция (44,0\%), Италия $(44,4 \%)$ и Франция $(45,3 \%)$. Сравнение налогообложения хозяйствующих субъектов в РК с мировой практикой показывает много общего. Для Республики Казахстан наибольший интерес представляют налоговые системы европейских государств. Даже учитывая позитивные результаты европейской налоговой гармонизации с момента начала ее реализации: полную отмену внутренних таможенных пошлин в интеграционном сообществе, введение единого по способу взимания НДС, начало работы в области гармонизации прямых налогов, структура национальных налоговых систем пока неоднородна, дифференциация обусловлена разной ролью тех или иных налогов для развития той или иной страны), поскольку государства следуют разным концепциям национального экономического развития (рис. 2). 
Қаржы жжәне есеп / Финансы и учет

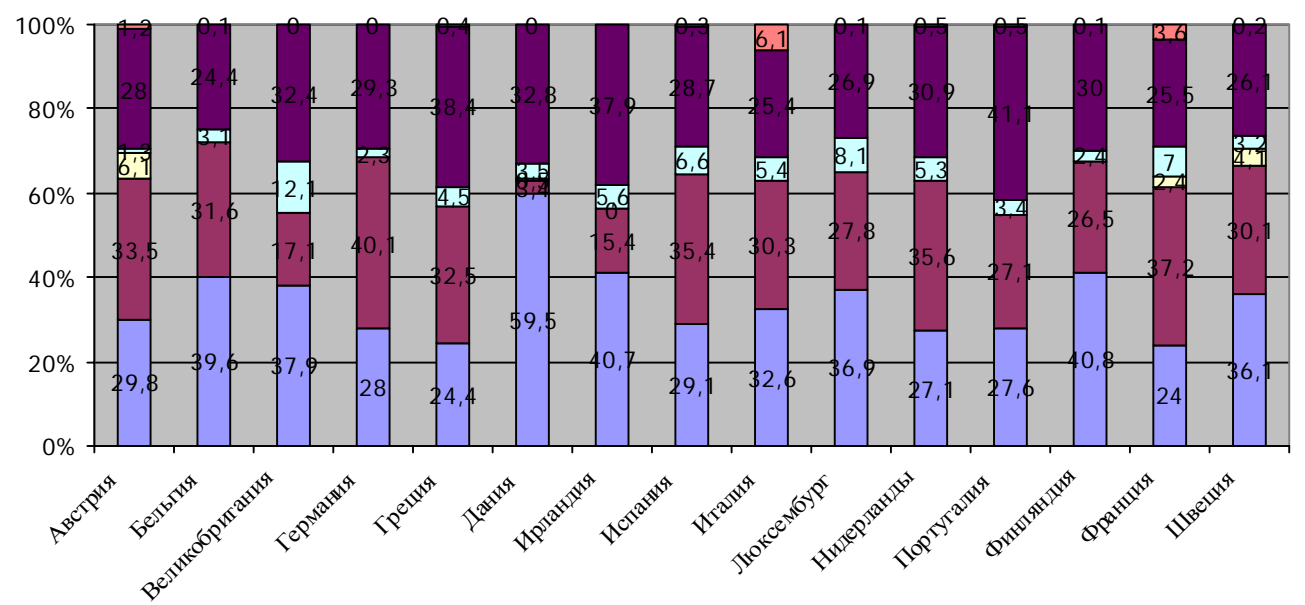

\begin{tabular}{|ll|}
\hline$\square$ Подоходные налоги & $\square$ Социальные налоги и сборы $\boldsymbol{\square}$ Налог на фонд оплаты труда \\
$\square$ Налоги на имущество & $\square$ Налоги на товары и услуги $\quad \square$ Прочие \\
\hline
\end{tabular}

Рисунок 2. Структура налоговых систем зарубежных стран

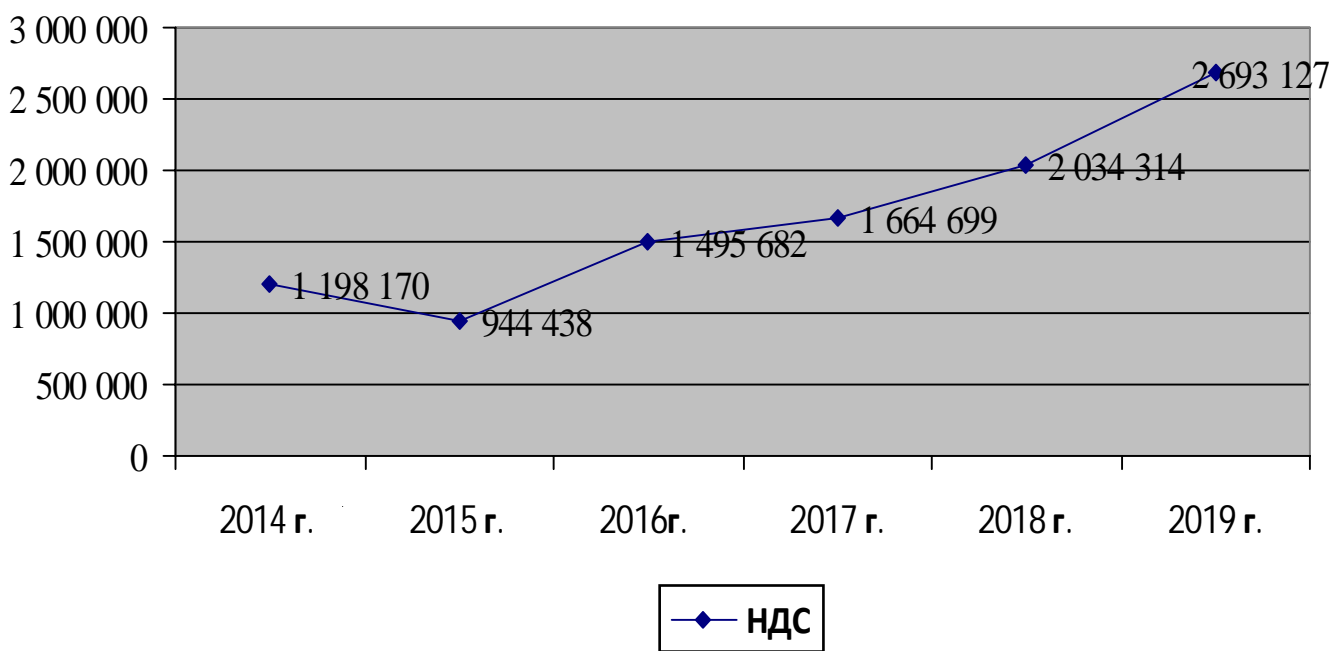

Рисунок 3. Динамика поступлений НДС в государственный бюджет Казахстана в 2014-2019 гг., (млн тенге)*

*Составлен по даннымм Министерства финансов РК [5]

Всего в рамках группировки можно выделить три наиболее характерные модели макроэкономического развития: англосаксонскую (неолиберальную), южноевропейскую и социальную рыночную, для каждой из которых роль налогов в национальной экономике в целом, а также определенных их видов будет иметь разное значение. Анализ зарубежной статистики налоговых доходов государства позволяет 202 ориентировочно определить главные направления политики налогового изъятия, а также степень участия отдельных налогов в этом процессе, т.е. налоговую структуру данного процесса. Основные направления процесса налогового изъятия могут быть сгруппированы следующим образом: корпоративный налог и прочие налоги на прибыль компаний; взносы предпринимателей в фонды социального страхования; косвен- 
ные налоги, которые уплачиваются за счет прибавочной стоимости; подоходные налоги с населения; налоги, отражающие национальные особенности налоговых систем.

Анализ поступления системообразующих налогов, имеющих высокий удельный вес в налоговых поступлениях государственного бюджета Казахстана показывает, что одним из таких налогов является налог на добавленную стоимость (НДС). Так, данные рисунка 2 показывают, что в 2019 г. в государственный бюджет Казахстана поступило 2 693,1 млрд тг. налога на добавленную стоимость, что почти в 2,2 раза больше показателя 2014 года (рис. 3).

Поступления НДС с произведенных в Казахстане товаров увеличились с 333,9 млрд тг. в 2014 г. до 525,3 млрд тг. в 2016 г. и в 2019 году до 1221,0 млрд тенге или почти в 3,6 раза. Большая часть НДС была возмещена плательщикам: в 2014-2019 гг. в среднем 75,82\%. Практика показала, что низкая фискальная отдача от внутреннего НДС обусловлена высокой экспортной ориентированностью отечественной экономики, на что указывает незначительная доля «отечественного налога» в общих поступлениях налога - 27,9\% в 2014 г., 35,1\% в 2016 г. и 24,9\% в 2019 году. При этом самыми распространенными способами минимизации налоговых обязательств по НДС являются: искусственное формирование налогового кредита с помощью использования фиктивных банкротов, фаль- шивых накладных действующих предприятий и накладных предыдущих налоговых периодов; осуществление виртуальных финансово-хозяйственных операций; реализация продукции через упрощенную систему налогообложения; осуществление операций фиктивного экспорта. На величину продуктивности НДС влияют налоговые льготы, уклонение от уплаты [5].

Показатель бюджетной эффективности НДС, отражающий, сколько поступлений налога в процентах к ВВП приходится на $1 \%$ номинальной ставки в Казахстане колеблется в пределах 19-27,3\%, тогда как средний показатель бюджетной эффективности НДС в странах ЕС составляет 41\%, что обусловлено более низкой производительностью НДС в Казахстане.

Вторым крупным налогом является корпоративный подоходный налог, который уплачивают субъекты хозяйствования - юридические лица, которые осуществляют хозяйственную деятельность, как на территории Казахстана, так и за ее пределами. Так, в 2016 г. в государственный бюджет поступило 1437,4 млрд тг. корпоративного подоходного налога, что меньше уровня 2019 года на 510,0 млрд тенге. Рассчитывая показатель налогового бремени, определим эффективную ставку налога как отношение величины налоговых поступлений к величине совокупной прибыли предприятий (табл. 1, рис. 4).

Таблица 1

Динамика поступления КПН и основных финансово-хозяйственных показателей средних и крупных предприятий за 2014-2019 гг.*

\begin{tabular}{|l|c|c|c|c|c|c|}
\hline \multicolumn{1}{|c|}{ Показатель } & 2014 & 2015 & 2016 & 2017 & 2018 & 2019 \\
\hline \multicolumn{1}{|c|}{1} & 2 & 3 & 4 & 5 & 6 & 7 \\
\hline $\begin{array}{l}\text { Налоги и другие обязательные } \\
\text { платежи в бюджет (фактически } \\
\text { перечисленные), млрд тенге }\end{array}$ & 6420,4 & 4827,2 & 6023,3 & 6810,9 & 7890,0 & 9216,5 \\
\hline Поступления КПН, млрд тенге & 1169,7 & 1224,6 & 1437,4 & 1538,8 & 1687,6 & 1974,8 \\
\hline
\end{tabular}


Каржы энәне есеп / Финансы и учет

\begin{tabular}{|l|r|r|r|r|r|r|}
\hline \multicolumn{1}{|c|}{1} & \multicolumn{1}{c|}{2} & \multicolumn{1}{c|}{3} & \multicolumn{1}{c|}{4} & \multicolumn{1}{c|}{5} & \multicolumn{1}{c|}{7} \\
\hline Доля КПН в общей сумме налогов, \% & 18,2 & 25,4 & 29,4 & 22,6 & 21,4 & 21,4 \\
\hline $\begin{array}{l}\text { Совокупная прибыль до } \\
\text { налогообложения, млрд тенге }\end{array}$ & 5100,7 & $-1856,1$ & 4673,9 & 8819,0 & 9730,7 & 11013,5 \\
\hline Рентабельность (убыточность), \% & 17,0 & $-5,0$ & 17,8 & 24,3 & 23,0 & 24,2 \\
\hline
\end{tabular}

*Составлена по данным Комитета по статистике [6]

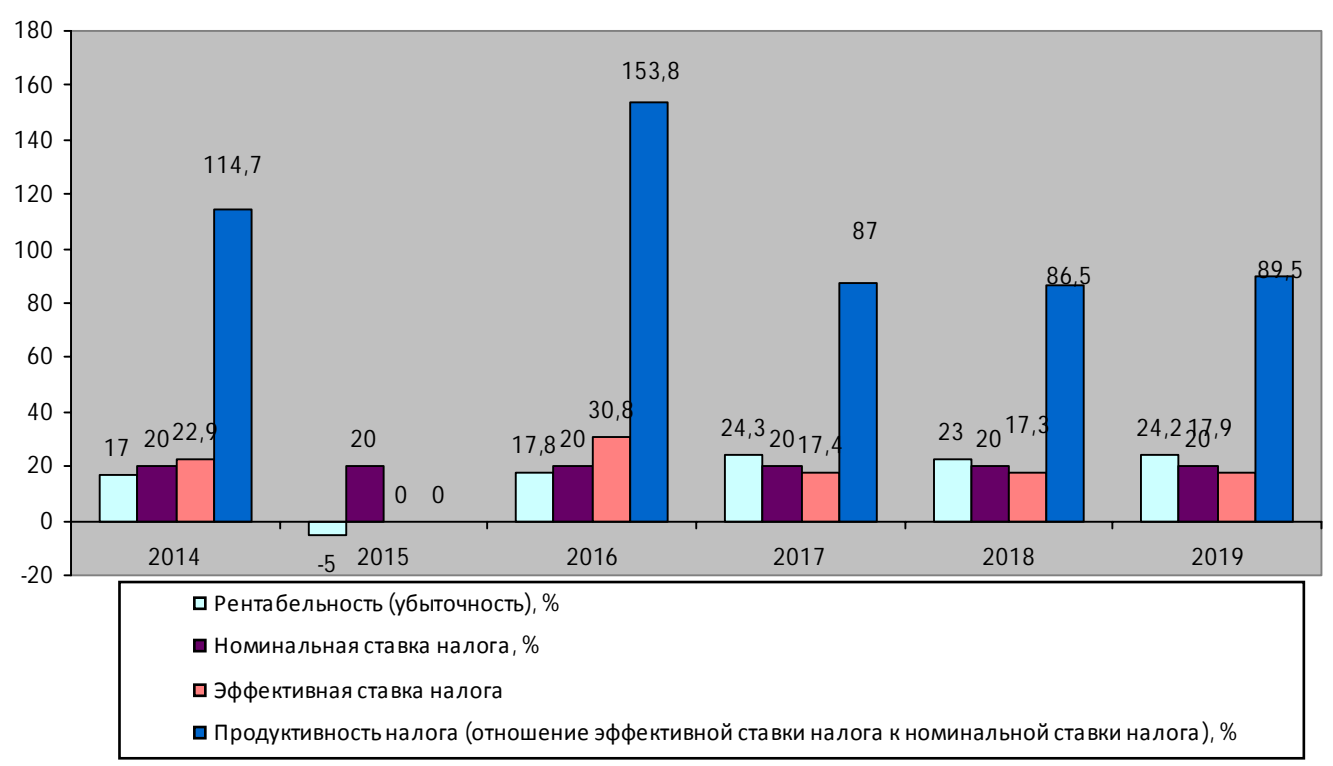

\section{Рисунок 4. Показатели эффективности и продуктивности КПН за 2014-2019 гг.*}

*Составлен по данным Министерства финансов РК [5]

Данные рисунка 4 показывают, что продуктивность налога за анализируемый период снизилась с 114,7\% (эффективная ставка 22,9\%) в 2014 году до 89,5\% (эффективная ставка 17,9\%) в 2019 году, при этом максимальная продуктивность отмечается в 2016 году при эффективной ставке $30,8 \%$. То есть, продуктивность налога с прибыли предприятий колебалась в 20142016 гг. в пределах 114,7-153,8\%, а в 2017 году снизилась до 87\%. Такая значительная разница связана с авансовым методом его уплаты, когда платежи в текущем году рассчитываются, исходя из результатов прошлого. Несмотря на положительные тенденции к увеличению поступлений от КПН, его доля в структуре налоговых поступлений все же остается значительной и в среднем составляет $23,0 \%$.

Следующим налогом является индивидуальный подоходный налог, взимаемый с доходов физических лиц, которые получают доходы из источников их происхождения в Казахстане. Поступления индивидуального подоходного налога в течение 2016-2019 г. росли, и, по данным Министерства финансов Республики Казахстан, в 2019 г. они составили 876,3 млрд тг. По сравнению с 2016 г. эти поступления выросли на 184,5 млрд тг., или на $26,7 \%$. Несмотря на рост поступлений ИПН в государственный бюджет, в Казахстане налогообложение доходов граждан имеет серьезные внутренние фундаментальные недостатки, которые негативно влияют на восприятие его обществом. 
Каржы жжәне есеп / Финансы и учет

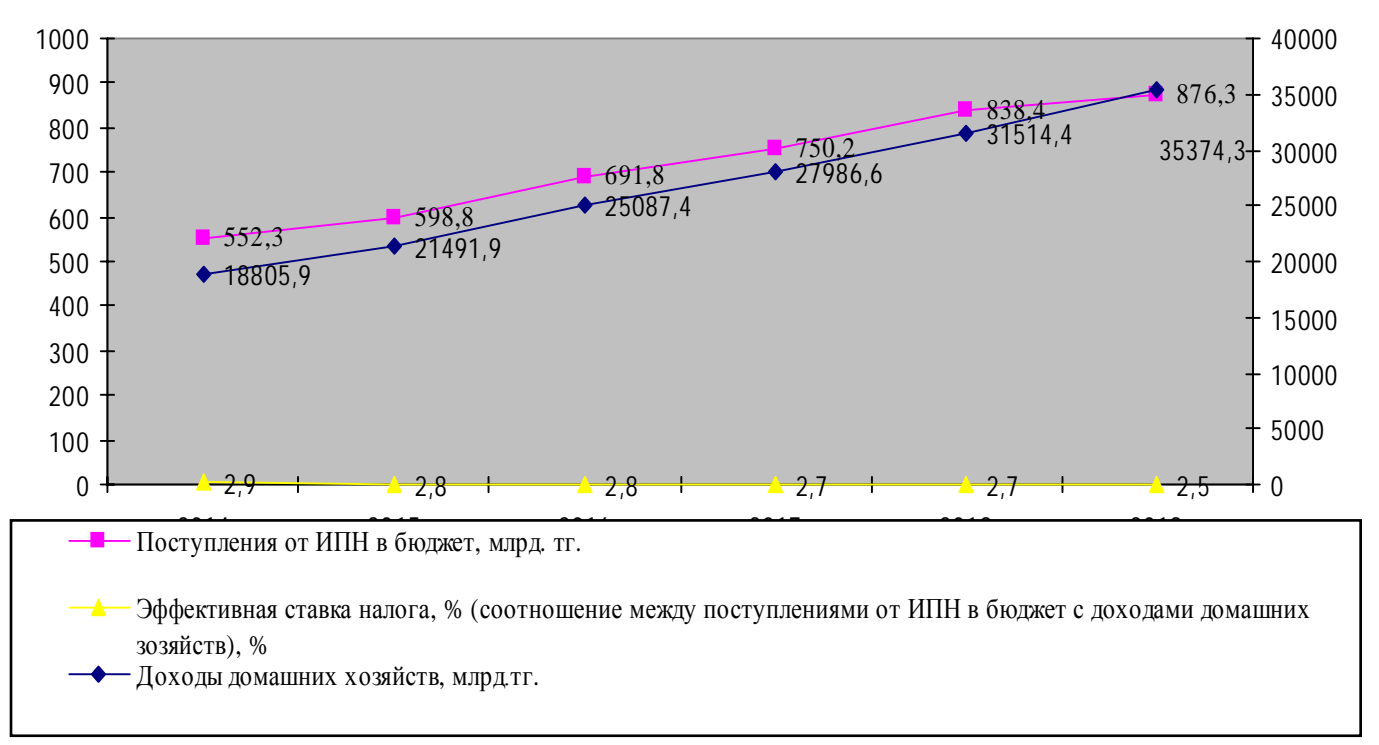

Рисунок 5. Показатели эффективной ставки ИПН в 2014-2019 гг.*

*Составлен по данным Министерства финансов РК [5]

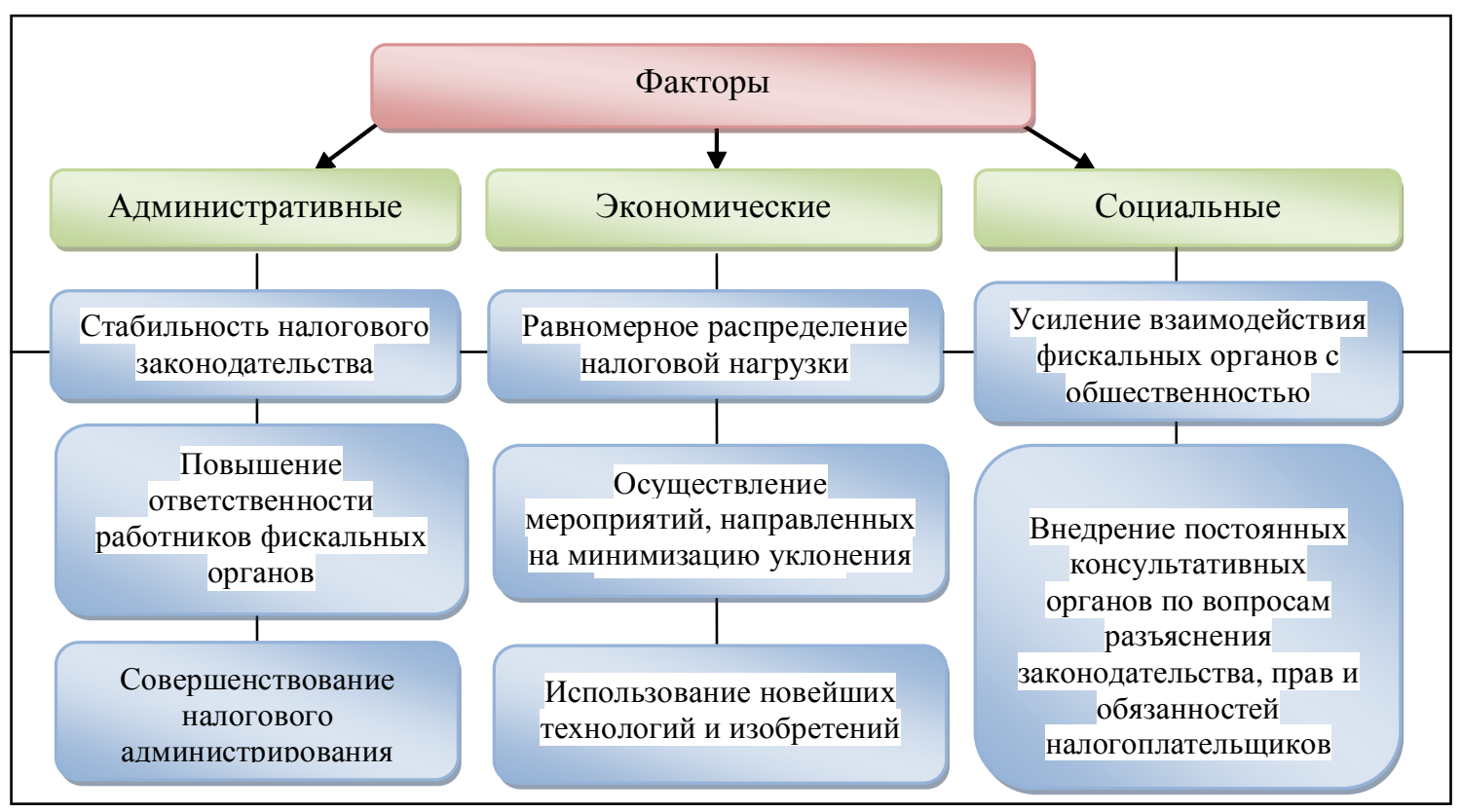

\section{Рисунок 6. Направления оптимизации системы администрирования налогов в Казахстане}

Как показывают данные рисунка 5, реальная эффективная ставка ИПН является достаточно низкой и колеблется в течение 2014-2019 гг. в пределах 2,7\% при номинальном значении $10 \%$. Однако, необходимо учитывать, что малоимущие слои на- селения, в структуре собственных расходов, платят значительно больший объем средств, чем состоятельные. Это связано с тем, что для большинства граждан с невысоким достатком единственным источником дохода является заработная плата. Все это свиде- 
Қаржы жжәне есеп / Финансы и учет

тельствует о неотложной необходимости разработать в Казахстане эффективную систему налогообложения доходов физических лиц, которая остановила бы нарастание социального неравенства среди населения. Также из серьезных проблем в вопросе индивидуального налогообложения в Казахстане является вопрос совершенствования механизма использования в практике вычетов.

Таким образом, по нашему мнению, можно констатировать, что эффективность действия основных налогов не всегда высокая вследствие несовершенных механизмов их применения [7]. Приведенное понимание двойственной сущности природы администрирование налогов дает возможности комплексно подойти к механизму оптимизации системы администрирования в направлении повышения качества и его эффективности. То есть необходимо выявить проблемы администрирования налогов в Казахстане, выявить направления их преодоления и реализовать потенциал системы администрирования налогов (рис. 6).

Выводы. Таким образом, Правительство, проводя налоговое регулирование, стремится достичь различных целей: от увеличения налоговых доходов в улучшение регулирования, которыми руководствуются налогоплательщики при расчете и уплате налогов. Основными факторами оптимизации системы администрирования налогов в Казахстане должны быть административные, экономические и социальные факторы. Реформирование налогов на доходы приобретает важное значение, т.к. поможет решить проблему теневого сектора экономики, равномерного распределения налоговой нагрузки среди отраслей экономики и поможет эффективному наполнению доходной части государственного бюджета Казахстана. В связи с этим, в условиях возрастающей зависимости государственного бюджета Казахстана от налогообложения сырьевого сектора будет нарастать необходимость изучения проблемных вопросов совершенствования методологии оценки налогового механизма. Экономика требует более мудрой налоговой политики, которая бы не подрывала условий воспроизводства. Налоги не должны гасить стремление производителя наращивать выпуск продукции. Следующая ступень развития концепции налогообложения связана с пониманием того, что манипуляция налоговыми ставками, увязка налогов с использованием ресурсов превращает их в мощный регулятор хозяйственных пропорций.

\section{ЛИТЕРАТУРА}

1. Оспанов М.Т. Методологические и концептуальные основы Кодекса Республики Казахстан о налогах и других обязательных платежах в бюджет (Налогового кодекса). Алматы: Познание, 1994. - С. 19-40.

2. Карагусова Г. Налоги: сущность и практика использования. - Алматы: Қаржы Қаражат, 1994. - С. 10-15.

3. Дуберман Ю. Налоговый закон: во благо или во вред. - Алматы // Налоговый конгресс. - 1994. - № 14. - С. 10.

4. Нурумов А.А., Берстембаева Р.К. Финансовые аспекты децентрализации в Республике Казахстан // Государственный аудит. - 2019. - №2 (43). - С. 54-62.

5. Официальный интернет-ресурс Министерства финансов Республики Казахстан. http://www. minfin.kz. (Дата обращения: 15.01.2019 г.).

6. Статистика // Комитет статистики Министерства национальной экономики Республики Казахстан [Электронный ресурс]. -2020. URL: http:// www.stat.kz. (Дата обращения: 13.10.2020 г.). 
7. Есенгельдин Б., Аймурзина Б.Т. Проблемы эффективности использования активов государства субъектами квазисектора // Вестник КазУЭФМТ. - 2020. - № 1. - С. 140-148.

\section{REFERENCES}

1. Ospanov M.T. Metodologicheskie i konceptual'nye osnovy Kodeksa Respubliki Kazahstan o nalogah i drugih objazatel'nyh platezhah v bjudzhet (Nalogovogo kodeksa). -Almaty: Poznanie, 1994. - S. 19-40 [in Russian].

2. Karagusova G. Nalogi: sushhnost' i praktika ispol' zovanija. - Almaty: Karzhy Karazhat, 1994. - S. 10-15 [in Russian].

3. Duberman Ju. Nalogovyj zakon: vo blago ili vo vred. - Almaty // Nalogovyj kongress. 1994. - № 14. - S. 10 [in Russian].

4. Nurumov A.A., Berstembaeva R.K. finansovye aspekty decentralizacii v Respublike Kazahstan // Gosudarstvennyj audit. - 2019. - №2 (43). - S. 54-62 [in Russian].

5. Oficial'nyj internet-resurs Ministerstva Finansov Respubliki Kazahstan. http://www. minfin.kz. (Data obrashhenija: 15.01.2019 g.) [in Russian].

6. Statistika // Komitet statistiki Ministerstva nacional'noj jekonomiki Respubliki Kazahstan [Jelektronnyj resurs].-2020. URL: http:// www.stat.kz (Data obrashhenija: 13.10.2020 g.) [in Russian].

7. Esengel'din B., Ajmurzina B.T. Problemy jeffektivnosti ispol'zovanija aktivov gosudarstva sub\#ektami kvazisektora // Vestnik Kazahskogo universiteta jekonomiki, finansov i mezhdunarodnoj torgovli. - 2020. - № 1. - S. 140-148 [in Russian].

\section{Б.Т. Аймурзина, Б.С. Есенгельдин, М.Ж. Каменова}

\section{ҚАЗАҚСТАНДАҒЫ ҚАЗІРГІ ЗАМАНҒЫ САЛЫҚ МЕХАНИЗМІНІҢ ТИІМДІЛІГІН БАҒАЛАУ}

\section{Андатпа}

Мақалада қазіргі заманғы салық механизмі мақсаттарының кешенді жүйесі әлеуметтік дамудың басым қажеттіліктерінің иерархиясын ескере отырып құрылуы керектігі және салықтардың қаржылық сипаты мен мақсатын ескеру қажет екендігі баяандалған. Тәжірибе көрсеткендей, салықтық реттеудің басты мақсаты қоғамның оңтайлы әлеуметтік-экономикалық дамуын қамтамасыз ету болуы тиіс. Қоғамның стратегиялық қажеттіліктерін қамтамасыз ету кезінде салықтық реттеудің фискалдық, экономикалық және әлеуметтік мақсаттарын бөліп көрсету қажет.

Мақала авторлары елдің әлеуметтік-экономикалық даму міндеттерінің жиынтығын қазіргі жағдайда тиімді шешуді қамтамасыз ететін салық саясатының әртүрлі субъектілерінің экономикалық мүдделері арасында ғылыми негізделген ымыраға қол жеткізу арқылы салық механизмін жетілдіру мәселелерін қарастырған. Қазақстанның салық жүктемесі деңгейіне, соңғы жылдары мемлекеттік бюджеттің кіріс бөлігіне қосылған құн салығы, корпоративтік табыс салығы және жеке табыс салығы түсімдерінің серпініне талдау жүргізілген. Салық механизмін жетілдірудің негізгі бағыттары мыналарды қамтиды: елдің бюджет жүйесіне салық түсімдерінің қажетті деңгейін қамтамасыз ету, салық түсімдерін ұлғайту үшін ынталандыру жасау, салық әдістерімен елде әлеуметтік тепе-теңдікті сақтау, әр түрлі экономикалық жағдайларда салық төлеушілер үшін әділ жағдайлар мен тиісті ынталандыру жасау, ел дамуының әр кезеңінде салық механизмінің тиімділігін бағалау.

Мақалада қазіргі заманғы салық механизмінің жай-күйін бағалауды жетілдіру бойынша нақты ұсыныстар берілген. 
Қаржы жнәне есеп / Финансы и учет

\section{B. Aimurzina, B. Yessengeldin, M. Kamenova}

\section{ASSESSMENT OF THE EFFECTIVENESS OF THE MODERN TAX MECHANISM IN KAZAKHSTAN}

The article notes that today the complex system of goals of the modern tax mechanism should be built taking into account the hierarchy of dominant needs of social development and must take into account the financial nature and purpose of taxes. As practice shows, the main goal of tax regulation should be to ensure optimal socio-economic development of society. When ensuring the strategic needs of the company, it is necessary to allocate fiscal, economic and social goals of tax regulation.

The authors of the article consider the issues of improving the functioning of tax policy by developing and implementing measures to modernize the tax mechanism by achieving a scientifically based compromise between the economic interests of various subjects of tax policy, which provides the most effective solution to the set of problems of socio-economic development of the country in the existing conditions. Authors analyzed the level of the tax burden of Kazakhstan, the dynamics of receipts of value added tax, corporate income tax and individual income tax in the revenue part of the state budget in recent years. It is emphasized that the main directions of improving the tax mechanism should be: ensuring the necessary level of tax revenue in the country's budget system, creating incentives to increase tax revenues, maintaining social balance in the country by tax methods, creating fair conditions and appropriate incentives for taxpayers in various economic conditions, evaluating the effectiveness of the tax mechanism at each stage of the country's development.

The article offers specific recommendations for improving the assessment of the state of the modern tax mechanism. 
DOI 10.52260/2304-7216.2020.4(41).24

ӘОЖ 657.631.8

FTAMP 06.35.31

\section{ШАҒЫН ЖӘНЕ ОРТА КӘСІПОРЫНДАРДАҒЫ ЕСЕП САЯСАТЫН КҰРУДЫН МАНЫЗДЫЛЫҒЫ МЕН МӘСЕЛЕЛЕРІ}

Мақ̧алада шазын кәсіпорындардаzы бухгалтерлік есепте құалыптасатын ақ̧параттың пайдалылыгын анықтайтын талаптар мен бухгалтерлік ақппараттың сапалық сипаттамалары, сонымен ққатар есеп саясаты - бұл ұйымдаzы бухгалтерлік есеп ережелерін белгілейтін негізгі құжаттардың бірі екендігі құарастырылган, шагын кәсіпорын кез келген басққа шаруашылық субъектісімен қатар бухгалтерлік есеп жүргізу мақссатында есеп саясатын жасаува міндетті екендігі айтылван.

Бұл мақ̆алада шавын кәсіпорындардың есеп саясатын құалыптастыруга әсер ететін факторлар құарастырылады. Атап айтқ̧анда, жеңілдетілген бухгалтерлік есепті жүзеге асыратын шавын кәсіпорындардың есеп саясатын қ̧алыптастыру тәртібі ашылды.

Кілт сөздер: халықаралық құаржылық есеп стандарттары (ХҚЕС), бухгалтерлік есеп жалпы құавидаттары (БЕЖҚ), нарықтық құатынастар, есеп саясаты, жоспарлау, нормалау, бухгалтерлік есепті құалпына келтіру, шавын кәсіпкерлік, есеп саясаты, бухгалтерлік ақпарат, экономика, қзаржылық есептілік.

Ключевые слова: международные стандарты финансовый отчетности (МСФО), международные стандарты бухгалтерского учета (МСБУ), взаимоотношения, бухгалтерский учет, планирование, нормирование, возрождение учета, малые предприятия, налоговый учет, учетная политика, учетная информация, экономика, финансовая отчетность.

Keywords: international financial reporting standards (IFRS), international accounting standards (IAS), relationships, accounting, planning, rationing, revival of accounting, small enterprise, accounting policy, accounting information, economy, financial reporting.

JEL classification: M 41

Kipicпе. Қазіргі мемлекеттік «Бизнестің жыл картасы 2020» бағдарламаға сай шағын және орта кәсіпорын, әсіресе шағын кәсіпорын елдің әлеуметтік-экономикалық және саяси өмірінде маңызды рөл атқарады. Соған орай шағын және орта кәсіпорын- дарының Қазақстан экономикасындағы орнын қарастырамыз. Және де есеп саясатын құрастырудағы негізгі мәселерді шешу маңызды болып табылады.

Біріншіден, шағын және орта кәсіпорындардың Қазақстан экономикасын- 
Карэны энәне есеп / Финансы и учет

дағы орнын ашып көрейік.

Сонымен, кәсіпорындардың үш түрі бар: ipi, орта және шағын. Олардың кешені бірін-бірі толықтырады және экономиканың бүкіл құрылымын құрайды.

Iрі бизнес негізінен елдің экономикалық және техникалық қуатын анықтайды. Iрі кәсіпорындар - бұл экономиканың «қаңқасы», экономикалық тұрақтылықтың негізі.

Орта кәсіпорын ішкі экономикалық жағдайларға көбірек тәуелді, сондай-ақ өз тобында отандық ірі және шетелдік капиталдар мен бәсекелесуге мәжбүр. Бұл орта кәсіпкерліктің протекционистік мемлекеттік экономикалық саясат жүргізу және нарықтық қатынастардың белгілі бір ережелерін қалыптастыру арқылы ішкі нарықты қорғауға деген қызығушылығын анықтайды және де орта кәсіпорын пен ұлттық мүдделер арасындағы тығыз байланысты анықтайды.

Зерттеудің мақсаты мен міндеттері. Зерттеудің негізгі мақсаты халықаралық қаржылық есептілік стандарттарына және халықаралық аудит стандарттарына сәйкес шағын және орта кәсіпорындағы есеп саясатын ұйымдастырудың негізгі аспектілерін қарау болып табылады. Экономикалық шығындардың себептерінің бірі есеп саясатын дұрыс емес немесе дұрыс құрмау болып табылады деп болжанады.

Осылайша, әсіресе әр түрлі қызмет түрлері бар шағын және орта кәсіпорындарда мәселе тұр және құрылыстағы есеп саясатын дұрыс ұйымдастырудың ерекше қажеттілігі пайда болады.

Бәсекелестік жағдайында ұйымды басқару жүйесінің теориясы мен практикасын дамытуға нақты қажеттілік пайда болды, тиісінше кәсіпорындардың жұмысы басқарудың тиімді жүйесін және оның ішкі жүйесін қалыптастыруды талап етеді, сөйтіп кәсіпорындағы есеп саясаты қалыптасады.

Кәсіпорынды басқаруда есеп саясатының тұжырымдамасын әзірлеу мәселесі өзекті. Қойылған мақсаттың мазмұны зерт- теудің келесі міндеттерін шешу арқылы ашылады. Біріншіден, кәсіпорында басқару бақылауының маңызды және қажетті аспектісі ретінде әрекет ететін және оның қызметіне ішкі тәуелсіз баға беретін есеп саясатын ұйымдастыруды зерттеу. Екіншіден, шағын кәсіпорындардың есеп саясатының үрдісінің болашақта дамыту бойынша басымды бағыттарын негіздеу және ұсыныстар әзірлеу.

Әдістер - зерттеу сипаттау әдісін, салыстырмалы талдау мен қорытуды пайдалану арқылы жүргізілді. Зерттеу көздері салық аудиті мәселелері бойынша ғылыми мақалалар болды. Ұсынылған жұмыста қазақстандық компанияларда салық аудитін жүргізу тәжірибесі қолданылды.

Әдебиеттік шолу. Есеп саясаты ұғымы туралы әр түрлі ғалымдардың ойын қарастырайық.

«Кәсіпорынның есеп саясаты» ұғымы 1980 жылдың аяғында, Халықаралық бухгалтерлік есеп стандарттарына сәйкес Комитет шығарған стандарттарда қолданылатын «accounting policies» ағылшын тіліндегі аудармасы ретінде қарастыруға болады. «Есептік саясат» ұғымы алғаш рет Қазақстан Республикасының Қаржы министрлігінің 2007 жылғы 28 ақпандағы № 234-III бұйрығымен өзгертілген Қазақстан Республикасында бухгалтерлік есеп пен қаржылық есептілік туралы Заңда айтылып отыр [1].

М.Қ. Әлиевтің пікірінше, есеп саясаты ұйымдағы бухгалтерлік есеп процесінің барлық ұйымдастырушылық, техникалық, әдістемелік аспектілерін көрсетеді [2, 119 б.].

Есеп саясаты - кәсіпорынның қаржылық есептілікті жасау мен ұсыну уақытында қолданатын қағидалар, келісімдер, ережелер мен практика болып табылады.(XҚEC IAS 8 «Халықаралық қаржылық есептілік стандарты) [3].

Л.В. Назарованың пікірінше, «кәсіпорынның есеп саясаты - жарғылық және өзге де қызметтің экономикалық оқиғаларының фактілерін бастапқы бақылау (құжат- 
тау және түгендеу), құндық өлшеу (бағалау және калькуляция), ағымдағы топтастыру (шоттар және қосарлы жазу) мен қорытынды тұжырымға (баланстық қорытынды және есептілік) бухгалтерлік есептің қойылған әдістерін реттеу» [4, 109 б.].

М.А. Алтынбековтың пікірінше, есеп саясаты - бұл «қаржылық есептілікті дайындау және ұсыну үшін ұйым қолданатын нақты қағидалар, негіздер, келісімдер, ережелер мен тәжірибе» (IAS 8 «Есеп саясаты, бухгалтерлік есеп бағалауларындағы өзгерістер және қателіктер»). Компанияның есеп саясаты бухгалтерлік есеп процесін реттейтін нормативтік-құқықтық актілерге (НҚА) сай жасалады. Аталған актілер бухгалтерлік есепті реттеу жүйесін құрайды [5].

Осы бес тұжырымдама бірін-бірі толықтырады, дегенмен кәсіпорынның есеп саясаты барлық ұйымдардың меншік нысанының ұйымдық-құқықтық формасына қарамастан әзірленеді.

Негізгі бөлім. Шағын кәсіпорын, оның ішінде жеке кәсіпкерлік, бұқаралық сипатына байланысты, елдің әлеуметтік-экономикалық және ішінара саяси деңгейін анықтайтын шағын иеленушілердің үлкен тобын білдіреді. Халықтың көп бөлігі кәсіпорындардың осы түрінде қызмет істейді, яғни жұмыспен қамтылған, сонымен қатар олар тауарлардың және қызметтердің тікелей өндірушісі және тұтынушысы болады.

Дүниежүзілік тәжірибе көрсеткендей, экономикадағы шағын және орта кәсіпорынның рөлі соншалықты жоғары, сондықтан оларды асыра бағалау мүмкін емес. Бұл мемлекет өмірінің барлық салаларына әсер етеді: кейбір елдерде шағын және орта кәсіпорын жұмысшылар санында, өндірілген тауарлар көлемінде, орындалған жұмыстар мен көрсетілген қызметтер көлемінде маңызды рөл атқарады. Экономика үшін шағын кәсіпкерліктің икемділігін арттыратын негізгі мәселелер олардың икемділігі болып табылады. Шағын және орта кәсіпорынның дамуымен бірге сарапшылар елдердің өзгеріп жатқан экономикалық жағдайларға қалай бейімделетінін зерттейді. Қазақстан үшін шағын кәсіпорынның қалыптасуы жоғары дамыған қоғам мен жоғары дамыған экономика үшін көпір болуы керек, сондықтан кейбір статистикаға назар аударайық.

Қазіргі әлемдік экономиканың құрылымы үлкен және кішігірім өндіріс нысандарының және, тиісінше, басқарудың барлық салаларында, соның ішінде сыртқы экономикалық байланыстардағы ірі және кіші бизнестің үйлесімімен сипатталады.

Шағын кәсіпорындардың жеңілдетілген бухгалтерлік есеп жүйесінде сапалы есептік ақпараттың қалыптасуына есептік саясат және маманданған бухгалтерлік пайымдау сияқты факторлар да әсер етеді. Бұл есептік саясат бухгалтерлік есепті жүргізудің техникалық, әдістемелік қаржылық және салықтық аспектілерін қамтамасыз ету жолымен шағын кәсіпорынның өзі мен есептік ақпараттың сыртқы қолданушылары арасындағы қызығушылақтардың балансын қамтамасыз етеді.

Сонымен қатар маманданған бухгалтерлік пайымдау есептік ақпарат сапасына тікелей әсер етеді, себебі ол қызығушылығы бар қолданушылар жағынан шағын кәсіпорындардың жеңілдетілген бухгалтерлік есеп жүйесіндегі шарушылық өмірдің фактілерін объективті түрде көрсетеді.

1-кестеде шағын кәсіпорында есеп саясатын құру барысындағы кәсіби бухгалтерлік пайымдама қарастырылған.

Қазіргі нарықтық қатынастар жағдайында шағын кәсіпорындар үшін есеп саясатының маңыздылығы және оның көрсеткіштерінің рөлі басқару шешімдерін қабылдау, кәсіпорынның нарықтағы жағдайын анықтау кезінде өте маңызды болмақ. Есеп саясатының ережелері мен тұжырымдамалары негізінде жүзеге асырылатын қаржылық есептеменің деректері бойынша кәсіпорынның мүліктік және қаржылық жағдайы, оның төлем қабілеті, 
Қаржы жжәне есеп / Финансы и учет

шаруашылық етудің негізгі ережелері, (нашарлауындағы) үрдістер және т.б. көркәсіпорын қызметінің жақсаруындағы сеткіштер белгіленеді.

\section{Шағын кәсіпорында есеп саясатын құру барысында кәсіби бухгалтерлік пайымдаманы қолдану*}

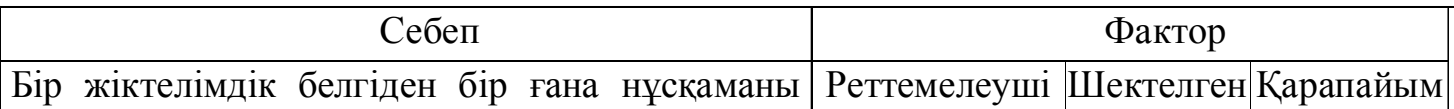

таңдауға болатын, жеке объектілер есебін вариация

тәртіпке келтіретін қолда бар нормативті-

құқықтық әдістерінің вариациялық қатары

Бірнеше жіктелімдік белгіден бір ғана нұсқа-

маны таңдауға болатын, жеке обектілер есебін

тәртіпке келтіретін қолда бар нормативті-

құқықтық әдістерінің вариациялық қатары

Тек біреуін міндетті таңдау шартынсыз жеке

обектілер есебін тәртіпке келтіретін қолда бар

нормативті-құқықтық әдістерінің вариациялық

қатары

Жеке обектілер есебін нормативті-құқықтық

әдісінде анықтылықтың жоқ болу жағдайында

қолда бар варияциялық қатар

Бухгалтерлік есепті жүргізудің нұсқалық тәсіл-

дері заңнамаларға қарама-қайшылықта болады

Жеке обектілерге бухгалтерлік есепті жүргізуге

нормативті-құқықтық тәсілдерінің жоқ болуы

Жеке обектілер бойынша қолда бар бухгалтер-

лік есептің нормативтік-құқықтық тәсілдері,

шағын кәсіпорындардың қаржылық шаруашы-

лық қызметтерінің жағдайы мен нәтижелерін

нақтылы көрсетуге мүмкіндік бермейді

*[6] дереккөз негізінде автор (лар) құрастырган

Қазіргі нарықтық қатынастар жағдайында шағын кәсіпорындар үшін есеп саясатының маңыздылығы және оның көрсеткіштерінің рөлі басқару шешімдерін қабылдау, кәсіпорынның нарықтағы жағдайын анықтау кезінде өте маңызды болмақ. Есеп саясатының ережелері мен тұжырымдамалары негізінде жүзеге асырылатын қаржылық есептеменің деректері бойынша кәсіпорынның мүліктік және қаржылық жағдайы, оның төлем қабілеті, шаруашылық етудің негізгі ережелері, кәсіпорын қызметінің жақсаруындағы (нашарлауындағы) үрдістер және т.б. көрсеткіштер белгіленеді.
Заңды тұлға болып табылатын кәсіпорын мекеме филиалдардың, өкілдіктердің, бөлімдердің және дербес балансқа бөлінген басқа да құрылымдық бөлімшелердің өндірісі мен шаруашылығындағы мүліктерді қоса алғанда, мүлік пен олардың қалыптасу көздерінің құрамын көрсететін қаржылық есеп беруді есеп саясатының ережелері мен тұжырымдамалары негізінде жасайды. Қаржылық есеп беру Қазақстан Республикасы Қаржы министрлігінде әзірленетін және бекітілген типтік нысандар бойынша жасалады. Қазақстан Республикасының «Бухгалтерлік есеп және қаржылық есеп» 
Заңына сәйкес, кәсіпкерлер және ұйымдар бухгалтерлік есепті және қаржылық есепті құруын жүргізуге міндетті [7].

Шағын және орта кәсіпорындарының бухгалтерлік есебін ұйымдастырудағы есеп саясаттының маңыздылығы жоғары болып табылады. Есеп саясатын дұрыс қалыптастыру бухгалтерлік есеп процесіне қатыса- тын ұйымның барлық бөлімшелерінің тиімді өзара іс-қимылын қамтамасыз етіп отырады және туындаған мәселелерді шешуге шығындарды (материалдық, еңбек) азайтып отырады [8].

Жалпы ұйым есеп саясатының қалыптастыруына бірнеше факторлар әсер етеді (факторлар 1-суретте көрсетілген).

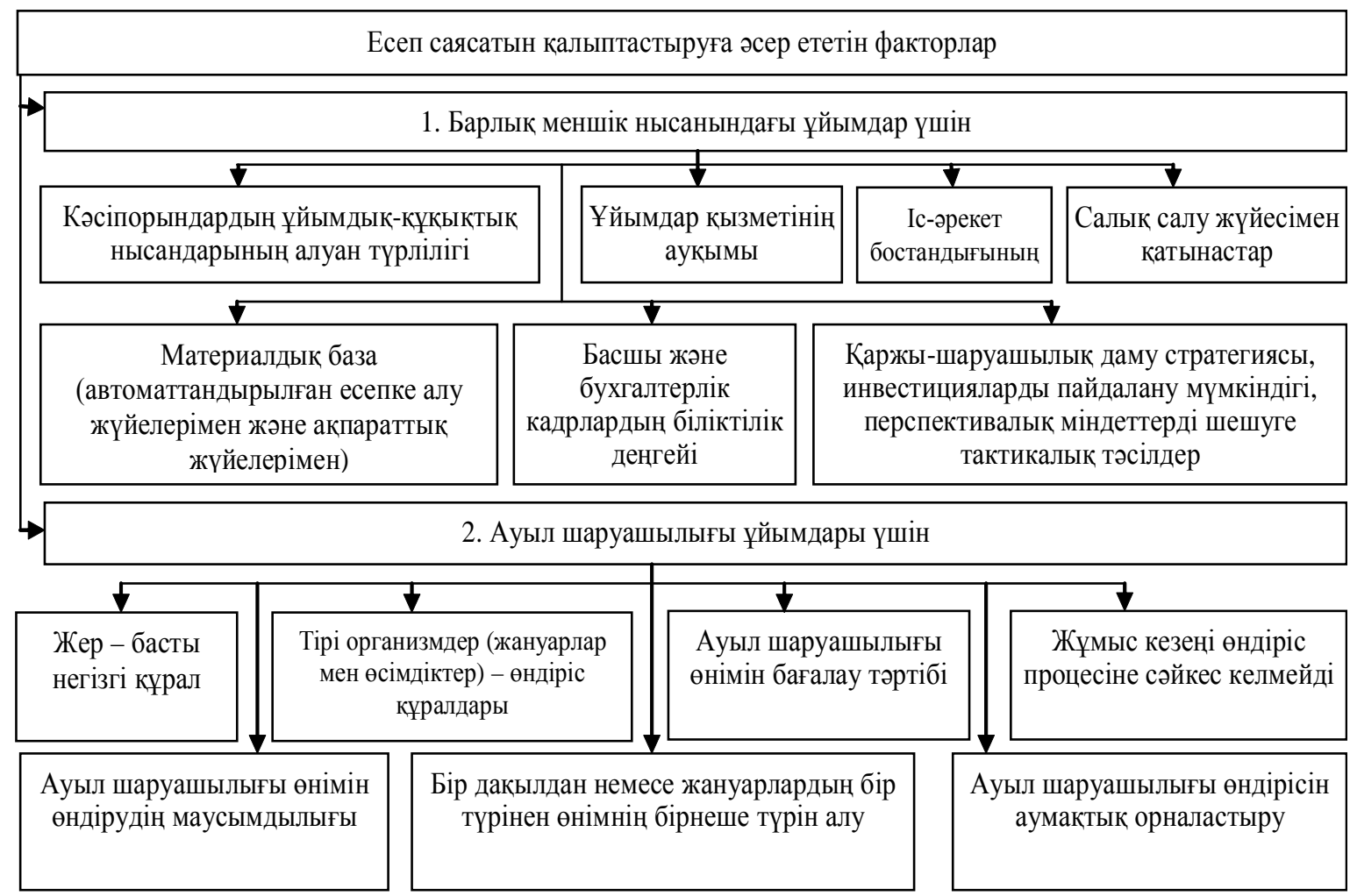

\section{1-сурет. Есеп саясатына әсер ететін негізгі факторлар*}

*[9] дереккөз негізінде автор (лар) құрастырган

Осы факторлардың әрқайсысын негізге ала отырып ұйым өз есеп саясатын ұйымдастырады. Негізгі мәселелердің бірікәсіпорында жасалынатын есептік саясаттың құрамы болып келеді. Мамандардың кейбіреулері есептік саясаттың екі түрін бөлек құруларын ұсынады: алғашқысын бухгалтерлік есебінің мақсатына, екіншісін салықты салудың мақсатына, ал өзгелері бірыңғай есеп саясатын құру тиімдірек және ұтымдырақ деп ойлайды, атап айтқанда жекелеген объектісі және операциясына байланысты бухгалтерлік және салық жазуларын біріктіру керек деп ойлайды.

Шағын кәсіпорындардың бухгалтерлік есебінің жеңілдетілген жүйесіндегі есеп саясатының қалыптасу негізінде жататын және басқа да факторларды көрсетуді қажет етудің негізгі факторы - шағын кәсіпорындардың бухгалтерлік есебінің ерекшеліктерін анықтайтын заңнамалардың арнайы нормалары болып келеді.

Мұнда шағын кәсіпорындардың бухгалтерлік есебінің жеңілдетілген жүйесіндегі есеп саясатының қалыптасуында ұстанымдық рольді шағын кәсіпорынның түрі атқа- 
рады - заңды тұлға немесе жеке кәсіпкер. Бұл әр түрлі түрлерінің шағын кәсіпорындарда бухгалтерлік есепті ұйымдастыру мен жүргізудің сұрақтарында біркелкіліктің жоғын түсіндіреді.

Шағын кәсіпорындардың мөлшері келесі фактор болып келеді. Себебі өзінің есептік ерекшеліктері бар микрокәсіпорындар олардың ішінен бөлініп шығады.

Шағын кәсіпорындардың есеп саясатының қалыптасуының ерекшеліктері қарастырылған факторларды анықтайды. Бірақ берілген ғылыми зерттеуде шағын кәсіпорындардың бухгалтерлік есебінің жеңілдетілген жүйесіндегі есеп саясаты қарастырылады. Сондықтан шағын кәсіпорындардың бухгалтерлік есебінің жеңілдетілген жүйесінде есеп саясатының қалыптасуына әсер ететін қажетті фактор есеп саясатының қалыптасуының ұстанымдарына сәйкес болуы болып табылады.

Шағын кәсіпорындардың бухгалтерлік есебінің жеңілдетілген жүйесінде есеп саясатының қалыптасуына әсер ететін факторларды талдай отырып, оның сатыларын қарастыруға өту қажет.

Есеп саясатының зерттеу үрдісі шағын кәсіпорындардың есеп саясатының қалыптасу үрдісіне әсерін тигізетін байыпты өзгешеліктерді айқындау мақсатымен бухгалтерлік есеп пен есептіліктің қалыптасқан жүйесінің, шағын кәсіпорынның ұйымдық құрылымының және оның шаруа жүргізу шарттарының кешендік зерттемені болжайтын даярлық сатыдан басталады. Даярлық сатының сапасынан шағын кәсіпорындардың бухгалтерлік есебінің жеңілдетілген жүйесіне максималды сәйкес есеп саясатының жобасын қалыптастыруды болжау негізгі болып келетін есеп саясатты талқылау сатысында нақты шешімдерді қабылдау тәуелді болады.

Есеп саясатының жобасын даярлау кезінде есеп ақпаратының сапасын жоғарылату сұрақтарында шағын кәсіпорындар үшін тәжірибелік мағына және прогрессивті

\section{4}

жолы болып келетін қызығушылық танытқан пайдаланушылардың кең ауқымының қажеттіліктеріне сәйкес болу керектігінен бастау керек. Демек, шағын кәсіпорынның есеп саясатының жобасын шаруашылықтың нақты жағдайлары мен перспективаларын модельдеу керек.

Шағын кәсіпорындардың бухгалтерлік есебінің жеңілдетілген жүйесінде есеп саясатының қалыптасуының келесі сатысы бағалау және бақылау сатысы болып келеді. Бұл сатыда:

1. Есеп саясатының жобасында көрсетілген бухгалтерлік есептіліктің өзгертулері туралы ақпаратты тану және айқындау ережелеріне сәйкес бағаланады;

2. Берілген ақпаратты айқындауда бақылау жүргізіледі.

Қажет болғанда, бағалау және бақылау сатысының нәтижесі бойынша түзету сатысында есеп саясатының жобасының жағдайларын қайта қарау және пысықтау жүргізіледі.

Шағын кәсіпорындардың бухгалтерлік есебінің жеңілдетілген жүйесіндегі есеп саясатының қалыптасудың соңғы сатысы шағын кәсіпорынның есеп саясаты туралы жағдайлар бекітілетін ұйымдық-басқару құжаты даярлайтын есеп саясаты бекітілетін сатысы болып келеді.

Сонымен, шағын кәсіпорындардың бухгалтерлік есебінің жеңілдетілген жүйесіндегі есеп саясатының қалыптасуы сапалы есеп ақпаратын қалыптастыруға бағытталған шағын кәсіпорындар үшін бухгалтерлік есебінің жеңілдетілген жүйесін қарастыратын бухгалтерлік есеп саласындағы іс қолданыстағы заңнамалық және нормативтік-құқықтық актілердің талаптарына максималды сәйкес келетін терең көпсатылы үрдіс.

Қорытынды. Осыған байланысты есеп саясатының екі түрін ажыратуға болады: формалды және тиімді. Тиімді есеп саясатын ішкі құжаттамада белгіленген, кәсіпорынды дамыту стратегиясына сәйкес және қолда- 
ныстағы заңнама аясында бухгалтерлік есеп жүйесінің әсерін барынша арттыруға ықпал ететін есеп жүргізудің қағидалары, әдістері мен ережелерінің жиынтығы ретінде анықтауға болады.

Сонымен, қорытындылап кететін болсақ, осы жоғары айтылған мәселелер орындалған кезде шағын және орта кәсіпорындарындағы есеп саясаты қалыптастыры- лады. Біздің пікіріміз бойынша, есеп саясаты дегеніміз ұйымның бухгалтерлік есепті жүргізу ережелерін қолдану саласындағы мүдделерін қорғайтын құжат болып табылады. Онда есепке алудың қағидалары мен әдістерін пайдалана отырып, шаруашылық қызмет туралы шынайы және жедел ақпарат алуға мүмкіндік беретін нормалар көзделуі керек.

\section{ӘДЕБИЕТТЕР}

1. Бухгалтерлік есепке алу және қаржылық есептілік туралы» Қазақстан Республикасының 28.02.2007 ж. № 234-ІІІ Заңы (28.12.2019 жылғы өзгертулер мен толықтырулар) ҚР Қаржы министрлігінің ресми интернет-ресурсы. www. пnline.zakпn (Жүгінген күні: 11.02.2020 ж.).

2. Әлиев М.Қ., Алтынбеков М.А., Түсібаева Г.С., Юсупов Ұ.Б., Есенбаева А.Е. Шағын және орта кәсіпорындағы бухгалтерлік есеп пен салық есебін ұйымдастыру: Оқу құралы. - Астана, 2016. - 288 б.

3. «Халықаралық Қаржылық есеп стандарттары». www. Минфин.kz (Жүгінген күні: 11.02.2020 ж.).

4. Назарова Л.В. Шаруашылық жүргізуші субъектілердегі бухгалтерлік есеп. - Алматы: Экономика, 2011. - 322 б.

5. Алтынбеков М.А., Түсібаева Г.С., Юсупов Ұ.Б. Учетная политика как системо образующий фактор бухгалтерского учета в организации // Вестник университета «Туран». Алматы, 2016. - № 3(71). - С. 138-144.

6. Ұлттық экономика министрлігі Статистика комитеті. https:/gender.stat.gov.kz/page/ frontend/detail?id=106\&slug=1-2018\&cat_id=6\& lang=ru (Жүгінген күні: 11.02.2020 ж.).

7. Төреханова А.О., Смыкова М.Р., Тютюникова М.Р. Қазақстандағы шағын бизнестің даму динамикасын талдау // ҚазЭҚХСУ Жаршысы. - 2019. - № 3. - Б. 8-14.

8. Әлиев М.Қ, Алтынбеков М.А., Түсібаева Г.С., Юсупов Ұ.Б., Есенбаева А.Е. Қаржылық есеп. - Астана: ҚазЭҚХСУ, 2016. - 296 б.

9. «Халықаралық Қаржылық есеп стандарттары». www.Минфин.kz (Жүгінген күні: 11.02.2020 ж.).

\section{REFERENCES}

1. Byhgalterlik ecepke aly zhane karzhylyk eceptilik turaly» Kazakhstan Respublikasynyn 28.02.2007 zh. № 234-III Zany (28.12.2019 zhylgy ozgertyler men tolyktyrylar) KR Karzhy ministrliginin resmi internet-resyrsy. www. online.zakon (Zhugingen kyni: 11.02.2020 zh.) [in Kazakh].

2. Aliev M.K, Altynbekov M.A., Tusibaeva G.S., Jusupov U.B. Esenbaeva A.E. Shagyn zhane orta kasiporyndagy buhgalterlik esep pen salyk esebin ujymdastyru: Oku kuraly. - Astana, 2016. 288 b. [in Kazakh].

3. «Halykapalyk Karzhylyk ecep standarttary». www.Minfin.kz (Zhugingen kyni: 11.02.2020 zh.) [in Kazakh]. 
4. Nazarova L.V. Sharyashylyқ zhyrgizyshi cyb\#ektilerdegi byhgalterlik ecer». - Almaty: Ekonomika, 2011. - 322 b. [in Kazakh].

5. Altynbekov M.A., Tusibaeva G.S., Jusupov U.B. Uchetnaja politika kak sistemoobrazujushhij faktor buhgalterskogo ucheta v organizacii // Vestnik universiteta «Turan». - Almaty, 2016. - № 3(71). -S. 138-144 [in Russian].

6. Ulttyq ekonomika ministrligi Statistika komiteti. https://gender.stat.gov.kz/page/frontend/ detail?id=106\&slug=1-2018\&cat_id=6\& lang=ru (Zhugingen kuni: 11.02.2020 zh.) [in Kazakh].

7. Torehanova A.O., Smykova M.R., Tjutjunikova M.R. Kazakhstandagy shagyn biznestin damu dinamikasyn taldau // KazJeKHSU Zharshysy. -2019. - № 3. - Б. 8-14.

8. Aliev M.K., Altynbekov M.A., Tusibaeva G.S., Jusupov U.B., Esenbaeva A.E. Karzhylyk esep. - Astana: KazJeKHSU, 2016. - 296 b. [in Kazakh].

9. «Halykaralyk Karjylyk ecep standarttary». www.Minfin.kz (Zugingen kuni: 11.02.2020 zh.) [in Kazakh].

\section{Н.А. Кудайбергенов, А.М. Адилова, М.К. Алиев, М.А. Алтынбеков \\ ВАЖНОСТЬ И ПРОБЛЕМЫ ФОРМИРОВАНИЯ УЧЕТНОЙ ПОЛИТИКИ НА МАЛЫХ И СРЕДНИХ ПРЕДПРИЯТИЯХ}

\section{Аннотация}

В статье рассмотрены требования и качественные характеристики бухгалтерской информации в системе учета на малых предприятиях, определяющие ее полезность.

Отмечено, что малое предприятие наравне с любым другим хозяйствующим субъектом обязано составлять учетную политику для целей ведения бухгалтерского учета. Учетная политика является одним из основных документов, который устанавливает правила ведения бухгалтерского учета в организации.

В данной статье рассмотрены факторы, влияющие на формирование учетной политики малых предприятий. В частности, раскрыт порядок формирования учетной политики малых предприятий, осуществляющих упрощенный бухгалтерский учет.

\section{N. Kudaibergenov, A. Adilova, M. Aliyev, M. Altynbekov \\ ISSUES RELATED TO THE FORMATION OF ACCOUNTING POLICIES FOR SMALL AND MEDIUM-SIZED BUSINESSES}

\section{Annotation}

The article considers the requirements and qualitative characteristics of accounting information in the accounting system for small enterprises that determine its usefulness.

In the scientific article, it is noted that a small enterprise, along with any other business entity, is required to draw up an accounting policy for the purposes of accounting. The accounting policy is one of the main documents that sets the rules for accounting in an organization.

This article discusses the factors that influence the formation of accounting policies of small enterprises. In particular, the procedure for forming the accounting policy of small enterprises engaged in simplified accounting is disclosed.

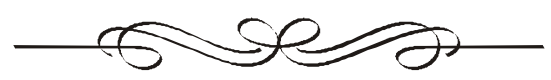


DOI 10.52260/2304-7216.2020.4(41).25

UDC 675.5

SCSTI 06.35.01

F. Seidakhmetova*, doctor of economics, professor $^{l}$

E. Karabayev, PhD student ${ }^{2}$

Almaty Academy of Economics and Statistics ${ }^{l}$

Almaty $c$.

L.N. Gumilyov Eurasian National University ${ }^{2}$

Nur-Sultan c.

e-mail: favziy@inbox.ru

* - main author (author for correspondence)

\section{ACTUAL ISSUES OF PERSONNEL TRAINING IN THE FIELD OF ACCOUNTING AND STATE AUDIT}

The current Kazakhstani education system in the field of training accounting and auditing personnel unites numerous links, including colleges, universities, postgraduate education, etc. Continuous learning systems such as express courses, seminars, conferences, courses, etc. become more relevant. At the same time, the priority of higher and postgraduate education in Kazakhstan is the trinity of education, science and production. The directions for further effective development of the new system of governmental audit and financial control by improving the quality of training and the effectiveness of external governmental audit were also identified.

The article presents the results of training specialists of higher education in the field of accounting and state audit. According to the authors, in the context of distance learning in connection with the COVID-19 pandemic in Kazakhstan, as in the entire international space, there are problems associated with shortcomings and unpreparedness for such changes in education. For several years, the authors have been analyzing the current system of training highly qualified specialists in the field of accounting and audit. The paper provides the existing information on the training of such personnel in the context of a dual training system, which is widely covered in Internet resources.

To improve the status of these specialists in this area, it is proposed to systematically monitor and publish analytical reviews based on special generally accepted research methods and techniques such as questionnaires, observation, etc. In addition, the area of scientific research should be expanded, based on positive world experience.

Keywords: state audit, accounting, economics, education distance learning, higher education, audit, security,dual education.

Кілт сөздер: мемлекеттік аудит, есеп, экономика, білім ққашықтықтан оқыту, жовары білім, аудит, құауіпсіздік,дуальды білім беру.

Ключевые слова: государственный аудит, бухгалтерский учет, экономика, образование дистанционное обучение, высшее образование, аудит, безопасность, дуальное образование.

JEL classification: L 81, N 60, R 51

Introduction. Object: The article provides information on personnel training in the accounting and audit system of the Republic of Kazakhstan. It also describes the experience of teaching the specialty state audit, which has been introduced since 2016. At the heart of public audit training is a dual system. ...lure.

Methods. The theoretical and methodological basis for writing this article is the work of foreign and Kazakh scientists, as well as regulations 
Қаржы жнәне есеп / Финансы и учет

and legislative acts of Kazakhstan in the field of education

Findings. The relationship between the measures and results of research based on the experience of Kazakhstan and other countries in the framework of ten-year cycles ending, and the provisions of the theories of education in audit.

Conclusions. The relationship between measures and research results based on the experience of Kazakhstan and other countries in the context of distance learning in connection with the global coronavirus pandemic.

A scientific study of the modern system of higher and postgraduate education of training auditors in the Republic of Kazakhstan deserves special attention, since there are many unresolved problems in this area. Identification of deficiencies in this area, taking into account the influence of certain aspects on the economy of Kazakhstan, will contribute to the further development of audit activity. Astudy of world experience in training similar cadres shows that in Western countries a system of so-called "continuing education" is developed in this direction. The professional competence of representatives of this profession, universally recognized in the world, shows that it is based on criteria such as a certain level of general education, followed by a special higher education, advanced training and passing exams in the relevant disciplines, as well as work experience in the specialty. To maintain the level of professional competence, auditors need to monitor changes in accounting in the relevant national and international standards.

Describing the objects to be audited, we note that in recent years they have clearly demonstrated that the conduct of electronic business is gaining more and more popularity in the world. In this regard, many companies are introducing electronic document management methods in their activities. Digital technologies are also developing in the field of transformation of traditional business models. Therefore, internal auditors should pay more attention to identifying risks and understanding the business. The huge amount of data generated using new technologies, and their untapped potential, necessitate the digitalization of auditing.

Literature review. While previous literature review studies have explored the current status of accounting education, a literature review that focuses explicitly on auditing education is scarce. The objective of this scoping review was to map the existing studies that assess the relevance of undergraduate, graduate auditing education to meet contemporary auditing and accounting practices. The scoping review followed by E. Karabayev (2019) that has main stages: (1) identifying questions; (2) identifying studies; (3) study selection; (4) collating, summarizing and reporting the results. As has been claimed by professor F. Seidakhmetova (2010-2018), the shift in auditing education is occurring more slowly than the demand of profession. Emphasis should be given to content as a gap still exists between auditing educators and practitioners. Since 2016, recruitment in the specialty 5B050800 "State Audit" has been carried out in the Republic of Kazakhstan at three levels of study: bachelor's-master'sdoctoral degree. Describing the training of specialists in the field of governmental audit, it can be noted that this work is actively carried out mainly in the L.N. Gumilyov ENU. The staffing issues of the governmental audit system cover three areas:

- certification of persons applying for the qualification "State Auditor";

- retraining and advanced training of employees of external governmental audit and internal governmental audit;

- training of specialists in the field of governmental audit in the system of higher and postgraduate education (bachelor's, master's, $\mathrm{PhD}$ doctoral studies. According to the law "On state audit and financial control", the main goal is to create a comprehensive system of state audit taking into account international experience $[1,2]$.

Findings and discussion. The formation and development of state audit in our country can be illustrated according to the table 1 below. It provides information on the evolution of government audit in Kazakhstan. 


\section{Development of the state audit in Kazakhstan*}

\begin{tabular}{|c|c|}
\hline Date & Events \\
\hline April 1996 & $\begin{array}{l}\text { Decree of the President of Kazakhstan «On approval of the regulation } \\
\text { on the Accounts Committee for monitoring the execution of the } \\
\text { republican budget» }\end{array}$ \\
\hline June 1996 & $\begin{array}{l}\text { Decree of the President of Kazakhstan «On the issues of the Accounts } \\
\text { Committee for monitoring the execution of the republican budget» }\end{array}$ \\
\hline May 2000 & Accounts Committee joined INTOSAI \\
\hline October 2000 & Accounts Committee joined ASOSAI \\
\hline September 2001 & $\begin{array}{l}\text { «The concept of development of the system of control over the } \\
\text { execution of the republican and local budgets in the Republic of } \\
\text { Kazakhstan» }\end{array}$ \\
\hline January 2002 & $\begin{array}{l}\text { Law of the Republic of Kazakhstan «On control over the execution of } \\
\text { the republican and local budgets» }\end{array}$ \\
\hline August 2002 & $\begin{array}{l}\text { Decree of the President of Kazakhstan «On approval of the regulation } \\
\text { on the Accounts Committee for monitoring the execution of the } \\
\text { republican budget» }\end{array}$ \\
\hline August 2002 & $\begin{array}{l}\text { Standards of internal and external control over the execution of the } \\
\text { republican and local budgets }\end{array}$ \\
\hline 28 October 2003 & The Accounts Committee joined EUROSAI \\
\hline October 2004 & $\begin{array}{l}\text { State financial control standards and rules for organizing and } \\
\text { conducting external control over the execution of the republican budget } \\
\text { and evaluating the effectiveness of programs }\end{array}$ \\
\hline 8 September 2006 & $\begin{array}{l}\text { The Accounts Committee approved the Rules for the external control } \\
\text { over the execution of the republican budget, registered at the Ministry } \\
\text { of Justice of the Republic of Kazakhstan on October 7, 2006 }\end{array}$ \\
\hline 2 May 2011 & $\begin{array}{l}\text { Decree of the President of Kazakhstan dated May 2, } 2011 \text { No. } 67 \\
\text { «On Improvement of the External State Financial Control Bodies } \\
\text { in the Regions» }\end{array}$ \\
\hline 12 November 2015 & $\begin{array}{l}\text { The Head of State signed the Law of the Republic of Kazakhstan } \\
\text { «On State Audit and Financial Control» }\end{array}$ \\
\hline 22 December 2017 & $\begin{array}{l}\text { A joint meeting of the Accounts Committee of the Republic of } \\
\text { Kazakhstan, the National Audit Office of the PRC and the Accounts } \\
\text { Chamber of the Republic of Kyrgyzstan was held in Astana at which } \\
\text { the results of a parallel audit of health performance in these SCO } \\
\text { member states }\end{array}$ \\
\hline
\end{tabular}

*Compiled by the author [2]

As you can see, the development of the state audit has its own history which is constantly being improved.

The professional competence of representatives of this profession is based on the fact that they must have a certain levelof general education, followed by special education, advanced training and passing examinations in the relevant disciplines, as well as work experience in the spe- cialty. To maintain the level of professional competence, it is also necessary to follow the changes in the field of accounting and auditing, in the relevant national and international regulations, regulations.

Widespread computerization, rapid changes in the technological processes of accounting and auditing imply a decrease in the services of accounting workers. Recently, forecasts of future 


\section{Қаржы жеән есеп / Финансы и учет}

professions have been published in the media, in which it is often mentioned that there is no need for the future of an accountant or auditor. Despite such assumptions, the demand for this profession, including the acquisition of knowledge in continuing education, continues to grow. At the same time, in many commercial universities, the training of students and undergraduates in the specialty "Accounting and Auditing" occurs solely for the sake of obtaining a diploma, which does not provide the necessary theoretical and practical skills in the chosen specialty. There are facts of acquiring diplomas without training, which also contributes to a decrease in the prestige of professional education in the field of accounting.

Given the situation with the COVID-19 pandemic, the training of accounting and government audit specialists requires the search for new, more effective methods, forms and means to improve all aspects of training. There are a lot of educational institutions in Kazakhstan that train specialists in the field of accounting and audit. For example, in recent years, numerous accredited training centers have appeared to award professional accountants the qualification "Professional Accountant". To obtain such a title, one must have a higher education, some practical experience in lower accounting positions and successfully pass exams at licensed centers.

These organizations, on a paid basis, develop special training modules, receive and evaluate exams and issue a certificate of conferring the title of Professional Accountant. At the same time, the growing demand for such certification indicates an annual increase in the cost of training in accounting training centers, regardless of the fact that educational services are not always of the appropriate quality. Speaking in general about the training of a Professional Accountant, we emphasize that in the Republic of Kazakhstan there are cases of a lack of objectivity and a formal approach to taking exams at certification centers. The content of individual textbooks in the modules does not always reflect the existing practice, and the questions of exams and test tasks are not sufficiently related to the professional activities of an accountant. The level of knowledge and education are to a certain extent nominal.

It should be noted that Kazakhstan approved the "Rules for the organization of dual education in institutions of technical and vocational education organizations" For the development of dual education in the new Labor Code of the Republic of Kazakhstan, the concepts of "dual education", "contract on dualeducation", a new article "Dual education" (Article 119) [3].

Changes and addi-tions were made to the Law of the Republic of Kazakhstan "On Education" in terms of the conceptual apparatus, definition of the competence of the Ministry of Education and Science of the Republic of Kazakhstan, local executive bodies, increasing practice to $60 \%$ in educational programs [4].

According to the regulations of Kazakhstan, dual training is a form of personnel training that combines training in the organization of education with mandatory periods of training and practice at the enterprise with the provision of jobs. The training of governmental audit specialists is carried out on the basis of dual training on the basis of the Republican state enterprise on the right of economic management "Center for the Study of Financial Violations" under the Accounts Committee. Training is carried out in the context of 5 disciplines approved by the regulatory decree of the Accounts Committee dated December 15, 2015 No. 22 NK "On approval of the Rules for certification of persons applying for the qualification of a state auditor" [5]:

- "Keeping accounting and financial reporting in government institutions in accordance with international financial reporting standards for the public sector";

- "Accounting and financial reporting in the quasi-public sector in accordance with international financial reporting standards";

- "Audit of financial statements";

- "Performance audit";

- "Compliance audit".

Describing the preparation of the state auditor, we emphasize that their number is increasing from year to year. The total number of those 
enrolled in the above-mentioned improvement courses only and the number of applicants for the title of state auditor is growing from year to year. Having passed the competitive selection, applicants take exams, and then are interviewed. Details of this are published in the reports of the Accounts Committee.

It should be especially noted that in-depth research is not carried out in the republic on the quantitative and qualitative composition of training specialists for the profession of accountant and state auditor. The world experience of developed countries proves that in order to assess the level of professionalism of accountants and state auditors, a certification system is needed that would comprehensively assess their status. What is important here is their professional competence in the performance of their duties.

One of the possible ways to further develop these professions is the differentiated division of the membership of accountants, auditors, as well as accounting and auditing organizations. The classification criteria for individuals can be age, seniority, level of training, experience, availability of certificates, etc., and for legal entities who are busy preparing and taking exams - an independent examination of textbooks, a questionnaire survey, observations, reputation and others.

Many questions arise in connection with the transition to remote operation(Distance Learning). This leads to the widespread use of information systems (IS), computer networks and mobile communications. An analysis of the DL practice of Kazakhstani universities is periodically published on the Internet. However, the problems of training accounting and auditing personnel arising from the existing realities of life remain insufficiently resolved.

Significant disadvantages of DL include the lack of the necessary interaction between teachers and students, the impossibility of timely control over educational activities, etc. A particular problem in the introduction of DL is the high material and labor costs for development and support. This greatly complicates the educational process in the university system of training accounting and auditing personnel.

The current disadvantages of information systems include the lack of the ability to analyze the test results of students and build individual learning paths based on these results.

The creation of an intelligent scalable information and educational environment is possible with the use of modern cloud technologies, the use of which allows solving such problems as:

1) the ability to use modern software;

2) widely use electronic educational resources and services;

$3)$ to reduce the costs of educational institutions for building local information infrastructures due to the efficient use of computing resources concentrated in the cloud and elastically allocated to users in accordance with their requests [6].

An important area of expanding access to information is the development of autonomous electronic educational and methodological complexes (EMC), fully covering the content of disciplines in the specialty of accounting, and state audit, including a theoretical course, tasks and tasks of seminars and practical classes, tasks of a laboratory workshop, materials for independent work etc., requiring no effort to install them [7].

In connection with the above, an important problem of these specialties is the creation of a national cloud repository, i.e. places where any data, electronic educational resources, etc. are stored and maintained on the basis of agreements, standards and technologies common for educational institutions and teachers. The data in the repository must be saved as files available for further distribution over the network. Wikipedia describes the experience of a repository for storing programs written in one language (for example, CPAN for Perl) and intended for one platform [8].

With a certain modification, the repositories can be used in version control systems in the field of higher and postgraduate education for training personnel in these specialties. Such an educational environment can be effectively built on the basis of a national cloud scientific and educational infrastructure. The creation of a single national data center for the training of accountants and auditors 


\section{Қаржы ж⿻上е есеп / Финансы и учет}

in the higher education system can significantly reduce costs, as well as increase the security of stored resources.

Since educators use information, a significant part of which is concentrated on the Internet, there is a problem of control and management of access and protection of information, which does not always comply with certain rules and regulations. Hence, new goals are put forward for the "creators" of the so-called information products.

With the availability of modern digital technologies, most of the activity takes place in the virtual world, in which legal and ethical standards must be observed. The involvement of personal mobile and other means of communication in the educational process creates certain conditions for the emergence of various threats and vulnerabilities. One of the main problems continues to be the lack of personnel to service technical devices. With regard to accounting specialties, the lack of uniform software standards is relevant.

In this regard, it is important to study all available means of communication in education, which would expand the possibilities of virtual communication. The education system as a whole, including in the field of training personnel for accounting and auditing in general, faces new tasks related to preparing a person to work in the virtual world.

Informatization of the training system in the field of accounting and audit should be carried out by ensuring information security, aimed at coun- tering the negative impacts of the information services industry. The quality and scale of coverage of the information infrastructure should foster user confidence in information technology. The purpose of information security also includes information security, i.e. protection from technical means and systems, as well as protection of students and trainees.

Conclusion. Consequently, the above problems require a revision of the existing programs, methodological and educational literature in the training of personnel in the specialty "Accounting and Audit". This is relevant in connection with the expansion of international educational integration in the DL system, aimed at the formation of a single educational space in the preparation of accounting and state audit specialists.

To achieve this goal, it is necessary to periodically conduct monitoring and provide an analytical review based on a questionnaire and survey of representatives of various Kazakh and foreign universities that train specialists in this field.

The priority should be the formation of highly qualified specialists focused on the modernization and innovative development of the country's economy, and the quality and scope of information should contribute to the confidence of users of their activities. Thus, in order to improve the status of the profession of an accountant and state audit, conditions must be created to ensure an increase in his professional level, based on the experience, knowledge and competence of this specialist.

\section{REFERENCES}

1. Seidakhmetova F.S., Karabayev E.B. Aktual'nye voprosy informacionnoj bezopasnosti v sisteme obrazovanija Kazahstana, Razvitie finansov, buhgalterskogo uchjota i audita v sovremennyh koncepcijah upravlenija. - Simferopol', 2020. -442 s.

2. Karabayev E.B. Modern formation, development and becoming of anexternal state auditin the Republic of Kazakhstan, Globalniye problemy modernizacii nacionalnoy ekonomiki // IX Mejdunarodnaya nauchno-prakticheskaya konferenciya. - 2020. - $320 \mathrm{~s}$.

3. Zakon Respubliki Kazahstan ot 12 nojabrja 2015 goda № 392-V «O gosudarstvennom audite i finansovom kontrole». - [ER]. Rezhim dostupa: /http://adilezan.kz [in Russian].

4. Trudovoj kodeks Respubliki Kazahstan ot 23 nojabrja 2015 goda № 414-V Trudovogo kodeksa [in Russian].

5. Zakon Respubliki Kazahstan «Ob obrazovanii» № 319-III ot 27 ijulja 2007 g. Podrobnee: https://kodeksy-kz.com/ka/ob_obrazovanii.htm [na russkom]. 
6.Ob utverzhdenii Pravil attestacii lic, pretendujushhih na naznachenie ... adilet.zan.kz/rus/ docs/V1500012720 [in Russian].

7. Vorotnickij Ju.I. Mobil'nye komp'juternye ustrojstva v «oblachnoj» informacionno-obrazovatel'noj srede obshheobrazovatel'noj shkoly / Ju.I. Vorotnickij, M. Zekov, A. Kurbackogo. Minsk: RIVSh, 2012. - 100 s. [in Russian].

8. Kontent-repozitorij. http://www.cpan.org/misc/cpan-faq.html

\title{
ЛИТЕРАТУРА
}

1. Сейдахметова Ф.С., Карабаев Е.Б. Актуальные вопросы информационной безопасности в системе образования Казахстана, Развитие финансов, бухгалтерского учета и аудита в современных концепциях управления. - Симферополь, 2020. - 442 с.

2. Карабаев Э.Б. Modern formation, development and becoming of anexternal state auditin the Republic of Kazakhstan, Глобальные проблемы модернизации национальнойэкономики // IX Междунар. науч.-практич. конф. - 2020. - 320 с.

3. Закон РК от 12 ноября 2015 года № 392-V «О государственном аудите и финансовом контроле». - [ER]. Режим доступа: /http://adilezan.kz

4. Трудовой кодекс РК от 23 ноября 2015 года № 414-V Трудового кодекса.

5. Закон РК «Об образовании» № 319-III от 27 июля 2007 г. Подробнее: https://kodeksykz.com/ka/ob_obrazovanii.htm [на русском].

6. Об утверждении Правил аттестации лиц, претендующих на назначение ... adilet.zan. kz/rus/docs/V1500012720.

7. Воротницкий Ю.И. Мобильные компьютерные устройства в «облачной» информационно-образовательной среде общеобразовательной школы / Ю.И. Воротницкий, М. Зеков, А. Курбацкий. - Минск: РИВШ, 2012. - 100 с.

8. Контент-репозиторий. http://www.cpan.org/misc/cpan-faq.html

\author{
Ф.С. Сейдахметова, Э.Б. Карабаев \\ БУХГАЛТЕРЛІК ЕСЕП ЖӘНЕ МЕМЛЕКЕТТІК АУДИТ САЛАСЫНДА \\ КАДРЛАР ДАЯРЛАУ МӘСЕЛЕЛЕРІ
}

Андатпа

Бухгалтерлік және аудиторлық персоналды даярлау саласындағы қазіргі қазақстандық білім беру жүйесі көптеген буындарды, соның ішінде колледждерді, университеттерді, жоғары оку орнынан кейінгі білім беруді және т.б. біріктіреді. Жедел курстар, семинарлар, конференциялар, курстар және т.б. сияқты үздіксіз оқыту жүйелері өзекті бола түсуде. Бұл ретте Қазақстандағы жоғары және жоғары оқу орнынан кейінгі білім берудің басымдығы білім, ғылым және өндірістің үштұғырлығы болып табылады. Сондай-ақ оқыту сапасын және сыртқы мемлекеттік аудиттің тиімділігін арттыру есебінен мемлекеттік аудиттің және қаржылық бақылаудың жаңа жүйесін одан әрі тиімді дамыту бағыттары айқындалды.

Мақалада есеп және мемлекеттік аудит саласындағы жоғары білім мамандарын даярлау нәтижелері ұсынылған. Авторлардың пікірінше, COVID-19 пандемиясына байланысты қашықтықтан оқыту жағдайында Қазақстанда да, бүкіл халықаралық кеңістікте де білім берудегі кемшіліктер мен осындай өзгерістерге дайындалмауға байланысты проблемалар бар. Авторлар бірнеше жыл бойы есеп және аудит саласында жоғары білікті мамандарды даярлаудың қолданыстағы жүйесіне талдау жүргізеді. Жұмыста дуальды оқыту жүйесі жағдайында осындай кадрларды 
Карәсы жеәне есеп / Финансы и учет

даярлау туралы қолда бар ақпарат келтірілген, ол интернет ресурстарда кеңінен жария етілген.

Осы саладағы мамандардың мәртебесін арттыру үшін жүйелі түрде мониторинг жүргізу және сауалнама, байқау және т.б. сияқты зерттеудің жалпы қабылданған арнайы әдістері мен әдістеріне негізделген сараптамалық шолуларды жариялау ұсынылады. Сонымен қатар тиімді шетелдік тәжірибені ескере отырып ғылыми зерттеу облысын кеңейту керек.

\section{Ф.С. Сейдахметова, Э.Б. Карабаев \\ ВОПРОСЫ ПОДГОТОВКИ КАДРОВ В ОБЛАСТИ БУХГАЛТЕРСКОГОУЧЕТА И ГОСУДАРСТВЕННОГО АУДИТА}

Аннотация

Нынешняя казахстанская система образования в области подготовки бухгалтерского и аудиторского персонала объединяет многочисленные звенья, в т.ч. колледжи, университеты, послевузовское образование и т.д. Системы непрерывного обучения, такие как экспресс-курсы, семинары, конференции, курсы и т.д. становятся более актуальными. При этом приоритетом высшего и послевузовского образования в Казахстане является триединство образования, науки и производства. Также определены направления дальнейшего эффективного развития новой системы государственного аудита и финансового контроля за счет повышения качества обучения и эффективности внешнего государственного аудита.

В статье представлены результаты подготовки специалистов высшего образования в области учета и государственного аудита. По мнению авторов, в условиях дистанционного обучения в связи с пандемией COVID-19 в Казахстане, как и во всем международном пространстве имеются проблемы, связанные с недостатками и неподготовленностью к подобным переменам в образовании. Авторами в течение нескольких лет проводится анализ действующей системы подготовки высококвалифицированных специалистов в сфере учета и аудита. В работе приведена существующая информация о подготовке таких кадров в условиях дуальной системы обучения, которая широко освещена в интернет ресурсах.

Для повышения статуса данных специалистов предлагается систематически проводить мониторинг в этой сфере и публиковать аналитические обзоры, основанные на специальных общепринятых методах и приемах исследования, таких как анкетирование, наблюдение и др. Помимо этого, следует расширять область научных исследований, опираясь на положительный мировой опыт. 
DOI 10.52260/2304-7216.2020.4(41).26

UDC 657.1:393.37

SCSTI 06.35.31

A. Kazhmukhametova*, c.s.c., assoc. professor ${ }^{l}$

G. Tussibayeva, $P h D$, assoc. professor ${ }^{l}$

B. Akimova, $P h D$, assoc. professor ${ }^{2}$

Kazakh University of Economics, Finance and International Trade ${ }^{l}$

Nur-Sultan $c$.

L.N. Gumilyov Eurasian National University ${ }^{2}$

Nur-Sultan $c$. e-mailigulmira_80@mail.ru

* - main author (author for correspondence)

\section{ACCOUNTING COMPONENT OF FINANCIAL RESULTS OF PUBLIC CATERING ENTERPRISES}

Properly organized operational and accounting records are essential for controlling the formation of financial results. The article reveals a feature of the economic activity of public catering enterprises, which determines the features of accounting. On the one hand, it is intended to reflect the processes of production (cooking), and on the other - the processes of trade (sales). The costs associated with the sale of products and promotion of products on the market, both industrial and commercial enterprises are defined as the cost of circulation. The paper focuses on the classification and accounting of income and expenses in the field of nutrition. Attention is paid to a relatively new type of service as catering, which has been gaining momentum in recent years. The issue of synthetic and analytical accounting of financial results and disclosure of information in financial statements is discussed. Based on the results of the study, the authors recommended reasonable measures to increase profitability and improve accounting for financial results.

Keywords: public catering, accounting, income, expenses, distribution costs, margin, financial result, catering, service sector, prime cost.

Кілт сөздер: қовамдық тамақтану, бухгалтерлік есеп, кірістер, шызыстар, бөлу шывындары, маржа, қзаржылық нәтиже, кейтеринг, құызмет көрсету саласы, өзіндік құн.

Ключевые слова: общественное питание, бухгалтерский учет, доходы, расходы, издержки обращения, наценка, финансовый результат, кейтеринг, сфера услуг, себестоимость.

JEL classification: L 81, M 41

Introduction. The financial results of an enterprise are determined primarily by the quality indicators of the products produced by the enterprise, the level of demand for these products, since, as a rule, the bulk of the financial results is profit (loss) from the sale of products (works, services). To date, the financial performance of many enterprises has been affected by the corona crisis. Among the most affected the sphere of public catering. In turn, public catering plays an important role in the life of society. The catering industry is the largest employer for residents of Kazakhstan.
Many related industries that provide services to cafes and restaurants depend on the state and development of this sphere and financial results: tenants, designers, builders, equipment suppliers, farmers, food suppliers, advertising agencies, food delivery service providers, and other service companies. Competent accounting, timely response to demand, changes in market conditions, tax legislation-these are the mechanisms for a positive financial result of public catering enterprises.

The purpose of the study is to study the organization of accounting for financial results in public 
catering enterprises and develop proposals for increasing profitability and improving the accounting of income and expenses.

In the course of the research, such methods and sources of research as observation, method of analysis and generalization of theoretical factual material, method of comparative analysis of normative documents, scientific literature on the research problem were used.

Literature review. The research is based on the study, systematization, analysis of domestic and foreign literature, generalization of theory and practice in the field of accounting features of the financial result of public catering enterprises.

Regulatory regulation of the sphere of public catering included in the system of internal trade is considered in the sources $[1,2,3]$. Properly organized accounting of financial results contributes to the growth of income and increase of business profitability. Modern theory and practice of accounting features in the field of nutrition are covered in the works of V. Nazarova [3], Yu.a. Babaev, A. Petrov [6], G. Nikolaeva [7]. The specifics of accounting for catering services are covered in the work of V. Avdeev [8].

Revenue reflection in accordance with the International financial reporting standard 15 "Revenue from contracts with customers" is disclosed in the works of V. Sidneva [4].

Issues of synthetic accounting of income and expenses according to the rules of accounting in Kazakhstan are considered in the works of N. Tashtanova [9], V. Nazarova [10].

However, the domestic literature does not cover the issues of analytical accounting component of financial results in the field of public catering, classification of income and costs of circulation in the field of food, features of accounting for catering services at Kazakhstani enterprises.

Main part. The main purpose of public catering enterprises is to produce their own products (cooking food) for subsequent sale to customers or organizations.

Along with the products of their own production, public catering enterprises also sell some purchased goods. Food enterprises carry out independent economic activities and in this respect do not differ from other enterprises. Meals are provided mainly by small private enterprises. Food is a vital necessity for the majority of workers, employees, students and a significant number of other groups of the country's population. Currently, public catering companies perform both functions directly related to the organization of food, and functions related to the organization of leisure.

According to the Law of 26 January 2011, No. 400-IV «On regulation of commercial activities» is developed "Rules of trade" that define «The exercise of trade objects of public catering», and defines requirements necessary to be fulfilled by organizations engaged in entrepreneurial activities in the sphere of public catering, regardless of ownership and departmental subordination $[1,2]$.

From the point of view of accounting, the final financial result of an enterprise is the difference between income and expenses. This indicator is the most important in the company's activity and characterizes the level of its success or failure.

Income is the gross receipt of economic benefits for the reporting period in the normal course of business, resulting in an increase in its capital. Capital increase means every increase in capital, in addition to the contributions of the founders. Only funds of financial benefits acquired or available for receipt are entered into profit.

The issues of determining the financial results of an enterprise are one of the main and especially important issues that are important for accounting and financial analysis. According to $\mathrm{V}$. Nazarova, profit recognition is expressed in the reflection of the corresponding amounts in the financial statements. Profit can be obtained from: the sale of inventory; the provision of services; the transfer to use of assets belonging to the enterprise and bringing remuneration (interest), royalties and dividends [3].

Food companies charge a fee for the services they provide for the production, sale and organization of consumption, which can be called the price of services. This fee is a trade premium 
to the price of purchased raw materials and goods, as well as a mark-up on public catering products. Therefore, the gross income of a food company can be represented as the sum of surcharges on products sold. Gross income as an economic category is a part of the selling price of public catering products, which is intended to cover the costs of production and circulation of the catering enterprise and generate profit. In accordance with IFRS 15 «Revenue from contracts with customers», an organization's income is recognized as an increase in economic benefits resulting from the receipt of assets (cash, other property) and / or repayment of liabilities, which leads to an increase in the capital of this organization, with the exception of contributions from participants (property owners) [4].

Income leads to an increase in the profit and capital of the owner only at the expense of the profit remaining at the disposal of the owner and transferred to the economic entity for expanding activities and solving social problems. Public catering services can be divided by type of classification of income from the main activity (table 1).

\section{Classification of incomes of public catering enterprises by types of services performed*}

Table 1

\begin{tabular}{|l|l|}
\hline \multicolumn{1}{|c|}{ Service name } & \multicolumn{1}{c|}{ Types of services performed } \\
\hline 1. Catering services & $\begin{array}{l}\text { - cafe catering services; } \\
\text { - canteen catering services; } \\
\text { - bar catering services; } \\
\text { - catering services for other types of businesses }\end{array}$ \\
\hline $\begin{array}{l}\text { 2. Services for the production } \\
\text { of culinary products } \\
\text { and confectionery }\end{array}$ & $\begin{array}{l}\text { - according to orders of consumers; } \\
\text { - production of dishes from the customer's raw materials; } \\
\text { - production of dishes and culinary products at home }\end{array}$ \\
\hline $\begin{array}{l}\text { 3. Services for the organization } \\
\text { of consumption and maintenance }\end{array}$ & $\begin{array}{l}\text { - waiter and dish washer services at home; } \\
\text { - organization and maintenance of celebrations and ritual } \\
\text { events; } \\
\text { - catering and servicing of participants of conferences, } \\
\text { seminars, etc.; } \\
\text { - delivery of culinary products, confectionery and } \\
\text { consumer services }\end{array}$ \\
\hline $\begin{array}{l}\text { 4. Services for the sale } \\
\text { of culinary products }\end{array}$ & $\begin{array}{l}\text { - take-home lunch vacations; } \\
\text { - sales through the store and cooking departments; } \\
\text { - sale of culinary products outside the company }\end{array}$ \\
\hline 5. Leisure services & $\begin{array}{l}\text { - organization of music services; } \\
\text { - provision of table games, slot machines, billiards, etc.; } \\
\text { - organization of concerts and video programs }\end{array}$ \\
\hline
\end{tabular}

* Compiled by the authors based on sources [3, 5, 6]

The main income for a trade organization is sales revenue, which is the sum of trade surcharges and trade discounts that fall on goods sold. Therefore, according to the sources of creation, there is a distinction between income received from trade allowances and income received from trade discounts.

In the struggle for survival and additional income, modern enterprises are undergoing complex structuring processes. In this regard, there is a new trend in the food industry - catering, which implies several areas of activity in the field of providing public catering services and related leisure and entertainment services. Demand for specialized catering services is growing, especially for large and medium-sized companies [7]. 
The income of the organization on the provision of catering services is recognized as income from the main type of activity. Revenue received by the organization from the provision of catering services is accepted for accounting in the amount calculated in monetary terms, equal to the amount of receipt of funds and other property and (or) the amount of receivables.

If the amount of the receipt covers only a part of the revenue, the revenue accepted for accounting is determined as the amount of the receipt and accounts receivable (in the part not covered by the receipt).

In accordance with the accounting rules, revenue is recognized in accounting if the following conditions are met:

- the organization has the right to receive revenues arising from a particular agreement or confirmed in any other appropriate way;

- the amount of revenue can be determined;

- there is confidence that as a result of a specific operation, there will be an increase in the economic benefits of the organization;

- the organization provided a service to the customer;

- expenses incurred or to be incurred in connection with the provision of the service can be determined [8].

If at least one of the above conditions is not met in respect of funds and other assets received by the catering company in payment, then accounts payable, and not revenue, are recognized in the accounting of the organization. In the accounting of public catering companies, revenue from sales is recorded at the time of its recognition. For services, revenue recognition requires that the service is provided to the customer.

The basis for recording revenue from the provision of services is: a contract for the provision of services, including catering services, and a certificate of acceptance and delivery of services. Since the form of the act of services rendered has not been approved by law, the catering company can develop such a form itself and fix it in the appendix to the accounting policy.

Accounting for expenses of public catering enterprises is important for the formation of financial results of the enterprise in order to correctly calculate the tax base, since the object of taxation for profit tax is inextricably linked with the concept of income and expenses of the enterprise. In public catering enterprises and other branches of material production, cost accounting should help to identify savings reserves and reduce costs. Since most part of expenses of the enterprises of public catering is formed by costs of production and circulation, organize their accounting in the enterprise should be developed by accounting item, the cost items of production and circulation, determined the types of costs and non-core activities.

Public catering companies are engaged not only in the sale, but also in the organization of production and consumption of products. Along with storerooms, production and trade units include workshops for the production of semi-finished products and confectionery, buffets, and a smallscale retail chain.

Accounting for the costs of circulation and production of trade enterprises should ensure timely, complete and reliable reflection of actual expenses, as well as control over the use of material, labor and financial resources.

In order to plan, record and report the costs of circulation and production, it is recommended that trade enterprises use the nomenclature of items of circulation and production costs presented in table 2.

Businesses are given the right to reduce and expand the list of articles within a cost envisaged under the Model provision on structure of expenses on manufacture and production realization (works, services), included in the cost of products (works, services) and about the order of forming financial results considered at the taxation of profit.

Accounting for all income and expenses is maintained in the accounts of sections 6 «Incom» and 7 «Expenses» of the Standard chart of accounts.

For analytical accounting of income and expenses from the main activities that affect the gross income of the catering company, it is recommended to open the following accounts. 


\section{Nomenclature of items of costs of circulation and production of trade and public catering enterprises*}

\begin{tabular}{|l|l|}
\hline $\begin{array}{c}\text { Article } \\
\text { number }\end{array}$ & \multicolumn{1}{|c|}{ Name of the article } \\
\hline 1. & Transport cost \\
\hline 2. & The cost of labor \\
\hline 3. & Deductions for social needs \\
\hline 4. & $\begin{array}{l}\text { Expenses for rent and maintenance of buildings, structures, premises, } \\
\text { equipment and inventory }\end{array}$ \\
\hline 5. & Depreciation of fixed assets \\
\hline 6. & Expenses for repair of fixed assets \\
\hline 7. & $\begin{array}{l}\text { Wear of sanitary and special clothing, table linen, dishes, appliances, } \\
\text { other equipment and household accessories }\end{array}$ \\
\hline 8. & Expenses for fuel, gas, and electricity for production needs \\
\hline 9. & Expenses for storage, part-time work, sorting and packaging of goods \\
\hline 10. & Advertising expenses \\
\hline 11. & The cost of paying interest for using the loan \\
\hline 12. & Loss of goods and technological waste packaging \\
\hline 13. & The cost of packaging \\
\hline 14. & Other expenses \\
\hline
\end{tabular}

*Compiled by the authors based on sources [5, 9]

\section{Accounting for financial results}

\begin{tabular}{|l|l|l|l|}
\hline 6010 & Revenue from sales of products and services & 7010 & Cost of products sold and services rendered \\
\hline 6020 & Return of products sold & 7100 & Expenses on sales of products and services \\
\hline 6030 & Discounts on prices and sales & 7210 & Administrative expenses remuneration \\
\hline 6110 & Remuneration income & 7310 & Remuneration expenses \\
\hline 6120 & Dividend income & 7320 & The cost of interest payments on finance lease \\
\hline 6140 & $\begin{array}{l}\text { Income from operations with real estate } \\
\text { investments }\end{array}$ & 7330 & $\begin{array}{l}\text { Expenses from changes in the fair value of } \\
\text { financial instruments }\end{array}$ \\
\hline 6160 & Other financing income & 7340 & Other financing costs \\
\hline 6210 & Income from disposal of assets & 7410 & Expenses on disposal of assets \\
\hline 6220 & Income from gratuitous assets & 7420 & Impairment losses on non-financial assets \\
\hline 6230 & Revenue from government subsidies & 7430 & The expenses from exchange rate difference \\
\hline 6250 & Foreign exchange gains & 7440 & Impairment of accounts receivable \\
\hline 6260 & Income from operating leases & 7470 & Impairment losses on financial instruments \\
\hline 6280 & $\begin{array}{l}\text { Income from recovery of an impairment loss } \\
\text { on financial assets }\end{array}$ & 7480 & Other expenses \\
\hline 6290 & Other income & 7710 & Corporate income tax expense \\
\hline
\end{tabular}

5710 «Total revenue»

Figure 1. System and relationship of accounts for generating financial results*

*Compiled by the authors based on sources [8, 9, 10] 


\section{Каржы энәне есеп / Финансы и учет}

To account 6010 «Income from sales of products and services»:

-6011 «Income from food services»;

-6012 «Income from services for the production of culinary products and confectionery»; -6013 «Income from catering services».

To account 7010 «Cost of products sold and services rendered»:

-7011 «Cost of food services»;

-7012 «Cost of services for the production of culinary products and confectionery»;

-7013 «Cost of catering services».

To reflect the financial result in the balance sheet at the end of the reporting period, data on income and expenses are written off to reduce the total income, that is, to account 5710 «Total income (loss)» (figure 1).

The financial result of operations for the reporting period is reflected in the Statement of profit and loss, which is compiled on the basis of data reflected in the accounts of sections 6 «Income» and 7 «Expenses» of the Standard chart of accounts.

To increase profitability and improve accounting of financial results in public catering enterprises, we recommend:

- influence the financial results within the framework of accounting policy, which can be achieved in various ways: by revising the company's asset estimates; distributing income and expenses between adjacent accounting periods; forming reserves for doubtful debts; using directcosting method;

- to analyze and predict changes in the internal and external conditions for the development of the business through managing profits. What influences the calculation and minimization of risks through real planning and evaluation of the company's performance, taking into account the factors that affect them. An important area of search for profit reserves is to reduce the cost of production and sales of products.

Conclusion. The financial result of a public catering company serves as a kind of indicator of the importance of this enterprise. As market conditions any company interested in obtaining a positive result from their activities, because the value of this index the company is able to expand its power and material interest to staff working in the enterprise, pay dividends to participants, etc.

Properly organized synthetic and analytical accounting of financial results contributes to the growth of revenues and profits, and increases the profitability of public catering enterprises. Only under these conditions accounting for financial results will provide:

- timeliness, legality and completeness of accounting for all income, expenses, losses in the field of public catering services;

- correct determination and accounting of financial results for individual structural divisions of the enterprise;

- effective control over the accuracy of setting trade surcharges, margins, prices for goods, raw materials and products of own production;

- compliance with the current tax system, search for opportunities to optimize taxes and other mandatory payments;

- identification and use of opportunities and reserves for revenue and profit growth, cost minimization, prevention of unproductive losses and losses;

- the correctness of accounting for the distribution of income and profit and the effectiveness of their use.

Thus, accounting for financial results is of particular importance in the organization of activities at an enterprise, since income and expenses are important elements of financial statements and are directly related to the assessment of financial results of a public catering enterprise.

\section{REFERENCES}

1. Zakon $\mathrm{RK} « \mathrm{O}$ regulirovanii torgovoy deyatel'nosti» ot 12 aprelya 2004 goda № 544-II (s izmeneniyami i dopolneniyami po sostoyaniyu na 25.06.2020 g.). online.zakon.kz [in Russian].

2. Prikaz i.o. Ministra natsional'noy ekonomiki Respubliki Kazakhstan ot 27 marta 2015 goda 
№ 264 «Ob utverzhdenii Pravil vnutrenney torgovli» (s izmeneniyami i dopolneniyami po sostoyaniyu na 14.10.2020 g.). online.zakon.kz [in Russian].

3. Nazarova V. L. Bukhgalterskiy uchet v otraslyakh: Uchebnik/ V. L. Nazarova; red. K.T. Taygashinovoi. - Izd. 2-ye, pererab. - Almaty: Ekonomika, 2014. - 425 s. [in Russian].

4. Sidneva V.P. Mezhdunarodnyye standarty finansovoy otchetnosti: Ucheb. posobiye. - M.: KNORUS, 2016. - 216 s. [in Russian].

5. Bukhgalterskiy uchet $\mathrm{v}$ torgovle i obshchestvennom pitanii: Ucheb. posobiye/YU.A. Babayev, A.M. Petrov. - M.: INFRA-M, 2015. - 352 s. [in Russian].

6. Nikolayeva G.A. Bukhgalterskiy uchet v torgovle: Optovaya torgovlya. Roznichnaya torgovlya. Obshchestvennoye pitaniye. Zagotovitel'nyye predpriyatiya / G.A. Nikolayeva. - M.: A-Prior, 2012. -352 s. [in Russian].

7. Avdeyev V. Uchet uslug keyteringa //Audit i nalogooblozheniye. - 2011. - № 5. wiseeconomist. ru/poleznoe70583 [in Russian].

8. Tashtanova N.N. Bukhgalterskiy uchet v torgovle i predpriyatiyakh obshchestvennogo pitaniya: Ucheb. posobiye. - Nur-Sultan: TOO Izdatel'stvo «Fortuna Poligraf», 2020. - 130 s. [in Russian].

9. Nazarova V.L. Osobennosti bukhgalterskogo ucheta na predpriyatiyakh obshchestvennogo pitaniya. online.zakon.kz/Document?doc_id [in Russian].

10. Mihajlina I.N. Osnovnye priemy organizacii ucheta i audita debitorskoj i kreditorskoj zadolzhennosti // Vestnik KazUEFMT. - 2019. - № 1. - S. 52-57.

\section{ЛИТЕРАТУРА}

1. Закон РК «О регулировании торговой деятельности» от 12 апреля 2004 года № 544-II (с изм. и доп. по сост. на 25.06.2020 г.).

2. Приказ и.о. Министра национальной экономики Республики Казахстан от 27 марта 2015 года № 264 «Об утверждении Правил внутренней торговли» (с изм. и доп. по сост. на 14.10.2020 г.). online.zakon.kz

3. Назарова В.Л. Бухгалтерский учет в отраслях: Учебник / В.Л. Назарова; ред. К.Т. Тайгашинова. - Изд. 2-е, перераб. - Алматы: Экономика, 2014. - 425 с.

4. Сиднева В.П. Международные стандарты финансовой отчетности: Учеб. пособие. - М.: КНОРУС, 2016. - 216 c.

5. Бухгалтерский учет в торговле и общественном питании: Учеб. пособие / Ю.А. Бабаев, А.М. Петров. - М.: ИНФРА-М, 2015. - 352 с.

6. Николаева Г.А. Бухгалтерский учет в торговле: Оптовая торговля. Розничная торговля. Общественное питание. Заготовительные предприятия / Г.А. Николаева. - М.: А-Приор, 2012. - 352 с.

7. Авдеев В. Учет услуг кейтеринга //Аудит и налогообложение. - 2011. - № 5. wiseeconomist.ru/poleznoe

8. Таштанова Н.Н. Бухгалтерский учет в торговле и предприятиях общественного питания: Учеб. пособие. - Нур-Султан: ТОО Изд-во «Фортуна Полиграф», 2020. - 130 с.

9. Назарова В.Л. Особенности бухгалтерского учета на предприятиях общественного питания. online.zakon.kz

10. Михайлина И.Н. Основные приемы организации учета и аудита дебиторской и кредиторской задолженности // Вестник КазУЭФМТ. - 2019. - № 1. - С. 52-57. 
Каржы жеәне есеп / Финансы и учет

\author{
А.А. Кажмухаметова, Г.С. Тусибаева, Б.Ж. Акимова \\ ҚОҒАМДЫҚ ТАМАҚТАНУ КӘСІПОРЫНДАРЫНЫН ҚАРЖЫЛЫҚ \\ НӘТИЖЕЛЕРІНІҢ ЕСЕПТІК ҚҰРАМЫ
}

\title{
Андатпа
}

Қаржылық нәтижелердің қалыптасуын бақылауда олардың дұрыс ұйымдастырылған жедел және бухгалтерлік есебі маңызды. Мақалада бухгалтерлік есеп ерекшеліктерін анықтайтын қоғамдық тамақтану кәсіпорындарының шаруашылық қызметінің ерекшелігі көрсетілген.

Бір жағынан, ол өндіріс процестерін (тамақ дайындау), екінші жағынан сауда (сату) процестерін көрсетуге арналған. Сауда және тамақтану кәсіпорындарын қамтитын, материалдық өндіріс салаларында шаруашылықтың қаражат айналымы жүйесіндегі өндіріс кезеңінде пайда болатын шығындар айналым шығындарын қамтиды. Өнімді сатуға және өндірілген өнімді нарықта жылжытуға байланысты шығындар өнеркәсіптік және сауда кәсіпорындарында айналым шығындары ретінде анықталады.

Бұл жұмыста тамақтану саласындағы кірістер мен шығындарды жіктеуге, есепке алуға баса назар аударылады. Соңғы жылдары қарқын алып келе жатқан кейтеринг сияқты салыстырмалы түрде жаңа қызмет түріне назар аударылды. Қаржы нәтижелерін топтамалық және талдамалық есепке алу, қаржы есептілігіндегі ақпаратты ашу мәселесі талқыланды. Зерттеу нәтижелері бойынша авторлар кірістерді арттыру және қаржылық нәтижелерді есепке алуды жетілдіру бойынша негізделген іс-шараларды ұсынды.

\section{А.А. Кажмухаметова, Г.С. Тусибаева, Б.Ж. Акимова \\ УЧЕТНАЯ СОСТАВЛЯЮЩАЯ ФИНАНСОВЫХ РЕЗУЛЬТАТОВ ПРЕДПРИЯТИЙ ОБЩЕСТВЕННОГО ПИТАНИЯ}

\section{Аннотация}

Важное значение в контроле за формированием финансовых результатов имеет правильно организованный на предприятии их оперативный и бухгалтерский учет. В статье раскрыта особенность хозяйственной деятельности предприятий общественного питания, которая определяет особенности ведения бухгалтерского учета.

С одной стороны, он призван отражать процессы производства (приготовление пищи), а с другой - процессы торговли (реализации). Расходы, связанные с реализацией продукции и продвижением на рынке произведенной продукции, и у промышленных, и у торговых предприятий определяют как издержки обращения.

В работе акцентировано внимание на классификации, учете доходов и расходов в сфере питания. Уделено внимание сравнительно новому вид услуг как кейтеринг, который в последние годы набирает обороты. Обсужден вопрос синтетического и аналитического учета финансовых результатов, раскрытия информации в финансовй отчетности. По результатам исследования авторами рекомендованы обоснованные мероприятия по повышению доходност и совершенствованию учета финансовых результатов.

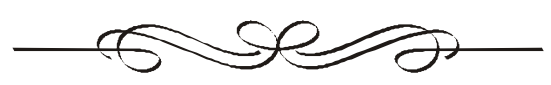


DOI 10.52260/2304-7216.2020.4(41).27

УДК $336.71(574)$

ГРНТИ 06.73.55

С.Ж. Есенгельдинова*, м.э.н., cm. преподаватель

Т.М. Усенбаев, к.э.н., доиент

С.О. Бозшагулова, м.э.н., cm. преподаватель Казахский университет экономики, финансов и международной торговли 2. Нур-Султан e-mail: s_Esengeldinova@kuef.kz

* - основной автор (автор для корреспонденции)

\section{РАЗВИТИЕ ПЛАТЕЖНОЙ СИСТЕМЫ КАЗАХСТАНА В УСЛОВИЯХ ФИНАНСОВОЙ ГЛОБАЛИЗАЦИИ}

В статье рассмотрены вопросы развития технологии электронного банковского обслуживания, в условиях конкурентной борьбы требующие от банков оперативной, безопасной и удобной системы в возможности самообслуживания клиентов из дома, офиса или мультимедийного киоска, эффективного мониторинга в повышении качества обслуживания клиентов. Указано, что при стремительном росте безналичных операций важной проблемой остается необходимость реализации программы развития национальной платежной системь Казахстана (НСП). Проведен анализ основных индикаторов платежного рынка, показаны количество функиионирующих платежных систем в Казахстане и его участники. Определены количество и суммы транзакиий, проведенных через Межбанковскую систему переводов денег (МСПД) и Систему межбанковского клиринга (СМК), денежные переводы из РК за рубеж за последние годы.

Авторами предложены рекомендации развития платежной системы: реализация программы развития наииональной платежной системы Казахстана (НПС), необходимость разработки нащионального стандарта работы системы, сертификация всех банкоматов и POS-терминалов, криптографическая защита каналов связи, внедрение инноваций, включая бесконтактные платежи с применением банковских карт и технологии NFC, развития интернет-торговли.

Ключевые слова: платежный рынок, платежная система, электронные услуги, денежные переводы, банкомат, транзакиия, платежные карточки, клиринг, интернет-торговля, эмитент.

Кілт сөздер: төлем нарывы, төлем жүйесі, электрондық қыызметтер, ақұша аударымдары, банкомат, транзакиия, төлем карточкалары, клиринг, интернет-сауда, эмитент.

Keywords: payment market, payment system, electronic services, money transfers, ATM, transaction, payment cards, clearing, online trading, issuer.

JEL classification: G 35

Введение. Во всем мире широко используются платежные системы, которые постоянно развиваются и совершенствуются. Тем не менее, теория и организация платежных систем остается не достаточно изученным аспектом экономической науки.

Платежная система любого государст- ва является важной составляющей современной денежной системы позволяющая организовывать расчеты наличными и безналичными деньгами при осуществлении внутренних и международных платежей [1].

Реформирование платежной системы напрямую связано с развитием новых тех- 
Қаржы жнәне есеп / Финансы и учет

нологий, усилением важности вопроса эффективности и безопасности проведения платежей и переводов денег.

Быстрые технологические перемены, происходящие на национальном и международном уровнях, требуют постоянного внимания по поддержке безопасности и эффективности платежных систем со стороны Национального банка [2].

Отметим, что важной особенностью текущего состояния платежной системы Казахстана является большая доля наличных платежей. Одним из приоритетных задач является сокращение доли наличных платежей и полный переход на систему безналичных платежей с использованием новейших информационных технологий, обеспечивающая безопасное проведение всех платежей и без задержек во времени.

В связи с этим, цель данного исследования заключается в проведении анализа и оценки текущего состояния платежной системы Казахстана в современных экономических условиях, выработке комплекса мер по ее совершенствованию.

Методы. Для решения задач исследования применялись статистический анализ, сравнительный анализ, метод группировки, а также методы изучения информационных материалов и экспертные методы.

Обзор литературы. В последнее время особенно актуальные вопросы по изучению проблем формирования, функционирования и развития платежных систем государства, которые освещены в работах отечественных ученых: Г.С Сейткасимова, А.А Ильяса, А.К. Саулембекова, А.Т. Джумабековой [3, 4].

При изучении организационно-практических аспектов функционирования платежных систем, отражены перспективы развития и его совершенствование в работах российских ученых: В.Ю. Иванова, Д.А. Кочергина, С.Е. Дубовой, А.С. Обаевой $[5,6,7]$.

В проведении анализа использованы статистические данные текущего состояния банковского сектора страны и комитета по контролю и надзору финансового рынка и финансовых организаций НБ РК $[8,9]$.

Отметим что, несмотря на достаточное количество исследований в области платежной системы, недостаточно изученной остаются проблемы криптографической защиты каналов связи, увеличения кибер-угроз, внедрения инноваций, включая бесконтактные платежи с применением банковских карт и технологии NFC, развития интернет-торговли, необходимости разработки национального стандарта работы системы, сертификации всех банкоматов и POS-терминалов.

Обзор литературы выявил важность продолжения исследований в области изучения платежной системы в Казахстане с учетом зарубежного опыта.

Основная часть. На казахстанском рынке функционируют платежные системы Национального Банка - Межбанковская система переводов денег (далее - МСПД) и Система межбанковского клиринга (далее - СМК), обеспечивающие функционирование финансовой системы страны.

По состоянию на 1 января 2019 года в реестр платежных систем включено 20 платежных систем, из них 1 системно значимая платежная система, 3 значимые платежные системы, 16 иных платежных систем (табл. 1).

Развитие платежных услуг обеспечивает эффективное обслуживание финансовой системы государства и играет важную роль в развитии реального сектора экономики. В последние годы платежная система активно меняется, развиваясь в ключе цифровизации и внедрения инноваций, положительный эффект для держателей платежных карт выражается в повсеместной доступности удобных и простых инструментов оплаты.

На территории Казахстана к концу 2019 года в обращении находилось 31,2 млн платежных карточек - на 42,9\% больше, 
чем в аналогичном периоде прошлого года (21,8 млн карточек).

Следует отметить, что за последние три года количество платежных карточек в обращении увеличилось в среднем на
$26,8 \%$, количество держателей карточек на $55 \%$ и составило 27,8 млн. В среднем на одного жителя страны, приходится около 1,7 платежной карточки, по сравнению с 2014 годом (рис.1).

Виды платежной системы Казахстана, (ед)*

\begin{tabular}{|c|c|c|}
\hline $\begin{array}{c}\text { Вид платежной } \\
\text { системы }\end{array}$ & Наименование платежной системы & $\begin{array}{l}\text { Количество } \\
\text { участников }\end{array}$ \\
\hline $\begin{array}{l}\text { Системно значимая } \\
\text { платежная система }\end{array}$ & Межбанковская система переводов денег & 43 \\
\hline $\begin{array}{l}\text { Значимая платежная } \\
\text { система }\end{array}$ & $\begin{array}{l}\text { Система межбанковского клиринга } \\
\text { Золотая Корона } \\
\text { MasterCardEurope SA }\end{array}$ & $\begin{array}{l}34 \\
17 \\
19 \\
\end{array}$ \\
\hline $\begin{array}{l}\text { Иные } \\
\text { платежные системы }\end{array}$ & $\begin{array}{l}\text { VISA International } \\
\text { ANELIK } \\
\text { BLIZKO } \\
\text { CONTACT } \\
\text { FASTER } \\
\text { MONEYGRAM } \\
\text { Вестерн Юнион } \\
\text { Международные денежные переводы ЛИДЕР } \\
\text { Платежная система AO «Народный Банк } \\
\text { Казахстана» } \\
\text { Система массовых электронных платежей } \\
\text { ЮНИСТРИМ } \\
\text { DinersClubInternational } \\
\text { UnionРаy International Сo. Ltd } \\
\text { Интелэкспресс } \\
\text { Атеrican Express } \\
\text { Платежная система «Мир» }\end{array}$ & $\begin{array}{c}22 \\
22 \\
1 \\
2 \\
6 \\
1 \\
2 \\
21 \\
12 \\
11 \\
11 \\
1 \\
9 \\
1 \\
1\end{array}$ \\
\hline
\end{tabular}

* Составлена авторами на основе данных [8]

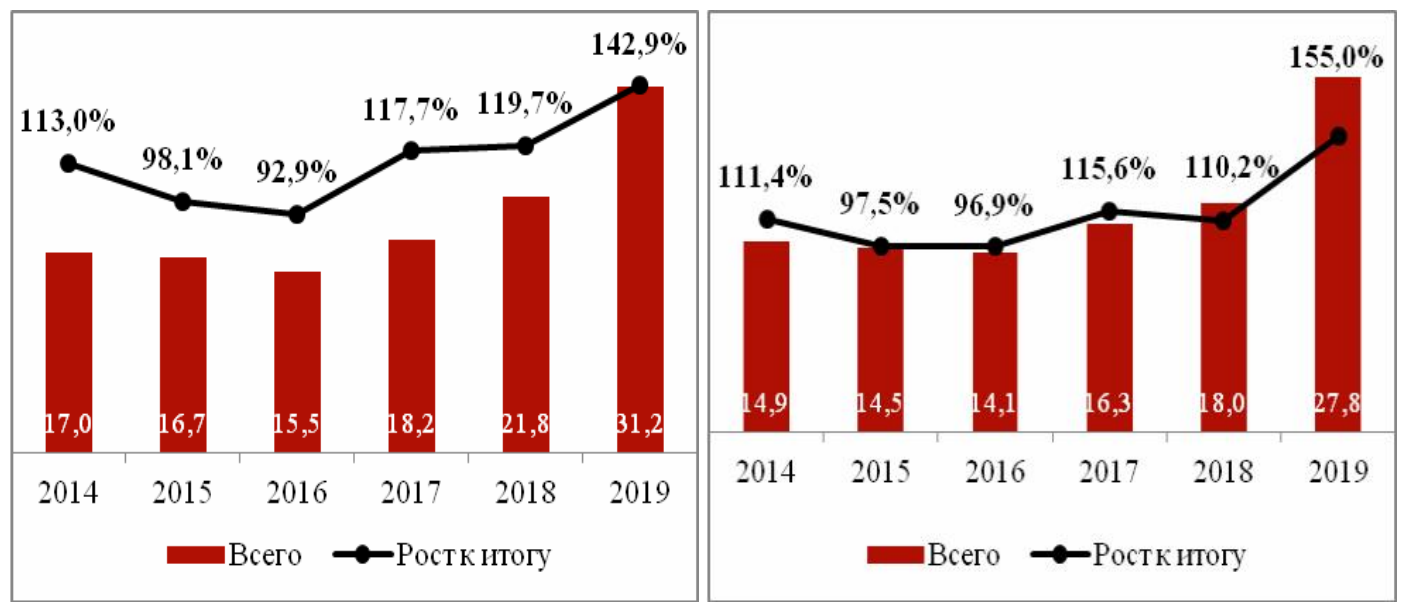

Рисунок 1. Платежные карточки в обращении и количество держателей платежных карточек в РК, (мЛн)*

*Составлен авторами на основе данных [8] 
Кроме того, сохраняется тенденция роста безналичных платежей и переводов денег, улучшения качества и расширения платежных сервисов и в целом перехода на дистанционные каналы обслуживания клиентов. рот по картам казахстанских эмитентов составил 24,1 трлн тенге, рост по сравнению с 2018 годом - на 52\%. Количество транзакций за данный период составило 1,2 млрд при годовом росте почти вдвое (на 94,1\%).

Объем безналичных платежей и переводов денег с использованием платежных карточек в Казахстане за 2019 год составил 10,6 трлн тенге, увеличившись более чем в 2 раза по сравнению с 2018 годом $(6,4$ трлн тенге) (рис.2).

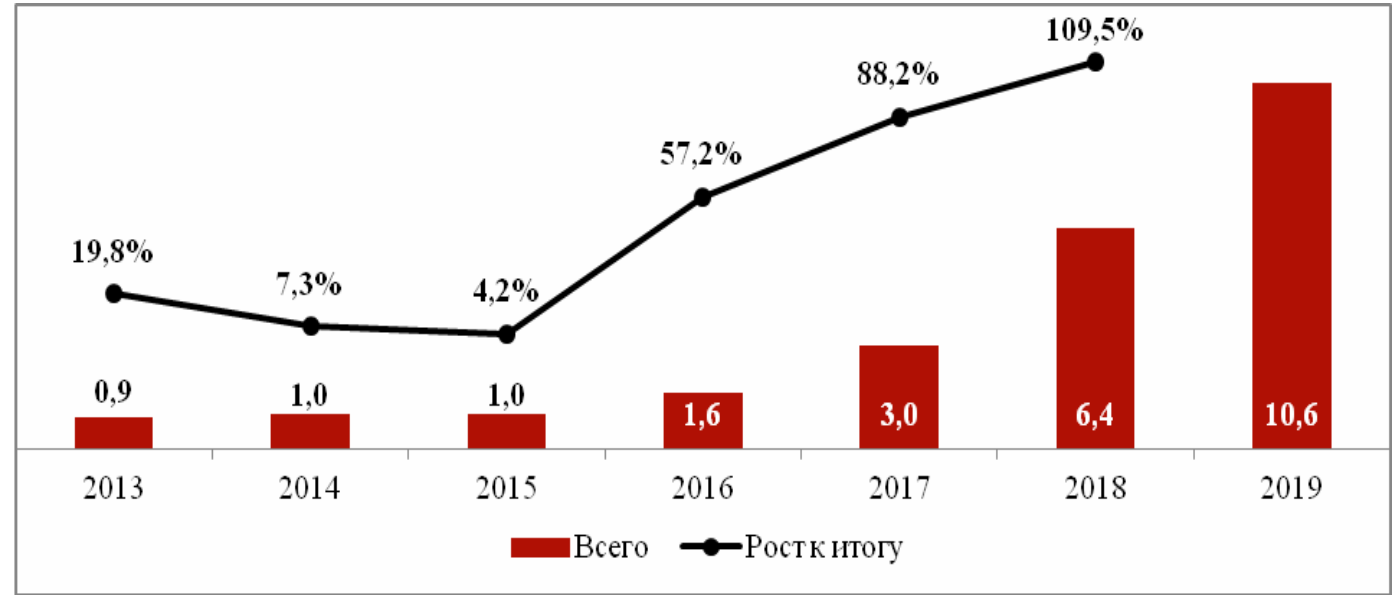

Рисунок 2. Объем безналичных платежей в РК, (трлн тенге)*

*Составлен авторами на основе данных [9]

$68 \%$ безналичных операций осуществлено через интернет и мобильный банкинг - 7,1 трлн тенге; 30,7\% объема, или 3,2 трлн тенге, приходилось на POS-терминалы. Объем безналичных операций че- рез банкоматы и банковские киоски составил 161,4 млрд и 316,3 млн тенге. Безналичные транзакции в Казахстане в основном проводятся на оплату товаров и услуг (рис. 3).

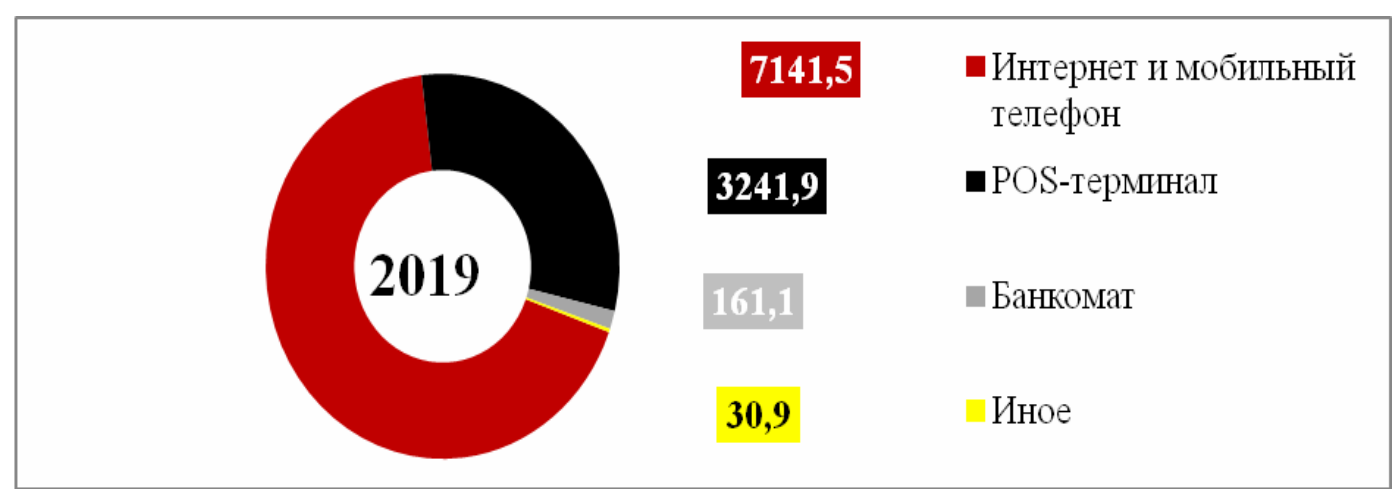

Рисунок 3. Объем безналичных платежей в разрезе операций, (млрд тенге)* *Составлен авторами на основе данных [9] 
За 2019 год через сервисы платежных организаций было проведено 35,4 млн транзакций на сумму 669, 9 трлн тенге, что в целом свидетельствует о благоприятных правовых и экономических условиях ведения платежными организациями бизнеса, а также о непрерывном спросе на представляемые ими платежные услуги. В рамках оказываемых услуг платежные органи- зации предоставляют сервис по оплате услуг операторов сотовой связи, коммунальных услуг, налоговых платежей, медицинских услуг, погашению займов и т.д. Платежными организациями для оказания платежных услуг на конец 2019 года использовалось более 80 тысяч электронных терминалов (рис. 4).

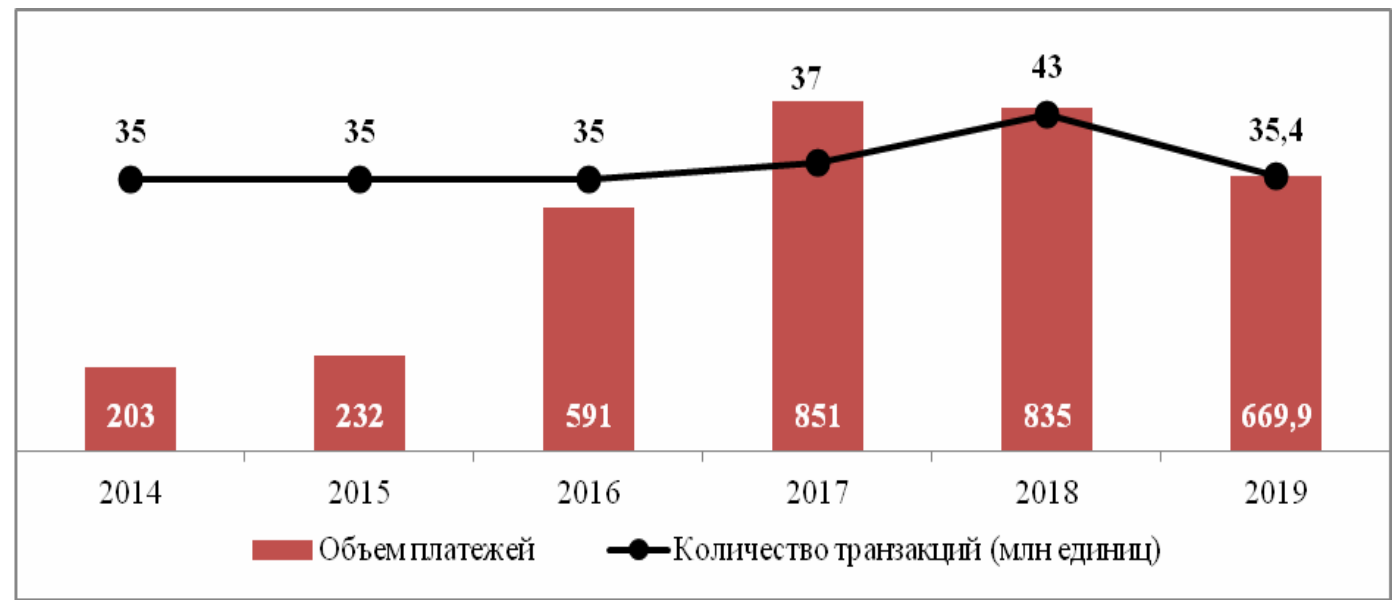

Рисунок 4. Динамика потоков безналичных платежей, (трлн тенге)*

*Составлен авторами на основе данных [9]

Следует отметить, что осуществление платежных услуг и их значительный рост на рынке сопровождается деятельностью Национального банка в рамках выполнения регуляторных и контрольных функций в функционировании платежной системы.

Выводы. Развитие платежного рынка Казахстана и укрепление платежной инфраструктуры является одним из приоритетных направлений по повышению эффективности функционирования экономики, в связи с этим для активизации процесса предстоит в будущем сделать большую работу, и, в первую очередь:

- при реализации программы развития национальной платежной системы Казахстана (НСП) необходимо разработать национальный стандарт работы системы, провести сертификацию всех банкоматов и POS-терминалов;
- сформулировать технические стандарты форматов электронных платежных документов;

- составить стандарты криптографической защиты каналов связи;

- внести корректировки в законодательные акты, легализующие и регулирующие осуществление электронных банковских операций через телекоммуникационные сети;

- внедрить инновационные технологии, включая бесконтактные платежи с применением банковских карт и технологии NFC, а также развивать интернет-торговлю.

Таким образом, вышеуказанные направления определят ускоренный переход страны к cashless-экономике, что принесет выгоду для всех вовлеченных сторон, в первую очередь, с точки зрения безопасности и удобства, оптимизации расходов 
Қаржы жнәне есеп / Финансы и учет

на финансовые операции, ускорения денежного оборота, улучшения налогового адми- нистрирования и, соответственно, сокращения теневой экономики.

\section{ЛИТЕРАТУРА}

1. Сейкасимов Г.С. Банковское дело: Учебник. - 3-е, доп. и перараб. - Астана: ИПЦ КазУЭФМТ, 2016. - 608 с.

2. Мусина А.А., Парусимова Н.И., Усенбаев Т.М. Клиентоориентированность как основа цифровизации банковского обслуживания // Вестник КазУЭФМТ. - 2019. - № 4. - С.120-128.

3. Ильяс А.А., Саулембекова А.К. Платежная система Республики Казахстан: теория и практика. - Алматы: Экономика, 2009. - 208 с.

4. Джумабекова А.Т. Организация деятельности центрального банка: Учеб. пособие. - Астана: Изд. КазУЭФМТ, 2013. - 220 с.

5. Иванов В.Ю. Некоторые теоретические и практические аспекты законодательства о национальной платежной системе // Банковское право. - 2011. - № 6. - С. 71-78.

6. Кочергин Д.А. Электронные деньги: Учебник. - М.: Изд-во «Маркет ДС»; центр исследований платежных систем и расчетов (ЦИПСиР). - 2011. - 424 с.

7. Дубовая С.Е., Обаева А.С. Платежные системы: Учеб. пособие. - Киров: МЦНИП, 2014. $-453 \mathrm{c}$.

8. Расчеты Ranking.kz на основе данных комитета по контролю и надзору финансового рынка и финансовых организаций НБ РК январь 2020 г. Интернет-ресурс://www.kfn.kz/ (Дата обращения: 28.02.2020 г.).

9. Обзор «Текущее состояние банковского сектора РК по состоянию январь 2020 года»). Интернет-ресурс //: www.nationalbank.kz (Дата обращения: 20.05.2020 г.).

\section{REFERENCES}

1. Sejkasimov G.S. Bankovskoe delo: Uchebnik. - Izd. 3-e, dop. i perarab. - Astana: IPC KazUJeFMT, 2016. - 608 s. [in Russian].

2. Musina A.A., Parusimova N.I. , Usenbayev T. M. Customer focus as the basis for digitalization of banking services // Messenger KazUEFMT. - 2019. - No. 4. - S. 120-128 [in Russian].

3. Il'jas A.A., Saulembekova A.K. Platezhnaja sistema Respubliki Kazahstan: teorija i praktika. -Almaty: Jekonomika, 2009. - 208 s. [in Russian].

4. Dzhumabekova A.T. Organizacija dejatel' nosti central' nogo banka: Ucheb. posobie. - Astana: Izd. KazUJeFMT, 2013. - 220 s. [in Russian].

5. Ivanov V.Ju. Nekotorye teoreticheskie i prakticheskie aspekty zakonodatel'stva o nacional' noj platezhnoj sisteme // Bankovskoe pravo. - 2011. - № 6. - S. 71-78 [in Russian].

6. Kochergin D.A. Jelektronnye den' gi: Uchebnik. - M.: Izd-vo «Market DS»; centr issledovanij platezhnyh sistem i raschetov (CIPSiR). - 2011. - 424 s. [in Russian].

7. Dubovaja S.E., Obaeva A.S. Platezhnye sistemy: Ucheb. posobie. - Kirov: MCNIP, 2014. -453 s. [in Russian].

8. Ranking Calculations.kz based on data from the Committee for control and supervision of the financial market and financial organizations of the national Bank of Kazakhstan January 2020. Internet resource: // www. kfn. kz/.(Accessed: 28.02.2020 g.) [in Russian].

9. Review «Current state of the banking sector of the Republic of Kazakhstan as of January 2020 g.»). Internet resource - www.nationalbank.kz (Accessed: 20.05.2020 g.) [in Russian]. 


\title{
С.Ж. Есенгельдинова, Т.М. Усенбаев, С.О. Бозшагулова \\ ҚАРЖЫЛЫҚ ЖАһАНДАНУ ЖАҒДАЙЫНДА ҚАЗАҚСТАННЫҢ ТӨЛЕМ ЖҮЙЕСІН ДАМЫТУ
}

\begin{abstract}
Андатпа
Мақалада авторлар бәсекелестік жағдайында банктерден жедел, қауіпсіз және ыңғайлы жүйені, үйден, кеңседен немесе мультимедиялық дүңгіршектен клиенттерге өзін-өзі қызмет көрсету мүмкіндігін, клиенттерге қызмет көрсету сапасын жақсартуға тиімді мониторинг жүргізуді талап ететін электрондық банктік қызмет көрсету технологиясын дамыту мәселелерін қарастырды. Қолма-қол ақшасыз операциялардың қарқынды өсуі кезінде Қазақстанның ұлттық төлем жүйесін (ҰТЖ) дамыту бағдарламасын іске асыру қажеттілігінде маңызды проблема болып қалатыны көрсетілген. Төлем нарығының негізгі индикаторларына талдау жүргізді, Қазақстанда жұмыс істеп тұрған төлем жүйелерінің санын және оған қатысушыларды көрсетті. Банкаралық ақша аудару жүйесі (БААЖ) және банкаралық клиринг жүйесі (БКЖ) арқылы жүргізілген транзакциялардың саны мен сомасы, ҚР-дан соңғы жылдары шетелге ақша аударымдары айқындалды.

Авторлар Қазақстанның ұлттық төлем жүйесін (ҰТЖ) дамыту бағдарламасын іске асыру, жүйе жұмысының ұлттық стандартын әзірлеу қажеттілігі туралы, барлық банкоматтар мен POSтерминалдарды сертификаттау, байланыс арналарын криптографиялық қорғау, Банктік карталар мен NFC технологияларын қолдана отырып жанасусыз төлемдерді қоса алғанда инновацияларды енгізу, интернет-сауданы дамыту сияқты төлем жүйесін дамыту ұсынымдарын ұсынды.
\end{abstract}

\section{S. Yessengeldinova, T. Ussenbayev, S. Bozshagulova \\ DEVELOPMENT OF THE PAYMENT SYSTEM OF KAZAKHSTAN IN THE CONTEXT OF FINANCIAL GLOBALIZATION}

\begin{abstract}
Annotation
The authors of the article consider the development of e-banking technology, which in a competitive environment requires banks to have an operational, safe and convenient system for self-service of customers from home, office or multimedia kiosk, effective monitoring in improving the quality of customer service. The article indicates that with the rapid growth of non-cash transactions, an important problem remains in the need to implement the program for the development of the national payment system of Kazakhstan (NPS). The authors analyzed the main indicators of the payment market, showed the number of functioning payment systems in Kazakhstan and its participants. The number and amounts of transactions conducted through the Interbank money transfer system (IMTS) and the interbank clearing system (ICS), money transfers from Kazakhstan abroad in recent years are determined.

In the article, the authors offer recommendations for the development of the payment system: implementation of the program for the development of the national payment system of Kazakhstan (NPS), the need to develop a national standard for the system, certification of all ATMs and POS terminals, cryptographic protection of communication channels, introduction of innovations, including contactless payments using Bank cards and NFC technology, development of Internet Commerce.
\end{abstract}

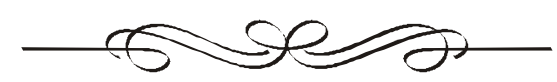




\section{Б.А. Абжалова*, докторант PhD}

А.Е. Шахарова, к.э.н., доцент

Евразийский нащиональный университет

им. Л.Н. Гумилева

2. Нур-Султан

e-mail: shaharovaaliya@yandex.kz

* - основной автор (автор для корреспонденции)

\section{ЦИФРОВАЯ ТРАНСФОРМАЦИЯ ВНЕШНЕГО ГОСУДАРСТВЕННОГО АУДИТА РЕСПУБЛИКИ КАЗАХСТАН}

В статье исследуются ключевые аспекты информатизации органов внешнего государственного аудита в Республике Казахстан, которые оцениваются как на достаточно высоком уровне. В силу огромного объема информации, подлежащей постоянному анализу в целях обеспечения быстроты и точности принимаемых решений, действенный государственный аудит не может существовать и развиваться без высокоэффективной системь управления, основанной на иифровых технологиях. В работе проанализированы основные результаты трансформации государственного аудита за 2015-2019 годы и определень основные направления по совершенствованию деятельности органов внешнего государственного аудита посредством применения современных иифровых технологий. Сделаны выводы и предолжены пути решения множества проблем в области информатизации органов государственного аудита, в частности Счетного комитета РК. Для дальнейшей иифровой трансформации аудиторской деятельности предлагается повышение эффективности существующей информационной системы, а также создание качественно новой единой изифровой транзакционной среды посредством интеграџии базы данных государственных органов.

Ключевые слова: внешний государственный аудит, финансовый контроль, Счетный комитет, внешние органы государственного аудита, информационные системы, система управления рисками, фиансовые нарушения, процедурные нарушения, автоматизаџия данных, иифровые технологии, дистанционные проверки.

Кілт сөздер: сыртқы мемлекеттік аудит, құаржылық бақылау, Есеп комитеті, мемлекеттік аудиттің сыртқы органдары, ақпараттық жүйелер, тәуекелдерді басқьару жүйесі, қаржылық бұзушылықтар, рәсімдік бұзушылықтар, деректерді автоматтандыру, ииифрлық технологиялар, қุашықтықтан тексерулер.

Keywords: external state audit, financial control, Accounts Committee, external state audit bodies, information systems, risk management system, financial violations, procedural violations, data automation, digital technologies, remote checks.

Введение. В современных реалиях социально-экономические, технологические и политические изменения имеют сильное влияние на систему государственного аудита, заставляя ее меняться в соответствии с текущей ситуацией. Это вынуждает органы государственного аудита 240 искать новые подходы, чтобы успевать за глобальными изменениями и отвечать вызовам современности.

В силу огромного объема информации, подлежащей постоянному анализу в целях обеспечения быстроты и точности принимаемых решений, действенный государст- 
венный аудит не может существовать и развиваться без высокоэффективной системы управления, основанной на цифровых технологиях. За счет автоматизации процессов управления с применением соответствующих информационных систем обеспечивается высокий уровень оперативного реагирования на изменения, происходящие в значительном массиве объектов государственного аудита.

Фундаментом для цифровой трансформации экономики Казахстана послужила государственная программа «Информационный Казахстан-2020», поспособствовавшая переходу страны к информационному обществу. Вместе с тем, госпрограмма дала толчок для совершенствования госуправления, создания института «открытое и мобильное правительство», роста доступности информационной инфраструктуры как для корпоративных структур, так и для населения. Однако ускоренный темп развития информационных и цифровых технологий в глобальном масштабе диктует свои установки, и как итог Казахстан переход к следующему шагу - разработке новой госпрограммы «Цифровой Казахстан», одним из основных направлений которой стал «Переход на цифровое государство». В совокупности на реализацию программы до 2022 года планируется направить более 108,7 млрд тенге [1].

Поэтому в настоящий момент достаточно актуальным является вопрос цифровой трансформации, как внешнего аудита, так и всей системы государственного аудита.

Целью научной статьи является анализ основных результатов государственного аудита в Республике Казахстан и предложение рекомендаций по дальнейшей цифровой трансформации органов внешнего государственного аудита.

Для достижения поставленной цели в статье были использованы следующие методы исследования: системный и формально-логический подходы, методы теорети- ческого, статистического, информационнокоммуникационного и экономического моделирования, а также графического анализа.

Обзор литературы. Проблемы государственного аудита нашли свое отражение в значительном числе научных исследований как отечественных, так и зарубежных ученых. Прежде всего необходимо отметить фундаментальные работы А.Б. Зейнельгабдина [2] в области исследования системы внешнего государственного аудита. Большой вклад в развитие теории и практики государственного аудита внесли Ш.У. Ниязбековой [3], Л.М. Сембиевой [4], Л.3. Бейсеновой [5], Б.А. Алибековой и др. Труды ученых заложили основу для разработки современной теории и методологии внешнего государственного аудита, получившего развитие благодаря работам А.О. Бурякова, А.В. Варнавского [6], В.Г. Панкова, С.Н. Рябухина и многих других ученых. Среди зарубежных исследований в области государственного аудита следует выделить работы Р.Адамса, Д.Ирвина, Э.Аренса и Дж. Лоббека.

Несмотря на то, что государственный аудит и финансовый контроль широко исследован в казахстанской научной литературе, фундаментальные труды в области цифровизации внешнего государственного аудита немногочисленны.

Неизученными остаются вопросы, связанные с автоматизацией и цифровизацией государственного аудита и финансового контроля, а также механизмов трансформации органов государственного аудита. Практически не исследовались возможности использования инновационных технологий для обработки и анализа информации с целью уменьшения рисков, связанных с человеческим фактором в процессе проведения государственного аудита.

Основная часть. Становлению государственного аудита в Республике Казахстан послужило Послание Президента РК народу Казахстана от 14 декабря 2012 года 
Қаржы жжәне есеп / Финансы и учет

«Стратегия «Казахстан-2050»: новый политический курс состоявшегося государства». В Послании было отмечено, что необходимо создание комплексной системы государственного аудита на основе самого передового мирового опыта [7].

На основании Концепции внедрения государственного аудита, в 2015 году был принят Закон Республики Казахстан от 12 ноября 2015 года «О государственном аудите и финансовом контроле», согласно которого целью государственного аудита является повышение эффективности управления и использования бюджетных средств, активов государства и субъектов квазигосударственного сектора [8].

Этапы становления и развития государственного аудита в Республике Казахстан отражены в рисунке 1 .

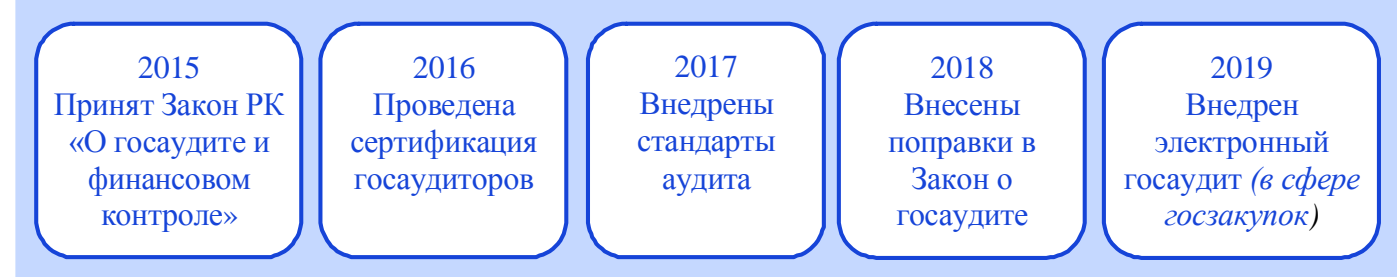

Рисунок 1. Этапы развития государственного аудита в РК

Основными результатами трансформации государственного аудита за 20152019 годы стали (табл. 1, рис. 2):

- переход на камеральные проверки, благодаря которому удалось снизить нагрузку на объекты аудита, сократить затраты на проведение проверок, а также обеспечить охват и уменьшить удельный вес нарушений с 38 до $2 \%$;

- использование отбора по Системе управления рисками привело к увеличению выявляемости нарушений почти в 2 раза с $30 \%$ в 2015 году до 55\% в 2019 году;

- вместо комплексных проверок акцент смещен на точечный аудит сомнительных платежей и процедур, в результате которого в 6,5 раз уменьшились плановые проверки с 3268 в 2015 году до 500 в 2019 году;

- длительность проверок сократилась с 30 дней до 1-9 дней;

- сумма возмещений в бюджет выросли в 4 раза с 2,7 млрд тенге в 2015 году до 10,4 млрд тенге в 2019 году;

- недопущено искажений консолидированной финансовой отчетности АРБП на сумму 1 трлн тенге (всего охвачено 10,8 трлн тенге);

- внедрен электронный аудит госзакупок [9]. 


\section{Трансформация государственного аудита с использованием информационных систем, в том числе СУР*}

\begin{tabular}{|l|l|}
\hline \multicolumn{1}{|c|}{$\begin{array}{c}\text { Государственный финансовый } \\
\text { контроль }\end{array}$} & \multicolumn{1}{c|}{\begin{tabular}{c}
\multicolumn{1}{c|}{ Государственный } \\
аудит
\end{tabular}} \\
\hline $\begin{array}{l}\text { Проверки по периодичности } \\
1 \text { раз в 2 года }\end{array}$ & $\begin{array}{l}\text { Формирование Перечня объектов проверки } \\
\text { по СУР }\end{array}$ \\
\hline Длительность проверки -30 дней & Длительность проверки - от 1 до 9 дней \\
\hline Комплексная проверка & $\begin{array}{l}\text { Точечный охват вопросов (по конкретному } \\
\text { договору и платежу) }\end{array}$ \\
\hline
\end{tabular}

*Составлена авторами по данным Министерства финансов Республики Казахстан

Кол-во проверок (өо.)

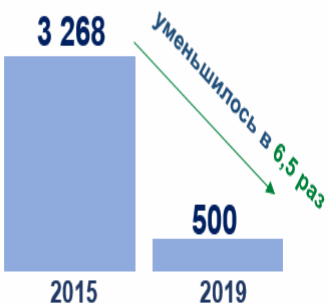

Снижена

административная нагрузка
Выявляемость (\%)

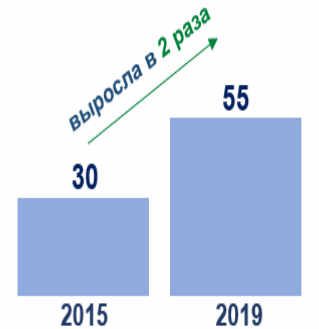

Повысилась

эффективность проверок
Сумма возмещения (мпро.та)

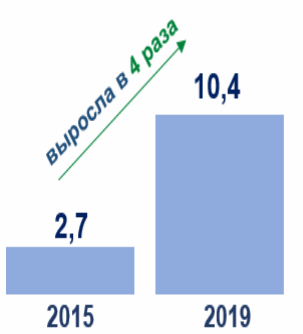

Увеличилось возмещение в бюджет

Рисунок 2. Основные результаты трансформации государственного аудита за 2015-2019 гг.*

*Данные Министерства финансов Республики Казахстан

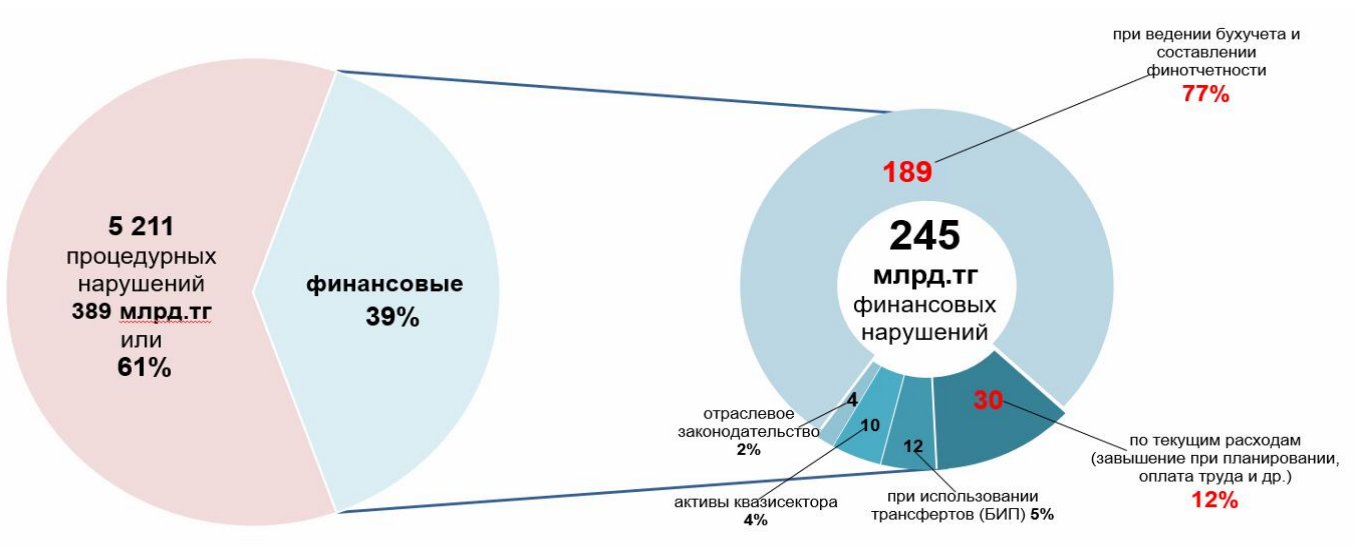

Рисунок 3. Структура выявленных нарушений за 2019 г.*

*Данные Министерства финансов Республики Казахстан 
Стоит отметить, что по принятым поправкам НПА в сфере государственного аудита нарушения были разделены на финансовые и процедурные, финансовые выражаются в суммовом значении, а процедурные в количественном. Так, в 2019 году установлено 634 млрд тенге нарушений, из них финансовых на сумму 245 млрд тенге или $39 \%$, процедурных - 5211 на сумму 389 млрд тенге, или 69\%. Основная доля выявленных финансовых нарушений приходится на бухучет и текущие расходы (рис. 3) [10].

Что касается государственных закупок,

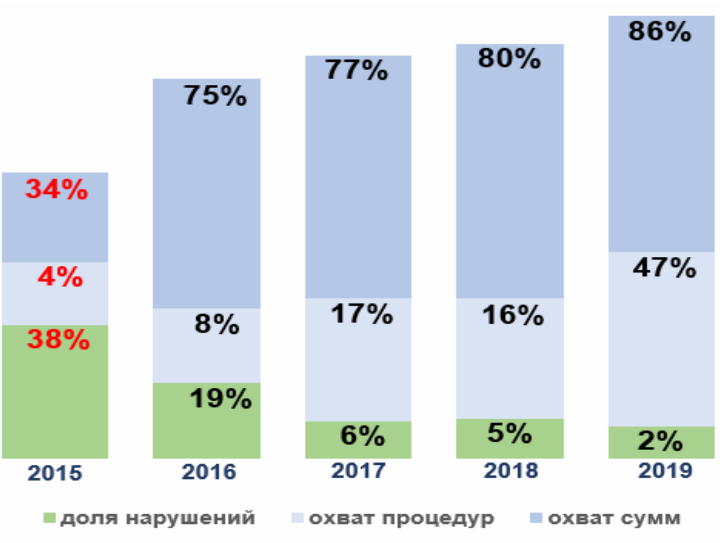

Рисунок 4. Результаты аудита госзакупок за 2015-2019 гг.* то благодаря СУР охват государственных закупок в суммовом выражении в 2019 году составила $86 \%$, а в количественном $-47 \%$. Автоматизация камерального контроля увеличила охват госзакупок в 12 раз с $4 \%$ в 2015 году до 47\% в 2019 году, а также повысила грамотность организаторов госзакупок, сократив удельный вес нарушений с 38 до $2 \%$. С развитием дистанционных методов проверок нарушения по госзакупкам снизились в 765 раз с 232,8 млрд тенге в 2015 году до 0,3 млрд тенге в 2019 году (рис.4, 5) [10].

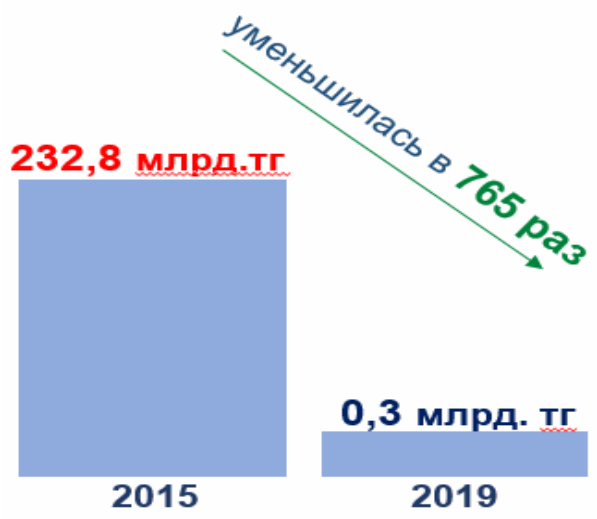

Рисунок 5. Сумма нарушений госзакупок за 2015-2019 гг.*

*Данные Министерства финансов Республики Казахстан

По данным Министерства финансов РК, одним из главных достижений цифровой трансформации государственного аудита стало сокращение коррупционных рисков, основной причиной которых являлся контакт аудиторов с объектом. Ввиду развития дистанционных проверок государственные аудиторы стали меньше контактировать с объектом проверки. Так, если в 2015 году на проведение 6168 проверок было затрачено 139 тыс. ревизоро-дней или $100 \%$ от всей деятельности, то в 2019 году - 92,7 тыс. ревизоро-дней, из них на аудит 41 тыс. ревизоро-дней для проведения 3451 проверок, остальные ресурсы были направлены на дистанционные про244 верки через ИС.

Несмотря на положительные результаты проделанных работ в сфере цифровизации государственного аудита, для успешной автоматизации и цифровизации государственного аудита этих мер недостаточно. В связи с этим, в целях дальнейшей цифровизации государственного аудита необходима интеграция органов внешнего госаудита с базами данных других государственных органов, что повлечет минимизацию коррупциогенности. То есть необходимо увеличить ресурсы, затраченные на дистанционные проверки, до $80 \%$, и только $20 \%$ на предполагаемые риски - инвентаризация, контрольный осмотр и др. [9]. 

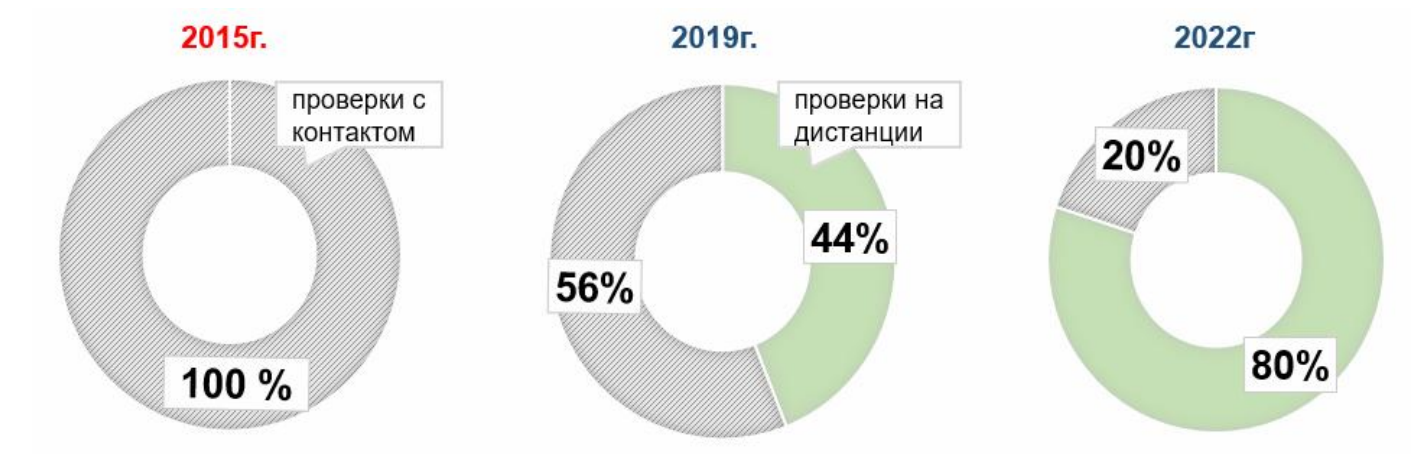

Рисунок 6. Перспективы цифровой трансформации государственного аудита посредством интеграции базы данных государственных органов РК*

\section{*Данные Министерства финансов Республики Казахстан}

На сегодняшний день Счетный комитет РК, как высший орган внешнего государственного аудита, обладает достаточно высоким уровнем информатизации, однако в его деятельности присутствует ряд нерешенных проблем. Так, Счетный комитет имеет доступ к большому количеству информационных систем, данные из которых во многом обрабатываются вручную, что обусловлено низким качеством данных, отсутствием инструментов, недостаточной технологической квалификацией персонала [10]. В связи с этим, перед Счетным комитетом встает необходимость решения следующих задач: дальнейшее снижение трудоемкости традиционного аудита, повышение объективности выводов и системности анализа. Для этого необходимо повысить качество данных, внедрить инструменты визуальной аналитики и математической обработки данных, приглашать опытных аналитиков данных и одновременно «выращивать» свои кадры.

Вместе с тем, все государственные аудиторы в будущем должны также стать «цифровыми», т.е. все операции должны производиться с помощью автоматизированного рабочего места, что помимо удобства позволяет обеспечить защищенное подключение и дает доступ к большим вычислительным мощностям [6].
Как уже было показано по результатам 2015-2019 годов, цифровизация позволит значительно сократить время на проведение проверки за счет работы только с подозрительными операциями (СУР, точечные проверки) и автоматического выявления типовых нарушений. У каждого объекта проверки появится «цифровой двойник», данные по нему будут накапливаться и использоваться в дальнейшей работе органов государственного аудита.

Таким образом, цифровая трансформация органов внешнего государственного аудита, в частности Счетного комитета РК, должна быть направлена на три ключевых аспекта:

1) автоматизация операционных процессов органов государственного аудита;

2) оценка перспектив использования инновационных технологий обработки и анализа информации;

3) интеграция ИС органов государственного аудита как между собой, так и базами данных других государственных органов с целью получения достоверных сведений о совершаемых операциях объектов государственного аудита в режиме реального времени.

Вышеизложенные предложения в перспективе должны привести к:

- сокращению временных и трудовых 
Қаржы жжәне есеп / Финансы и учет

затрат на проведение аудиторских и экспертно-аналитических мероприятий органов государственного аудита;

- повышению качества и объективности выводов, сделанных по результатам проверок.

Заключение. В современных реалиях ускоренное развитие цифровых и информационных технологий требуют дальнейшей трансформации деятельности органов государственного аудита: сокращении временных и трудовых затрат на проведение аудиторских и экспертно-аналитических мероприятий за счет сокращения числа рутинных операций, формированию автоматизированных алгоритмов выявления нарушений. Однако проведенное исследование информатизации органов государственного аудита, в частности Счетного комитета РК, позволило сделать вывод о наличии множества еще не решенных проблем: большой объем информаций, по сей день обрабатываемых вручную, низкое качество накоп- ленных данных, существенная часть которых является устаревшей и нуждается в пояснениях, недостаточная технологическая квалификация кадров.

Таким образом, предложенные в статье рекомендации позволят обеспечить, вопервых, необходимый уровень защиты от внесения изменений и фальсификаций данных, предоставляемых объектами проверки, во-вторых, прозрачность данных, накапливаемых органами государственного аудита.

Более того, основным преимуществом интеграции информационной системы Счетного комитета с базами данных государственных органов будет являться многократное повышение скорости обмена информацией, обеспечение их достоверности, неизменности и сопоставимости, возможность дальнейшего автоматизированного анализа, построение эффективной системы взаимодействия с органами государственного аудита, объектами государственного аудита и другими внешними пользователями.

\section{ЛИТЕРАТУРА}

1. Постановление Правительства РК от 12 декабря 2017 года №827 «Об утверждении Государственной программы «Цифровой Казахстан»». Режим доступа: http://adilet.zan.kz/ rus/docs/P1700000827

2. Зейнельгабдин А.Б. Государственный аудит как инструмент управления экономикой // Государственный аудит. - 2013. - №6. - С. 18-20.

3. Назаренко О.В., Ниязбекова Ш.У. Организация финансов государственных учреждений в условиях реформирования // Экономика города в период структурных преобразований: теория, методология, практика. - 2017. - С. 585-593.

4. Sembiyeva L.M., Beisenova L.Z. Details of performance audit organization in the Republic of Kazakhstan // Известия национальной академии наук Республики Казахстан. - 2019 (2). - C. 246-252.

5. Бейсенова Л.3., Алибекова Б.А., Шахарова А.Е. Организация и проведение оценки эффективности деятельности государственных органов // Вестник КАРГУ. - 2019. - № 1(93). - С. 63-67.

6. Бурякова А.О., Варнавский А.В. Цифровизация деятельности Счетной палаты Российской Федерации // Управленческие науки. - 2019. - № 9(4). - С. 38-43.

7. Стратегия «Казахстан-2050»: новый политический курс состоявшегося государства. Послание Президента Республики Казахстан - Лидера нации Н.А. Назарбаева народу Казахстана. - Астана, 2012. 14 дек. Режим доступа: http://adilet.zan.kz/rus/docs/K1200002050 
8. Закон РК от 12 ноября 2015 года № 392-V ЗРК «О государственном аудите и финансовом контроле». Режим доступа: http://adilet.zan.kz/rus/docs/Z1500000392

9. Официальный интернет-ресурс Министерства финансов Республики Казахстан. www.minfin.gov.kz

10. Официальный интернет-ресурс Счетного комитета по контролю за использованием республиканского бюджета Республики Казахстан. www.esep.kz

\section{REFERENCES}

1. Postanovlenie Pravitel’stva RK ot 12 dekabrya 2017 goda № 827 «Ob utverzhdenii Gosudarstvennoj programmy «Cifrovoj Kazahstan» [Resolution of the Government of the Republic of Kazakhstan dated December 12, 2017 № 827 «On approval of the state program «Digital Kazakhstan». Available at: http://adilet.zan.kz/rus/docs/P1700000827 [in Russian].

2. Zeinelgabdin A.B. Gosudarstvennyj audit kak instrument upravleniya ekonomikoj [State audit as a tool of economic management] // Gosudarstvennyj audit [Public audit] . - 2013. - № 6. S. 18-20 [in Russian].

3. Nazarenko O.V., Niyazbekova Sh.U. Organizaciya finansov gosudarstvennyh uchrezhdenij v usloviyah reformirovaniya [Organization of Finance of state institutions in the conditions of reform] // Ekonomika goroda v period strukturnyh preobrazovanij: teoriya, metodologiya, praktika [City economy in the period of structural transformations: theory, methodology, practice]. - 2017. - S. 585-593 [in Russian].

4. Sembiyeva L.M., Beisenova L.Z. Details of performance audit organization in the Republic of Kazakhstan // Izvestiya nacional'noj akademii nauk Respubliki Kazahstan [Proceedings of the national Academy of Sciences of the Republic of Kazakhstan]. - 2019 (2). - S. 246-252.

5. Beisenova L.Z., Alibekova B.A., Shakharova A.E. Organizaciya i provedenie ocenki effektivnosti deyatel'nosti gosudarstvennyh organov [Organization and conduct of performance evaluation of state bodies] // Vestnik KARGU [Bulletin of the KARGU]. - 2019. - № 1(93). - S. 63-67. ISSN: 2518-1998 [in Russian].

6. BuryakovaA.O., Varnavsky A.V. Cifrovizaciya deyatel'nosti Schetnoj palaty Rossijskoj Federacii // Upravlencheskie nauki [Digitalization of the accounts chamber of the Russian Federation] // Upravlencheskie nauki [Management science]. - 2019. - № 9(4). - S. 38-43 [in Russian].

7. Strategiya «Kazahstan-2050»: novyj politicheskij kurs sostoyavshegosya gosudarstva. Poslanie Prezidenta Respubliki Kazahstan - Lidera nacii N.A. Nazarbaeva narodu Kazahstana [Strategy «Kazakhstan-2050: a new political course of the established state». Message of the President of the Republic of Kazakhstan - Leader of the nation N.A. Nazarbayev to the people of Kazakhstan]. Nur-Sultan, 2012. Available at: http://adilet.zan.kz/rus/docs/K1200002050 [in Russian].

8. Zakon Respubliki Kazahstan ot 12 noyabrya 2015 goda № 392-V ZRK «O gosudarstvennom audite i finansovom kontrole» [Law of the Republic of Kazakhstan №392-V of November 12, 2015 «On state audit and financial control». Available at: http://adilet.zan.kz/rus/docs/Z1500000392 [in Russian].

9. Official Internet resource of the Ministry of Finance of the Republic of Kazakhstan. www.minfin.gov.kz

10. Official Internet resource of the Accounting Committee for control over the use of the Republican budget of the Republic of Kazakhstan. www.esep.kz 
Каржы жеәне есеп / Финансы и учет

\author{
Б.А. Абжалова, А.Е. Шахарова \\ КАЗАҚСТАН РЕСПУБЛИКАСЫНЫН СЫРТКЫ МЕМЛЕКЕТТІК \\ АУДИТІН ЦИФРЛЫҚ ТРАНСФОРМАЦИЯЛАУ
}

Аңдатпа

Мақалада Қазақстан Республикасындағы сыртқы мемлекеттік аудит органдарын ақпараттандырудың негізгі аспектілері қарастырылады, олар жеткілікті жоғары деңгейде деп бағаланады. Қабылданатын шешімдердің жеделдігі мен дәлдігін қамтамасыз ету мақсатында тұрақты талдауға жататын ақпараттың үлкен көлеміне байланысты тиімді мемлекеттік аудит цифрлық технологияларға негізделген жоғары тиімді басқару нақты жүйесіз өмір сүре алмайды және дами алмайды. Мақалада 2015-2019 жылдардағы мемлекеттік аудитті трансформациялаудың негізгі нәтижелері талданады және қазіргі заманғы цифрлық технологияларды пайдалану негізінде сыртқы мемлекеттік аудит органдарының қызметін жетілдірудің негізгі бағыттары айқындалады. Мемлекеттік аудит органдарын, атап айтқанда Қазақстан Республикасының Есеп комитетін ақпараттандыру, автоматтандыру саласындағы көптеген өзекті мәселелерді шешу жолдары ұсынылған. Аудиторлық қызметті одан әрі цифрлық трансформациялау үшін қолданыстағы ақпараттық жүйенің тиімділігін арттыру, сондай-ақ мемлекеттік органдардың деректер базасын интеграциялау есебінен сапалы жаңа Бірыңғай жүйелі цифрлық транзакциялық орта құру ұсынылады.

\title{
B. Abzhalova, A. Shakharova \\ DIGITAL TRANSFORMATION OF THE EXTERNAL STATE AUDIT OF THE REPUBLIC OF KAZAKHSTAN
}

\section{Annotation}

The article discusses the key aspects of informatization of external state audit bodies in the Republic of Kazakhstan, which are assessed as being at a fairly high level. Due to the huge amount of information that is subject to constant analysis in order to ensure the efficiency and accuracy of decisions made, an effective state audit cannot exist and develop without a highly effective management system based on digital technologies. The article analyzes the main results of the transformation of state audit for 20152019 and identifies the main directions for improving the activities of external state audit bodies based on the use of modern digital technologies. The author also draws conclusions and suggests ways to solve many problems in the field of informatization of state audit bodies, in particular the Accounts Committee of the Republic of Kazakhstan. For further digital transformation of audit activities, it is proposed to increase the efficiency of the existing information system, as well as to create a qualitatively new unified digital transaction environment by integrating the database of state bodies. 


\author{
G. Amirova*, PhD student \\ L.N. Gumilyov Eurasian National University \\ Nur-Sultan c. \\ e-mail: gulnur8383@mail.ru \\ * - main author (author for correspondence)
}

\title{
ORGANIZATIONAL AND FINANCIAL ASPECTS OF THE SCIENTIFIC SPHERE DEVELOPMENT IN KAZAKHSTAN
}

This paper analyzed the state and trends in science, identifies positive and negative factors affecting the development of Kazakhstani science, identifies priority directions for its development. The article revealed the scientific potential of Kazakhstan in terms of the following indicators: the number of organizations performing $R \& D$; the number personnel involved in the implementation of $R \& D$; the internal $R \& D$ expenditures. Significant factors limiting innovation in Kazakhstan are low scientific potential: lack of competent staff; lack of internal $R \& D$ expenditures. It revealed that in Kazakhstan with the existing system of financing science, there is no opportunity to increase the Research and Development $(R \& D)$ expenses. The results allowed concluding that it is necessary to strengthen the relationship between the science and real sector, commercialization of the scientific activities' results on the basis of the public-private partnerships.

Keywords: science, scientific sphere, higher education, entrepreneurship, $R \& D$, innovation, innovative activity, innovative personnel, $R \& D$ expenses, science and business.

Кілт сөздер: вылым, вылыми сала, жовары білім, кәсіпкерлік, ҒЗТКЖ, инновачия, инновачиялық қыззмет, инновачиялық кадрлар, ҒЗТКЖ-ва арналган шывындар, вылылм және бизнес.

Ключевые слова: наука, научная сфера, высшее образование, предпринимательство, НИОКР, инновачия, инноваџионная деятельность, инновачионные кадры, затраты на НИОКР, наука и бизнес.

JEL classification: 0 31, 033

Introduction. Implementation of the most important Kazakhstani strategic documents, such as the Kazakhstan-2050, the 100 concrete steps to implement the 5 Institutional Reforms, the Third Modernization of Kazakhstan and the Moder-nization of Public Consciousness, Entry the club of top 30 most developed countries of the world, accelerated and high-quality economic growth, innovative and high-tech development requires:

- mobilization of the country's research potential and international research implementation;

- support the research system and technological modernization.

In this regard, an urgent task is to analyze the state and trends in science, identifies positive and negative factors affecting the development of

Kazakhstani science, identifies priority directions for its development.

The objectives of the article:

- analysis of scientific potential;

- analysis the financing of $R \& D$;

- conclusions and recommendations for scientific sphere further development.

Brief literature review. In Kazakhstan, the enterprises' research and innovation activities remain very low. So, according to many researchers [1-3], innovation has not a positive and significant effect on entrepreneurship development.

Kazakhstan's economy is characterized by unstable dynamics and is still mainly focused on the extractive industries, which does not allow for a transition to a new qualitative level of development, increasing competitiveness and positive 
Қаржы жнәне есеп / Финансы и учет

structural changes [4].

According to many researchers [5-6], at any link in the science-production cycle, various obstacles may arise that inhibit the innovation process or reduce the effectiveness of innovation.

These include: and research orders;

- monopolies in science and industry;

- unhealthy competition in the markets for scientific products, investment and consumer goods.

According to scientists [7-9], education and science are the main factors of the economy. The articles of famous scientists [10-12] emphasize

*Compiled according to the Bureau of National Statistics that without a corresponding higher education and modern research institutions, with qualified and educated people, no country is able to ensure real sustainable economic development.

Thus, it is necessary to clearly define innovative goals, create institutional conditions, and mobilize the scientific potential for the transition to a new type of development.

Main part. Let's analyze the main factors in the scientific sphere development in Kazakhstan.

According to the Bureau of National Statistics, 386 organizations were engaged in R\&D in 2019, which is 41 units more than in 2012 (345 organizations) (table 1).

Table 1

\section{The total number of organizations performing $R \& D$ by sector of activity, 2012-2019, units*}

\begin{tabular}{|c|c|c|c|c|c|c|c|c|c|}
\hline \multirow{2}{*}{$\begin{array}{l}\text { Organization, } \\
\text { sector }\end{array}$} & \multicolumn{8}{|c|}{ Years } & \multirow{2}{*}{$\begin{array}{l}\text { Modifica- } \\
\text { tion } 2019 \\
2012(+/-)\end{array}$} \\
\hline & 2012 & 2013 & 2014 & 2015 & 2016 & 2017 & 2018 & 2019 & \\
\hline Entrepreneurship & 105 & 110 & 149 & 154 & 149 & 146 & 149 & 158 & 53 \\
\hline Higher education & 121 & 112 & 105 & 103 & 103 & 99 & 95 & 92 & -29 \\
\hline Government & 69 & 78 & 101 & 94 & 100 & 101 & 103 & 100 & 31 \\
\hline Non-profit & 50 & 41 & 37 & 39 & 31 & 40 & 37 & 36 & -14 \\
\hline Total & 345 & 341 & 392 & 390 & 383 & 386 & 384 & 386 & 41 \\
\hline
\end{tabular}

Despite the fact that the scientific organizations network is undergoing intensive development in Nur-Sultan city, Almaty city continues to be the leader in science and innovation in Kazakhstan. 138 organizations were engaged in R\&D in Almaty in 2019 or $36 \%$ of all research organizations in Kazakhstan.

In table 1 the data also indicate that $41 \%$ of the total number of organizations belonged to the entrepreneurial (business) sector in 2019, which includes production/sale enterprises of goods or services.

The number of organizations in the entrepreneurship sector increased by 53 units in 2019 compared to 2012.

The higher education sector is the second largest number of scientific organizations. The higher education sector includes higher education institutions, regardless of the legal status, sources of their financing, associated with them or experimental stations and clinics, research institutes that are under their control. 92 units in higher education sector were engaged in $R \& D$ in 2019. The number of organizations in the higher education sector decreased by 29 units compared to 2012.

The Government sector is represented by ministries that ensure the satisfaction of the society' and public administration needs. Non-profit organizations, mainly or fully financed and controlled by the State, are also included in this sector. The number of organizations in Govern- 
ment sector has an extensive network of R\&D. Their number of units in this sector is not stable and varies from year to year. So, in 2019, Research and Development was carried out by 100 units. This is 31 units more than in 2012.

Non-profit sector is the smallest number of organizations performing R\&D in 2019. Nonprofit sector includes organizations that do not aim at making a profit (foundations, professional societies, public organizations, etc.). Their number was 36 units in 2019.

Thus, in 2019 compared to 2012 the reduction of organizations occurred in the non-profit sector and in the higher education sector, by 14 and 29 units, respectively.

The number of organizations performing research in the higher education sector reached a minimum in 2019, decreasing to 29 units compared to 2012.

In 201921843 people were involved in $\mathrm{R} \& \mathrm{D}$, including 14124 research experts (table 2).

Table 2

Personnel involved in the implementation of R\&D, 2012-2019, (people)*

\begin{tabular}{|c|c|c|c|c|c|c|c|c|c|}
\hline \multirow[b]{2}{*}{ Name } & \multicolumn{8}{|c|}{ Years } & \multirow{2}{*}{$\begin{array}{c}\text { Modifi- } \\
\text { cation } \\
2019 / 2012 \\
(+/-)\end{array}$} \\
\hline & 2012 & 2013 & 2014 & 2015 & 2016 & 2017 & 2018 & 2019 & \\
\hline Researchers & 13494 & 17195 & 18930 & 18454 & 17421 & 17205 & 17454 & 14124 & 630 \\
\hline Technicians & 4731 & 3586 & 3882 & 3692 & 3326 & 2797 & 2836 & 2734 & -1997 \\
\hline Other & 2179 & 2931 & 2981 & 2589 & 2238 & 2079 & 2088 & 1985 & -194 \\
\hline Total & 20404 & 23712 & 25793 & 24735 & 22985 & 22081 & 22378 & 21843 & 1439 \\
\hline
\end{tabular}

*Compiled according to the Bureau of National Statistics

We can see from the data in table 2 that from 2012-2014 the dynamics of the personnel number engaged in R\&D is positive. However, since 2015 the science sphere in Kazakhstan has suffered a radical reduction in staff amid increased crisis phenomena in the economy and, as a result, a reduction in the level of wages. Organizations involved in technical testing, engineering surveys and architectural bureaus were most affected. Also, it should be noted that the decrease in personnel in the science sphere follows the decrease in the contribution of the industry to economic growth.

So, next we examine in more detail the problem of organizing the financing of $R \& D$ carried out from the state budget and the private sector (table 3).

Table 3

Internal R\&D expenditures by main sources of financing, 2012-2019, (mln tenge)*

\begin{tabular}{|c|c|c|c|c|c|c|c|c|c|}
\hline \multirow{2}{*}{ Name } & \multicolumn{8}{|c|}{ Years } & \multirow{2}{*}{$\begin{array}{l}\text { Modifica- } \\
\text { tion 2019/ } \\
2012(+/-)\end{array}$} \\
\hline & 2012 & 2013 & 2014 & 2015 & 2016 & 2017 & 2018 & 2019 & \\
\hline State $b$ & 30712 & 39273 & 43343 & 40719 & 35440 & 35979 & 32145 & $35 c$ & 5254 \\
\hline Own funds & 14073 & 17836 & 19858 & 25356 & 26338 & 28187 & 34251 & 37710 & 23637 \\
\hline Other financing & 3467 & 4563 & 3145 & 3227 & 4770 & 4717 & 5827 & 4568 & 1101 \\
\hline Total & 51253 & 61672 & 66347 & 69302 & 66600 & 68884 & 72224 & 82333 & 31080 \\
\hline
\end{tabular}

*Compiled according to the Bureau of National Statistics 
Қаржы жнәне есеп / Финансы и учет

In table 3 we can see than more than half of all internal $R \& D$ expenditures are covered from the State budget.

So, the internal R\&D expenditures in 2019 amounted to 82333 million tenge, of which:

-37 710 million tenge - own funds;

- 35966 million tenge - total budget funds;

-4568 million tenge - other financing.

The volume of budgetary funds in all internal R\&D expenditures in 2019 compared to 2012 increased by 31080 million tenge.

The reduction of budgetary funds in financing $R \& D$ since 2015 has forced organizations to use their own funds more actively. As a result, the share of financing from own sources in 2019 compared to 2012 increased by 23637 million tenge. In addition, a decrease in government spending on Research and Development forced organizations engaged to look for other sources of funding, such as loans, the share of which increased by 1101 million tenge in 2019 compared to 2012.

Among the main sources of funding science sphere there are almost no business representatives. According to the OECD for US and EU companies the share of the real sector in total Research and Development expenses at the level of $60-65 \%$ is optimal. And at the same time, financing of R\&D in many developed and developing countries at the level of $60-75 \%$ is carried out precisely by the entrepreneurial sector of the national economy.

Thus, an analysis of R\&D expenses indicates that with the existing system in financing science sphere in Kazakhstan there is no opportunity to increase the expenditures on R\&D.

The main consumer of $R \& D$ is the manufacturing sector, which has been reducing its activity recently. This affects negatively in production.

Table 4 presents data on internal R\&D expenditures by types.

Table 4

Internal R\&D expenditures by types, 2012-2019, (mln tenge)*

\begin{tabular}{|l|c|c|c|c|c|c|c|c|c|}
\hline \multirow{1}{*}{ Name } & \multicolumn{7}{|c|}{ Years } & $\begin{array}{c}\text { Modifica- } \\
\text { tion 2019/ } \\
2012(+/-)\end{array}$ \\
\cline { 2 - 10 } & 2012 & 2013 & 2014 & 2015 & 2016 & 2017 & 2018 & 2019 \\
\hline $\begin{array}{l}\text { Internal R\&D } \\
\text { expenditures, } \\
\text { total }\end{array}$ & 51253 & 61672 & 66347 & 69302 & 66600 & 68884 & 72224 & 82333 & 31080 \\
\hline $\begin{array}{l}\text { Fundamental } \\
\text { research }\end{array}$ & 12063 & 18197 & 15260 & 15838 & 13809 & 10785 & 10629 & 11044 & -1019 \\
\hline $\begin{array}{l}\text { Applied } \\
\text { research }\end{array}$ & 28898 & 33369 & 38394 & 36959 & 35841 & 40909 & 43278 & 52620 & 23722 \\
\hline $\begin{array}{l}\text { Experimental } \\
\text { development }\end{array}$ & 10291 & 10106 & 12692 & 16505 & 16949 & 17188 & 18317 & 18666 & 8375 \\
\hline
\end{tabular}

*Compiled according to the Bureau of National Statistics

The data in table 4 show that the overall reduction in internal $R \& D$ expenditures most negatively affected the funding of fundamental research. In 2019 their volume decreased by 1 019 million tenge compared to 2012. In this period, the applied research expenditures increased by 23722 million tenge. It should also be noted that the amount of Experimental development expenditures in 2019 compared to 2012 increased by 8375 million tenge.

Conclusion. The science is an essential part of the national heritage, a fundamental resource for the country's economic and social transformations. The country's science and scientific potential largely determine its place in the global community, in solving internal problems. 
Significant factors limiting innovation in Kazakhstan are low scientific potential:

- lack of competent staff;

- lack of internal R\&D expenditures.

Since 2015, the scientific sphere in Kazakhstan has been undergoing a radical reduction in staff amid growing crisis in the economy and, as a result, a reduction in the level of wages.

Among the main sources of funding for science there are almost no business representatives. According to the OECD, at present, for US and EU companies, the share of the real sector in total Research and Development expenses at the level of $60-65 \%$ is optimal. Financing of research in many developed countries of the world at present at the level of $60-75 \%$ is carried out precisely by the entrepreneurial sector.

An analysis of R\&D expenses indicates that with the existing system in financing science sphere in Kazakhstan there is no opportunity to increase the expenditures on $R \& D$. In addition, the main consumer of $\mathrm{R} \& \mathrm{D}$ is the manufacturing sector, which has been reducing its activity recently. This affects negatively in production.

In this situation, we believe that it is necessary to strengthen the relationship between the science and real sector, commercialization of the scientific activities' results on the basis of the public-private partnerships.

\section{REFERENCES}

1. Smirnova Y.V. (2016). University - industry knowledge transfer in an emerging economy: Evidence from Kazakhstan // Science and Public Policy. - № 43 (5). - P. 702-712.

2. Kireyeva A.A., Mussabalina D.S., Tolysbaev B.S. (2018). Assessment and Identification of the Possibility for Creating IT Clusters in Kazakhstan Regions // Economy of Region. - № 14(2). - P. 463-473.

3. Pukala R. (2016). Use of neural networks in risk assessment and optimization of insurance cover in innovative enterprises // Engineering Management in Production and Services. - № 8(3). P. 43-56.

4. Kurmanov N., Tolysbayev B., Aibossynova D. \& Parmanov N. (2016). Innovative activity of small and medium-sized enterprises in Kazakhstan and factors of its development // Economic Annals-XXI. - № 158 (3-4 (2)). - P. 57-60. http://dx.doi.org/10.21003/ea.V158-13

5. Kurmanov N., Aliev U. \& Suleimenov Sh. (2019). Analysis of the Efficiency of Innovation Management in the Countries of the Eurasian Economic // Polish Journal of Management Studies. № 19(1). - P. 204-214. http://dx.doi.org/10.17512/pjms. 2019.19.1.15

6. Aryn E., Amirova G. Mehanizmintegracii obrazovanija, nauki i proizvodstva s primeneniem setevogo podhoda [Mechanism of Integration ofEducation, Science and Production with the Application of the Network Approach] // Central Asia’s Affairs. - 2019. - № 2. - P. 37-47.

7. Aurik G. \& Astri G. (2018). An Analysis of Differences in Students' Entrepreneurial Competencies between the Management and Entrepreneurship Study Programmes at the School of Business and Management (SBM) Institut Teknologi Bandung (ITB) // Journal of Entrepreneurship Education. - № 21(4). - P. 1-11.

8. Centobelli P., Cerchione R. \& Esposito E. (2019). Exploration and exploitation in the development of more entrepreneurial universities: A twisting learning path model of ambidexterity // Technological Forecasting and Social Change. - № 141. - P. 172-194.

9. Etzkowitz H. (2002). MIT and the Rise of Entrepreneurial Science. - London: Routledge. - 232 p.

10. Mueller P. (2006). Exploring the knowledge filter: How entrepreneurship and university industry relationships drive economic growth // Research policy. - № 35(10). - P. 1499-1508.

11. Naushad M. (2018). A study on the antecedents of entrepreneurial intentions among Saudi 
Қаржы жнәне есеп / Финансы и учет

students // Entrepreneurship and Sustainability Issue. - № 5(3). - P. 600-617.

12. Papagiannis G.D. (2018). Entrepreneurship education programs: The contribution of courses, seminars and competitions to entrepreneurial activity decision and to entrepreneurial spirit and mindset of young people in Greece // Journal of Entrepreneurship Education. - № 21(1). - P. 1-21.

\section{ЛИТЕРАТУРА}

1. Smirnova Y.V. 2016. University - industry knowledge transfer in an emerging economy: Evidence from Kazakhstan // Science and Public Policy. - № 43 (5). - S. 702-712.

2. Kireyeva A.A., Mussabalina D.S., Tolysbaev B.S. (2018). Assessment and Identification of the Possibility for Creating IT Clusters in Kazakhstan Regions // Economy of Region. - № 14 (2). - S. 463-473.

3. Pukala R. (2016). Use of neural networks in risk assessment and optimization of insurance cover in innovative enterprises // Engineering Management in Production and Services. - № 8(3). - P. 43-56.

4. Kurmanov N., Tolysbayev B., Aibossynova D., Parmanov N. (2016). Innovative activity of small and medium-sized enterprises in Kazakhstan and factors of its development // Economic Annals-XXI. - № 158 (3-4 (2)). - S. 57-60. http://dx.doi.org/10.21003/ea.V158-13

5. Kurmanov N., Aliev U., Suleimenov Sh. (2019). Analysis of the Efficiency of Innovation Management in the Countries of the Eurasian Economic // Polish Journal of Management Studies. - № 19 (1). - S. 204-214. http://dx.doi.org/10.17512/pjms.2019.19.1.15

6. Арын Е., Амирова Г. Механизм интеграции образования, науки и производства с применением сетевого подхода // Central Asia’s Affairs. - 2019. - № 2. - C. 37-47.

7. Aurik G. \& Astri G. (2018). An Analysis of Differences in Students' Entrepreneurial Competencies between the Management and Entrepreneurship Study Programmes at the School of Business and Management (SBM) Institut Teknologi Bandung (ITB) // Journal of Entrepreneurship Education. - № 21(4). - P. 1-11.

8. Centobelli P., Cerchione R. \& Esposito E. (2019). Exploration and exploitation in the development of more entrepreneurial universities: A twisting learning path model of ambidexterity // Technological Forecasting and Social Change. - № 141. - P. 172-194.

\section{$232 \mathrm{p}$}

9. Etzkowitz H. (2002). MIT and the Rise of Entrepreneurial Science. - London: Routledge,

10. Mueller P. (2006). Exploring the knowledge filter: How entrepreneurship and university industry relationships drive economic growth // Research policy. - № 35(10). - P. 1499-1508.

11. Naushad M. (2018). A study on the antecedents of entrepreneurial intentions among Saudi students // Entrepreneurship and Sustainability Issue. - № 5(3). - P. 600-617.

12. Papagiannis G.D. (2018). Entrepreneurship education programs: The contribution of courses, seminars and competitions to entrepreneurial activity decision and to entrepreneurial spirit and mindset of young people in Greece // Journal of Entrepreneurship Education. - № 21(1). - P. 1-21. 


\title{
Г.К. Амирова
}

\section{ҚАЗАҚСТАННЫН ҒЫЛЫМИ САЛАСЫН ДАМЫТУДЫН ҰЙЫМДАСТЫРУШЫЛЫҚ ЖӘНЕ ҚАРЖЫЛЫҚ АСПЕКТІЛЕРІ}

\begin{abstract}
Андатпа
Мақалада ғылым саласының қазіргі жағдайы мен негізгі тенденцияларына талдау жасалып, қазақстандық ғылым мен инновациялық салаға әсер ететін оң және теріс факторларды анықтау қарастырылған. Еліміздің ғылыми саласын одан әрі дамыту үшін ұсыныстар ұсынылды. Мақалада Қазақстанның ғылыми әлеуеті келесі көрсеткіштер бойынша қарастырылады: ғылыми ұйымдардың саны, ғылыми кадрлардың саны, ҒЗТКЖ қаржыландыру көлемі мен көздері. Зерттеу нәтижелері бойынша Қазақстандағы инновацияларды шектейтін факторлар анықталды: құзыретті персоналдың жетіспеушілігі және ҒЗТКЖ-ға жұмсалатын шығындардың төмен деңгейі. Қазақстанда ғылым мен зерттеулерді қаржыландырудың қолданыстағы жүйесі кезінде ғылыми-зерттеу және тәжірибелік-конструкторлық жұмыстарды орындауға арналған шығындарды ұлғайту мүмкіндігі жоқ екені анықталды. Алынған нәтижелер қазіргі жағдайда ғылым мен экономиканың нақты секторымен өзара байланысын күшейту, мемлекеттік-жеке меншік әріптестік негізінде ғылыми қызмет нәтижелерін коммерцияландыру қажет деген қорытынды жасауға мүмкіндік берді.
\end{abstract}

\section{Г.К. Амирова}

\section{ОРГАНИЗАЦИОННЫЕ И ФИНАНСОВЫЕ АСПЕКТЫ РАЗВИТИЯ НАУЧНОЙ СФЕРЫ КАЗАХСТАНА}

\begin{abstract}
Аннотация
В статье проводится анализ состояния и основных тенденций в науке, выявление позитивных и негативных факторов, влияющих на казахстанскую науку и инновационную сферу. Предложены рекомендации для дальнейшего развития научной сферы страны. В статье научный потенциал Казахстана рассматривается по следующим показателям: количество научных организаций, численность научных кадров, объем и источники финансирования НИОКР. По результатам исследования определены факторы, ограничивающие инновации в Казахстане: нехватка компетентного персонала и низкий уровень расходов на НИОКР. Полученные результаты позволили сделать вывод, что в сложившейся ситуации необходимо усиление взаимосвязи науки с реальным сектором экономики, коммерциализация результатов научной деятельности на основе государственночастного партнерства.
\end{abstract}

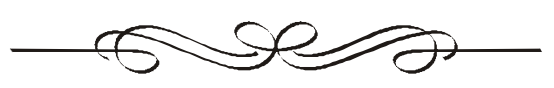


Абжалова Б.А.

Абильдина А.Ш.

Аймағамбетова А.Д.

Аймурзина Б.Т.

Айтқалиева А.М.

Акимова Б.Ж.

Алашбаева Н.М.

Алтынбеков М.А.

Амирова Г.К.

Андекина Р.Э.

Аркенова Ж.Р.

Әділова А.М.

Әлиев М.к.

Байғабұлова К.К.

Беделбаева А.E.

Бозшағұлова С.O.

Борисова Е.И.

Будешов Е.Г.

Валиева М.М.

Дуламбаева Р.T.

Елшібаев Р.К.
$\mathrm{PhD}$ докторанты, Л.Н. Гумилев атындағы Еуразия ұлттық университеті, Нұр-Сұлтан қ.

э.ғ.к., «Ғ. Дәукеев атындағы Алматы энергетика және байланыс университеті» КеАҚ, Алматы қ.

э.ғ.к., аға оқытушы, Қорқыт Ата атындағы Қызылорда университеті, Қызылорда қ.

э. ғ. д., профессор, Қазақ экономика, қаржы және халықаралық сауда университеті, Нұр-Сұлтан қ.

$\mathrm{PhD}$ докторанты, Қазақ экономика, қаржы және халықаралық сауда университеті, Нұр-Сұлтан қ.

$\mathrm{PhD}$, доцент, Л.Н. Гумилев атындағы Еуразия ұлттық университеті, Нұр-Сұлтан қ.

магистр, аға оқытушы, Қазақ экономика, қаржы және халықаралық сауда университеті, Нұр-Сұлтан қ.

$\mathrm{PhD}$, қауымдастырылған профессор, Қазақ экономика, қаржы және халықаралық сауда университеті, Нұр-Сұлтан қ. $\mathrm{PhD}$ докторанты, Л.Н. Гумилев атындағы Еуразия ұлттық университеті, Нұр-Сұлтан қ.

$\mathrm{PhD}$, доцент м.а., «Тұран-Астана» университеті, Нұр-Сұлтан қ. $\mathrm{PhD}$ докторанты, аға оқытушы, Қазтұтынуодағы Қарағанды экономикалық университеті, Қарағанды қ.

$\mathrm{PhD}$, доцент, Абылай хан атындағы Қазақ халықаралық қатынастар және әлем тілдері университеті, Алматы қ. э.ғ.д., профессор, Қазақ экономика, қаржы және халықаралық сауда университеті, Нұр-Сұлтан қ.

э.ғ.к., қауымдастырылған профессор, Л.Н. Гумилев атындағы Еуразия ұлттық университеті, Нұр-Сұлтан қ.

магистр, аға оқытушы, И. Жансүгіров атындағы Жетісу мемлекеттік университеті, Талдықорған қ.

магистр, аға оқытушы, Қазақ экономика, қаржы және халықаралық сауда университеті, Нұр-Сұлтан қ.

э.ғ.к., доцент, Қазтұтынуодағы Қарағанды экономикалық университеті, Қарағанды қ.

$\mathrm{PhD}$ докторанты, Қазтұтынуодағы Қарағанды экономикалық университеті, Қарағанды қ.

э.ғ.к., доцент, М. Қозыбаев атындағы Солтүстік Қазақстан университеті, Петропавл қ.

э.ғ.д., профессор, Қазақстан Республикасы Президентінің жанындағы Мемлекеттік басқару академиясы, Нұр-Сұлтан қ. э.ғ.к., қауымдастырылған профессор, Нархоз университеті, Алматы қ. 
Есембекова Д.Т.

Есенгельдин Б.С.

Есенгельдинова С.Ж.

Есіркепова А.M.

Есқалиева А.Ж.

Естурлиева А.И.

Жанбаев Р.А.

Жаныбаева 3.К.

Желю В.

Жуманова Б.К.

Ибрагимова Н.В.

Иғалиева Л.Н.

Имашев А.Б.

Каменова М.Ж.

Копылова О.В.

Кулубеков М.Т.

Кушебина Г.М.

Қажмұхаметова А.А.

Қазыбаева А.М.

Карабаев Э.Б.

Кұдайбергенов Н.А.

Легостаева А.А.
$\mathrm{PhD}$ докторанты, М. Қозыбаев атындағы Солтүстік Қазақстан университеті, Петропавл қ.

э.ғ.д., профессор, Қазақ экономика, қаржы және

халықаралық сауда университеті, Нұр-Сұлтан қ.

магистр, аға оқытушы, Қазақ экономика, қаржы және халықаралық сауда университеті, Нұр-Сұлтан қ.

э.ғ.д., профессор, Қазақстан Республикасы Президентінің

жанындағы Мемлекеттік басқару академиясының Шымкент қаласы бойынша филиалы

магистр, аға оқытушы, «Х. Досмухамедов атындағы Атырау университеті» АҚ ҰК, Атырау қ.

э.ғ.к., доцент, Ш. Есенов атындағы Каспий мемлекеттік технологиялар және инжиниринг университеті, Ақтау қ. э.ғ.к., «Ғ. Дәукеев атындағы Алматы энергетика және байланыс университеті» КеАҚ, Алматы қ.

э.ғ.к., доцент, Қазақ экономика, қаржы және халықаралық сауда университеті, Нұр-Сұлтан қ.

$\mathrm{PhD}$ докторы, профессор, К. Охридский атындағы София университеті, София қ., Болгария

э.ғ.к., доцент, Қазақ экономика, қаржы және халықаралық сауда университеті, Нұр-Сұлтан қ.

экономика магистрі, Қазақ экономика, қаржы және халықаралық сауда университеті, Нұр-Сұлтан қ.

магистр, аға оқытушы, «Х. Досмухамедов атындағы Атырау университеті» АҚ ҰК, Атырау қ.

$\mathrm{PhD}$, аға оқытушы, Қазақ экономика, қаржы және халықаралық сауда университеті, Нұр-Сұлтан қ.

э.ғ.Д., профессор, Қазақ экономика, қаржы және

халықаралық сауда университеті, Нұр-Сұлтан қ.

э.ғ.к., доцент, М. Қозыбаев атындағы Солтүстік Қазақстан университеті, Петропавл қ.

э.ғ.к., М. Дулатов атындағы Қостанай инженерлік-экономикалық университеті, Қостанай қ.

э.ғ.к., доцент, М. Дулатов атындағы Қостанай инженерлікэкономикалық университеті, Қостанай қ.

э.ғ.к., доцент, Қазақ экономика, қаржы және халықаралық сауда университеті, Нұр-Сұлтан қ.

$\mathrm{PhD}$, доцент, Алматы Менеджмент университеті, Алматы қ. $\mathrm{PhD}$ докторанты, Л.Н. Гумилев атындағы Еуразия ұлттық университеті, Нұр-Сұлтан қ.

э.ғ.к., доцент, Абылай хан атындағы Қазақ халықаралық қатынастар және әлем тілдері университеті, Алматы қ.

э.ғ.к., профессор, Қазтұтынуодағы Қарағанды экономикалық университеті, Қарағанды қ. 
Лұқпанова Ж.О.

Маканова А.У.

Мусина А.A.

Мухан Б.C.

Мұсатаева A.A.

Накипова Г.Е.

Несіпбаев P.E.

Ниязов М.Н.

Нурпеисова М.М.

Нурумов А.A.

Оразбаева К.Н.

Рахимбекова A.E.

Рахметова A.M.

Саду Ж.Н.

Сейдахметова Ф.С.

Смағұлов К.Е.

Смағұлова Г.С.

Темірбаева Г.Р.

Тулеметова А.С.

Тургамбаев М.К.

Тургинбаева А.H.

Турекулова Д.М. э.ғ.к., доцент, Қазақ экономика, қаржы және халықаралық сауда университеті, Нұр-Сұлтан қ.

$\mathrm{PhD}$ докторанты, Әл-Фараби атындағы Қазақ Ұлттық университеті, Алматы қ.

э.ғ.д., профессор, Қазақ экономика, қаржы және халықаралық сауда университеті, Нұр-Сұлтан қ.

$\mathrm{PhD}$ докторанты, M. Әуезов атындағы Оңтүстік Қазақстан университеті, Шымкент қ.

$\mathrm{PhD}$, доцент, Қазтұтынуодағы Қарағанды экономикалық университеті, Қарағанды қ.

э.ғ.д., профессор, ғылыми жұмыс, стратегиялық және инновациялық даму жөніндегі проректор, Қазтұтынуодағы Қарағанды экономикалық университеті, Қарағанды қ.

$\mathrm{PhD}$ докторанты, Қазтұтынуодағы Қарағанды экономикалық университеті, Қарағанды қ.

$\mathrm{PhD}$ докторанты, Қазақ экономика, қаржы және халықаралық сауда университеті, Нұр-Сұлтан қ.

э.ғ.к., профессор, «Нархоз университеті» КеАҚ, Алматы қ.

э.ғ.д., профессор, «Қаржы академиясы» АҚ, Нұр-Сұлтан қ.

т.ғ.д., профессор, Қазақ экономика, қаржы және халықаралық сауда университеті, Нұр-Сұлтан қ.

$\mathrm{PhD}$, доцент, Қазақ экономика, қаржы және халықаралық сауда университеті, Нұр-Сұлтан қ.

э.ғ.к., профессор, Қазтұтынуодағы Қарағанды экономикалық университеті, Қарағанды қ.

э.ғ.к., аға оқытушы, Қазақ экономика, қаржы және

халықаралық сауда университеті, Нұр-Сұлтан қ.

э.ғ.д., профессор, Алматы Экономика және статистика академиясы, Алматы қ.

$\mathrm{PhD}$, доцент, Әл-Фараби атындағы Қазақ ұлттық университеті, Алматы қ.

э.ғ.к., доцент, Әл-Фараби атындағы Қазақ Ұлттық

университеті, Алматы қ.

э.ғ.д., профессор, Ө.А. Байқоңыров атындағы Жезқазған университеті, Жезқазған қ.

э.ғ.к., профессор, М. Әуезов атындағы Оңтүстік Қазақстан университеті, Шымкент қ.

$\mathrm{PhD}$ докторанты, Қазтұтынуодағы Қарағанды экономикалық университеті, Қарағанды қ.

э.ғ.д., профессор, Әл-Фараби атындағы Қазақ ұлттық университеті, Алматы қ.

э.ғ.д., профессор, Қазақ экономика, қаржы және халықаралық сауда университеті, Нұр-Сұлтан қ. 
Турекулова А.Н.

Турсумбаева М.Ж.

Түсібаева Г.С.

Уахитжанова А.М.

Укубасова Г.С.

Үсенбаев Т.М.

Шайкин Д.Н.

Шаймерденова А.К.

Шалабаева А.Ж.

Шахарова А.E.
$\mathrm{PhD}$, аға оқытушы, Қазақ экономика, қаржы және халықаралық сауда университеті, Нұр-Сұлтан қ. э.ғ.к., доцент, Қазақ экономика, қаржы және халықаралық сауда университеті, Нұр-Сұлтан қ.

$\mathrm{PhD}$, қауымдастырылған профессор, Қазақ экономика, қаржы және халықаралық сауда университеті, Нұр-Сұлтан қ. аға оқытушы, «Қаржы академиясы» АҚ, Нұр-Сұлтан қ. $\mathrm{PhD}$, э.ғ.к., профессор, Қазақ экономика, қаржы және халықаралық сауда университеті, Нұр-Сұлтан қ. э.ғ.к., доцент, Қазақ экономика, қаржы және халықаралық сауда университеті, Нұр-Сұлтан қ.

э.ғ.к., профессор, М. Қозыбаев атындағы Солтүстік Қазақстан университеті, Петропавл қ.

магистр, оқытушы, Қазақ экономика, қаржы және халықаралық сауда университеті, Нұр-Сұлтан қ. $\mathrm{PhD}$ докторанты, Қазтұтынуодағы Қарағанды экономикалық университеті, Қарағанды қ.

э.ғ.к., доцент, Л.Н. Гумилев атындағы Еуразия ұлттық университеті., Нұр-Сұлтан қ. 
Абжалова Б.А.

Абильдина А.Ш.

Адилова А.М.

Аймагамбетова А.Д.

Аймурзина Б.Т.

Айткалиева А.М.

Акимова Б.Ж.

Алашбаева Н.М.

Алиев М.К.

Алтынбеков М.А.

Амирова Г.К.

Андекина Р.Э.

Аркенова Ж.Р.

Байгабулова К.К.

Беделбаева A.E.

Бозшагулова С.O.

Борисова Е.И.

Будешов Е.Г.

Валиева М.М.

Дуламбаева P.T.

Елшибаев Р.К. докторант $\mathrm{PhD}$, Евразийский национальный университет имени Л.Н. Гумилева, г. Нур-Султан

к.э.Н., НАО «Алматинский университет энергетики и связи имени Г. Даукеева», г. Алматы

$\mathrm{PhD}$, доцент, Казахский университет международных отношений и мировых языков имени Абылай хана, г. Алматы к.э.н., старший преподаватель, Кызылординский университет имени Коркыт Ата, г. Кызылорда д.э.н., профессор, Казахский университет экономики, финансов и международной торговли, г. Нур-Султан докторант $\mathrm{PhD}$, Казахский университет экономики, финансов и международной торговли, г. Нур-Султан $\mathrm{PhD}$, доцент, Евразийский национальный университет имени Л.Н. Гумилева, г. Нур-Султан магистр, старший преподаватель, Казахский университет экономики, финансов и международной торговли, г. Нур-Султан

д.э.н., профессор, Казахский университет экономики, финансов и международной торговли, г. Нур-Султан $\mathrm{PhD}$, ассоциированный профессор, Казахский университет экономики, финансов и международной торговли, г. Нур-Султан докторант $\mathrm{PhD}$, Евразийский национальный университет имени Л.Н. Гумилева, г. Нур-Султан

$\mathrm{PhD}$, и.о. доцента, Университет «Туран-Астана», г. Нур-Султан докторант $\mathrm{PhD}$, старший преподаватель, Карагандинский экономический университет Казпотребсоюза, г. Караганда к.э.н., ассоциированный профессор, Евразийский национальный университет имени Л.Н. Гумилева, г. Нур-Султан магистр, старший преподаватель, Жетысуский государственный университет имени И. Жансугурова, г. Талдыкорган магистр, старший преподаватель, Казахский университет экономики, финансов и международной торговли, г. Нур-Султан к.э.н., доцент, Карагандинский экономический университет Казпотребсоюза, г. Караганда докторант $\mathrm{PhD}$, Карагандинский экономический университет Казпотребсоюза, г. Караганда к.э.н., доцент, Северо-Казахстанский университет имени М. Козыбаева, г. Петропавловск д.э.н., профессор, Академия государственного управления при Президенте Республики Казахстан, г. Нур-Султан к.э.н., ассоциированный профессор, Университет Нархоз, г. Алматы 
Есембекова Д.Т.

Есенгельдин Б.С.

Есенгельдинова С.Ж.

Есиркепова А.М.

Ескалиева А.Ж.

Естурлиева А.И.

Жанбаев Р.А.

Жаныбаева 3.К.

Желю В.

Жуманова Б.К.

Ибрагимова Н.В.

Игалиева Л.Н.

Имашев А.Б.

Кажмухаметова А.А.

Казыбаева А.М.

Каменова М.Ж.

Карабаев Э.Б.

Копылова О.В.

Кудайбергенов Н.А.

Кулубеков М.Т.

Кушебина Г.М.

Легостаева А.А. докторант $\mathrm{PhD}$, Северо-Казахстанский университет имени М. Козыбаева, г. Петропавловск

д.э.н., профессор, Казахский университет экономики, финансов и международной торговли, г. Нур-Султан магистр, старший преподаватель, Казахский университет экономики, финансов и международной торговли, г. Нур-Султан

д.э.н., профессор, Филиал Академии государственного управления при Президенте Республики Казахстан по городу Шымкент

магистр, старший преподаватель, НК АО «Атырауский университет имени Х. Досмухамедова», г. Атырау

к.э.н., доцент, Каспийский государственный университет технологий и инжиниринга имени Ш. Есенова, г. Актау к.э.Н., НАО «Алматинский университет энергетики и связи имени Г. Даукеева», г. Алматы

к.э.н., доцент, Казахский университет экономики, финансов и международной торговли, г. Нур-Султан

$\mathrm{PhD}$, профессор, Софийский университет имени К. Охридского, г. София, Болгария

к.э.н., доцент, Казахский университет экономики, финансов и международной торговли, г. Нур-Султан

магистр экономики, Казахский университет экономики, финансов и международной торговли, г. Нур-Султан магистр, старший преподаватель, НК АО «Атырауский университет имени Х. Досмухамедова», г. Атырау $\mathrm{PhD}$, старший преподаватель, Казахский университет экономики, финансов и международной торговли, г. Нур-Султан

к.э.н., доцент, Казахский университет экономики, финансов и международной торговли, г. Нур-Султан

$\mathrm{PhD}$, доцент, Алматы Менеджмент Университет, г. Алматы д.э.н., профессор, Казахский университет экономики, финансов и международной торговли, г. Нур-Султан докторант $\mathrm{PhD}$, Евразийский национальный университет имени Л.Н. Гумилева, г. Нур-Султан

к.э.н., доцент, Северо-Казахстанский университет имени М. Козыбаева, г. Петропавловск

к.э.н., доцент, Казахский университет международных отношений и мировых языков имени Абылай хана, г. Алматы к.э.н., Костанайский инженерно-экономический университет имени М. Дулатова, г. Костанай

к.э.н., доцент, Костанайский инженерно-экономический университет имени М. Дулатова, г. Костанай

к.э.н., профессор, Карагандинский экономический университет Казпотребсоюза, г. Караганда 
Лукпанова Ж.О.

Маканова А.У.

Мусатаева A.A.

Мусина А.A.

Мухан Б.C.

Накипова Г.Е.

Несипбаев P.E.

Ниязов М.Н

Нурпеисова М.М.

Нурумов А.A.

Оразбаева К.Н.

Рахимбекова A.E.

Рахметова A.M.

Саду Ж.Н.

\section{Сейдахметова Ф.С.}

Смагулов К.Е.

Смагулова Г.С.

Темирбаева Г.P.

Тулеметова А.С.

Тургамбаев М.К.

Тургинбаева А.Н.

Турекулова Д.М. к.э.н., доцент, Казахский университет экономики, финансов и международной торговли, г. Нур-Султан

докторант $\mathrm{PhD}$, Казахский Национальный университет имени аль-Фараби, г. Алматы

$\mathrm{PhD}$, доцент, Карагандинский экономический университет Казпотребсоюза, г. Караганда

д.э.н., профессор, Казахский университет экономики, финансов и международной торговли, г. Нур-Султан докторант $\mathrm{PhD}$, Южно-Казахстанский университет имени М. Ауэзова, г. Шымкент

д.э.н., профессор, проректор по научной работе, стратегическому и инновационному развитию,

Карагандинский экономический университет Казпотребсоюза, г. Караганда докторант $\mathrm{PhD}$, Карагандинский экономический университет Казпотребсоюза, г. Караганда докторант $\mathrm{PhD}$, Казахский университет экономики, финансов и международной торговли, г. Нур-Султан к.э.н., профессор, НАО «Университет Нархоз», г. Алматы д.э.н., профессор, АО «Финансовая академия», г. Нур-Султан д.т.н., профессор, Казахский университет экономики, финансов и международной торговли, г. Нур-Султан $\mathrm{PhD}$, доцент, Казахский университет экономики, финансов и международной торговли, г. Нур-Султан к.э.н., профессор, Карагандинский экономический университет Казпотребсоюза, г. Караганда к.э.н., старший преподаватель, Казахский университет экономики, финансов и международной торговли, г. Нур-Султан

д.э.н., профессор, Алматинская академия экономики и статистики, г. Алматы

$\mathrm{PhD}$, доцент, Казахский Национальный университет имени аль-Фараби, г. Алматы к.э.н., доцент, Казахский Национальный университет имени аль-Фараби, г. Алматы д.э.н., профессор, Жезказганский университет имени О.А. Байконурова, г. Жезказган к.э.н., профессор, Южно-Казахстанский университет имени М. Ауэзова, г. Шымкент докторант $\mathrm{PhD}$, Карагандинский экономический университет Казпотребсоюза, г. Караганда д.э.н., профессор, Казахский Национальный университет имени аль-Фараби, г. Алматы

д.э.н., профессор, Казахский университет экономики, финансов и международной торговли, г. Нур-Султан 
Турекулова А.Н.

Турсумбаева М.Ж.

Тусибаева Г.С.

Уахитжанова А.М.

Укубасова Г.С.

Усенбаев Т.М.

Шайкин Д.Н.

Шаймерденова А.К.

Шалабаева А.Ж.

Шахарова А.E.
$\mathrm{PhD}$, старший преподаватель, Казахский университет экономики, финансов и международной торговли, г. Нур-Султан

к.э.н., доцент, Казахский университет экономики, финансов и международной торговли, г. Нур-Султан $\mathrm{PhD}$, ассоциированный профессор, Казахский университет экономики, финансов и международной торговли, г. Нур-Султан

старший преподаватель, АО «Финансовая академия», г. Нур-Султан

$\mathrm{PhD}$, к.э.н., профессор, Казахский университет экономики, финансов и международной торговли, г. Нур-Султан к.э.н., доцент, Казахский университет экономики, финансов и международной торговли, г. Нур-Султан к.э.н., профессор, Северо-Казахстанский университет имени М. Козыбаева, г. Петропавловск магистр, преподаватель, Казахский университет экономики, финансов и международной торговли, г. Нур-Султан докторант $\mathrm{PhD}$, Карагандинский экономический университет Казпотребсоюза, г. Караганда к.э.н., доцент, Евразийский национальный университет имени Л.Н. Гумилева, г. Нур-Султан 
Abzhalova B.A.

Abildina A.Sh.

Adilova A.M.

Aimagambetova A.D.

Aimurzina B.T.

Aitkalieva A.M.

Akimova B.Zh.

Alashbaeva N.M.

Aliev M.K.

Altynbekov M.A.

Amirova G.K.

Andekina R.E.

Arkenova Zh.R.

Baigabulova K.K.

Bedelbaeva A.E.

Bozshagulova S.O.

Borisova E.I.

Budeshov E.G.

Valieva M.M.

Dulambayeva R.T.

Elshibaev R.K.
$\mathrm{PhD}$ student, Eurasian national university named after L.N. Gumilyov, Nur-Sultan

candidate of economics, NAO «Almaty university of energy and communications named after G. Daukeev», Almaty

$\mathrm{PhD}$, associate professor, Kazakh university of international relations and world languages named after Abylai Khan, Almaty

candidate of economics, senior lecturer, Kyzylorda university named after Korkyt Ata, Kyzylorda

doctor of economics, professor, Kazakh university of economics, finance and international trade, Nur-Sultan

$\mathrm{PhD}$ student, Kazakh university of economics, finance and international trade, Nur-Sultan

$\mathrm{PhD}$, associate professor, Eurasian national university named after L.N. Gumilyov, Nur-Sultan

master of economics, senior lecturer, Kazakh university of economics, finance and international trade, Nur-Sultan

doctor of economics, professor, Kazakh university of economics, finance and international trade, Nur-Sultan

$\mathrm{PhD}$, associate professor, Kazakh university of economics, finance and international trade, Nur-Sultan

$\mathrm{PhD}$ student, Eurasian national university named after L.N. Gumilyov, Nur-Sultan

$\mathrm{PhD}$, associate professor, Turan-Astana university, Nur-Sultan

$\mathrm{PhD}$ student, senior lecturer, Karaganda economic university of Kazpotrebsoyuz, Karaganda

candidate of economics, associate professor, Eurasian national university named after L.N. Gumilyov, Nur-Sultan

master of economics, senior lecturer, Zhetysu state university named after I. Zhansugurov, Taldykorgan

master of economics, senior lecturer, Kazakh university of economics, finance and international trade, Nur-Sultan

candidate of economics, associate professor, Karaganda economic university of Kazpotrebsoyuz, Karaganda

$\mathrm{PhD}$ student, Karaganda economic university of Kazpotrebsoyuz, Karaganda

candidate of economics, associate professor, North Kazakhstan university named after M. Kozybayev, Petropavlovsk

doctor of economics, professor, Academy of public administration under the President of the Republic of Kazakhstan, Nur-Sultan candidate of economics, associate professor, Narkhoz University, Almaty 
Esembekova D.T.

Esengeldin B.S.

Esengeldinova S.Zh.

Esirkepova A.M.

Eskalieva A.Zh.

Esturlieva A.I.

Zhanbayev R.A.

Zhanybayeva Z.K.

\section{Zhelyu V.}

Zhumanova B.K.

Ibragimova N.V.

Igalieva L.N.

Imashev A.B.

Kazhmukhametova A.A.

Kazybayeva A.M.

Kamenova M.Zh.

Karabaev E.B.

Kopylova O.V.

Kudaibergenov N.A.

Kulubekov M.T.

Kushebina G.M.

Legostaeva A.A.
$\mathrm{PhD}$ student, North Kazakhstan university named after M. Kozybayev, Petropavlovsk

doctor of economics, professor, Kazakh university of economics, finance and international trade, Nur-Sultan

master of economics, senior lecturer, Kazakh university of economics, finance and international trade, Nur-Sultan

doctor of economics, professor, Branch of the Academy of public administration under the President of the Republic of Kazakhstan in the city of Shymkent

master of economics, senior lecturer, NC JSC «Atyrau University named after Kh. Dosmukhamedova», Atyrau

candidate of economics, associate professor, Caspian state university of technology and engineering named after Sh. Esenov, Aktau

candidate of economics, NAO «Almaty university of energy and communications named after G. Daukeev», Almaty

candidate of economics, associate professor, Kazakh university of economics, finance and international trade, Nur-Sultan

$\mathrm{PhD}$, professor, Sofia university named after K. Ohridsky,

Sofia, Bulgaria

candidate of economics, associate professor, Kazakh university of economics, finance and international trade, Nur-Sultan

master of economics, Kazakh university of economics, finance and international trade, Nur-Sultan

master of economics, senior lecturer, NC JSC «Atyrau University named after Kh. Dosmukhamedova», Atyrau

$\mathrm{PhD}$, senior lecturer, Kazakh university of economics, finance and international trade, Nur-Sultan

candidate of economics, associate professor, Kazakh university of economics, finance and international trade, Nur-Sultan

$\mathrm{PhD}$, associate professor, Almaty Management University, Almaty

doctor of economics, professor, Kazakh university of economics,

finance and international trade, Nur-Sultan

$\mathrm{PhD}$ student, Eurasian national university named after L.N. Gumilyov, Nur-Sultan

candidate of economics, associate professor, North Kazakhstan university named after M. Kozybayev, Petropavlovsk

candidate of economics, associate professor, Kazakh university

of international relations and world languages named after Abylai Khan, Almaty

candidate of economics, Kostanay engineering and economic university named after M. Dulatov, Kostanay

candidate of economics, associate professor, Kostanay engineering and economic university named after M. Dulatov, Kostanay

candidate of economics, professor, Karaganda economic university of Kazpotrebsoyuz, Karaganda 
Lukpanova Zh.O.

Makanova A.U.

Musataeva A.A.

Musina A.A.

Muhan B.S.

Nakipova G.E.

Nesipbayev R.E.

Niyazov M.N.

Nurpeisova M.M.

Nurumov A.A.

Orazbayeva K.N.

Rakhimbekova A.E.

Rakhmetova A.M.

Sadu Zh.N.

Seidakhmetova F.S.

Smagulov K.E.

Smagulova G.S.

Temirbayeva G.R.

Tulemetova A.S.

Turgambayev M.K.

Turginbaeva A.N.

Turekulova D.M. candidate of economics, associate professor, Kazakh university of economics, finance and international trade, Nur-Sultan

$\mathrm{PhD}$ student, Kazakh National university named after Al-Farabi, Almaty

$\mathrm{PhD}$, associate professor, Karaganda economic university of Kazpotrebsoyuz, Karaganda

doctor of economics, professor, Kazakh university of economics, finance and international trade, Nur-Sultan

$\mathrm{PhD}$ student, South Kazakhstan university named after M. Auezov, Shymkent

doctor of economics, professor, Vice-Rector for research, strategic and innovative development, Karaganda economic university of Kazpotrebsoyuz, Karaganda

PhD student, Karaganda state university of economics Kazpotrebsoyuz, Karaganda

$\mathrm{PhD}$ student, Kazakh university of economics, finance and international trade, Nur-Sultan

candidate of economics, professor, NAO «Narkhoz University», Almaty

doctor of economics, professor, JSC «Financial Academy», Nur-Sultan

doctor of technical sciences, professor, Kazakh university of economics, finance and international trade, Nur-Sultan

$\mathrm{PhD}$, associate professor, Kazakh university of economics, finance and international trade, Nur-Sultan

candidate of economics, professor, Karaganda economic university of Kazpotrebsoyuz, Karaganda

candidate of economics, senior lecturer, Kazakh university of economics, finance and international trade, Nur-Sultan

doctor of economics, professor, Almaty academy of economics and statistics, Almaty

$\mathrm{PhD}$, associate professor, Kazakh National university named after Al-Farabi, Almaty

candidate of economics, associate professor, Kazakh National university named after Al-Farabi, Almaty

doctor of economics, professor, Zhezkazgan university named after O.A. Baikonurov, Zhezkazgan

candidate of economics, professor, South Kazakhstan university named after M. Auezov, Shymkent

$\mathrm{PhD}$ student, Karaganda economic university of Kazpotrebsoyuz, Karaganda

doctor of economics, professor, Kazakh National university named after Al-Farabi, Almaty

doctor of economics, professor, Kazakh university of economics, finance and international trade, Nur-Sultan 
Turekulova A.N.

Tursumbayeva M.Zh.

Tusibayeva G.S.

Uakhitzhanova A.M.

Ukubasova G.S.

Usenbayev T.M.

Shaikin D.N.

Shaimerdenova A.K.

Shalabaeva A.Zh.

Shakharova A.E.
$\mathrm{PhD}$, senior lecturer, Kazakh university of economics, finance and international trade, Nur-Sultan

candidate of economics, associate professor, Kazakh university of economics, finance and international trade, Nur-Sultan

$\mathrm{PhD}$, associate professor, Kazakh university of economics, finance and international trade, Nur-Sultan

senior lecturer, JSC «Financial Academy», Nur-Sultan

$\mathrm{PhD}$, candidate of economics, professor, Kazakh university of economics, finance and international trade, Nur-Sultan

candidate of economics, associate professor, Kazakh university of economics, finance and international trade, Nur-Sultan

candidate of economics, professor, North Kazakhstan university named after M. Kozybayev, Petropavlovsk

master of economics, lecturer, Kazakh university of economics, finance and international trade, Nur-Sultan

$\mathrm{PhD}$ student, Karaganda economic university of Kazpotrebsoyuz, Karaganda

candidate of economics, associate professor, Eurasian national university named after L.N. Gumilyov, Nur-Sultan 
Журнал включен в Перечень изданий Комитета по контролю в сфере образования и науки МОН РК и направлен для публикаций результатов научных исследований по направлениям освещения актуальных вопросов экономической теории и практики: актуальные вопросы экономики, менеджмент, маркетинг, финансы, учет и аудит.

\section{ТРЕБОВАНИЯ К ОФОРМЛЕНИЮ СТАТЕЙ В «ВЕСТНИКЕ КазУЭФМТ»}

\section{Общие требования}

Все статьи принимаются через электронную почту vestnik@ kuef.kz.

Статьи, не соответствующие требованиям к оформлению, не рассматриваются. Пользователям необходимо поддерживать актуальность своих контактных данных и другой информации, указанной в профиле. Проверьте правильность указания e-mail, поскольку всю переписку редакция будет вести с Вами по электронной почте.

Статьи принимаются на казахском, русском и английском языках. Объем статьи, включая библиографию, должен быть не менее 6 и не более 10 страниц (не более).

Подаваемая рукопись должна:

- представлять академическую и научную ценность;

- иметь определенную значимость и оригинальность, а также практическое значение;

- вносить вклад в более ранние исследования по этой теме;

- тщательно вычитана и отредактирована.

Технические требования к оформлению статьи:

- формат - Microsoft Word, формулы в редакторе формул (Microsoft Equation).

- шрифт - Times New Roman;

- размер шрифта - 14;

- межстрочный интервал - одинарный;

- ширина всех полей - 2 см;

- абзацный отступ - 1 см;

В журнал могут быть представлены оригинальные научные статьи, которые являются окончательным отчетом о законченном экспериментальном исследовании.

\section{Порядок оформления статьи}

Автор указывает:

УДК - на основе системы Универсальной десятичной классификации информации, используемой во всём мире для систематизации произведений науки, литературы и искусства, периодической печати, различных видов документов и организации картотек. Указывается в верхнем левом углу рукописи.

ГРНТИ - на основе Государственного рубрикатора научно-технической информации, применяемого для систематизации документов в Электронном Каталоге. ГРНТИ по своей теме можно определить на сайте http://grnti.ru/ или http://lib.gup.kz.

Указывается в верхнем левом углу рукописи.

Помимо УДК и ГРНТИ можно указать коды по классификации JEL (JEL Classification). Коды, указанные автором, должны четко отражать область исследований. Автор может использовать коды классификации JEL из двух или трех областей, если они 
охвачены исследованием. Коды по классификации JEL можно найти на сайте: http:// nfmte.com/assets/docs/jel.doc. Коды JEL указываются после ключевых слов.

Ключевых слова переводятся на три языка (казахский, русский, английский языки кілт сөздер, ключевые слова, keywords).

\section{Автор (авторы)}

Перед названием статьи в правом верхнем углу указывается ФИО автора (авторов). После ФИО авторов должны быть написаны: ученая степень и ученое звание, место работы, город (для зарубежных авторов также указывается страна). Название организации или учреждения указывается в именительном падеже, при этом название должно быть полным, без сокращений.

Если есть несколько авторов, они сами принимают решение относительно порядка их упоминания в названии статьи (рекомендуемый вариант - в зависимости от вклада в исследование). Список авторов включает только тех лиц, которые действительно приняли участие в исследовании и согласились нести полную ответственность за его содержание. Количество авторов не более 4.

\section{Название статьи}

Название статьи должно полностью отражать тему исследования и его содержание. Оно должно быть коротким и конкретным (не более 10 слов). Кроме того, оно должно быть привлекательным для внимания читателя и написано с использованием научного стиля. Уместно указывать объект исследования или конкретизировать его с помощью двоеточия или скобок. Не рекомендуется использовать сокращения, кроме общепринятых и известных.

\section{Структура статьи}

Материал в рукописи должен строиться по принципу «от общего к конкретному». Статья должна состоять из следующих разделов (это не исключает наличия дополнительных подразделов), что соответствует международным стандартам:

\section{Аннотация}

Аннотоция должна быть информативной и структурированной. В аннотации необходимо приводить только то, что сделано в статье (рассмотрено, выявлено, определено, показано, проанализировано и т.д.) (22-25 строчек или не менее 150 слов). Аннотация пишется на основном языке рукописи (в начале статьи), в конце статьи, после списка литературы, должна быть аннотация на казахском и/или русском и/или английском языках (в зависимости от основного языка рукописи).

\section{Ключевые слова (на трех языках)}

Количество ключевых слов должно составлять не менее 10. Там не должно быть предложений, а только слова или группы слов. Если объект исследования не упоминается в названии документа (включая страну, регион), его следует добавить в список ключевых слов.

\section{Введение (26-32 строчек или не менее 200 слов)}

Во введении должны быть обоснованы и разъяснены научные вопросы, актуальность, цель, задачи, материалы и методы исследования. Цель описывает основные результаты в краткой и конкретной форме, достижение которых является целью данного исследования. 
Цель не должна копировать название рукописи. Memoды исследования описываются кратко и конкретным образом. Если предлагаемые методы и процедуры используются в других работах, автор должен ссылаться на исходные источники. Должны быть представлены теории, перспективы, формулы, уравнения. Если в статье используются общеизвестные статистические процедуры, автор не должен описывать их сущность, достаточно просто указать их.

Автору следует конкретизировать проблему, по которой проведено данное исследование. Введение не должно быть длинным, автор должен избегать использования таблиц и цифр.

\section{Обзор литературы (20-22 строчек или не менее 150 слов)}

Автор должен описать проделанный анализ и обобщение соответствующих работ (статей, монографий, докладов, тезисов и т.д.), которые описывают суть проблемы и/или дают представление о предыдущих исследованиях по ее решению. Обзор литературы должен соответствовать цели исследования и представлять результаты критического анализа аналитической базы для тестирования гипотезы исследования.

Литературный обзор должен охватывать работы, которые были опубликованы как в Казахстане (монографии, научные статьи, в том числе и в настоящем журнале университета), так и за пределами страны, то есть проблема должна изучаться на глобальном уровне. При необходимости также анализируются нормативные правовые акты, с указанием конкретных авторов.

Рекомендуется завершить обзор литературы изложением нерешенных вопросов, выявлением противоречий в результатах и результатах предыдущих исследований, обоснованием необходимости продолжения исследований в этой области и выбора конкретной темы (направления) этого изучения.

Основная часть (анализ, результаты и обсуждение)

Включает в себя эмпирические или теоретические данные, полученные в процессе проведенного исследования. Рекомендуется использовать рисунки, таблицы (в совокупности не более 5).

\section{Выводы (15 строчек или не менее 100 слов)}

В этом разделе излагаются основные идеи статьи, формулируются полученные результаты и их новизна. Предложения, выводы и рекомендации должны подтвердить достижение поставленных целей и задач исследования. Необходимо наметить возможность практического использования полученных результатов и предложить направления для дальнейших научных исследований.

Наименование обозначенных разделов (текст с абзаца) выделять полужирным шрифтом (введение, обзор литературы, основная часть, выводы).

В тексте статьи ссылки на источники обязательны. Сноски (ссылки) на использованную литературу печатаются в квадратных скобках.

Литература оформляется в последовательности ссылок по тексту и в соответствии с Межгосударственным Стандартом ГОСТ 7.1-2003 «Библиографическая запись. Библиографическое описание. Общие требования и правила составления» (Принят Межгосудар270 
ственным Советом по стандартизации, метрологии и сертификации (протокол № 12 от 2 июля 2003 г.).

Название списка литературы должно иметь стандартный подзаголовок «Литература», «Әдебиеттер», «References» (от 6 до 15 источников, желательно книги, брошюры, статьи из журналов казахстанских и зарубежных авторов).

Источники литературы в статьях на русском и казахском языках должны представляться на языке оригинала. После этого необходимо привести второй Список литературы (References) c транслитерацией. В статье, написанной на английском языке, источники на русском и казахском языках приводятся с транслитерацией. Для этого можно использовать сайт: http://translit.net

Статьи на казахском и английском языках должны иметь профессиональный перевод (запрещается автоперевод с интернета).

Источник литературы содержит: автор (ы), полное наименование источника. - Место издания: издательство, год выпуска. - Количество страниц (образец ниже).

Например:

Литература

1. Лаврушин О.И. Банковское дело: современная система кредитования: Учеб. пос./ О.И. Лаврушин, О.Н. Афанасьева. - 7-е изд. - М.: КНОРУС, 2013. - 360 с.

2. Указ Президента Республики Казахстан от 30 мая 2013 года № 577 «О Концепции по переходу Республики Казахстан к «зеленой экономике». https://online.zakon.kz/Document $/$ ?docid=31399596\#pos=0;167.

3. Регионы Казахстана (2018). Комитет статистики Министерства национальной экономики Республики Казахстан. - Астана, 30 c. http://stat.gov.kz/faces/wcnav_externalld/publicationsCompilations?_afrLoop=9713740891393549\#\%40\%3F_afrLoop\%3D9713740891393549\%26_ adf.ctrl-state\%3D19favud3d_54

4. Hong, C.Y., Lee, Y.C., Tsai, M.C. and Tsai, Y.C., 2018. Agricultural Sector Input Technical Coefficients, Demand Changes and CO2 Emissions after the Financial Crisis: Environmental Input-Output Growth Factor Model Approach // International Journal of Energy Economics and Policy.- № 8(6). - P. 339-345.

5. Шумакова О.В. Теоретические аспекты устойчивого развития сельских территорий в современной науке // Современные проблемы науки и образования. - 2013. - № 6. -C.1-8

6. Marshall, A. (1980). The principles of Economics (Macmillan and Co., Ltd.). - London: Macmillan and Co., Ltd. econlib.org. - Retrieved from http//www.econlib.ord/library/ Marshall/marP.html.

7. Қазақстан Республикасының агроөнеркәсіптік кешенін дамытудың 2017-2021 жылдарға арналған мемлекеттік бағдарламасы. Қазақстан Республикасы Президентінің 2017 жылғы 14 ақпандағы № 420 Жарлығы. http://adilet.zan.kz/kaz/docs/P1600000894

\section{References}

1. Lavrushin O.I. Bankovskoe delo: sovremennaja sistema kreditovanija: Ucheb. pos. [Banking: the modern system of lending: training manual] / O.I. Lavrushin, O.N. Afanas'eva. - 7-e izd. - M.: KNORUS, 2013. - 360 s. [in Russian]

2. Ukaz Prezidenta Respubliki Kazahstan ot 30 maja 2013 goda № 577 «O Koncepcii po perehodu Respubliki Kazahstan k «zelenoj jekonomike» [Decree of the President of the Republic of Kazakhstan dated may 30, 2013 No. 577 «On the Concept of transition of the Republic of Kazakhstan to the» green economy»]. https://online.zakon.kz/Document/?docid= 31399596\#pos=0;167 [in Russian] 
3. Regiony Kazahstana (2018). Komitet statistiki Ministerstva nacional'noj jekonomiki Respubliki Kazahstan. [Regions Of Kazakhstan (2018). Statistics Committee of the Ministry of national economy of the Republic of Kazakhstan]. - Astana, 30 s. http://stat.gov.kz/faces/ wcnav_externalId/publicationsCompilations?_afrLoop=9713740891393549\#\%40\%3F_ afrLoop\%3D9713740891393549\%26_adf.ctrl-state\%3D19favud3d_54 [in Russian]

4. Hong, C.Y., Lee, Y.C., Tsai, M.C. and Tsai, Y.C., 2018. Agricultural Sector Input Technical Coefficients, Demand Changes and CO2 Emissions after the Financial Crisis: Environmental Input-Output Growth Factor Model Approach. International Journal of Energy Economics and Policy. - № 8(6). - P. 339-345.

5. Shumakova O.V. Teoreticheskie aspekty ustojchivogo razvitija sel'skih territorij v sovremennoj nauke [Theoretical aspects of sustainable development of rural areas in modern science] // Sovremennye problemy nauki i obrazovanija. - 2013. - № 6. - S.1-8. [in Russian]

6. Marshall, A. (1980). The principles of Economics (Macmillan and Co., Ltd.). - London: Macmillan and Co., Ltd. econlib.org. - Retrieved from http//www.econlib.ord/library/ Marshall/ marP.html.

7. Agroonerkasiptik keshendi zhane auyldyk aumaktardy damytudy memlekettik retteu turaly Kazakstan Respublikasynyn 2005 zhylgy 8 shildedegi No. 66 Zany [Law of the Republic of Kazakhstan dated July 8, 2005. - No. 66. About State Regulation of Agribusiness Development and Rural Areas Development]. http://adilet.zan.kz/kaz/docs/Z050000066 [in Kazakh]

Срок рассмотрении статьи редакцией от трех до шести месяцев. Датой сдачи статьи считается день получения редакцией ее окончательного варианта

В статье не допускается использование:

- жирного, курсивного и подчеркнутого шрифта в основном тексте;

- автоматического и принудительного переноса, знаков принудительного разрыва строк, страниц;

- фотографий;

- цветных элементов.

В статье допускается в совокупности не более 5-ти таблиц, выполненных в Word и рисунков (Word, группировать). Даются ссылки на источники в квадратных скобках.

Если рукопись не соответствует требованиям, она возвращается на доработку. Датой сдачи статьи считается день ее получения редакцией ее окончательного варианта.

\section{ОПЛАТА ПРОИЗВОДИТСЯ ПОСЛЕ ПРИНЯТИЯ СТАТЬИ И СООБЩЕНИЯ ОТ РЕДАКЦИИ}

К статье прилагаются:

\section{Сведения об авторе}

Фамилия Имя Отчество (полностью) на казахском, русском и английском языках

Должность, ученая степень, звание (полностью) на казахском, русском и английском языках

Организация (полностью) на казахском, русском и английском языках

Адрес

Страна (полностью) на казахском, русском и английском языках

Телефон раб., сотовый

E-mail

Название статьи (полностью) на казахском, русском и английском языках 
Дополнительная информация: для зарубежных авторов указывается страна

В конце статьи на отдельной странице указать сведения об авторах на трех языках: фамилия, имя, отчество, должность, степень, звание, полное название организации, служебный телефон, мобильный, E-mail.

Окончательная версия статьи должна подаваться со всеми прилагающимися документами (статья, сведения об авторах, антиплагиат).

Все статьи подлежат экспертизе рецензентами. При необходимости статья отправляется на доработку автору или отклоняется. Редакционная коллегия оставляет за собой право отклонить ее от печати при несоответствии настоящим требованиям по структуре и оформлению и не вступать в переписку с авторами.

Ответственность за содержание и оформление статьи несет автор статьи.

\section{ПУБЛИКАЦИОННАЯ ЭТИКА}

Редакция журнала «Вестник КазУЭФМТ» придерживается этических принципов на всех этапах работы с публикациями. Мы соблюдаем Этический кодекс Комитета по этике научных публикаций (Committee on Publication Ethics, COPE) и стремимся следовать его рекомендациям. Мы надеемся на следование принципам этичного поведения от всех сторон, вовлеченных в процесс работы с публикациями: авторов, редакторов и рецензентов.

\section{Общие обязанности и ответственность редакции}

Редакторы оценивают статью на основе исключительно ее академических достоинств и научной значимости.

Учредитель журнала не вправе вмешиваться в процесс принятия решений о публикации. Процесс принятия решений отделен от конъюнктурных, политических и любых других соображений.

Редакторы не должны использовать неопубликованную информацию в собственных исследованиях без письменного согласия автора. Редакция защищает конфиденциальность индивидуальной информации, полученной от авторов, и предупреждает рецензентов, что им так же необходимо следовать этому.

Редакторы не отменяют принятого решения о публикации статьи, если только в связи с публикацией не обнаружатся нарушения законодательства или этики.

При подозрении о наличии недобросовестного поведения или при получении жалоб и обвинений в недобросовестном поведении автора (-ов) редакция принимает меры, руководствуясь рекомендациями СОРЕ. Это распространяется как на опубликованные, так и на еще не опубликованные материалы.

Редакторы могут отклонить статью самостоятельно без экспертной оценки рецензентов, если она будет сочтена не соответствующей тематике журнала либо требуемому уровню качества. Это решение должно быть принято беспристрастно, на основании исключительно содержания статьи, а критерии принятия такого решения должны быть четко изложены автору.

Редакторы и рецензенты должны различать критические замечания о неправомерном поведении и критические замечания об ограничениях и недостатках исследования. 
Научные дискуссии - лучший способ повысить качество науки, они поощряемы.

Редакторы, сотрудники КазУЭФМТ, члены легии могут представлять собственные исследования к публикации в журнале, оценка их статей должна быть не менее беспристрастной, чем статей других авторов.

\section{Этические принципы для авторов}

Авторы должны представить объективное обоснование научной значимости своей исследовательской работы. Допускается публикация обзорных статей при наличии оригинальных выводов и/или рекомендаций.

Авторы гарантируют, что представленные в редакцию статьи являются оригинальными, и что в случае использования в статье других работ это должным образом указано. Плагиат неприемлем в любой из его форм: дословного копирования без ссылки на источник, перефразирования без ссылки на источник, а также самоплагиата (если элементы статьи ранее опубликованы, авторы обязаны на это сослаться). Заведомо ложные и недостоверные сведения являются недопустимыми.

Авторы гарантируют, что представленные в редакцию статьи не находятся на рассмотрении в других изданиях. Представление статьи одновременно в несколько изданий представляет собой неэтичное поведение и неприемлемо.

Автор, представляющий статью, должен обеспечить согласие всех соавторов (при их наличии) с ее окончательным вариантом и с ее представлением к публикации в журнале.

Источник финансирования исследований, при наличии такового, должен быть объявлен и указан, его роль в проведении исследований и/или подготовке статьи должна быть изложена.

\section{Этические принципы для рецензентов}

Рецензенты должны соглашаться на рецензирование только тех статей, для оценки которых они обладают достаточными знаниями и которые они могут прорецензировать своевременно.

Рецензент должен отказаться от подготовки рецензии, если участвовал в какой-либо работе, связанной с подготовкой статьи, или в описываемых в ней исследованиях.

Рецензент должен уважать конфиденциальность рецензии и не раскрывать никакие детали статьи или рецензии во время или после рецензирования никому за исключением тех лиц, кому это разрешено редакцией (например, редактору).

Рецензент не вправе использовать информацию, полученную в ходе рецензирования, для собственной выгоды, для выгоды либо для дискредитирования других лиц или организаций.

Рецензент должен заявить редактору о возможном конфликте интересов, связанном с рецензированием статьи, или обратиться за советом к редактору, если не уверен, составляет ли сложившаяся ситуация конфликт интересов.

Оценка должна проводиться объективно, заключения должны быть четко сформулированы и аргументированы, чтобы авторы могли использовать их для улучшения работы. 


\title{
Қазақ экономика, қаржы және халықаралық сауда университетінің ЖАРШЫСЫ
}

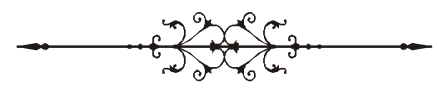 \\ ВЕСТНИК \\ Казахского университета экономики, \\ финансов и международной торговли
}

Беттеуші/верстка: Баркова О.

Жаршы авторлардың электрондық түпнұсқасы негізінде басылып шығарылған Вестник сверстан и отпечатан с электронной версии авторских оригиналов

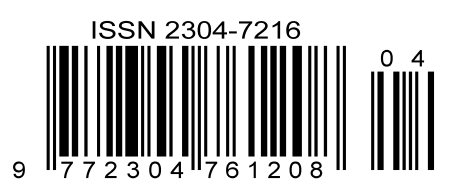

Басуға 21.12.20. қол қойылды. Пішімі 70x100 1/10. Көлемі 27,5 б.т. Таралымы 300 дана. Тапсырыс 674. Подписано к печати 21.12.20. Формат 70х100 1/10. Объем 27,5 уч.-изд.л. Тираж 300 экз. Заказ 674.

Қазақ экономика, қаржы және хальқаральққ сауда университетінің, баспа-полиграфиялық орталывы. Астана қ., Жұбанов көшесі, 7

Университеттің менеджмент жүйесі ISO 9001 сәйкестігіне сертификатталған Система менеджмента университета сертифицирована на соответствие ISO 9001

Приказом председателя Комитета по контролю в сфере образования и науки (ККСОН) Министерства образования и науки (МОН) Республики Казахстан от 15.11.2019 г. № 771 журнал включен в перечень научных изданий, рекомендуемых ККСОН МОН

Республики Казахстан для публикации основных результатов научной деятельности по направлению «Экономика» 